ГБОУ ВПО Саратовский ГМУ им. В.И. Разумовского

Минздрава России

\title{
Влияние терагерцевых волн на сложные живые биообъекты
}

Под редакцией заслуженного деятеля науки РФ, профессора В.Ф. Киричука 
УДК 615.847-092.9

ББК 53.6

B 586

В монографии представлены современные данные о влиянии электромагнитных волн терагерцевого диапазона на частотах клеточных метаболитов молекулярного спектра излучения и поглощения оксида азота 150,176-150,664 ГГц и атмосферного кислорода 129 ГГц на постстрессорные нарушения системной гемодинамики, перфузии микроциркуляторного русла, функционального состояния эндотелия сосудов, реологических свойств крови, различных показателей гемостаза. Показаны некоторые механизмы положительного влияния электромагнитных волн на нарушенные показатели гемодинамики, перфузии тканей, состояния эндотелия сосудов микроциркуляторного русла, на показатели реологии крови и гемостаза в условиях экспериментов на белых крысах при остром и длительном стрессах.

Для врачей всех специальностей, применяющих в лечении больных электромагнитные волны терагерцевого диапазона на частотах клеточных метаболитов оксида азота и атмосферного кислорода, а также для аспирантов, ординаторов и студентов старших курсов медицинских вузов.

Авторский коллектив: В.Ф. Киричук, Т.С. Великанова, В.В. Великанов, О.Н. Антипова, А.А. Цымбал.

Под редакцией заслуженного деятеля науки РФ, профессора В.Ф. Киричука.

Рецензенты: доктор мед. наук, профессор С.В. Клаучек; доктор мед. наук, прфессор В.Ф. Пятин

Одобрено к изданию Редакционно-издательским

Советом Университета

ISBN 978-5-7213-0553-5

(C) В.Ф. Киричук, О.Н. Антипова, Т.С. Великанова, В.В. Великанов, А.А. Цымбал, 2014

(С) ГБОУ ВПО Саратовский ГМУ им. В.И. Разумовского Минздрава России, 2014 
Посвящается светлой памяти доктора медицинских наук, профессора Евгения Викторовича Андронова

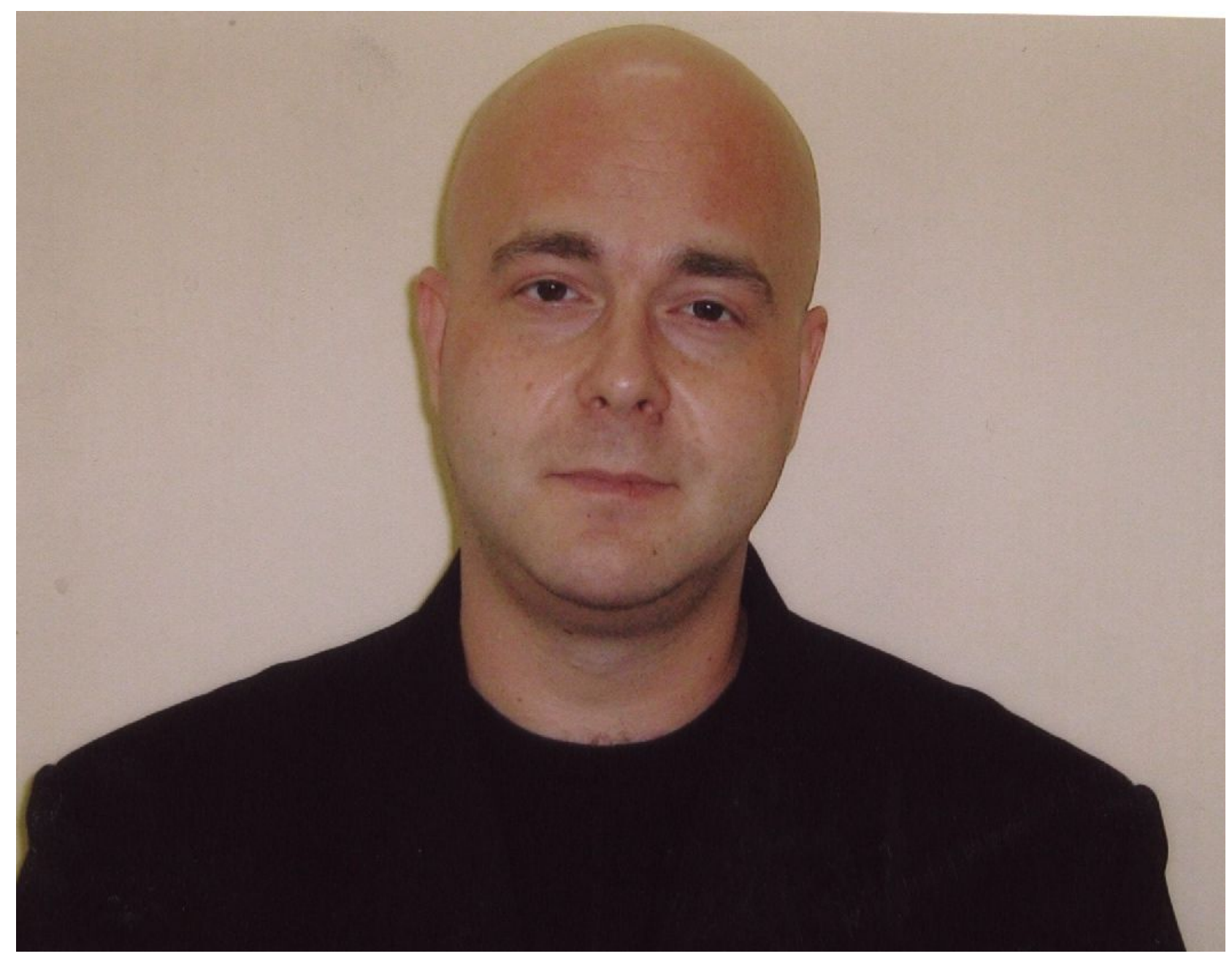

«Ученик не бывает выше своего учителя но, и усовершенствовавшись, будет всякий, как учитель его» Лука,VI: 40

Пауло КОЭЛЬО. Книга воина света. 
«Значимость ученика в жизни Учителя и коллектива, в котором он работал, особенно оценивается тогда, когда ученик преждевременно уходит в иной мир».

В.Ф. Киричук

\section{Профессор Евгений Викторович Андронов}

Е.В. Андронов родился в 1974 году в г. Саратове. В 1997 году с отличием окончил Саратовский государственный медицинский университет по специальности лечебное дело. В том же году был зачислен в клиническую ординатуру по специальности «клиническая физиология» при кафедре нормальной физиологии. В 1999 году был зачислен в аспирантуру при кафедре нормальной физиологии, которую досрочно окончил в 2000 году, защитив кандидатскую диссертацию на тему «Половые и возрастные различия в тромбоцитарном и коагуляционном звене гемостаза и системе фибринолиза у здоровых людей и больных инфарктом миокарда». С 2000 по 2005 год работал в должности ассистента кафедры нормальной физиологии. В 2005 году приказом ректора переведен на должность доцента. В 2007 году Е.В. Андронову присвоено звание доцента при кафедре нормальной физиологии. Е.В. Андроновым велась активная научная работа по изучению влияния терагерцевого излучения на частоте оксида азота на показатели системы гемостаза. В 2008 году Е.В. Андронов защитил диссертацию на соискание ученой степени доктора медицинских наук на тему «Экспериментальное изучение влияния электромагнитных волн тервагерцевого диапазона на частотах оксида азота на внутрисосудистый компонент микроциркуляции». Является автором более 100 научных работ и соавтором 4 патентов на изобретения. В 2005 г. стал победителем конкурса В. Потанина среди молодых преподавателей России.

С 2004 по 2007 год работал в должности заместителя декана лечебного факультета. В 2007 году исполнял обязанности начальника научного отдела СГМУ.

Награжден почетной грамотой руководителя Федерального агентства по здравоохранению и социальному развитию. В 2013 году Е.В. Андронову объявлена благодарность губернатора Саратовской области за добросовестный труд и высокий профессионализм в работе.

Коллектив кафедры нормальной физиологии им. И.А. Чуевского 


\section{РАЗДЕЛ I}

ВЛИЯНИЕ ЭЛЕКТРОМАГНИТНОГО ОБЛУЧЕНИЯ ТЕРАГЕРЦЕВОГО ДИАПАЗОНА НА ЧАСТОТАХ МОЛЕКУЛЯРНОГО СПЕКТРА ИЗЛУЧЕНИЯ

И ПОГЛОЩЕНИЯ ОКСИДА АЗОТА

150,176 - 150,664 ГГЦ

НА ПОСТСТРЕССОРНЫЕ НАРУШЕНИЯ СИСТЕМНОЙ ГЕМОДИНАМИКИ 


\section{СПИСОК СОКРАЩЕНИЙ}

КВЧ - крайне высокие частоты

МСИП - молекулярный спектр излучения и поглощения

ТГЧ - терагерцевые частоты

ЭМИ - электромагнитное излучение

$\mathrm{NO}$ - оксид азота 


\section{ВВЕДЕНИЕ}

Стресс представляет собой неспецифический компонент физиологических и патологических нейрогуморальных реакций, возникающих в организме под действием любых условий, угрожающих нарушению гомеостаза [Селье Г., 1960; Барабой В.А., 1991]. Стрессорная реакция развивается в ответ на действие необычных по качеству, интенсивности или продолжительности раздражителей за счет активации двух ведущих стресс-реализующих систем: гипоталамо-симпато-адреналовой и гипоталамо-гипофизарнонадпочечниковой [Меерсон Ф.З., 1981; Барабой В.А., 1991]. Стресс-реакция имеет большое значение в адаптации организма человека и животных к изменяющимся условиям окружающей среды. Однако интенсивные и длительно действующие стрессоры приводят к развитию нарушений, способствующих возникновению ряда заболеваний. В основе неблагоприятных последствий стресса лежит дисбаланс в деятельности стрессреализующих, обусловливающих реакцию организма на действующий стрессор, и стресслимитирующих систем, которые способны ограничивать повреждающее действие гормонов и метаболитов, выделяющихся в ходе стресс-реакции [Малышев И.Ю., Манухина Е.Б., 1998, 2000].

Неуклонный рост заболеваний, вызванных стрессорными повреждениями на клеточном, тканевом, организменном уровнях биосистемы, диктует необходимость поиска новых методов, средств профилактики, коррекции и системного подхода к терапии «болезней адаптации», в том числе заболеваний сердечно-сосудистой системы, которые занимают первое место среди причин смертности населения. Они составляют около 55\% от общей смертности и являются самыми высокими среди показателей стран Западной Европы [Меерсон Ф.З., 1993; Берсудский С.О., 2002; Гафаров В.В., Благинина М.Ю., 2005; Белоусов Ю.Б., Белоусов Д.Ю., Григорьев В.Ю. и соавт., 2006; Оганов Р.Г., Масленникова Г.Я., 2000, 2007].

В настоящее время доказана роль стресса как главного этиологического фактора ишемической болезни сердца, атеросклероза, гипертонической болезни и многих других заболеваний сердечно-сосудистой системы [Берсудский С.О., 2002; Миняев В.А., Вишняков Н.И., 2002; Паршина С.С., 2006]. Устранение данного этиологического фактора риска и развития сердечно - сосудистой патологии практически невозможно из-за интенсификации производственных процессов, урбанизации, радикально меняющих уровень воздействия физических и психических перегрузок на организм современного человека и закономерно влекущих за собой развитие «болезней адаптации» [Меерсон Ф.3., 1993; Тожиев М.С., Шестов Д.Б., Воробьёв В.И. и др., 2000; Берсудский С.О., 2002]. 
Ведущую роль в патогенезе заболеваний сердечно-сосудистой системы играет нарушение кровоснабжения органов и тканей [Чернух А.M., 1984; Stokes K.Y., Granger D.N., 2004].

Изменения регионарного, в частности, коронарного, мозгового, почечного кровотока и системной гемодинамики являются основными причинами возникновения недостаточности кровообращения [Чернух A.M., 1984; Stokes K.Y., Granger D.N., 2004].

Для коррекции нарушений гемодинамики используют широкий спектр препаратов, обладающих свойствами вазодилататоров. Однако фармакотерапия всегда сопровождается возникновением различной степени выраженности побочных эффектов [Баркаган 3.С., Момот А.П., 2001; Leopold J.A., 1997]. Также многие авторы отмечают высокую стоимость медикаментозного лечения и значительные трудности в применении фармацевтических средств, поскольку эффективность традиционной терапии при определённых заболеваниях системы кровообращения часто оказывается резко сниженной [Бокарев И.Н., 2000]. Далеко не всегда удается достигнуть оптимального результата; развиваются нежелательные побочные реакции, имеется ряд противопоказаний, ограничивающих применение лекарственных средств [Иванов С.Г., 1993; Киричук В.Ф., 1999; Головачева Т.В., 2002; Машковский М.Д., 2005; Паршина С.С., Головачева Т.В., Киричук В.Ф. и др., 2009].

В связи с этим в настоящее время ведутся поиски новых немедикаментозных методов коррекции указанных нарушений. Одним их таких методов является низкоинтенсивное излучение миллиметрового и субмиллиметрового диапазона частот [Киричук В.Ф. и др., 1999; Головачева Т.В. и др., 2000; Паршина С.С., 2006; Киричук В.Ф., Креницкий А.П., Майбородин А.В., Тупикин В.Д., 2006; Андронов Е.В., 2008, Антипова О.Н., 2009] .

Известно, что в процессе жизнедеятельности клетка вырабатывает электромагнитные колебания весьма широкого диапазона [Пресман А.С., 1968; Девятков Н.Д., Голант М.Б., Бецкий О.В., 1991; Veyret B., Bouthet C., Deschaux P. et al., 1991]. Однако преимущественно узкий миллиметровый и субмиллиметровый диапазон используется клетками для обмена информацией, необходимой для регуляции внутриклеточных функций и межклеточных взаимодействий. В пользу этого свидетельствует факт проявления ряда эффектов как отдельных клеток, так и организма в целом в ответ на низкоинтенсивные «информационные» воздействия в миллиметровом и субмиллиметровом диапазонах частот [Киричук В.Ф. и др., 2001, 2002].

Электромагнитные КВЧ-колебания достаточно широко вошли в медицинскую практику и показали свою эффективность в лечении широкого ряда заболеваний, оказывая 
нормализующее (восстанавливающее) действие на основные механизмы развития общепатологических процессов, лежащих в основе любых заболеваний [Бецкий О.В., Лебедева Н.Н., 2002]. Этот аспект их действия получил название КВЧ-терапии, которая, в частности, применяется в комплексном лечении заболеваний сердечно-сосудистой системы - острого инфаркта миокарда и нестабильной стенокардии [Лебедева А.Ю., 1998; Киричук В.Ф., Головачева Т.В., Чиж А.Г., 1999; Паршина С.С., 2006; Водолагин А.В., 2008]. Преимуществами такого воздействия являются: высокая эффективность, неинвазивность, практическое отсутствие побочных реакций и противопоказаний к применению, невысокая стоимость, хорошая сочетаемость с другими методами лечения [Бецкий О.В., Девятков Н.Д., Лебедева Н.Н., 2000].

При классической КВЧ-терапии, широко вошедшей в практику лечения многих заболеваний [Девятков Н.Д., Голант Н.Б., Бецкий О.В., 1991, 1994; Киричук В.Ф., Головачева Т.В., Чиж А.Г., 1999; Бецкий О.В., Девятков Н.Д., Лебедева Н.Н., 2000а, 2000б; Синицын Н.И., Петросян В.И., Елкин В.А. и др., 2000; Паршина С.С., Головачева Т.В., Киричук В.Ф. и др., 2009], электромагнитное воздействие осуществляется на частотах 42,2 ГГц и 53,5 ГГц [Девятков Н.Д., Голант Н.Б., Бецкий О.В., 1994; Архипов М.Е., Новицкий Я.М., Перфильев В.Е. и др., 1999; Киричук В.Ф., Головачева Т.В., Чиж А.Г., 1999; Бецкий О.В., Девятков Н.Д., Лебедева Н.Н., 2000; Федоров А.С., Королев Л.С., Беляков С.В., 2000]. В настоящее время исследуются вопросы взаимодействия биологических объектов с электромагнитными полями всего миллиметрового и субмиллиметрового диапазона частот [Архипов М.Е., Новицкий Я.М., Перфильев В.Е. и др., 1999; Федоров А.С., Королев Л.С., Беляков С.В., 2000; Киричук В.Ф., Майбородин А.В., Волин М.В. и др., 2002; Киричук В.Ф., Малинова Л.И., Креницкий А.П. и др., 2003; Киричук В.Ф., Креницкий А.П., Майбородин А.В., Тупикин В.Д., 2006].

В последние годы появилось новое направление информационной терапии терагерцевая терапия [Бецкий О.B., 2003]. Терагерцевый диапазон частот электромагнитных волн располагается на шкале электромагнитных волн между КВЧ и оптическим инфракрасным диапазонами и интересен, прежде всего, тем, что именно в нем находятся молекулярные спектры излучения и поглощения (МСИП) различных клеточных метаболитов: NO, СО, активные формы кислорода и др. [Башаринов и др., 1968; Мериакри В.В., 2002; Бецкий О.В., Креницкий А.П., Майбородин А.В., Тупикин В.Д., 2003; Бецкий O.В., Креницкий А.П., Майбородин А.B., 2007; Rothman L.S., Barbe A., Chris Benner D., 2003]. Есть мнение, что реакционная способность молекул, возбужденных терагерцевым квантом, будет на порядок выше, чем при возбуждении КВЧ-квантом [Бецкий О.В., Креницкий А.П., Майбородин А.В., Тупикин В.Д., 2003]. К особенностям терагерцевых 
волн (ТГВ) относится также и то, что ТГЧ-излучение свободно проникает сквозь одежду и кожу до мышц человека [Конако Ф., Фэйтс Д., 2002]. Изучение биологических эффектов ТГЧ-излучения представляет значительный интерес как для теоретической, так и для практической медицины. Учитывая, что клетки живого организма излучают широкий спектр ТГЧ-колебаний [Девятков Н.Д., Голант Н.Б., Бецкий О.В., 1991], исследование воздействия на живые объекты ТГЧ-волн, имитирующих молекулярные спектры излучения и поглощения биологически активных веществ, также могло бы расширить современные представления о механизмах клеточной и межклеточной регуляции функций организма [Киричук В.Ф., Андронов Е.В., Антипова О.Н и др. 2009; Киричук В.Ф., Цымбал А.А., Андронов Е.В. 2009; Киричук В.Ф., Андронов Е.В., Антипова О.Н., Ефимова Н.В. и др. 2009; Киричук В.Ф., Кулапина Е.Г. и др. 2009, 2010]. Совершенно закономерно наибольший интерес вызывает электромагнитное излучение на частотах молекулярного спектра оксида азота, который является не только универсальным регулятором физиологических и метаболических процессов в отдельной клетке и в организме в целом, но и осуществляет межклеточные взаимодействия, функционируя как сигнальная молекула практически во всех органах и тканях человека и животных [Марков X.M., 1996; Снайдер C.Х., Бредт Д.С., 1992; Furchgott R.F., 1980, 1991; Moncada S., Palmer R.U., Higgs E.A., 1995; Ignarro L.G. et al.,1987, 1995, 1999;].

Оксид азота является нейромедиатором, вазодилататором, мощным фактором гемостаза и антиагрегантом [Furchgott R.F., 1980, 1991; Ignarro L.G. et al.,1987, 1995, 1999].

Учитывая значение оксида азота в регуляции гемодинамики, изучение влияния излучения на частотах его молекулярного спектра с целью поиска возможности немедикаментозной коррекции ее нарушений представляет несомненный научный и практический интерес. Еще более перспективным представляется исследование возможности предотвращения развития гемодинамических нарушений при помощи данного вида излучения. До недавнего времени считалось, что это электромагнитное излучение миллиметрового диапазона частот не оказывает влияние на интактный организм, однако в работах ряда авторов[Чуян Е.Н., Темурьянц Н.А., Туманянц Е.Н., и др., 2002] показан антистрессорный эффект предварительного облучения на классических частотах КВЧ ( $\lambda=5,6$ и 7,1 мм). Возможность подобного эффекта у волн терагерцевого диапазона в литературе не описана.

Проведенные эксперименты по исследованию влияния электромагнитного излучения миллиметрового диапазона на частотах молекулярного спектра излучения и поглощения оксида азота в условиях in vitro показали, что данный вид излучения оказывает ингибирующее воздействие на функциональную активность тромбоцитов у 
больных нестабильной стенокардией [Киричук В.Ф., Майбородин А.В., Волин М.В. и др., 2000; Киричук В.Ф., Майбородин А.В., Волин М.В. и др., 2001; Киричук В.Ф., Волин М.В., Креницкий А.П. и др., 2002]. Вместе с тем при изучении влияния ЭМИ КВЧ-NO на реологические параметры крови больных стабильной стенокардией в условиях in vitro было обнаружено статистически достоверное повышение вязкости цельной крови [Киричук В.Ф., Малинова Л.И., Креницкий А.П. и др., 2003].

Экспериментальные исследования показали, что на модели нарушений коагуляционных свойств крови при иммобилизационном стрессе под влиянием ТГЧ электромагнитного излучения на частотах молекулярного спектра оксида азота 150,176150,664 ГГц наблюдается восстановление основных показателей коагуляционного звена гемостаза [Киричук В.Ф., Цымбал А.А., Антипова О.Н. и др., 2004; Цымбал А.А., 2007].

Кроме того, доказано, что ТГЧ-облучение на частотах МСИП оксида азота 150,176 - 150,664 ГГц обладает выраженным восстанавливающим влиянием на нарушенные реологические свойства крови у белых крыс в состоянии острого иммобилизационного стресса [Киричук В.Ф., Антипова О.Н. и др., 2004; Антипова О.Н., 2009; Киричук В.Ф., Антипова О.Н., Андронов Е.В., 2009]. Также отмечено, что ТГЧ-облучение на указанных частотах способно восстанавливать нарушения качественного и количественного состава эритроцитов, вызванные иммобилизацией [Киричук В.Ф., Антипова О.Н. и др., 2004; Киричук В.Ф., Помошникова О.И., Антипова О.Н., 2004].

В доступной литературе не обнаружено сведений, характеризующих влияние ТГЧизлучения на частотах МСИП оксида азота (NO) на нарушенную гемодинамику в магистральных сосудах. Кроме того, отсутствуют сведения о его возможности предотвращения нарушений гемодинамики.

Все вышеперечисленное послужило основанием для разработки оптимальных режимов воздействия облучения терагерцевыми электромагнитными волнами на частотах МСИП оксида азота 150,176 - 150,664 ГГц, при которых возможно восстановление нарушенной гемодинамики, в частности линейной скорости кровотока.

Целью нашего исследования является определение влияния облучения электромагнитными волнами терагерцевого диапазона на частотах молекулярного спектра излучения и поглощения оксида азота 150,176 - 150,664 ГГц на стрессорные нарушения показателей гемодинамики у белых крыс, находящихся в состоянии острого иммобилизационного стресса, и разработка оптимальных режимов воздействия терагерцевыми волнами на указанных частотах, при которых наблюдается наибольший нормализующий эффект. 


\section{ГЛАВА I}

БИОЛОГИЧЕСКИЕ И БИОФИЗИЧЕСКИЕ ЭФФЕКТЫ

\section{ЭЛЕКТРОМАГНИТНОГО ИЗЛУЧЕНИЯ КВЧ- И ТГЧ- ДИАПАЗОНОВ И ПРИМЕНЕНИЕ ИХ В МЕДИЦИНСКОЙ ПРАКТИКЕ}

\section{1. Современные представления о физических и биологических механизмах} КВЧ воздействия

В работах многих авторов отмечается, что в процессе своей жизнедеятельности клетка вырабатывает электромагнитные колебания весьма широкого диапазона, но различные биологические эффекты клеток и организма проявляются лишь на низкоинтенсивные, информационные воздействия, то есть при крайне малых мощностях электромагнитных колебаний [Пресман А.С., 1968; Девятков Н.Д., Голант М.Б., Бецкий О.В., 1991; Майбородин А.В., Креницкий А.П., Тупикин В.Д. и др., 2001; Киричук В.Ф., Майбородин А.В., Волин М.В. и др., 2000; Киричук В.Ф., Волин М.В., Креницкий А.П. и др., 2002; Киричук В.Ф., Малинова Л.И., Креницкий А.П. и др., 2003; Киричук В.Ф., Креницкий А.П., Майбородин А.В. и др., 2005; Webb S.J., Booth A.D., 1971; Webb S.J., 1980; Taylor L.S, 1981; Veyret B., Bouthet C., Deschaux P. et al., 1991]. Показано, что энергия квантов КВЧ излучения, во-первых, меньше энергии теплового движения молекул, а, во-вторых, значительно меньше энергии водородных (самых слабых) связей в молекулах живых организмов. Поэтому очевидно, что механизм биологического действия КВЧ излучения не может быть связан с повреждающим воздействием на живой организм [Девятков Н.Д., Голант М.Б., 1985; Девятков Н.Д., Голант М.Б., Бецкий О.В., 1991].

Отсюда следует, что только этот узкий диапазон КВЧ волн используется клетками для обмена информацией в процессах регуляции внутриклеточных функций и межклеточных взаимодействий [Девятков Н.Д., Бецкий О.В., 1985; Девятков Н.Д., Голант М.Б., Бецкий О.В., 1991; Киричук В.Ф., Головачева Т.В., Чиж А.Г., 1999; Киричук В.Ф., Майбородин А.В., Волин М.В. и др., 2000; Киричук В.Ф., Малинова Л.И., Креницкий А.П. и др., 2003; Киричук В.Ф., Креницкий А.П., Майбородин А.В. и др., 2005], а вне этих интервалов частот значительно снижается или отсутствует [Frohlich H., 1980; Kaiser F., 1983; Keilmann F., 1983].

На протяжении трех с половиной десятилетий был накоплен громадный массив экспериментальных и клинических данных [Девятков Н.Д., Бецкий О.В., 1985; Голант 
М.Б., 1986; Девятков Н.Д., Голант М.Б., Бецкий О.В., 1991, 1994, 1997; Бецкий О.В., Лебедева Н.Н., 2001; Петросян В.И., Майбородин А.В., Дубовицкий С.А. и др., 2005; Паршина С.С., Киричук В.Ф., Головачева Т.В. и др., 2005; Dardelhon M., Averbeck D., Berteaud A., 1979], разработаны и изготовлены различные технические устройства для проведения КВЧ терапии и сформулированы общие требования к таким устройствам [Беляков С.В., Бецкий О.В., Яременко Ю.Г., 1998].

Таким образом, в последние десятилетия в результате фундаментальных исследований в России было создано новое перспективное направление медицины - КВЧ терапия (крайне высокочастотная терапия, микрорезонансная терапия, миллиметровая терапия). Отсутствие побочных эффектов, значительное сокращение сроков лечения стимулировали разработку более совершенной физиотерапевтической аппаратуры в крайне высокочастотном диапазоне. КВЧ терапия позволяет на практике использовать новейшие знания биологии, биофизики, техники сверхвысоких частот и новых медицинских информационных технологий [Девятков Н.Д., Голант М.Б., Бецкий О.В., 1991, 1994; Голант М.Б., 1997; Киричук В.Ф., Головачева Т.В., Чиж А.Г. 1999; Бецкий О.В., Девятков Н.Д., Лебедева Н.Н., 2000; Синицын Н.И., Петросян В.И., Елкин В.А. и др., 2000; Betskii O.V., 1994].

Большое количество теоретических [Девятков Н.Д., Бецкий О.В., Голант М.Б., 1991; Бецкий О.В., Девятков Н.Д., 1996; Бессонов А.Е., Калмыкова Е.А., Конягин Б.А., 1999] и экспериментальных [Колбун Н.Д., 1991; Куропатова Е.С., 1994; Воторопин С.Д., Кожемякин А.М., 1998] исследований позволяет сделать вывод о том, что в диапазоне КВЧ существуют информационные каналы воздействия ЭМИ на организм человека, которые для каждого являются строго индивидуальными. Особо следует отметить влияние КВЧ при воздействии на биологически активные зоны (Захарьина-Геда), точки акупунктуры [Катин А.Я., 1995; Голанд М.Б., Гедымин Л.Е., Новикова Л.Н., 1995]. Организм человека способен избирательно различать близкие ему по смыслу ММ волны, реагируя на них быстрым изменением ЭЭГ, ЭКГ и другими, то есть, организм отвечает заранее предопределенной реакцией, которая, при правильном использовании метода, является эффективнейшим средством в плане лечения многих заболеваний. Именно на этом принципе и строится КВЧ терапия [Девятков Н.Д., Голант М.Б., Бецкий О.В., 1991; Киричук В.Ф., Головачева Т.В., Чиж А.Г., 1999].

К КВЧ колебаниям принято относить электромагнитные волны частотой 30-300 ГГц, то есть КВЧ является одним из поддиапазонов СВЧ (сверх высокие частоты) - колебаний (частоты свыше 300 МГц) [Девятков Н.Д., Голант М.Б., Бецкий О.В., 1991; Голант М.Б., 1997]. КВЧ излучение является 
электромагнитным колебанием, обладающим волновыми и квантовыми свойствами [Девятков Н.Д., Голант М.Б., Бецкий О.В., 1991], а также высокой когерентностью [Киричук В.Ф., Головачёва Т.В., Чиж А.Г., 1999; Frohlich Н., 1968, 1979].

Высокая эффективность КВЧ терапии подтверждает, что человеческий организм обладает электромагнитным информационным каркасом, способным реагировать на воздействие электромагнитных колебаний сверхмалых $\left(\sim 10^{-18} \div 10^{-21} \mathrm{BT} / \mathrm{M}^{2}\right.$ Гц $)$ подпороговых мощностей. Глубина проникновения в ткани ЭМИ КВЧ не превышает 0,3 0,5 мм, а используемые мощности излучения - 1,0 - 10,0 мВт [Киричук В.Ф., Головачева Т.В., Чиж А.Г., 1999].

В настоящее время единого мнения о физических механизмах взаимодействия миллиметровых волн с биологическими объектами не существует, так как неизвестно ключевое звено, связывающее метаболизм клетки с ЭМИ. Тем не менее, можно считать, что электромагнитное излучение низкой интенсивности является универсальным механизмом передачи информации как между живыми объектами, так и между клетками в пределах биологического объекта. Данное утверждение основано на двух убедительных фундаментальных положениях: способности живых объектов, во-первых, генерировать собственное КВЧ излучение и, во-вторых, реагировать на внешнее КВЧ воздействие [Девятков Н.Д., Голант М.Б., Бецкий О.В., 1991; Бецкий О.В., 1991, 1997, 2003, 2004; Родштат И.В., 1997; Гапочка Л.Д., Гапочка М.Г., Королев А.Ф. и др., 2000; Синицын Н.И., Петросян В.И., Елкин В.А. и др., 2000; Шуб Г.М., Петросян В.И., Синицын Н.И. и др., 2000].

Сформулированы следующие критерии информационного характера взаимодействия: оно наблюдается или при уровнях мощности облучения 1-10 мВт и ниже, или при повышении температуры облучаемого живого объекта не более чем на $0,1^{\circ} \mathrm{C}$ [Девятков Н.Д., Бецкий О.В., 1985; Девятков Н.Д., Голант М.Б., Бецкий О.В., 1991, 1994]. Отсюда следует, что только этот узкий диапазон КВЧ волн используется клетками для обмена информацией в процессах регуляции внутриклеточных функций и межклеточных взаимодействий [Девятков Н.Д., Бецкий О.В., 1985; Девятков Н.Д., Голант М.Б., Бецкий О.В, 1991; Киричук В.Ф., Головачева Т.В., Чиж А.Г., 1999; Киричук В.Ф., Майбородин А.В., Волин М.В. и др., 2000; Киричук В.Ф., Малинова Л.И., Креницкий А.П. и др., 2003; Киричук В.Ф., Креницкий А.П., Майбородин А.В. и др., 2005] , а вне этих интервалов частот значительно снижается или отсутствует [Frohlich H., 1980; Kaiser F., 1983; Keilmann F., 1983]. 
В настоящее время, несмотря на огромное количество исследований в области электромагнитных колебаний миллиметрового диапазона и данных литературы, описывающих особенности влияния мм волн на различные биологические микро - и макрообъекты, нет единого мнения о механизме воздействия электромагнитного излучения (ЭМИ) КВЧ диапазона. Предложено множество гипотез, объясняющих чувствительность организма к КВЧ воздействию (мембранная, связанная с резонансными спектрами воды, с формированием белковых подструктур и др.) [Родштат И.В., 1991, 2005; Бецкий О.В., 1995, 1997; Киричук В.Ф., Головачева Т.В., Чиж А.Г., 1999]. Однако ни одна из них не имеет универсального характера.

Возможными первичными мишенями КВЧ в организме являются форменные элементы крови и тонкая кожа, высокая чувствительность к миллиметровым волнам которых доказана экспериментально [Девятков Н.Д., Голант М.Б., Бецкий О.В., 1991; Голант М.Б., Гедымин Л.Е., Новикова Л.Н. и др., 1995; Киричук В.Ф., Майбородин А.В., Волин М.В. и др., 2000; Киричук В.Ф., Малинова Л.И., Креницкий А.П. и др., 2003; Киричук В.Ф., Креницкий А.П., Майбородин А.В. и др., 2005; Паршина С.С., Киричук В.Ф., Головачева Т.В. и др., 2005].

Согласно одной из гипотез механизм КВЧ влияния предполагает наличие корреляционной активации собственных электромагнитных полей клеток организма при внешнем облучении [Афромеев В.И., Субботина Т.Н., Яшин А.А., 1997, 1998; Нефедов Е.И., Протопопов А.А., Хадарцев А.А. и др., 1998].

Имеет место биоэнергетическая точка зрения на механизм взаимодействия ЭМИ мм-диапазона с биологическим объектом с отведением особой роли двойного резонанса при наличии модуляции мощности излучения [Гапеев А.Б., 1997]. Конечным терапевтическим эффектом такого воздействия являются восстановительные процессы, ликвидирующие патологию клетки, которые достигаются биофизическими и биохимическими реакциями, протекающими с затратой энергии. Таким образом, здесь имеет место инициирование внешним биоинформационным сигналом соответствующих энергетических процессов [Афромеев В.И., Субботина Т.Н., Яшин А.А., 1997; Нефёдов Е.И., Протопопов А.А., Хадарцев А.А. и др., 1998; Яшин А.А., 2000].

Многочисленными биофизическими экспериментами с использованием экранированных камер подтверждается роль электромагнитного поля окружающей среды как одного из регулирующих факторов в процессе роста и развития многоклеточных организмов или колоний одноклеточных [Якунов А.В., 1997]. Рядом 
авторов получены экспериментальные данные о регистрации собственного излучения клетки в момент своего деления [Del Giudice E., Doglia S., Milani M. et al., 1989].

В настоящее время наиболее признанной и научно обоснованной является радиофизическая теория механизма воздействия ЭМИ КВЧ на живой объект, выдвинутая и разработанная академиком Н.Д. Девятковым и его сотрудниками (1985 - 1994). Информационное действие ММ волн опосредуется через формирование белковых подструктур, которые в дальнейшем регулируют метаболические процессы клетки, то есть излучение воздействует на собственную информационно управляющую систему организма [Голант М.Б., Сотников О.С., 1987; Бецкий О.В., Девятков Н.Д., 1996]. Показано, что в ряде случаев клетки организма, ослабленные в силу тех или иных причин, не могут самостоятельно восстановить свой гомеостаз. Влияние КВЧ излучения в данной ситуации нормализует функционирование повреждённых клеточных структур [Девятков Н.Д., Голант М.Б., Бецкий О.В., 1991; Бецкий О.В., Девятков Н.Д., 1996]. Излучение низкой интенсивности может запускать (инициировать) цепочку последовательных реакций, сопровождающихся трансформацией энергии и приводящих к положительному эффекту, то есть взаимодействие «ЭМИ КВЧ - биосистема» носит опосредованный характер и может оказывать нормализующий эффект в сложно организованных биологических объектах.

В результате проведенных исследований были выявлены взаимосвязи между функциональным состоянием органа в норме или при патологии и особенностями спектра его собственного КВЧ излучения, а также нормализация нарушенного КВЧ спектра под влиянием внешнего воздействия [Девятков Н.Д., Голант М.Б., Бецкий О.В., 1991; Киричук В.Ф., Головачева Т.В., Чиж А.Г., 1999]. Полученные данные свидетельствуют в пользу роли КВЧ излучения как механизма межклеточного обмена информацией [Киричук В.Ф., Майбородин А.В., Волин М.В. и др., 2000; Киричук В.Ф., Волин М.В., Креницкий А.П. и др., 2002; Киричук В.Ф., Малинова Л.И., Креницкий А.П. и др., 2003].

Колебания КВЧ диапазона носят шумовой (беспорядочный) характер при нормальной жизнедеятельности клеток. Клетки обладают электрической симметрией, которая подвержена нарушению в силу многих патологических причин. Как следствие этого по принципу Ле-Шателье происходит генерации когерентных (упорядоченных) электромагнитных колебаний КВЧ диапазона, что способствует нормализации нарушенной функции клеток [Девятков Н.Д., Голант М.Б., 1983; Бецкий О.В., Девятков Н.Д., Кислов В.В., 1998; Бецкий О.В., Лебедева Н.Н., 2001]. Можно сделать вывод о том, что внешнее имитированное КВЧ облучение способствует воспроизведению указанных клеточных 
регулирующих воздействий и таким образом приводит к нормализации нарушенных регуляторных механизмов - гуморальных, гормональных, нервных, иммунных и т.д. Соответственно этому происходит восстановление нарушенных функций отдельных тканей, органов, функциональных систем, адаптационно-компенсаторной функции организма [Девятков Н.Д., Арзуманов Ю.Л., Бецкий О.В., Лебедева Н.Н., 1995; Голант М.Б., 1997; Киричук В.Ф., Головачева Т.В., Чиж А.Г., 1999; Бецкий О.В., Лебедева Н.Н., 2001].

Следует отметить, что организм человека состоит приблизительно из $10^{15}$ клеток, а каждая клетка является достаточно автономным образованием. Следовательно, для обеспечения нормальной работы такой сложной системы необходим определенный механизм синхронизации их функций. В работах Н.Д. Девяткова, М.Б. Голанта, О.В. Бецкого (1991, 1997), В.Ф. Киричука, Л.И. Малиновой, А.П. Креницкого и др. (2003) появились научно обоснованные доказательства того, что КВЧ излучение ММ диапазона используется биологическими объектами в целях управления межклеточными взаимосвязями. Поэтому был сделан вывод о том, что биологический объект обладает собственным набором внутренних частот волновых процессов и, соответственно, может участвовать в явлении биорезонанса на этих частотах с излучениями при внешних воздействиях электромагнитных колебаний. Цель этого взаимодействия - направленная коррекция параметров гомеостаза организма независимо от отклонений, обусловленных патологией или повреждением. Следовательно, КВЧ облучение помогает нормализации функционирования поврежденных структур [Девятков Н.Д., Голант М.Б., Бецкий О.В., 1991; Бецкий О.В., Девятков Н.Д., 1996].

Авторы утверждают, что КВЧ излучение воздействует непосредственно на собственную информационно-управляющую систему организма. Данный эффект опосредуется через формирование белковых подструктур, которые в дальнейшем способствуют регуляции метаболических процессов в клетке.

Академик Н.Д. Девятков и др. $(1991,1996)$ убедительно доказывают, что эффекты воздействия ММ волн опосредуется через возбуждение акустоэлектрических волн в мембранах только тех клеток, у которых есть изначальные признаки патологии. В дальнейшем происходит генерация клетками сигналов управления восстановительными процессами.

Необходимо отметить, что в вышеперечисленных работах отражены преимущественно вопросы информационного взаимодействия в системе «КВЧ-генератор - биологический объект». Однако рядом исследователей рассматриваются механизмы передачи информации от одного живого объекта к другому [Гурвич А.Г., 1990; Киричук 
В.Ф., Майбородин А.В., Волин М.В. и др., 2000; Киричук В.Ф., Волин М.В., Креницкий А.П. и др., 2002; Киричук В.Ф., Малинова Л.И., Креницкий А.П. и др., 2003].

Известно, что ещё в конце 70-х годов Frohlich Н. теоретически доказал, что когерентные (синфазные) колебания отдельных участков плазматических мембран клеток совершаются именно в диапазоне крайне высоких частот $\left(10^{10}-10^{11} \Gamma ц\right)$. Они возникают и поддерживаются здесь, используя энергию процессов метаболизма. Возможно, это и есть акусто-электрические волны, которые являются отличительным свойством всех живых клеток. Генерация таких колебаний в живых клетках происходит именно в КВЧ диапазоне. При возникновении различных заболеваний происходит деструкция и гибель клеток, поэтому данные колебания сначала начинают затухать, а в дальнейшем могут исчезнуть полностью. Воздействие электромагнитных волн, находящихся в КВЧ диапазоне, на клетки кожи приводит к синхронизации угасающих колебаний в мембранах клеток. При дальнейшем поддержании этих колебаний на их нормальном физиологическом уровне возможно достижение положительного лечебного эффекта [Бецкий О.В., Девятков Н.Д., 1996].

Основной точкой приложения ЭМИ ММД, по информационной теории М.Б. Голанта $(1985,1989,1991)$, является мембранная информационная система. Доказано, что КВЧ излучение оказывает выраженное влияние на мембраны клеток, способствует перемешиванию ее липидных слоев и белковых компонентов [Голант М.Б., 1989]. Эти процессы перестраивают функциональную активность клетки, подвергнутой ЭМИ ММ диапазона [Девятков Н.Д., Голант М.Б., Бецкий О.В., 1991].

C точки зрения W.R. Adey (1996), КВЧ облучение является фактором возбуждения молекулярных рецепторов мембран клеток, при распространении которого по межклеточным пространствам происходит воздействие на отрицательно заряженные гликопротеиновые нити гликокаликса мембран клеток. В ряде работ отмечено, что КВЧоблучение оказывает влияние на активность $\mathrm{Na}^{+}, \mathrm{K}^{+}-$и $\mathrm{Ca}^{++}$-АТФазы, увеличивая её и регулируя тем самым проницаемость мембран для указанных ионов [Рубин В.И., Садчиков Д.В., Мельникова Г.Я и др., 1990; Рубин В.И., Мельникова Г.Я., 1991; Melnik R.L., Rubenstein Ch.P., Birenbaum L., 1982]. Миллиметровое излучение приводит к ускорению активного трансмембранного транспорта $\mathrm{Na}^{+}$, изменению проницаемости мембран эритроцитов для $\mathrm{K}^{+}$, увеличению ионной проводимости бислойных липидных мембран в условиях in vitro [Бецкий О.В., Девятков Н.Д., 1996]. Доказано, что существуют резонирующие «окна» по отношению к действию переменных электромагнитных полей на проницаемость мембран нервных клеток к ионам кальция 
[Adey W.R., 1996].

Рядом исследователей установлено, что первичной мишенью для ЭМИ является не собственно клетка организма, а водная среда верхней части кожного покрова (водный матрикс организма) [Синицин Н.И., Петросян В.И., Ёлкин В.А., 2000; Петросян В.И., Синицин Н.И., Ёлкин В.А., 2000]. Из данного утверждения можно сделать вывод, что энергия КВЧ волн поглощается молекулами свободной воды, водных растворов, белков и липидов. [Петросян В.И., Девятков Н.Д., Гуляев Ю.В. и др., 1997; Петросян В.И., Синицин Н.И., Ёлкин В.А., 2000; Родштат И.В., 2005; Matzkin S., Benes L., Block N. et al., 1983; Gandhi 0., 1984; Grundler W., Keilmann F., Frohlich H., 1977; Tuengler P., Keilmann F., Gensel L., 1979; Khurgin Yu. I., Kudryashova V.A., Zavizion V.A., 1994]. Данный процесс приводит к повышению химической активности молекул структурированной воды живого организма. В последующем возбуждение передается до уровня белков клеточной мембраны, как информационный сигнал, по принципу триггерного эффекта [Бецкий О.В., Девятков Н.Д., 1996].

В.И. Петросян, Н.Д. Девятков, Ю.В. Гуляев и др. (1997), В.И. Петросян, Н.И. Синицын, В.А. Елкин и др. (2000), указывают на существование феномена резонансной прозрачности водных и биологических сред в миллиметровом диапазоне. Он обусловлен особенностями строения молекулы воды. Данный феномен является наиболее вероятным механизмом распространения локального КВЧ воздействия по организму. Согласно данным V.I. Gaiduk (1994), КВЧ излучение усиливает термодинамическую и кинетическую активность молекул воды.

По мнению И.В. Родштата (1985, 1991, 1997, 2005), энергия электромагнитных миллиметровых волн при воздействии на молекулы воды, связанные с белковыми структурами коллагена, приводит к изменению гидратной оболочки белковых молекул. Этот процесс влечет за собой значительное изменение функциональной активности белка [Ленинджер А., 1985]. Известно, что электромагнитные волны быстро затухают в тонком слое кожи, и глубина проникновения КВЧ-волн в организм человека равняется примерно 0,3-0,5 мм [Родштат И.В., 1991, 1997, 2005; Бецкий О.В., 1995, 1997; Khizhnyak Y.P., Betskii O.V., Voronkov V.N., Yaremenko Yu. D., 1994]. Из вышесказанного можно сделать вывод, что первичная рецепция КВЧ колебаний происходит преимущественно в коже. Многие исследователи свидетельствуют об изменении температуры поверхности кожи при воздействии на нее электромагнитных волн миллиметрового диапазона [Бецкий О.В., Девятков Н.Д., Кислов В.В., 1998; Nelson D.A., Nelson M.T., Walters T.J., Mason P.А., 2000; Walters T.J., Blick D.W., Johnson L.R. et al., 2000]. 
Доказано, что первичными акцепторами КВЧ энергии выступают также кровеносные сосуды и клетки крови [Девятков Н.Д., Голант М.Б., Бецкий О.В., 1991; Голант М.Б., Гедымин Л.Е., Новикова Л.Н. и др., 1995], благодаря циркуляции которых влияние КВЧ облучения распространяется даже на те области организма, которые удалены от места непосредственно подвергнутого облучению. Однако установлено, что выраженность воздействия КВЧ колебаний в данном случае снижается по мере удаления от облученного участка кожи [Голант М.Б., Гедымин Л.Е., Новикова Л.Н. и др., 1995].

\section{2. Биофизические основы применения волн терагерцевого диапазона частот}

В настоящее время внимание многих исследователей обращено на терагерцевый диапазона частот, поскольку именно в этом диапазоне сосредоточены частотные спектры поглощения и излучения важнейших клеточных метаболитов ( $\mathrm{NO}, \mathrm{O}_{2}, \mathrm{CO}_{2}, \mathrm{CO}, \mathrm{OH}-$ и др.) [Башаринов А.Е., Тучков Л.Г., Поляков В.М., 1967; Киричук В.Ф., Майбородин А.В., Волин М.В. и др., 2000; Майбородин А.В., Креницкий А.П., Тупикин В.Д. и др., 2001; Киричук В.Ф., Андронов Е.В., Майбородин А.В. и др., 2004; Андронов Е.В., 2008].

Фундаментальной основой функционирования сложных биологических систем являются молекулы-метаболиты, стабильные и строго воспроизводимые молекулярные структуры биосреды. Поэтому детерминированное управление их реакционной способностью излучением, совпадающим по спектрам их излучения и поглощения, может направленно регулировать процесс метаболизма в биосреде. Анализ биомедицинских эффектов ЭМИ на частотах молекулярных спектров атмосферных газов-метаболитов показывает прямую связь спектров заданного метаболита и его свойств в биосреде. Это соответствует представлениям о веществе и поле как о единой системе [Бецкий О.В., Кислов В.В., Лебедева Н.Н., 2004; Бецкий О.В., Майбородин А.В., Будник М.И. и др., 2006].

Развитие терагерцевой терапии и, в частности, методы и устройства спектральномолекулярной терагерцевой терапии, основанной на повышенной реакционной и диффузионной способности экзогенных и эндогенных молекул-метаболитов газов атмосферного воздуха и аэрозолей $\mathrm{O}_{2}, \mathrm{CO}_{2}, \mathrm{NO}, \mathrm{H}_{2} \mathrm{O}$ и др., путём воздействия на них электромагнитного излучения терагерцевого и ИК-диапазонов частот переходит из стадии исследования на этап создания промышленных образцов физиотерапевтической аппаратуры, методов и средств измерения её параметров и их сертификацию [Бецкий О.В., Кислов В.В., Лебедева Н.Н., 2004; Бецкий О.В., Майбородин А.В., Будник М.И. и др., 2006; Бецкий О.В., Креницкий А.П., Майбородин А.В. и др., 2006; Креницкий А.П., Майбородин А.В., Киричук В.Ф. и др., 2007]. 
Для высокочастотной части терагерцевого диапазона и ИК-диапазона в настоящее время применяют программу расчета спектров молекул газов-метаболитов и аэрозолей с использованием международной базы данных молекулярных спектров высокого разрешения HITRAN [Бецкий О.В., Креницкий А.П., Майбородин А.В. и др., 2007; Rothman L.S., Barbe A., Chris Benner D. et al, 2003; Rothman L.S., Jacquemart D., Barbe A. et al, 2005], созданный с участием космического агентства (NASA). В этих работах представлены молекулярные HITRAN-спектры газов-метаболитов молекул $\mathrm{O}_{2}, \mathrm{CO}_{2}$, $\mathrm{NO}$ и паров воды, принимающих участие в процессе дыхания (экзогенные молекулыметаболиты), так и в эндогенных биохимических реакциях. Таким образом, перспективным направлением терагерцевой биомедицинской технологии является использование HITRAN-спектров для точного выбора частот активации молекулметаболитов [Бецкий O.В., Креницкий А.П., Майбородин А.В. и др., 2007; Goldman, R.R. Gamache, A. Perrin, et al., 2000; Rothman L.S., Barbe A., Chris Benner D. et. al, 2003 ].

Электромагнитное излучение терагерцевого диапазона частот (ЭМИ ТГЧ) - это распространяющееся в пространстве, в средах и тканях электромагнитное поле сверхвысокой частоты. Терагерцевый диапазон частот (ТГЧ) лежит на границе между электроникой и фотоникой от 100 ГГц до 10 ТГц $\left(1\right.$ ТГц $=10^{3}$ ГГц $)$ или в длинах волн от 3 мм до $30 \mu$. С одной стороны, он определен частотно-временным ограничением (более 100 ГГц) электронных переходов в полупроводниковых структурах, a с другой максимальной длиной волны квантовых переходов лазерных структур. Этот диапазон волн находится на шкале электромагнитных волн между КВЧ-диапазоном и оптическим инфракрасным диапазоном и частично перекрывает высокочастотную частот КВЧдиапазона (100-300 ГГц) и низкочастотную часть инфракрасного диапазона [Гершензон Е.М., Малов Н.Н., Мансуров А.Н., 2002].

Максимальная энергия кванта $\mathrm{h} v$ в классическом КВЧ - диапазоне составляет $1,17 \cdot 10^{-3}$ эВ, а в терагерцевом на два порядка выше, то есть $\sim 10^{-1}$ эВ. Ниже энергии кванта в КВЧ - диапазоне оказываются энергия вращения молекул вокруг связей $\left(10^{-4}-10^{-3}\right.$ эВ), энергия куперовских пар при сверхпроводимости $\left(10^{-6}-10^{-4}\right.$ эВ) и энергия магнитного упорядочения $\left(10^{-6}-10^{-4}\right.$ эВ) [Гершензон Е.М., Малов Н.Н., Мансуров А.Н., 2002]. В терагерцевом диапазоне частот энергия кванта больше указанных фундаментальных энергетических состояний вещества, включая дополнительный (по сравнению с классическими КВЧ), более высокий уровень молекулярного состояния вещества энергию колебательных уровней молекул $\left(10^{-2}-10^{-1}\right.$ эВ), который уже близок к энергии ионизации. Энергия взаимодействия при равенстве сил притяжения и отталкивания молекул имеет значение порядка $10^{-1}-10^{-2}$ эВ [Конако Ф., Фэйтс Д., 2002; Rothman L.S., 
Barbe A., Chris Benner D. et al, 2003]. Таким образом, можно полагать, что реакционная способность молекул будет на два порядка выше, чем при возбуждении КВЧ - квантом.

ЭМИ ТГЧ как физический фактор, действующий на биологические объекты, характеризуется рядом биотропных параметров: частотой и соответствующей ей длиной волны, интенсивностью, плотностью потока мощности, направленностью, градиентом поля, наличием или отсутствием модуляции, видом модуляций, поляризацией [Бецкий О.В., Лебедева Н.Н., 2001].

Биологические эффекты ТГЧ излучения регистрируются при плотности потока мощности излучения значительно ниже $10 \mathrm{mBT} / \mathrm{cm}^{2}$. При такой низкой интенсивности излучения интегральный нагрев облучаемых объектов в эксперименте не превышает $0,1^{\circ} \mathrm{C}$. Поэтому ЭМИ ТГЧ относится к «информационным», нетепловым воздействиям [Бецкий О.В., Лебедева Н.Н., 2001].

В настоящее время, благодаря интенсивной научно-исследовательской работе в области биологии, радиофизики, электроники и медицине создается новое перспективное направление в СВЧ-физиотерапии, диагностике и экологии, которое можно назвать «терагерцевая терапия», «терагерцевая диагностика» и «терагерцевая экология» [Бецкий О.В., Креницкий А.П., Майбородин А.В. и др., 2003].

1.2.1. Влияние электромагнитного облучения терагерцевого диапазона на экспериментально вызванные нарушения внутрисосудистого компонента микроциркулящии

Представление о форменных элементах крови как первичной мишени ТГЧизлучения в организме обусловливает особый интерес исследователей к изучению механизмов реакции эритроцитов и тромбоцитов человека на ЭМИ терагерцового диапазона [Киричук В.Ф., Волин М.Ф., Креницкий А.П., 2002; Помошникова О.И., 2006; Иванов А.Н., 2006].

Эритроциты, обусловливающие вязкостные свойства крови, обладают выраженной чувствительностью к воздействию ТГЧ- облучения в условиях in vitro. В работе Н.В. Мамонтовой [Мамонтова Н.В., 2006] был установлен факт нормализации нарушенных вязкостных свойств цельной крови, агрегационной способности и деформируемости эритроцитов больных нестабильной стенокардией, находящихся в естественном электромагнитном поле, под влиянием ЭМИ ТГЧ на частоте 240 ГГц, наиболее выраженной при 15- минутном режиме облучения. Также показано статистически достоверное восстановление нарушенных вязкостных свойств цельной крови, агрегации и деформируемости эритроцитов больных нестабильной стенокардией, находящихся в 
скрещенных магнитном и электрическом полях, под влиянием ЭМИ ТГЧ-диапазона на частоте оксида азота 240 ГГц, наиболее эффективное при 15-минутном режиме облучения [Киричук В.Ф., Андронов Е.В., Мамонтова Н.В., и др., 2005].

Авторами также отмечено, что продолжительность нормализующего воздействия ЭМИ ТГЧ- диапазона на частоте оксида азота 240 ГГц на вязкостные свойства цельной крови, способность эритроцитов к агрегации и их деформируемость у больных нестабильной стенокардией в условиях in vitro составляет 30 минут [Киричук В.Ф., Андронов Е.В., Мамонтова Н.В., и др., 2005].

Н.В. Мамонтовой [Мамонтова Н.В., 2006] показано, что облученный ЭМИ ТГЧ на частоте оксида азота 240 ГГц донатор оксида азота - изокет оказывает более выраженный эффект в восстановлении измененных вязкостных свойств цельной крови, агрегационной способности и деформируемости эритроцитов больных нестабильной стенокардией, чем не облученный, что может быть использовано для восстановления нарушенных функциональных свойств эритроцитов и реологических показателей крови больных ИБС в клинической практике.

Результаты исследования О.Н. Антиповой и соавторов [Киричук В.Ф., Антипова О.Н. и др., 2004; Киричук В.Ф., Антипова О.Н., Тупикин В.Д. и др., 2006; Киричук В.Ф., Антипова О.Н., Андронов Е.В. и др., 2009] свидетельствуют о том, что воздействие ТГЧизлучения на частотах МСИП оксида азота 150,176-150,664 ГГц в течение 15 и 30 минут на животных, находящихся в состоянии острого иммобилизационного стресса, вызывает полное восстановление вязкости цельной крови при различных скоростях сдвига, способности эритроцитов к агрегации и их деформируемости. Анализ результатов исследования реологических свойств крови у животных, находящихся в состоянии длительного стресса, показал восстановление вязкостных свойств крови при малых и больших скоростях сдвига, частичное восстановление способности эритроцитов к агрегации и снижение их деформируемости.

О.И. Помошниковой [Помошникова О.И., 2006] установлено, что ТГЧ- облучение на частотах оксида азота 150,176-150,664 ГГц частично или полностью нормализует постстрессовые нарушения во внутрисосудистом компоненте микроциркуляции за счет восстановления количественного и качественного состава эритроцитов в зависимости от режима и времени облучения. 15-минутный режим облучения является, по данным автора, наиболее эффективным в восстановлении нарушенного качественного и количественного состава эритроцитов.

Ежедневное предварительное ТГЧ-облучение в течение 30 минут животных, находящихся в состоянии хронического стресса, восстанавливает среднюю концентрацию 
гемоглобина в эритроците, а также средний диаметр и агрегационную способность эритроцитов [Киричук В.Ф., Помошникова О.И., Антипова О.Н. и др., 2004].

Авторами проведен сравнительный анализ влияния непрерывного и дробного режимов ТГЧ-облучения на частотах молекулярного спектра излучения и поглощения оксида азота 150,176-150,664 ГГц на нарушенный качественный и количественный состав эритроцитов крови белых крыс обоего пола, находящихся в состоянии острого иммобилизационного стресса, который показал, что дробные режимы в течение 5 и 30 минут более эффективны, нежели непрерывные в тех же временных диапазонах [Киричук В.Ф., Помошникова О.И., Антипова О.Н. и др., 2004].

Влияние предварительного и последующего ТГЧ-облучения на частотах молекулярного спектра излучения и поглощения оксида азота 150,176-150,664 ГГц на качественный и количественный состав эритроцитов крови иммобилизированных белых крыс неоднозначно. Так, предварительное ТГЧ-воздействие более эффективно предупреждает постстрессовые нарушения в во внутрисосудистом компоненте микроциркуляции у стрессированных животных по сравнению с облучением на фоне развившегося острого иммобилизационного стресса [Помошникова О.И., 2006].

В условиях эксперимента in vitro А.П. Креницкий, А.В. Майбородин, В.Д. Тупикин и соавт. [Креницкий А.П., Майбородин А.В., Тупикин В.Д. и др., 2004] показали также нормализацию функциональной активности тромбоцитов больных нестабильной стенокардией при воздействии ЭМИ ТГЧ на частоте оксида азота 240 ГГц. Так, при облучении обогащенной тромбоцитами плазмы больных нестабильной стенокардией в условиях in vitro на частоте оксида азота 240 ГГц в течение 15 минут наблюдалось значительное снижение агрегационной активности кровяных пластинок, что сопровождалось статистически достоверным уменьшением максимального размера образующихся тромбоцитарных агрегатов, максимальной скорости образования наибольших тромбоцитарных агрегатов, максимальной степени агрегации. Аналогичные сдвиги произошли в агрегационной активности тромбоцитов больных нестабильной стенокардией при облучении обогащенной тромбоцитами плазмы в течение 30 минут. Однако, эти изменения, как правило, были выражены в меньшей степени, чем при 15 минутном облучении.

При облучении ЭМИ ТГЧ на частоте молекулярного спектра излучения и поглощения оксида азота 400 ГГц обогащенной тромбоцитами плазмы больных нестабильной стенокардией в условиях эксперимента in vitro Е.В. Андронов и В.Ф. Киричук [Андронов Е.В., Киричук В.Ф., 2006] показали также значительное снижение агрегационной способности кровяных пластинок, что сопровождалось статистически 
достоверным уменьшением максимального размера образующихся тромбоцитарных агрегатов, максимальной скорости образования наибольших тромбоцитарных агрегатов, максимальной степени и скорости агрегации.

Установлено, что в условиях эксперимента in vivo воздействие ТГЧ-излучения на частотах оксида азота 150,176-150,664 ГГц в течение 5 и 15 минут на животных, находящихся в состоянии острого иммобилизационного стресса, вызывает частичное восстановление функциональной активности тромбоцитов, что проявляется в уменьшении максимального размера тромбоцитарных агрегатов, максимальной скорости образования наибольших тромбоцитарных агрегатов, максимальной степени агрегации и максимальной скорости агрегации. При 30 минутном облучении животных ЭМИ ТГЧ на частотах оксида азота 150,176-150,664 ГГц, находящихся в состоянии острого иммобилизационного стресса, наблюдается полное восстановление функций тромбоцитов.

По данным авторов, при сравнении предшествующего и последующего воздействия на животных, находящихся в состоянии иммобилизационного стресса, ТГЧволнами на частотах оксида азота 150,176-150,664 ГГц наблюдается различная степень восстановления функций тромбоцитов. Предварительное ТГЧ-воздействие в непрерывном режиме более эффективно предупреждает постстрессовые нарушения в функциональной активности тромбоцитов у стрессированных крыс-самцов по сравнению с облученными животными на фоне развившегося острого иммобилизационного стресса [Киричук В.Ф., Антипова О.Н. и др., 2008].

С.В. Суховой и соавт. [Сухова С.В., Кораблева Т.С., Бондарев А.В., 2007] изучено влияние ЭМИ на частоте атмосферного кислорода 129,0 ГГц на функциональную активность тромбоцитов белых крыс в состоянии иммобилизационного стресса. Показано, что под воздействием ТГЧ - облучения 129,0 ГГц в течение 5 минут происходит нормализация нарушенной функциональной активности тромбоцитов белых крыс-самцов на фоне иммобилизационного стресса.

Авторы считают, что посредниками действия ЭМИ ТГЧ в клетках и биологических жидкостях являются активные формы кислорода (АФК), которые предположительно образуются ферментативно за счет изменения гидратации белковых молекул и повышения активности циклооксигеназы, ксантиноксидазы [Поцелуева М.M., Пустовидко А.В., Евтодиенко Ю.В., 1998]. АФК, в свою очередь, за счет $\mathrm{Ca}^{2+}$ стимулируют растворимую гуанилатциклазу, что приводит к накоплению цГМФ в клетках эндотелия сосудов и повышению активности NO-синтазы, что увеличивает продукцию NO [Cooke J., 1998]. Это может быть одним из механизмов осуществления как антистрессорного, так и 
антиагрегационного эффектов ТГЧ - волн на частоте МСИП атмосферного кислорода 129,0 ГГц [Сухова С.В., Кораблева Т.С., Бондарев А.В., 2007].

Особого внимания заслуживают результаты исследований, свидетельствующих о влиянии ЭМИ ТГЧ на различные физиологические системы человека и животных. Не вызывает сомнения тот факт, что в реализации биологических эффектов ЭМИ ТГЧ принимают участие центральная и периферическая нервные системы, а также защитнорегуляторные системы организма, к которым можно отнести, прежде всего систему гемостаза, иммунную и нейроэндокринную системы.

В.Ф. Киричук, О.Н. Антипова и соавт. [Киричук В.Ф., Антипова О.Н. и др., 2004] отметили, что животные, подвергнутые пятидневному иммобилизационному стрессу, начиная со 2-3-х суток эксперимента, становились тревожными, агрессивными, остро и неадекватно реагировали на слабые раздражители. Отмечалось резкое увеличение двигательной активности. Некоторые животные теряли в весе и выглядели вялыми и апатичными. Исходя из собственных и литературных данных, авторы предполагают, что тяжелый стресс, вызванный хронической гипокинезией, вызывает активацию симпатикоадреналовой системы, что является важнейшей причиной патологических изменений высшей нервной деятельности, в частности, изменений в поведении животных (высокие уровни возбудимости и тревожности), зарегистрированные авторами. Однако при применяемом авторами ежедневном 30 минутном облучении животных, находящихся в состоянии хронического иммобилизационного стресса, ЭМИ ТГЧ на частотах оксида азота 150,176-150,664 ГГц наблюдалась визуальная нормализация их поведенческих реакций - отсутствовала выраженная тревожность, не проявлялась агрессивность, отмечалась адекватная реакция на посторонние раздражители [Киричук В.Ф., Антипова О.Н. и др., 2004].

Согласно предположениям В.Ф. Киричука, О.Н. Антиповой и соавторов ЭМИ ТГЧ ограничивает развитие стресс-реакции за счет возрастания функциональной активности антиноцицептивной системы и ограничения чрезмерной активации стресс-реализующих механизмов, что служит доказательством стресспротективной функции ЭМИ этого диапазона [Киричук В.Ф., Антипова О.Н. и др., 2004].

Делая вывод, авторы отмечают, что ТГЧ- облучение на частотах 150,176-150,664 ГГц проявляет выраженное антистрессорное действие, a 30 минутное облучение животных является эффективным в восстановлении микроциркуляции и характеризуется оптимальной степенью нормализации функции тромбоцитов, эритроцитов и гемореологических показателей у животных, находящихся в состоянии длительного стресса [Киричук В.Ф., Антипова О.Н. и др., 2004]. 


\subsection{2. Клинические исследования влияния электромагнитного облучения}

терагерцевого диапазона на течение различных патологических процессов

Впервые в клинической практике [Паршина С.С., Киричук В.Ф., Головачева Т.В. и др., 2004; Паршина С.С., 2006] использовано ЭМИ ТГЧ на частотах оксида азота 150,176150,664 ГГц у здоровых добровольцах и пациентов с сердечно-сосудистой патологией. Так, в группе здоровых добровольцев во время сеанса отмечались некоторые субъективные ощущения: разнообразный дискомфорт в области шеи, чувство недостатка воздуха и жара в голове. Ни в одном случае появление вышеописанных симптомов не послужило причиной прекращения сеанса. В связи с этим авторы предполагают, что влияние ЭМИ ТГЧ на частотах оксида азота 150,176-150,664 ГГц на здоровый организм способно вызвать целый каскад физиологических и биохимических реакций, выраженность которых будет зависеть от исходного состояния пациента, особенностей его нервной системы.

При проведении сеансов ЭМИ ТГЧ на частотах оксида азота 150,176-150,664 ГГц у пациентов с патологией сердечно-сосудистой системы в анамнезе отмечено появление субъективных ощущений и колебаний показателей гемодинамики, аналогичных изменениям данных параметров при облучении у здоровых лиц. Вместе с тем, применение ЭМИ ТГЧ на частотах оксида азота 150,176-150,664 ГГц у пациентов с сердечнососудистой патологией в стадии ремиссии показало отсутствие серьезных осложнений и позволило авторам исследования перейти к следующему этапу - использованию ЭМИ ТГЧ на частотах оксида азота 150,176-150,664 ГГц у пациентов, находящихся на стационарном лечении по поводу ИБС: нестабильной стенокардии и гипертонической болезни. У всех больных в результате лечения отмечен выраженный антиангинальный эффект, отмечалось снижение артериального давления - как систолического, так и диастолического показателей на 15-20 мм рт. ст. Отмечено положительное действие ЭМИ ТГЧ на частотах оксида азота 150,176-150,664 ГГц на состояние системы гемокоагуляции: отмечалось удлинение времени свертывания крови и АЧТВ, снижение уровня фибриногена [Паршина С.С., Киричук В.Ф., Головачева Т.В. и др., 2004; Паршина С.С., 2006].

Авторы, делая выводы, отмечают, что ЭМИ ТГЧ на указанных частотах оксида азота обладает мощным вазоактивным, антиангинальным и гипокоагуляционном эффектами и является теоретически и экспериментально обоснованным методом лечения больных с сердечно - сосудистой патологией [Паршина С.С., Киричук В.Ф., Головачева Т.В. и др., 2004; Паршина С.С., 2006].

Установлено, что на фоне общепринятой терапии при применении ЭМИ ТГЧ облучения на частотах оксида азота 150,176-150,664 ГГц отмечается благоприятное 
течение ожогового раневого процесса. Так, по данным Н.В. Островского, С.М. Никитюка, В.Ф. Киричука и соавт. [Островский Н.В., Никитюк С.М., Киричук В.Ф. и др., 2004] при лечении поверхностных ожогов после первого сеанса ТГЧ - терапии микробная обсемененность ожогового отделяемого снизилась в сотни раз. После 2-3 сеанса у всех больных появились островки активной эпителизации раны, практически у всех больных снижалась выраженность болевого синдрома, улучшалось общее самочувствие, нормализовался режим сна. После 5-7 сеанса наступала полная эпителизация ожоговой раны.

По мнению авторов, механизм комбинированной терагерцевой терапии на раневой процесс заключается в вазодилатации и нормализации микроциркуляторных расстройств, улучшении сосудистой трофики и тканевого обмена, усилении фагоцитоза, ингибиции свободных кислородных радикалов, прямым воздействием на пролиферацию фибробластов [Островский Н.В., Никитюк С.М., Киричук В.Ф. и др., 2004].

Таким образом, представленные результаты исследований свидетельствуют о значительном влиянии волн терагерцевого диапазона частот на функциональные показатели микроциркуляции как в условиях эксперимента, так и при клинических испытаниях. Однако в доступной литературе отсутствуют данные об изменениях системной гемодинамики и, в частности, линейной скорости кровотока под влиянием электромагнитного излучения терагерцевого диапазона на частотах молекулярного спектра излучения и поглощения оксида азота 150,176-150,664 ГГц, что и являлось целью настоящего исследования. 


\section{ГЛАВА ІІ}

\section{ВЛИЯНИЕ НЕПРЕРЫВНОГО ЭЛЕКТРОМАГНИТНОГО ОБЛУЧЕНИЯ ТЕРАГЕРЦЕВОГО ДИАПАЗОНА НА ЧАСТОТАХ МОЛЕКУЛЯРНОГО СПЕКТРА ИЗЛУЧЕНИЯ И ПОГЛОЩЕНИЯ ОКСИДА АЗОТА 150,176 - 150,664 ГГЦ НА СИСТЕМНУЮ ГЕМОДИНАМИКУ У БЕЛЫХ КРЫС-САМЦОВ В УСЛОВИЯХ ОСТРОГО ИММОБИЛИЗАЦИОННОГО СТРЕССА}

2.1. Изменение линейной скорости кровотока в магистральных сосудах у интактных крыс-самцов под влиянием электромагнитного излучения терагерцевого диапазона на частотах МСИП оксида азота 150,176 - 150,664 ГГц

С целью изучения безопасности облучения терагерцевыми волнами на частотах МСИП оксида азота 150,176 - 150,664 ГГц провели серию экспериментов на интактных животных, подвергнутых непрерывному воздействию в течение 15 минут.

Установлено, что воздействие терагерцевых волн на частотах МСИП NO 150,176 150,664 ГГц не вызывает изменения линейной скорости кровотока в таких магистральных сосудах, как брюшная аорта, бедренная и сонная артерии у интактных белых крыс-самцов, о чем свидетельствует отсутствие статистически достоверных отличий в показателях гемодинамики животных группы контроля и облученных животных.

Данное наблюдение показывает отсутствие влияния указанного режима ТГЧоблучения на частотах МСИП NO 150,176 - 150,664 ГГц на системную гемодинамику интактных крыс-самцов, что согласуется с данными других авторов об отсутствии влияния на организм здорового человека и животных волн миллиметрового и субмиллиметрового диапазонов частот [Бецкий О.В., Лебедева Н.Н., 1991; Киричук В.Ф. и др., 2001; Помошникова О.И., 2006].

2.2. Изменение линейной скорости кровотока в магистральных сосудах у белых крыс-самцов при остром иммобилизационном стрессе

Для установления степени воздействия острого иммобилизационного стресса на показатели гемодинамики среднюю линейную, среднюю линейную систолическую, среднюю линейную диастолическую скорости кровотока и градиент давления в магистральных сосудах - брюшной аорте, бедренной и сонной артериях проводили исследование на двух группах животных: интактных (группа контроля) и находящихся в состоянии острого иммобилизационного стресса (группа сравнения).

В результате проведенных исследований обнаружено значительное изменение всех исследуемых показателей гемодинамики в брюшной аорте и бедренной артерии у крыссамцов, находящихся в состоянии острого иммобилизационного стресса. При анализе 
допплерограмм обеих групп животных обнаружено статистически достоверное увеличение средней линейной скорости кровотока, средней линейной систолической скорости кровотока, средней линейной диастолической скорости кровотока и градиента давления у белых крыс-самцов, находящихся в состоянии острого иммобилизационного стресса.

Установлено, что в сонной артерии статистически достоверных изменений в показателях системного кровотока между группой контроля (интактные животные) и животными, находящимися в состоянии острого иммобилизационного стресса, не обнаружено, что, по-видимому, указывает на стабильный уровень кровоснабжения головного мозга в условиях острого стресса.

Таким образом, при остром иммобилизационном стрессе происходит нарушение гемодинамики в брюшной аорте и бедренной артерии, что выражается в увеличении таких показателей, как средняя линейная, средняя линейная систолическая, средняя линейная диастолическая скорости кровотока и градиент давления, при этом не отмечается изменений указанных показателей гемодинамики в сонной артерии.

2.3. Влияние непрерывного ТГЧ-облучения на частотах МСИП оксида азота 150,176 - 150,664 ГГц на нарушенную линейную скорость кровотока в магистральных сосудах у белых крыс-самцов, находящихся в состоянии острого иммобилизационного стресса

Для выявления эффекта облучения терагерцевыми волнами на частотах молекулярного спектра излучения и поглощения оксида азота 150,176 - 150,664 ГГц на системную гемодинамику, а также для выявления его зависимости от времени экспозиции электромагнитных волн и выбора оптимального режима облучения была проведена серия экспериментов по изучению влияния непрерывного режима ТГЧ-облучения на линейную скорость кровотока у крыс-самцов в состоянии острого иммобилизационного стресса. Облучение крыс-самцов, находящихся в состоянии острого иммобилизационного стресса, проводили в течение 5, 15 и 30 минут.

Установлено, что воздействие непрерывного ТГЧ-облучения на частотах молекулярного спектра излучения и поглощения оксида азота в течение 5 минут на животных, находящихся в состоянии острого иммобилизационного стресса, вызывает в брюшной аорте и бедренной артерии полное восстановление нарушенных показателей системной гемодинамики. Это выражается в статистически достоверном уменьшении таких показателей системной гемодинамики, как средняя линейная, средняя линейная систолическая, средняя линейная диастолическая скорости кровотока и градиента давления по сравнению с группой животных, находящихся в состоянии острого 
иммобилизационного стресса (группа сравнения) и ее отсутствие по сравнению с группой контроля.

При увеличении времени экспозиции электромагнитных волн до 15 минут непрерывного режима ТГЧ-облучения крыс-самцов в брюшной аорте и бедренной артерии не происходит дальнейшего нарастания эффекта на показатели системной гемодинамики. Такие ее показатели, как средняя линейная скорость кровотока, средняя линейная систолическая скорость кровотока, средняя линейная диастолическая скорость кровотока и градиент давления статистически достоверно не отличаются от показателей группы контроля, то есть происходит полное восстановление гемодинамики в указанных сосудах, нарушенных острым иммобилизационным стрессом.

При увеличении времени облучения крыс-самцов, находившихся в состоянии острого иммобилизационного стресса, электромагнитными волнами ТГЧ-диапазона на частотах МСИП оксида азота 150,176 - 150,664 ГГц до 30 минут наблюдается такой же эффект на нарушенные показатели гемодинамики в брюшной аорте и бедренной артерии, как и при 15-минутном режиме. Следовательно, зависимость эффекта терагерцовых волн на указанном диапазоне частот от дозы облучения нелинейная, что характерно также и для волн миллиметрового и субмиллиметрового диапазона частот [Бецкий О.В., Лебедева H.H., 2001].

Таким образом, при непрерывном воздействии электромагнитным облучением терагерцевого диапазона на частоте МСИП оксида азота 150,176 - 150,664 ГГц в течение 5, 15 и 30 минут в брюшной аорте и бедренной артерии крыс-самцов, находящихся в состоянии острого иммобилизационного стресса, происходит полное восстановление нарушенных показателей линейной скорости кровотока, причем наиболее эффективным является 5-минутный режим непрерывного ТГЧ - облучения.

Установлено, что при воздействии непрерывного режима ТГЧ-облучения на частотах молекулярного спектра излучения и поглощения оксида азота 150,176 - 150,664 ГГц в течение 5, 15 и 30 минут в сонной артерии животных, находящихся в состоянии острого иммобилизационного стресса, значительных статистически достоверных различий в линейной скорости кровотока не наблюдается ни по сравнению с животными из группы контроля, ни с крысами-самцами, находившимися в состоянии острого иммобилизационного стресса. Это еще раз доказывает, что терагерцевые волны на частоте оксида азота 150,176 - 150,664 ГГц не оказывают влияния на системную гемодинамику в головном мозге экспериментальных животных - самцов белых крыс.

Таким образом, на основании полученных данных можно отметить, что эффективность непрерывного режима воздействия на нарушенные показатели системной 
гемодинамики не зависит от времени облучения животных. Так, 5-, 15- и 30-минутная экспозиция ТГЧ-волн вызывает полное восстановление нарушенных показателей гемодинамики в брюшной аорте и бедренной артерии. Следовательно, наиболее эффективным режимом является 5-минутная экспозиция электромагнитных волн на частотах МСИП NO 150,176 - 150,664 ГГц. Ни один из исследованных временных режимов воздействия терагерцевыми волнами на частоте молекулярного спектра излучения и поглощения оксида азота не влияет на показатели системной гемодинамики в сонной артерии.

\section{Выводы}

Полученные данные свидетельствуют о том, что при воздействии на интактных крыс-самцов 15-минутным непрерывным ТГЧ-облучением изменений исследуемых показателей линейной скорости кровотока не происходит. Это свидетельствует о безопасности воздействия волн терагерцевого диапазона на интактных животных.

Установлено, что у белых крыс-самцов в результате острой стрессорной реакции, развивающейся при иммобилизации, происходит нарушение системной гемодинамики в брюшной аорте и бедренной артерии, что выражается в статистически достоверном увеличении таких показателей, как средняя линейная, средняя линейная систолическая, средняя линейная диастолическая скорости кровотока и градиент давления. Нарушения системной гемодинамики в сонной артерии при этом не развиваются.

При непрерывном режиме ТГЧ-облучения крыс-самцов, находящихся в состоянии острого иммобилизационного стресса, наиболее эффективной является 5-минутная экспозиция терагерцевых волн. При этом режиме воздействия ТГЧ-облучения крыссамцов в состоянии острого стресса происходит полное восстановление нарушенных показателей системной гемодинамики в брюшной аорте и бедренной артерии, что выражается в отсутствии статистически достоверных различий в таких показателях гемодинамики, как средняя линейная, средняя линейная систолическая, средняя линейная диастолическая скорости кровотока и градиент давления животных данной группы по сравнению с показателями группы контроля. Непрерывное ТГЧ-облучение в течение 15 и 30 минут крыс-самцов в состоянии острого иммобилизационного стресса также приводит к полному восстановлению нарушенных показателей гемодинамики в указанных магистральных сосудах.

Обнаружено, что при воздействии непрерывного режима ТГЧ-облучения на частотах молекулярного спектра излучения и поглощения оксида азота 150,176 - 150,664 ГГц в течение 5, 15 и 30 минут в сонной артерии животных, находящихся в состоянии острого иммобилизационного стресса, значительных статистически достоверных 
различий в линейной скорости кровотока не наблюдается ни по сравнению с животными из группы контроля, ни по сравнениюс крысами-самцами, находившимися в состоянии острого иммобилизационного стресса.

Таким образом, эффективность непрерывного режима волн терагерцевого диапазона на частотах МСИП оксида азота 150,176 - 150,664 ГГц на стрессорные нарушения показателей системной гемодинамики не зависит от времени его экспозиции.

\section{ГЛАВА ІІІ}

\section{ВЛИЯНИЕ ПРЕДВАРИТЕЛЬНОГО НЕПРЕРЫВНОГО ТГЧ-ОБЛУЧЕНИЯ} \НА ЧАСТОТАХ МОЛЕКУЛЯРНОГО СПЕКТРА ИЗЛУЧЕНИЯ И ПОГЛОЩЕНИЯ ОКСИДА АЗОТА 150,176 - 150,664 ГГЦ НА СТРЕССОРНЫЕ НАРУШЕНИЯ СИСТЕМНОЙ ГЕМОДИНАМИКИ У БЕЛЫХ КРЫС-САМЦОВ

Для изучения возможности предотвращения развития характерных для острой стресс-реакции нарушений гемодинамики в магистральных сосудах была проведена серия экспериментов, в которых крысы-самцы подвергались непрерывному ТГЧ-облучению до начала действия стрессора. Продолжительность облучения крыс-самцов в данных группах составляла 5,15 и 30 минут.

3.1. Линейная скорость кровотока в различных магистральных сосудах при превентивном облучении на частотах оксида азота 150,176 - 150,664 ГГц у белых крыс-самцов при остром стрессе

3.1.1.Влияние предварительного непрерывного режима ТГЧ - облучения на частотах МСИП оксида азота 150,176 - 150,664 ГГц на нарушенные показатели линейной скорости кровотока в брюшной аорте у белых крыс-самцов, находящихся в состоянии острого иммобилизационного стресса

Установлено, что в брюшной аорте крыс-самцов, подвергнутых непрерывному превентивному режиму ТГЧ-облучения на частотах МСИП оксида азота 150,176 - 150,664 ГГц в течение 5 минут, возникает адаптивная реакция к стрессорному агенту, так как исследуемые показатели гемодинамики остаются в пределах физиологической нормы, характерной для контрольной группы животных: исследуемые показатели гемодинамики статистически достоверно не отличаются от данных группы контроля. В то же время это выражается в статистически достоверном по сравнению с группой животных, находящихся в состоянии острого иммобилизационного стресса (группа сравнения), изменении таких показателей системной гемодинамики, как средняя линейная, средняя 
линейная систолическая, средняя диастолическая линейная скорости кровотока и градиента давления.

При увеличении времени экспозиции электромагнитных волн до 15 минут непрерывного превентивного режима ТГЧ-облучения крыс-самцов в брюшной аорте не происходит дальнейшего нарастания его эффекта. При этом такие показатели системной гемодинамики, как средняя линейная скорость кровотока, средняя линейная систолическая скорость кровотока, средняя линейная диастолическая скорость кровотока и градиент давления статистически достоверно не отличаются от данных группы контроля.

При увеличении времени облучения крыс-самцов электромагнитными волнами ТГЧ диапазона на частотах МСИП оксида азота 150,176 - 150,664 ГГц до 30 минут дальнейшего роста эффекта на гемодинамику в брюшной аорте не отмечается.

Следовательно, зависимость эффекта от дозы облучения не линейная, что характерно для волн миллиметрового и субмиллиметрового диапазона частот [Бецкий О.В., Лебедева Н.Н., 2001]. Необходимо отметить, что показатели системной гемодинамики: средняя линейная, средняя линейная систолическая, средняя линейная диастолическая скорости кровотока и градиент давления - статистически достоверно отличаются от данных группы животных, подвергнутых острому иммобилизационному стрессу, и статистически достоверно не отличаются от животных контрольной группы.

Таким образом, воздействие превентивного режима электромагнитного облучения терагерцевого диапазона на частотах молекулярного спектра излучения и поглощения оксида азота 150,176 - 150,664 ГГц в течение 5, 15 и 30 минут полностью предотвращает нарушения линейной скорости кровотока в брюшной аорте, которые возникают в результате острого иммобилизационного стресса. Наиболее эффективным является 5минутный режим предварительного режима ТГЧ-облучения.

3.1.2. Влияние предварительного непрерывного ТГЧ - облучения на частотах МСИП оксида азота 150,176 - 150,664 ГГц на нарущенные показатели линейной скорости кровотока в бедренной артерии у бельх крыс-самцов, находящихся в состоянии острого иммобилизационного стресса

Выявлено, что в бедренной артерии крыс-самцов, подвергнутых непрерывному предварительному режиму ТГЧ-облучения на частотах МСИП оксида азота 150,176 150,664 ГГц в течение 5 минут, наблюдается сохранение исследуемых показателей гемодинамики на уровне контрольных значений. Это выражается в статистически достоверном различии с показателями группы сравнения и статистически достоверно не отличаются от группы контроля. Данные результаты также указывают на адаптогенный 
эффект этого режима облучения на гемодинамику в вышеуказанной магистральной артерии.

Дальнейшее увеличение времени облучения крыс-самцов электромагнитными волнами ТГЧ-диапазона на частотах МСИП оксида азота 150,176 - 150,66 ГГц до 15 минут не приводит к возрастанию его эффекта на нарушенные показатели гемодинамики в бедренной артерии. Это выражается в статистически достоверном по сравнению с группой животных, подвергнутых острому иммобилизационному стрессу (группа сравнения), отличии средней линейной, средней линейной систолической, средней линейной диастолической скоростей кровотока и градиента давления. При этом исследуемые показатели гемодинамики статистически достоверно не отличаются от данных контрольной группы животных.

Выявлено, что пролонгирование времени экспозиции электромагнитных волн терагерцевого диапазона на частотах МСИП оксида азота 150,176 - 150,664 ГГц до 30 минут при их воздействии на крыс-самцов не вызывает в бедренной артерии дальнейшего нарастания биологического эффекта. На это указывает статистически достоверное отличие исследуемых показателей системной гемодинамики по сравнению с группой животных, находящихся в состоянии острого иммобилизационного стресса. Средняя линейная, средняя линейная систолическая, средняя линейная диастолическая скорости кровотока и градиент давления статистически достоверно не отличаются от данных группы контроля.

Таким образом, воздействие превентивного режима ЭМИ ТГЧ - облучения на частотах МСИП оксида азота 150,176 - 150,664 ГГц в течение 5, 15 и 30 минут полностью предотвращает нарушение показателей гемодинамики в бедренной артерии, которое возникает в результате острого иммобилизационного стресса. Наиболее эффективным является 5-минутный режим предварительного ТГЧ-облучения.

\subsection{3. Влияние предварительного непрерывного ТГЧ - облучения на частотах} МСИП оксида азота 150,176 - 150,664 ГГц на нарушенные показатели линейной скорости кровотока в сонной артерии у белых крыс-самцов, находящихся в состоянии острого иммобилизационного стресса

Обнаружено, что в сонной артерии крыс-самцов при воздействии непрерывного превентивного режима ТГЧ-излучения на частотах МСИП оксида азота 150,176 - 150,664 ГГц в течение 5 минут на фоне действия стрессорного агента не наблюдается значительных отличий показателей гемодинамики (средней линейной, средней линейной систолической, средней линейной диастолической скоростей кровотока и градиента давления) как по сравнению с группой животных, подвергнутых острому 
иммобилизационному стрессу, так и по сравнению с контрольной группой белых крыс самцов. Это, вероятно, указывает на централизацию кровотока во время действия стрессорного фактора, которым является острый иммобилизационный стресс, и как результат поддержание перфузии жизненно важного органа - головного мозга на постоянном стабильном уровне.

Выявлено, что дальнейшее увеличение времени экспозиции электромагнитных волн ТГЧ диапазона указанного спектра оксида азота до 15 и 30 минут не вызывает в сонной артерии каких-либо гемодинамических изменений по сравнению с группами контроля и сравнения. Это выражается в статистически достоверном отсутствии различий исследуемых показателей: средней линейной, средней линейной систолической, средней линейной диастолической скоростей кровотока и градиента давления как с данными контрольной группы животных, так и с некоторыми показателями гемодинамики животных в состоянии острого иммобилизационного стресса.

Следовательно, при воздействии предварительного непрерывного режима ТГЧ облучения на частотах молекулярного спектра излучения и поглощения оксида азота 150,176 - 150,664 ГГц в течение 5, 15 и 30 минут в сонной артерии животных, находящихся в состоянии острого иммобилизационного стресса, значительных, статистически достоверных различий в линейной скорости кровотока не наблюдается ни по сравнению с животными из группы контроля, ни с крысами - самцами, находившимися в состоянии острого иммобилизационного стресса.

При сравнении показателей системной гемодинамики у животных, подвергнутых предшествующему стрессу ТГЧ - облучению в течение 5, 15 и 30 минут, не отмечается зависимости эффективности ТГЧ - воздействия от времени облучения. Так, предшествующее стрессу ТГЧ- облучение в течение 5 минут в брюшной аорте полностью предотвращает развитие характерных для острой стресс - реакции нарушений системной гемодинамики. Предшествующее стрессу 15 и 30 минутное ТГЧ - облучение также полностью предотвращает развитие изменений исследуемых показателей гемодинамики в брюшной аорте. При этом все показатели гемодинамики животных, подвергнутых ТГЧ облучению в течение 15 и 30 минут, статистически достоверно не отличаются как от данных группы контроля, так и различных временных режимах облучения животных.

Предшествующее стрессу ТГЧ - облучение в течение 5 минут в бедренной артерии также полностью предотвращает развитие характерных для острой стресс - реакции нарушений системной гемодинамики. Дальнейшее увеличение времени экспозиции до 15 и 30 минут не приводит к нарастанию эффекта ТГЧ - облучения предшествующего стрессу. 
5, 15 и 30 минутное превентивное непрерывное ТГЧ - облучение на частотах МСИП оксида азота 150,176 - 150,664 ГГц в сонной артерии значительных изменений не вызывает, так как статистически достоверных изменений показателей системной гемодинамики по сравнению с группами контроля и сравнения не выявлено, что указывает, по-видимому, на поддержание перфузии головного мозга на постоянном уровне.

Таким образом, в предотвращении нарушений в показателях гемодинамики наиболее эффективным временным режимом предшествующего стрессу ТГЧ - облучения является 5 минутная экспозиция электромагнитных волн.

3.2. Сравнительная характеристика линейной скорости кровотока в различных магистральных сосудах при острой стресс - реакции и различных режимах облучения терагерцевыми волнами на частотах МСИП оксида азота

3.2.1. Сравнительная характеристика показателей системной гемодинамики в брюшной аорте жсивотных, подвергнутых ТГЧ - облучению до и после иммобилизации

При сравнении показателей гемодинамики брюшной аорты животных, подвергнутых в течение 5 минут предшествующему стрессу ТГЧ - облучению, и животных, у которых ТГЧ - облучение на частотах МСИП оксида азота проводилось после иммобилизации, в брюшной аорте отмечается незначительная, но более выраженная нормализация показателей системной гемодинамики у животных первой группы.

Средняя линейная, средняя линейная систолическая, средняя линейная диастолическая скорости кровотока и градиент давления в брюшной аорте животных, подвергнутых предварительному ТГЧ - облучению в течение 5 минут, статистически достоверно не отличаются от показателей у животных, подвергнутых такой же временной экспозиции ТГЧ - волн на фоне развившегося острого иммобилизационного стресс. Следовательно, эффективность двух указанных режимов одинакова.

Воздействие 15 минутного режима ТГЧ - облучения на частотах МСИП оксида азота на фоне развившегося иммобилизационного стресса приводит к полному восстановлению нарушенных показателей гемодинамики в брюшной аорте, a предварительное ТГЧ - облучение той же временной экспозиции также полностью предотвращает развитие нарушений гемодинамики. Но 15 минутное воздействие ТГЧ облучения на частотах МСИП оксида азота перед острым иммобилизационным стрессом приводит к более выраженной нормализации показателей гемодинамики по сравнению с воздействием такого же временного режима, но после острого иммобилизационного стресса. 
Следовательно, эффективность влияния обоих режимов ТГЧ - облучения на частотах МСИП оксида азота на показатели гемодинамики в указанном магистральном сосуде экспериментальных животных одинакова, так как отсутствует достоверная разница между ними у животных при применении обоих способов облучения.

Воздействие 30 минутной экспозиции электромагнитных волн ТГЧ - диапазона на частотах оксида азота 150,176 - 150,664 ГГц на животных с развившимся иммобилизационным стрессом приводит к полной нормализации показателей гемодинамики, а предшествующее стрессу - полностью предотвращает развитие нарушений в брюшной аорте.

Установлено, что при воздействии 30 минутного режима ТГЧ - облучения как на фоне острого иммобилизационного стресса, так и предшествующего стрессу ТГЧ облучения в брюшной аорте имеются статистически достоверные различия только в средней линейной скорости кровотока при ее отсутствии в других показателях гемодинамики, это указывает на меньшую эффективность превентивного 30 минутного режима облучения ТГЧ - волнами.

Таким образом, эффективность влияния на показатели гемодинамики в брюшной аорте при применении предварительного и непрерывного режимов облучения ЭМИ ТГЧ на частотах оксида азота в течение 5 и 15 минут одинакова. При сравнении 30-ти минутного непрерывного и превентивного ТГЧ - облучения наибольшей эффективностью обладает непрерывный режим.

\subsection{2. Сравнительная характеристика показателей системной гемодинамики в} бедренной артерии жнивотных, подвергнутых ТГЧ - облучению до и после иммобилизации

Влияние превентивного режима электромагнитного облучения волнами терагерцевого диапазона на частотах МСИП оксида азота 150,176 - 150,664 ГГц в течение 5 минут на гемодинамику крыс - самцов в бедренной артерии полностью предотвращает развитие нарушений в ее показателях, которые вызывает острый иммобилизационный стресс. ТГЧ - облучение, проводившееся после острого иммобилизационного стресса, также вызывает полную нормализацию нарушенной гемодинамики в бедренной артерии.

Статистически достоверных различий в показателях гемодинамики в бедренной артерии между группой животных, подвергнутых как превентивному 5 минутному режиму ТГЧ облучения на частотах МСИП, так и этому же временному режиму после действия стрессора не обнаружено, то - есть данные режимы облучения обладают одинаковой эффективностью. 
Установлено, что влияние 15 минутного режима ТГЧ - облучения на крыс - самцов перед острым иммобилизационным стрессом полностью предотвращает развитие нарушений гемодинамики в бедренной артерии. 15 минутное облучение животных ТГЧ волнами на фоне уже развившегося острого иммобилизационного стресса способствует полному восстановлению нарушенной средней линейной, средней линейной систолической, средней линейной диастолической скоростей кровотока и градиента давления.

Статистически достоверных различий в показателях гемодинамики в бедренной артерии между группой животных, подвергнутых ТГЧ - облучению на частотах МСИП оксида азота на фоне острого иммобилизационного стресса, и группой животных, которые подверглись превентивному режиму облучения, не установлено. Следовательно, эффективность влияния обоих режимов облучения на показатели гемодинамики в указанном магистральном сосуде одинакова.

Влияние электромагнитного излучения терагерцевого диапазона на частотах МСИП оксида азота в течение 30 минут на крыс - самцов перед острым иммобилизационным стрессом на показатели гемодинамики в бедренной артерии проявляется в предотвращении изменений в показателях гемодинамики: средней линейной, средней линейной систолической, средней линейной диастолической скоростей кровотока и градиента давления. Аналогичный восстанавливающий эффект вызывает и 30 минутное облучение ТГЧ - волнами и на фоне острого иммобилизационного стресса. Наиболее эффективным является непрерывный 30-ти минутный режим ТГЧ - облучения, так как имеется статистически достоверные различия в показателях средней линейной диастолической скорости кровотока.

Таким образом, эффективность влияния на показатели гемодинамики в брюшной аорте при применении предварительного и непрерывного режимов ЭМИ ТГЧ на частотах оксида азота в течение 5 и 15 минут одинакова. При сравнении 30-ти минутного непрерывного и превентивного ТГЧ - облучения наибольшей эффективностью обладает непрерывный режим.

3.2.3. Сравнительная характеристика показателей системной гемодинамики в сонной артерии жсивотных, подвергнутых ТГЧ - облучению до и после иммобилизации

Обнаружено, что в сонной артерии белых крыс - самцов статистически значимых различий между группами животных, подвергнутых ТГЧ - облучению на фоне острого стресса, и с превентивным воздействием волн терагерцового диапазона на частотах 
МСИП оксида азота с одинаковыми временными экспозициями 5, 15, 30 минут не установлено.

Таким образом, эффективность всех временных режимов ТГЧ - облучения на частотах МСИП оксида азота в сонной артерии крыс - самцов при остром иммобилизационном стрессе на показатели гемодинамики не проявляется.

\section{Резюме}

Полученные данные свидетельствуют, что превентивное ТГЧ - облучение крыс-самцов способно предотвращать развитие характерных для острой стресс - реакции нарушений показателей гемодинамики. При сравнении показателей гемодинамики животных, подвергнутых действию электромагнитного излучения терагерцевого диапазона на частотах МСИП оксида азота 150,176 - 150,664 ГГц до начала действия стрессора, и животных, не подвергавшихся ТГЧ - облучению, обнаружено предотвращающее воздействие ТГЧ - облучения на стрессорные нарушения показателей системной гемодинамики в исследуемых сосудах: брюшной аорте и бедренной артерии. Эффективность предотвращающего стрессорные нарушения показателей гемодинамики ТГЧ - волн не зависит от времени предварительного облучения животных.

При сравнении показателей гемодинамики крыс-самцов, подвергнутых ТГЧ облучению до начала действия стрессора, и животных, у которых ТГЧ - воздействие проводилось на фоне развившегося острого иммобилизационного стресса, обнаружено, что одинаковая временная экспозиция ТГЧ - волн на частотах МСИП оксида азота 150,176 - 150,664 ГГц оказывает различной степени выраженности нормализующее влияние в зависимости от применения до начала действия стресса или на фоне развившегося стресса. Так, 5 и 15 минутная экспозиция ТГЧ - волн в брюшной аорте и бедренной артерии до начала действия стрессора обладает одинаковым предотвращающим и нормализующим влиянием на стрессорные нарушения показателей гемодинамики по сравнению с такими же временными режимами ТГЧ - облучения, проведенного на фоне развившегося острого иммобилизационного стресса. 30 минутное превентивное ТГЧ облучение обладает большим предотвращающим действием на показатели гемодинамики по сравнению с нормализующим эффектом облучения на фоне развившегося иммобилизационного стресса.

В сонной артерии воздействие как непрерывного, так и превентивного ЭМИ ТГЧ диапазона на частотах МСИП оксида азота в течение 5,15 и 30 минут не вызывает изменения показателей линейной скорости кровотока как по сравнению с контрольной группой животных, так и с группой животных, находящихся в состоянии острого 
иммобилизационного стресса, что указывает на поддержание перфузии головного мозга на постоянном уровне.

\section{ГЛАВА IV \\ ВЛИЯНИЕ ДРОБНОГО РЕЖИМА ТГЧ-ОБЛУЧЕНИЯ НА ЧАСТОТАХ МОЛЕКУЛЯРНОГО СПЕКТРА ОКСИДА АЗОТА 150,176 - 150,664 ГГЦ НА СИСТЕМНУЮ ГЕМОДИНАМИКУ БЕЛЫХ КРЫС-САМЦОВ, НАХОДЯЩИХСЯ В СОТОЯНИИ ОСТРОГО ИММОБИЛИЗАЦИОННОГО СТРЕССА}

В литературе имеются указания на существенную зависимость эффективности электромагнитного воздействия от ряда факторов, в частности, от выбора режима облучения [Чуян Е.Н., Темурянц Н.А., Московчук О.Б., и др., 2003]. В ряде клинических исследований [Паршина С.С., 1994, Семенова С.В.,1994, Киричук В.Ф. и др.,1999] показано, что дробные режимы КВЧ - облучения обладают большей эффективностью по сравнению с соответствующими непрерывными режимами. В связи с этим были проведены серии экспериментов на крысах-самцах, подвергавшихся дробному ТГЧ облучению на фоне острого иммобилизационного стресса.

4.1. Влияние дробного ТГЧ - облучения на частотах МСИП оксида азота 150,176 - 150,664 ГГц на нарушенные показатели линейной скорости кровотока в брюшной аорте у белых крыс-самцов, находящихся в состоянии острого иммобилизационного стресса

При дробном режиме ТГЧ - облучения на частотах МСИП оксида азота общей продолжительностью 5 минут в брюшной аорте белых крыс-самцов, находящихся в состоянии острого иммобилизационного стресса, происходит полная нормализация нарушенной линейной скорости кровотока. Это выражается в восстановлении таких показателей как средняя линейная, средняя линейная систолическая, средняя линейная диастолическая скорости кровотока и градиента давления.

Исследуемые показатели гемодинамики опытной группы статистически достоверно отличаются от данных группы сравнения и статистически достоверно не отличаются от контрольной группы животных.

Дальнейшее увеличение времени дробного режима ТГЧ - облучения до 15 минут в брюшной аорте белых крыс - самцов также приводит к полной нормализации нарушенных показателей гемодинамики. Это выражается в нормализации средней линейной, средней линейной систолической, средней линейной диастолической скоростей кровотока и градиента давления. 
Установлено, что статистически достоверные различия между группой животных, подвергнутых дробному режиму ТГЧ - облучения общей продолжительностью 15 минут, и контрольной группой животных отсутствуют, но имеются статистически значимые различия с группой животных, находящихся в состоянии острого иммобилизационного стресса.

Дальнейшее увеличение времени экспозиции электромагнитных волн до 30 минут не ведет к росту эффективности на нарушенные показатели гемодинамики по сравнению с 5 и 15 минутным ТГЧ - облучением на частотах молекулярного спектра излучения и поглощения оксида азота.

Статистически достоверные различия между показателями гемодинамики контрольной группой и животными, подвергнутыми дробному режиму ТГЧ - облучения общей продолжительностью 30 минут на фоне острого иммобилизационного стресса в брюшной аорте, отсутствуют.

Таким образом, дробный режим ТГЧ - облучения общей продолжительностью 5,15 , и 30 минут приводит к полному восстановлению показателей линейной скорости кровотока в брюшной аорте. Так как при увеличении времени экспозиции роста эффекта не происходит, следовательно, самым эффективным временным режимом является дробное ТГЧ - облучение общей продолжительностью 5 минут.

4.2. Влияние дробного ТГЧ - облучения на частотах МСИП оксида азота 150,176 - 150,664 ГГц на нарушенные показатели линейной скорости кровотока в бедренной артерии у белых крыс-самцов, находящихся в состоянии острого иммобилизационного стресса

Дробное ТГЧ - облучение обшей продолжительностью 5 минут в бедренной артерии у белых крыс - самцов, находящихся в состоянии острого иммобилизационного стресса, приводит к полному восстановлению нарушенных показателей линейной скорости кровотока. Это выражается в полном восстановлении средней линейной, средней линейной систолической, средней линейной диастолической скоростей кровотока и градиента давления.

Показатели линейной скорости кровотока животных, подвергнутых дробному ТГЧ - облучению общей продолжительностью 5 минут статистически достоверно не отличаются от данных контрольной группы животных.

Увеличение общей продолжительности дробного режима ТГЧ - облучения до 15 минут не приводит к дальнейшему увеличению эффекта ТГЧ волн на нарушенные показатели гемодинамики в бедренной артерии. 
Такие показатели гемодинамики как средняя линейная, средняя линейная систолическая, средняя линейная диастолическая скорости кровотока и градиент давления статистически достоверно не отличаются от данных контрольной группы животных, но имеют статистически значимые различия по сравнению с группой животных находящихся в состоянии острого иммобилизационного стресса.

Увеличение общей продолжительности дробного режима ТГЧ - облучения до 30 минут в бедренной артерии также не вызывает дальнейшего роста эффекта по сравнению с 5 и 15 минутным дробным ТГЧ - облучением.

Показатели гемодинамики группы животных, подвергнутых дробному режиму ТГЧ облучения общей продолжительностью 30 минут статистически достоверно не отличаются от данных контрольной группы животных.

Таким образом, дробный режим ТГЧ - облучения общей продолжительностью 5,15 , и 30 минут приводит к полному восстановлению нарушенных показателей линейной скорости кровотока в бедренной артерии.

Самым эффективным является дробное ТГЧ - облучение общей продолжительностью 5 минут.

\section{3. Влияние дробного ТГЧ - облучения на частотах МСИП оксида азота 150,176} - 150,664 ГГц на нарушенные показатели линейной скорости кровотока в сонной артерии у белых крыс-самцов, находящихся в состоянии острого иммобилизационного стресса

Обнаружено, что в сонной артерии крыс - самцов при воздействии дробного режима ТГЧ - облучения общей продолжительностью 5 минут на частотах МСИП оксида азота 150,176 - 15,664 ГГц не наблюдается значительных отличий показателей средней линейной, средней линейной систолической, средней линейной диастолической скоростей кровотока и градиента давления по сравнению с группой животных, подвергнутых острому иммобилизационному стрессу и контрольной группой животных. Это, вероятно, указывает на централизацию кровотока во время действия стрессорного фактора, которым является острый иммобилизационный стресс, и как результат поддержания перфузии жизненно важного органа - головного мозга на постоянном уровне.

Статистически достоверных различий в группах контроля, сравнения и группе животных, подвергнутых дробному ТГЧ - облучению общей продолжительностью 5 минут, не обнаружено.

Выявлено, что дальнейшее увеличение времени экспозиции электромагнитных волн дробного режима ТГЧ - облучения общей продолжительностью 15 и 30 минут не вызывает в сонной артерии каких-либо изменений по сравнению с группами контроля и 
сравнения. Это выражается в статистически достоверном отсутствии различий исследуемых показателей: средней линейной, средней систолической, средней диастолической скоростей кровотока и градиента давления по сравнению с контрольной группой животных и животных в состоянии острого иммобилизационного стресса.

Таким образом, в сонной артерии значительных, статистически значимых изменений у животных, подвергнутых дробному режиму ТГЧ - облучения на частотах МСИП оксида азота 150,176 - 150,664 ГГц общей продолжительностью 5, 15 и 30 минут по сравнению с группой интактных животных и животных, находящихся в состоянии острого иммобилизационного стресса не отмечается. Это, по-видимому, указывает на поддержание кровоснабжения головного мозга на постоянном, стабильном уровне.

Следовательно, дробное ТГЧ - облучение общей продолжительностью 5, 15 и 30 минут в брюшной аорте и бедренной артерии приводит к полному восстановлению нарушенных в ходе острого иммобилизационного стресса показателей линейной скорости кровотока. Наиболее эффективен дробный режим общей продолжительностью 5 минут. В сонной артерии изменений при дробном режиме ТГЧ - облучения общей продолжительностью 5, 15 и 30 минут по сравнению с контрольной группой и группой сравнения не отмечается.

\section{4. Сравнительная характеристика показателей линейной скорости кровотока} в брюшной аорте животных, подвергнутых ТГЧ - облучению на фоне острого стресса в непрерывном и дробном режимах

При сравнении показателей гемодинамики животных, подвергнутых дробному режиму облучения общей продолжительностью 5 минут на фоне стресса, и животных, у которых ТГЧ - облучение на частотах МСИП оксида азота проводилось в 5-ти минутном непрерывном режиме, статистически достоверных различий не отмечено, то-есть, отмечается одинаковая эффективность двух указанных режимов.

Воздействие непрерывного 15 минутного ТГЧ - облучения на частотах МСИП оксида азота на фоне развившегося иммобилизационного стресса приводит к полному восстановлению нарушенной линейной скорости кровотока, дробное ТГЧ - облучение общей продолжительностью 15 минут также полностью восстанавливает основные показатели гемодинамики. Статистически достоверных различий в показателях гемодинамики в сравниваемых группах не отмечается. Таким образам, эффективность дробного режима ТГЧ - облучения обшей продолжительностью 15 минут и непрерывного 15-ти минутного ТГЧ облучения одинакова.

Воздействие 30 минутного непрерывного режима ТГЧ - облучения на частотах молекулярного спектра излучения и поглощения оксида азота приводит к полному 
восстановлению нарушенных в результате острого иммобилизационного стресса показателей линейной скорости кровотока. Дробное ТГЧ - облучение общей продолжительностью 30 минут также вызывает восстановление показателей системной гемодинамики. Однако отмечаются статистически значимые различия в сравниваемых группах. В связи с этим эффективность непрерывного режима на нарушенную линейную скорость кровотока выше дробного.

Таким образом, в брюшной аорте при применении дробного и непрерывного режимов ТГЧ - облучения продолжительностью 5 и 15 минут отмечена их одинаковая эффективность в восстановлении нарушенных показателей гемодинамики. При использовании 30 минутного режима ТГЧ - облучения отмечена большая эффективность непрерывного режима по сравнению с дробным.

\section{5. Сравнительная характеристика показателей линейной скорости} кровотока в бедренной артерии животных, подвергнутых ТГЧ - облучению на фоне острого стресса в непрерывном и дробном режимах

При сравнении показателей линейной скорости кровотока животных, которые были подвергнуты дробному режиму ТГЧ - облучения на фоне острого иммобилизационного стресса общей продолжительностью 5 минут и группы животных, подвергнутых непрерывному ТГЧ - облучению на фоне стресса в течение 5 минут, установлено, что оба режима одинаково эффективны, так как между этими группами в показателях гемодинамики нет статистически достоверных различий.

Установлено, что при воздействии дробного режима ТГЧ - облучения на частотах молекулярного спектра излучения и поглощения оксида азота 150,176 - 15,664 ГГц общей продолжительностью 15 минут отмечается полное восстановление нарушенных показателей линейной скорости кровотока при остром стрессе. При применении такой же временной экспозиции электромагнитных волн в непрерывном режиме также отмечено полное восстановление нарушенных показателей системной гемодинамики. Статистически значимые различия показателей гемодинамики этих групп отсутствуют, то - есть, эффективность их одинакова. 
Обнаружено, что при воздействии дробного и непрерывного режимовТГЧ облучения на частотах МСИП оксида азота 150,176 - 150,664 ГГц продолжительностью 30 минут на фоне острого иммобилизационного стресса отмечается полное восстановление нарушенных показателей системной гемодинамики в обоих случаях. Эффективность их одинакова, так как отсутствуют статистически значимые различия в показателях линейной скорости кровотока.

Таким образом, в бедренной артерии при применении дробного и непрерывного режимов ТГЧ - облучения продолжительностью 5, 15 и 30 минут отмечена их одинаковая эффективность в восстановлении нарушенных показателей гемодинамики.

\section{6. Сравнительная характеристика показателей линейной скорости кровотока в сонной артерии животных, подвергнутых ТГЧ-облучению на фоне острого стресса в непрерывном и дробном режимах}

Установлено, что в сонной артерии при применении дробного режима ТГЧ облучения на частотах МСИП оксида азота и непрерывного ТГЧ - облучения в течение 5,15 и 30 минут статистически достоверных различий в линейной скорости кровотока по сравнению с контрольной группой животных и группой животных, находящихся в состоянии острого иммобилизационного стресса, не отмечено, то-есть, уровень кровоснабжения головного мозга не изменяется.

Таким образом, при дробном и непрерывном режимах воздействия на животных, находящихся в состоянии иммобилизационного стресса, ТГЧ-волнами на частотах МСИП оксида азота наблюдается одинаковая степень восстановления нарушенных показателей гемодинамики.

\section{Резюме}

При дробном режиме облучения крыс-самцов на фоне иммобилизационного стресса наиболее эффективным является облучение общей продолжительностью 5 минут. Эффективность дробного ТГЧ - облучения общей продолжительностью 5, 15 и 30 минут на постстресорные нарушения линейной скорости кровотока в брюшной аорте и бедренной артерии одинакова с непрерывным облучением соответствующей продолжительности, то есть эффективность ТГЧ-воздействия не зависит от выбора режима облучения. В сонной артерии воздействие как непрерывного, так и дробного ЭМИ ТГЧ диапазона на частотах МСИП оксида азота в течение 5, 15 и 30 минут не вызывает изменения показателей линейной скорости кровотока как по сравнению с контрольной группой животных, так и с группой животных, находящихся в состоянии острого иммобилизационного стресса. 


\section{ГЛАВА V}

\section{ВЛИЯНИЕ ИНГИБИТОРА NO - СИНТАЗЫ L-NAMЕ И ОБЛУЧЕНИЯ ЭЛЕКТРОМАГНИТНЫМИ ВОЛНАМИ ТЕРАГЕРЦЕВОГО ДИАПАЗОНА НА ЧАСТОТАХ МОЛЕКУЛЯРНОГО СПЕКТРА ИЗЛУЧЕНИЯ И ПОГЛОЩЕНИЯ ОКСИДА АЗОТА 150,176 - 150,664 ГГЦ НА СИСТЕМНУЮ ГЕМОДИНАМИКУ КРЫС - САМЦОВ, ПОДВЕРГНУТЫХ ОСТРОМУ ИММОБИЛИЗАЦИОННОМУ СТPECСУ}

Для изучения механизма положительного эффекта терагерцевых волн на частотах молекулярного спектра излучения и поглощения оксида азота 150,176-150,664 ГГц на линейную скорость кровотока крыс-самцов, подвергнутых острому иммобилизационному стрессу, исследовались показатели гемодинамики в магистральных сосудах: брюшной аорте, бедренной и сонной артериях до и после проведения облучения в течение 30 минут на фоне введения ингибитора эндотелиальной NO-синтазы L-Name.

Как указывалось в главе 3, обнаружено статистически достоверное увеличение показателей линейной скорости кровотока в брюшной аорте и бедренной артерии после проведения однократной 3-х часовой иммобилизации крыс-самцов по сравнению с группой контроля. Введение ингибитора NO-синтазы L-Name приводило к дальнейшему повышению линейной скорости кровотока в брюшной аорте и бедренной артерии. Такие показатели гемодинамики как средняя линейная, средняя линейная систолическая, средняя линейная диастолическая скорости кровотока и градиент давления в брюшной аорте и бедренной артерии животных, подвергнутых острому иммобилизационному стрессу на фоне действия L-Name, статистически достоверно увеличивались как по сравнению с группой контроля, так и с группой стрессированных животных. После облучения стрессированных животных в течение 30-ти минут на фоне введения блокатора эндотелиальной NO-синтазы линейная скорость кровотока продолжала увеличиваться как по сравнению с контролем, так и группой белых крыс - самцов, находящихся в состоянии острого стресса, статистически достоверно не отличаясь от данных группы животных, находящихся в состоянии острого стресса, которым был введён L-Name.

Таким образом, при введении ингибитора NO-синтазы L-Name отмечается значительное увеличение линейной скорости кровотока в брюшной аорте и бедренной артерии белых крыс - самцов, подвергнутых острому иммобилизационному стрессу, а также отсутствие эффекта 30-ти минутного облучения терагерцевыми волнами на 
частотах молекулярного спектра излучения и поглощения оксида азота 150,176-150,664 ГГц животных, подвергнутых острому иммобилизационному стрессу на фоне действия ингибитора эндотелиальной NO-синтазы L-Name.

Обнаружено, что в сонной артерии отсутствуют статистически значимые изменения показателей линейной скорости кровотока как у белых крыс - самцов, находящихся в состоянии острого иммобилизационного стресса на фоне введения ингибитора NOS - L-NAME, так и у животных, подвергнутых острому стрессу с введением NOS - L-NAME совместно с ТГЧ - облучением на частотах молекулярного спектра излучения и поглощения оксида азота 150,176 - 150,664 ГГц по сравнению с контролем и животными, подвергнутыми острому стрессу.

Таким образом, изменений линейной скорости кровотока в сонной артерии при введении животным ингибитора NOS - L-NAME не происходит, что указывает на поддержание кровоснабжения головного мозга на постоянном уровне.

\section{Резюме}

Показано отсутствие нормализующего эффекта на показатели гемодинамики 30-ти минутного облучения терагерцевыми волнами на частотах молекулярного спектра излучения и поглощения оксида азота 150,176-150,664 ГГц в брюшной аорте и бедренной артерии животных, находящихся в состоянии острого иммобилизационного стресса, на фоне действия ингибитора эндотелиальной NO-синтазы L-Name. Это свидетельствует о роли эндогенного оксида азота и эндотелиальной NO-синтазы в механизмах потенцирования положительного корригирующего эффекта облучения на частотах МСИП оксида азота 150,176-150,664 ГГц на нарушенные показатели линейной скорости кровотока. 30-ти минутное облучение терагерцовыми волнами на частотах молекулярного спектра излучения и поглощения оксида азота 150,176-150,664 ГГц в сонной артерии животных, находящихся в состоянии острого иммобилизационного стресса на фоне действия ингибитора эндотелиальной NO-синтазы L-Name, не вызывает каких-либо изменений ни по сравнению с контрольной группой животных, ни с группой животных, находящихся в состоянии острого иммобилизационного стресса. По-видимому, это указывает на централизацию кровотока во время действия стрессорного агента, в результате чего происходит поддержание кровоснабжения жизненно важного органа головного мозга на постоянном уровне.

\section{ЗАКЛЮЧЕНИЕ}

В основе изменения функционирования организма при стрессе лежит активация стресс-реализующих систем и, соответственно, действие медиаторов этих систем 
[Гриневич В.В. и др., 1999; Пшенникова М.Г. и др., 2000]. Среди них центральное место занимают гормоны и медиаторы гипоталамо-гипофизарно-надпочечниковой и симпатоадреналовой систем: кортикотропин-рилизинг-фактор, адренокортикотропный гормон, катехоламины, глюкокортикоиды [Селье Г., 1960; Панин Л.Е., 1983].

Нами изучены особенности гемодинамики у интактных и стрессированных животных. Обнаружено, что у животных в состоянии острого иммобилизационного стресса увеличивается линейная скорость кровотока в брюшной аорте и бедренной артерии, что выражается в статистически достоверном увеличении основных показателей гемодинамики: средней линейной, средней линейной систолической, средней линейной диастолической скоростей кровотока и градиента давления. Это связано с воздействием гормонов и медиаторов стресс-реализующих систем как непоредственно на гладкомышечные клетки сосудов, так и на их эндотелий [Киричук В.Ф., 2005; Takeda Н., 1992; Naesh O. et al., 1993]. В конечном итоге вследствие избыточного поступления в кровь катехоламинов и глюкокортикостероидов, которые являются мощными вазоконстрикторами, происходит сужение сосудов, увеличивается общее периферическое сопротивление, что, несомненно, приводит к нарушению гемодинамики и адекватного кровоснабжения органов и тканей [Власов Т.Д., 2002; Киричук В.Ф. 2008]

Кроме того, известно, что одним из ведущих факторов этиологии и патогенеза заболеваний сердечно-сосудистой системы является патологический стресс [Меepсон Ф.3. 1993; Берсудский С.О., 2002; Гафаров В.В., Благиниа М.Ю., 2005; Белоусов Ю.Б., Белоусов Д.Ю., Григорьев В.Ю. и соавт., 2006; Оганов Р.Г., Масленникова Г.Я., 2000, 2007]. Стресс является компонентом адаптации организма к окружающей среде. Вследствие увеличения ритма жизни современного общества и количества стрессорных ситуаций, происходит подъем заболеваемости так называемыми болезнями адаптации, к которым относят и ряд заболеваний сердечно-сосудистой системы [Меерсон Ф.З. 1993]. В основе неблагоприятных последствий стресса лежит дисбаланс деятельности стрессреализующих и стресс-лиммитирующих систем [Манухина Е.Б., Малышев И.Ю. 2000]. При действии чрезмерных по силе или продолжительности раздражителей происходит срыв стресс-лимитирующих систем, которые способны ограничивать повреждающее действие гормонов и медиаторов стресс-реализующих систем. В настоящее время принято различать центральные (ГАМК, опиоидэргические) и переферические (простагландины, антиаоксиданты) стресс-лимитирующие системы. Абсолютно уникальной является стресс-лимитирующая система оксида азота, которая имеет как центральный, так и периферический компонент [Манухина Е.Б., Малышев И.Ю. 2000]. Доказано, что при ряде заболеваний сердечно - сосудистой системы имеет место нарушение синтеза оксида 
азота эндотелием, вследствие чего развиваются локальные и системные нарушения гемодинамики [Лямина Н.П., Сенчихин В.Н., Долотовская П.В., Сипягина А.Г., 2001]. Следовательно, изменения гемодинамики у животных в состоянии стресса являются не только аналогичными, но и гомологичными (имеющими ту же природу), изменениям линейной скорости кровотока у больных с заболеваниями сердечно-сосудистой системы. Все выше изложенное дает основания считать нарушения гемодинамики у животных в состоянии имммобилизационного стресса точной моделью нарушений линейной скорости кровотока у больных с заболеваниями сердечно-сосудистой системы.

В настоящее время для коррекции нарушений гемодинамики у больных с заболеваниями сердечно-сосудистой системы используется широкий спектр медикаментозных препаратов, обладающих свойствами вазоконстрикторов. Однако классические схемы медикаментозной терапии часто оказываются недостаточно эффективными, фармакотерапия сопровождается развитием различной степени выраженности побочных эффектов [Лоуренс Д.Р., Бенитт П.Н., 1993; Машковский М.Д. 2005]. Все это обусловливает необходимость поиска новых немедикаментозных методов коррекции. Одним из таких методов является использование волн миллиметрового и субмиллиметрового диапазонов частот.

Электромагнитные волны крайне высокой частоты (КВЧ-волны) уже достаточно давно и успешно применяются в лечении ряда заболеваний [Девятков Н.Д., Голант М.Б., Бецкий О.В., 1991, 1994; Киричук В.Ф., Головачева Т.В., Чиж А.Г., 1999, Бецкий О.В., Девятков Н.Д., Лебедева Н.Н., 2000а, 2000б; Синицын Н.И., Петросян В.И., Елкин В.А. и др., 2000; Паршина С.С., Головачева Т.В., Киричук В.Ф. и др., 2009]. КВЧ-терапия, в частности, доказала свою эффективность в комплексном лечении болезней сердечно-сосудистой системы - острого инфаркта миокарда и нестабильной стенокардии [Головачева Т.В., 1991; Семенова С.В., 1994; Паршина С.С., Киричук В.Ф., Головачева Т.В., 1995; Киричук В.Ф., Головачева Т.В., Чиж А.Г., 1999; Люсов В.А., Волон Н.А., Гафурова Р.М. и др., 2000; Паршина С.С., Головачева Т.В., Старостина Н.В. и др., 2000, Паршина С.С., 2006; Паршина С.С., Головачева Т.В., Киричук В.Ф. и др., 2009]. К числу преимуществ данного способа следует отнести высокую результативность, неинвазивность, небольшое количество побочных реакций и противопоказаний к применению, невысокую стоимость лечения, возможность сочетания с другими методами терапии, отсутствие побочных эффектов и отдаленных неблагоприятных результатов, высокую эффективность в виде монотерапии и удобство применения в стационаре [Девятков Н.Д., Голант М.Б., Бецкий О.В., 1991, 1994; Арзуманов Ю.Л., Бецкий О.В., Девятков Н.Д. и др., 1997; Гедымин Л.Е., и др., 2000, Киричук В.Ф., Головачева Т.В., Чиж А.Г., 1999; Гедымин Л.Е., Голант М.Б., 
Колпикова Т.В. и др., 2000; Паршина С.С., 2006; Водолагин А.В., 2008; Паршина С.С., Головачева Т.В., Киричук В.Ф. и др., 2009].

Как известно, при классической КВЧ-терапии электромагнитное воздействие осуществляется на частотах 42,2 ГГц и 53,5 ГГц [Девятков Н.Д., Голант М.Б., Бецкий О.В., 1994; Архипов М.Е., Новицкий Я.М., Перфильев В.Е. и др., 1999; Киричук В.Ф., Головачева Т.В., Чиж А.Г., 1999; Бецкий О.В., Девятков Н.Д., Лебедева Н.Н., 2000; Федоров А.С., Королев Л.С., Беляков С.В., 2000]. Помимо этого, в настоящее время исследуются вопросы взаимодействия биологических объектов с электромагнитными полями всего миллиметрового и субмиллиметрового диапазона частот.

Терагерцевая терапия (ТГЧ-терапия) является относительно новым, но весьма перспективным методом физиотерапевтического воздействия [Бецкий О.В., Креницкий А.П. и др., 2003]. Терагерцевый диапазон частот лежит на границе между электроникой и фотоникой от 100 ГГц до 10 ТГц (1 ТГц $=10^{3}$ ГГц) или в длинах волн от 3 мм до 30 мм. Снизу он определен частотно-временным ограничением (более 100 ГГц) электронных переходов в полупроводниковых структурах, а сверху - максимальной длиной волны квантовых переходов лазерных структур. Этот диапазон волн находится на шкале электромагнитных волн между КВЧ - диапазоном и оптическим инфракрасным (ИК) диапазоном и частично перекрывает высокочастотную часть КВЧ диапазона (100 ГГц 300 ГГц) и низкочастотную часть ИК диапазона.

Молекулярные спектры излучения и поглощения (МСИП) многих биологически активных веществ (оксида азота - NO, оксида углерода - CO, молекулярного кислорода и его активных форм и др.) находятся в терагерцовом диапазоне [Башаринов А.Е., Тучков Л.Г., Поляков В.М., Аланов Н.И., 1968; Мериакри В.В., 2002; Бецкий О.В., Креницкий А.П., Майбородин А.В., Тупикин В.Д., 2003; Бецкий О.В., Креницкий А.П., Майбородин A.B., 2007; Rothman L.S., Barbe A., Chris Benner D., 2003]. Среди перечисленных метаболитов наибольшим значением в регуляции физиологических процессов обладает, безусловно, оксид азота (NO) [Снайдер С.Х., Бредт Д.С., 1992; Марков Х.М., 1996; Furchgott R.F., 1980, 1991; Ignarro L.G. et al.,1987, 1995, 1999; Moncada S., Palmer R.U., Higgs E.A., 1995].

Проведенные нами исследования свидетельствуют, что электромагнитное облучение терагерцевого диапазона на частотах МСИП оксида азота 150,176 - 150,664 ГГц не оказывает влияния на линейную скорость кровотока интактных животных. При этом все показатели гемодинамики статистически достоверно не отличаются от показателей интактных животных. 
В то же время наши исследования по изучению влияния электромагнитного излучения терагерцевого диапазона на частотах МСИП оксида азота 150,176 - 150, 664 ГГц на стрессорные нарушения линейной скорости кровотока у белых-крыс показали способность данного вида облучения нормализовать нарушенные показатели гемодинамики. Так, установлено, что эффективность ТГЧ-воздействия на частотах МСИП оксида азота 150,176 - 150,664 ГГц не зависит от времени экспозиции электромагнитных волн: 5, 15 и 30 минутные экспозиции вызывают полное восстановление нарушенных показателей гемодинамики у крыс-самцов в состоянии острого иммобилизационного стресса. Отмечалась нелинейная зависимость эффекта от дозы облучения [Бецкий О.В., Лебедева Н.Н., 2001].

Предложено несколько подходов к объяснению механизмов воздействия на биологические объекты (на организменном, клеточном и молекулярном уровнях) ЭМИ миллиметрового и субмиллиметрового диапазонов. Наиболее полным представляется подход, развитый в работах Н.Д. Девяткова, М.Б. Голанта, О.В. Бецкого [1991], О.В. Бецкого [1995, 1997], О.В. Бецкого, Н.Д. Девяткова, В.В. Кислова [1998], О.В. Бецкого, Н.Н. Лебедевой [2002]. В реализации эффектов ТГЧ-облучения участвуют биохимические механизмы, приводящие к активации различных ферментных систем [Киричук В.Ф., Цымбал А.А., Андронов Е.В. 2009].

Установлено, что КВЧ-воздействие на классических частотах (42,2 и 53,5 ГГц) обладает выраженным воздействием на мембраны клеток, стимулирует перемешивание ее липидных слоев и белковых компонентов [Девятков Н.Д., Голант М.Б., Бецкий О.В., 1991]. Существуют данные о способности КВЧ-волн вызывать изменения гидратации белковых структур мембранных рецепторов [Бецкий О.В., 1997].

Другим из возможных механизмов действия ТГЧ-облучения на частотах МСИП NO является активация эндогенного оксида азота [Киричук В.Ф. и др., 2005]. Согласно одной из теорий [Бецкий О.В. и др., 1998] при облучении энергия КВЧ и ТГЧ - излучения расходуется на переходы молекул из одного энергетического состояния в другое. При используемых в медико-биологической практике уровнях мощности КВЧ и ТГЧ экзогенное воздействие электромагнитного излучения приводит к изменению вращательной составляющей полной энергии молекул. При совпадении частоты проводимого облучения с частотой вращения полярных молекул возможна перекачка энергии излучения молекуле, сопровождающаяся увеличением ее вращательной кинетической энергии, влияющей на ее реакционную способность.

Согласно другому мнению, изменения вращательной составляющей энергии молекулы оксида азота не происходит [Ковалев А.А.,2006]. Полагают, что наличие на 
внешней орбитали неспаренного электрона придает молекуле NO парамагнитные свойства [Парселл Э., 1971]. При интеграции в пространственную сетку водородных связей воды (растворении) таких молекул, магнитные силы спинов их неспаренных электронов способны взаимодействовать с магнитными моментами протонов. В подобной магнитной системе внешнее высокочастотное поле может возбуждать относительные колебания спинов, называемые спиновыми волнами [Ивановский В.И., Черникова Л.А., 1981]. Периодическое изменение ориентации спина гидратированной парамагнитной молекулы способно инициировать волнообразную динамику спинов протонов пространственной сетки водородных связей [Захаров С.Д., Иванов А.В. и др., 2003]. Граничная частота спиновых волн составляет порядка $10^{10}-10^{11}$ Гц $(10-100$ ГГц) [Кулагин Н.А., Свиридов Д.Т., 1986], они имеют квантовую природу [Китель Ч., 1978] и возбуждаются по механизму спин-волнового резонанса [Ивановский В.И., Черникова Л.А., 1981]. Это означает, что спиновые волны могут возбуждаться электромагнитными излучениями определенных длин волн, относящихся к миллиметровому и субмиллиметровому диапазону. При растворении в водной фазе биосистемы молекула NO утрачивает вращательную активность, но сохраняет способность поглощать электромагнитное излучение частотой своего вращательного спектра. Следовательно, одним из возможных механизмов действия электромагнитного излучения на частотах молекулярного спектра излучения и поглощения оксида азота является преобразование энергии электромагнитного излучения в поток магнитного порядка (спиновых волн) от растворенных молекул NO на гидратированный комплекс клеточных и внеклеточных белков [Ковалев А.А.,2006]. Изменение гидратации белковой молекулы изменяет и ее активность.

Не исключена возможность взаимодействия ТГЧ-волн с NO-синтазами [Киричук В.Ф., Андронов Е.В., Мамонтова Н.В. 2008; Киричук В.Ф., Цымбал А.А., Андронов Е.В. 2009; Киричук В.Ф., Андронов Е.В., Антипова О.Н. и др. 2009; Киричук В.Ф., Андронов Е.В., Антипова О.Н., Ефимова Н.В. и др. 2009]. Результатом подобного взаимодействия может являться ускорение внутримолекулярного переноса электронов (с FAD на FMN и с FMN на оксидазный домен) [Горрен А.К.Ф., Майер Б. 1998], что приводит к увеличению скорости катализа. Кроме того, возможно взаимодействие ТГЧ-излучения с гемом NOсинтазы и/или гуанилатциклазы - главной мишени эндогенного оксида азота, приводящее к переходу его в высокоспиновое состояние, что сопровождается увеличением сродства NO-синтазы к L-аргинину и повышению активности фермента. Таким образом, при облучении ТГЧ-волнами на частотах молекулярного спектра излучения и поглощения оксида азота возможно увеличение реакционной способности и/или концентрации 
эндогенного оксида азота. Так, показано, что введение ингибитора NO-синтазы L-NAME животным, находящимся в состоянии оксидативного стресса, блокирует восстанавливающий эффект терагерцевого облучения на частоте молекулярного спектра излучения и поглощения оксида азота [Киричук В.Ф., Цымбал А.А., Андронов Е.В., 2009].

Условно можно выделить три уровня реализации эффектов повышения активности NO под влиянием ТГЧ-воздействия на линейную скорость кровотока при стрессе: непосредственное влияние на гладкомышечные клетки сосудов - аутокринное действие; эндотелий опосредованное паракринное действие и экстравазальные эффекты, NOзависимыми изменениями нервной и гуморальной регуляции [Киричук В.Ф., Цымбал А.А., Андронов Е.В. 2009].

Аутокринное действие оксид азота проявляется в том, что, проникая в гладкомышечные сосудистые клетки, активирует гуанилатциклазу, которая увеличивает образование цГМФ [Северина И.С. 1998]. В результате увеличивается скорость продукции цГМФ в мышечных клетках. Высвобождение и накопление цГМФ приводит к активации фермента цГМФ - зависимой протеинкиназы [Ванин А.Ф., 1998]. Потенциальными мишенями для цГМФ-зависимой протеинкиназы (тип I) в сосудистых гладкомышечных клетках, являются $\mathrm{Ca}^{2+}$ зависимые калиевые каналы и IRAG - белки, участвующие в модулировании входа внеклеточных и высвобождении внутриклеточных ионов кальция. Фосфорилирование этих двух белков может снижать концентрацию цитозольного кальция, что ведет к расслаблению сосудов [Feil R., Lohmann S.M., Hugo de Jonge, et.al., 2003].

Паракринное влияние оксида азота через эндотелий может быть связано с выделением эндотелиальными клетками как непосредственно оксида азота, так и ряда эндотелийзависимых вазодилататоров (ацетилхолина, брадикинина, гистамина), которые тормозят образование эндотелиального сосудосуживающего фактора эндотелина - I и высвобождение норадреналина окончаниями симпатических нейронов, препятствует осуществлению чрезмерных эффектов других вазоконстрикторов (ангиотензина, тромбоксана $\mathrm{A}^{2}$ ) [Машина С.Ю., Смирин Б.В., Малышев И.Ю. и соавт., 2001, Манухина Е.Б., Машина С.Ю., Власова М.А. и др., 2004].

Нами впервые установлено, что облучение животных терагерцевыми волнами на частотах МСИП оксида азота 150,176 - 150,664 ГГц до начала действия стрессора способно предотвращать развитие характерных для острой стресс-реакции нарушений линейной скорости кровотока. Такие показатели гемодинамики как линейная скорость кровотока при ТГЧ-облучении животных перед иммобилизацией статистически 
достоверно ниже, чем у животных, подвергнутых иммобилизации без предшествующего стрессу ТГЧ-облучению.

До настоящего времени считается, что электромагнитное облучение миллиметрового и субмиллиметрового диапазонов частот оказывает эффект только на организм с измененным функциональным состоянием, а интактные животные и здоровые люди невосприимчивы к этому виду излучения [Девятков Н.Д., Голант М.Б., Бецкий О.В., 1991]. Наши данные так же показывают, что при облучении интактных животных ТГЧволнами на частотах МСИП NO 150,176 - 150,664 ГГц не вызывает изменения линейной скорости кровотока. Однако, предшествующее действию стрессора ТГЧ-облучение изменяет протекание стрессорной реакции, что выражается в отсутствии стрессорных нарушений линейной скорости кровотока. По всей видимости, воздействуя на интактный организм, ТГЧ-облучение не изменяет основных физиологических параметров, но воздействует на механизмы регуляции, изменяя реактивность организма.

Известно, что часть синтезированного оксида азота может связываться в комплексы, которые образуют физиологически активное депо [Ванин А.Ф., 1998]. Это депо может не только связывать, но и постепенно высвобождать NO. Депонирование оксида азота происходит в стенках сосудов и начинается при повышении его концентрации. По-видимому, этим и объясняется эффективность профилактических курсов ТГЧ-облучения, так как доказано, что формирование NO-депо является важной частью адаптивных реакций [Пшенникова М.Г. и др., 2000; Машина С.Ю. и др., 2001; Манухина Е.Б. и др., 2004].

Отдельного внимания заслуживают NO-зависимые изменения нейрогуморальной регуляции функций организма. Активация NO-эргических нейронов в центральной нервной системе предупреждает гиперсекрецию основных гипоталамо-гипофизарных стрессорных гормонов: адренокортикотропина, рилизинг-фактора кортикотропина и др. [Kostoglou-Athanassiou I., 1998]. Так же NO-эргические нейроны богато иннервируют мозговое вещество надпочечников, непосредственно контактируя с хромаффинными клетками, и при активации блокируют выброс катехоламинов надпочечниками [Addicks К., 1994]. Кроме того, оксид азота способен блокировать выделение катехоламинов из нервных окончаний [Манухина Е.Б., Малышев И.Ю., 2000; Addicks K., 1994].

Исследования показали [Цымбал А.А., 2007], что ТГЧ-облучение на частотах МСИП оксида азота 150,176 - 150,664 ГГц белых крыс самцов способно снижать уровень кортикостероидов у животных в состоянии стресса и предотвращать повышение их уровня при облучении до начала действия стрессора. 
NO-эргическая система находится в тесной взаимосвязи с другими стресслимитирующими системами. Так, оксид азота потенцирует ГАМК-эргическую систему за счет блокады ГАМК-трансаминазы [Paul V. et al., 2000], приводя к увеличению концентрации ГАМК, и стимулирует высвобождение опиоидных пептидов в мозгу, вследствие чего потенцирует опиоид-эргическую стресс-лимитирующую систему [Armstead W.M., 1998].

Увеличение активности NO-эргической стресс-лимитирующей системы, возможно, и объясняет более высокую эффективность предшествующего стрессу ТГЧ-воздействия на частотах МСИП оксида азота, поскольку при данном режиме облучения изначально блокируется гиперпродукция стресс-гормонов, обусловливающих развитие характерных нарушений гемодинамики. Полученные нами данные хорошо согласуются с экспериментальными исследованиями других авторов. Так, Е.Н. Чуян и соавт. [2003] показали, что стресс-лимитирующее действие ЭМИ КВЧ с длинами волн 5,6 и 7,1 мм зависит от последовательности воздействия электромагнитного облучения.

Таким образом, предшествующее стрессу ТГЧ-воздействие изменяет протекание стресс-реакции, повышают устойчивость животных к действию стрессора. Данный эффект является экспериментальным обоснованием для создания специального медицинского оборудования, разработки и внедрения в практическую медицину нового направления физиотерапии «Терагерцевая терапия» - «ТГЧ-профилактика» [Киричук В.Ф., Цымбал А.А., Андронов Е.В., 2009].

Нами проведена серия экспериментов с целью сравнения эффективности ТГЧвоздействия на стрессорные нарушения линейной скорости кровотока в непрерывном и дробном режимах облучения. Установлено, что ТГЧ воздействие в дробном и непрерывном режимах общей продолжительностью 5 и 15 минут одинаково эффективно снижает повышенные показатели гемодинамики в брюшной аорте и бедренной артерии. В сонной артерии при применении дробного и непрерывного режима облучения статистически достоверных различий не обнаружено ни по сравнению с группой контрольных животных, ни с животными, подвергнутыми острому иммобилизационному стрессу.

Таким образом, можно выделить основные закономерности влияния электромагнитного излучения терагерцевого диапазона на частотах МСИП оксида азота на стрессорные нарушения линейной скорости кровотока у белых крыс:

1. ТГЧ-излучение на частотах МСИП оксида азота 150,176 - 150,664 ГГц не оказывает влияние на линейную скорость кровотока в магистральных сосудах у интактных животных. 
2. ТГЧ-излучение на частотах МСИП оксида азота является эффективным методом коррекции гемодинамических нарушений, вызванных иммобилизационным стрессом.

3. Эффективность ТГЧ-воздействия не зависит от времени экспозиции электромагнитных волн. 5, 15 и 30 минутное ТГЧ - облучение приводит к полному восстановлению нарушенных в результате острого имммобилизационного стресса показателей линейной скорости кровотока в брюшной аорте и бедренной артерии, увеличение времени облучения не приводит к дальнейшему роста эффекта ТГЧ - волн, следовательно, наиболее эффективным является 5 минутный режим ТГЧ - облучения. В сонной артерии при применении всех временных режимов статистически достоверных различий по сравнению с группами контроля и сравнения не обнаружено.

4. ТГЧ-облучение способно предотвращать характерные для стресс-реакции нарушения линейной скорости кровотока в исследуемых магистральных сосудах.

5. Эффективность ТГЧ-воздействия зависит от режима облучения. ТГЧ-облучение в дробном и превентивном режимах менее эффективны по сравнению с непрерывным режимом облучения.

Полученные результаты хорошо согласуются с данными других авторов о влиянии ТГЧ-излучения на частотах МСИП оксида азота 150,176 - 150,664 ГГц на микро- и макроциркуляцию, реологию крови, систему гемостаза. Так, в работах В.Ф. Киричука, А.А. Цымбала, О.Н. Антиповой, и др. [2004, 2005, 2006] показано, что проводимое параллельно с действием стрессорного агента облучение ТГЧ - электромагнитным излучением на частотах молекулярного спектра излучения и поглощения оксида азота предупреждает развитие стресс-зависимых изменений в системе гемостаза, что свидетельствует о принципиальной возможности коррекции этих изменений данным видом излучения. Облучение животных в значительной мере предотвращает гиперкоагуляционный эффект стресса, что обусловлено снижением активности протромбинового комплекса, замедлением скорости формирования фибринового сгустка, нормализацией антикоагулянтной активности крови.

ТГЧ-воздействие на частотах молекулярного спектра излучения и поглощения оксида азота 150,176-150,664 ГГц оказывает положительное влияние на коагуляционные свойства крови у животных, находящихся в состоянии иммобилизационного стресса. Наиболее эффективными в восстановлении показателей гемокоагуляции являются 15-ти и 30-ти минутные режимы облучения. При 5-ти минутном режиме облучения положительный эффект на показатели, характеризующие коагуляционный потенциал крови, незначителен [Киричук В.Ф., Цымбал А.А., Антипова О.Н., и др., 2004, 2005, 2006]. 
Экспериментальные исследования показали положительное восстанавливающее влияние ТГЧ-воздействия на частотах МСИП оксида 150,176 - 150664 ГГц азота на качественный и количественный состав эритроцитов крови белых крыс, находящихся в состоянии иммобилизационного стресса. Наиболее эффективным в этом отношении является 15-минутный режим облучения. При 5-ти и 30-ти минутных режимах облучения выраженность восстанавливающего эффекта на исследуемые показатели эритроцитов было менее значительно [Киричук В.Ф., Помошникова О.И., Антипова О.Н., и др. 2004, Помошникова О.И., 2006].

Выявлено положительное влияние ТГЧ-воздействия на частоте молекулярного спектра излучения и поглощения оксида азота 150,176-150,664 ГГц на реологические свойства крови у животных, находящихся в состоянии иммобилизационного стресса. Наиболее эффективными в восстановлении показателей реологии крови являются 15 -ти и 30-ти минутные режимы облучения. При 5-ти минутном режиме облучения выраженный положительный эффект на показатели, характеризующие реологические свойства крови, незначителен [Киричук В.Ф., Антипова О.Н. и др., 2004, 2007].

На основании всех выше изложенных данных можно сделать выводы о нормализующем влиянии электромагнитного излучения терагерцевого диапазона на частотах МСИП оксида азота 150,176 - 150,664 ГГц на нарушения микро- и макроциркуляции у животных в состоянии острого иммобилизационного стресса.

Изменение под влиянием ТГЧ-воздействия линейной скорости кровотока, функциональной активности тромбоцитов, реологических свойств крови, коагуляционного звена гемостаза, качественного и количественного состава эритроцитов и поведенческой реакции животных и гормонального баланса позволяют говорить об общем антистрессорном эффекте ТГЧ-волн [Киричук В.Ф., Цымбал А.А., Антипова О.Н., и др., 2004, 2005, 2006; Киричук В.Ф., Помошникова О.И., Антипова О.Н., 2004, 2006; Киричук В.Ф., Антипова О.Н. и др., 2004, 2007; Киричук В.Ф., Великанова Т.С. и др., 2008; Цымбал А.А., 2007; Киричук В.Ф., Цымбал А.А., 2010].

Таким образом, для клинического использования ЭМИ ТГЧ на частотах МСИП оксида азота 150,176 - 150,664 ГГц имеются все необходимые теоретические и экспериментальные предпосылки. На основании результатов данной работы была проведена клиническая апробация действия электромагнитного ТГЧ-излучения на частотах МСИП оксида азота. В настоящее время изучено влияние ЭМИ ТГЧ на здоровых донорах-добровольцах и пациентах с заболеваниями сердечно-сосудистой системы [Паршина С.С., Киричук В.Ф., Головачева Т.В., 2004; Паршина С.С., 2006; Водолагин А.В., 2008; Паршина С.С., Головачева Т.В., Киричук В.Ф., 2009 ]. 
Первый опыт клинического использования электромагнитного излучения терагерцового диапазона на частотах МСИП оксида азота 150,176 -150,664 ГГц свидетельствует о целесообразности дальнейшего изучения и применения ЭМИ КВЧ-NO у больных с сердечно-сосудистой патологией [Паршина С.С., 2006; Водолагин А.В., 2008; Паршина С.С., Головачева Т.В., Киричук В.Ф., 2009].

ЭМИ КВЧ-NO обладает мощным вазоактивным эффектом, требующим всестороннего исследования. Полученные клинические данные об вазоконстрикторном, антиагрегантном, антиангинальном и гипокоагуляционном эффекте ЭМИ КВЧ-NO позволяют говорить о возможности его использования у больных с ишемической болезнью сердца, в частности, с нестабильной стенокардией [Паршина С.С., Киричук В.Ф., Головачева Т.В., 2004; Паршина С.С., 2006; Водолагин А.В., 2008; Паршина С.С., Головачева Т.В., Киричук В.Ф., 2009]

Таким образом, в условиях эксперимента на животных нами получены новые данные о характере воздействия ТГЧ-облучения на частотах МСИП оксида азота 150,176 - 150,664 ГГц на нарушенную гемодинамику у животных в условиях острого стресса. Показано что, ТГЧ-облучение способно восстанавливать стрессорные нарушения гемодинамики у белых крыс-самцов. Показана зависимость эффекта ТГЧ-волн на стрессорные нарушения линейной скорости кровотока от режима облучения. Впервые показана способность ТГЧ-облучения на указанных частотах предотвращать развитие характерных для острой стресс-реакции нарушений линейной скорости кровотока.

Полученные нами данные позволяют рекомендовать использование электромагнитного излучения терагерцевого диапазона на частотах МСИП оксида азота 150,176 - 150,664 ГГц в клинической практике для нормализации нарушений гемодинамики при различных, в том числе сердечно-сосудистых, заболеваниях, а также как метод, обладающий выраженным антистрессорным эффектом.

\section{ЛИТЕРАТУРА}

1. Авдонин П.В. Рецепторы и внутриклеточный кальций: биологические и технические мембраны / П.В. Авдонин, В.А.Ткачук // «Наука». - 1994. - С.6-57.

2. Адаптационные реакции организма и система свертывания крови / А.М. Антонов, Н.В. Беликина, С.А. Георгиева, О.П. Желтова и др.// Х съезд всесоюзного физиологического общества им. И.П. Павлова: Матер. Всесоюзн. конф.-1964.-Т. 2.-С. 47.

3. Адаптационные реакции организма как показатели, определяющие эффективность КВЧ-терапии у больных нестабильной стенокардией: новые подходы в лечении / С.С. Паршина, Т.В. Головачева, Н.В. Старостина и др.// 12-й Российский симпозиум с 
международ. участием "Миллиметровые волны в биологии и медицине": Сб. докладов. М.: ИРЭ РАН. 2000. - С. 37-39.

4. Активность тромбоцитов и функциональное состояние эндотелия у больных с нестабильной стенокардией с благоприятными и неблагоприятными исходами / И.В. Воскобой, А.В. Семенов, В.Ф. Киричук и др.// Кардиология. - 2002. - № 9. - С. 4-11.

5. Андронов Е.В. Экспериментальное изучение влияния электромагнитных волн терагерцового диапазона на частотах оксида азота на внутрисосудистый компонент микроциркуляции: Автореф. дис... докт. мед. наук / Е.В. Андронов. - Саратов, 2008.- 50 с.

6. Антипова О.Н. Экспериментальное обоснование использования электромагнитных волн терагерцового диапазона для восстановления нарушенных реологических свойств крови и функциональной активности тромбоцитов: Автореф. дис... докт. мед. наук / О.Н. Антипова. - Саратов, 2009. - 48c.

7. Аршавский И.А. Биологические и медицинские аспекты проблемы адаптации и стресс в свете данных по физиологии онтнгенеза / И.А. Аршавский // В кн.: Актуальные вопросы современной физиологии.- М.: Наука, 1976.-С. 144-191.

8. Балуда В.П. Роль простагландинов и простациклина в регуляции процесса агрегации и реакции освобождения тромбоцитов в норме и при патологии / В.П. Балуда, Г.Н. Сушкевич, Т.И. Лукьянова // Патологическая физиология и эксперимент. терапия. 1980. - №4.- C.80-85.

9. Барабой В.А. Механизмы стресса и перекисное окисление липидов./ В.А. Барабой //Успехи современной биологии. - 1991. - Т 11. - вып 6. - С. 923 - 931.

10. Баркаган 3.С. Система гемостаза / 3.С. Баркаган // В кн: Руководство по гематологии под ред. А.И. Воробьева. - М.: Медицина. - 1985.

11. Белоусов Ю.Б., Белоусов Д.Ю., Григорьев В.Ю. и др. Фармакоэкономический анализ применения левомиседана у больных с тяжелой декомпенсированной хронической сердечной недостаточностью. - Сердечная недостаточность, 2006, Т.7, №1, с.32 - 38

12. Берсудский С.О. Общий адаптационный синдром. - В кн. Общая патология. Саратов: Изд-во Саратовского медицинского университета, 2002, с.79-84.

13. Берклеевский курс физики- Пер с англ. / Э. Парселл - М.: Наука, 1971. - Т. 2. - 323 c.

14. Бецкий О.В. История становления КВЧ терапии и десятилетние итоги работы Медицинской ассоциации КВЧ / О.В. Бецкий, Н.Н. Лебедева // Миллиметровые волны в биологии и медицине. - 2002. - №4. - С. 10-17. 
15. Бецкий О.В. Лечение электромагнитными полями. Ч. 1. Источники и свойства электромагнитных волн / О.В. Бецкий, Н.Д. Девятков, Н.Н. Лебедева // Биомедицинская радиоэлектроника. - 2000. - № 7. - С. 3-9.

16. Бецкий О.В. Лечение электромагнитными полями. Ч. 2. / О.В. Бецкий, Н.Д. Девятков, Н.Н. Лебедева // Биомедицинская радиоэлектроника. - 2000. - № 10. - С. 3-13.

17. Бецкий О.В. Механизм воздействия низкоинтенсивных миллиметровых волн на биологические объекты (биофизический подход) / О.В. Бецкий // Миллиметровые волны в биологии и медицине. М. ИРЭ РАН. - 1997. - С. 135-137.

18. Бецкий О.В. Механизмы первичной рецепции низкоинтенсивных миллиметровых волн у человека / О.В. Бецкий // 10-й Российский симпозиум с международ. участием «Миллиметровые волны в медицине и биологии»: Сб. докладов. - М.:ИРЭ РАН. 1995. С. $135-138$.

19. Бецкий О.В. Миллиметровые волны низкой интенсивности в биологии и медицине / О.В. Бецкий, Н.Д. Девятков, В.В. Кислов // Биомедицинская электроника. - 1998. - №10. - C. 13-29.

20. Бецкий O.В. Современные представления о механизмах воздействия низкоинтенсивных миллиметровых волн на биологические объекты / О.В. Бецкий, Н.Н. Лебедева //Миллиметровые волны в биологии и медицине. - 2001. - № 3. - С. 5 - 18.

21. Биофизичесние эффекты волн терагерцового диапазона и перспективы развития новых направлений в биомедицинской технологии: «Терагерцовая терапия» и «Терагерцовая диагностика» / О.В. Бецкий, А.П. Креницкий, А.В. Майбородин и др. // Биомедицинские технологии и радиоэлектроника. - 2003. - №12. - С. 3-6.

22. Ванин А.Ф. Динитрозильные комплексы железа и $\mathrm{S}$-нитрозотиолы - две возможные формы стабилизации и транспорта оксида азота в биосистемах / А.Ф. Ванин // Биохимия. - 1998. - Т. 63. - № 7. - С. 924-928.

23. Ванин А.Ф. Оксид азота и его обнаружение в биосистемах методом электронного парамагнитного резонанса / А.Ф. Ванин // Успехи физических наук. - 2000. - Т. 170. - №4. - C. $455-458$.

24. Влияние КВЧ-облучения на функции тромбоцитов и эритроцитов белых крыс, находящихся в состоянии стресса / В.Ф. Киричук, О.Н. Антипова и др. // Цитология. 2005. - T. 47. - №1. - C. 64 - 70 .

25. Влияние миллиметровой терапии на нарушения локальной сократимости у больных острым инфарктом миокарда с эпизодами безболевой ишемии миокарда / В.А. Люсов, Н.А. Волон, Р.М. Гафурова и др. // 12-й Российский симпозиум с международ. 
участием "Миллиметровые волны в биологии и медицине": Сб. докладов. М.: ИРЭ РАН. 2000. - C. $82-83$.

26. Влияние различных режимов облучения волнами терагерцового диапазона на восстановление реологических свойств крови при стресс-реакции у белых крыс / В.Ф. Киричук, О.Н. Антипова и др.// «Миллиметровые волны в медицине и биологии»: Сборник трудов 14 Росс. Симп. с межд. участием.- Москва, 2007.- С. 148-151.

27. Влияние электромагнитного излучения терагерцового диапазона на частотах молекулярного спектра излучения и поглощения оксида азота на восстановление качественного и количественного состава эритроцитов крови (in vivo) / В.Ф. Киричук, О.И. Помошникова, О.Н. Антипова и др. // Биомедицинские технологии и радиоэлектроника. - 2004. - №11. - С. 21 - 27.

28. Влияние ТГЧ - терапии - NO на систему гемостаза у больных стабильной стенокардией высоких функциональных классов / А.В. Водолагин, С.С. Паршина, Т.В. Головачева и др. // 15 Российский симпозиум с межд. участием «Миллиметровые волны в биологии и медицине»: Сб. трудов. - М.: ЗАО «МТА - КВЧ». - 2009. - С. 43-46.

29. Водолагин А.В. Патогенетические особенности течения и коррекция диссеминированного внутрисосудистого свертывания крови у больных стенокардией высоких функциональных классов: Автореф. дис... канд. мед. наук / А.В. Водолагин. Саратов, 2008. - 24c.

30. Восстановление микроциркуляторных расстройств под воздействием ЭМИ КВЧ на частотах оксида азота in vivo / В.Ф. Киричук, О.Н. Антипова и др. // MМ волны в биологии и медицине. - 2004. - №2(34). - С. 57-69.

31. Воскобой И.В., Киричук В.Ф., Юданова Л.С. Состояние сосудистотромбоцитарного гемостаза у больных с различными формами стенокардии // российские медицинские вести. 2000,Т. 5, № 1. С. 32-36.

32. Гемокоагуляция и электромагнитное излучение терагерцового диапазона молекулярного спектра оксида азота / В.Ф. Киричук, А.А. Цымбал, О.Н. Антипова и др. // Биомедицинские технологии и радиоэлектроника. - 2004. - №11. - С. 28 - 34.

33. Гемореология и электромагнитное излучение КВЧ-диапазона / В.Ф. Киричук, Л.И. Малинова, А.П. Креницкий и др. // Изд-во СарГМУ. - Саратов, 2003. - 188с.

34. Головачева Т.В. Использование ЭМИ КВЧ при сердечно-сосудистой патологии / Т.В. Головачева // Миллиметровые волны нетепловой интенсивности в медицине: Сб. науч. работ.- М., 1991.-С. 54-57.

35. Влияние КВЧ - терапии на систему гемостаза у больных стабильной стенокардией высоких функциональных классов / Т.В. Головачева, С.С. Паршина, В.Ф. Киричук и др. // 
15 Российский симпозиум с межд. участием «Миллиметровые волны в биологии и медицине»: Сб. трудов. - М.: ЗАО «МТА - КВЧ». - 2009. - С. 41-43.

36. Горрен А.К.Ф. Универсальная и комплексная энзимология синтазы оксида азота / А.К.Ф. Горрен, Б. Майер // Биохимия. - 1998. - Т. 63. - №7. - С. 870 - 880.

37. Гриневич В.В. Иерархические взаимоотношения между органами гипоталамогипофизарно-адреналовой системы при воспалении / В.В. Гриневич, Е.А. Поскребышева, Н.А. Савелов // Успехи физиол. наук. - 1999. - Т. 30. - №4. - С. 50 - 66.

38. Девятков Н.Д. Миллиметровые волны и их роль в процессах жизнедеятельности / Н.Д. Девятков, Н.Б. Голант, О.В. Бецкий // М.: Радио и связь. - 1991. - 168с.

39. Девятков Н.Д. Особенности медико-биологического применения миллиметровых волн / Н.Д. Девятков, Н.Б. Голант, О.В. Бецкий // М.: ИРЭ РАН, 1994. - 160с.

40. Депонирование оксида азота у крыс различных генетических линий и его роль в антистрессорном эффекте адаптации к гипоксии / М.Г. Пшенникова, Б.В. Смирин, О.Н. Бондаренко и др. // Росс. физиол. журнал им. И.М. Сеченова. - 2000. - Т.86. - № 2. - С. $174-181$.

41. Закономерности сдвигов в функциональной активности тромбоцитов под влиянием электромагнитных КВЧ-колебаний на частотах молекулярного спектра излучения и поглощения оксида азота / В.Ф. Киричук, А.В., Майбородин, М.В. Волин и др. // 12 Российский симпозиум с межд. участием «Миллиметровые волны в биологии и медицине»: Сб. докладов. - М.: ИРЭ РАН. - 2001. - С. 96-97.

42. Значение эндотелиальной NO - синтазы в осуществлении положительного эффекта терагерцовых волн на частоте МСИП оксида азота 240 ГГц на агрегационную активность тромбоцитов больных нестабильной стенокардией / В.Ф. Киричук, Е.В. Андронов, О.Н. Антипова и др. // 15 Российский симпозиум с межд. участием «Миллиметровые волны в биологии и медицине»: Сб. трудов. - М.: ЗАО «МТА - КВЧ». - 2009. - С. 103-106.

43. Значение эндотелиальной NO - синтазы в осуществлении коррегирующего воздействия терагерцовых волн на реологические свойства крови белых крыс в состоянии стресса / В.Ф. Киричук, Е.В. Андронов, О.Н. Антипова и др. // 15 Российский симпозиум с межд. участием «Миллиметровые волны в биологии и медицине»: Сб. трудов. - М.: ЗАО «MТА - КВЧ». - 2009. - С. 106-108.

44. Иванов С.Г. О сравнительной эффективности немедикаментозных и лекарственных методов лечения гипертонической болезни / С.Г. Иванов // Тер. Архив.- 1993.- №1.- С.4447

45. Ивановский В.И. Физика магнитных явлений / В.И. Ивановский, Л.А.Черникова Москва: Изд-во МГУ. 1981. - 112 С. 
46. Изменение функциональной активности тромбоцитов под влиянием электромагнитных КВЧ-колебаний на частотах молекулярного спектра излучения и поглощения оксида азота / В.Ф. Киричук, А.В. Майбородин, М.В. Волин и др. // «Вопросы медико-биологических наук». Экспериментальные исследования процессов адаптации. Межвузовский сб. научных работ. - Саранск, 2000. - вып.5. - С. 50-56.

47. Измерение радиотепловых и плазменных излучений в СВЧ-диапазоне / А.Е. Башаринов, Л.Г. Тучков, В.М. Поляков и др. - М.: Советское радио, 1968. - 380 с.

48. Ингибирование Fc-рецептор-зависимой агрегации тромбоцитов моноклональным антителом против комплекса гликопротеинов IIb-IIIa / Д.В. Виноградов, Т.Н. Власик, Т.Г. Агафонова и др. // Биохимия. - 1991. - Т. 56. - № 5. - С. 787 - 798.

49. Индуцированная АДФ агрегация тромбоцитов у больных с гипертонической болезнью с различной степенью гипертрофии миокарда левого желудочка/ Е.В.Балякина, Е.В. Аталанов., 3.А. Габбасов и др.// Тер. Архив. - 1991. - Т. 63. - №12 - С. 50 - 54.

50. Катехоламины, оксид азота и устойчивость к стрессорным повреждениям: влияние адаптации к гипоксии / М.Г. Пшенникова, Е.В. Попкова, Н.А. Бондаренко, и др. // Российский физиол. журнал им. И.М. Сеченова. - 2002. - Т. 88. - № 4. - С. 485 - 495.

51. Квазиоптический КВЧ генераторный комплекс моделирования детерминированных шумов для биофизических исследований / А.П. Креницкий, А.В. Майбородин, О.В. Бецкий и др. // Биомедицинские технологии и радиоэлектроника. 2003. - №2. - C. 17-24.

52. Киричук В.Ф. Антитромбогенная активность стенки сосудов, гемостаз и реологические свойства крови у больных нестабильной стенокардией / В.Ф. Киричук, И.В. Воскобой // Терапевт. Архив. - 2000а. - № 12. - С. 47-50.

53. Киричук В.Ф. Взаимосвязь антитромбогенной активности стенки сосудов и свойств крови у больных нестабильной стенокардией / В.Ф. Киричук, И.В. Воскобой, А.П. Ребров // Тромбоз, гемостаз, реология. -2001. - № 5. - С. 31-34.

54. Киричук В.Ф. Возможности коррекции патологии гемокоагуляции методом терагерцовой терапии/ В.Ф. Киричук, А.А. Цымбал, О.Н. Антипова // Микроциркуляция в клинической практике: Материалы 2 Всероссийской конференции с международным участием. - Москва, 2006. - С. 86.

55. Киричук В.Ф. К вопросу о значении деформируемости эритроцитов / В.Ф. Киричук, И.В. Погожильский // Организация гемостатической помощи. - Саратов, 1988. $132 \mathrm{c}$.

56. Киричук В.Ф. КВЧ-терапия. / В.Ф. Киричук, Т.В. Головачева, А.Г. Чиж - Саратов: Издательство Сар.ГМУ. - 1999. - 360 с. 
57. Киричук В.Ф. Механизмы сосудисто-тромбоцитарного звена системы гемостаза / В.Ф. Киричук, А.А. Свистунов, П.В. Глыбочко // Клинико-физиологические аспекты. Саратов, СГМУ, 1998. - 35c.

58. Киричук В.Ф. Показатели сосудисто-тромбоцитарного механизма гемостаза и ближайший прогноз нестабильной стенокардии / В.Ф. Киричук, Ю.Г. Шварц // Кардиология. - 1998. - № 5. - С. 14-17.

59. Киричук В.Ф. Состояние гемостаза в различных областях сосудистой стенки и гемостаз / В.Ф. Киричук // Тез. Всесоюзн. конфер. - Полтава, 1981.

60. Киричук В.Ф. Состояние сосудисто-тромбоцитарного гемостаза у больных с различными формами нестабильной стенокардии / В.Ф. Киричук, И.В. Воскобой, Л.С. Юданова // Российские мед. Вести. - 2000. - № 1. - С. 32-35.

61. Киричук В.Ф. Физиология крови / В.Ф. Киричук. - Из-во СарГМУ. - Саратов, 1999. $-89 \mathrm{c}$.

62. Киричук В.Ф. Физиология крови / В.Ф. Киричук. - Из-во СарГМУ. - Саратов, 2002. $-102 \mathrm{c}$.

63. Киричук В.Ф. Физиология крови / В.Ф. Киричук. - Из-во СарГМУ. - Саратов, 2005. $-102 \mathrm{c}$.

64. Киричук В.Ф. Механизмы реализации физиологических эффектов волн терагерцового диапазона на частотах оксида азота / в.Ф. Киричук, А.Н. Иванов, А.А. Цымбал и др. // Миллиметровые волны в биологии и медицине. - 2009. - № 3. - С. 58-66.

65. Киричук В.Ф. Дисфункция эндотелия / В.Ф. Киричук, П.В. Глыбочко, А.И. Пономарева. - Саратов: Изд-во СарГМУ. - 2008. - 112с.

66. Киттель Ч. Введение в физику твердого тела / Ч. Киттель // М.:Наука, 1978. - 150 с.

67. Ковалев А.А. О биотропности вращательных спектров и нескомпенсированных магнитных моментов биологически активных молекул / А.А. Ковалев // Миллиметровые волны в биологии и медицине. 2006. - № 3(43). - С. 78 - 81.

68. Конако Ф. Терагерцовые волны / Ф. Конако, Д. Фэйтс // Ж. «Ломоносов».-2002.№5.

69. Коррекция NO-зависимых сердечно-сосудистых нарушений с помощью адаптации к гипоксии / С.Ю. Машина, Б.В. Смирин, И.Ю. Малышев и др. // Росс. физиол. журнал им. И.М. Сеченова. - 2001. - Т. 87. - № 1. - С. 110 - 117.

70. Коррекция острых стресс-зависимых нарушений системы гемостаза с помощью аппарата КВЧ-NO/ В.Ф. Киричук, А.А Цымбал., О.Н. Антипова и др.// Медицинская техника. - 2005. -№1. - С.29-33. 
71. Кузник Б.И. Форменные элементы крови, сосудистая стенка, гемостаз и тромбоз / Б.И. Кузник, В.Н. Скипетров. - М.: «Медицина», 1974. - 197с.

72. Кулагин Н.А. Методы расчета электронных структур свободных и примесных ионов. / Н.А. Кулагин, Д.Т. Свиридов - М.: Наука, 1978. - 117 с.

73. Лебедева А. Ю. Применение электромагнитных волн миллиметрового диапазона в кардиологии / А. Ю. Лебедева // Биомед. радиоэлектрон. - 1998. - № 2. - С. 49-54.

74. Левтов В.А. Реология крови / В.А. Левтов, С.А. Регирер, Н.Х. Шадрина - М.: Медицина, 1982. - 272 с.

75. Лоуренс Д.Р. Клиническая фармакология / Д.Р. Лоуренс, П.Н. Бенитт М.:Медицина 1993. Т. 1. - 640 С.

76. Лупинская 3.А. Эндотелий сосудов основной регулятор местного кровотока / 3.А. Лупинская // Вестник КРСУ. - 2003. - Т. 3. - №7.

77. Мазуров А.В. Наследственные дефекты мембранных гликопротеидов тромбоцитов / А.В. Мазуров, С.А. Васильев // Гематол. и Трансфуз. - 1994а. - Т.39. - С.34-38.

78. Мазуров А.В. Структура и функции мембранных гликопротеидов тромбоцитов/ А.В. Мазуров, С.А. Васильев // Гематол. и Трансфуз. - 1994б. - Т.39. - С.29-34.

79. Малышев И.Ю. Стресс, адаптация и оксид азота / И.Ю. Малышев, Е.Б. Манухина // Биохимия. - 1998. - Т.63. - №7. - С. 992 - 1006.

80. Манухина Е.Б. Стресс-лимитирующая система оксида азота / Е.Б. Манухина, И.Ю. Малышев // Росс. физиол. журнал им. И.М. Сеченова. - 2000. - Т.86. - №. 10. - С. 1283 1292.

81. Марков Х.М. Окись азота и окись углерода - новый класс сигнальных молекул / Х.М. Марков // Успехи физиологических наук. - 1996. - Т. 27. - №4. - С. 30-44.

82. Марков Х.М. Оксид азота и сердечно-сосудистая система / Х.М. Марков // Успехи физиологических наук. - 2001. - Т. 32. - № 3. С. 49 - 65.

83. Меерсон Ф.З. Адаптация, стресс и профилактика / Ф.3. Меерсон // Наука. - М. 1981. $-425 \mathrm{c}$.

84. Меньщикова Н.К. Оксид азота в организме млекопитающих при различных функциональных состояниях / Н.К. Меньщикова, Н.К. Зигков, В.П. Реутов // Биохимия. 2000. - T.65. - № 4. - C. 485 - 503.

85. Мериакри В.В. Состояние и перспективы развития линий передачи субмиллиметрового диапазона волн и устройств на их основе / В.В. Мериакри // Успехи современной радиоэлектроники. - 2002. - №12. 
86. Механизмы передачи сигнала оксидант - оксид азота в сосудистой ткани / М.С. Волин, К.А. Дэвидсон, П.М. Каминска и др. // Биохимия. - 1998. - Т. 63 - № 7. - С. 958 965.

87. Микроциркуляция и электромагнитное излучение ТГЧ-диапазона / В.Ф. Киричук, А.П. Креницкий, А.В. Майбородин, В.Д. Тупикин // - Саратов: Изд -во СарГМУ, 2006. $391 \mathrm{c}$.

88. Миняев В.А., Вишняков Н.И. Общественное здоровье и здравоохранение. Москва6 «МЕДпресс - информ», 2002.

89. Мищенко В.П. Сосудистая стенка как эффекторный регулятор процесса свертывания крови и фибринолиза: Автореф. дисс... докт. мед. наук. / В.П. Мищенко. Новосибирск, 1972. - 32с.

90. Молекулярные HITRAN-спектры газов метаболитов в терагерцовом и ИК диапазонах частот и их применение в биомедицинских технологиях / О.В. Бецкий, А.П. Креницкий, А.В. Майбородин и др. //Биомедицинские технологии и радиоэлектроника. 2007. - № 7. - C. 5 - 9 .

91. Невзорова В.А. Роль окиси азота в регуляции легочных функций / В.А. Невзорова, М.В. Зуга, Б.И. Гельцер // Тер. архив. - 1997. - Т.69. - №3. - С. 68 - 73.

92. Никитина Н.М. Состояние антитромбогенной активности сосудистой стенки у больных стабильной стенокардией. Взаимосвязь с гемореологическими нарушениями / Н.М. Никитина, В.Ф. Киричук, А.Н. Егорова // Тромбоз, гемостаз и реология. - 2002. №2. - C. 33-37.

93. Оганов Р.Г. Сердечно - сосудистые заболевания в Российской Федерации во второй половине XX века: тенденции, возможные причины, перспективы / Р.Г. Оганов, Г.Я. Масленикова // Кардиология. - 2000. - № 6. - С. 65-69.

94. Оганов Р.Г., Масленикова Г.Я. Демографическая ситуация и сердечно - сосудистые заболевания в России: пути решения проблем / Р.Г. Оганов, Г.Я. Масленикова // Кардиоваскулярная терапия и профилактика. - 2007. - Т.6. - № 8. - С.7-14

95. Оксид азота и электромагнитное излучение КВЧ / В.Ф. Киричук, А.П. Креницкий, А.В. Майбородин и др. // Биомедицинские технологии и радиоэлектроника. - 2002. - №10. - C. 95-108.

96. Определение чувствительности плечевой артерии к напряжению сдвига на эндотелий как метод оценки состояния эндотелий-зависимой вазодилятации с помощью ультразвука высокого разрешения у больных с артериальной гипертонией / Т.В. Балахонова, Г.Н. Соболева, О.Ю. Атьков, Ю.А. Карпов // Кардиология. - 1998. - Т.38. №3. - C. 37. 
97. Панин Л.Е. Биохимические механизмы стресса / Л.Е. Панин - Новосибирск: Наука, 1983. - 232 c.

98. Паршина С.С. Адаптационные механизмы системы гемостаза и реологии крови у больных с различными формами стенокардии: Дисс... докт. мед. наук / С.С. Паршина; ГОУ ВПО «Саратовский ГМУ Росздрава» - Саратов, 2006. - 360 с.

99. Паршина С.С. Первые результаты клинического применения электромагнитного излучения терагерцового диапазона на частотах молекулярного спектра оксида азота в кардиологии / С.С. Паршина, В.Ф. Киричук, Т.В. Головачева // Современные аспекты диагностики, лечения и профилактики в кардиологии: Сбор. науч. трудов. - Саратов, 2005. - C. 109-111.

100. Паршина С.С. Новые аспекты клинического использования терагерцовой терапии на частотах молекулярного спектра оксида азота у больных стенокардией / С.С. Паршина, Т.В. Головачева, В.Ф. Киричук и др. // Миллиметровые волны в биологии и медицине. - 2009. - № 4. - С.37-56

101. Первый опыт клинического применения электромагнитного излучения терагерцового диапазона на частотах молекулярного спектра оксида азота / С.С. Паршина, В.Ф. Киричук, Т.В. Головачева и др. // Биомедицинские технологии и радиоэлектроника. 2004. - № 11. - С. 46 - 54.

102. Петренко Ю.М. Новые источники оксида азота, и их возможная физиологическая роль и значение / Ю.М. Петренко, Д.А. Шашурин, В.Ю. Плетнев // Эксперим. Клинич. Фармакол. - 2001. - Т. 64. - № 2. - С. 72 - 80.

103. Помошникова О.И. Влияние ТГЧ-излучения на частотах молекулярного спектра излучения и поглощения оксида азота 150,176 - 150,664 ГГц на качественный и количественный состав эритроцитов крови белых крыс, находящихся в состоянии иммобилизационного стресса. Автореф дисс... канд. мед. наук. / О.И. Помошникова; СарГМУ. - Саратов, 2006. - 23 с.

104. Превентивное антистрессорное действие ЭМИ КВЧ / Е.Н. Чуян, Н.А. Темурьянц, Е.Н. Темурьянц и др. // Миллиметровые волны в биологии и медицине. - 2002. - №2(26). - C.44-51.

105. Пресман А.С. Электромагнитные поля и живая природа / А.С. Пресман - М.: Наука, 1968. - 230 с.

106. Применение ММ-волн в клинической медицине (последние достижения) / Ю.Л. Арзуманов, О.В. Бецкий, Н.Д. Девятков, Н.Н. Лебедева // 11-й Российский симпозиум с международ. участием «Миллиметровые волны в медицине и биологии»: Сб. докладов. - М.:ИРЭ РАН. 1997. С. 9-13. 
107. Реутов В.П. NO-синтетазная и нитритредуктазная компоненты цикла оксида азота / В.П. Реутов, Е.Г. Сорокина // Биохимия. - 1998. - Т. 63. - №7. - С. 1029 - 1040.

108. Рецепторная регуляция активности тромбоцитов / А.Г. Муляр, М.Т. Гасанов, Е.Н. Ющук и др. // Экспериментальная и клиническая фармакология. - 2004. - Т. 67. №1. - С. $61-68$.

109. Ройтман Е.В. Клиническая гемореология / Е.В. Ройтман // Тромбоз, гемостаз, реология. - 2003.- № 3. - С. 13-27.

110. Роль свободного и депонированного оксида азота в адаптации к гипоксии сердечно-сосудистой системы / Е.Б. Манухина, С.Ю. Машина, М.А. Власова и др. // Регионарное кровообращение и микроциркуляция. - 2004. - №3. - С. 4 - 11.

111. Роль электромагнитных волн в процессах жизнедеятельности / Н.И. Синицын, В.И. Петросян, В.А. Елкин и др. // Актуальные проблемы электронного машиностроения: Матер. междунар. научно-техн. конф. - Саратов, 2000. - С. 483-490.

112. Россошанская С.И. Антитромбогенная активность стенки сосудов у больных хронической сердечной недостаточности 2 функционального класса / С.И. Россошанская, В.Ф. Киричук, А.П. Ребров // Клиническая лабораторная диагностика. - 2005. - № 10. - С. $46-49$.

113. Россошанская С.И. Антитромбогенная активность стенки сосудов у больных хронической сердечной недостаточности 2 функционального класса / С.И. Россошанская, В.Ф. Киричук, А.П. Ребров // Клиническая лабораторная диагностика. - 2005. - № 10. - С. $46-49$.

114. Салей А.П., Редкий М.И. Роль оксида азота в формировании мотивационного поведения и обучения / А.П. Салей, М.И. Редкий // Вестник ВГУ. - 2003. - № 1. - C. $75-80$.

115. Северина И.С. YC-1 аналогичное потенцирование NO-зависимой активации растворимой гуанилатциклазы производными протопорфироина IX / И.С. Северина, Н.В. Пятакова, А.Ю. Щеголев // Биохимия. - 2006. - Т. 71. - № 3. - С. 426 - 431.

116. Северина И.С. Растворимая гуанилатциклаза в молекулярном механизме физиологических эффектов окиси азота / И.С. Северина // Биохимя. - 1998. - Т. 63. - № 7. - C. $939-997$.

117. Северина И.С. Растворимая форма гуанилатциклазы в молекулярном механизме физиологических эффектов окиси азота и в регуляции процесса агрегации тромбоцитов / И.С. Северина // Бюл. эксперим. биол. и мед. - 1995. - № 3. - С. 230 -235.

118. Селье Г. Очерки об адаптационном синдроме / Г. Селье - М.: Медицина, 1960. - $254 \mathrm{c}$. 
119. Семенова С.В. Влияние электромагнитного излучения миллиметрового диапазона на функциональное состояние системы гемостаза у больных инфарктом миокарда / С. В. Семенова // Автореф. дис. ... канд. мед. наук. - Саратов, 1994. - 25 с.

120. Снайдер С.Х. Биологическая роль окиси азота / С.Х. Снайдер, Д.С. Бредт // В мире науки. - 1992. - №7. - С.15-24.

121. Структурные престройки в водной фазе клеточных суспензий белковых растворов при светокислородном эффекте / С.Д. Захаров, А.В. Иванов, Е.Б. Вольф и др. / Квантовая электроника. - 2003. - Т. 33. - №2. - С. 149 - 162.

122. Субботина В.Г. Влияние антагонистов кальции на агрегацию у больных с ишемической болезнью сердца Автореф. дисс... канд. мед. наук. /В.Г. Субботина; СарГМУ. - Саратов, 1995. - 25 с.

123. Суточная продукция NO у больных артериальной гипертонией II стадии / Н.П. Лямина, В.Н. Сенчихин, П.В. Долотовская, А.Г. Сипягина // Росс. кардиол. журн. 2001. - № 32. - C. 34-7.

124. Сухова С.В. Характер изменения агрегационной функции тромбоцитов под влиянием электромагнитного излучения терагерцового диапазона на частоте молекулярного спектра излучения и поглощения кислорода 129,0 ГГц у животных при экспериментальном стрессе: Автореф. дис... канд. мед. наук / С.В. Сухова.- Саратов, 2008.- 22c.

125. Тенденция развития и схемотехнические решения аппаратуры для КВЧтерапии / М.Е. Архипов, Я.М. Новицкий, В.Е. Перфильев и др. // Физика волновых процессов и радиотехнические системы.-1999.-№3-4.-С. 56-58.

126. Тромбоциты в реакциях системы гемостаза на КВЧ-воздействие / В.Ф. Киричук, М.В. Волин, А.П. Креницкий и др. // Изд. Сар.ГМУ. - Саратов, 2002. - 180с.

127. Тромбоциты/ А.Ш. Бышевский, С.Л. Галян, И.А. Дементьева и др. Тюмень, 1996. - 250 C.

128. Федоров А.С., Королев Л.С., Беляков С.В. Модифицированные аппараты серии «Явь» / А.С. Федоров, Л.С. Королев, С.В. Беляков // Миллиметровые волны в биологии и медицине: Сб. докладов. 12-й Российский симпозиум с международ. участием - М.: ИРЭ РАН, 2000. -С. 159-163.

129. Физиологические механизмы биологических эффектов низкоинтенсивного ЭМИ КВЧ / Е.Н. Чуян, Н.А. Темурьянц, О.Б. Москвичук и др. - Симферополь, 2003. $448 \mathrm{c}$.

130. Физиология системы гемостаза / В.П. Балуда, М.В. Балуда, Н.И. Деянов и др.// M, 1995. - 244c. 
131. Функциональная активность тромбоцитов у больных с фибрилляцией предсердий и ишемическая болезнь сердца. Механизмы патогенеза или компенсации?/ В.Ф. Киричук, Н.А. Железнякова, М.В. Волин и др. // Кардиология. - 2005. - № 2. - С. 5-9.

132. Цымбал А.А. Изменение концентрации кортикостерона - объективного маркера острого и хронического стресса и терагерцовая терапия/ А.А. Цымбал //Аспирантские чтения: Матер. межрегион. конф. посвящ. 150 летию В.И. Разумовского. Саратов, 2007. - С. $175-176$.

133. Чазов Е.И. Эндотелий сосудов человека и атеросклероз (проблемы и перспективы) / С.И. Чазов // Актуальные проблемы современной ангиологии: Тез. докл. ZX сессии общего собрания АМН СССР. - Л, 1990. - С.9-11.

134. Чернух, А. М. Микроциркуляция / А. М. Чернух, П. Н. Александров, О. В. Алексеев. - М.: Медицина, 1984. -429 с.

135. Шитикова А.С. Тромбоцитарный гемостаз / А.С. Шитикова - СПб.: Изд-во СПбГМУ, 2000. - 227 с.

136. Электромагнитное излучение миллиметрового диапазона как метод патогенетической терапии заболеваний сердечно-сосудистой системы / Т.В. Головачева, В.Д. Петрова, С.С. Паршина и др. // Миллиметровые волны в биологии и медицине.-2000.T.17,№1.-C. 18-25.

137. Электромагнитное излучение терагерцового диапазона на частотах оксида азота как метод регуляции концентрации нитритов крови / В.Ф. Киричук, А.Н. Иванов, Е.Г. Кулапина и др. // 15 Российский симпозиум с межд. участием «Миллиметровые волны в биологии и медицине»: Сб. трудов. - М.: ЗАО «МТА - КВЧ». - 2009. - С. 108111.

138. Acute stress affects cytokines and nitric oxide production by alveolar macrophages differently / J.H.A. Persoons, K. Schomagel, J. Breve et al. // Amer. J. Resp. Crit. Care Med. - 1995. - V.153. - P. 619 - 624.

139. Addicks K. Nitric oxide modulates sympathetic neurotransmission at the prejunctional level / K. Addicks, W. Bloch, M. Feelisch // Microsc. Res. Technique. - 1994. №29. - Р. 161 - 168.

140. Alterations of the nitric oxide pathway in cerebral arteries from spontaneously hypertensive rats / A.M. Briones, M.J. Alonso, R. Hernanz et. al. // J. Cardiovasc. Pharmacol. 2002. - V.39. - P. 378-388.

141. Amir S. Nitric oxide in the Nervous System. / S. Amir - N. Y.: Academic Press. (Eds. Vincent S.), 1995. - 162 p. 
142. Antibody responses of mice exposed to low-power microwaves under combined, pulse-and-amplitude modulation / B. Veyret, C. Bouthet, P. Deschaux et al. // Bioelectromagnetics. - 1991. - V.12. - P. $47-56$.

143. Armstead W.M. Nitric oxide contributes to opioid release from glia during hypoxia / W.M. Armstead //Brain Res. - 1998. - V.813. - P. 398 - 401.

144. Association of phospholamban with a cGMP kinase signaling complex / A. Koller, J. Schlossmann, K. Ashman et al. // Biochem. Biophys. Res. Commun. - 2003. V.300. - P. 155-160.

145. Basal release of niric oxide from aortic rings is greater in female rabbits than male rabbits: implications for atherosclerosis / T. Hayashi, J. Fucuto, L. Ignarro, G. Chaudhuri // Proc Nati Acad Sci USA. - 1992. - V. 89. - P. 1259-11263.

146. Bredt D.S. Nitric oxide in the nervous system. / D.S. Bredt - N.Y.: Academic press. (Eds. Vincent S.). - 1995. - 121 p.

147. Caramelo C. Effects of nitric oxide on red blood cell: changes in erythrocyte resistance to hypotonic hemolysis and potassium efflux by experimental maneuvers that decrease nitric oxide / C. Caramelo, A. Riesco, J. Outeirino // Biochem Biophys Res Commun. - 1994. V. 15. - P. 447-454.

148. Cardiovascular protection by oestrogen - a calcium antagonist effect? / P. Collins, G. Rosano, C. Jiang et al. // Lancet. - 1993. - V. 341. - P. 1264-1265.

149. Chisdal P. Action of No donor on the excitation-contraction pathway activated by noradrenaline in rat superior mesenteric artery / P. Chisdal, J.P. Gomez, N. Morel // J. Physiol. (L.). - 2000. - V.522 (Pt 1). - P. 83 - 96.

150. Circulating nitrite/nitrate levels increase with follicular development: indirect evidence for estradiol mediated NO release / M. Rosselli, B. Imthurm, E. Macas et al. // Biochem Biophys Res Commun. - 1994. - V.202. - P. 1543-1552.

151. Clement B. Enzymology and Biochemistry / B. Clement, M.H. Shultze-Mosgau, H. Wohlers - London:. Eds. M. Feelish, R. Busse, S. Moncada, 1994.- 115 p.

152. Conformational changes in platelet glycoprotein IIb - IIIa (aIIb b3-integrine) stimulated by monoclonal antibody to the N-terminal region of glycoprotein IIIa / S.G. Khaspekova, T.V. Bysova, V.V. Lukin et al. // Biochemistry.-1996.-V.61.-P.412-428.

153. Coronary artery spasm and vasoconstriction. The case for a distinction / A. Maseri, G. Davies, D. Hacket, J.C. Kaski // Circulation. - 1990. - V.81. - P. 1983-1991.

154. Coronary vasodilatation and improvement in endothelial dysfunction with endothelin ETA receptor blockade / J.P.J. Halcox, K.R.A. Nour, G. Zalos, A.A. Quyumi // Circ. Res. - 2001. - V. 89. - P. $969-976$. 
155. Cyclic GMP-dependent protein kinases and the cardiovascular system / R. Feil, S.M. Lohmann, H. de Jonge, et.al. // Circulation research. - 2003. - V. 93. - P. 907-916.

156. Cyclic GMP-independent mechanisms contribute to the inhibition of platelet adhesion by nitric oxide donor: A role for $\alpha$-actinin nitration / S. Marcondes, M. H. M. Cardoso, R. P. Morganti et al. // Published online before print. - 2006. - 10.1073/pnas.0509397103

157. De Oliveira Elais M. Nitric oxide modulates Na, K-ATPase activity through cyclic GMP pathway in proximal rats trachea / M. De Oliveira Elais, W. Tavares de Lima, Y.B. Vannuchi // Eur J. Pharmacol - 1999. - 367. - P. 307-314.

158. Deficient platelet-derived nitric oxide and enchanced hemostasis in mice lacking the NOS III gene / J. Freedman, R. Sauter, E.M. Battinelli et. al. // Circ. Res. - 1994. - V. 84. P. 1416-1421.

159. Detection of an epitope specific for the dissociated form of glycoprotein IIIa of platelet membrane glycoprotein IIb-IIIa complex and its expression on the surface of adherent platelets / S.G. Khaspekova, T.N. Vlasik, T.V. Bysova et al. // Brit. J. Haematil.-1993.-V.85.-P. 332-340.

160. Direct measurement of nitric oxide in human beings / P. Vallance, S. Patton, K. Bhagat et al. // Lancet. - 1995. - V.345. - P. 153-154.

161. Diuretics, beta-blockers, and the risk of sudden cardiac death in hypertensive patients / A. Hoes, D. Grobbee, J. Lubsen et al. // Ann. Intern. Med. - 1995. - V. 123. - P. 481487.

162. Durante W. Endothelium-derived relaxing factor inhibits thrombin-induced platelet aggregation by inhibiting platelet phospholipase-C / W. Durante, M.H. Kroll, P.M. Vanhoutte // Blood. - 1992. - V.79. - P. 110-116.

163. Dynamic activation of endothelial nitric oxide synthase by Hsp 90 / G. GarciaGardena, R. Fan, V. Shah, et.al. // Nature. - 1998. - V. 392. - P. 821-824.

164. Effect of exogenous nitric oxide and inhibitors of nitric oxide synthase on the hypothalamo-pituitary pathway / J. Weidenfeld, S. Feldman, F.G. De Keyser, H. Ovadia // J. Chem. Neuroanat. - 1999. - V.8. - P. 165 - 173.

165. Effects of acetylcholine and spermine NONOate on erythrocyte hemorheologic and oxygen carrying properties / R. Mesquita, I. Pires, C. Saldanha et al. // Clin. Hemorheol. 2001. - V.25. - P. 153-163.

166. Effects of nitric oxide on red blood cell deformability / M. Bor-Kucukatay, R.B. Wenby, H.J. Meiselman, et.al.// Am. J. Physiol. Heart Circ. Physiol. - 2003. - V. 284. - № 5. P. 1577-1584. 
167. Endothelial nitric oxide synthase interaction with G-protein-coupled receptors / M.B. Marrero, V.J. Venema, H. Ju et al. // Biochem. J. - 1999. - V.343. - P. 335-340.

168. Endothelium-derived relaxing factor produced and released from artery and vein is nitric oxide / L.G. Ignarro, G.M. Buga, K.S. Wood et al. // Proc. Nat. Acad. Shi. USA. 1987a. - V.84. - P. 9265 - 9269.

169. Endotoxin stimulates an endogenous pathway regulating corticotrophin-releasing hormone and vasopressin release involving the generation of nitric oxide and carbon monoxide / I. Kostoglou-Athanassiou, A. Costa, P. Navarra et al. // J. Neuroimmunol. - 1998. - V.86. - P. $104-109$.

170. Estrogen pretreatment directly potentiates endothelium-dependent vasorelaxation of porcine coronary arteries / D. Bell, H. Rensberger, D. Koritnik, A. Koshy // Am J Physiol. 1995. - V. 268. - P. H377-H383.

171. Expression of inducible nitric oxide synthase and heat shock proteins in periapical inflammatory lesions / T. Suzuki, H. Kumamoto, K. Ooya et al. // J. Oral Pathol. Med. - 2002. V.31 - P. $488-493$.

172. Ferreira S.H. Biology of Nitric Oxide / S.H. Ferreira, I.D.G. Duarte - London: Portland Press. $-1992 .-317$ p.

173. Formation of nitric oxide from L-arginine in the central nerves system: a transduction mechanism for stimulation of the soluble guanylatecyclase / R.G. Knowles, M. Palacios, R.M. Palmer, S. Moncada // Proc. Nat. Acad. Shi. USA. - 1989. - V.86. - P. 5159 5162.

174. Fulton D. Post-translation control of endothelial nitric oxide synthase: why isnt calcium/calmodulin enough? / D. Fulton, J.P. Gratton, W.C. Sessa // J. Pharmacol. Exp. Ther. 2001. - V. 299. - P. 818-824.

175. Furchgott R.F. Endothelium-dependent and -independent vasodilation involving cyclic GMP: relaxation induced by nitric oxide, carbon monoxide and light / R.F. Furchgott, D. Jothianandan // Blood Vessels. - 1991. - V. 28. - P. 52 - 61.

176. Furchgott R.F. The obligatory role of endothelial cells in the regulation of arterial smooth muscle by acetylcholine / R.F. Furchgott, J.V. Zawadzki // Nature. - 1980. - V. 299. - P. 373-376.

177. Fuster V. Cellular and molecular mechanisms of endothelial cell dysfunction / V. Fuster, Z.A. Fayad, J.J. Badimon // Lancet. - 1999. - V. 353. - P. 5-9.

178. Garthwaite. Nitric oxide signalling in the central nervous system / J. Garthwaite, C. Boulton // Annu. Rev. Physiol. — 1995. —V. 57. —P. 683-706. 
179. Gaseous transmitters and neuroendocrine regulation / D.W. Brann, G.K. Bhat, C.A. Lamar, V.B. Mahesh // Neuroendocrinology. - 1997.- V.65. - P. 385 - 395.

180. Gerzer R. The separation of the heme and apoheme forms of soluble guanylate cyclase / R. Gerzer, C.V. Radany, D.Z. Garbers // Biochem. Biophis. Res. Commun. - 1982. №108. - Р. 678-686.

181. Gookin J.L. Inducible nitric oxide synthase mediates early epithelial repair of porcine ileum / J.L. Gookin, J.M. Rhoads, R.A. Argenzio // Am. J. Physiol. Gastrointest. Liver Physiol. - 2002. - V.283. - P. 157-168.

182. Grzelak A. Peroxynitrate activates K-Cl cotransport in human erytrocytes / A. Grzelak, J. Mazur, G. Bartosz // Cell. Biol. Int. - 2001. - V.25. - P. 1163-1165.

183. Han P. Verapamil and collagen induced platelet reaction evidence for a role for intracellular calcium in platelet activation / P. Han, C. Boatwright, N.C. Ardlie // Thromb. Haemostas.-1983.-V.50.-P. 537-540.

184. Hashimoto S. Functional pool of cyclic AMF in rabit platelets / S. Hashimoto // Thrombos. Haemostasis.-1983.-V.49.-P.8-12.

185. Ignarro L.G. Activation of purified soluble guanylate cyclase by arachidonic acid requires absence of enzyme-bound heme / L.G. Ignarro, K.S. Wood // Bichem. Biophys. Acta. 1987b. - V.928. - P. $160-170$.

186. Ignarro L.G. Biosynthesis and metabolism of endothelium-derived nitric oxide / L.G. Ignarro // Annu. Rev. Pharmacol. Toxicol. - 1990. - V.30. - P. 535 - 560.

187. Ignarro L.G. Nitric oxide: biochemistry, molecular biology and therapeutic implication / L.G. Ignarro, F. Murad // Adv. Pharmacol. - 1995. - V.34. - P. 1 - 516.

188. Immobilisation-induced stress activates neuronal nitric oxide synthase (n NOS) mRNA and protein in hypothalamic-pituitary-adrenal axis in rats / J. Kishimoto, T. Tsuchia, P.C. Emson, Y. Nacayama // Brain Res. - 1996. - V.720. - P. 159 - 171.

189. Increase in renal medullary nitric oxide synthase activity in rats / M. Szentivanyi, A.P. Zou, C.Y. Maeda et al. // Hypertension. - 2000. - V.35. - P. $418-423$.

190. Inhibition of platelet aggregation by S-nitroso-cysteine via cGMP-independent mechanisms: evidence of inhibition of thromboxane A2 synthesis in human blood platelets / D. Tsikas , M. Ikic, K.S. Tewes et al. // FEBS Lett. - 1999. - V. 442. - P. 162-166.

191. Inhibition of platelet P2Y2 and $\alpha 2 \mathrm{~A}$ receptor signaling by cGMP-dependent protein kinase / B. Aktas, P. Honig-Liedl, et.al. // Biochen. Pharmacol. - 2002. - V. 64. - P. 433439. 
192. Ju H. Direct interaction of endothelial nitric oxide synthase and caveolin-1 inhibits synthase activity / H. Ju, V.J. Venema, R.C. Venema // J. Biol. Chem. - 1997. - V. 272. - P. 18522-18525.

193. Ju H. Inhibitory interactions of the bradykinin B2 receptor with endothelial nitricoxide synthase / H. Ju, V.J. Venema, M.B. Marrero // J. Biol. Chem. - 1998. - V. 273. - P. 24025-24029.

194. Jubelin B.C. Erytrocytes may synthesize their own nitric oxide / B.C. Jubelin, J.L. Gierman // Am J. Hypertens. - 1996. - V.9. - P. 1214-1219.

195. Konturek S. Role of nitric oxide in the digestive systems / S. Konturek, P. Konturek // Digestion. - 1995. - V.375. - P. 546 - 549.

196. Korbut R. The effect of prostacyclin and nitric oxide on deformability of red blood cells in septic shock in rats / R. Korbut, R.J. Gryglewski // J. Physiol. Pharmacol. - 1996. - V.47. - P. 591-599.

197. Kung C. F. Different mechanisms of endothehal dysfunction with aging and hypertension in rat aorta / C. F.Kung, T. F. Luscher // Hypertension -1995 -V 25, N2, P 194-200

198. Leopold, J.A. New developments in nitrosovasodilator therapy / J.A. Leopold, J. Loscalzo // Vasc. Med.- 1997.-№ 2.-P. 190-202.

199. Lovich T.A. Co-localization of GABA with nicotinamide adenine dinucleotide phosphate-dependent diaphorase in neurons in the dorsolateral periaqueductal grey matter of the rat / T.A. Lovich, N.L. Paul // Neurosci. Lett. - 1999. - V.272. - P. 167 - 170.

200. Marin J. Role of vascular nitric oxide in physiological and pathological conditions / J. Marin, M.A. Rodriges-Martinex // Pharmacol. Ther. - 1997. - V.76. - P. 111-134.

201. Marjanovic J.A. Stimulatory roles of nitric-oxide synthase 3 and guanylyl cyclase in platelet activation / J.A. Marjanovic, Z. Li, A. Stojanovic // The Journal of biological chemistry. - 2005. - V.280. - №45. - P. 37430-37438.

202. Matsuoka I. Mepacrine-induced elevation of cyclic GMP levels and acceleration of reversal of ADP-induced aggregation in washed rabbit platelets / I. Matsuoka, T. Suzuki // J. Cyclic Nucleotide Protein Phosphor. Res. - 1983. - V.9. - P. 5341 - 5353.

203. Mechanism of vascular smooth muscle relaxation by organic nitrates, nitrites, nitroprusside and nitric oxide: evidence for the involvement of S-nitrosothiols as active intermediates / L.G. Ignarro, H. Lippton, J.C. Edwards et al. // J. Pharmacol. Exp. Ther. - 1981. - V.218. - P. $739-749$.

204. Mellion B.Th. Evidence for the inhibitory roloe of guanosint 3,5, monophosphate in ADP-induced human platelet aggregation in the presence of nitric oxide and related 
vasodilators / B.Th. Mellion, L.G. Ignarro, E.V. Ohlstein et al. // Blood. - 1981. - №57. - P. 946949.

205. Modulation of endogenous antioxidant enzymes by nitric oxide in rat C-6 glial cells. / K. Dobashi, K. Pahan, A. Chahal, I. J. Singh // Neurochem. - 1997. - V.68. - P. 1806 1903.

206. Mombouli J.V. Endothelial dysfunction: from physiology to therapy / J.V. Mombouli, P.M. Vanhoutte // J Mol Cell Cardiol. - 1999. - V.31. - P. 61-74.

207. Moncada S. Nitric oxide: physiology, patophysiology and farmacology/ S. Moncada, R.U. Palmer, E.A. Higgs //Pharmacol. Rev. 1995. - V 1, N 2. - P/ 165 - 173.

208. Monsuy D. On the mechanism of nitric oxide formation upon oxidative cleavage of $\mathrm{C}=\mathrm{N}(\mathrm{OH})$ bonds by NO-synthases and cytochromes P450 / D. Monsuy, J.L. Boucher, B. Clement // Biochimie. - 1995. - V. 77. - P. 661.

209. Morbidity and mortality in the Swedish trial in old patients with hypertension (STOP-Hypertension) / B. Dahlof, L.H. Lindholm, L. Hansson et al. // Lancet. - 1991. - V. 338. - P. 1281-1285.

210. Münzel T. Explaining the Phenomenon of Nitrate Tolerance / T. Münzel, A. Daiber, A. Mülsch // AHA Circulation Research. - 2005. - V. 97. - P. 618 - 645.

211. Naesh O. Platelet activation in mental stress / O. Naesh, C. Haedersdal, J. Hindberg // Clin. Phisiol. - 1993. - V.13. - P. 299 - 307.

212. Nitric oxide activates cyclooxigenase enzymes / D. Salvemini, T.P. Misko, J.L. Masferrer et al. // Proc. Nat. Acad. Sci. USA. - 1993. - V.90. - P. 7240 - 7244.

213. Nitric oxide as a signaling molecule in the vascular system: an overview / L.G. Ignarro, G. Cirino, A. Casino et al. // J. Cardiovasc Pharmacol. - 1999. - V.34. - P. 979 886.

214. Nitric oxide decreases cytokine-induced endothelial activation: NO selectively reduces endothelial expression of adhesion molecules and proinflammatory cytokines / $\mathrm{R}$. De Caterina, P. Libby, H. Peng et.al. // J. Clin. Invest. - 1995. - V. 96. - P. 60-68.

215. Nitric oxide stimulates prostaglandin synthesis in cultured rabbit gastric cells / H. Uno, T. Arakawa, T. Fucuda et al. // Prostaglandins. - 1997. - V.53. - P. 153 - 162.

216. Nitric Oxide synthase expression in endothelial cells exposed to mechanical forces / T. Ziegler, P. Silacci, V.J. Harrison et al. // J Am Heart Associat. - 1998. - V.32. - P. 351-355.

217. Non-invasive detection of endothelial dysfunction in children and adults at risk of atherosclerosis / D.S. Celermajer, K.E. Sorensen, V.M. Gooch et al. // Lancet. - 1992. V.340(8828). - P. 1111-1115. 
218. Nozaki - Taguchi N. Involvement of nitric oxide in peripheral antinociception mediated by kappa- and delta-opioid receptors / N. Nozaki - Taguchi, T. Yamamoto // Anesth. Analg. - 1998. - V.8. - P. 393 - 398.

219. Ozone exposure activates oxidative stress responses in murine skin / G. Valacchi, A. van der Vliet, B.C. Schock et al. // Toxicology. - 2002. - V.179. - P. 163-170;

220. Palmer R.M. Nitric oxide release account for the biological activity of endothelium-derived relaxing factor / R.M. Palmer, A.G. Ferrige, S. Moncada // Nature. - 1987. - V.327. - P. $524-526$.

221. Palmer R.M. Vascular endothelial cells synthesize nitric oxide from L-arginine / R.M. Palmer, D.S. Ashton, S. Moncada // Nature. - 1988. - V.333. - P. $6174-6646$.

222. Pataki I. Further evidence that nitric oxide modifies acute and chronic morphine actions in mice / I. Pataki, G. Telegdy // Eur. J. Pharmacol. - 1998. - V.357. - P. 157 - 162.

223. Paul V. A role of nitric oxide as an inhibitor of gamma-amonobutyric acid transaminase in rat brain / V. Paul, A.R. Jayakumar // Brain Res. Bull. - 2000. - V.51. - P. 43 46.

224. Petrov V. Role of cyclic GMP in atrial-natriuretic-peptide stimulation of erythrocyte $\mathrm{Na} / \mathrm{H}$ exchange by soluble and particulate guanylate cyclase / V. Petrov, A. Amery // Eur. J. Biochem. - 1994. - V.221. - P. 195-199.

225. Prevention of water immersion stress-induced gastric lesions through the enhancement of nitric oxide synthase activity in rats / K. Tachi, H. Goto, T. Hayakawa, S. Sugiyama // Aliment. Pharmacol. Ther. - 1996. - V.10. - P. 97 - 103.

226. Pritchard K.A. Heat shock protein 90 mediates the balance of nitric oxide and superoxide anion from endothelial nitric oxide synthase / K.A. Pritchard, A.W. Ackerman, E.R. Gross // J. Biol. Chem. - 2001. - V.276. - P. 17621 - 17624.

227. Ramachi G. Intracellular calcium mobilization is triggered by clustering of membrane glycoprotein in concavalin A-stimulated platelets / G. Ramachi, M. Torti, F. Cinigaglia et al. // J. Cell Biochem.-1993.-V.11.-P.241-249.

228. Rand M.J. Nitric oxide as a neurotransmitter in peripheral nerves: nature of transmitter and mechanism of transmission / M.J. Rand, C.J. Li // Ann. Rev. Physiol. - 1995. V.57. - P. 659-682.

229. Red blood cell rheological alterations in hypertension induced by chronic inhibition of nitric oxide synthesis in rats / M. Bor-Kucukatay, O. Yalcin, O. Gokalp et.al // Clin. Hemorheol. - 2000. - V.22. - P. 267-275.

230. Reed G.L. Platelets in rections of cardiovascular system / G.L. Reed, M.L. Fitzgerald, J. Polgar // Blood. - 2000. - V.96. - P. 3334 - 3342. 
231. Reinhard M. Actin-based motility: stop and go with Ena/Vasp proteins / M. Reinhard, T. Jarchau, U. Walter // Trends Biochem. - 2001. - V.26. - P. 243-249.

232. Role of c-Src in regulation of endothelial nitric oxide synthase expression during exercise training / M.E. Davis, H. Cai, G.R. Drummond, et.al. // Am. J. Physiol. Heart Circ. Physiol. - 2003. - V. 284. - P. 1449-1453.

233. Ruggeri Z.M. Platelets in atherothrombosis / Z.M. Ruggeri // Nat.Med.-2002. V.8. - P. $1227-1234$.

234. Schwarz U.R. Taming platelets with cyclic nucleotides / U.R. Schwarz, U. Walter, M. Eigenthaler // Biochem. Pharmacol. - 2001. - V.2. - P. 15-28.

235. Snyder S.H. Nitric oxide as a neuronal messenger / S.H. Snyder, D.S. Bredt // TIPS - 1991. - V.12. - P. 125 - 128.

236. Soloviev A. Nitric oxide but not peroxynitrite relaxes a-toxin permeabilized smooth muscle of rat tail artery / A. Soloviev, P. Hellstrand, A. Stefanov // J. Vasc. Res. —1997. -V. 34 (1). -P. 138.

237. Soloviev A. Nitric oxide decreases myofilament $\mathrm{Ca}^{2+}$-sensitivityi rat tail artery smooth muscle independent of guanylyl cyclase activation / A. Soloviev, P. Hellstrand, A. Stefanov // J. Vasc. Res. - 1996. —V. 33 (2). -P. 43.

238. Steer M.L. Cyclic nucleotides in hemostasis and thrombosis / M.L. Steer, E.W. Salzman // Adv. Cyclic Nucleotides Res.-1980.-N12.-P. 71-92.

239. Stepol A. Stress and illness. / A. Stepol // Physiol. - 1993. - V.6. - № 2. - P. 76 77.

240. Stokes K. Y. The microcirculation: a motor for the systemic inflammatory response and large vessel disease induced by hypercholesterolaemia? / K.Y. Stokes, D.N. Granger // J. Physiol. - 2004. - V.562 - № 3. - P. 647 - 653.

241. Sun J. Functional interaction of endothelial nitric oxide synthase with a voltagedependent anion channel / J. Sun, J.K. Liao // Proc. Natl. Acad. Sci. USA. - 2002. - V.99. - P. $13108-13113$.

242. Takeda H. Stress-induced gastric mucosal lesion and platelet aggregation in rats / H. Takeda // J. Clin. Gastroenterol. - 1992. - V.14. - P. 145 - 148.

243. The HITRAN molecular spectroscopic database: edition of 2000 including updates through 2001 / L.S. Rothman, A. Barbe, D. Chris Benner et. al // Journal of Quantitative Spectroscopy \& Radiative Transfer. - 2003. - № 82. - P. 5 - 44.

244. Vane J.R. Regulatory function of the vascular endothelium / I.R. Vane, E.E. Anggard, R.V. Bottiyu // N. Engl. J. Med. - 1990. - V.323. - P. 27-36. 
245. Vanhatalo S. Nitric oxide synthase in the hypothalamo-pituitary pathway/ S. Vanhatalo, S. Soinila // J. Chem. Neuroanat. - 1995. - V.8. - P. 165 - 173.

246. Vanhoutte P.M. Endothelial dysfunction and atherosclerosis / H.V. Vanhoutte // Eur. Heart. J. - 1997. - 18. Suppl. E:E 19-E 29.

247. Vanhoutte P.M. Other endothelium - derived vasoactive factors / P.M. Vanhoutte // Circulation. - 1993. - Suppl. V: V9. - V.17.

248. Wink D.A. Chemical biology of nitric oxide: insights into regulatory, cytotoxic, and cytoprotective mechanisms of nitric oxide / D.A. Wink, J.B. Mitchell // Free Radic. Biol. Med. - 1998. - V.25. - P. $434-456$.

249. Yong C.B. Flow-dependent regulation of endothelial nitric oxide synthase: role of protein kinases / C.B. Yong, J. Hanjoong // Am. J. Physiol. Cell Physiol. - 2003. - V.285. - P. $499-508$.

250. Zhang J. Nitric oxide in the nervous system / J. Zhang, S.H. Snyder // Ann. Rev. Pharmacol. Toxicol. - 1995. - V.35. - P. 213 - 233.

251. Ziegler A. Stress - was dann? / A. Ziegler // Vop. - 1994. - V.16. - № 5. - P. 312 $-315$. 


\section{РАЗДЕЛ II}

\section{ВЛИЯНИЕ ЭЛЕКТРОМАГНИТНОГО ОБЛУЧЕНИЯ}

ТЕРАГЕРЦЕВОГО ДИАПАЗОНА НА ЧАСТОТАХ МОЛЕКУЛЯРНОГО СПЕКТРА ИЗЛУЧЕНИЯ И ПОГЛОЩЕНИЯ ОКСИДА АЗОТА 150,176 - 150,664 ГГЦ НА СТРЕССОРНЫЕ ИЗМЕНЕНИЯ ПЕРФУЗИИ МИКРОЦИРКУЛЯТОРНОГО РУСЛА И ФУНКЦИОНАЛЬНОГО СОСТОЯНИЯ ЭНДОТЕЛИЯ СОСУДОВ 


\section{СПИСОК СОКРАЩЕНИЙ}

КВЧ - крайне высокие частоты

МСИП - молекулярный спектр излучения и поглощения

ТГЧ - терагерцевые частоты

$\mathrm{NO}$ - оксид азота 


\section{ВВЕДЕНИЕ}

Актуальной проблемой современного здравоохранения по-прежнему остается профилактика и лечение сердечно-сосудистых заболеваний, в частности, нестабильной стенокардии и инфаркта миокарда в связи с высокой их распространенностью в структуре общей заболеваемости, инвалидности и смертности трудоспособного населения [Миняев, Вишняков, 2002, 34-35; Фармакоэкономический анализ ... , 2006, с. 32-38]. Заболевания сердечно-сосудистой системы лидируют среди причин инвалидности и смертности в России [Оганов, 1993, с. 4 - 8; Паршина, 2006, с. 32 - 40].

В настоящее время доказана роль стресса как главного этиологического фактора ишемической болезни сердца, атеросклероза, гипертонической болезни и многих других заболеваний [Миняев, Вишняков, 2002, 34-35; Берсудский, 2002, с. 79-84]. Устранение данного этиологического фактора сердечно - сосудистой патологии практически невозможно из-за роста интенсивности производственных процессов, что закономерно влечет за собой развитие «болезней адаптации» [Аршавский, 1976, с. 144-191; Меерсон, 1981, с. 120-137; Берсудский, 2002, с. 79-84].

Стресс представляет собой неспецифический компонент физиологических и патологических нейрогуморальных реакций, возникающих в организме под действием любых условий, угрожающих нарушением гомеостаза [Селье, 1960, с. 15; Барабой, 1991, с. 923-931]. Стрессорная реакция развивается в ответ на действие необычных по качеству, интенсивности или продолжительности раздражителей за счет активации двух ведущих стресс-реализующих систем: гипоталамо-симпато-адреналовой и гипоталамо-гипофизарнонадпочечниковой [Меерсон, 1981, с. 120-137; Барабой, 1991, с. 923-931]. Стресс-реакция имеет большое значение в адаптации организма человека и животных к изменяющимся условиям окружающей среды. Однако интенсивные и длительно действующие стрессоры приводят к развитию нарушений, способствующих возникновению ряда заболеваний. В основе неблагоприятных последствий стресса лежит дисбаланс в деятельности стрессреализующих, обусловливающих реакцию организма на действующий стрессор, и стресслимитирующих систем, которые способны ограничивать повреждающее действие гормонов и метаболитов, выделяющихся в ходе стресс-реакции [Малышев, Манухина 1998, c. 992-1006; Манухина, Малышев, 2000, с. 1283-1292].

В последнее время проблема стресса, адаптации и профилактики стрессорных повреждений выдвинулась в число наиболее актуальных проблем современной биологии и медицины [Stepol, 1993, p. 76-77]. Интерес к этой проблеме вызван резкими изменениями условий жизни человека, обусловленными интенсификацией производственных процессов, 
урбанизацией, а также ростом так называемых "болезней адаптации" [Аршавский И.А., 1976 c. 144-191; Меeрсон, 1981, c. 120-137; Ziegler, 1994, p. 312-315].

Особое значение среди болезней адаптации имеют заболевания сердечнососудистой системы, включающие целый ряд нозологических форм, среди которых наиболее серьезными являются гипертоническая и ишемическая болезни (их доля составляет 30-35\%), и такие их проявления как острый инфаркт миокарда и стенокардия [Меерсон, 1981, с. 120-137].

Ведущую роль в патогенезе заболеваний сердечно-сосудистой системы играет нарушение микроциркуляции [Чернух, Александров, Алексеев, 1984, с. 4-7; Stokes, Granger, 2004, p. 647 - 653]. При этом наблюдается ряд неблагоприятных изменений, которые охватывают все звенья микроциркуляции, в том числе и функциональную активность тромбоцитов [Моисеев, Лапотников, Карцев, 1986, с. 30-33; Киричук, Шварц, 1998, с. 14-17; Киричук, Воскобой, 2000, с. 47-50; Bolton, 1985, p. 89-101; Thrombin generation ..., 1997, p. 522; Kirichuk, Voskoboy, 2000, p.79].

Для коррекции нарушений микроциркуляции используют широкий спектр препаратов: вазадилататоторов, антиагрегантов, дезагрегантов, прямых и непрямых антикоагулянтов. Кроме того, в ряде случаев требуется назначение длительной терапии с целью первичной и вторичной профилактики. Однако фармакотерапия всегда сопровождается возникновением различной степени выраженности побочных эффектов [Словарь справочник..., 2005, с. 503-504]. В связи с этим в настоящее время ведутся поиски новых немедикаментозных методов коррекции указанных нарушений. На сегодняшний день к таковым можно отнести электромагнитное излучение крайне высокочастотного и терагерцового диапазонов частот [Лебедева, 1998, с. 49-54; Бецкий, 2002, c. 10-17].

Электромагнитные КВЧ-колебания достаточно широко вошли в медицинскую практику и показали свою эффективность в лечении широкого ряда заболеваний, оказывая нормализующее (восстанавливающее) действие на основные механизмы развития общепатологических процессов, лежащих в основе любых заболеваний [Бецкий, 2002, с. 10-17]. Этот аспект их применения получил название КВЧ-терапии, которая, в частности, применяется в комплексном лечении заболеваний сердечно-сосудистой системы - острого инфаркта миокарда и нестабильной стенокардии [Лебедева, 1998, с. 49-54; Киричук, Головачева, Чиж, 1999, с. 6-7;]. КВЧ - терапия имеет ряд достоинств перед фармакологическими средствами: неинвазивность, практическое отсутствие побочных реакций и противопоказаний к применению, доступность и хорошая сочетаемость с другими методами лечения [Бецкий, 2000, с. 3-9]. 
В последние годы появилось новое направление - ТГЧ - терапия, эффективность которой доказана при лечении ряда заболеваний, в том числе и сердечно - сосудистой системы [Биофизические эффекты ..., 2003, с. 3-6; Первый опыт ..., 2004, с. 46-54; Терагерцовые волны ... , 2005, с. 4-16; Паршина, 2006, с. 32 - 40; Паршина, Киричук, Головачева, 2005, с. 109-111].

Терагерцевый диапазон частот (ТГЧ) лежит на границе между электроникой и фотоникой. С одной стороны он определен частотно-временным ограничением (более 100 ГГц) электронных переходов в полупроводниковых структурах, a c другой максимальной длиной волны квантовых переходов лазерных структур. Этот диапазон волн находится на шкале электромагнитных волн между КВЧ- и оптическим инфракрасным диапазонами и частично перекрывает высокочастотную часть КВЧдиапазона (100-300 ГГц) и низкочастотную инфракрасного диапазона [Гершензон, Малов, Мансуров, 2000, с. 145-146]. Максимальная энергия кванта hv в классическом КВЧ диапазоне составляет $1,17 \cdot 10^{-3}$ эВ, а в терагерцевом на два порядка выше, то есть $\sim 10^{-1}$ эВ. Ниже энергии кванта в КВЧ - диапазоне оказываются энергия вращения молекул вокруг связей $\left(10^{-4}-10^{-3}\right.$ эВ), энергия куперовских пар при сверхпроводимости $\left(10^{-6}-10^{-4}\right.$ эВ) и энергия магнитного упорядочения $\left(10^{-6}-10^{-4}\right.$ эВ) [Гершензон, Малов, Мансуров, 2000, с. 145-146]. В терагерцевом диапазоне частот энергия кванта больше указанных фундаментальных энергетических состояний вещества, включая дополнительный (по сравнению с классическими КВЧ), более высокий уровень молекулярного состояния вещества - энергию колебательных уровней молекул $\left(10^{-2}-10^{-1}\right.$ эВ), который уже близок к энергии ионизации. Энергия взаимодействия при равенстве сил притяжения и отталкивания молекул имеет значение порядка $10^{-1}-10^{-2}$ эВ [Конако, Фэйтс , 2002, с. 15 18.].

Таким образом, можно полагать, что реакционная способность молекул при воздействии на них терагерцовых электромагнитных волн будет на два порядка выше, чем при возбуждении КВЧ - квантом. К особенностям терагерцовых волн (ТГВ) относится также и то, что ТГЧ-излучение свободно проникает сквозь одежду и кожу до мышц человека [Молекулярные HITRAN-спектры ..., 2007, с.5-9.].

В связи с тем, что в терагерцевом диапазоне электромагнитных волн находятся спектры излучения и поглощения важнейших клеточных метаболитов $\left(\mathrm{NO} ; \mathrm{O}_{2} ; \mathrm{CO}_{2} ; \mathrm{OH}^{-}\right.$ и др.) [Квазиоптический КВЧ ..., 2003. с. 17-24; Терагерцовые волны ... , 2005, с. 4-16; Молекулярные HITRAN-спектры ... , 2007, с.5-9.], представляет интерес изучение эффектов и механизмов действия ТГЧ - волн на частотах молекулярных спектров излучения и поглощения (МСИП) тех или иных клеточных метаболитов на нарушенные 
функции микроциркуляторного звена системы гемостаза и состояние сердечно сосудистой системы [Биофизические эффекты ..., 2003, с. 3-6; Антистрессорное действие ..., 2004, с. 12-20; Влияние электромагнитного ..., 2004, с. 21-27; Первый опыт . . , 2004, с. 46-54; Терагерцовые волны ... , 2005, с. 4-16; Паршина, 2006, с. 32 - 40 ; Паршина, Киричук, Головачева, 2005, с. 109-111].

В частности, оксид азота участвует в реализации многих важных физиологических функций, таких как вазодилатация, бронходилатация, нейротрансмиссия, агрегация тромбоцитов, реакции иммунной системы, регуляция тонуса гладких мышц, состояние памяти, является важным регулятором почечной гемодинамики и гломерулярной фильтрации, а также некоторых патологических процессов [Голиков, 2004, с. 9 - 15; Ignarro, Wood, 1987, p. 160 - 170; Snyder, Bredt, 1991, p. 125 - 128; Lowenstein, 1994, p. 227-237; Lloyd-Jones, 1996, p. 365-375; Hart, 1999, p. 1407-1417; Michel, 1999, p. 5-7; Oscillations in the Numan ..., 1999, p. 298-309; Nitric oxide .. , 2000, p. 11609-11613; Battinelli E., Loscalzo, 2000, p. 3451-3459; Vascular hyporesponsiveness ..., 2000, p. 507-517; Davis, Cai, Drummond, 2003, p. 1449-1453; Murad, 2003, p. 299-307; Regulation of nitric ... , 2003, p. 12504-12509; Nitric oxide suppresses ..., 2007, p. 61-67; Effect of effective ... , 2007, p. $66-69]$.

В литературе широко представлены работы по изучению влияния ЭМИ ТГЧ на частотах МСИП оксида азота 150,176 - 150,662 ГГц на нарушенные функции форменных элементов крови: тромбоцитов и эритроцитов [Антистрессорное действие ..., 2004, с. 1220; Влияние электромагнитного ..., 2004, 21-27]. Также отмечено, что ТГЧ-облучение на указанных частотах способно восстанавливать нарушения качественного и количественного состава эритроцитов, вызванные иммобилизацией [Антистрессорное действие ..., 2004, с. 12-20; Влияние электромагнитного ..., 2004, с. 21-27]. Кроме того, доказано, что ТГЧ-облучение на частотах МСИП оксида азота 150,176 - 150,664 ГГц обладает выраженным восстанавливающим влиянием на нарушенные реологические свойства крови у белых крыс в состоянии острого иммобилизационного стресса [Антистрессорное действие ..., 2004, с. 12-20; Влияние электромагнитного ... , 2004, с. 21 27].

В доступной литературе имеются данные о влиянии электромагнитных волн терагерцевого диапазона на частотах МСИП оксида азота 150,176-150,664 Ггц на внутрисосудистый компонент микроциркуляции: функциональную ативность тромбоцитов, реологию крови, гемокоагуляцию и отсутствуют данные о физиологических эффектах терагерцевого излучения указанных диапазонов частот на 
перфузию тканей и состояние эндотелия у белых крыс, находящихся в состоянии острого иммобилизационного стресса.

Bce вышеперечисленное послужило основанием для изучения возможностей коррекции и предотвращения изменений перфузии тканей и состояния эндотелия сосудов с помощью терагерцевых волн на частотах МСИП оксида азота 150,176 - 150,664 ГГц.

\title{
ЦЕЛЬ ИССЛЕДОВАНИЯ
}

Изучить влияние облучения электромагнитными волнами терагерцевого диапазона на частотах молекулярного спектра излучения и поглощения оксида азота 150,176 150,664 ГГц на экспериментально вызванные изменения перфузии микроциркуляторного русла кожи и состояние эндотелия микрососудов у белых крыс, находящихся в состоянии острого иммобилизационного стресса.

\author{
ГЛАВА V
}

\section{ВЛИЯНИЕ ЭЛЕКТРОМАГНИТНЫХ ВОЛН ТЕРАГЕРЦЕВОГО ДИАПАЗОНА НА РАЗЛИЧНЫЕ КОМПОНЕНТЫ МИКРОЦИРКУЛЯЦИИ (ОБЗОР ЛИТЕРАТУРЫ)}

\section{1. Влияние электромагнитного облучения крайне высокочастотного и терагерцевого диапазонов на нарушенные процессы в системе микроциркуляции}

Изменения регионарного, в частности, коронарного, мозгового, почечного кровотока и системной гемодинамики, в том числе недостаточность кровообращения, связаны, прежде всего, с нарушениями микроциркуляции [Чернух, Александров, Алексеев, 1984, c.8; Stokes, Granger, 2004, p. 647 - 653].

Микроциркуляторное русло является местом, где в конечном итоге реализуется транспортная функция сердечно-сосудистой системы и обеспечивается транскапиллярный обмен, создающий необходимый для жизни тканевой гомеостаз, и именно поэтому микроциркуляторные расстройства часто становятся неотъемлемым звеном патогенеза широчайшего круга заболеваний различных органов и систем [Чернух, Александров, Алексеев, 1984, с. 7-15.].

Различают внутрисосудистый, сосудистый и внесосудистый компоненты нарушений микроциркуляции. Нарушения внесосудистого компонента микроциркуляции носят преимущественно вторичный характер, а ключевая роль в развитии микроциркуляторных сдвигов принадлежит сосудистому и внутрисосудистому компонентам [Чернух, Александров, Алексеев, 1984, с. 53.]. 
К внутрисосудистым нарушениям микроциркуляции относят расстройства реологических свойств крови, связанные с изменением суспензионной стабильности форменных элементов и вязкости крови, патологию гемокоагуляционного и сосудистотромбоцитарного механизмов гемостаза, что приводит к сдвигам в скорости кровотока в микрососудах и ухудшает перфузию крови через микроциркуляторное русло [Чернух, Александров, Алексеев, 1984, с. 54-60].

Поддержание оптимального функционального состояния эндотелия сосудов и жидкого состояния крови в сосудистом русле - одно из кардинальных условий сохранения постоянства внутренней среды организма, функционирования органов и физиологических систем организма, нарушение которых может вести к различным патологическим состояниям и гибели организма [Киричук, 1999, с. 50; Киричук, 2002, с. 58; Киричук, 2005 с. 79; Шахматов, Киселев, 2004, с. 106-107; Момот, 2006, с. 120-173].

Среди множества факторов окружающей среды, вызывающих значимые изменения функционального состояния биологических систем различного уровня организации, особая роль принадлежит электромагнитным излучениям [Grundler, Kaiser, 1992, p. 551$559]$.

Естественные и искусственные источники электромагнитной энергии разного диапазона оказывают выраженное воздействия на живые организмы. Некоторые электромагнитные излучения (ЭМИ) хорошо известны и давно используются в промышленности, быту, клинической практике, например, инфракрасное, ультрафиолетовое, ультравысокочастотное, классическое крайневысокочастотное (КВЧ).

Электромагнитные КВЧ колебания достаточно широко вошли в медицинскую практику и показали свою эффективность в лечении широкого круга заболеваний, оказывая нормализующее (восстанавливающее) действие на основные механизмы развития общепатологических процессов, лежащих в основе многочисленных заболеваний [Киричук, Головачева, Чиж, 1999, с. 311-320; Бецкий, Лебедева, 2001, с. 5-19].

Этот аспект их применения получил название КВЧ- терапии, которая, в частности, применяется в комплексном лечении заболеваний сердечно-сосудистой системы - острого инфаркта миокарда и нестабильной стенокардии [Головачева, 1991, с. 54-57; Паршина, 1994, с. 13-40; Семенова, 1994, с. 10-21; Киричук, Паршина, Головачева, 1997, с. 20-22]. Так, многочисленными исследованиями показано благоприятное влияние ЭМИ КВЧ на динамику показателей гемостаза и фибринолиза, что может играть важную роль в профилактике нарушений функционального состояния тромбоцитов и гиперкоагуляции у больных инфарктом миокарда [Семенова, 1994, с. 10-21], стенокардией [Паршина, 1994, с 14-20]. 
Обязательным условием для поддержания гомеостаза в целом является нормальное функционирование системы гемостаза [Профилактика тромбозов ..., , 1992, с. 153-154; Балуда, Балуда, Деянов, 1995, с. 189 - 195]. Изменения в системе гемостаза представляют один из универсальных механизмов ответа организма на патогенное воздействие и имеются практически при всех заболеваниях [Киричук, Шварц, 1998, с.14-17; Баркаган, Момот, 1999, с. 201-202; Киричук, Головачева, Чиж, 1999, с. 311-320; Kirichuk, Voskoboy, 1996, p. 150-156]. Так, у больных нестабильной стенокардией отмечаются достаточно выраженные нарушения антитромбогенной активности сосудистой стенки [Воскобой, 1995, с.15-17; Киричук, Воскобой, 2000, с. 47-50].

В ряде работ показано ограничение внутрисосудистого свертывания крови у больных стенокардией под влиянием КВЧ волн. Благоприятный эффект КВЧ терапии на систему гемостаза выражается в повышении антикоагулянтной (уровня гепарина, активности антитромбина-ІІІ) и фибринолитической активности крови, снижение содержания комплексных соединений мономеров фибрина [Киричук, 2002, с. 58; Киричук, 2005 с. 79].

КВЧ-терапия помогает нормализовать нарушенную антитромбогенную активность сосудистой стенки у больных рассматриваемой нозологии [Влияние ЭМИ ..., , 1997, с. $22-$ 24].

Перспективно использование КВЧ-терапии для нормализации системы гемостаза у больных острым инфарктом миокарда. Отмечены благоприятное влияние КВЧвоздействия на свертывающую и противосвертывающую системы крови [Семенова, 1994, c. 10-21], положительная динамика биохимических показателей, характеризующих состояние системы гемостаза [Рубин, Мельникова, 1991, с. 355-361]. В.Ю. Ушаковым, В.Ф. Киричуком, Т.В. Головачевой и др. [1995], положительная динамика коагуляционного, антикоагулянтного и фибринолитического звеньев системы гемостаза отмечена при использовании КВЧ-терапии в качестве компонента комплексного лечения больных острым инфарктом миокарда.

Корригирующее воздействие КВЧ-терапии на систему гемостаза у больных с начальными признаками нарушения мозгового кровообращения проявляется в снижении агрегационной функции тромбоцитов, а также уменьшении активности плазменных факторов свертывания крови [Киричук, Головачева, Чиж, 1999, с. 6-7].

При классической КВЧ-терапии электромагнитное воздействие осуществляется, как правило, на частотах 42,2 ГГц и 53,5 ГГц [Тенденции развития ... , 1999, с. 56-68; Киричук, Головачева, Чиж, 1999, с. 6-7]. Исследуется также взаимодействие биологических объектов с более широким диапазоном миллиметровых волн, в частности, 
с излучениями, имитирующими молекулярные спектры излучения и поглощения (МСИП) ряда биологически активных веществ [Закономерности сдвигов ... , 2000, с. 96-97; Изменение функциональной ..., 2000, с. 13-21; Информационное взаимодействие ... , 2000, с. 91-93; Комплекс для исследования ..., 2001, с. 21-38]. При изучении механизмов эффективности применения КВЧ-терапии у больных нестабильной стенокардией было обнаружено ее выраженное положительное влияние на систему гемостаза, нарушения которой служат одним из основных патогенетических факторов данного заболевания [Киричук, Шварц, 1998, с. 14-17; Kirichuk, Voskoboy, 1996, p. 150-156]. Показано, что использование КВЧ-терапии в качестве компонента комплексного лечения больных нестабильной стенокардией оказывает антиангинальный, гипокоагуляционный и гипохолестеринемический эффект [Головачева, 1991, с. 54-57; Киричук, Головачева, Чиж, 1999, с. 6-7; Адаптационные реакции ... , 2000, с. 37-39].

В литературе имеются данные, отражающие положительную динамику в состоянии тромбоцитарного звена системы гемостаза у больных нестабильной стенокардией в течение курса комплексной терапии (с применением КВЧ - воздействия) по сравнению с традиционной медикаментозной. Так, было обнаружено, что при применении комплексной терапии существует тенденция к более выраженному снижению как активации, так и агрегации кровяных пластинок больных нестабильной стенокардией [Характеристика изменений ..., 2000, с. 99-101].

При рассмотрении влияния различных методов терапии больных нестабильной стенокардией на агрегацию тромбоцитов была констатирована тенденция к более выраженной нормализации всех исследуемых показателей, характеризующих данное свойство кровяных пластинок: выраженное увеличение времени достижения максимального радиуса тромбоцитарных агрегатов и максимального времени агрегации; снижение максимальной степени и максимальной скорости агрегации. При стандартной (медикаментозной) терапии к окончанию курса лечения наблюдалась гиперагрегационная тенденция в изменении ряда показателей (максимального радиуса тромбоцитарных агрегатов и максимальной скорости их образования) [Тромбоциты в реакциях ..., 2002, с. 198-243]. При использовании комплексного (с применением КВЧтерапии) метода лечения нестабильной стенокардии данные параметры имели тенденцию к уменьшению, что свидетельствовало о нормализации агрегационной способности кровяных пластинок [Тромбоциты в реакциях ..., 2002, с. 198-243].

Следовательно, использование КВЧ-терапии в качестве компонента комплексного лечения больных нестабильной стенокардией эффективнее медикаментозной терапии. КВЧ-воздействие оказывает многостороннее благотворное влияние на функционирование 
тромбоцитарного звена системы гемостаза, воздействуя как на активацию, так и агрегацию кровяных пластинок, что наряду со сведениями об антиангинальном, гипокоагуляционном и гипохолестеринемическом эффектах [Головачева, 1991, с. 54-57; Семенова, 1994, с. 10-21; Киричук, Головачева, Чиж, 1999, с. 6-7; Адаптационные реакции ... , 2000, с. 37-39], подтверждает патогенетическую направленность действия КВЧтерапии.

Экспериментальными и клиническими исследованиями доказано, что под влиянием ЭМИ КВЧ происходит нормализация процессов микроциркуляции, выражающаяся в уменьшении периваскулярных нарушений и неравномерности диаметра венул и артериол [Жуков, 1995, с. 129-130].

Особое значение имеют результаты исследований тромбоцитарных эффектов КВЧизлучения, имитирующего молекулярный спектр излучения и поглощения оксида азота (NO) [Тромбоциты в реакциях ... , 2002, с. 198-243], являющегося нейротрансмиттером, эндогенным вазодилататором, мощным фактором гемостаза, ингибитором агрегации тромбоцитов [Северина, 1995, с. 230-235; Северина, 1998, с. 939-997; Matsuoka, Suzuki, 1983, p. 5341-5353; Endothelium-derived relaxing ..., 1987 p. 9265-9269; Knowles, Palacios, Palmer, Moncada 1989, p. 5159-5162; Furchgott, Jothianandan, 1991, p. 52-61]. При анализе показателей исходной функциональной активности тромбоцитов больных нестабильной стенокардией было зафиксировано, что функциональная активность (активация и агрегация) тромбоцитов больных нестабильной стенокардией превышает функциональную активность кровяных пластинок у здоровых людей (группа контроля) по большинству параметров [Закономерности сдвигов ... , 2000, с. 96-97; Изменение функциональной ..., 2000, с. 13-21; Тромбоциты в реакциях ..., 2002, с. 198-243]. Исследования в условиях in vitro показали наличие выраженного ингибирующего воздействия КВЧ - волн на частотах МСИП NO на функциональную активность тромбоцитов больных нестабильной стенокардией [Закономерности сдвигов ..., 2000, с. 96-97, Изменение функциональной ... 2000, с. 13-21; Тромбоциты в реакциях ..., 2002, с. 198-243].

Многочисленными клиническими и экспериментальными исследованиями доказано, что КВЧ облучение является одним из наиболее действенных физиотерапевтических методов и обладает обезболивающим действием, нормализующим влиянием на реологические свойства крови, являясь при этом антиоксидантом физической природы [Паршина, Киричук, 1991, с. 54-55; Семенова, 1994, с. 10-21; Влияние ЭМИ ... , 1997, 22-24]. 
Сравнительно недавно применяются в медицинской практике и вызывают большой интерес низкоинтенсивные излучения терагерцевого диапазона частот [Первый опыт ... , 2004, с. 46-54; Комплексное лечение ..., 2004, с. 55-61].

Электромагнитное излучение терагерцевого диапазона частот (ЭМИ ТГЧ) - это распространяющееся в пространстве, в средах и тканях электромагнитное поле сверхвысокой частоты.

Терагерцевый диапазон частот (ТГЧ) лежит на границе между электроникой и фотоникой от 100 ГГц до 10 ТГц (1 ТГц $=10^{3}$ ГГц) или в длинах волн от 3 мм до 30 мм. Снизу он определен частотно-временным ограничением (более 100 ГГц) электронных переходов в полупроводниковых структурах, а сверху - максимальной длиной волны квантовых переходов лазерных структур. Этот диапазон волн находится на шкале электромагнитных волн между КВЧ-диапазоном и оптическим инфракрасным диапазоном и частично перекрывает высокочастотную частот КВЧ-диапазона (100-300 ГГц) и низкочастотную часть инфракрасного диапазона [Гершензон, Малов, Мансуров, 2002, с. 145 - 148; Биофизические эффекты ..., 2003, с. 3-6]. Максимальная энергия кванта $\mathrm{h} v$ в классическом КВЧ - диапазоне составляет $1,17 \cdot 10^{-3}$ эВ, а в терагерцевом на два порядка выше, то есть $\sim 10^{-1}$ эВ. Ниже энергии кванта в КВЧ - диапазоне оказываются энергия вращения молекул вокруг связей $\left(10^{-4}-10^{-3}\right.$ эВ), энергия куперовских пар при сверхпроводимости $\left(10^{-6}-10^{-4}\right.$ эВ) и энергия магнитного упорядочения $\left(10^{-6}-10^{-4}\right.$ эВ) [Гершензон, Малов, Мансуров, 2002, с. 145 - 148]. В терагерцевом диапазоне частот энергия кванта больше указанных фундаментальных энергетических состояний вещества, включая дополнительный (по сравнению с классическими КВЧ), более высокий уровень молекулярного состояния вещества - энергию колебательных уровней молекул $\left(10^{-2}-10^{-1}\right.$ эВ), который уже близок к энергии ионизации. Энергия взаимодействия при равенстве сил притяжения и отталкивания молекул имеет значение порядка $10^{-1}-10^{-2}$ эВ [Конако, Фэйтс, 2002, 23-27; The HITRAN molecular ..., 2003, p. 5 - 44].

Таким образом, можно полагать, что реакционная способность молекул при воздействии на них терагерцевых электромагнитных волн будет на два порядка выше, чем при возбуждении КВЧ - квантом. [Бецкий, Лебедева, 2001, с. 5-19].

Исследование изменений активации кровяных пластинок под действием ТГЧ облучения на частотах МСИП оксида азота 150,176-150,664 ГГц показало, что оно более эффективно, по сравнению с классическими частотами - 42,2 и 53,5 ГГц [Тромбоциты в реакциях ..., 2002, с. 198-243].

Так, отмечалась тенденция к более выраженному снижению всех показателей активации тромбоцитов под влиянием ТГЧ-воздействия на частотах МСПИ NO 150,176- 
150,664 ГГц. Данное воздействие вызывало более выраженные сдвиги всех показателей агрегатограммы, характеризующих агрегацию кровяных пластинок. Была показана статистически достоверная разница между влиянием ТГЧ - электромагнитных волн на частотах МСПИ NO 150,176-150,664 ГГц и классических КВЧ - диапазонов на максимальную скорость образования тромбоцитарных агрегатов и максимальную степень агрегации [Закономерности сдвигов ..., 2000, с. 96-97; Изменение функциональной ... , 2000 с. 13-21; Тромбоциты в реакциях ... , 2002, с. 198-243]. Кроме того, ТГЧ-воздействие на частотах МСПИ NO 150,176-150,664 ГГц вызывало статистически достоверные изменения большего количества показателей агрегационной способности кровяных пластинок, нежели классическое, и уровни достоверности различий в первом случае были намного выше [Закономерности сдвигов ..., 2000, с. 96-97; Изменение функциональной ... , 2000 с. 13-21; Тромбоциты в реакциях ..., 2002, с. 198-243 ].

Таким образом, ТГЧ-воздействие на частотах МСПИ NO 150,176-150,664 ГГц более эффективно ингибирует повышенную функциональную активность тромбоцитов (как активацию, так и агрегацию) больных нестабильной стенокардией, чем классическое КВЧ-облучение. Возможные причины данного факта можно будет обозначить после точного выяснения механизма действия каждого из указанных видов электромагнитного облучения, однако можно предположить, что большая эффективность ТГЧ-колебаний на частотах МСПИ NO 150,176-150,664 ГГц связана с их более узконаправленным воздействием на некоторые важные механизмы внутриклеточной регуляции (обмен оксида азота и связанные с этим процессы) [Закономерности сдвигов ..., 2000, с. 96-97; Изменение функциональной ..., 2000 с. 13-21; Тромбоциты в реакциях ..., 2002, с. 198$243]$.

Следовательно, нормализация нарушенной функциональной активности тромбоцитов служит одним из проявлений лечебного действия электромагнитных волн миллиметрового диапазона больных нестабильной стенокардией. Они обладают способностью ингибировать активацию и агрегацию кровяных пластинок также в условиях in vitro. Помимо классических видов КВЧ-колебаний на частотах 42,2 и 53,5 ГГц, выраженными тромбоцитарными эффектами обладают также ТГЧ-волны на частотах молекулярного спектра излучения и поглощения оксида азота 150,176-150,664 ГГц. Исследования в условиях in vitro показали, что ТГЧ-воздействие на частотах МСПИ NO является более эффективным по сравнению с классическими электромагнитными волнами КВЧ - диапазона, что позволяет рассматривать его как возможный перспективный метод лечения больных нестабильной стенокардией. 
В литературе широко представлены работы по изучению влияния ЭМИ ТГЧ на частотах МСИП оксида азота 150,176 - 150,662 ГГц на нарушенные функции форменных элементов крови: тромбоцитов и эритроцитов [Профиллактика и коррекция ..., 2008, с. 54-63; Антистрессорное действие ..., 2004, с. 12-20; Влияние электромагнитных . . , 2004, c. 21-27; Киричук, 2006 с. 80].

Электромагнитное облучение терагерцевого диапазона на частотах молекулярного спектра излучения и поглощения оксида азота 156,176 - 156,664 ГГц в условиях in vivo способствует не только восстановлению нарушенных агрегационных свойств тромбоцитов у животных в состоянии острого иммобилизационного стресса, но и их предотвращению на фоне развивающегося стресса. Кроме того, установлено, что на агрегационную активность тромбоцитов интактных животных электромагнитное облучение терагерцевого диапазона на частотах МСИП оксида азота 156,176 - 156,664 ГГц не влияет, то есть не нарушает нормального функционирования микроциркуляторного звена системы гемостаза.

Следовательно, электромагнитное облучение КВЧ - и ТГЧ - диапазонов способствует нормализации нарушенной функциональной активности тромбоцитов как в условиях in vivo, так и in vitro, причем ТГЧ - облучение на частотах молекулярного спектра излучения и поглощения оксида азота более эффективно в коррекции нарушенной активности кровяных пластинок, чем электромагнитное излучение классических частот (42,2 ГГц и 53,5 Ггц).

В последние годы появилось новое направление - ТГЧ - терапия, эффективность которой доказана при лечении ряда заболеваний, в том числе и сердечно - сосудистой системы [Биофизические эффекты ..., 2003, с. 3-6; Первый опыт ..., 2004, с. 46-54; Терагерцовые волны ... , 2005, с. 4-16; Паршина, 2006, с. 6-7; Паршина, Киричук, Головачева, 2005, с. 109-111]. Терагерцевая терапия представляется новым и довольно перспективным методом физиотерапевтического воздействия [Биофизические эффекты ... , 2003, c. 3-6].

Биологические эффекты ТГЧ-облучения регистрируются при плотности потока мощности излучения значительно ниже $10 \mathrm{mBT} / \mathrm{cm}^{2}$. При такой низкой интенсивности облучения интегральный нагрев облучаемых объектов в эксперименте не превышает 0,1 ${ }^{\circ}$ С. Поэтому ЭМИ ТГЧ относится к «информационным», нетепловым воздействиям [Бецкий, Лебедева, 2001, с. 5-19].

В настоящее время область исследований биологических эффектов ЭМИ ТГЧ занимает особое место в электромагнитобиологии. Изучение действия ЭМИ ТГЧ на биологические объекты началось около 10 лет тому назад учеными Саратовского 
государственного медицинского университета им. В.И. Разумовского, ОАО «Центральный научно-исследовательский институт измерительной аппаратуры» (г.Саратов), ИРЭ РАН (г.Москва), Медико-технической ассоциации КВЧ (г.Москва). Выявлены особые свойства указанных волн, проявляющиеся при взаимодействии с различными веществами, прежде всего с клеточными метаболитами, оказывающими регулирующее влияние на различные функции организма [Бецкий, Креницкий, Майбородин, Киричук, 2006, URL: http://www.fips.ru]. Благодаря интенсивной научно-исследовательской работе в области биологии, радиофизики, электроники и медицине создается новое перспективное направление в СВЧ-физиотерапии, диагностике и экологии, которое можно назвать «терагерцевая терапия», «терагерцевая диагностика» и «терагерцевая экология» [Биофизические эффекты ..., 2003, с. 3-6].

5.2. Влияние электромагнитного облучения терагерцевого диапазона на стрессорные нарушение внутрисосудистого компонента микроциркуляции

\subsection{1 Влияние электромагнитного облучения терагерцевого диапазона на} частотах 240 ГГц и 400 ГГц МСИП оксида азота на стрессорные нарушение внутрисосудистого компонента микроциркуляции

Представление о форменных элементах крови как первичной мишени ТГЧизлучения в организме обусловливает особый интерес исследователей к изучению механизмов реакции эритроцитов и тромбоцитов человека на ЭМИ терагерцевого диапазона [Тромбоциты в реакциях ... , 2002, с 311-327; Помошникова, 2006, с. 13-19].

В работе Н.В. Мамонтовой [Мамонтова, 2006, с. 12-20] был установлен факт нормализации нарушенных вязкостных свойств цельной крови, агрегационной способности и деформируемости эритроцитов больных нестабильной стенокардией, находящихся в естественном электромагнитном поле, под влиянием ЭМИ ТГЧ на частоте 240 ГГц, наиболее выраженной при 15- минутном режиме облучения. Также показано статистически достоверное восстановление нарушенных вязкостных свойств цельной крови, агрегации и деформируемости эритроцитов больных нестабильной стенокардией, находящихся в скрещенных магнитном и электрическом полях, под влиянием ЭМИ ТГЧдиапазона на частоте оксида азота 240 ГГц, наиболее эффективное при 15-минутном режиме облучения [Влияние терагерцовых ... , 2005, с. 34-38].

Авторами также отмечено, что продолжительность нормализующего воздействия ЭМИ ТГЧ- диапазона на частоте оксида азота 240 ГГц на вязкостные свойства цельной крови, способность эритроцитов к агрегации и их деформируемость у больных 
нестабильной стенокардией в условиях in vitro составляет 30 минут [Влияние терагерцовых ..., 2005, с. 34-38].

Н.В. Мамонтовой [Мамонтова, 2006, с. 12-20] показано, что облученный ЭМИ ТГЧ на частоте оксида азота 240 ГГц донатор оксида азота - изокет оказывает более выраженный эффект в восстановлении измененных вязкостных свойств цельной крови, агрегационной способности и деформируемости эритроцитов больных нестабильной стенокардией, чем не облученный, что может быть использовано для восстановления нарушенных функциональных свойств эритроцитов и реологических показателей крови больных ИБС в клинической практике.

В условиях эксперимента in vitro Е.В. Андронов и др. [2004] показали нормализацию функциональной активности тромбоцитов больных нестабильной стенокардией при воздействии ЭМИ ТГЧ на частотах оксида азота 240 ГГц. Так, при облучении обогащенной тромбоцитами плазмы больных нестабильной стенокардией в условиях in vitro на частотах МСИП оксида азота 240 ГГц в течение 15 минут наблюдалось значительное снижение увеличенной агрегационной активности кровяных пластинок, что сопровождалось статистически достоверным уменьшением максимального размера образующихся тромбоцитарных агрегатов, максимальной скорости образования наибольших тромбоцитарных агрегатов, максимальной степени агрегации. Аналогичные сдвиги произошли в агрегационной активности тромбоцитов больных нестабильной стенокардией при облучении обогащенной тромбоцитами плазмы в течение 30 минут. Однако, эти изменения, как правило, были выражены в меньшей степени, чем при 15 минутном облучении [Андронов, 2008, с. 12-42].

Сравнительный анализ эффективности воздействия терагерцевого облучения на частоте МСИП оксида азота 240 ГГц на образцы плазмы больных нестабильной стенокардией в зависимости от формируемого поля (естественного электромагнитного и скрещенных магнитном и электрическом), установлено, что более выраженным нормализующим эффектом на нарушенную агрегационную активность тромбоцитов обладал 15 - минутный режим облучения в естественном электромагнитном поле [Андронов, 2008, с. 12-42].

Влияние указанных частот электромагнитных волн терагерцевого диапазона на агрегационную способность тромбоцитов не только в условиях in vitro, но и in vivo. Так, при облучении терагерцевыми волнами на частоте МСИП оксида азота 240 ГГц в течение 15 минут белых крыс-самцов в состоянии острого оксидативного стресса имеется тенденция к восстановлению нарушенных показателей агрегационной активности тромбоцитов, вязкостных свойств крови, функциональных параметров эритроцитов, 
коагуляционного потенциала и фибринолитической активности крови [Андронов, 2008, с. $12-42]$.

При введении блокатора эндотелиальной NO- синтазы L-Name белым крысамсамцам в состоянии острого оксидативного стресса и облученным в течение 15 минут терагерцевыми волнами на частоте 240 ГГц тенденции к восстановлению нарушенных свойств тромбоцитов, функциональных параметров эритроцитов, коагуляционной и фибринолитической активности не отмечалось [Андронов, 2008, с. 12-42 ]. Это свидетельствует о том, что в реализации эффекта терагерцевого облучения на частотах указанного молекулярного спектра оксида азота принимает участие эндотелиальная NO синтаза [Андронов, 2008, с. 12-42].

При облучении ЭМИ ТГЧ на частоте молекулярного спектра излучения и поглощения оксида азота 400 ГГц обогащенной тромбоцитами плазмы больных нестабильной стенокардией в условиях эксперимента in vitro показано также снижение повышенной агрегационной способности кровяных пластинок, что сопровождалось статистически достоверным уменьшением максимального размера образующихся тромбоцитарных агрегатов, максимальной скорости образования наибольших тромбоцитарных агрегатов, максимальной степени и скорости агрегации [Андронов, Киричук, 2006, с. 22-27].

При сравнительном анализе эффективности воздействия двух режимов облучения на частотах 240 и 400 ГГц на измененную агрегационную активность тромбоцитов больных нестабильной стенокардией установлено, что облучение образцов крови на частоте МСИП оксида азота 400 ГГц оказывает более выраженный положительный корригирующий эффект на функциональную активность кровяных пластинок до уровня относительно здоровых доноров [Андронов, 2008, с. 12-42].

Таким образом, получены новые данные о возможностях использования электромагнитных волн терагерцевого диапазона на частотах молекулярного спектра излучения и поглощения оксида азота 240 ГГц и 400 ГГц для коррекции нарушенной функциональной активности тромбоцитов, агрегационной способности эритроцитов и вязкостных свойств цельной крови в практической медицине и некоторых механизмах их действия.

5.2.2. Влияние электромагнитного облучения терагерцевого диапазона на частотах 150,176-150,664 ГГи МСИП оксида азота на стрессорные нарушения внутрисосудистого компонента микроциркуляции

В последние годы установлено положительное влияние ЭМИ ТГЧ диапазона на частотах МСИП оксида азота 150,176 - 150,664 ГГц на функциональную активность 
тромбоцитов больных нестабильной стенокардией [Тромбоциты в реакциях ..., 2002, с. 198-243], что является перспективной предпосылкой для дальнейшего развития исследований в направлении изучения влияния ЭМИ данного диапазона на другие звенья системы гемостаза. Однако существуют данные, что по сравнению с КВЧ - диапазоном электромагнитных волн энергия кванта ТГЧ диапазона на порядок выше и близка к энергии ионизации [Биофизические эффекты ... , 2003, с. 3-6]. Следовательно терагерцевый диапазон частот представляется более перспективным с точки зрения использования в клинической медицине. В связи с этим определенный интерес представляют исследования по изучению эффектов ЭМИ терагерцевого диапазона на частотах МСИП NO 150,176 - 150,664 ГГц, так как результаты экспериментальных и клинических исследований ряда авторов показали, что оксид азота оказывает выраженное антистрессорное действие за счет активации стресс-лимитирующих механизмов [Малышев, Манухина 1998, с. 992-1006; Манухина, Малышев, 2000, с. 1283-1292]. В частности, представлены данные по экспериментальному обоснованию использования ТГЧ - облучения на частотах МСИП оксида азота 150,176-150,664 ГГц на модели иммобилизационного стресса у животных, а также при лечении больных с заболеваниями сердечно - сосудистой системы для коррекции нарушений в микроциркуляции и подтверждения антистрессорного эффекта данного вида излучения [Профиллактика и коррекция ..., 2008, с. 54-63; Антистрессорное действие ..., 2004, с. 12-20; Влияние электромагнитных ..., 2004, с. 21-27; Электродинамическая модель .., , 2004, с. 35-45; Первый опыт ..., 2004, с. 46-54; Применение электромагнитного ..., 2004, с. 62-64].

Острый иммобилизационный стресс у белых крыс-самцов сопровождается гиперкоагуляционными сдвигами в системе гемостаза, снижением антикоагулянтной активности крови и угнетением ее фибринолитического потенциала, обнаружением ранних продуктов деградации фибриногена и растворимых фибрин-мономерных комплексов, характерных для внутрисосудистой активации процесса свертывания крови [Цымбал, 2007, с. 12-19].

ТГЧ-воздействие на частотах МСИП оксида азота 150,176-150,664 ГГц на нарушенные коагуляционные и фибринолитические свойства крови животных в состоянии острого иммобилизационного стресса оказывает положительный восстанавливающий эффект на нарушенные показатели прокоагулянтной, антикоагулянтной и фибринолитической активности крови [Цымбал, 2007, с. 12-19].

Результаты исследования О.Н. Антиповой и соавторов [Антистрессорное действие ... , 2004, с. 12-20; Способ профилактики ..., 2006, URL: http://www.fips.ru; Сравнительная эффективность ..., 2009, с. 55-62] свидетельствуют о том, что воздействие ТГЧ-излучения 
на частотах МСИП оксида азота 150,176-150,664 ГГц в течение 15 и 30 минут на животных, находящихся в состоянии острого иммобилизационного стресса, вызывает полное восстановление вязкости цельной крови при различных скоростях сдвига, способности эритроцитов к агрегации и их деформируемости. Анализ результатов исследования реологических свойств крови у животных, находящихся в состоянии длительного стресса, показал восстановление вязкостных свойств крови при малых и больших скоростях сдвига, частичное восстановление способности эритроцитов к агрегации и снижение их деформируемости.

О.И. Помошниковой [Помошникова, 2006, с. 13-19] установлено, что ТГЧоблучение на частотах оксида азота 150,176-150,664 ГГц частично или полностью нормализует постстрессорные нарушения во внутрисосудистом компоненте микроциркуляции за счет восстановления количественного и качественного состава эритроцитов в зависимости от режима и времени облучения. 15-минутный режим облучения является, по данным автора, наиболее эффективным в восстановлении нарушенного качественного и количественного состава эритроцитов.

Авторами проведен сравнительный анализ влияния непрерывного и дробного режимов ТГЧ-облучения на частотах молекулярного спектра излучения и поглощения оксида азота 150,176-150,664 ГГц на нарушенный качественный и количественный состав эритроцитов крови белых крыс обоего пола, находящихся в состоянии острого иммобилизационного стресса, который показал, что дробные режимы в течение 5 и 30 минут более эффективны, нежели непрерывные в тех же временных диапазонах [Влияние электромагнитного ..., 2004, с. 21-27].

Влияние предварительного и последующего ТГЧ-облучения на частотах молекулярного спектра излучения и поглощения оксида азота 150,176-150,664 ГГц на качественный и количественный состав эритроцитов крови иммобилизированных белых крыс неоднозначно. Так, предварительное ТГЧ-воздействие более эффективно предупреждает постстрессорные нарушения в внутрисосудистом компоненте микроциркуляции у стрессированных животных по сравнению с облучением на фоне развившегося острого иммобилизационного стресса [Помошникова, 2006, с. 13-19].

Установлено, что в условиях эксперимента in vivo воздействие ТГЧ-излучения на частотах оксида азота 150,176-150,664 ГГц в течение 5 и 15 минут на животных, находящихся в состоянии острого иммобилизационного стресса, вызывает частичное восстановление функциональной активности тромбоцитов, что проявляется в уменьшении максимального размера тромбоцитарных агрегатов, максимальной скорости образования наибольших тромбоцитарных агрегатов, максимальной степени агрегации и 
максимальной скорости агрегации. При 30 минутном облучении животных ЭМИ ТГЧ на частотах оксида азота 150,176-150,664 ГГц, находящихся в состоянии острого иммобилизационного стресса, наблюдается полное восстановление функций тромбоцитов.

По данным авторов, при сравнении предшествующего и последующего воздействия на животных, находящихся в состоянии иммобилизационного стресса, ТГЧволнами на частотах оксида азота 150,176-150,664 ГГц наблюдается различная степень восстановления функций тромбоцитов. Предварительное ТГЧ-воздействие в непрерывном режиме более эффективно предупреждает постстрессовые нарушения в функциональной активности тромбоцитов у стрессированных крыс-самцов по сравнению с облученными животными на фоне развившегося острого иммобилизационного стресса [Профилактика и коррекция ..., 2008, с. 54-63].

В.Ф. Киричук, О.Н. Антипова и соавт. [Антистрессорное действие ..., 2004, с. 12 20] отметили, что животные, подвергнутые пятидневному иммобилизационному стрессу, начиная со 2-3-х суток эксперимента, становились тревожными, агрессивными, остро и неадекватно реагировали на слабые раздражители.

Делая вывод, авторы отмечают, что ТГЧ-облучение на частотах 150,176-150,664 ГГц проявляет выраженное антистрессорное действие, a 30 минутное облучение животных является эффективным в восстановлении микроциркуляции и характеризуется оптимальной степенью нормализации функции тромбоцитов, эритроцитов и гемореологических показателей у животных, находящихся в состоянии длительного стресса [Антистрессорное действие ..., 2004, с. 12-20].

\subsection{3. Влияние электромагнитного облучения терагерцевого диапазона на} частоте 129,0 ГГи МСИП атмосферного кислорода на нарушение внутрисосудистого компонента микроциркуляции при остром стрессе

В литературе широко представлены работы по изучению влияния ЭМИ ТГЧ на частотах МСИП оксида азота 150,176 - 150,662 ГГц на нарушенные функции форменных элементов крови: тромбоцитов и эритроцитов [Профиллактика и коррекция ..., 2008, 5463; Антистрессорное действие ..., 2004, с. 12-20; Влияние электромагнитного ... , 2004, с. 21-27; Киричук, 2006, с. 80]. Описано также довольно перспективное использование терагерцевых волн частотой 129,0 ГГц, соответствующей второму максимуму спектра излучения и поглощения молекулярного кислорода [Киричук, 2006, с. 80]. Поскольку недостаток кислорода в органах и тканях ведет к нарушению окислительных процессов, изменяя нормальное функционирование и жизнедеятельность всего организма в целом, обусловливая гипоксию и ишемию, важным является изучение ЭМИ на частоте МСИП молекулярного кислорода. Так, показано влияние ЭМИ частотой 129,0 ГГц на 
реологические свойства крови и структурно - функциональные особенности эритроцитов больных стабильной стенокардией в условиях in vitro [Киричук, 2006, с. 80]. Отмечен факт увеличения содержания оксигемоглобина в крови человека на 3-5\% в процессе дыхания атмосферным воздухом, облучаемым электромагнитными волнами частотой 129,0 ГГц [Комплекс для исследования ..., 2001, с. 21-38].

Так, по данным С.В. Суховой [2009], непрерывный и дробный режимы электромагнитного облучения на частоте МСИП атмосферного кислорода 129,0 ГГц способствуют восстановлению нарушенной агрегационной активности тромбоцитов крыссамцов в состоянии острого иммобилизационного стресса. Степень восстановления нарушенной функциональной активности тромбоцитов зависит от режима облучения [Сухова, 2009, с. 19-20].

Эффективность непрерывного ТГЧ - воздействия на частоте атмосферного кислорода 129,0 ГГц зависит от времени экспозиции животного на фоне острого иммобилизационного стресса. Наиболее эффективным в восстановлении нарушенной агрегационной активности тромбоцитов самцов является непрерывное облучение в течение 5 минут; 15 и 30 минут воздействия угнетают агрегацию тромбоцитов [Сухова, 2009, c. 19-20].

Эффективность дробного режима ТГЧ-воздействия на крыс-самцов на фоне острого иммобилизационного стресса на частоте атмосферного кислорода 129,0 ГГц зависит от времени экспозиции. Наиболее эффективным в восстановлении нарушенной агрегационной активности тромбоцитов самцов является дробный режим облучения общей продолжительностью 15 минут; дробный режим облучения общей продолжительностью 5 минут частично восстанавливает нарушенную агргационную активность тромбоцитов, а дробный режим облучения общей продолжительностью 30 минут вызывает угнетение процесса агрегации кровяных пластинок [Сухова, 2007, с. 63; Микроциркуляторные изменения ..., 2007, с. 87].

Сравнительный анализ влияния электромагнитного облучения терагерцевого диапазона на частоте МСИП атмосферного кислорода 129,0 ГГц на нарушенную функциональную активность тромбоцитов у крыс-самцов в состоянии острого иммобилизационного стресса показал, что непрерывный режим ТГЧ облучения в течение 5 минут более эффективно восстанавливают основные показатели агрегационной активности тромбоцитов, чем дробный режим облучения общей продолжительностью 5 минут [Сухова, 2007, с. 77; Микроциркуляторные изменения ..., 2007, с. 87].

Предшествующее острому иммобилизационному стрессу ТГЧ - облучение на частоте МСИП атмосферного кислорода 129,0 ГГц способно предотвращать развитие 
стрессорных нарушений функциональной активности тромбоцитов у крыс самцов. Более выраженным эффектом обладают 15 и 30 минутные режимы, в то время как при непрерывном режиме на фоне острого стресса восстановление происходит на 5 минуте воздействия [Влияние ЭМИ ... , 2008, с. 40-48; Сухова, 2007, с. 77; Сухова, 2009, с. 19-20].

Таким образом, получены новые данные о возможностях использования электромагнитных волн терагерцевого диапазона на частоте молекулярного спектра излучения и поглощения атмосферного кислорода 129,0 ГГц в клинической практике для коррекции нарушений во внутрисосудистом компоненте микроциркуляции.

5.3. Влияние электромагнитного облучения терагерцевого диапазона на стрессорные нарушения реологических свойств крови

Гемореология (реология крови) - наука, изучающая поведение крови при течении (в потоке), то есть свойства потока крови и её компонентов, а также реологию структур клеточной мембраны форменных элементов крови, прежде всего эритроцитов. Реологические свойства крови определяются вязкостью цельной крови и её плазмы, способностью эритроцитов к агрегации и деформации их мембран [Киричук, 2005, с. 79].

В настоящее время общепризнанно влияние реологических свойств крови на состояние внутрисосудистого компонента микроциркуляции [Киричук, Воскобой, 2000 с. 47-50; Ройтман , 2003, с. 13-27; Помошникова , 2006 с. 13-19].

Исследование реологических свойств крови и изучение влияния на текучесть крови сосудистой стенки служит источником ряда диагностических показателей и позволяет судить о некоторых патологических нарушениях и результатах лечебного вмешательства. В частности, они играют важную роль в патогенезе ряда заболеваний, в основе которых лежат ишемические нарушения [Киричук В.Ф., Шварц, 1998 с. 14-17].

Нарушения в системе микроциркуляции могут привести к недостаточности кровообращения в пораженном участке, гипоксии тканей и их дистрофии [Ройтман, 2003, c. 13.-27].

Задачей гемореологии является исследование деформации и текучести клеточных и плазматических элементов крови и их соотношения со стенками микрососудов. В этой связи, для характеристики кровотока в нормальных и патологических условиях важное значение имеет концентрация эритроцитов, взаимодействие их между собой, эластичность и форма эритроцитов, взаимодействие эритроцитов и крови в целом со стенкой микрососудов, вязкость плазмы и цельной крови [Чернух, Александров, Алексеев, 1984, с. 8; Помошникова, 2006, с. 13-19; Киричук, 2005 с. 79 ].

Реологические свойства крови характеризуются условиями потока, потоковыми свойствами частиц, т.е. свойствами частиц при определенных условиях потока, 
текучестью крови [Ройтман, 2003, с. 13-27; Киричук, 2005, с. 79]. Условия потока условия, при которых существует течение жидкости. Они определяются геометрией сосуда и прилагаемыми усилиями [Ройтман, 2003, с. 13-27; Киричук, 2005, с. 79].

Основными факторами, определяющими условия потока крови являются: диаметр сосуда и его изменения при вазоконстрикции и вазодилатации; сосудистые бифуркации и слияния; прилагаемое (движущее) давление крови (например, разница давлений на артериальном и венозном концах кровеносного сосуда); взаимодействие клеток крови, которое зависит от показателя гематокрита, скорости потока крови, близости форменных элементов к сосудистой стенке, физических свойств соседних клеток крови [Ройтман, 2003, c. 13-27].

Текучие, или реологические, свойства крови обусловлены интегральной величиной - вязкостью [Киричук, 2005 с. 79].

Принципиальными факторами, влияющими на вязкость крови, являются величина показателя гематокрита, свойства белков плазмы, агрегация и деформируемость клеточных элементов, причем вязкостные свойства крови определяются, в основном, эритроцитами [Фолков, Нил, 1976, с.; Изучение агрегатного ... , 1996, с. 7-10; Plasma viscosity ..., 1990, p. 1029-1032; Wannamethee, Shaper, Whincup, 1994, p 112-118].

Эритроцитам, в силу их большого объёмного и количественного содержания в крови, принадлежит ведущая роль в формировании клеточного компонента вязкости крови [Помошникова, 2006, с.13-19].

Отмечена прямая корреляционная связь между показателем гематокрита и вязкостью крови при низких скоростях сдвига [Изучение агрегатного ..., 1996, с. 7-10; Plasma viscosity ..., 1990, p. 1029-1032; Wannamethee, Shaper, Whincup, 1994, p 112-118]. Величина стандартного гематокрита равна 45\%. Повышение показателя гематокрита приводит к увеличению вязкости крови, что вызывает снижение кровотока в сосудах с малым диаметром [Wannamethee, Shaper, Whincup, 1994, p 112-118].

Агрегация эритроцитов - их способность создавать в цельной крови или модельной среде «монетные столбики» и их трехмерные конгломераты и цепи [Ройтман, 2003, с. 13-27; Киричук, 1999, с. 50; Киричук, 2002, с.58; Киричук, 2005, с. 79].

Агрегация эритроцитов, в основном, зависит от следующих факторов: 1) ионного состава среды: при повышении общего осмотического давления плазмы эритроциты сморщиваются и утрачивают способность к агрегации; 2) поверхностно-активных веществ, изменяющих поверхностный заряд, и их влияние может быть различным; 3) концентрации фибриногена и иммуноглобулинов; 4) контакта с инородными 
поверхностями, как правило, сопровождаемое нарушением нормальной агрегации эритроцитов [Киричук, 1999, с. 50; Киричук, 2002, с.58; Киричук, 2005, с. 79].

Основное значение для оценки реологических свойств крови на уровне микроциркуляции имеет не только агрегация, но и деформируемость эритроцитов.

Деформируемость эритроцитов - их способность деформироваться в сдвиговом потоке при прохождении через капилляры и поры, способность к плотной упаковке [Ройтман, 2003, с. 13-27; Киричук, 2005, с. 79].

Основными факторами, от которых зависит деформируемость эритроцитов, являются: 1) осмотическое давление окружающей среды (плазмы крови); 2) соотношение внутриклеточного кальция и магния, концентрация АТФ; 3) продолжительность и нтенсивность приложенных к эритроциту внешних воздейсвий (механических и химических), меняющих липидный состав мембраны или нарушающий структуру спектриновой сети; 4) состояние цитоскелета эритроцита, в состав которого входит спектрин; 5) вязкость внутриклеточного содержимого эритроцитов в зависимости от концентрации и свойств гемоглобина [Киричук, 1999, с. 50; Киричук, 2002, с.58; Киричук, 2005, c. 79].

Таким образом, основными факторами, которые определяют вязкость цельной крови являются: 1) агрегация и деформируемость эритроцитов; 2) величина гематокрита повышение показателя, как правило сопровождается увеличением вязкости крови; 3) концентрация фибриногена, растворимых комплексов фибринмономера и продуктов деградации фибрина/фибриногена - повышение их содержания в крови увеличивает её вязкость; 4) соотношение альбумин/фибриноген и соотношение альбумин/глобулин снижение данных соотношений сопровождается повышением вязкости крови; 5) содержание циркулирующих иммунных комплексов - при повышении их уровня в крови вязкость возрастает; 6) геометрия сосудистого русла [Киричук, 2005, с. 79].

В эндотелии синтезируется ряд физиологически активных веществ [по Гомазкову О.А., 2000; Дедову И.И. с соавт., 2001, с дополнениями]:

1) регуляторы тонуса сосудистой стенки: вазоконстрикторы (эндотелин 1-2, ангиотензин II, тромбоксан $\left(\mathrm{TXA}_{2}\right)$, простагландины $\mathrm{H}_{2}$ и $\mathrm{G}_{2}$ ) и вазодилататоры (NO (оксид азота) простагландин $\mathrm{I}_{2}$, эндотелиальный гиперполяризующий фактор (EDHF), брадикинин, С-натрийуретический пептид, адреномедулин, эндотелин-3);

2) регуляторы гемостаза и антитромбоза: протромбогенные факторы (тромбоцитарный ростковый фактор (PDGF) ингибитор тканевого активатора плазминогена (PAI - I), фактор Виллебранда (VIII фактор свертывания), ангиотензин IV, 
эндотелин - I) и антитромбогенные факторы (NO, тканевый активатор плазминогена ( $\mathrm{t}$ PA), простациклин ( $\left.\mathrm{PGI}_{2}\right)$;

3) регуляторы роста сосудов: стимуляторы (эндотелин - I, ангиотензин - II, супероксидные радикалы, факторы роста) и ингибиторы миграции и пролиферации миоцитов (NO, простациклин ( $\left.\mathrm{PGI}_{2}\right)$, C-натрийуретический пептид;

4) регуляторы адгезии лейкоцитов;

5) регуляторы воспаления, проницаемости сосудов, апаптоза компонентов сосудистой стенки [Лазерная доплеровская ..., 2005, с. 46; Corrrection of endothelial ... , 2000, p. 706-713; Minson, Berry, Joyner, 2001, p. 1619-1626].

Хорошо известно, что у здоровых людей эндотелиальная стенка сосудов антитромбогенна, обладает высокой антиагрегационной, антикоагулянтной и фибринолитической активностью, обусловленной синтезом эндотелиальными клетками простациклина, оксида азота (NO) и других естественных антиагрегантов, антитромбина III(АТІІІ) и активаторов плазминогена [Балуда, Балуда, Деянов, 1995, с. 189 - 195; Киричук, 1999, с. 50; Киричук, 2002, с. 58; Киричук, 2005, с. 79].

Эндотелий - место образования ряда факторов релаксации, в частности, NO, эндотелиального фактора гиперполяризации, простациклина, а также констрикторных агентов (эндотелинов, простаноидов и т.д.). Считается, что баланс между факторами релаксации и констрикции определяет релаксацию сосудов и соответственно величину местного кровотока, являясь одним из факторов, определяющих вязкость крови [Киричук, 2005, c. 79].

Гемореологические нарушения при ИБС могут существенно влиять на течение этой болезни, развитие осложнений и характер микроциркуляторных нарушений. Они также могут быть предвестниками развития этого заболевания или его первопричиной, поэтому на ранних стадиях ишемической болезни сердца показано лечение, направленное на коррекцию гемореологических нарушений [Ройтман, 2003, с. 13-27; Becker, 1993, p. 353358; Ernst, 1994, p. 151-152].

Влияние электромагнитного облучения КВЧ диапазона частоты МСИП оксида азота (150,1 - 150,6 ГГц) на реологические свойства крови различно в зависимости от времени экспозиции и мощности облучения: увеличение времени облучения приводило, как правило, к более выраженному увеличению вязкости цельной крови больных стабильной стенокардии и практически здоровых лиц. Аналогичная закономерность выявлена при нарастании мощности излучения. При всех режимах облучения ЭМИ частоты МСИП NO изменения функциональных параметров эритроцитов были разнонаправлены: установлено 
повышение агрегационной способности эритроцитов и понижение деформируемости их мембран [Киричук, 2005, с. 79].

Имеется существенная зависимость влияния ЭМИ миллиметрового диапазона от количества форменных элементов периферической крови в исходном состоянии. Максимальная выраженность изменений реологических параметров цельной крови при облучении ЭМИ миллиметрового диапазона определяется оптимальным соотношением в крови эритроцитов, лейкоцитов и тромбоцитов [Киричук, 2005, с. 79]. Сравнительный анализ влияния ЭМИ миллиметрового диапазона на «классических» частотах $(42,2$ и 53,5 ГГц) и частотах МСИП NO (150,1 - 150,6 ГГц) и О 2 (129 ГГц) показал, что выраженность эффекта указанных частот на реологические свойства крови увеличивается в направлении $42,2 \rightarrow 129 \rightarrow 53,5 \rightarrow 150,1-150,6$ ГГц [Киричук, 2005, с. 79].

Влияние ЭМИ миллиметрового диапазона различных частот (42,2 ГГц, 53,5 ГГц, 129,0 ГГц, 150,1 - 150,6 ГГц) на вязкость цельной крови зависит от распространенности атеросклеротического процесса в коронарных артериях и наличия артериальной гипертензии: с увеличением числа коронарных артерий, вовлеченных в атеросклеротический процесс, возрастают индексы эффективности для вязкости цельной крови, агрегационной способности эритроцитов и деформируемости их мембран; наличие артериальной гипертензии у пациента приводит к достоверно более высоким индексам эффективности для вязкости цельной крови, агрегационной способности эритроцитов и деформируемости их мембран [Киричук, 2002, с. 58].

О.Н. Антиповой [2010] показано, что влияние непрерывного и дробного режимов облучения электромагнитных волн терагерцового диапазона на частотах молекулярного спектра излучения и поглощения оксида азота 150,176-150,664 ГГц на крыс-самцов в состоянии острого иммобилизационного стресса в течение 15 и 30 минут нормализует нарушенную вязкость крови и функциональную активность эритроцитов. [Профилактика стресс-зависимых ..., 2006, с. 84-85; Восстановление реологических ..., 2006, с. 227-238; Влияние различных ..., 2007, с. 148-151].

Доказана роль эндогенного оксида азота и эндотелиальной NO-синтазы в механизмах положительного корригирующего влияния терагерцового облучения на частотах молекулярного спектра излучения и поглощения оксида азота 150,176-150,664 ГГц на показатели реологии крови у белых крыс в состоянии острого иммобилизационного стресса. Об этом свидетельствует отсутствие нормализующего эффекта 15- минутного терагерцового облучения на нарушенные реологические свойства крови при введении блокатора эндотелиальной NO-синтазы - L-Name белым крысам- 
самцам, находящимся в состоянии острого стресса. [Значение эндотелиальной ..., , 2009, с. 74-81; О роли эндотелиальной ... ,2009, с. 284-285].

Превентивные непрерывные и дробные 15- и 30-минутные воздействия предохраняют реологические свойства крови от острых стресс-опосредованных изменений. Превентивное дробное облучение общей продолжительностью 5 минут предотвращает развитие стрессорных нарушений вязкости крови в сосудах микроциркуляции и функциональной активности эритроцитов. [Эффективность различных ... , 2009, с. 63-74; Антипова, ..., 2008, с. 23-25].

Предварительное и последующее иммобилизационному стрессу ТГЧ - облучение на частотах молекулярного спектра излучения и поглощения оксида азота 150,176-150,664 ГГц на качественный и количественный состав эритроцитов крови белых крыс оказывает неодинаковый эффект. Так, предварительное ТГЧ-воздействие более эффективно предупреждает постстрессорные нарушения во внутрисосудистом компоненте микроциркуляции у животных, подвергнутых острому иммобилизационному стрессу, по сравнению с облучением на фоне развившегося острого иммобилизационного стресса [Помошникова , 2006, с. 13-19].

Воздействие непрерывного терагерцового облучения волнами указанного диапазона частот на фоне хронического (длительного) иммобилизационного стресса на животных в течение 15 и 30 минут нормализует только деформируемость эритроцитов. Превентивное терагерцовое облучение в течение 15 минут предотвращает стрессзависимые нарушения вязкости крови в сосудах крупного и среднего калибра, сохраняет нормальную агрегацию и деформируемость эритроцитов, а 30-минутное - полностью предупреждает развитие стрессорных нарушений в реологических свойствах крови. [Сравнительная характеристика ..., 2008 с. 63].

При ежедневном 30 минутном облучении животных, находящихся в состоянии длительного иммобилизационного стресса, ТГЧ-электромагнитным полем на частотах молекулярного спектра излучения и поглощения оксида азота наблюдается восстановление нарушенных вязкостных свойств крови при малых и больших скоростях сдвига, частичное восстановление способности эритроцитов к агрегации и снижение их деформируемости. Это подтверждается отсутствием статистически достоверных различий указанных показателей реологии крови по сравнению с данными группы контроля [Антистрессорное действие ..., 2004, с. 12-20].

Установлено выраженное увеличение вязкости цельной крови как при малых, так и при больших скоростях сдвига $\left(300,200,150,100,50\right.$ и $\left.20 \mathrm{c}^{-1}\right)$ у крыс при хроническом иммобилизационном стрессе, что проявляется в статистически достоверном отличии 
результатов этой группы животных по сравнению с данными группы контроля. Индексы агрегации (ИАЭ) и деформируемости эритроцитов (ИДЭ) также статистически достоверно увеличивались по сравнению с группой контроля, что указывает на увеличение агрегационной способности эритроцитов и их деформируемости [Антистрессорное действие ..., 2004, с. 12-20].

Результаты экспериментов на животных, которые на фоне хронического иммобилизационного стресса подвергались ежедневному воздействию ТГЧ-облучения на частотах оксида азота 150,176-150,664 ГГц, свидетельствуют о визуальной нормализации их поведенческих реакций. У таких животных отсутствовала выраженная тревожность, не проявлялась агрессивность, отмечалась адекватная реакция на посторонние раздражители [Антистрессорное действие ..., 2004, с. 12-20].

Непрерывное ТГЧ-излучение электромагнитных волн терагерцевого диапазона на частоте молекулярного спектра излучения и поглощения атмосферного кислорода 129,0 ГГц, воздействуя на крыс-самцов, находящихся в состоянии острого стресса в течение 15 и 30 минут, полностью восстанавливает нарушенные вязкостные свойства крови, функциональную активность эритроцитов - их агрегацию и деформируемость. Превентивные 15- и 30-минутные облучения предотвращают развитие постстрессорных нарушений в реологических свойствах крови. [ТГЧ - облучение .., , 2007, с. 50-53; Микроциркуляторные изменения ..., 2007 с. 87; Влияние ЭМИ ..., 2008, с 41-48].

Следовательно, электромагнитное облучение терагерцевого диапазона на частотах 150,176-150,664 ГГц оксида азота восстанавливает частично или полностью нарушенния реологических свойств крови при остром и хроническом иммобилизационном стрессе.

Таким образом, приведенные данные экспериментальных исследований свидетельствуют о выраженном влиянии электромагнитных волн терагерцевого диапазона частот на внутрисосудистый компонент микроциркуляции.

Ключевая роль в развитии микроциркуляторных сдвигов принадлежит сосудистому и внутрисосудистому компонентам [Чернух, Александров, Алексеев, 1984, с. 53.]. Остается не изученным какой эффект оказывают волны терагерцевого диапазона на частотах молекулярного спектра излучения и поглощения оксида азота 150,176-150,664 ГГц на периферическую перфузию ткани, функциональное состояние эндотелия. Это и данные литературы послужили поводом для исследования влияния электромагнитных волн на частотах оксида азота 150,176-150,664 ГГц на сосудистый компонент микроциркуляции. 


\section{ГЛАВА VI}

\section{ВЛИЯНИЕ НЕПРЕРЫВНОГО ТЕРАГЕРЦЕВОГО ОБЛУЧЕНИЯ НА ЧАСТОТАХ ОКСИДА АЗОТА 150,176-150,664 ГГЦ НА ИЗМЕНЕНИЯ ПЕРФУЗИИ МИКРОЦИРКУЛЯТОРНОГО РУСЛА И ФУНКЦИОНАЛЬНОГО СОСТОЯНИЯ ЭНДОТЕЛИЯ СОСУДОВ У БЕЛЫХ КРЫС ПРИ ОСТРОМ СТРЕССЕ}

\section{1. Влияние облучения терагерцевыми волнами на частотах молекулярного}

спектра излучения и поглощения оксида азота 150,176-150,664 ГГц на показатели перфузии микроциркуляторного русла и функциональное состояние эндотелия сосудов у интактных крыс-самцов

Для изучения безопасности облучения терагерцовыми волнами на частотах МСИП NO 150,176 - 150,664 ГГц была проведена серия экспериментов на интактных животных, подвергнутых непрерывному облучению в течение 30 минут. Установлено, что воздействие терагерцевых волн не вызывает изменения перфузии микроциркуляторного русла. При этом показатель перфузии (М), среднеквадратическое отклонение перфузии и коэффициент вариации у животных, подвергнутых 30 минутному облучению терагерцевыми волнами, находились в пределах вариабельности группы контроля.

Для изучения изменений механизмов модуляции микрокровотока под влиянием терагерцевых волн у интактных животных было проведено сравнение результатов амплитудно-частотного анализа ЛДФ-грамм животных, подвергнутых 30 минутному облучению, и группы контроля. Результаты амплитудно-частотного анализа ЛДФ-грамм свидетельствуют, что у крыс-самцов, подвергнутых облучению терагерцевыми волнами в течение 30 минут, не происходит значительного изменения как активных, так и пассивных механизмов регуляции микрокровотока. Значения амплитуд эндотелиальных, вазомоторных, пульсовых и дыхательных колебаний у животных данной группы статистически достоверно не отличаются от показателей контрольной группы.

Отсутствие статистически значимых изменений показателей перфузии и механизмов регуляции микрокровотока у интактных животных, подвергнутых терагерцевому облучению в течении 30 минут, свидетельствует о безопасности воздействия терагерцевыми волнами на частотах МСИП оксида азота 150,176 - 150,664 ГГц.

Для установления изменения функциональных резервов микрокровотока у интактных животных под влиянием терагерцевых волн на частотах оксида азота 150,176 150,664 ГГц проводилось сравнение с контролем результатов пробы с быстрым нагреванием у животных данной группы. У животных, подвергнутых облучению 
терагерцевыми волнами, отмечаются изменения ЛДФ-грамм при проведении термопробы по сравнению с контрольными.

Данные, полученные при проведении термопробы, показывают, что у крыс-самцов, подвергнутых облучению терагерцевыми волнами в течение 30 минут, отмечается статистически достоверное по сравнению с группой контроля увеличение максимальной перфузии. При этом различия исходной и перфузии после восстановления кровотока, а также резерва капиллярного кровотока у данных групп статистически недостоверны.

Увеличение максимальной перфузии при термопробе с быстрым нагреванием отражает стимуляцию индуцированного выброса оксида азота эндотелием, что свидетельствует об увеличении функциональных резервов микрокровотока.

Таким образом, облучение интактных крыс-самцов терагерцевыми волнами на указанных частотах МСИП оксида азота в течение 30 минут не вызывает изменения перфузии и модуляции микрокровотока. Однако под влиянием терагерцовых волн у крыссамцов возрастает индуцированный выброс оксида азота эндотелием, что свидетельствует об увеличении функциональных резервов сосудистого компонента микроциркуляции.

\section{2. Изменение перфузии микроциркуляторного русла и функционального} состояния эндотелия у белых крыс-самцов при остром иммобилизационном стрессе

Для установления степени воздействия острого иммобилизационного стресса на периферическую перфузию была проведена лазерная допплеровская флоуметрия животных двух групп: интактных (группа контроля) и находящихся в состоянии острого иммобилизационного стресса (группа сравнения).

В результате проведенных исследований обнаружено, что у крыс-самцов, подвергнутых 3-х часовой иммобилизации, происходит изменение перфузии микроциркуляторного русла. Это выражается в статистически достоверном по сравнению с группой контроля снижении показателя перфузии (M), что свидетельствует об уменьшении кровотока в микроциркуляторном русле. У животных при остром иммобилизационном стрессе по сравнению с контрольной группой происходило также статистически достоверное снижение среднего квадратичного отклонения перфузии и коэффициента вариации, что отражает уменьшение модуляции микроциркуляторного кровотока и угнетение активных механизмов регуляции микрокровотока, таких как эндотелиальная секреция и вазомоторная активность.

С целью детального изучения изменений механизмов модуляции микрокровотока при остром иммобилизационном стрессе было проведено сравнение результатов амплитудночастотного анализа ЛДФ-грамм групп контроля и животных в состоянии острого иммобилизационного стресса. Результаты амплитудно-частотного анализа ЛДФ-грамм 
свидетельствуют, что у крыс-самцов при остром иммобилизационном стрессе происходит изменение как активных, так и пассивных механизмов регуляции кровотока.

Так, установлено, что у крыс-самцов в состоянии острого иммобилизационного стресса происходит статистически достоверное уменьшение амплитуды эндотелиальных колебаний, что характеризует, прежде всего, снижение базальной продукции оксида азота эндотелием. Также у этих животных отмечается статистически достоверное уменьшение вазомоторных колебаний, что указывает на рост периферического сопротивления. При этом не обнаружено статистически достоверного изменения амплитуды дыхательных колебаний у крыс-самцов в состоянии острого иммобилизационного стресса, однако, отмечено статистически достоверное снижение амплитуды пульсовых (сердечных, кардиальных) колебаний, что свидетельствует об уменьшении притока артериальной крови в сосуды микроциркуляции.

Для установления изменения функциональных резервов микрокровотока у животных при остром стрессе проводилось сравнение с контролем результатов пробы с быстрым нагреванием у животных данной группы. У животных при остром иммобилизационном стрессе отмечаются изменения ЛДФ-грамм при проведении термопробы по сравнению с интактными животными.

Данные, полученные при проведении термопробы, показывают, что у крыс-самцов в состоянии острого иммобилизационного стресса отмечается статистически достоверное по сравнению с группой контроля снижение как исходной, так и максимальной перфузии, а также перфузии после восстановления исходного кровотока. Снижение максимальной перфузии при термопробе с быстрым нагреванием отражает угнетение индуцированного выброса оксида азота эндотелием. Статистически достоверное увеличение резерва капиллярного кровотока на фоне сниженной максимальной перфузии свидетельствует о том, что у крыс-самцов в состоянии острого иммобилизационного стресса происходит спазм приносящих микрососудов, то есть исходно функционирует меньшее количество капилляров.

Таким образом, у крыс-самцов в состоянии острого иммобилизационного стресса происходит нарушение периферической перфузии, что проявляется снижением среднего показателя перфузии, угнетением активных механизмов регуляции микрокровотока, уменьшением базальной и индуцированной вазодилатирующей активности эндотелия микрососудов (снижение базального и индуцированного выделения оксида азота), ростом периферического сопротивления, спазмом приносящих сосудов, уменьшением числа функционирующих капилляров и обеднением микроциркуляторного русла. 
6.3. Влияние непрерывного ТГЧ-облучения на частотах МСИП оксида азота 150,176 - 150,664 ГГц на изменения перфузии микроциркуляторного русла и функционального состояния эндотелия $\mathbf{y}$ белых крыс при остром иммобилизационном стрессе

Для выявления биологического эффекта терагерцевых волн на частотах молекулярного спектра излучения и поглощения оксида азота 150,176 - 150,664 ГГц на нарушения перфузии была проведена серия экспериментов по изучению изменений показателей лазерной допплеровской флоуметрии под влияния непрерывного ТГЧоблучения в течение 30 минут у крыс-самцов в состоянии острого иммобилизационного стресса.

Результаты исследований свидетельствуют, что у крыс-самцов, находящихся в состоянии острого стресса, под влиянием облучения терагерцовыми волнами на частотах молекулярного спектра излучения и поглощения оксида азота 150,176 - 150,664 ГГц происходит восстановление перфузии микроциркуляторного русла. Под влиянием терагерцевых волн у крыс-самцов, находящихся в состоянии острого стресса, происходит восстановление перфузионного показателя (M), при этом он статистически достоверно не отличается от данных группы контроля.

У крыс-самцов данной группы отмечается статистически достоверное по сравнению с группой животных, находящихся в состоянии острого стресса и не подвергнутых ТГЧоблучению, увеличение среднеквадратического отклонения перфузии и коэффициента вариации. При этом следует отметить, что имеется тенденция к увеличению значений среднеквадратического отклонения перфузии и особенно коэффициента вариации у животных данной группы по сравнению с группой контроля, что свидетельствует о более интенсивной модуляции микрокровотока и механизмов его регуляции.

Установлено, что под влиянием электромагнитных волн указанного терагерцевого диапазона у крыс-самцов, находящихся в состоянии острого иммобилизационного стресса, происходит восстановление активных и пассивных механизмов модуляции микрокровотока. Данные амплитудно-частотного анализа ЛДФ-грамм показывают, что после облучения терагерцевыми волнами на частотах молекулярного спектра оксида азота крыс-самцов в состоянии острого иммобилизационного стресса происходит статистически достоверное увеличение амплитуд эндотелиальных и вазомоторных колебаний по сравнению с группой животных в состоянии острого иммобилизационного стресса, не подвергавшихся ТГЧ-воздействию. Это отражает увеличение вазодилатирующей активности эндотелия (активацию базальной продукции оксида азота) и снижение периферического сопротивления. Также происходит увеличение амплитуды пульсовых 
(кардиальных) колебаний, что свидетельствует об увеличении притока артериальной крови в микроциркуляторное русло. Все показатели амплитудно-частотного анализа ЛДФграмм животных данной группы статистически достоверно не отличаются от данных группы контроля. Показано, что под воздействием облучения терагерцевыми волнами указанной частоты у крыс-самцов в состоянии острого иммобилизационного стресса восстанавливаются показатели функциональной пробы с быстрым нагреванием.

При анализе результатов функциональной пробы с быстрым нагреванием у крыссамцов, подвергнутых облучению терагерцевыми волнами на частотах молекулярного спектра оксида азота на фоне острого иммобилизационного стресса, обнаружена полная нормализация исходной и максимальной перфузии, а также перфузии после восстановления кровотока. Нормализация максимальной перфузии у этих животных свидетельствует о восстановлении индуцированной секреции оксида азота эндотелием. Bсе показатели функциональной пробы с быстрым нагреванием у животных, подвергнутых облучению терагерцевыми волнами на частотах МСИП оксида азота 150,176-150,664 ГГц на фоне острого стресса, находятся в пределах вариабельности группы контроля.

Таким образом, под влиянием облучения электромагнитными волнами терагерцевого диапазона на частотах молекулярного спектра излучения и поглощения оксида азота 150,176 - 150,664 ГГц у крыс-самцов в состоянии острого иммобилизационного стресса происходит восстановление измененной периферической перфузии, что проявляется повышением среднего показателя перфузии, активацией механизмов регуляции микрокровотока, нормализацией сниженной базальной и индуцированной вазодилатирующей активности эндотелия микрососудов (базального и индуцированного выделения оксида азота), уменьшением периферического сопротивления и повышением притока артериальной крови в микроциркуляторное русло.

\section{Резюме}

Полученные данные свидетельствуют о том, что облучение интактных крыссамцов терагерцевыми волнами на частотах молекулярного спектра излучения и поглощения оксида азота 150,176 - 150,664 ГГц в течение 30 минут не вызывает изменения перфузии и модуляции микрокровотока. Однако под влиянием терагерцевых волн у крыс-самцов возрастает индуцированный выброс оксида азота эндотелием, что свидетельствует об увеличении функциональных резервов сосудистого компонента микроциркуляции. 
Обнаружено, что у крыс-самцов в состоянии острого иммобилизационного стресса происходит изменение периферической перфузии, что проявляется снижением среднего показателя перфузии, угнетением активных механизмов регуляции микрокровотока, уменьшением базальной и индуцированной вазодилатирующей активности эндотелия микрососудов (снижение базального и индуцированного выделения оксида азота), ростом периферического сопротивления, спазмом приносящих сосудов, уменьшением числа функционирующих капилляров и обеднением микроциркуляторного русла.

Установленно, что под влиянием облучения электромагнитными волнами терагерцевого диапазона на частотах молекулярного спектра излучения и поглощения оксида азота 150,176 - 150,664 ГГц у крыс-самцов в состоянии острого иммобилизационного стресса происходит восстановление нарушеной периферической перфузии, что проявляется повышением среднего показателя перфузии, активацией механизмов регуляции микрокровотока, нормализацией сниженной базальной и индуцированной вазодилатирующей активности эндотелия микрососудов (базального и индуцированного выделения оксида азота), уменьшением периферического сопротивления и повышением притока артериальной крови в микроциркуляторное русло.

\section{ГЛАВА VІІ}

ВЛИЯНИЕ НЕПРЕРЫВНОГО ПРЕВЕНТИВНОГО ТЕРАГЕРЦЕВОГО

ОБЛУЧЕНИЯ НА ЧАСТОТАХ МОЛЕКУЛЯРНОГО СПЕКТРА ИЗЛУЧЕНИЯ И

ПОГЛОЩЕНИЯ ОКСИДА АЗОТА 150,176-150,664 ГГЦ НА ИЗМЕНЕНИЯ

ПЕРФУЗИИ МИКРОЦИРКУЛЯТОРНОГО РУСЛА КОЖИ И СОСТОЯНИЕ ЭНДОТЕЛИЯ СОСУДОВ ПРИ ОСТРОМ ИММОБИЛИЗАЦИОННОМ СТРЕССЕ

7.1. Влияние предшествующего иммобилизации облучения терагерцевыми волнами на частотах молекулярного спектра излучения и поглощения оксида азота 150,176 - 150,664 ГГц на показатели перфузии тканей и состояние эндотелия у белых крыс-самцов при остром стрессе

С целью изучения возможности предотвращения развития характерных для острой стресс-реакции нарушений перфузии тканей была проведена серия экспериментов, в которых крысы-самцы подвергались непрерывному облучению терагерцевыми волнами до начала действия стрессора. Результаты исследований свидетельствуют, что у крыссамцов, подвергнутых облучению терагерцевыми волнами на частотах молекулярного спектра излучения и поглощения оксида азота 150,176 - 150,664 ГГц перед иммобилизацией, происходит изменение протекания стрессорной реакции. Это 
выражается в отсутствии характерных для животных в состоянии острого иммобилизационного стресса изменений ЛДФ-грамм. Установлено, что у животных, подвергнутых облучению терагерцевыми волнами перед иммобилизацией, перфузионный показатель (М) статистически достоверно выше по сравнению с группой животных в состоянии острого стресса, не подвергавшихся действию терагерцевых волн. Величина перфузионного показателяэтих животных находится в пределах вариабельности контрольной группы. У животных данной группы отмечается статистически достоверное по сравнению с группой животных, находящихся в состоянии острого стресса и не подвергнутых ТГЧ-облучению, увеличение среднеквадратического отклонения перфузии и коэффициента вариации. Значения среднеквадратического отклонения перфузии и коэффициента вариации у животных, подвергнутых облучению терагерцевыми волнами перед иммобилизацией, статистически достоверно не отличаются от группы контроля. Данный факт свидетельствует о способности терагерцевых волн полностью предотвращать снижение интенсивности модуляции микрокровотока при остром иммобилизационном стрессе.

Установлено, что под влиянием предшествующего иммобилизации облучения волнами терагерцевого диапазона у крыс-самцов при остром иммобилизационном стрессе, не происходит характерных изменений активных и пассивных механизмов модуляции микрокровотока. Анализ амплитудно-частотных характеристик осцилляций кровотока в микроциркуляторном русле свидетельствует, что облучение терагерцевыми волнами крыс-самцов перед иммобилизацией препятствует изменению амплитуд эндотелиальных и вазомоторных колебаний при остром иммобилизационном стрессе. При этом указанные показатели у животных опытной группы статистически достоверно выше, чем у животных в состоянии острого иммобилизационного стресса, не подвергавшихся воздействию терагерцевых волн. Это отражает способность ТГЧ-волн сохранять нормальные показатели вазодилатирующей активности эндотелия, снижающуюся при острой стрессреакции, и периферического сопротивления, которое у животных в состоянии острого стресса повышено. Вариабельность амплитуды пульсовых (кардиальных) колебаний у животных, подвергнутых ТГЧ-облучению перед иммобилизацией, в значительной степени перекрывает квартиль диапазоны как контрольной группы, так и группы животных в состоянии острого стресса. Среднее значение амплитуды кардиальных колебаний у данной группы животных имеет статистически недостоверную тенденцию к снижению по сравнению с группой контроля, что свидетельствует о преимущественном влиянии данного диапазона электромагнитных волн на активные механизмы модуляции микрокровотока (вазодилатирующую активность эндотелия и периферическое 
сопротивление). Указанная тенденция, возможно, связана с перераспределением кровотока в организме и свидетельствует в пользу того, что терагерцевые волны не блокируют стрессорную реакцию, что нарушало бы процесс адаптации, а только модулируют ее протекание, препятствуя нарушению функций эндотелия сосудов.

Показано, что воздействие облучения терагерцевыми волнами на крыс-самцов перед иммобилизацией способно предотвращать характерные для острого иммобилизационного стресса нарушения показателей функциональной пробы с быстрым нагреванием кожи.

При анализе результатов функциональной пробы с быстрым нагреванием кожи у крыс-самцов, подвергнутых облучению терагерцевыми волнами на частотах молекулярного спектра оксида азота перед иммобилизацией, установлены достоверные различия исходной и максимальной перфузии, перфузии после восстановления кровотока и резерва капиллярного кровотока по сравнению с животными в состоянии острого иммобилизационного стресса, не подвергавшимися действию терагерцовых волн. Все показатели функциональной пробы с быстрым нагреванием животных, подвергнутых облучению терагерцевыми волнами на частотах МСИП оксида азота 150,176-150,664 ГГц перед иммобилизацией, находятся в пределах вариабельности группы контроля. Отсутствие статистически значимых изменений максимальной перфузии у этих животных свидетельствует о способности терагерцовых волн препятствовать нарушению индуцированной секреции оксида азота эндотелием при остром иммобилизационном стрессе.

Таким образом, облучение электромагнитными волнами терагерцевого диапазона на частотах МСИП оксида азота 150,176 - 150,664 ГГц крыс-самцов перед иммобилизацией способно предотвращать характерные для острого иммобилизационного стресса изменения периферической перфузии. Терагерцевые волны указанной частоты препятствуют снижению среднего показателя перфузии, нарушению механизмов модуляции микрокровотока. Облучение терагерцевыми волнами крыс-самцов перед иммобилизацией обеспечивает сохранение нормальной базальной и индуцированной вазодилатирующей активности эндотелия микрососудов (базального и индуцированного выделения оксида азота), а также периферического сопротивления в условиях острого иммобилизационного стресса. Облучение перед иммобилизацией у крыс-самцов частично препятствует изменению амплитуды кардиальных осцилляций. Указанная тенденция, возможно, связана с перераспределением кровотока в организме и свидетельствует в пользу того, что терагерцевые волны не блокируют стрессорную реакцию, что нарушало бы процесс адаптации, а только модулируют ее протекание, оказывая преимущественное 
влияние на сохранение нормального функционирования активных механизмы модуляции микрокровотока, реализуемых эндотелием сосудов.

7.2. Сравнительная характеристика влияния различных режимов облучения терагерцевыми волнами на частотах МСИП оксида азота 150,176-150,664 ГГц на изменения перфузии микроциркуляторного русла кожи и состояния эндотелия сосудов при острой стресс - реакции

Для выявления наиболее эффективного режима воздействия терагерцовыми волнами на изменения сосудистого компонента микроциркуляции был проведен сравнительный анализ состояния периферической перфузии у животных, подвергавшихся облучению терагерцевыми волнами на частотах МСИП NO 150,176-150,664 ГГц до и после иммобилизации.

При сравнении показателей перфузии микроциркуляторного русла животных, подвергнутых предшествующему стрессу воздействию терагерцовыми волнами, и животных, у которых ТГЧ - облучение на частотах МСИП оксида азота проводилось после иммобилизации, отмечается тенденция к увеличению среднеквадратического отклонения перфузии и коэффициента вариации у животных первой группы.

Однако, тенденция к увеличению среднеквадратического отклонения перфузии и коэффициента вариации у животных, подвергнутых облучению терагерцевыми волнами на фоне острого иммобилизационного стресса, по сравнению с крысами-самцами, у которых ТГЧ-воздействие проводилось до иммобилизации статистической достоверности не достигает.

При сравнительном анализе амплитудно-частотных характеристик осцилляций кровотока в микроциркуляторном русле у крыс-самцов, подвергнутых облучению терагерцевыми волнами на фоне острого имообилизационного стресса, и животными, у которых ТГЧ-воздействие проводилось перед иммобилизацией, отмечается тенденция к увеличению амплитуды эндотелиальных, вазомоторных, дыхательных и, в большей степени, пульсовых колебаний.

Тенденции к различию амплитуды эндотелиальных, вазомоторных, дыхательных и пульсовых колебаний у животных, подвергнутых воздействию терагерцовых волн до и после стресса, статистической достоверности не достигают. Указанные тенденции, вероятно, отражают явления перестройки механизмов модуляции микрокровотока, вызванных терагерцевыми волнами, и связаны с тем, что регистрация показателей у животных, подвергнутых ТГЧ-воздействию на фоне острого стресса, проводилась сразу после облучения. 
В результате сравнительного анализа установлено, что у крыс-самцов, подвергнутых облучению терагерцовыми волнами до иммобилизации, и животных, у которых ТГЧвоздействие проводилось на фоне иммобилизационного стресса, имеются различия в показателях функциональной пробы с быстрым нагреванием.

Установлено, что у крыс-самцов, подвергнутых облучению терагерцевыми волнами до иммобилизации, перфузия после восстановления кровотока при проведении функциональной пробы с быстрым нагреванием статистически достоверно выше по сравнению с группой животных, у которых ТГЧ-воздействие проводилось на фоне иммобилизационного стресса. Это свидетельствует о более длительной вазодилатации в ответ на быстрое нагревание, что связано с более длительным индуцированным выделением оксида азота, что можно рассматривать, как более выраженную адаптивную реакцию микроциркуляции. Статистически достоверных различий в исходной перфузии, максимальной перфузии и резерве капиллярного кровотока у животных, подвергнутых облучению терагерцевыми волнами на фоне острого иммобилизационного стресса, и крысами-самцами, у которых ТГЧ-воздействие проводилось до иммобилизации, не выявлено.

Таким образом, эффективность влияния на среднюю перфузию микрокроциркуляторного русла при применении предшествующего иммобилизации ТГЧоблучения на частотах оксида азота и воздействие терагерцевыми волнами на фоне развившегося иммобилизационного стресса одинакова. У животных, подвергнутых ТГЧвоздействию на фоне острого иммобилизационного стресса, отмечается тенденция, не достигающая статистической достоверности, к более активной модуляции перфузии по сравнению с группой крыс-самцов, у которых облучение терагерцевыми волнами проводилось перед иммобилизацией. Указанные тенденции, вероятно, отражают явления перестройки механизмов модуляции микрокровотока, вызванных терагерцевыми волнами, и связаны с тем, что регистрация показателей у животных, подвергнутых ТГЧвоздействию на фоне острого стресса, проводилась сразу после облучения. У животных, подвергнутых облучению терагерцевыми волнами перед иммобилизацией, отмечается более продолжительный индуцированный выброс оксида азота при проведении функциональной пробы с быстрым нагреванием по сравнению с крысами-самцами, подвергнутыми ТГЧ-облучению на фоне острого иммобилизационного стресса. Этот факт можно рассматривать как более выраженную адаптивную реакцию микроциркуляции в случае применения предварительного режима воздействия терагерцевыми волнами на частотах МСИП оксида азота у крыс-самцов при остром иммобилизационном стрессе. 


\section{Резюме}

Установлено, что облучение электромагнитными волнами терагерцевого диапазона на частотах молекулярного спектра излучения и поглощения оксида азота 150,176 150,664 ГГц крыс-самцов перед иммобилизацией способно предотвращать характерные для острого иммобилизационного стресса нарушения периферической перфузии. Терагерцевые волны указанной частоты препятствуют снижению среднего показателя перфузии, нарушению механизмов модуляции микрокровотока. Показано, что облучение терагерцевыми волнами крыс-самцов перед иммобилизацией обеспечивает сохранение нормальной базальной и индуцированной вазодилатирующей активности эндотелия микрососудов (базального и индуцированного выделения оксида азота), а также периферического сопротивления в условиях острого иммобилизационного стресса. Облучение перед иммобилизацией у крыс-самцов частично препятствует нарушению амплитуды кардиальных осцилляций. Указанная тенденция, возможно, связана с перераспределением кровотока в организме и свидетельствует в пользу того, что терагерцевые волны не блокируют стрессорную реакцию, что нарушало бы процесс адаптации, а только модулируют ее протекание, оказывая преимущественное влияние на сохранение нормального функционирования активных механизмов модуляции микрокровотока, реализуемых эндотелием сосудов.

В ходе сравнительного анализа двух режимов воздействия терагерцевыми волнами обнаружено, что эффективность влияния на среднюю перфузию микрокроциркуляторного русла при применении предшествующего иммобилизации ТГЧ-облучения на частотах оксида азота и воздействие терагерцевыми волнами на фоне развившегося иммобилизационного стресса одинакова. У животных, подвергнутых ТГЧ-воздействию на фоне острого иммобилизационного стресса, отмечается тенденция, не достигающая статистической достоверности, к более активной модуляции перфузии по сравнению с группой крыс-самцов, у которых облучение терагерцевыми волнами проводилось перед иммобилизацией. Указанные тенденции, вероятно, отражают явления перестройки механизмов модуляции микрокровотока, вызванных терагерцевыми волнами, и связаны с тем, что регистрация показателей у животных, подвергнутых ТГЧ-воздействию на фоне острого стресса, проводилась сразу после облучения. У животных подвергнутых облучению терагерцовыми волнами перед иммобилизацией, отмечается более продолжительный индуцированный выброс оксида азота при проведении функциональной пробы с быстрым нагреванием по сравнению с крысами-самцами, подвергнутыми ТГЧ-облучению на фоне острого иммобилизационного стресса. Этот факт можно рассматривать как более выраженную адаптивную реакцию микроциркуляции в 
случае применения предварительного режима воздействия терагерцевыми волнами на частотах МСИП оксида азота у крыс-самцов при остром иммобилизационном стрессе.

\section{ГЛАВА VIII}

ХАРАКТЕР ИЗМЕНЕНИЙ ПЕРФУЗИИ МИКРОЦИРКУЛЯТОРНОГО РУСЛА И ФУНКЦИОНАЛЬНОГО СОСТОЯНИЯ ЭНДОТЕЛИЯ СОСУДОВ ПОД

\section{ВЛИЯНИЕМ ОБЛУЧЕНИЯ ТЕРАГЕРЦЕВЫМИ ВОЛНАМИ НА ЧАСТОТАХ} МСИП ОКСИДА АЗОТА 150,176 - 150,664 ГГЦ ПРИ ОСТРОМ СТРЕССЕ У БЕЛЫХ КРЫС-САМЦОВ НА ФОНЕ ДЕЙСТВИЯ БЛОКАТОРА NO-СИНТАЗЫ L-NAMЕ

Для изучения механизма положительного действия терагерцевых волн на частотах молекулярного спектра излучения и поглощения оксида азота 150,176-150,664 ГГц на изменения сосудистого компонента микроциркуляции белых крыс-самцов, подвергнутых острому иммобилизационному стрессу, проводилось исследование роли синтазы оксида азота в реализации указанного эффекта. С целью установления значения эндотелиальной NO-синтазы в реализации эффекта терагерцевых волн проводилась лазерная допплеровская флоуметрия на фоне введения неспецифического ингибитора NO-синтазы L-NAME у крыс-самцов трех групп: интактных, находящихся в состоянии острого иммобилизационного стресса и подвергнутых облучению терагерцевыми волнами при остром иммобилизационном стрессе.

8.1. Изменение перфузии микроциркуляторного русла и функционального состояния эндотелия сосудов у интактных белых крыс-самцов под влиянием блокатора NO-синтазы L-NAME

Введение неспецифического блокатора NO-синтазы L-NAME интактным крысамсамцам вызывает резкое изменение перфузии микроциркуляторного русла кожи. Под влиянием L-NAME у крыс-самцов происходит статистически достоверное уменьшение показателя перфузии в 1,7 раза и угнетение механизмов модуляции микрокровотока, что выражается в статистически достоверном уменьшении среднеквадратического отклонения перфузии в 3,29 раз и коэффициента вариации в 1,73 раз.

Анализ амплитудно-частотных осцилляций кровотока в микроциркуляторном русле свидетельствует о существенном изменении по сравнению с контролем механизмов его модуляции у крыс-самцов, которым был введен ингибитор NO-синтазы L-NAME. Так установлено, что под влиянием ингибитора NO-синтазы L-NAME у животных происходит статистически достоверное снижение амплитуды эндотелиальных колебаний 
более чем в 4 раза, что свидетельствует об угнетении базальной продукции эндотелием оксида азота. Одновременно с этим происходит статистически достоверное уменьшение амплитуды вазомоторных колебаний в 3,5 раза, что отражает рост периферического сопротивления. Под влиянием ингибитора NO-синтазы L-NAME у крыс-самцов происходит изменение и пассивных механизмов модуляции кровотока. Это выражается в статистически достоверном снижении по сравнению с группой контроля амплитуды дыхательных в 2,6 раза и пульсовых колебаний в 1,6 раза, что отражает снижение притока крови в микроциркуляторное русло кожи. Следует отметить, что под влиянием ингибитора NO-синтазы L-NAME у крыс-самцов происходит в большей степени угнетение активных механизмов модуляции кровотока в микроциркуляторном русле кожи: снижение вазодилатирующей активности эндотелия сосудов и повышение тонуса микрососудов.

При введении ингибитора NO-синтазы L-NAME у крыс-самцов происходит изменение параметров функциональной пробы с быстрым нагреванием. Установлено, что у крыс-самцов, которым был введен ингибитор NO-синтазы L-NAME, происходит статистически достоверное уменьшение исходной в 1,7 раза и максимальной перфузии в 1,4 раза, а также перфузии после восстановления кровотока в 1,4 раза по сравнению с группой контроля. Резерв капиллярного кровотока у животных на фоне введения ингибитора NO-синтазы L-NAME имеет значительную вариабельность, которая перекрывает диапазон вариабельности группы контроля, вследствие чего изменения данного показателя статистически недостоверны. Статистически достоверное снижение максимальной перфузии при проведении функциональной пробы с быстрым нагреванием у крыс-самцов на фоне введения ингибитора NO-синтазы L-NAME свидетельствует об уменьшении индуцированной продукции оксида азота эндотелием.

Таким образом, введение ингибитора NO-синтазы L-NAME интактным крысам-самцам приводит к резкому изменению перфузии микроциркуляторного русла кожи. Это выражается как в снижении среднего показателя перфузии, так и в угнетении механизмов модуляции микрокровотока. Под влиянием ингибитора NO-синтазы L-NAME в большей степени происходит угнетение активных механизмов модуляции микрокровотока. Ингибитор NO-синтазы L-NAME вызывает у крыс-самцов уменьшение базальной и индуцированной вазодилатирующей активности эндотелия микрососудов (снижение базального и индуцированного выделения оксида азота), рост периферического сопротивления, спазм приносящих сосудов и уменьшение притока крови в микроциркуляторное русло кожи. 


\section{2. Изменение перфузии микроциркуляторного русла и функционального}

состояния эндотелия сосудов у белых крыс-самцов, находящихся в состоянии острого иммобилизационного стресса, на фоне введения блокатора NO-синтазы L-NAME

При острой стрессорной реакции у крыс-самцов на фоне введения L-NAME происходит дальнейшее ухудшение перфузии микроциркуляторного русла кожи. У животных, подвергнутых иммобилизации на фоне введения L-NAME, отмечается тенденция, не достигающая статистической достоверности, к снижению перфузионного показателя, среднеквадратического отклонения перфузии и коэффициента вариации по сравнению с группой крыс-самцов, не подвергавшихся иммобилизации на фоне введения блокатора NO-синтазы L-NAME.

Результаты амплитудно-частотного анализа ЛДФ-грамм свидетельствуют, что у крыс-самцов при острой стресс-реакции на фоне введения блокатора NO-синтазы LNAME происходит статистически достоверное изменение только амплитуды пульсовых колебаний по сравнению с группой крыс-самцов, которые получали L-NAME, но не подвергались иммобилизации. Это свидетельствует о том, что при острой стрессорной реакции у крыс-самцов на фоне введения L-NAME происходит снижение притока артериальной крови в микроциркуляторное русло кожи. При сравнении величины амплитуд эндотелиальных и вазомоторных колебаний у животных, подвергавшихся и не подвергавшихся иммобилизации на фоне введения блокатора NO-синтазы L-NAME, статистически значимых отличий не обнаружено. Вероятно, это связано с блокадой активных механизмов модуляции микрокровотока под влиянием блокатора NO-синтазы L-NAME.

При сравнении данных, полученных при проведении функциональной пробы с быстрым нагреванием, у животных, подвергавшихся и не подвергавшихся иммобилизации на фоне введения блокатора NO-синтазы L-NAME, выявлена лишь тенденция, не достигающая статистической достоверности, к снижению исходной и максимальной перфузии, а также перфузии после восстановления кровотока у животных, подвергнутых иммобилизации на фоне введения L-NAME. У обеих групп животных обнаружены низкие значения как исходной, так и максимальной перфузии, а также перфузии после восстановления исходного кровотока. Это свидетельствует о том, что индуцированная вазодилатация (индуцированный выброс оксида азота) резко нарушается под влиянием ингибитора NO-синтазы L-NAME.

У крыс-самцов, которым вводился ингибитор NO-синтазы L-NAME, при остром стрессе отмечаются более выраженные изменения перфузии микроциркуляторного русла 
кожи по сравнению с животными, находящихся в состоянии острого иммобилизационного стресса, не получавших L-NAME. Установлено, что у крыс-самцов, подвергнутых иммобилизации на фоне введения L-NAME, перфузионный показатель, среднеквадратическое отклонение перфузии и коэффициент вариации статистически достоверно меньше, чем у животных, подвергнутых иммобилизации без L-NAME.

Сравнение амплитудно-частотных характеристик осцилляций кровотока в микроциркуляторном русле крыс-самцов, подвергнутых иммобилизации с введением LNAME, и животных, у которых иммобилизации проводилась без введения ингибитора NO-синтазы, показало, что у животных первой группы угнетение как активных, так и пассивных механизмов модуляции кровотока более выражено, чем у второй. У крыссамцов, подвергнутых иммобилизации на фоне введения L-NAME, амплитуда эндотелиальных, вазомоторных, дыхательных и пульсовых колебаний статистически достоверно меньше, чем у животных, подвергнутых иммобилизации без L-NAME.

Полученные данные свидетельствуют о том, что у животных, находящихся в состоянии острого иммобилизационного стресса, на фоне введения L-NAME более выражено снижение вазодилатирющей активности эндотелия (базальной продукции оксида азота), выше периферическое сопротивление и снижен приток крови в микроциркуляторное русло по сравнению с крысами-самцами, подвергнутыми иммобилизации без L-NAME.

При проведении функциональной пробы с быстрым нагреванием были обнаружены различия у животных, подвергнутых иммобилизации с введением и без введения ингибитора NO-синтазы L-NAME. Так,

установлено, что у животных, находящихся в состоянии острого иммобилизационного стресса, на фоне введения ингибитора NO-синтазы исходная и максимальная перфузия, а также перфузия после восстановления исходного кровотока статистически достоверно ниже, чем у животных, подвергнутых иммобилизации без введения L-NAME. Это свидетельствует о том, что введение ингибитора NO-синтазы L-NAME у животных при острой стресс-реакции вызывает более выраженное угнетение индуцированной секреции оксида азота эндотелием сосудов.

Таким образом, у животных, при острой стресс-реакции на фоне введения ингибитора NO-синтазы L-NAME происходит ухудшение параметров кровотока в микроциркуляторном русле кожи. При острой стрессорной реакции у крыс-самцов на фоне введения L-NAME происходит снижение притока артериальной крови в микроциркуляторное русло кожи по сравнению с крысами-самцами, которые подвергались введению ингибитора NO-синтазы без иммобилизации. Введение 
ингибитора NO-синтазы L-NAME крысам-самцам приводит к усилению нарушения перфузии микроциркуляторного русла кожи при остром иммобилизационном стрессе. Это выражается как в снижении среднего показателя перфузии, так и в угнетении механизмов модуляции микрокровотока у крыс-самцов, подвергнутых иммобилизации с введением ингибитора NO-синтазы, по сравнению с животными, подвергнутыми иммобилизации без введения L-NAME. Под влиянием ингибитора NO-синтазы L-NAME в большей степени происходит угнетение активных механизмов модуляции микрокровотока. Ингибитор NOсинтазы L-NAME вызывает у крыс-самцов, находящихся в состоянии острого иммобилизационного стресса, более выраженное уменьшение базальной и индуцированной вазодилатирующей активности эндотелия микрососудов (снижение базального и индуцированного выделения оксида азота), стимулирует рост периферического сопротивления, спазм приносящих сосудов и уменьшение притока крови в микроциркуляторное русло кожи.

8.3. Влияние облучения терагерцевыми волнами на частотах молекулярного спектра излучения и поглощения оксида азота 150,176 - 150,664 ГГц на изменения в сосудистом компоненте микроциркуляции у белых крыс-самцов, находящихся в состоянии острого иммобилизационного стресса, на фоне введения блокатора NOсинтазы L-NAME

Облучение терагерцевыми волнами на частотах молекулярного спектра излучения и поглощения оксида азота 150,176 - 150,664 ГГц крыс-самцов, находящихся в состоянии острого иммобилизационного стресса, на фоне введения ингибитора NO-синтазы LNAME не вызывает у них изменений перфузии микроциркуляторного русла кожи. При этом показатель перфузии, среднеквадратическое отклонение перфузии и коэффициент вариации у животных данной группы статистически достоверно не отличаются от показателей крыс-самцов, находящихся в состоянии острого иммобилизационного стресса, на фоне введения ингибитора NO-синтазы L-NAME. Данный факт свидетельствует о том, что терагерцевые волны не реализуют своего положительного эффекта на перфузию микроциркуляторного русла кожи у крыс-самцов, находящихся в состоянии острого иммобилизационного стресса, при введении ингибитора NO-синтазы L-NAME.

Установлено, что под влиянием волн терагерцевого диапазона у крыс-самцов, находящихся в состоянии острого иммобилизационного стресса, на фоне введения ингибитора NO-синтазы L-NAME не происходит восстановления ни активных, ни пассивных механизмов модуляции микрокровотока. Данные амплитудно-частотного анализа ЛДФ-грамм показывают, что после облучения терагерцевыми волнами на 
частотах молекулярного спектра оксида азота крыс-самцов в состоянии острого иммобилизационного стресса на фоне введения ингибитора NO-синтазы не происходит статистически значимого изменения амплитуд эндотелиальных, вазомоторных, дыхательных и пульсовых колебаний по сравнению с группой животных в состоянии острого иммобилизационного стресса на фоне введения L-NAME, не подвергавшихся ТГЧ-воздействию.

Это указывает на то, что при введении L-NAME облучение терагерцевыми волнами не оказывает восстанавливающего действия на механизмы модуляции кровотока в микроциркуляторном русле кожи у крыс-самцов, находящихся в состоянии острого иммобилизационного стресса.

Показано, что под воздействием облучения терагерцевыми волнами у крыс-самцов в состоянии острого иммобилизационного стресса на фоне введения ингибитора NOсинтазы не происходит изменения параметров функциональной пробы с быстрым нагреванием.

У крыс-самцов в состоянии острого иммобилизационного стресса на фоне введения L-NAME, подвергнутых облучению терагерцевыми волнами, не обнаружена статистически достоверная динамика исходной и максимальной перфузии, перфузии после восстановления кровотока, а также резерва капиллярного кровотока по сравненияю с крысами-самцами в состоянии острого стресса на фоне введения L-NAME, не подвергавшимися действию терагерцевых волн.

Полученные данные свидетельствуют о том, что облучение терагерцевыми волнами указанной частоты у животных в состоянии остого иммобилизационного стресса на фоне введения ингибитора NO-синтазы L-NAME не обладает способностью восстанавливать индуцированную продукцию оксида азота.

Таким образом, под влиянием облучения электромагнитными волнами терагерцевого диапазона на частотах молекулярного спектра излучения и поглощения оксида азота 150,176 - 150,664 ГГц у крыс-самцов в состоянии острого иммобилизационного стресса на фоне введения ингибитора NO-синтазы L-NAME не происходит восстановление измененной периферической перфузии и не изменяются механизмы модуляции микрокровотока. При введении L-NAME терагерцевые волны не способны нормализовать сниженную базальную и индуцированную вазодилатирующую активность эндотелия микрососудов (базальную и индуцированную секрецию оксида азота). Введение L-NAME полностью блокирует уменьшение периферического сопротивления и повышение притока артериальной крови в микроциркуляторного русло кожи, вызываемое терагерцевыми волнами у белых крыс-самцов в состоянии острого 
иммобилизационного стресса. Следовательно, введение ингибитора NO-синтазы L-NAME полностью блокирует реализацию положительного влияния терагерцевых волн на частотах молекулярного спектра излучения и поглощения оксида азота 150,176 - 150,664 ГГц на нарушения кровотока в микроциркуляторном русле кожи крыс-самцов при остром иммобилизационном стрессе.

\section{Резюме}

В результате проведенных исследований установлено, что введение ингибитора NOсинтазы L-NAME интактным крысам-самцам приводит к резкому изменению перфузии микроциркуляторного русла кожи. Это выражается как в снижении среднего показателя перфузии, так и в угнетении механизмов модуляции микрокровотока. Под влиянием ингибитора NO-синтазы L-NAME в большей степени происходит угнетение активных механизмов модуляции микрокровотока. Ингибитор NO-синтазы L-NAME вызывает у крыс-самцов уменьшение базальной и индуцированной вазодилатирующей активности эндотелия микрососудов (снижение базального и индуцированного выделения оксида азота), рост периферического сопротивления, спазм приносящих сосудов и уменьшение притока крови в микроциркуляторное русло кожи.

Установлено, что у животных при острой стресс-реакции на фоне введения ингибитора NO-синтазы L-NAME происходит ухудшение параметров кровотока в микроциркуляторном русле кожи. При острой стрессорной реакции у крыс-самцов на фоне введения L-NAME происходит снижение притока артериальной крови в микроциркуляторное русло кожи по сравнению с крысами-самцами, которые подвергались введению ингибитора NO-синтазы без иммобилизации. Введение ингибитора NO-синтазы L-NAME крысам-самцам приводит усилению изменения перфузии микроциркуляторного русла кожи при остром иммобилизационном стрессе. Это выражается как в снижении среднего показателя перфузии, так и в угнетении механизмов модуляции микрокровотока у крыс-самцов, подвергнутых иммобилизации с введением ингибитора NO-синтазы, по сравнению с животными, подвергнутыми иммобилизации без введения L-NAME. Под влиянием ингибитора NO-синтазы L-NAME в большей степени происходит угнетение активных механизмов модуляции микрокровотока. Ингибитор NOсинтазы L-NAME вызывает у крыс-самцов, находящихся в состоянии острого иммобилизационного стресса, более выраженное уменьшение базальной и индуцированной вазодилатирующей активности эндотелия микрососудов (снижение базального и индуцированного выделения оксида азота), стимулирует рост 
периферического сопротивления, спазм приносящих сосудов и уменьшение притока крови в микроциркуляторное русло кожи.

Показано, что под влиянием облучения электромагнитными волнами терагерцевого диапазона на частотах молекулярного спектра излучения и поглощения оксида азота 150,176 - 150,664 ГГц у крыс-самцов в состоянии острого иммобилизационного стресса на фоне введения ингибитора NO-синтазы L-NAME не происходит восстановление нарушеной периферической перфузии и не изменяются механизмы модуляции микрокровотока. При введении L-NAME терагерцевые волны не способны нормализовать сниженную базальную и индуцированную вазодилатирующую активность эндотелия микрососудов (базальную и индуцированную секрецию оксида азота). Введение L-NAME полностью блокирует уменьшение периферического сопротивления и повышение притока артериальной крови в микроциркуляторного русло кожи, вызываемое терагерцевыми волнами у белых крыс-самцов в состоянии острого иммобилизационного стресса.

Таким образом, введение ингибитора NO-синтазы L-NAME полностью блокирует реализацию положительного влияния терагерцевых волн на частотах молекулярного спектра излучения и поглощения оксида азота 150,176 - 150,664 ГГц на нарушения кровотока в микроциркуляторном русле кожи крыс-самцов при остром иммобилизационном стрессе.

\section{ЗАКЛЮЧЕНИЕ}

Развитие и тяжесть течения заболеваний сердечно-сосудистой системы в значительной степени определяют нарушения микрогемодинамики, в том числе периферической перфузии тканей кровью [Оганов, 2002, с. 5-9]. Изменения регионарного, в частности, коронарного, мозгового, почечного кровотоков и системной гемодинамики, в том числе недостаточность кровообращения, связаны, прежде всего, с нарушениями микроциркуляции [Влияние электромагнитного ... , 2010, с. 158-162; Изменение функционального ... , 2010, с. 30-37; Stokes, Granger, 2004, p. 647 - 653]. Экспериментальные исследования показали существенную взаимосвязь изменений механизмов регуляции в периферических сосудах (сосудах кожи) с течением инфаркта миокарда [Халепо, Молотков, Ешкина, 2009, с. 11-15.].

Проведенные нами исследования показали, что у животных в состоянии острого иммобилизационного стресса возникают значительные изменения микроциркуляции и, в частности, ее сосудистого компонента. Так, установлено, что у крыс-самцов в состоянии острого иммобилизационного стресса происходит нарушение периферической перфузии 
микроциркуляторного русла кожи. Это проявляется снижением среднего показателя перфузии и угнетением активных механизмов регуляции микрокровотока.

Как известно, в основе изменения функционирования организма при стрессе лежит активация стресс-реализующих систем и, соответственно, действие медиаторов этих систем [Гриневич, Поскребышева, Савелов, 1999, с. 50 - 66; Депонирование оксида азота ..., 2000, с. 174 - 181]. Среди них центральное место занимают гормоны и медиаторы гипоталамо-гипофизарно-надпочечниковой, симпато-адреналовой и тиреоидной осей стрессорной реакции: кортико-тропин-рилизинг-фактор, кортикотропин, катехоламины, глюкокортикоиды, йодированные гормоны щитовидной железы [Селье, 1960, с. 158-160; Панин, 1983, с. 32-36].

Ключевое значение в регуляции сосудистого компонента микроциркуляции принадлежит эндотелию сосудов [Киричук, Глыбочко, Пономарева, 2008, с. 12-15]. Повреждение эндотелия сосудов и обнажение субэндотелиальных слоев запускает реакции агрегации тромбоцитов, процесса свертывания крови, препятствующие кровопотере, вызывает спазм сосуда, прекращается образование антиагрегантов [Лупинская, 2003, с. 57-62; Киричук, Глыбочко, Пономарева, 2008, с. 12-15]. При кратковременном действии повреждающих агентов эндотелий продолжает выполнять защитную функцию, препятствуя кровопотере [Лупинская, 2003, с. 57-62]. При продолжительном повреждении эндотелий начинает играть ключевую роль в патогенезе ряда системных патологий [Киричук, Глыбочко, Пономарева, 2008, с. 12-15]. Это объясняется участием эндотелия в активации ренин-ангиотензиновой и симпатической стресс-реализующих систем, переключением активности эндотелия на синтез оксидантов, вазоконстрикторов, агрегантов и тромбогенных факторов [Гомазков, 2001, с. 50-58].

Обнаруженное нами уменьшение базальной и индуцированной вазодилатирующей активности эндотелия микрососудов у крыс-самцов, находящихся в состоянии острого иммобилизационного стресса, связано со снижением базальной и индуированной продукции эндотелием оксида азота - мощного эндогенного вазодилататора и повышенной секреции вазоконстрикторов. Снижение продукции оксида азота у этих животных может быть связано с повышением активности гипоталамо-гипофизарнонадпочечниковой оси стрессорной реакции, так как известно, что глюкокортикоиды вызывают угнетение активности NO-синтазы эндотелия [Невзорова, Зуга, Гельцер, 1997, c. 68-73]. Кроме того показано, что в условиях 3-х часовой иммобилизации у крыс-самцов происходит снижение концентрации в крови нитритов - стабильных метаболитов оксида азота [Влияние электромагнитного ..., 2010, с. 132-135.]. Другим механизмом реализации данного эффекта является повышение концентрации в крови эндотелина I у крыс-самцов, 
подвергнутых 3-х часовой иммобилизации [Влияние терагерцовых .., , 2009, с. 19 - 21; Куртукова, 2009, с. 99-100]. Известно, что поврежденный эндотелий синтезирует большое количество эндотелинов, вызывающих вазоконстрикцию [Куртукова, 2009, с. 97-98; Killy, Baffigand, Smith, 1996, p. 363-380]. Большие дозы эндотелинов, введенные добровольцам [Killy, Baffigand, Smith, 1996, p. 363-380], приводят к значительным изменениям гемодинамики: снижению частоты сердечных сокращений и ударного объема сердца, увеличению сосудистого сопротивления [Killy, Baffigand, Smith, 1996, p. 363-380].

Катехоламины, воздействуя через $\alpha$-адренорецепторы, вызывают увеличение сосудистого тонуса и периферического сопротивления [Патологическая физиология ... , 2007, с. 327-348]. Изменение эндотелиальной секреции и повышенная продукция катехоламинов объясняют снижение амплитуды вазомоторных колебаний, обнаруженное при анализе амплитудно-частотных осцилляций микрокровотока в сосудистом русле кожи крыс-самцов, находящихся в состоянии острого иммобилизационного стресса.

Вследствие изменения эндотелиальной секреции, а также избыточного поступления катехоламинов и глюкокортикостероидов в кровь происходит вазоконстрикция сосудов микроциркуляторного русла кожи, что выражается в снижении амплитуды кардиальных колебаний у крыс-самцов в состоянии острого стресса, выявленное нами при амплитудночастотном анализе кривых изменения перфузии микроциркуляторного русла кожи, и уменьшение числа функционирующих капилляров, обнаруженное при проведении функциональной пробы с быстрым нагревом кожи животных.

В конечном итоге у животных в состоянии острого стресса происходит снижение среднеквадратического отклонения и коэффициента вариации, что обусловлено угнетением, прежде всего, активных механизмов модуляции микрокровотока, и снижение среднего показателя перфузии, связанное со спазмом приносящих сосудов, уменьшением числа функционирующих капилляров и обеднения микроциркуляторного русла кожи кровью.

Известно, что одним из ведущих факторов этиологии и патогенеза заболеваний сердечно-сосудистой системы является патологический стресс [Меерсон, 1981, с. 120-137; Берсудский, 2002, с. 79-84; Фармакоэкономический анализ ..., 2006, с. 32-38; Оганов, 2000, с. 65-69; Оганов, Масленникова, 2007, с. 7-14]. Стресс является компонентом адаптации организма к окружающей среде. Вследствие увеличения ритма жизни современного общества и количества стрессорных ситуаций происходит подъем заболеваемости так называемыми болезнями адаптации, к которым относят и ряд заболеваний сердечно-сосудистой системы [Меерсон, 1981, с. 120-137]. В основе неблагоприятных последствий стресса лежит дисбаланс деятельности стресс- 
реализующих и стресс-лиммитирующих систем [Манухина, Малышев, 2000, с. 12831292]. При действии чрезмерных по силе или продолжительности раздражителей происходит срыв стресс-лимитирующих систем, которые способны ограничивать повреждающее действие гормонов и медиаторов стресс-реализующих систем. В настоящее время принято различать центральные (ГАМК, опиоидэргические) и периферические (простагландины, антиоксиданты) стресс-лимитирующие системы. Абсолютно уникальной является стресс-лимитирующая система оксида азота, которая имеет как центральный, так и периферический компонент [Манухина, Малышев, 2000, с. 1283-1292]. Доказано, что при ряде заболеваний сердечно - сосудистой системы имеет место нарушение синтеза оксида азота эндотелием, вследствие чего развиваются локальные и системные нарушения гемодинамики [Суточная продукция ..., 2001, с. 34-7]. Следовательно, изменения периферической перфузии и функционального состояния эндотелия у животных в состоянии стресса являются не только аналогичными, но и гомологичными (имеющими ту же природу) изменениям микроциркуляции у больных с заболеваниями сердечно-сосудистой системы. Все выше изложенное дает основания считать нарушения периферической перфузии и функционального состояния эндотелия у животных в состоянии имммобилизационного стресса точной моделью нарушений микроциркуляции у больных с заболеваниями сердечно-сосудистой системы.

В настоящее время для коррекции нарушений микроциркуляции и, в частности, ее внутрисосудистого компонента у больных с заболеваниями сердечно-сосудистой системы используется широкий спектр медикаментозных препаратов, вызывающих вазодилатацию. Однако классические схемы медикаментозной терапии часто оказываются недостаточно эффективными, фармакотерапия сопровождается развитием различной степени выраженности побочных эффектов [Лоуренс, Бенитт, 1993, с. 175-180; Словарь справочник ..., 2005, с. 230-231; Справочник Видаль, 2010, с. 1629-1631]. Все это обусловливает необходимость поиска новых немедикаментозных методов коррекции. Одним из таких методов является использование волн миллиметрового и субмиллиметрового диапазонов частот.

Электромагнитные волны крайне высокой частоты (КВЧ-волны) уже достаточно давно и успешно применяются в лечении ряда заболеваний [Девятков, Голант, Бецкий, 1991, с. 123-129; Девятков, 1994, с. 130-135; Киричук, Головачева, Чиж, 1999, с. 311-320; Бецкий, 2000, с. 3-9; Бецкий, 2000, с. 3-13; Роль электромагнитных ... , 2000, с. 483-490; Новые аспекты ..., 2009, с. 37-56]. КВЧ-терапия, в частности, доказала свою эффективность в комплексном лечении болезней сердечно-сосудистой системы - острого инфаркта миокарда и нестабильной стенокардии [Головачева, 1991, с. 54-57; Семенова, 1994, с. 10- 
21; Паршина, Киричук, Головачева, 2005, с. 109-111; Киричук, Головачева, Чиж, 1999, с. 311-320; Влияние миллиметровой ..., 2000, с. 82-83; Адаптационные реакции ..., 2000, с. 37-39; Паршина, 2006, с. 32 - 40; Новые аспекты ... , 2009, с. 37-56]. К числу преимуществ данного способа следует отнести высокую результативность, неинвазивность, небольшое количество побочных реакций и противопоказаний к применению, невысокую стоимость лечения, возможность сочетания с другими методами терапии, отсутствие побочных эффектов и отдаленных неблагоприятных результатов, высокую эффективность в виде монотерапии и удобство применения в стационаре [Девятков, Голант, Бецкий, 1991, с. 123-129, Девятков, 1994, с. 130-135; Применение ММ-волн ... , 1997, с. 9-13; Киричук, Головачева, Чиж, 1999, с. 311-320; Паршина, 2006, с. 32 - 40; Водолагин, 2008, с. 15-18; Новые аспекты ..., 2009, с. 37-56].

Как известно, при классической КВЧ-терапии электромагнитное воздействие осуществляется на частотах 42,2 ГГц и 53,5 ГГц [Девятков, 1994, с. 130-135; Тенденция развития ..., 1999, с. 56-58; Киричук, Головачева, Чиж, 1999, с. 311-320; Бецкий, 2000, с. 3-9; Федоров, Королев, Беляков, 2000, с. 159-163]. Помимо этого, в настоящее время исследуются вопросы взаимодействия биологических объектов с электромагнитными полями всего миллиметрового и субмиллиметрового диапазона частот.

Терагерцевая терапия (ТГЧ-терапия) является относительно новым, но весьма перспективным методом физиотерапевтического воздействия [Биофизические эффекты ... , 2003, с. 3-6]. Терагерцевый диапазон частот лежит на границе между электроникой и фотоникой от 100 ГГц до 10 ТГц (1 ТГц $=10^{3}$ ГГц) или в длинах волн от 3 мм до 30 мм. Снизу он определен частотно-временным ограничением (более 100 ГГц) электронных переходов в полупроводниковых структурах, а сверху - максимальной длиной волны квантовых переходов лазерных структур. Этот диапазон волн находится на шкале электромагнитных волн между КВЧ - диапазоном и оптическим инфракрасным (ИК) диапазоном и частично перекрывает высокочастотную часть КВЧ диапазона (100 ГГц 300 ГГц) и низкочастотную часть ИК диапазона [Биофизические эффекты ... , 2003, с. 3$6]$.

Молекулярные спектры излучения и поглощения (МСИП) многих биологически активных веществ (оксида азота - NO, оксида углерода - CO, молекулярного кислорода и его активных форм и др.) находятся в терагерцевом диапазоне [Измерение радиотепловых ..., 1968 с. 203-205; Мериакри, 2002, с. 15-18; Биофизические эффекты ... , 2003, с. 3-6; Молекулярные HITRAN-спектры ..., 2007, с. 5-9; Профилактика нарушений ..., 2011, с. 4-8; The HITRAN ... , 2003, р. 5-44]. Среди перечисленных метаболитов наибольшим значением в регуляции физиологических процессов обладает, безусловно, оксид азота 
(NO) [Снайдер, 1992, с. 15-24; Марков, 1996, с. 30-44; Furchgott, Zawadzki, 1980, p. 373376;; Ignarro, Wood, 1987, Furchgott, 1991, p. 52-61 p. 160 - 170; Ignarro, 1995, p. 1-516; Nitric oxide ..., 1999, p. 979-886].

Проведенные нами исследования свидетельствуют, что электромагнитное облучение терагерцевыми волнами на частотах МСИП оксида азота 150,176 - 150,664 ГГц интактных крыс-самцов в течение 30 минут не вызывает изменения средней величины перфузии и модуляции микрокровотока. Полученные результаты согласуется с данными других авторов об отсутствии существенного влияния на организм здорового человека и животных волн миллиметрового и субмиллиметрового диапазонов частот [Бецкий, Лебедева, 2001, с. 5-19; Киричук, Воскобой, Ребров, 2001, с. 31-34; Помошникова, 2006, с. 15-17; Цымбал, 2007, с. 11-20, Антипова, 2009, с. 40-41].

Однако, при проведении функциональной пробы с быстрым нагреванием, кожи, которая используется для определения функциональных резервов микроциркуляции [Крупаткин, Сидоров, 2005 с. 105-110], нами обнаружено под влиянием терагерцевых волн у крыс-самцов возрастает индуцированная вазодилатация, связанная с повышенным выделением оксида азота эндотелием. Этот факт свидетельствует об увеличении функциональных резервов сосудистого компонента микроциркуляции. Известно, что часть синтезированного оксида азота может связываться в комплексы, которые образуют физиологически активное депо [Ванин, 1998, с. 924-928]. Это депо может не только связывать, но и постепенно высвобождать NO. Депонирование оксида азота происходит в стенках сосудов и начинается при повышении его концентрации. По-видимому, формированием депо оксида азота и объясняется увеличение функциональных резервов сосудистого компонента микроциркуляции, так как доказано, что формирование NO-депо является важной частью адаптивных реакций [Депонирование оксида ..., 2000, с. 174-181; Коррекция NO-зависимых ... , 2001, с. 110-117; Роль свободного ..., 2004, с. 4-11].

В результате проведенных исследований нами установлено, что под влиянием облучения электромагнитными волнами терагерцевого диапазона на частотах молекулярного спектра излучения и поглощения оксида азота 150,176 - 150,664 ГГц у крыс-самцов в состоянии острого иммобилизационного стресса происходит восстановление нарушеной периферической перфузии, что проявляется повышением среднего показателя перфузии, активацией механизмов регуляции микрокровотока. При анализе амплитудно-частотных осцилляций микрокровотока выявлено, что под влиянием терагерцевых волн происходит стимуляция, в первую очередь, активных механизмов модуляции кровотока: увеличение эндотелиальной секреции вазодилататоров и снижение периферического сопротивления. Уменышение периферического сопротивления вызывает 
изменение и пассивных механизмов модуляции кровотока, что выражается в увеличении амплитуды кардиальных колебаний. Кроме того установлено, что под влиянием терагерцевых волн у крыс-самцов в состоянии острого иммобилизационного стресса нормализуются показатели термопробы, что свидетельствует о восстановлении параметров индуцированной вазодилатации и характеризует повышение функциональных резервов сосудистого компонента микроциркуляции. Стимуляция активных и пассивных механизмов модуляции кровотока терагерцовыми волнами вызывает у крыс-самцов при остром стрессе увеличение притока артериальной крови в микроциркуляторного русло, что и обусловливает восстановление перфузионного показателя.

В настоящее время предложено несколько подходов к объяснению механизмов воздействия на биологические объекты (на организменном, клеточном и молекулярном уровнях) ЭМИ миллиметрового и субмиллиметрового диапазонов. Наиболее полным представляется подход, развитый в работах Н.Д. Девяткова, М.Б. Голанта, О.В. Бецкого [Девятков, Голант, Бецкий, 1991, с. 123-129], О.В. Бецкого [Бецкий, 1997, с. 135-137], О.В. Бецкого, Н.Д. Девяткова, В.В. Кислова [Бецкий, Девятков, Кислов , 1998 с. 13-29], О.В. Бецкого, Н.Н. Лебедевой [Бецкий, Лебедева, 2001, с. 5-19]. В реализации эффектов ТГЧоблучения участвуют биохимические механизмы, приводящие к активации различных ферментных систем [Механизм действия ... , 2009, с. 47-55].

Одним из возможных механизмов действия ТГЧ-облучения на частотах МСИП NO является активация эндогенного оксида азота [Влияние КВЧ-облучения ... , 2005, с. 6470]. Согласно одной из теорий [Бецкий, Девятков, Кислов, 1998, с. 13-29] при облучении энергия КВЧ и ТГЧ - излучения расходуется на переходы молекул из одного энергетического состояния в другое. При используемых в медико-биологической практике уровнях мощности КВЧ и ТГЧ экзогенное воздействие электромагнитного излучения приводит к изменению вращательной составляющей полной энергии молекул. При совпадении частоты проводимого облучения с частотой вращения полярных молекул возможна перекачка энергии излучения молекуле, сопровождающаяся увеличением ее вращательной кинетической энергии, влияющей на ее реакционную способность [Бецкий, Девятков, Кислов, 1998, с. 13-29].

Согласно другому мнению, изменения вращательной составляющей энергии молекулы оксида азота не происходит [Ковалев, 2006, с. 78-81]. Полагают, что наличие на внешней орбитали неспаренного электрона придает молекуле NO парамагнитные свойства [Парселл, 1971, с. 301-302]. При интеграции в пространственную сетку водородных связей воды (растворении) таких молекул, магнитные силы спинов их неспаренных электронов способны взаимодействовать с магнитными моментами протонов. В подобной магнитной 
системе внешнее высокочастотное поле может возбуждать относительные колебания спинов, называемые спиновыми волнами [Ивановский, Черникова, 1981, с. 86-93]. Периодическое изменение ориентации спина гидратированной парамагнитной молекулы способно инициировать волнообразную динамику спинов протонов пространственной сетки водородных связей [Структурные престройки, ... , 2003, с. 149-162]. Граничная частота спиновых волн составляет порядка $10^{10}-10^{11}$ Гц $(10-100$ ГГц) [Кулагин, Свиридов, 1978, с. 56-64], они имеют квантовую природу [Киттель, 1978, с. 78-83] и возбуждаются по механизму спин-волнового резонанса [Ивановский, Черникова, 1981, с. 86-93]. Это означает, что спиновые волны могут возбуждаться электромагнитными излучениями определенных длин волн, относящихся к миллиметровому и субмиллиметровому диапазону. При растворении в водной фазе биосистемы молекула NO утрачивает вращательную активность, но сохраняет способность поглощать электромагнитное излучение частотой своего вращательного спектра. Следовательно, одним из возможных механизмов действия электромагнитного излучения на частотах молекулярного спектра излучения и поглощения оксида азота является преобразование энергии электромагнитного излучения в поток магнитного порядка (спиновых волн) от растворенных молекул NO на гидратированный комплекс клеточных и внеклеточных белков [Ковалев, 2006, с. 78-81]. Изменение гидратации белковой молекулы изменяет и ее активность.

Не исключена возможность взаимодействия ТГЧ-волн непосредственно с NOсинтазами [Оксид азота ... , 2008, с. 83-91; Механизм действия ... , 2009, с. 47-55; Значение эндотелиальной ..., , 2009, с. 103-106; Значение эндотелиальной ..., , 2009, с. 106108]. Результатом подобного взаимодействия может являться ускорение внутримолекулярного переноса электронов (с FAD на FMN и с FMN на оксидазный домен) [Горрен, Майер, 1998, с. 870-880], что приводит к увеличению скорости катализа. Кроме того, возможно взаимодействие ТГЧ-излучения с гемом NO-синтазы и/или гуанилатциклазы - главной мишени эндогенного оксида азота, приводящее к переходу его в высокоспиновое состояние, что сопровождается увеличением сродства NO-синтазы к Lаргинину и повышению активности фермента. Следовательно, при облучении терагерцевыми волнами в качестве первичной мишени может выступать NO-синтазная компонента цикла эндогенного оксида азота.

Обнаруженное нами увеличение амплитуды эндотелиальных колебаний под влиянием облучения терагерцевыми волнами у крыс-самцов в состоянии острого стресса отражают нормализацию эндотелиальной секреции: повышение продукции вазодилататоров (оксида азота) и снижение продукции вазоконстрикторов. Данные 
биохимических тестов подтверждают полученные результаты лазерной допплеровской флоуметрии, свидетельствующие о повышении продукции оксида азота. Так, известно, что облучение белых крыс-самцов, находящихся в состоянии острого иммобилизационного стресса, электромагнитными волнами терагерцевого диапазона на частотах молекулярного спектра излучения и поглощения оксида азота 150,176 - 150,664 ГГц приводит к статистически достоверному повышению концентрации нитритов плазмы крови - стабильных метаболитов оксида азота, по сравнению с группой животных в состоянии острого и длительного иммобилизационного стресса, не подвергавшихся ТГЧвоздействию [Влияние электромагнитного ..., 2010, с. 132-135]. Одним из важных маркеров дисфункции эндотелия, наряду со сниженной продукцией оксида азота, является повышенная концентрация в сыворотке крови эндотелина I - мощного вазоконстриктора [Лупинская, 2003, с. 57-62; Киричук, Глыбочко, Пономарева, 2008, с. 12-15]. Известно, что под влиянием ТГЧ-облучения на частотах МСИП оксида азота 150,176 - 150,664 ГГц у крыс-самцов в состоянии острого иммобилизационного стресса имеется тенденция к снижению продукции эндотелина I. Курсовое воздействие ТГЧ-волн на животных при длительном стрессе вызывает статистически достоверное снижение в крови повышенной концентрации эндотелина I [Влияние терагерцовых ... , 2009, с. 19-21 ].

Таким образом, под влиянием облучения терагерцевыми волнами на частотах МСИП оксида азота 150,176 - 150,664 ГГц происходит нормализация баланса продукции вазоконстрикторных и вазодилататорных агентов эндотелиоцитами, то есть облучение волнами указанной частоты способно корректировать эндотелиальную дисфункцию. [Влияние терагерцовых ..., 2009, с. 19-21; Влияние электромагнитного . . , 2010, с. 132135].

В восстановлении нормальной секреторной активности эндотелия немаловажную роль играют нейроэндокринные механизмы, вызывающие под влиянием терагерцевых волн уменьшение активности осей стрессорной реакции, и, в частности, гипоталамогипофизарно-надпочечниковой, так как известно, что глюкокортикостероиды вызывают угнетение продукции оксида азота [Невзорова, Зуга, Гельцер, 1997, с. 68-73]. Показано, что ТГЧ-облучение вызывает статистически достоверное снижение выброса кортикотропина у белых крыс, подвергнутых 3-х часовой иммобилизации, особенно выраженное в первые 30 минут иммобилизационного стресса. Известно, что кортикотропин регулирует продукцию глюкокортикостероидов корой надпочечников [Киричук, Иванов, 2008, с. 65-71]. Исследования показали [Цымбал, 2007, с. 15-20], что ТГЧ-облучение на частотах МСИП оксида азота 150,176 - 150,664 ГГц белых крыссамцов способно снижать уровень кортикостероидов у животных в состоянии стресса и 
предотвращать повышение их уровня при облучении до начала действия стрессора. Данные морфологических и морфометрических исследований гипофиза и надпочечников свидетельствуют, что у крыс-самцов, подвергнутых облучению терагерцевыми волнами на частотах МСИП оксида азота 150,176 - 150,664 ГГц на фоне острого стресса, происходит умеренное снижение повышенной активность гипофизарно-надпочечниковой оси стрессорной реакции, ограничивая выброс гормонов и истощение надпочечников [Влияние электромагнитного ... , 2009, с. 511-516]. Снижение активности гипоталамогипофизарно-надпочечниковой оси вероятно связано с активацией NO-эргических нейронов в центральной нервной системе, которые предупреждают гиперсекрецию основных гипоталамо-гипофизарных стрессорных гормонов: кортикотропина, рилизингфактора кортикотропина и др. [Endotoxin stimulates ... , 1998, p. 104-109].

Обнаруженное нами восстановление амплитуды вазомоторных колебаний под влиянием терагерцевых волн у крыс-самцов при остром стрессе связано, в первую очередь, с нормализацией функций эндотелия и повышением им продукции оксида азота. Паракринное действие оксида азота на гладкие мышцы сосудов проявляется в том, что, проникая в гладкомышечные сосудистые клетки, он активирует гуанилатциклазу, которая увеличивает образование цГМФ [Северина, 1998, с. 939-997]. В результате увеличивается скорость продукции цГМФ в мышечных клетках. Высвобождение и накопление цГМФ приводит к активации фермента цГМФ - зависимой протеинкиназы [Ванин, 1998, с. 924928]. Потенциальными мишенями для цГМФ-зависимой протеинкиназы (тип I) в сосудистых гладкомышечных клетках, являются $\mathrm{Ca}^{2+-}$ зависимые калиевые каналы и IRAG - белки, участвующие в модулировании входа внеклеточных и высвобождении внутриклеточных ионов кальция. Фосфорилирование этих двух белков может снижать концентрацию цитозольного кальция, что ведет к расслаблению сосудов [Суclic GMPdependent ... , 2003, p. 907-916]. Вторым возможным паракринным механизмом реализации влияния оксида азота на тонус микрососудов через эндотелий может быть связано с выделением эндотелиальными клетками ряда эндотелийзависимых вазодилататоров (ацетилхолина, брадикинина, гистамина), которые тормозят образование эндотелиального сосудосуживающего фактора эндотелина - I и высвобождение норадреналина окончаниями симпатических нейронов, препятствует осуществлению чрезмерных эффектов других вазоконстрикторов (ангиотензина, тромбоксана $\mathrm{A}_{2}$ ) [Коррекция NO-зависимых ... , 2001, с. 110-117; Роль свободного ... , 2004, с. 4-11].

Выявленное снижение периферического сопротивления сосудов микроциркуляторного русла у крыс-самцов в состоянии острого стресса под влиянием терагерцовых волн на частотах МСИП оксида азота 150,176-150,664 ГГц может быть связано и со снижением 
выброса метаболитов стресс-реализующих систем, в частности, симпато-адреналовой оси. Экспериментальные исследования свидетельствуют, что при облучении животных, находящихся в состоянии острого иммобилизационного стресса, электромагнитными волнами терагерцового диапазона на частотах оксида азота 150,176 - 150,664 ГГц происходит статистически достоверное уменьшение концентрации катехоламинов в крови, что свидетельствует об ограничении активности симпатоадреналовой оси стрессорной реакции [Механизм действия, ..., 2009, с. 47-55]. Этот нейроэндокринный механизм регуляции может быть связан с повышением под влиянием терагерцевых волн активности NO-эргических нейронов, которые богато иннервируют мозговое вещество надпочечников, непосредственно контактируя с хромаффинными клетками, и при активации блокируют выброс катехоламинов надпочечниками [Addicks, Bloch, Feelisch, 1994, p. 161-168]. Кроме того, оксид азота способен блокировать выделение катехоламинов из нервных окончаний [Манухина, Малышев, 2000, с. 1283-1292; Addicks, Bloch, Feelisch, 1994, p. 161-168].

Таким образом, терагерцевые волны оказывают нормализующее влияние на активные механизмы модуляции микрокровотока, обеспечивая восстановление баланса продукции вазоактивных веществ эндотелием и вазодилатацию, обусловливающую снижение периферического сопротивления. Механизм данного эффекта сопряжен с активацией NOсинтазного компонента цикла эндогенного оксида азота и реализуется при участии как регуляторных систем эндотелия, так и за счет изменений нервной и эндокринной регуляции. Нормализация активных механизмов модуляции микрокровотока приводит к восстановлению нормальных показателей перфузии микроциркуляторного русла.

Участие NO-синтазного компонента цикла эндогенного оксида азота в реализации эффектов терагерцевых волн на сосудистый компонент микроциркуляции подтверждается нашими исследованиями изменением перфузии микроциркуляторного русла и функционального состояния эндотелия у крыс-самцов в состоянии острого стресса под влиянием ТГЧ-облучения на фоне введения неспецифического ингибитора NO-синтаз LNAME. Нами показано, что под влиянием облучения электромагнитными волнами терагерцевого диапазона на частотах молекулярного спектра излучения и поглощения оксида азота 150,176 - 150,664 ГГц у крыс-самцов в состоянии острого иммобилизационного стресса на фоне введения ингибитора NO-синтазы L-NAME не происходит восстановление нарушенной периферической перфузии и не изменяются механизмы модуляции микрокровотока. При введении L-NAME терагерцевые волны не способны нормализовать сниженную базальную и индуцированную вазодилатирующую активность эндотелия микрососудов (базальную и индуцированную секрецию оксида 
азота). Введение L-NAME полностью блокирует уменьшение периферического сопротивления и повышение притока артериальной крови в микроциркуляторного русло кожи, вызываемое терагерцевыми волнами у белых крыс-самцов в состоянии острого иммобилизационного стресса.

Таким образом, введение ингибитора NO-синтазы L-NAME полностью блокирует реализацию положительного влияния терагерцевых волн на частотах молекулярного спектра излучения и поглощения оксида азота 150,176 - 150,664 ГГц на нарушения кровотока в микроциркуляторном русле кожи крыс-самцов при остром иммобилизационном стрессе. Полученные данные согласуются с данными других авторов о роли NO-синтазы в реализации эффектов терагерцевых волн. Так, показано, что введение ингибитора NO-синтазы L-NAME животным, находящимся в состоянии оксидативного стресса, блокирует восстанавливающий эффект терагерцевого облучения на частоте молекулярного спектра излучения и поглощения оксида азота на нарушенную агрегацию тромбоцитов [Механизм действия, ... , 2009, с. 47-55]. Известно, что изменений концентрации нитритов и эндотелина I у крыс-самцов в состоянии острого стресса под влиянием терагерцевых волн на частотах МСИП оксида азота 150,176 - 150,664 ГГц не происходит при введение блокатора NO-синтазы (L-NAME) [Влияние терагерцовых ... , 2009, с. 19-21; Влияние электромагнитного ..., 2010, с. 132-135]. Также установлено, что терагерцевые волны не оказывают своего положительного влияния на гемодинамику в магистральных артериях у белых крыс-самцов при остром стрессе при введении L-NAME [Великанова, 2011, с. 23-24; Влияние ингибитора ... , 2011, с. 19-24]. Результаты собственных исследований и литературные данные позволяют заключить, что механизм действия терагерцевых волн на частотах МСИП оксида азота реализуется при непосредственном участии NO-синтазного компонента цикла эндогенного оксида азота.

Нами впервые установлено, что облучение животных терагерцевыми волнами на частотах МСИП оксида азота 150,176 - 150,664 ГГц до начала действия стрессора способно предотвращать развитие характерных для острой стресс-реакции нарушений сосудистого компонента микроциркуляции. Терагерцевые волны указанной частоты препятствуют снижению среднего показателя перфузии, нарушению механизмов модуляции микрокровотока. Показано, что облучение терагерцевыми волнами крыссамцов перед иммобилизацией обеспечивает сохранение нормальной базальной и индуцированной вазодилатирующей активности эндотелия микрососудов (базального и индуцированного выделения оксида азота), а также периферического сопротивления в условиях острого иммобилизационного стресса. Облучение перед иммобилизацией крыссамцов частично препятствует нарушению амплитуды кардиальных осцилляций. 
Указанная тенденция, возможно, связана с перераспределением кровотока в организме и свидетельствует в пользу того, что терагерцовые волны не блокируют стрессорную реакцию, что нарушало бы процесс адаптации, а только модулируют ее протекание, оказывая преимущественное влияние на сохранение нормального функционирования активных механизмов модуляции микрокровотока, реализуемых эндотелием сосудов.

До недавнего времени считалось, что электромагнитное облучение миллиметрового и субмиллиметрового диапазонов частот оказывает эффект только на организм с измененным функциональным состоянием, а интактные животные и здоровые люди невосприимчивы к этому виду излучения [Девятков, Голант, Бецкий, 1991, с. 123-129]. Наши данные так же показывают, что при облучении интактных животных ТГЧ-волнами на частотах МСИП NO 150,176 - 150,664 ГГц не вызывает изменения линейной скорости кровотока. Однако, как описано выше, нами установлено, что под влиянием терагерцевых волн у интактных животных увеличивается функциональный резерв микроциркуляции, что выражается в увеличении способности к индуцированной вазодилатации, однако при этом статистически значимого изменения перфузии и показателей, характеризующих механизмы ее модуляции, не обнаружено. По всей видимости, воздействуя на интактный организм, ТГЧ-облучение не изменяет основных физиологических параметров, но воздействует на механизмы регуляции, изменяя реактивность организма. Эффективность профилактических курсов ТГЧ-облучения в коррекции нарушений перфузии и функционального состояния эндотелия у крыс-самцов при остром стрессе, вероятно, связана с формированием физиологически активного депо оксида азота, которое формируется при повышении концентрации NO, и является важной частью адаптивных реакций [Депонирование оксида ..., 2000, с. 174 - 181 Коррекция NO-зависимых ... , 2001, с. 110-117; Роль свободного ... , 2004, с. 4-11].

Полученные нами данные хорошо согласуются с экспериментальными исследованиями других авторов. Так, Е.Н. Чуян и соавт. [Чуян, Темурьянц, Москвичук, 2003, с. 350-355] показали, что стресс-лимитирующее действие ЭМИ КВЧ с длинами волн 5,6 и 7,1 мм зависит от последовательности воздействия электромагнитного облучения. Кроме того, показано, что под влиянием КВЧ-облучения стимулируются активные механизмы модуляции микрокровотока в сосудистом русле кожи в точках воздействия [Чуян, Раваева, Трибрат, 2008, с. 82-90.].

Таким образом, предшествующее стрессу ТГЧ-воздействия изменяют протекание стресс-реакции, повышают устойчивость животных к действию стрессора. Данный эффект является экспериментальным обоснованием для создания специального медицинского оборудования, разработки и внедрения в практическую медицину нового направления 
физиотерапии «Терагерцевая терапия» - «ТГЧ-профилактика» [Механизм действия, ... , 2009 , c. 47-55].

Следовательно, в условиях эксперимента на животных нами получены новые данные о характере механизмов воздействия ТГЧ-облучения на частотах МСИП оксида азота 150,176 - 150,664 ГГц на изменения сосудистого компонента микроциркуляции, происходящие в организме при стрессе. Проведенные исследования позволяют выявить ряд эффектов данного облучения на клеточном, тканевом, системном и организменном уровнях. В реализации эффекта терагерцовых волн задействованы все уровни физиологической регуляции от нейроэндокринных изменений до ауторегуляции отдельных клеток. Механизм действия облучения волнами указанных частот непосредственно связан с NO-синтазным компонентом цикла оксида азота.

Полученные нами данные позволяют рекомендовать использование электромагнитного излучения терагерцового диапазона на частотах МСИП оксида азота 150,176 - 150,664 ГГц в клинической практике для нормализации нарушений микроциркуляции при различных, в том числе сердечно-сосудистых заболеваниях, а также как метод, обладающий выраженным антистрессорным эффектом.

\section{ЛИТЕРАТУРА}

1. Адаптационные реакции организма и система свертывания крови / А.М. Антонов, Н.В. Беликина, С.А. Георгиева [и др.] // Система свертывания крови и фибринолиз: материалы 10-й Всесоюзного съезда физиол. общества им. И.П. Павлова. Ереван, 1964. -С. 47-48.

2. Адаптационные реакции организма как показатели, определяющие эффективность КВЧ-терапии у больных нестабильной стенокардией: новые подходы в лечении / С.С. Паршина, Т.В. Головачева, Н.В. Старостина [и др.] // Миллиметровые волны в биологии и медицине: Сб. докладов 12-го Российского симпозиума с международным участием.- М.: ИРЭ РАН, 2000.-С. 37-39.

3. Андронов Е.В. Экспериментальное изучение влияния электромагнитных волн терагерцового диапазона на частотах оксида азота на внутрисосудистый компонент микроциркуляции: автореф. дис... докт. мед. наук. - Саратов: ГОУ ВПО «Саратовский ГМУ Росздрава», 2008.-50 с.

4. Андронов Е.В., Киричук В.Ф. Электромагнитное излучение терагерцового диапазона на частоте 400 ГГц оксида азота как фактор для коррекции агрегационной активности тромбоцитов больных нестабильной стенокардией в условиях in vitro // Саратовский научно-медицинский журнал.- 2006.- № 1.-С. 22-27. 
5. Антипова О.Н. Экспериментальное обоснование использования электромагнитных волн терагерцового диапазона для восстановления нарушенных реологических свойств крови и функциональной активности тромбоцитов: автореф. дис... докт. мед. наук . - Саратов: ГОУ ВПО «Саратовский ГМУ Росздрава», 2009. - 48c.

6. Антистрессорное действие электромагнитного излучения терагерцового диапазона частот молекулярного спектра оксида азота / В.Ф. Киричук, О.Н. Антипова // Биомедицинские технологии и радиоэлектроника.- 2004.- № 11.-С. 12-20.

7. Аппарат для лечения электромагнитными волнами крайне высоких частот / Бецкий О.В., Креницкий А.П., Майбородин А.В, Тупикин В.Д. - Патент «Роспатента» на полезную модель №50835 от 27 января 2006. [Электронный ресурс]. URL: http://www.fips.ru (дата обращения 05.12. 2009).

8. Аршавский И.А. Биологические и медицинские аспекты проблемы адаптации и стресс в свете данных по физиологии онтнгенеза / В кн.: Актуальные вопросы современной физиологии.- М.: Наука, 1976.-С. 144-191.

9. Балуда В.П., Балуда М.В., Деянов И.И. Физиология системы гемостаза. - М.: Медицина, 1995. - 245c.

10. Барабой В.А. Механизмы стресса и перекисное окисление липидов //Успехи современной биологии. - 1991. - Т 11. - вып 6. - С. 923 - 931.

11. Баркаган 3.С., Момот А.П. Основы диагностики нарушений гемостаза.- М.: Негодиамед-АО, 1999.- 224 с.

12. Берсудский С.О. Общий адаптационный синдром //В кн. Общая патология. Саратов: Изд-во Саратовского медицинского университета, 2002. - С. 79-84.

13. Бецкий О.В. Лечение электромагнитными полями. Ч. 1. Источники и свойства электромагнитных волн // Биомедицинская радиоэлектроника. - 2000. - № 7. - С. 3-9.

14. Бецкий О.В. Лечение электромагнитными полями. Ч. 2. // Биомедицинская радиоэлектроника. - 2000. - № 10. - С. 3-13.

15. Бецкий О.В. Механизм воздействия низкоинтенсивных миллиметровых волн на биологические объекты (биофизический подход) // Миллиметровые волны в биологии и медицине. М. ИРЭ РАН. - 1997. - С. 135-137.

16. Бецкий О.В., Девятков Н.Д., Кислов В.В. Миллиметровые волны низкой интенсивности в биологии и медицине // Биомедицинская радиоэлектроника. - 1998. №10. - C. 13-29.

17. Бецкий О.В., Лебедева Н.Н. История становления КВЧ терапии и десятилетние итоги работы Медицинской ассоциации КВЧ // Миллиметровые волны в биологии и медицине. - 2002. - №4. - С. 10-17. 
18. Бецкий О.В., Лебедева Н.Н. Современные представления о механизмах воздействия низкоинтенсивных миллиметровых волн на биологические объекты // Миллиметровые волны в биологии и медицине.-2001.- № 3.- С. 5-19.

19. Биофизические эффекты волн терагерцового диапазона и перспективы развития новых направлений в биомедицинской технологии: «Терагерцовая терапия» и «Терагерцовая диагностика» / О.В. Бецкий, А.П. Креницкий, А.В. Майбородин [и др.]// Биомедицинские технологии и радиоэлектроника.- 2003.- № 12.-С. 3-6.

20. Ванин А.Ф. Динитрозильные комплексы железа и S-нитрозотиолы - две возможные формы стабилизации и транспорта оксида азота в биосистемах // Биохимия. 1998. - T. 63. - № 7. - C. 924-928.

21. Великанова Т.С. Влияние электромагнитного облучения терагерцового диапазона на частотах молекулярного спектра излучения и поглощения оксида азота 150,176-150,664 ГГц на постстрессорные нарушения системной гемодинамики: автореф. дис. ... канд. мед. наук. - Саратов: ГОУ ВПО «Саратовский ГМУ Росздрава», 2011. - 25 с.

22. Влияние ингибитора NO-синтазы L-NAME и облучения электромагнитными волнами терагерцового диапазона на частотах молекулярного спектра излучения и поглощения оксида азота 150,176-150,664 ГГц на системную гемодинамику крыс-самцов, подвергнутых острому иммобилизационному стрессу / В.Ф. Киричук, Т.С. Великанова [и др.] // Биомедицинская радиоэлектроника. - 2011.-№1. - С. 19-24.

23. Влияние КВЧ-облучения на функции тромбоцитов и эритроцитов белых крыс, находящихся в состоянии стресса / В.Ф. Киричук, О.Н. Антипова[и др.] // Цитология. 2005. - T. 47. - №1. - C. 64 - 70.

24. Влияние миллиметровой терапии на нарушения локальной сократимости у больных острым инфарктом миокарда с эпизодами безболевой ишемии миокарда / В.А. Люсов, Н.А. Волон, Р.М. Гафурова [и др.] // Миллиметровые волны в биологии и медицине: Сб. докладов 12-го Российского симпозиума с международным участием.- М.: ИРЭ РАН, 2000.-С. 82-83.

25. Влияние различных режимов облучения волнами терагерцового диапазона на восстановление реологических свойств крови при стресс-реакции у белых крыс / В.Ф. Киричук, О.Н. Антипова [и др.] // Миллиметровые волны в медицине и биологии: Материалы 14-го Российского симп. с межд. участием.- М., 2007. - С.148-151.

26. Влияние терагерцовых волн на частотах молекулярного спектра оксида азота $150+0,75$ ГГц на изменение продукции и механизмов регуляции эндотелина I у крыссамцов, находящихся в состоянии острого и длительного стресса / Киричук В.Ф., 
Куртукова М.О. [и др.] // Вестник новых медицинских технологий. - 2009. - Т. 16. - №4. C. 19 - 21.

27. Влияние терагерцовых волн на частоте оксида азота, находящихся в скрещенных магнитном и электрическом полях, на реологические свойства крови больных нестабильной стенокардией / В.Ф. Киричук, Е.В. Андронов, Н.В. Мамонтова[и др.]// Биомедицинские технологии и радиоэлектроника.- 2005.- № 3.-С. 34-38.

28. Влияние ЭМИ ММД на антитромбогенную активность сосудистой стенки у больных нестабильной стенокардией / В.Ф. Киричук, Т.В. Головачева, Е.В. Карченова, С.С. Паршина // Миллиметровые волны в биологии и медицине: Сб. докладов 11-го Российского симпозиума с международным участием.- М.: ИРЭ РАН, 1997.-С. 22-24.

29. Влияние электромагнитного излучения на частотах оксида азота на периферическую перфузию тканей / В.Ф. Киричук, Т.С. Кириязи, Н.Е. Бабиченко // Вопросы патогенеза типовых патологических процессов: Труды II Всероссийской конференции с международным участием. - Новосибирск, 2010. - С. 158-162.

30. Влияние электромагнитного излучения терагерцового диапазона на частотах молекулярного спектра излучения и поглощения оксида азота на восстановление качественного и количественного состава эритроцитов крови (in vivo) / В.Ф. Киричук, О.И. Помошникова, О.Н. Антипова[и др.] // Биомедицинские технологии и радиоэлектроника.- 2004.- № 11.-С. 21-27.

31. Влияние электромагнитного излучения терагерцового диапазона частотой молекулярного спектра излучения и поглощения оксида азота $150+0,75$ ГГц на морфофункциональные нарушения микроциркуляции у белых крыс в состоянии острого и длительного стресса / И.О. Бугаева, В.Ф. Киричук, М.О. Куртукова // Саратовский научномедицинский журнал. - 2009. - Т.5. - №4. - С. 511 - 516.

32. Влияние электромагнитного излучения терагерцового диапазона на частотах оксида азота на концентрацию нитритов в плазме крови белых крыс, находящихся в состоянии иммобилизационного стресса / В.Ф.Киричук, Е.Г. Кулапина [и др.] // Бюллетень экспериментальной биологии и медицины. - 2010. - Т.149. - №2. - С. 132-135.

33. Влияние ЭМИ ТГЧ на частоте молекулярного спектра излучения и поглащения кислорода на функциональную активность тромбоцитов белых крыс в состоянии иммобилизационного стресса / В.Ф. Киричук, С.В. Сухова, О.Н. Антипова [и др.] // Биомед. технологии и радиоэлектроника. - 2008. - № 12. - С. 40-48.

34. Водолагин А.В. Патогенетические особенности течения и коррекция диссеминированного внутрисосудистого свертывания крови у больных стенокардией 
высоких функциональных классов: автореф. дис... канд. мед. наук . - Саратов: ГОУ ВПО «Саратовский ГМУ Росздрава», 2008. - 24c.

35. Воскобой И.В. Взаимосвязи функционального состояния тромбоцитов, антитромбогенной активности стенки сосудов и реологических свойств крови у больных нестабильной стенокардией: автореф. дис ... канд. мед. наук. - Саратов: ГОУ ВПО «Саратовский ГМУ Росздрава», 1995. - 20 с.

36. Восстановление реологических свойств крови ТГЧ-облучением на частотах молекулярного спектра излучения и поглощения оксида азота 150, 176-150,664 ГГц (in vivo) / В.Ф. Киричук, О.Н. Антипова, [и др.] // Глава в монографии «Микроциркуляция и электромагнитное излучение ТГЧ-диапазона» / Под ред. засл. деятеля науки РФ профессора В.Ф.Киричука. - Саратов: Изд-во СарГМУ, 2006.-С.227-238.

37. Гемореология и электромагнитное излучение КВЧ-диапазона / В.Ф. Киричук, Л.И. Малинова, А.П. Креницкий [и др.] - Саратов: Изд-во СГМУ, 2003. - 126 с.

38. Гершензон Е.М., Малов Н.Н., А.Н.Мансуров Молекулярная физика. - М: «Академия», 2002. - 272 С.

39. Голиков П.П. Оксид азота в клинике неотложных заболеваний. - М.: Медпрактика-М, 2004. - 180 с.

40. Головачева Т.В. Использование ЭМИ КВЧ при сердечно-сосудистой патологии // Миллиметровые волны нетепловой интенсивности в медицине: Сб. науч. работ.- М., 1991.-С. 54-57.

41. Гомазков О.А. Эндотелин в кардиологии: молекулярные, физиологические и патологические аспекты // Кардиология. - 2001. - №2. - С. 50-58.

42. Горрен А.К.Ф., Майер Б.Универсальная и комплексная энзимология синтазы оксида азота // Биохимия. - 1998. - Т. 63. - №7. - С. 870 - 880.

43. Гриневич В.В., Поскребышева Е.А., Савелов Н.А. Иерархические взаимоотношения между органами гипоталамо-гипофизарно-адреналовой системы при воспалении // Успехи физиол. наук. - 1999. - Т. 30. - №4. - С. 50 - 66.

44. Лоуренс Д.Р., Бенитт П.Н. Клиническая фармакология. - М.:Медицина, 1993.T. $1 .-640 \mathrm{C}$.

45. Девятков Н.Д. Особенности медико-биологического применения миллиметровых волн.- М.: ИРЭ РАН, 1994. - 160с.

46. Девятков Н.Д., Голант Н.Б., Бецкий О.В. Миллиметровые волны и их роль в процессах жизнедеятельности // М.: Радио и связь. - 1991. - 168с.

47. Депонирование оксида азота у крыс различных генетических линий и его роль в антистрессорном эффекте адаптации к гипоксии / М.Г. Пшенникова, Б.В. Смирин, О.Н. 
Бондаренко [и др.] // Росс. физиол. журнал им. И.М. Сеченова. - 2000. - Т.86. - № 2. - С. $174-181$.

48. Жуков Б.Н. Влияние ММ-волн на микроциркуляцию в эксперименте // Миллиметровые волны в биологии и медицине: Сб. докладов 10-го Российского симпозиума с международным участием.- М.: МТА КВЧ, 1995.-С. 129-130.

49. Закономерности сдвигов в функциональной активности кровяных пластинок под влиянием электромагнитных КВЧ-колебаний на частотах молекулярных спектров излучения и поглощения оксида азота / В.Ф. Киричук, А.В. Майбородин, М.В. Волин [и др.] // Миллиметровые волны в медицине и биологии: Сборник докладов 12 Российского симпозиума с международным участием. - М.: ИРЭ РАН, 2000. - С. 96-97.

50. Значение эндотелиальной NO - синтазы в осуществлении коррегирующего воздействия терагерцовых волн на реологические свойства крови белых крыс в состоянии стресса / В.Ф. Киричук, Е.В. Андронов, О.Н. Антипова [и др.] // Миллиметровые волны в биологии и медицине: Сб. трудов 15-го Российского симпозиума с международным участием.-М.: ЗАО «МТА - КВЧ». - 2009. - С. 106-108.

51. Значение эндотелиальной NO - синтазы в осуществлении положительного эффекта терагерцовых волн на частоте МСИП оксида азота 240 ГГц на агрегационную активность тромбоцитов больных нестабильной стенокардией / В.Ф. Киричук, Е.В. Андронов, О.Н. Антипова [и др.] // Миллиметровые волны в биологии и медицине: Сб. трудов 15-го Российского симпозиума с международным участием.-М.: ЗАО «МТА КВЧ». - 2009. - С. 103-106.

52. Значение эндотелиальной NO-синтазы в осуществлении корригирующего воздействия терагерцовых волн на нарушенные реологические свойства крови белых крыс в состоянии стресса / В.Ф. Киричук, Е.В. Андронов, О.Н. Антипова [и др.] // Миллиметровые волны в биологии и медицине. - 2009.- №1-2 (53-54). - С.74-81.

53. Иванов А.Н. Реакция тромбоцитов на электромагнитное излучение частотой молекулярного спектра излучения и поглощения оксида азота // Тромбоз, гемостаз и реология.- 2006.- № 3.-С. 51-57.

54. Каравайкин П.А. Выявление различных углеводных остатков в структуре гликопротеидных рецепторов на поверхности цитоплазматической мембраны тромбоцитов с использованием белков лектинов и изучение влияния иммобилизационного стресса на степень экспрессии гликопротеидных рецепторов // Молодые ученые здравоохранению региона: Материалы 68 науч.- практ. конф. студентов и молодых ученых Саратовского ГМУ. - Саратов, 2007. - С. 135 - 136. 
55. Ивановский В.И., Л.А. Черникова Физика магнитных явлений. - Москва: Издво МГУ. 1981. - 112 С.

56. Изменение функционального состояния эндотелия и периферической перфузии под влиянием электромагнитных волн терагерцового диапазона на частотах оксида азота у белых крыс в состоянии острого иммобилизационного стресса / В.Ф. Киричук, Кириязи Т.С. [и др.] // Биомедицинская радиоэлектроника. - 2010.-№12. - С. 30 $37-8$.

57. Изменение функциональной активности тромбоцитов под влиянием электромагнитных КВЧ-колебаний на частотах молекулярных спектров излучения и поглощения оксида азота / В.Ф. Киричук, А.В. Майбородин, М.В. Волин [и др.] // Вопросы медико-биологических наук: Межвузовский сборник научных работ. - Саранск, 2000. - Вып.. 5. - С.13-21.

58. Измерение радиотепловых и плазменных излучений в СВЧ-диапазоне / A.Е. Башаринов, Л.Г. Тучков, В.М. Поляков [и др.]. - М.: Советское радио, 1968. - 380 с.

59. Изучение агрегатного состояния крови больных, оперированных в условиях искусственного кровообращения на основе математической модели / Е.В. Ройтман, И.И. Дементьева, С.Ф. Леонова [и др.] // Гематол. и трансфизиол.-1996.-№5.-С. 7-10.

60. Информационное взаимодействие в живых объектах, подвергнутых воздействию электромагнитных КВЧ-колебаний на частотах молекулярных спектров поглощения и излучения оксида азота / В.Ф. Киричук, А.П. Креницкий, М.В. Волин [и др.] // Миллиметровые волны в медицине и биологии: Сборник докладов 12 Российского симпозиума с международным участием. - М., 2000. - С. 91-93.

61. Квазиоптический КВЧ генераторный комплекс моделирования детерминированных шумов для биофизических исследований / А.П. Креницкий, А.В. Майбородин, О.В. Бецкий [и др.] // Биомедицинские технологии и радиоэлектроника. 2003. - №2. - C. 17-24.

62. Киричук В.Ф., Паршина С.С., Головачёва Т.В. ЭМИ ММД в лечении стенокардии: отдаленные результаты // Миллиметровые волны в биологии и медицине: Сб. докладов 11-го Российского симпозиума с международным участием.- М.: ИРЭ РАН, 1997.-C. 20-22.

63. Киричук В.Ф. Возможности коррекции патологии гемокоагуляции методом терагерцовой терапии // Микроциркуляция в клинической практике: Материалы 2 Всероссийской конференции с международным участием. - Москва, 2006. - С. 86.

64. Киричук В.Ф. Физиология крови. - Из-во СарГМУ. - Саратов, 1999. - 89с.

65. Киричук В.Ф. Физиология крови. - Из-во СарГМУ. - Саратов, 2002. - 102с. 
66. Киричук В.Ф. Физиология крови. Киричук. - Из-во СарГМУ. - Саратов, 2005. $-102 \mathrm{c}$.

67. Киричук В.Ф., Антипова О.Н. Влияние превентивного терагерцового излучения на частотах оксида азота 150,176-150,664 ГГц на постстрессорные изменения реологии крови у белых крыс-самцов // Вестник новых медицинских технологий.- 2008.T.XV.- №4.- C.23-25.

68. Киричук В.Ф., Воскобой И.В. Антитромбогенная активность стенки сосудов, гемостаз и реологические свойства крови у больных нестабильной стенокардией с липопротеинемией различных типов // Терапевтический архив. - 2000. - Т. 72.- № 12.- С. 47-50.

69. Киричук В.Ф., Воскобой И.В., Ребров А.П. Взаимосвязь антитромбогенной активности стенки сосудов и свойств крови у больных нестабильной стенокардией // Тромбоз, гемостаз, реология. -2001. - № 5. - С. 31-34.

70. Киричук В.Ф., Глыбочко П.В., Пономарева А.И. Дисфункция эндотелия. Саратов: Изд-во СарГМУ, 2008. - 112 с.

71. Киричук В.Ф., Головачёва Т.В., Чиж А.Г. КВЧ-терапия. - Саратов: Изд-во СГМУ, 1999.- 360 c.

72. Киричук В.Ф. Регуляция функций организма. Гуморальная регуляция. Саратов: Изд-во СарГМУ, 2008 - 99 с.

73. Киричук В.Ф., Шварц Ю.Г. Показатели сосудисто-тромбоцитарного механизма гемостаза и ближайший прогноз нестабильной стенокардии // Кардиология.1998.- T. 38.- № 5.- C. 14-17.

74. Киттель Ч. Введение в физику твердого тела. - М.:Наука, 1978. - 150 с.

75. Ковалев А.А. О биотропности вращательных спектров и нескомпенсированных магнитных моментов биологически активных молекул // Миллиметровые волны в биологии и медицине. 2006. - № 3(43). - С. 78 - 81.

76. Комплекс для исследования тонких структур молекулярных спектров физических и биологических сред / А.В. Майбородин, А.П. Креницкий, В.Д. Тупикин [и др.] // VII Международ. конференция «Радиолокация-навигация-связь». - Воронеж, 2001.C. 21-38.

77. Комплексное лечение ожоговых ран терагерцовыми волнами молекулярного спектра оксида азота / Н.В. Островский, С.М. Никитюк, В.Ф. Киричук[и др.] // Биомедицинские технологии и радиоэлектроника.- 2004.- № 11.-С. 55-61.

78. Конако Ф., Фэйтс Д. Терагерцовые волны. - М.: Ломоносов, 2002. - 102 с. 
79. Коррекция NO-зависимых сердечно-сосудистых нарушений с помощью адаптации к гипоксии / С.Ю. Машина, Б.В. Смирин, И.Ю. Малышев [и др.] // Росс. физиол. журнал им. И.М. Сеченова. - 2001. - Т. 87. - № 1. - С. 110 - 117.

80. Курпаткин А.И. Оценка локальной эффекторной функции сенсорных афферентов кожи конечностей с помощью лазерной допплеровской флоуметрии // Росс. Физиол. журн. им. И.М. Сеченова. - 2002. - Т. 88. - №5.-с. 658-662.

81. Крупаткин А.И., Сидоров В.В. Лазерная допплеровская флоуметрия микроциркуляции крови. - М.: Медицина, 2005. - 254 с.

82. Кулагин Н.А., Свиридов Д.Т. Методы расчета электронных структур свободных и примесных ионов. - М.: Наука, 1978. - 117 с.

83. Куртукова М.О. Влияние электромагнитного облучения терагерцового диапазона на частотах молекулярного спектра излучения и поглощения оксида азота 150,176-150,664 ГГц на морфофункциональные изменения микроциркуляции у белых крыс при стрессе: дис. ... канд. мед. наук. - Саратов, 2009. - 168 с.

84. Лебедева А. Ю. Применение электромагнитных волн миллиметрового диапазона в кардиологии // Биомед. радиоэлектрон. - 1998. - № 2. - С. 49-54.

85. Лупинская 3.А. Эндотелий сосудов основной регулятор местного кровотока // Вестник КРСУ. - 2003. - Т. 3. - №7. -С. 57-62.

86. Малышев И.Ю., Манухина Е.Б. Стресс, адаптация и оксид азота // Биохимия. - 1998. - Т.63. - №7. - С. 992 - 1006.

87. Мамонтова Н.В. Характер сдвигов в нарушенных реологических свойствах крови под влиянием ТГЧ-волн на частоте оксида азота 240 ГГц: автореф. дис. ... канд. мед. наук. - Саратов: ГОУ ВПО «Саратовский ГМУ Росздрава», 2006.-24с.

88. Манухина Е.Б., Малышев И.Ю. Стресс-лимитирующая система оксида азота // Росс. физиол. журнал им. И.М. Сеченова. - 2000. - Т.86. - №. 10. - С. 1283 - 1292.

89. Марков Х.М. Окись азота и окись углерода - новый класс сигнальных молекул // Успехи физиологических наук. - 1996. - Т. 27. - №4. - С. 30-44.

90. Меерсон Ф.З. Адаптация, стресс и профилактика. - М.: Наука, 1981. - 425с.

91. Мериакри В.В. Состояние и перспективы развития линий передачи субмиллиметрового диапазона волн и устройств на их основе // Успехи современной радиоэлектроники. - 2002. - №12. - С. 15-18.

92. Механизм действия терагерцовых волн на частотах оксида азота с физиологической точки зрения/ Киричук В.Ф., Цымбал А.А., Андронов Е.В.// Миллиметровые волны в биологии и медицине. - №1-2 (53-54). - 2009. - С.47-55. 
93. Микроциркуляторные изменения при экспериментальной стресс реакции и облучении ЭМИ ТГЧ на частоте 129,0 Ггц / В.Ф. Киричук, С.В. Сухова, О.Н. Антипова [и др.] // Гемореология и микроциркуляция: Материалы VI Международной конференции. Ярославль, 2007. - С. 107.

94. Миняев В.А., Вишняков Н.И. Общественное здоровье и здравоохранение. Москва: «МЕДпресс - информ», 2002. - 237 с.

95. Моисеев С.И., Лапотников В.А., Карцев А.Н. Особенности изменения микроциркуляции при стенокардии напряжения // Терапевтический архив. - 1986.- Т. 58.№ 5.- С. 30-33

96. Молекулярные HITRAN-спектры газов метаболитов в терагерцовом и ИК диапазонах частот и их применение в биомедицинских технологиях / О.В. Бецкий, А.П. Креницкий, А.В. Майбородин [и др.]// Биомедицинские технологии и радиоэлектроника. 2007. - № 7. - С. 5 - 9 .

97. Момот А.П. Патология гемостаза. Принципы и алгоритмы клиниколабораторной диагностики. - Спб.: ФормаТ, 2006. - 208 с.

98. Невзорова В.А., Зуга М.В., Гельцер Б.И. Роль окиси азота в регуляции легочных функций // Тер. архив. - 1997. - Т.69. - №3. - С. 68 - 73.

99. Новые аспекты клинического использования терагерцовой терапии на частотах молекулярного спектра оксида азота у больных стенокардией / С.С. Паршина, Т.В. Головачева, В.Ф. Киричук [и др.] // Миллиметровые волны в биологии и медицине. 2009. - № 4. - C.37-56.

100. О роли эндотелиальной NO-синтазы в восстановлении нарушенных реологических свойств крови у белых крыс-самцов в состоянии иммобилизационного стресса под действием терагерцового облучения / В.Ф. Киричук, О.Н. Антипова, Е.В.Андронов [и др.] // Актуальные проблемы теоретической, экспериментальной, клинической медицины и фармации: Материалы 43-й Всероссийской конференции с межд. участием. - Тюмень, 2009. - С.284-285.

101. Оганов Р.Г. Сердечно- сосудистые заболевания в Российской Федерации во второй половине XX века: тенденции, возможные причины, перспективы // Кардиология.1993.- № 6.-C. 4-8.

102. Оганов Р.Г. Профилактика сердечно-сосудистых заболеваний: Возможности практичесого здравоохранения // Кардиоваскулярная терапия и профилактика. - 2002. №1. - C. 5-9. 
103. Оганов Р.Г. Сердечно - сосудистые заболевания в Российской Федерации во второй половине XX века: тенденции, возможные причины, перспективы // Кардиология. 2000. - № 6. - C. 65-69.

104. Оганов Р.Г., Масленикова Г.Я. Демографическая ситуация и сердечно сосудистые заболевания в России: пути решения проблем // Кардиоваскулярная терапия и профилактика. - 2007. - Т.6. - № 8. - С. 7-14.

105. Оксид азота и микроциркуляторное звено системы гемостаза/ В.Ф. Киричук, Е.В. Андронов, Н.В. Мамонтова// Успехи физиологических наук. - 2008. - Т. 39. - №4. C. $83-91$.

106. Панин Л.Е. Биохимические механизмы стресса. - Новосибирск: Наука, 1983. $232 \mathrm{c}$.

107. Парселл Э. Берклеевский курс физики / пер. с англ. - М.: Наука, 1971. - Т. 2. $323 \mathrm{c}$.

108. Паршина С.С. Адаптационные механизмы системы гемостаза и реологии крови у больных с различными формами стенокардии: дис. ... докт. мед. наук. - Саратов, 2006. $-360 \mathrm{c}$.

109. Паршина С.С. Влияние электромагнитного излучения миллиметрового диапазона на функциональное состояние системы гемостаза у больных стенокардией: автореф. дис. ... канд. мед. наук. - Саратов: ГОУ ВПО «Саратовский ГМУ Росздрава», 1994.-28c.

110. Паршина С.С., Киричук В.Ф. Действие электромагнитных волн миллиметрового диапазона на свёртывание крови и фибринолиз больных стенокардией // Военно-медицинский журнал. -1991.- № 11.-С.54-55.

111. Паршина С.С., Киричук В.Ф., Головачева Т.В. Первые результаты клинического применения электромагнитного излучения терагерцового диапазона на частотах молекулярного спектра оксида азота в кардиологии // Современные аспекты диагностики, лечения и профилактики в кардиологии: Сбор. науч. трудов. - Саратов, 2005. - C. 109-111.

112. Патологическая физиология / Н.Н. Зайко, Ю.В. Быць, А.В. Атаман[и др.]- К.: "Логос", 2007. - 640 с.

113. Первый опыт клинического применения электромагнитного излучения терагерцового диапазона на частотах молекулярного спектра оксида азота/ C.С. Паршина, В.Ф. Киричук, Т.В. Головачева[и др.] // Биомедицинские технологии и радиоэлектроника.2004.- № 11.-С. 46-54. 
114. Помошникова О.И. Влияние ТГЧ-излучения на частотах молекулярного спектра излучения и поглощения оксида азота 150,176-150,664 ГГц на качественный и количественный состав эритроцитов крови белых крыс, находящихся в состоянии иммобилизационного стресса: автореф. дис. ... канд. мед. наук. - Саратов: ГОУ ВПО «Саратовский ГМУ Росздрава», 2006.-23с.

115. Применение ММ-волн в клинической медицине (последние достижения) / Ю.Л. Арзуманов, О.В. Бецкий, Н.Д. Девятков, Н.Н. Лебедева // Миллиметровые волны в биологии и медицине: Сб. докладов 11-го Российского симпозиума с международным участием.- М.: ИРЭ РАН, 1997.-С. 9-13.

116. Применение электромагнитного излучения терагерцового диапазона на частотах молекулярного спектра оксида азота при лечении экспериментальной стафилококковой инфекции / Г.М. Шуб, А.В. Лепилин, О.А. Финохина [и др.] // Биомедицинские технологии и радиоэлектроника.- 2004.- № 11.-С. 62-64.

117. Профилактика и коррекция постстрессорных нарушений функциональной активности тромбоцитов у белых крыс электромагнитным излучением на частотах молекулярного спектра излучения и поглощения оксида азота / В.Ф. Киричук, О.Н. Антипова [и др.] // Биомедицинская радиоэлектроника. - 2008. - №5. - С.54-63.

118. Профилактика нарушений периферической перфузии у белых крыс при остром стрессе электромагнитным излучением терагерцового диапазона на частотах оксида азота 150,176-150,664 ГГц / В.Ф. Киричук, Кириязи Т.С. [и др.] // Биомедицинская радиоэлектроника. - 2011.-№1. - С. 4-8.

119. Профилактика стресс-зависимых нарушений реологических свойств крови воздействием ТГЧ-облучения на частотах молекулярного спектра излучения и поглощения оксида азота / В.Ф. Киричук, О.Н. Антипова [и др.] // Ангиология и сосудистая хирургия. - Приложение: Микроциркуляция в клинической практике: Материалы 2-й Всероссийской конференции с международным участием.- М.: Изд-во ИНФОМЕДИА Паблишерз, 2006.- С.84-85.

120. Профилактика тромбозов/ Балуда В.П., Деянов И.И., Балуда М.В.[и др.] Саратов: Изд-во СГУ, 1992. - 176 с.

121. Ройтман Е.В. Клиническая гемореология // Тромбоз, гемостаз, реология. 2003.- № 3. - C. 13-27.

122. Роль свободного и депонированного оксида азота в адаптации к гипоксии сердечно-сосудистой системы / Е.Б. Манухина, С.Ю. Машина, М.А. Власова [и др.] // Регионарное кровообращение и микроциркуляция. - 2004. - №3. - С. 4 - 11. 
123. Роль электромагнитных волн в процессах жизнедеятельности / Н.И. Синицын, В.И. Петросян, В.А. Елкин [и др.] // Актуальные проблемы электронного машиностроения: Матер. междунар. научно-техн. конф. - Саратов, 2000. - С. 483-490.

124. Рубин В.И., Мельникова Г.Я. Изменение биохимических тестов при КВЧтерапии больных инфарктом миокарда // Миллиметровые волны нетепловой интенсивности в медицине: Сб. науч. тр. М.- 1991. - С. 355-361.

125. Северина И.С. Растворимая гуанилатциклаза в молекулярном механизме физиологических эффектов окиси азота // Биохимя. - 1998. - Т. 63. - № 7. - С. 939 - 997.

126. Северина И.С. Растворимая форма гуанилатциклазы в молекулярном механизме физиологических эффектов окиси азота и в регуляции процесса агрегации тромбоцитов // Бюл. эксперим. биол. и мед. - 1995. - № 3. - С. $230-235$.

127. Селье Г. Очерки об адаптационном синдроме/ пер. с англ. - М.: Медицина, 1960. -254 c.

128. Семенова С.В. Влияние электромагнитного излучения миллиметрового диапазона на функциональное состояние системы гемостаза у больных инфарктом миокарда: автореф. дис... канд. мед. наук. - Саратов: ГОУ ВПО «Саратовский ГМУ Росздрава», 1994.- 25c.

129. Словарь справочник лекарственных препаратов / М.Д. Машковский, С.Д. Южаков. - М.: РИПОЛ классик, 2005. - 632[2] с.

130. Снайдер С.Х. Биологическая роль окиси азота // В мире науки. - 1992. - №7. C.15-24.

131. Способ профилактики и коррекции стрессорных нарушений организма // В.Ф. Киричук, О.Н. Антипова, В.Д. Тупикин и др. Патент № 284837. - 2006. - Бюл. № 16. [Электронный ресурc]. URL: http://www.fips.ru (дата обращения 05.12. 2009).

132. Справочник Видаль. Лекарственные препараты в России: Справ. - М.: АстраФармСервис, 2010. - 1728 с.

133. Справочник Видаль. Лекарственные средства ветеринарного назначения в России: Справ. -2-е изд.- М.: АстраФармСервис, 2004. - 480 с.

134. Сравнительная характеристика реакции на превентивное воздействие волнами терагерцового диапазона частот оксида азота у белых крыс в условиях длительного стресса / В.Ф. Киричук, О.Н. Антипова, А.А. Цымбал [и др.] // Материалы VI Сибирского физиологического съезда: Тез. докл., Т.ІІ. - Барнаул, 2008. - С.75.

135. Сравнительная эффективность различных режимов облучения волнами терагерцевого диапазона на восстановление реологических свойств крови при стресс- 
реакции у белых крыс / В.Ф. Киричук, О.Н. Антипова, Е.В. Андронов [и др.] // Журнал «Биомедицинская радиоэлектроника». - 2009. - №6. - С. 55 - 62.

136. Структурные престройки в водной фазе клеточных суспензий белковых растворов при светокислородном эффекте / С.Д. Захаров, А.В. Иванов, Е.Б. Вольф [и др.]/ Квантовая электроника. - 2003. - Т. 33. - №2. - С. 149 - 162.

137. Суточная продукция NO у больных артериальной гипертонией II стадии / Н.П. Лямина, В.Н. Сенчихин, П.В. Долотовская, А.Г. Сипягина // Росс. кардиол. журн. 2001. - № 32. - C. 34-7.

138. Сухова С.В. Характер изменения агрегационной функции тромбоцитов под влиянием электромагнитного излучения терагерцового диапазона на частоте молекулярного спектра излучения и поглащения кислорода 129,0 Ггц у животных при экспериментальном стрессе: автореф. дис. ... канд. мед. наук. - Саратов: ГОУ ВПО «Саратовский ГМУ Росздрава», 2009. - 22 с.

139. Сухова С.В., Бондарев А.В. Состояние микроциркуляторного звена системы гемостаза при экспериментальной стресс-реакции и при воздействии электромагнитным излучением (ЭМИ) терагерцового диапазона на частоте молекулярного спектра излучения и поглощения (МСИП) кислорода 129,0 Ггц // Актуальные проблемы экспериментальной и клинической медицины: Материалы 65-й юбилейной открытой научно-практической конференции молодых ученых с международным участием. - Волгоград, 2007. - С. 65.

140. Сухова С.В., Великанова Т.С. ЭМИ частотой 129,0 Ггц как средство профиллактики гемостатических нарушений при остром иммобилизационном стрессе у животных // Молодые ученые - здравоохранению региона: Материалы межрегиональной научно-практической конференции студентов и молодых ученых с международным участием. - Саратов, 2007. - С. 77.

141. ТГЧ - облучение на частоте атмосферного кислорода как метод терапии с целью восстановления реологических свойств крови при стресс-реакции // Киричук В.Ф., Фазилов Р.Г, Антипова О.Н. [и др.] // Гемореология и микроциркуляция: Материалы VI международной конференции.- Ярославль, 2007. - С.56.

142. Тенденции развития и схемотехнические решения аппаратуры для КВЧтерапии / М.Е. Архипов, Я.М. Новицкий, В.Е. Перфильев [и др.] // Физика волновых процессов и радиотехнические системы. - 1999. - Т.2.- №№ 3-4. - С. 56-68.

143. Терагерцовые волны и их применение. Биомедицинские аспекты / O.В. Бецкий, В.Ф. Киричук, А.П. Креницкий [и др.] // Миллиметровые волны в биологии и медицине. - 2005.- №3(39). - С.4-16. 
144. Тромбоциты в реакциях системы гемостаза на КВЧ-воздействие / В.Ф. Киричук, М.Ф. Волин, А.П. Креницкий [и др.]- Саратов: Изд-во СГМУ.- 2002.- 372с.

145. Фармакоэкономический анализ применения левомиседана у больных с тяжелой декомпенсированной хронической сердечной недостаточностью / Белоусов Ю.Б., Белоусов Д.Ю., Григорьев В.Ю. [и др.] // Сердечная недостаточность.- 2006.- Т.7.- №1.- С. $32-38$.

146. Федоров А.С., Королев Л.С., Беляков С.В. Модифицированные аппараты серии «Явь» // Миллиметровые волны в биологии и медицине: Сб. докладов 12-го Российского симпозиума с международным участием.- М.: ИРЭ РАН, 2000.-С. 159-163.

147. Фолков Б., Нил Э. Кровообращение. - М.: Медицина, 1976.- 164с.

148. Халепо О.В., Молотков О.В., Ешкина С.Л. Особенности периферического кровообращения в кожных покровах и состояние механизмов регуляции в динамике развития первичного трансмурального инфаркта миокарда // Патологическая физиология и экспериментальная терапия.-2009.- №4.- С. 11-15.

149. Характеристика изменений функциональной активности тромбоцитов больных нестабильной стенокардией под влиянием ЭМИ ММД в условиях in vitro / В.Ф. Киричук, М.В. Волин, С.С. Паршина, Н.В. Старостина // Миллиметровые волны в биологии и медицине: Сб. докладов 12-го Российского симпозиума с международным участием. - М.: ИРЭ РАН, 2000. - С. 99-101.

150. Цымбал А.А. Характер изменений нарушенных коагуляционных и фибринолитических свойств крови под влиянием терагерцовых волн на частотах оксида азота 150,176-150,664 ГГц: автореф. дис... канд. мед. наук . - Саратов: ГОУ ВПО «Саратовский ГМУ Росздрава», 2007. - 21 с.

151. Чернух, А.М., Александров П.Н., Алексеев О.В. Микроциркуляция. - М.: Медицина, 1984. -429 с.

152. Чуян Е.Н., Раваева М.Ю., Трибрат Н.С. Низкоинтенсивное электромагнитное излучение миллиметрового диапазона: влияние на процессы микроциркуляции // Физика живого. - 2008. - Т. 16. - №1. - С. 82-90.

153. Чуян Е.Н., Темурьянц Н.А., Москвичук О.Б. Физиологические механизмы биологических эффектов низкоинтенсивного ЭМИ КВЧ- Симферополь, 2003. - 448c

154. Шахматов И.И., Киселев В.И. Нарастание дезадаптивных сдвигов со стороны системы гемостаза по мере увеличения продолжительности гипокинезии // Фундаментальные исследования. - 2004. - № 2. - С. 106-107.

155. Электродинамическая модель взаимодействия терагерцовых волн и атмосферного воздуха с биосредой в скрещенных постоянных магнитном и электрическом 
полях / А.П. Креницкий, А.В. Майбородин, В.Д. Тупикин[и др.] // Биомедицинские технологии и радиоэлектроника.- 2004.- № 11.-С. 35-45.

156. Электромагнитное излучение терагерцового диапазона на частотах оксида азота в коррекции и профилактике нарушений функциональной активности тромбоцитов у белых крыс при длительном стрессе / В.Ф. Киричук, О.Н. Антипова[и др.] // Цитология. 2007. - T. 49. - №6. - С. 484 - 490.

157. Эффективность различных режимов облучения волнами терагерцового диапазона на восстановление реологических свойств крови при стресс-реакции у белых крыс / В.Ф. Киричук, О.Н. Антипова, Е.В. Андронов [и др.] // Миллиметровые волны в биологии и медицине. - 2009.- №1-2 (53-54). - С.63-74.

158. Addicks K., Bloch W., Feelisch M. Nitric oxide modulates sympathetic neurotransmission at the prejunctional level // Microsc. Res. Technique. - 1994. - №29. - P. 161 $-168$.

159. Battinelli E., Loscalzo J. Nitric oxide induces apoptosis in megakaryocytic cell lines // Blood. - 2000. - Vol. 95. - P. 3451-3459.

160. Becker, R.C. The role of blood viscosity in the development and progression of coronary artery disease // Cleveland Clin. J. Med.-1993.-V. 60. №5.- P. 353-358.

161. Bolton F.G. Disseminated intravascular coagulation // Int. Anest. Clin.- 1985.- Vol. 23.- N 2.- P. 89-101.

162. Corrrection of endothelial dysfunction in chronic heart failure: additional effects of exercise training and oral L-arginine supplementation /Hambrecht R., Hilbrich L., Erbs S. [et al.] // J. Am. Coll. Cardiol. - 2000. - Vol.-35.-№3.-P.706-713.

163. Cyclic GMP-dependent protein kinases and the cardiovascular system / R. Feil, S.M. Lohmann, H. de Jonge [et. al.] // Circulation research. - 2003. - V. 93. - P. 907-916.

164. Davis M.E. Cai H., Drummond G.R. Role of c-Src in regulation of endothelial nitric oxide synthase expression during exercise training // Am. J. Physiol. Heart Circ. Physiol. 2003. - V.284. - P. 1449-1453.

165. Effect of effective fractions and its compatibilities and proportions of xie-xin decoction on nitric oxide production in peritonea macrophages from rat / Y.X. Xiong, X.L. Meng, N. Yang, [et. al.] // Zhong Yao Cai. - 2007. - № 30 (1). - P. 66-69.

166. Endothelium-derived relaxing factor produced and released from artery and vein is nitric oxide / L.J. Ignarro, G.M. Buga, K.S. Wood [et al.] // Proc. Natl. Acad. Sci. USA. - 1987. Vol. 84. - P. 9265-9269.

167. Endotoxin stimulates an endogenous pathway regulating corticotrophin-releasing hormone and vasopressin release involving the generation of nitric oxide and carbon monoxide / 
I. Kostoglou-Athanassiou, A. Costa, P. Navarra [et al.] // J. Neuroimmunol. - 1998. - V.86. - P. $104-109$.

168. Ernst E. Le fibrinogene comme facteur de risqué cardiovasculaire: une metaanalysa et une revu de la literature // Energ Sant Serv. etude med.-1994.-V.5. - №1.- P. 151-152.

169. Furchgott R.F. Endothelium-dependent and - independent vasodilation involving cyclic GMP: relaxation induced by nitric oxide, carbon monoxide and light // Blood Vessels. 1991. - V. 28. - P. $52-61$.

170. Furchgott R.F., Jothianandan D. Endothelium-dependent and - independent vasodilation involving cyclic GMP: relaxation induced by nitric oxide, carbon monoxide and light // Blood Vessels. - 1991. - Vol. 28. - P. 52-61.

171. Furchgott R.F., Zawadzki J.V. The obligatory role of endothelial cells in the regulation of arterial smooth muscle by acetylcholine // Nature. - 1980. - V. 299. - P. 373-376.

172. Grundler W., Kaiser F. Mechanisms of electromagnetic interaction with cellular systems // Natur. wissens chaften.- 1992.-Vol. 79. - P. 551-559.

173. Hart C.M. Nitric oxide in adult lung disease // Chest. - 1999. - V.115.- N5. P.1407-1417.

174. Ignarro L.G., Murad F. Nitric oxide: biochemistry, molecular biology and therapeutic implication // Adv. Pharmacol. - 1995. - V.34. - P. 1 - 516.

175. Ignarro L.G., Wood K.S. Activation of purified soluble guanylate cyclase by arachidonic acid requires absence of enzyme-bound heme // Bichem. Biophys. Acta. - 1987. V.928. - P. $160-170$.

176. Killy D.G. Baffigand S.L., Smith T.W. Nitric oxide and Cardiac function// Circulat. Res. - 1996. - Vol. 79. - P. 363-380.

177. Kirichuk V., Voskoboy I. Platelet aggregation in patients with unstable angina by influence of some lectins // Haemostasis.- 2000.- (Suppl. 1).- P.79.

178. Kirichuk V.F., Voskoboy I.V. Interconnection of the functional state of platelets, antithrombogen activity of the vascular cell and reologic properties of blood in patients with unstable angina // Haemostasis. - 1996.- Vol. 6.- P. 162.

179. Knowles R.G., Palacios M., Palmer R.M., Moncada S. Formation of nitric oxide from L-arginine in the central nervous system: a transduction mechanism for stimulation of the soluble guanylate cyclase // Proc. Natl. Acad. Sci. USA. - 1989. - Vol. 86. - P. 5159-5162.

180. Laser Doppler evaluation of skin vasomotor reflexes during sympathetic stimulation in normals and in patients with primary Raynaud's phenomenon /Wollersheim H., Droste H. [et al.] // Int.J. Microcirc.-1991.- Vol. 10.- P.32-42. 
181. Lloyd-Jones D.M., Bloch K.D. The vascular biology of nitric oxide and its role in atherogenesis // Ann. Rev. Med.- 1996.-Vol. 47.-P. 365-375.

182. Lowenstein C.J., Dinerman J.L., Snyder S.H. Nitric oxide: a physiologic messengers // Ann. intern. Med. - 1994. - № 12. - P. 227-237.

183. Matsuoka I., Suzuki T. Mepacrine-induced elevation of cyclic GMP levels and acceleration of reversal of ADP-induced aggregation in washed rabbit platelets // J. Cyclic Nucleotide Protein Phosphor. Res. - 1983. - Vol. 9. - P. 5341-5353.

184. Michel J.B. Nitric Oxide and cardiovascular homeostasis // Firenze: Menarini International.-1999.-V.31.-P.5-7.

185. Minson C.T., Berry L.T., Joyner M.J. Nitric oxide and neurally mediated regulation of skin blood flow during local heating // J. Appl. Physiol. - 2001.- Vol.-91.-P.1619-1626.

186. Murad F. Nitric oxide - biogeneration, regulation, and relevance to human diseases // Frontiers in Bioscience. - 2003. - № 8. - P. 264-278.

187. Nitric oxide as a signaling molecule in the vascular system: an overview / L.G. Ignarro, G. Cirino, A. Casino [et al.] // J. Cardiovasc Pharmacol. - 1999. - №34. - P. 979 - 886.

188. Nitric oxide prevents cardiovascular disease and determines survival in polyglobulic mice over expressing erythropoietin / F.T. Ruschitzka, R.H. Wenger, T. Stallmach [et. al.] // PNAS. - 2000. - V. 97.- N. 21 - P. 11609-11613.

189. Nitric oxide suppresses preadipocyte differentiation in 3T3-L1 culture / $\mathrm{H}$. Kawachi, N.H. Moriya, T. Korai [et. al.] // Mol Cell Biochem. - 2007. - V. 300 (1-2). - P. 6167.

190. Oscillations in the Numan Cutaneous Blood Perfusion Signal Modified by Endothelium-Dependent and Endothelium-Independent Vasodilators /Kvernmo H.D., Stefanovska A. [et. al.] // Microvascular Research.-1999.-Vol.57-P. 298-309.

191. Plasma viscosity, fibrinogen and haematocrit in the course of unstable angina / J. Fuchs, A. Pinhas, E. Davidson [et al.] // Eur. Heart.- 1990.-Vol. 11.- P.1029-1032.

192. Regulation of nitric oxide consumption by hypoxic red blood cells / H.H. Tae, E. Qamirani, A.G. Nelson, [et. al.] // Proc Natl Acad Sci U S A. - 2003. - №100 (21). - P. 1250412509.

193. Snyder S.H., Bredt D.S. Nitric oxide as a neuronal messenger // TIPS - 1991. V.12. - P. $125-128$.

194. Stepol A. Stress and illness // Physiol. - 1993. - V.6. - № 2. - P. 76 - 77.

195. Stokes K.Y., Granger D.N. The microcirculation: a motor for the systemic inflammatory response and large vessel disease induced by hypercholesterolaemia? // J. Physiol. - 2004. - V.562. - № 3. - P. 647 - 653. 
196. The HITRAN molecular spectroscopic database: edition of 2000 including updates through 2001 / L.S. Rothman, A. Barbe, D. Chris Benner [et. al.] // Journal of Quantitative Spectroscopy \& Radiative Transfer. - 2003. - № 82. - P. 5 - 44.

197. Thrombin generation and platelet activation in pts with unstable angina treated with intravenous nitroglycerin and standart or low molecular heparin / J. Gorsky, P. Kurek, A. Birkholz [et al.] // Thrombosis and Haemostasis. XVIth Congress of the International Society on Thrombosis and Haemostasis. Florence, Italy.- 1997.- P. 522.

198. Vascular hyporesponsiveness in simulated microgravity: rollof nitric oxidedependent mechanisms /Sangha D.S., Vasziri N.D., Ding J. [et al.] // J. Appl.Physiol. 2000. - Vol. 88.- № 2. - P. 507 - 517.

199. Wannamethee G., Shaper A.G., Whincup P.H. Usehemic heart discase: association with Haematocrit in the British Regional Heart Study // J. Epidemiol. Community Health. 1994.-Vol. 48.-P.112-118.

200. Ziegler A. Stress - was dann? // Vop. - 1994. - V.16. - №5. - P. 312 - 315.

201. Wilson S.B.,Jennings P.E., Belch J.J.F. Detection of microvascular impairement in type I diabetics by laser Doppler flowmetry // Clin Physiol. - 1992.- Vol.-12.- P.195-208. 


\section{РАЗДЕЛ III}

ИСПОЛЬЗОВАНИЕ ЭЛЕКТРОМАГНИТНЫХ ВОЛН ТЕРАГЕРЦЕВОГО ДИАПАЗОНА ДЛЯ ВОССТАНОВЛЕНИЯ НАРУШЕННЫХ РЕОЛОГИЧЕСКИХ СВОЙСТВ КРОВИ 


\section{СПИСОК СОКРАЩЕНИЙ}

$\mathrm{NO}$ - оксид азота

АФК - активные формы кислорода

ГЦ - гуанилатциклаза

КВЧ - крайне высокие частоты

ММ-волны - миллиметровые волны

ММД - миллиметровый диапазон

МСИП - молекулярный спектр излучения и поглощения

$\mathrm{O}_{2}$ - молекулярный кислород

ТГЧ - терагерцевые частоты

ЭМИ - электромагнитное излучение 


\section{ВВЕДЕНИЕ}

Неуклонный рост заболеваний, вызванных стрессорными повреждениями на клеточном, тканевом, организменном уровнях биосистемы, диктует необходимость поиска новых методов, средств профилактики, коррекции и системного подхода к терапии «болезней адаптации», в том числе заболеваний сердечно-сосудистой системы, которые занимают первое место среди причин смертности населения. Они составляют около 55\% от общей смертности и являются самыми высокими среди показателей стран Западной Европы [Меерсон Ф.3.,1981; Меерсон Ф.3., 1993; Оганов Р.Г., Масленникова Г.Я., 2000; Берсудский С.О., 2002; Гафаров В.В., Благинина М.Ю., 2005; Киричук В.Ф., 2007].

В настоящее время доказана роль стресса как главного этиологического фактора ишемической болезни сердца, атеросклероза, гипертонической болезни и многих других заболеваний сердечно-сосудистой системы [Меерсон Ф.3.,1981; Берсудский С.О., 2002]. Устранение данного этиологического фактора риска и развития сердечно - сосудистой патологии практически невозможно из-за интенсификации производственных процессов, урбанизации, радикально меняющих уровень воздействия физических и психических перегрузок на организм современного человека и закономерно влекущих за собой развитие «болезней адаптации» [Тожиев М.С., Шестов Д.Б., Воробьёв В.И. и др., 2000; Меерсон Ф.3., 1993; Берсудский С.О., 2002].

Решение данной проблемы остается в большинстве случаев на уровне достижения длительных ремиссий, улучшения качества жизни и прогноза путем использования методов и средств современной фармакотерапии. Существующие в настоящее время медикаментозные методы коррекции микроциркуляции, в том числе её внутрисосудистого компонента - реологических свойств крови, системы гемостаза и фибринолиза у больных ишемической болезнью сердца (антиагрегантные, антикоагулянтные и тромболитические препараты) нередко оказываются недостаточно эффективными, требуют тщательный лабораторный и клинический контроль во время применения, имеют широкий спектр противопоказаний и побочных эффектов [Баркаган 3.С., Момот А.П., 2001; Leopold J.A., 1997]. Многие авторы отмечают высокую стоимость медикаментозного лечения и значительные трудности в применении фармацевтических средств, поскольку эффективность традиционной терапии при определённых заболеваниях системы кровообращения часто оказывается резко сниженной [Бокарев И.Н., 2000]. Далеко не всегда удается достигнуть оптимального результата; развиваются нежелательные побочные реакции, имеется ряд противопоказаний, ограничивающих применение лекарственных средств [Иванов С.Г., 1993; Киричук В.Ф. и др., 1999; Головачева Т.В. и др., 2000]. В этой связи возникает необходимость поиска новых 
перспективных методов лечения и профилактики не только кардиоваскулярных, но и огромного спектра других заболеваний. На сегодняшний день к таковым можно отнести электромагнитное излучение крайне высокочастотного и терагерцевого диапазонов частот (ТГЧ) [Лебедева А.Ю., 1998; Киричук В.Ф., Головачева Т.В., Чиж А.Г., 1999; Тамбиев А.Х., Кирикова Н.Н., 2000; Бецкий О.В., Лебедева Н.Н., 2002; Киричук В.Ф., Волин М.В., Креницкий А.П. и др., 2002; Киричук В.Ф., Малинова Л.И., Креницкий А.П. и др., 2003; Киричук В.Ф., Креницкий А.П., Майбородин А.В. и др., 2006; Родштат И.В., 2007].

Терагерцевый диапазон частот лежит на границе между электроникой и фотоникой от 100 ГГц до 10 ТГц (1 ТГц $=10^{3}$ ГГц) или в длинах волн от 3 мм до 30 мкм. [Гершензон Е.М., Малов Н.Н., Мансуров А.Н., 2002]. Установлено, что рассматриваемый диапазон волн используется живыми организмами для связи и управления, при этом сами живые организмы излучают колебания миллиметрового диапазона [Киричук В.Ф., Майбородин А.В., Волин М.В. и др., 2001; Киричук В.Ф., Креницкий А.П., Майбородин А.В. и др., 2002; Киричук В.Ф., Креницкий А.П., Малинова Л.И. и др., 2004]. Волны, возбуждаемые в организме при воздействии на него ТГЧ-излучения, в известной мере имитируют сигналы внутренней связи и управления (информационные связи) биологических объектов. В результате восстанавливается нормальное по спектру и мощности излучение, свойственное здоровому организму [Киричук В.Ф., Майбородин А.В., Волин М.В. и др., 2001; Киричук В.Ф., Креницкий А.П., Майбородин А.В. и др., 2002; Киричук В.Ф., Креницкий А.П., Малинова Л.И. и др., 2004]. Таким образом, представленный диапазон частот может корригировать функциональное состояние организма в пределах, присущих данному биологическому виду [Бецкий О.В., Девятков Н.Д., Кислов В.В., 1998; Конако Фредерико, Фэйтс Д., 2002]. Есть мнение, что реакционная способность молекул, возбужденных терагерцевым квантом, будет на порядок выше, чем при возбуждении КВЧ-квантом [Бецкий О.В., Креницкий А.П., Майбородин А.В., Тупикин В.Д., 2003]. К особенностям терагерцевых волн (ТГВ) относится также и то, что ТГЧ-излучение свободно проникает сквозь одежду и кожу до мышц человека [Конако Ф., Фэйтс Д., 2002].

Обращает на себя внимание тот факт, что в терагерцевом диапазоне частот в основном сосредоточены частотные спектры излучения и поглощения важнейших активных клеточных метаболитов ( $\mathrm{NO}, \mathrm{O}_{2}, \mathrm{CO}_{2}, \mathrm{CO}, \mathrm{OH}-$ и др.) [Башаринов А.Е., Тучков Л.Г., Поляков В.М., Аланов Н.И., 1967; Креницкий А.П., Майбородин А.В., Бецкий О.В. и др., 2003; Бецкий О.В., Киричук В.Ф., Бецкий О.В., Креницкий А.П., Майбородин А.В. и др., 2007; Rothman L.S., Barbe A., Chris Benner D. et al., 2003]. В связи с этим представляет интерес изучение эффектов и механизмов действия ТГЧ - волн на частотах молекулярных спектров излучения и поглощения (МСИП) тех или иных клеточных метаболитов на 
нарушенные функции микроциркуляторного звена системы гемостаза и реологические свойства крови [Бецкий О.В., Креницкий А.П., Майбородин О.В., Тупикин В.Д., 2003; Паршина С.С., Киричук В.Ф., Головачева Т.В. и др., 2004; Головачёва Т.В., Киричук В.Ф., Паршина С.С и др. 2006; Андронов Е.В., Киричук В.Ф. и др., 2007; Андронов Е.В., 2008].

Биофизические и физиологические эффекты волн терагерцевого диапазона частот дают основания и открывают перспективы развития новых направлений в биомедицинской технологии: «терагерцевая терапия», «терагерцевая диагностика» и «терагерцевая профилактика» [Бецкий О.В., Креницкий А.П., Майбородин А.В. и др., 2003; Киричук В.Ф., Майбородин А.В., Креницкий А.П. и др., 2006].

В доступной литературе не обнаружено сведений, характеризующих влияние ТГЧизлучения на частотах МСИП оксида азота 150,176-150,664 ГГц и частоте атмосферного кислорода 129,0 ГГц на нарушенные процессы в реологических свойствах крови и функциональной активности тромбоцитов в условиях целостного организма. Экспериментальное обоснование применения электромагнитного облучения на указанных частотах в клинической и теоретической практике, разработка оптимальных режимов воздействия электромагнитного излучения in vivo послужило основанием для проведения данной работы.

\section{ЦЕЛЬ ИССЛЕДОВАНИЯ}

Изучение закономерностей и механизмов воздействия волн терагерцевого диапазона на частотах молекулярных спектров излучения и поглощения оксида азота 150,176-150,664 ГГц и атмосферного кислорода 129,0 ГГц на нарушенные реологические свойства крови, функциональную активность тромбоцитов и разработка наиболее эффективных режимов воздействия на указанных частотах, обеспечивающих нормализацию реологии крови у экспериментальных животных в условиях иммобилизационного стресса.

\section{Глава IX}

\section{ВЛИЯНИЕ ИЗЛУЧЕНИЯ КРАЙНЕ ВЫСОКОГО И ТЕРАГЕРЦЕВОГО ДИАПАЗОНОВ ЧАСТОТ НА НАРУШЕННЫЕ ПРОЦЕССЫ В СИСТЕМЕ МИКРОЦИРКУЛЯЦИИ (ОБЗОР ЛИТЕРАТУРЫ)}

9.1. Биологические и биофизические эффекты электромагнитного излучения КВЧ и ТГЧ диапазонов и применение их в медицинской практике

9.1.1. Современные представления о физических и биологических механизмах КВЧ воздействия на микро - и макросистемы организма

В основу современного этапа освоения новых информационных медицинских технологий с применением электромагнитных волн миллиметрового (MМ) диапазона 
частот положено утверждение о том, что человеческий организм - это глубоко самоорганизующаяся и саморегулирующаяся система, состоящая из иерархически сложившихся подобных себе клеточных структур [Киричук В.Ф., Головачёва Т.В., Чиж А.Г., 1999; Бецкий О.В., Лебедева Н.Н., 2001]. Обоснованно высказывается предположение о позитивном влиянии волн ММ диапазона на восстановление нормального функционирования информационных управляющих систем организма [Лебедева Н.Н., Котровская Т.И,1999].

В окружающей нас природе отсутствуют монохроматические излучения диапазона крайне высокой частоты (КВЧ), так как они достаточно сильно поглощаются в атмосфере, воде и водных средах [Бецкий О.В., 1998; Киричук В.Ф., Головачёва Т.В., Чиж А.Г., 1999]. Вода, наряду с белками и липидами, выполняет исключительно важные функции в жизнедеятельности биологических объектов [Grundler W., Keilmann F., Frohlich H., 1977; Tuengler P., Keilmann F., Gensel L., 1979; Matzkin S., Benes L., Block N. et al., 1983; Gandhi O., 1984; Khurgin Y.I., Kudryashova V.A., Zavizion V.A.,1994]. Большая информационная энергоёмкость излучения КВЧ диапазона обратила внимание на этот факт ряда исследователей и дала возможность высказать множество оригинальных гипотез относительно особой роли электромагнитных излучений для поддержания гомеостаза биосистем, а также организма в целом [Голант М.Б., Брюхова А.К., Двадцатова Е.А. и др., 1983; Голант М.Б., 1986; Девятков Н.Д., Голанд Н.Б., Бецкий О.В., 1991; Киричук В.Ф., Головачева Т.В., Чиж А.Г., 1999; Киричук В.Ф., Андронов Е.В., Майбородин А.В. и др., 2004; Родштат И.В., 2005; Киричук В.Ф., Креницкий А.П., Майбородин А.В. и др., 2005; Паршина С.С., Киричук В.Ф., Головачева Т.В. и др., 2005; Киричук В.Ф., Креницкий А.П., Майбородин А.В., Тупикин В.Д., 2006; Frohlich H., 1979; Dardelhon M., Averbeck D., Berteaud A., 1979].

В работах многих авторов отмечается, что в процессе своей жизнедеятельности клетка вырабатывает электромагнитные колебания весьма широкого диапазона, но различные биологические эффекты клеток и организма проявляются лишь на низкоинтенсивные, информационные воздействия, то есть при крайне малых мощностях электромагнитных колебаний [Пресман А.С., 1968; Девятков Н.Д., Голант М.Б., Бецкий О.В., 1991; Майбородин А.В., Креницкий А.П., Тупикин В.Д. и др., 2001; Киричук В.Ф., Майбородин А.В., Волин М.В. и др., 2000; Киричук В.Ф., Волин М.В., Креницкий А.П. и др., 2002; Киричук В.Ф., Малинова Л.И., Креницкий А.П. и др., 2003; Киричук В.Ф., Креницкий А.П., Майбородин А.В. и др., 2005; Webb S.J., Booth A.D., 1971; Webb S.J., 1980; Taylor L.S, 1981; Veyret B., Bouthet C., Deschaux P. et al., 1991]. Показано, что 
энергия квантов КВЧ излучения, во-первых, меньше энергии теплового движения молекул, а, во-вторых, значительно меньше энергии водородных (самых слабых) связей в молекулах живых организмов. Поэтому очевидно, что механизм биологического действия КВЧ излучения не может быть связан с повреждающим воздействием на живой организм [Девятков Н.Д., Голант М.Б., 1985; Девятков Н.Д., Голант М.Б., Бецкий О.В., 1991].

Отсюда следует, что только этот узкий диапазон КВЧ волн используется клетками для обмена информацией в процессах регуляции внутриклеточных функций и межклеточных взаимодействий [Девятков Н.Д., Бецкий О.В., 1985; Девятков Н.Д., Голант М.Б., Бецкий О.В., 1991; Киричук В.Ф., Головачева Т.В., Чиж А.Г., 1999; Киричук В.Ф., Майбородин А.В., Волин М.В. и др., 2000; Киричук В.Ф., Малинова Л.И., Креницкий А.П. и др., 2003; Киричук В.Ф., Креницкий А.П., Майбородин А.В. и др., 2005], а вне этих интервалов частот значительно снижается или отсутствует [Frohlich H., 1980; Kaiser F., 1983; Keilmann F., 1983].

На протяжении трех с половиной десятилетий был накоплен громадный массив экспериментальных и клинических данных [Девятков Н.Д., Бецкий О.В., 1985; Голант М.Б., 1986; Девятков Н.Д., Голант М.Б. , Бецкий О.В., 1991, 1994, 1997; Бецкий О.В., Лебедева Н.Н., 2001; Петросян В.И., Майбородин А.В., Дубовицкий С.А. и др., 2005; Паршина С.С., Киричук В.Ф., Головачева Т.В. и др., 2005; Dardelhon M., Averbeck D., Berteaud A., 1979], разработаны и изготовлены различные технические устройства для проведения КВЧ терапии и сформулированы общие требования к таким устройствам [Беляков С.В., Бецкий О.В., Яременко Ю.Г., 1998].

Таким образом, в последние десятилетия в результате фундаментальных исследований в России было создано новое перспективное направление медицины - КВЧ терапия (крайне высокочастотная терапия, микрорезонансная терапия, миллиметровая терапия). Отсутствие побочных эффектов, значительное сокращение сроков лечения стимулировали разработку более совершенной физиотерапевтической аппаратуры в крайне высокочастотном диапазоне. КВЧ терапия позволяет на практике использовать новейшие знания биологии, биофизики, техники сверхвысоких частот и новых медицинских информационных технологий [Девятков Н.Д., Голант М.Б., Бецкий О.В., 1991, 1994; Голант М.Б., 1997; Киричук В.Ф., Головачева Т.В., Чиж А.Г. 1999; Бецкий О.В., Девятков Н.Д., Лебедева Н.Н., 2000; Синицын Н.И., Петросян В.И., Елкин В.А. и др., 2000; Betskii O.V., 1994].

Большое количество теоретических [Девятков Н.Д., Бецкий О.В., Голант М.Б., 
1991; Бецкий О.В., Девятков Н.Д., 1996; Бессонов А.Е., Калмыкова Е.А., Конягин Б.А., 1999] и экспериментальных [Колбун Н.Д., 1991; Куропатова Е.С., 1994; Воторопин С.Д., Кожемякин А.М., 1998] исследований позволяет сделать вывод о том, что в диапазоне КВЧ существуют информационные каналы воздействия ЭМИ на организм человека, которые для каждого являются строго индивидуальными. Особо следует отметить влияние КВЧ при воздействии на биологически активные зоны (Захарьина-Геда), точки акупунктуры [Катин А.Я., 1995; Голанд М.Б., Гедымин Л.Е., Новикова Л.Н., 1995]. Организм человека способен избирательно различать близкие ему по смыслу ММ волны, реагируя на них быстрым изменением ЭЭГ, ЭКГ и др., то есть, организм отвечает заранее предопределенной реакцией, которая, при правильном использовании метода, является эффективнейшим средством в плане лечения многих заболеваний. Именно на этом принципе и строится КВЧ терапия [Девятков Н.Д., Голант М.Б., Бецкий О.В., 1991; Киричук В.Ф., Головачева Т.В., Чиж А.Г., 1999].

К КВЧ колебаниям принято относить электромагнитные волны частотой 30-300 ГГц, то есть КВЧ является одним из поддиапазонов СВЧ (сверх высокие частоты) - колебаний (частоты свыше 300 МГц) [Девятков Н.Д., Голант М.Б., Бецкий О.В., 1991; Голант М.Б., 1997]. КВЧ излучение является электромагнитным колебанием, обладающим волновыми и квантовыми свойствами [Девятков Н.Д., Голант М.Б., Бецкий О.В., 1991], а также высокой когерентностью [Киричук В.Ф., Головачёва Т.В., Чиж А.Г., 1999; Frohlich Н., 1968, 1979].

Высокая эффективность КВЧ терапии подтверждает, что человеческий организм обладает электромагнитным информационным каркасом, способным реагировать на воздействие электромагнитных колебаний сверхмалых $\left(\sim 10^{-18} \div 10^{-21} \mathrm{~B}\right.$ т/м ${ }^{2}$ Гц $)$ подпороговых мощностей. Глубина проникновения в ткани ЭМИ КВЧ не превышает 0,3 0,5 мм, а используемые мощности излучения - 1,0 - 10,0 мВт [Киричук В.Ф., Головачева Т.В., Чиж А.Г., 1999].

В настоящее время единого мнения о физических механизмах взаимодействия миллиметровых волн с биологическими объектами не существует, так как неизвестно ключевое звено, связывающее метаболизм клетки с ЭМИ. Тем не менее, можно считать, что электромагнитное излучение низкой интенсивности является универсальным механизмом передачи информации как между живыми объектами, так и между клетками в пределах биологического объекта. Данное утверждение основано на двух убедительных фундаментальных положениях: способности живых объектов, во-первых, генерировать собственное КВЧ излучение и, во-вторых, реагировать на внешнее КВЧ воздействие 
[Девятков Н.Д., Голант М.Б., Бецкий О.В., 1991; Бецкий О.В., 1991, 1997, 2003, 2004; Родштат И.В., 1997; Гапочка Л.Д., Гапочка М.Г., Королев А.Ф. и др., 2000; Синицын Н.И., Петросян В.И., Елкин В.А. и др., 2000; Шуб Г.М., Петросян В.И., Синицын Н.И. и др., 2000].

Сформулированы следующие критерии информационного характера взаимодействия: оно наблюдается или при уровнях мощности облучения 1-10 мВт и ниже, или при повышении температуры облучаемого живого объекта не более чем на $0,1^{\circ} \mathrm{C}$ [Девятков Н.Д., Бецкий О.В., 1985; Девятков Н.Д., Голант М.Б., Бецкий О.В., 1991, 1994]. Отсюда следует, что только этот узкий диапазон КВЧ волн используется клетками для обмена информацией в процессах регуляции внутриклеточных функций и межклеточных взаимодействий [Девятков Н.Д., Бецкий О.В., 1985; Девятков Н.Д., Голант М.Б., Бецкий О.В, 1991; Киричук В.Ф., Головачева Т.В., Чиж А.Г., 1999; Киричук В.Ф., Майбородин А.В., Волин М.В. и др., 2000; Киричук В.Ф., Малинова Л.И., Креницкий А.П. и др., 2003; Киричук В.Ф., Креницкий А.П., Майбородин А.В. и др., 2005] , а вне этих интервалов частот значительно снижается или отсутствует [Frohlich H., 1980; Kaiser F., 1983; Keilmann F., 1983].

В настоящее время, несмотря на огромное количество исследований в области электромагнитных колебаний миллиметрового диапазона и данных литературы, описывающих особенности влияния мм волн на различные биологические микро - и макрообъекты, нет единого мнения о механизме воздействия электромагнитного излучения (ЭМИ) КВЧ диапазона. Предложено множество гипотез, объясняющих чувствительность организма к КВЧ воздействию (мембранная, связанная с резонансными спектрами воды, с формированием белковых подструктур и др.) [ [Родштат И.В., 1991, 2005; Бецкий О.В., 1995, 1997; Киричук В.Ф., Головачева Т.В., Чиж А.Г., 1999]. Однако ни одна из них не имеет универсального характера.

Возможными первичными мишенями КВЧ в организме являются форменные элементы крови и тонкая кожа, высокая чувствительность к миллиметровым волнам которых доказана экспериментально [Девятков Н.Д., Голант М.Б., Бецкий О.В., 1991; Голант М.Б., Гедымин Л.Е., Новикова Л.Н. и др., 1995; Киричук В.Ф., Майбородин А.В., Волин М.В. и др., 2000; Киричук В.Ф., Малинова Л.И., Креницкий А.П. и др., 2003; Киричук В.Ф., Креницкий А.П., Майбородин А.В. и др., 2005; Паршина С.С., Киричук В.Ф., Головачева Т.В. и др., 2005]. 
Согласно одной из гипотез механизм КВЧ влияния предполагает наличие корреляционной активации собственных электромагнитных полей клеток организма при внешнем облучении [Афромеев В.И., Субботина Т.Н., Яшин А.А., 1997, 1998; Нефедов Е.И., Протопопов А.А., Хадарцев А.А. и др., 1998].

Имеет место биоэнергетическая точка зрения на механизм взаимодействия ЭМИ мм-диапазона с биологическим объектом с отведением особой роли двойного резонанса при наличии модуляции мощности излучения [Гапеев А.Б., 1997]. Конечным терапевтическим эффектом такого воздействия являются восстановительные процессы, ликвидирующие патологию клетки, которые достигаются биофизическими и биохимическими реакциями, протекающими с затратой энергии. Таким образом, здесь имеет место инициирование внешним биоинформационным сигналом соответствующих энергетических процессов [Афромеев В.И., Субботина Т.Н., Яшин А.А., 1997; Нефёдов Е.И., Протопопов А.А., Хадарцев А.А. и др., 1998; Яшин А.А., 2000].

Многочисленными биофизическими экспериментами с использованием экранированных камер подтверждается роль электромагнитного поля окружающей среды как одного из регулирующих факторов в процессе роста и развития многоклеточных организмов или колоний одноклеточных [Якунов А.В., 1997]. Рядом авторов получены экспериментальные данные о регистрации собственного излучения клетки в момент своего деления [Del Giudice E., Doglia S., Milani M. et al., 1989].

В настоящее время наиболее признанной и научно обоснованной является радиофизическая теория механизма воздействия ЭМИ КВЧ на живой объект, выдвинутая и разработанная академиком Н.Д. Девятковым и его сотрудниками (1985 - 1994). Информационное действие ММ волн опосредуется через формирование белковых подструктур, которые в дальнейшем регулируют метаболические процессы клетки, то есть излучение воздействует на собственную информационно управляющую систему организма [Голант М.Б., Сотников О.С., 1987; Бецкий О.В., Девятков Н.Д., 1996]. Показано, что в ряде случаев клетки организма, ослабленные в силу тех или иных причин, не могут самостоятельно восстановить свой гомеостаз. Влияние КВЧ излучения в данной ситуации нормализует функционирование повреждённых клеточных структур [Девятков Н.Д., Голант М.Б., Бецкий О.В., 1991; Бецкий О.В., Девятков Н.Д., 1996]. Излучение низкой интенсивности может запускать (инициировать) цепочку последовательных реакций, сопровождающихся трансформацией энергии и приводящих к положительному эффекту, то есть взаимодействие «ЭМИ КВЧ - биосистема» носит опосредованный характер и может оказывать нормализующий эффект в сложно организованных биологических объектах. 
В результате проведенных исследований были выявлены взаимосвязи между функциональным состоянием органа в норме или при патологии и особенностями спектра его собственного КВЧ излучения, а также нормализация нарушенного КВЧ спектра под влиянием внешнего воздействия [Девятков Н.Д., Голант М.Б., Бецкий О.В., 1991; Киричук В.Ф., Головачева Т.В., Чиж А.Г., 1999]. Полученные данные свидетельствуют в пользу роли КВЧ излучения как механизма межклеточного обмена информацией [Киричук В.Ф., Майбородин А.В., Волин М.В. и др., 2000; Киричук В.Ф., Волин М.В., Креницкий А.П. и др., 2002; Киричук В.Ф., Малинова Л.И., Креницкий А.П. и др., 2003].

Колебания КВЧ диапазона носят шумовой (беспорядочный) характер при нормальной жизнедеятельности клеток. Клетки обладают электрической симметрией, которая подвержена нарушению в силу многих патологических причин. Как следствие этого по принципу Ле-Шателье происходит генерации когерентных (упорядоченных) электромагнитных колебаний КВЧ диапазона, что способствует нормализации нарушенной функции клеток [Девятков Н.Д., Голант М.Б., 1983; Бецкий О.В., Девятков Н.Д., Кислов В.В., 1998; Бецкий О.В., Лебедева Н.Н., 2001]. Можно сделать вывод о том, что внешнее имитированное КВЧ облучение способствует воспроизведению указанных клеточных регулирующих воздействий и таким образом приводит к нормализации нарушенных регуляторных механизмов - гуморальных, гормональных, нервных, иммунных и т.д. Соответственно этому происходит восстановление нарушенных функций отдельных тканей, органов, функциональных систем, адаптационно-компенсаторной функции организма [Девятков Н.Д., Арзуманов Ю.Л., Бецкий О.В., Лебедева Н.Н., 1995; Голант М.Б., 1997; Киричук В.Ф., Головачева Т.В., Чиж А.Г., 1999; Бецкий О.В., Лебедева Н.Н., 2001].

Следует отметить, что организм человека состоит приблизительно из $10^{15}$ клеток, а каждая клетка является достаточно автономным образованием. Следовательно, для обеспечения нормальной работы такой сложной системы необходим определенный механизм синхронизации их функций. В работах Н.Д. Девяткова, М.Б. Голанта, О.В. Бецкого (1991, 1997), В.Ф. Киричука, Л.И. Малиновой, А.П. Креницкого и др. (2003) появились научно обоснованные доказательства того, что КВЧ излучение ММ диапазона используется биологическими объектами в целях управления межклеточными взаимосвязями. Поэтому был сделан вывод о том, что биологический объект обладает собственным набором внутренних частот волновых процессов и, соответственно, может участвовать в явлении биорезонанса на этих частотах с излучениями при внешних воздействиях электромагнитных колебаний. Цель этого взаимодействия - направленная 
коррекция параметров гомеостаза организма независимо от отклонений, обусловленных патологией или повреждением. Следовательно, КВЧ облучение помогает нормализации функционирования поврежденных структур [Девятков Н.Д., Голант М.Б., Бецкий О.В., 1991; Бецкий О.В., Девятков Н.Д., 1996].

Авторы утверждают, что КВЧ излучение воздействует непосредственно на собственную информационно-управляющую систему организма. Данный эффект опосредуется через формирование белковых подструктур, которые в дальнейшем способствуют регуляции метаболических процессов в клетке.

Академик Н.Д. Девятков и соавт. (1991, 1996) убедительно доказывают, что эффекты воздействия ММ волн опосредуется через возбуждение акустоэлектрических волн в мембранах только тех клеток, у которых есть изначальные признаки патологии. В дальнейшем происходит генерация клетками сигналов управления восстановительными процессами.

Необходимо отметить, что в вышеперечисленных работах отражены преимущественно вопросы информационного взаимодействия в системе «КВЧ-генератор - биологический объект». Однако рядом исследователей рассматриваются механизмы передачи информации от одного живого объекта к другому [Гурвич А.Г., 1990; Киричук В.Ф., Майбородин А.В., Волин М.В. и др., 2000; Киричук В.Ф., Волин М.В., Креницкий А.П. и др., 2002; Киричук В.Ф., Малинова Л.И., Креницкий А.П., и др., 2003].

Известно, что ещё в конце 70-х годов Frohlich Н. теоретически доказал, что когерентные (синфазные) колебания отдельных участков плазматических мембран клеток совершаются именно в диапазоне крайне высоких частот $\left(10^{10}-10^{11} \Gamma ц\right)$. Они возникают и поддерживаются здесь, используя энергию процессов метаболизма. Возможно, это и есть акусто-электрические волны, которые являются отличительным свойством всех живых клеток. Генерация таких колебаний в живых клетках происходит именно в КВЧ диапазоне. При возникновении различных заболеваний происходит деструкция и гибель клеток, поэтому данные колебания сначала начинают затухать, а в дальнейшем могут исчезнуть полностью. Воздействие электромагнитных волн, находящихся в КВЧ диапазоне, на клетки кожи приводит к синхронизации угасающих колебаний в мембранах клеток. При дальнейшем поддержании этих колебаний на их нормальном физиологическом уровне возможно достижение положительного лечебного эффекта [Бецкий О.В., Девятков Н.Д., 1996].

Основной точкой приложения ЭМИ ММД, по информационной теории М.Б. Голанта $(1985,1989,1991)$, является мембранная информационная система. Доказано, что 
КВЧ излучение оказывает выраженное влияние на мембраны клеток, способствует перемешиванию ее липидных слоев и белковых компонентов [Голант М.Б., 1989]. Эти процессы перестраивают функциональную активность клетки, подвергнутой ЭМИ ММ диапазона [Девятков Н.Д., Голант М.Б., Бецкий О.В., 1991].

C точки зрения W.R. Adey (1996), КВЧ облучение является фактором возбуждения молекулярных рецепторов мембран клеток, при распространении которого по межклеточным пространствам происходит воздействие на отрицательно заряженные гликопротеиновые нити гликокаликса мембран клеток. В ряде работ отмечено, что КВЧоблучение оказывает влияние на активность $\mathrm{Na}^{+}, \mathrm{K}^{+}-$и $\mathrm{Ca}^{++}$-АТФазы, увеличивая её и регулируя тем самым проницаемость мембран для указанных ионов [Рубин В.И., Садчиков Д.В., Мельникова Г.Я и др., 1990; Рубин В.И., Мельникова Г.Я., 1991; Melnik R.L., Rubenstein Ch.P., Birenbaum L., 1982]. Миллиметровое излучение приводит к ускорению активного трансмембранного транспорта $\mathrm{Na}^{+}$, изменению проницаемости мембран эритроцитов для $\mathrm{K}^{+}$, увеличению ионной проводимости бислойных липидных мембран в условиях in vitro [Бецкий О.В., Девятков Н.Д., 1996]. Доказано, что существуют резонирующие «окна» по отношению к действию переменных электромагнитных полей на проницаемость мембран нервных клеток к ионам кальция [Adey W.R., 1996].

Рядом исследователей установлено, что первичной мишенью для ЭМИ является не собственно клетка организма, а водная среда верхней части кожного покрова (водный матрикс организма) [Синицин Н.И., Петросян В.И., Ёлкин В.А., 2000; Петросян В.И., Синицин Н.И., Ёлкин В.А., 2000]. Из данного утверждения можно сделать вывод, что энергия КВЧ волн поглощается молекулами свободной воды, водных растворов, белков и липидов. [Петросян В.И., Девятков Н.Д., Гуляев Ю.В. и др., 1997; Петросян В.И., Синицин Н.И., Ёлкин В.А., 2000; Родштат И.В., 2005; Matzkin S., Benes L., Block N. et al., 1983; Gandhi 0., 1984; Grundler W., Keilmann F., Frohlich H., 1977; Tuengler P., Keilmann F., Gensel L., 1979; Khurgin Yu. I., Kudryashova V.A., Zavizion V.A., 1994]. Данный процесс приводит к повышению химической активности молекул структурированной воды живого организма. В последующем возбуждение передается до уровня белков клеточной мембраны, как информационный сигнал, по принципу триггерного эффекта [Бецкий О.В., Девятков Н.Д., 1996].

В.И. Петросян, Н.Д. Девятков, Ю.В. Гуляев и др. (1997), В.И. Петросян, Н.И. Синицын, В.А. Елкин и др. (2000), указывают на существование феномена резонансной прозрачности водных и биологических сред в миллиметровом диапазоне. Он обусловлен особенностями строения молекулы воды. Данный феномен является наиболее вероятным 
механизмом распространения локального КВЧ воздействия по организму. Согласно данным V.I. Gaiduk (1994), КВЧ излучение усиливает термодинамическую и кинетическую активность молекул воды.

По мнению И.В. Родштата (1985, 1991,1997, 2005), энергия электромагнитных миллиметровых волн при воздействии на молекулы воды, связанные с белковыми структурами коллагена, приводит к изменению гидратной оболочки белковых молекул. Этот процесс влечет за собой значительное изменение функциональной активности белка [Ленинджер А., 1985]. Известно, что электромагнитные волны быстро затухают в тонком слое кожи, и глубина проникновения КВЧ-волн в организм человека равняется примерно 0,3-0,5 мм [Родштат И.В., 1991, 1997, 2005; Бецкий О.В., 1995, 1997; Khizhnyak Y.P., Betskii O.V., Voronkov V.N., Yaremenko Yu. D., 1994]. Из вышесказанного можно сделать вывод, что первичная рецепция КВЧ колебаний происходит преимущественно в коже. Многие исследователи свидетельствуют об изменении температуры поверхности кожи при воздействии на нее электромагнитных волн миллиметрового диапазона [Бецкий О.В., Девятков Н.Д., Кислов В.В., 1998; Nelson D.A., Nelson M.T., Walters T.J., Mason P.А., 2000; Walters T.J., Blick D.W., Johnson L.R. et al., 2000].

Доказано, что первичными акцепторами КВЧ энергии выступают также кровеносные сосуды и клетки крови [Девятков Н.Д., Голант М.Б., Бецкий О.В., 1991; Голант М.Б., Гедымин Л.Е., Новикова Л.Н. и др., 1995], благодаря циркуляции которых влияние КВЧ облучения распространяется даже на те области организма, которые удалены от места непосредственно подвергнутого облучению. Однако установлено, что выраженность воздействия КВЧ колебаний в данном случае снижается по мере удаления от облученного участка кожи [Голант М.Б., Гедымин Л.Е., Новикова Л.Н. и др., 1995].

Представление о форменных элементах крови как о первичной мишени КВЧ облучения в организме обусловливает особый интерес исследователей к изучению особенностей реакции эритроцитов и тромбоцитов человека на миллиметровое воздействие [Киричук В.Ф., Головачева Т.В., Чиж А.Г, 1999]. Эритроциты человека обладают выраженной чувствительностью к внешнему воздействию КВЧ облучением в условиях in vitro. В этих клетках наблюдается значительное изменение электрофоретической подвижности, как полагают, обусловленное изменением поверхностного электрического заряда эритроцитов [Кузмакнова М., Иванова Ст., 1995; Киричук В.Ф., Малинова Л.И., Креницкий А.П. и др., 2003].

Доказано, что форменные элементы крови обладают неодинаковой чувствительностью к различным диапазонам КВЧ облучения. При изучении изменения некоторых показателей гемореологии (вязкость крови, деформируемость и агрегация эритроцитов), а также характеристик фагоцитоза и 
перекисного окисления липидов у больных различными хроническими заболеваниями в условиях in vitro было установлено, что существует три типа реакции клеток крови больного (узко-, средне- и широкоспектральная чувствительность), описанные в работах М.В. Пославского $(1991,1995)$. Некоторые исследователи показали, что различные дозы низкоинтенсивного (0,8-5 мВт/см ${ }^{2}$ ) высокочастотного излучения могут как стимулировать, так и тормозить спонтанный гемолиз эритроцитов человека [Sajin G., Covacs E., Moraru R.P. et al., 2000].

ЭМИ миллиметрового диапазона частот оказывает выраженное ингибирующее воздействие на изменённую функциональную активность эритроцитов и тромбоцитов больных язвенной болезнью желудка и двенадцатиперстной кишки, а также нестабильной стенокардией в условиях in vitro [Махова Г.Е., 1998; Киричук В.Ф., Головачева Т.В., Чиж А.Г.,1999; Волин М.В. и др., 2000; Кошелева Н.А., 2002; Головачева Т.В., Паршина С.С., Субботина Н.В., 2002; Киричук В.Ф., Малинова Л.И., Креницкий А.П. и др. 2003; Киричук В.Ф., Креницкий А.П., Майбородин А.В. и др., 2005; Паршина С.С., Киричук В.Ф., Головачева Т.В. и др., 2005]. В ходе экспериментальных исследований установлено, что возможна нормализация нарушенных реологических свойств крови как в условиях in vitro, так и in vivo при КВЧ облучении. При этом происходит восстановление таких нарушенных показателей гемореологии как вязкость крови, показатель гематокрита, деформируемость и агрегационная способность эритроцитов, уровень фибриногена [Пославский М.В., 1991, 1995; Голант М.Б., 1991].

\subsection{2. Биофизические основы применения волн терагерцевого диапазона частот и} влияние ЭМИ ТГЧ диапазона на микро - и макросоставляющие структуры организма

В настоящее время внимание многих исследователей обращено на терагерцевый диапазона частот, поскольку именно в этом диапазоне сосредоточены частотные спектры поглощения и излучения важнейших клеточных метаболитов $\left(\mathrm{NO}, \mathrm{O}_{2}, \mathrm{CO}_{2}, \mathrm{CO}, \mathrm{OH}-\right.$ и др.) [Башаринов А.Е., Тучков Л.Г., Поляков В.М., 1967; Киричук В.Ф., Майбородин А.В., Волин М.В. и др., 2000; Майбородин А.В., Креницкий А.П., Тупикин В.Д. и др., 2001; Киричук В.Ф., Андронов Е.В., Майбородин А.В. и др., 2004; Андронов Е.В., 2008].

Фундаментальной основой функционирования сложных биологических систем являются молекулы-метаболиты, стабильные и строго воспроизводимые молекулярные структуры биосреды. Поэтому детерминированное управление их реакционной способностью излучением, совпадающим по спектрам их излучения и поглощения, может направленно регулировать процесс метаболизма в биосреде. Анализ биомедицинских 
эффектов ЭМИ на частотах молекулярных спектров атмосферных газов-метаболитов показывает прямую связь спектров заданного метаболита и его свойств в биосреде. Это соответствует представлениям о веществе и поле как о единой системе [Бецкий О.В., Кислов В.В., Лебедева Н.Н., 2004; Бецкий О.В., Майбородин А.В., Будник М.И. и др., 2006].

Развитие терагерцевой терапии и, в частности, методы и устройства спектральномолекулярной терагерцевой терапии, основанной на повышенной реакционной и диффузионной способности экзогенных и эндогенных молекул-метаболитов газов атмосферного воздуха и аэрозолей $\mathrm{O}_{2}, \mathrm{CO}_{2}, \mathrm{NO}, \mathrm{H}_{2} \mathrm{O}$ и др., путём воздействия на них электромагнитного излучения терагерцевого и ИК-диапазонов частот переходит из стадии исследования на этап создания промышленных образцов физиотерапевтической аппаратуры, методов и средств измерения её параметров и их сертификацию [Бецкий О.В., Кислов В.В., Лебедева Н.Н., 2004; Бецкий О.В., Майбородин А.В., Будник М.И., и др., 2006; Бецкий О.В., Креницкий А.П., Майбородин А.В. и др., 2006; Креницкий А.П., Майбородин А.В., Киричук В.Ф. и др., 2007].

Для высокочастотной части терагерцевого диапазона и ИК-диапазона в настоящее время применяют программу расчета спектров молекул газов-метаболитов и аэрозолей с использованием международной базы данных молекулярных спектров высокого разрешения HITRAN [Бецкий О.В., Креницкий А.П., Майбородин А.В. и др., 2007; Rothman L.S., Barbe A., Chris Benner D. et al, 2003; Rothman L.S., Jacquemart D., Barbe A. et al, 2005], созданный с участием космического агентства (NASA). В этих работах представлены молекулярные HITRAN-спектры газов-метаболитов молекул $\mathrm{O}_{2}, \mathrm{CO}_{2}$, $\mathrm{NO}$ и паров воды, принимающих участие в процессе дыхания (экзогенные молекулыметаболиты), так и в эндогенных биохимических реакциях. Таким образом, перспективным направлением терагерцевой биомедицинской технологии является использование HITRAN-спектров для точного выбора частот активации молекулметаболитов [Бецкий О.В., Креницкий А.П., Майбородин А.В. и др., 2007; Goldman, R.R. Gamache, A. Perrin, et al., 2000; Rothman L.S., Barbe A., Chris Benner D. et. al, 2003 ].

Электромагнитное излучение терагерцевого диапазона частот (ЭМИ ТГЧ) - это распространяющееся в пространстве, в средах и тканях электромагнитное поле сверхвысокой частоты. Терагерцевый диапазон частот (ТГЧ) лежит на границе между электроникой и фотоникой от 100 ГГц до 10 ТГц $\left(1\right.$ ТГц $=10^{3}$ ГГц $)$ или в длинах волн от 3 мм до $30 \mu$ м. С одной стороны, он определен частотно-временным ограничением (более 100 ГГц) электронных переходов в полупроводниковых структурах, а с другой максимальной длиной волны квантовых перходов лазерных структур. Этот диапазон волн 
находится на шкале электромагнитных волн между КВЧ-диапазоном и оптическим инфракрасным диапазоном и частично перекрывает высокочастотную частот КВЧдиапазона (100-300 ГГц) и низкочастотную часть инфракрасного диапазона [Гершензон Е.М., Малов Н.Н., Мансуров А.Н., 2002].

Максимальная энергия кванта $h v$ в классическом КВЧ - диапазоне составляет $1,17 \cdot 10^{-3}$ эВ, а в терагерцевом на два порядка выше, то есть $\sim 10^{-1}$ эВ. Ниже энергии кванта в КВЧ - диапазоне оказываются энергия вращения молекул вокруг связей $\left(10^{-4}-10^{-3}\right.$ эВ), энергия куперовских пар при сверхпроводимости $\left(10^{-6}-10^{-4}\right.$ эВ) и энергия магнитного упорядочения $\left(10^{-6}-10^{-4}\right.$ эВ) [Гершензон Е.М., Малов Н.Н., Мансуров А.Н., 2002]. В терагерцевом диапазоне частот энергия кванта больше указанных фундаментальных энергетических состояний вещества, включая дополнительный (по сравнению с классическими КВЧ), более высокий уровень молекулярного состояния вещества энергию колебательных уровней молекул $\left(10^{-2}-10^{-1}\right.$ эВ), который уже близок к энергии ионизации. Энергия взаимодействия при равенстве сил притяжения и отталкивания молекул имеет значение порядка $10^{-1}-10^{-2}$ эВ [Конако Ф., Фэйтс Д., 2002; Rothman L.S., Barbe A., Chris Benner D. et al, 2003]. Таким образом, можно полагать, что реакционная способность молекул будет на два порядка выше, чем при возбуждении КВЧ - квантом.

ЭМИ ТГЧ как физический фактор, действующий на биологические объекты, характеризуется рядом биотропных параметров: частотой и соответствующей ей длиной волны, интенсивностью, плотностью потока мощности, направленностью, градиентом поля, наличием или отсутствием модуляции, видом модуляций, поляризацией [Бецкий О.В., Лебедева Н.Н., 2001].

Биологические эффекты ТГЧ излучения регистрируются при плотности потока мощности излучения значительно ниже $10 \mathrm{mBT} / \mathrm{cm}^{2}$. При такой низкой интенсивности излучения интегральный нагрев облучаемых объектов в эксперименте не превышает $0,1{ }^{\circ} \mathrm{C}$. Поэтому ЭМИ ТГЧ относится к «информационным», нетепловым воздействиям [Бецкий О.В., Лебедева Н.Н., 2001].

В настоящее время, благодаря интенсивной научно-исследовательской работе в области биологии, радиофизики, электроники и медицине создается новое перспективное направление в СВЧ-физиотерапии, диагностике и экологии, которое можно назвать «терагерцевая терапия», «терагерцевая диагностика» и «терагерцевая экология» [Бецкий О.В., Креницкий А.П., Майбородин А.В. и др., 2003].

Рассмотрение данных литературы о действии ЭМИ ТГЧ на клеточном и субклеточном уровнях может помочь конкретизировать представления о возможных путях восприятия организмом данного вида излучения. В основе структурной 
организации клеток лежит мембранный универсальный принцип строения [Колесников С.И., 2006]. В настоящее время общепринята модель мозаичного строения клеточных мембран. Значение биомембран состоит в поддержании функционирования клеток различного типа, благодаря наличию в мембранах специализированных белковрецепторов, способных регулировать энергетические и биохимические процессы в клетке, а также обеспечивать связь между клетками в тканях многоклеточных организмов [Константинов В.М., Резанов А.Г., Фадеева Е.О., 2004]. Предполагается, что в клеточных мембранах существуют колебания дипольных групп. Это определяет возможность резонансного взаимодействия ЭМИ ТГЧ с мембранной структурой живой клетки [Девятков Н.Д., Голант Н.Б., Бецкий О.В., 1991].

В исследованиях Г.М. Шуба и др. $(2004,2007)$ выявлено влияние ЭМИ ТГЧ 150,176-150,664 ГГц на все стороны жизнедеятельности микроорганизмов при экспериментальной стафилококковой инфекции - морфологию, культуральные, физиологические, физические свойства и биохимический состав. Так, наблюдалось статистически значимое ингибирование деления и роста клеток стафилококка (штамм 209P) на желточно-солевом агаре в культуре, полученной от мышей опытной группы, получавших со вторых суток после заражения экспериментальной стафилококковой инфекцией ЭМИ ТГЧ 150,176-150,664 ГГц ежедневно 10 дней в течение 3 минут.

Показано влияние данного вида излучения на жизнедеятельность микроорганизмов. Так, в работах Н.В.Островского и др. (2004) ходе бактериологического исследования ожогового отделяемого микробная обсемененность раны составляла $10^{4}$ КОЕ/мл, выявлена ассоциация гемолитического штамма S.aureus и не гемолитического штамма S. Epidermidis. После 2-3 сеансов ЭМИ ТГЧ на частотах 150,176-150,664 ГГц в течение 15 минут микробная обсемененность раны S.aureus снизилась в 1000 раз, S. Epidermidis - в 100 раз, то есть наблюдалось статистически значимое ингибирование деления и роста клеток стафилококка.

Представление о форменных элементах крови как о первичной мишени ТГЧизлучения в организме обусловливает особый интерес исследователей к изучению механизмов реакции эритроцитов и тромбоцитов человека на ЭМИ терагерцевого диапазона [Киричук В.Ф., Волин М.Ф., Креницкий А.П. и др., 2002; Киричук В.Ф., Малинова Л.И., Креницкий А.П. и др., 2003].

Эритроциты, обусловливающие вязкостные свойства крови, обладают выраженной чувствительностью к воздействию ТГЧ облучения в условиях in vitro. Был установлен факт нормализации нарушенных вязкостных свойств цельной крови, агрегационной способности и деформируемости эритроцитов больных нестабильной стенокардией, 
находящихся в естественном электромагнитном поле, под влиянием ЭМИ ТГЧ на частоте 240 ГГц, наиболее выраженной при 15- минутном режиме облучения [Киричук В.Ф., Андронов Е.В., Мамонтова Н.В. и др., 2005, Киричук В.Ф., Андронов Е.В., Мамонтова Н.В. и др., Мамонтова Н.В., 2006]. Показано статистически достоверное восстановление нарушенных вязкостных свойств цельной крови, агрегации и деформируемости эритроцитов больных нестабильной стенокардией, находящихся в скрещенных магнитном и электрическом полях, под влиянием ЭМИ ТГЧ-диапазона на частоте оксида азота 240 ГГц, наиболее эффективное при 15-минутном режиме облучения [Киричук В.Ф., Андронов Е.В., Мамонтова Н.В. и др., 2005]. Авторами также отмечена продолжительность нормализующего воздействия ЭМИ ТГЧ- диапазона на частоте оксида азота 240 ГГц на вязкостные свойства цельной крови, способность эритроцитов к агрегации и их деформируемость у больных нестабильной стенокардией в условиях in vitro, которая составляет 30 минут [Киричук В.Ф., Андронов Е.В., Мамонтова Н.В. и др., 2005; Андроноа Е.В., 2008].

Н.В. Мамонтовой и соавт. (2006) показано, что облученный ЭМИ ТГЧ на частоте оксида азота 240 ГГц донатор оксида азота - изокет оказывает более выраженный эффект в восстановлении измененных вязкостных свойств цельной крови, агрегационной способности и деформируемости эритроцитов больных нестабильной стенокардией, чем не облученный, что может быть использовано для восстановления нарушенных функциональных свойств эритроцитов и реологических показателей крови больных ИБС в клинической практике.

В условиях эксперимента in vitro Е.В. Андронов и соавт. (2004; 2008) показали нормализацию функциональной активности тромбоцитов больных нестабильной стенокардией при воздействии ЭМИ ТГЧ на частотах оксида азота 240 ГГц. Так, при облучении обогащенной тромбоцитами плазмы больных нестабильной стенокардией в условиях in vitro на частоте 240 ГГц на частотах оксида азота в течение 15 минут наблюдалось значительное снижение повышенной агрегационной активности кровяных пластинок, что сопровождалось статистически достоверным уменьшением максимального размера образующихся тромбоцитарных агрегатов, максимальной скорости образования наибольших тромбоцитарных агрегатов, максимальной степени агрегации. Аналогичные сдвиги произошли в агрегационной активности тромбоцитов больных нестабильной стенокардией при облучении обогащенной тромбоцитами плазмы в течение 30 минут. Однако, эти изменения, как правило, были выражены в меньшей степени, чем при 15 минутном облучении.

При облучении ЭМИ ТГЧ на частоте молекулярного спектра излучения и 
поглощения оксида азота 400 ГГц обогащенной тромбоцитами плазмы больных нестабильной стенокардией в условиях эксперимента in vitro обнаружено значительное снижение увеличенной агрегационной способности кровяных пластинок, что сопровождалось статистически достоверным уменьшением максимального размера образующихся тромбоцитарных агрегатов, максимальной скорости образования наибольших тромбоцитарных агрегатов, максимальной степени и скорости агрегации [Андронов Е.В., 2008].

Изучено влияние ЭМИ на частоте атмосферного кислорода 129,0 ГГц на функциональную активность тромбоцитов белых крыс в состоянии острого иммобилизационного стресса [Сухова С.В. и др., 2007]. Отмечена полная или частичная нормализация повышенной функциональной активности тромбоцитов в зависимости от режима ТГЧ воздействия. Авторы считают, что посредниками действия ЭМИ ТГЧ в клетках и биологических жидкостях являются активные формы кислорода (АФК), которые предположительно образуются ферментативно за счет изменения гидратации белковых молекул и повышения активности циклооксигеназы, ксантиноксидазы [Поцелуева М.М., Пустовидко А.В., Евтодиенко Ю.В., 1998]. АФК, в свою очередь, за счет $\mathrm{Ca}^{2+}$ стимулируют растворимую гуанилатциклазу, что приводит к накоплению цГМФ в клетках эндотелия сосудов и повышению активности NO-синтазы, что увеличивает продукцию NO [Cooke J., 1998]. Это может быть одним из механизмов осуществления как антистрессорного, так и антиагрегационного эффектов ТГЧ - волн на частоте МСИП кислорода 129,0 ГГц [Сухова С.В., Кораблева Т.С., Бондарев А.В., 2007].

Особого внимания заслуживают результаты исследований, свидетельствующие о влиянии ЭМИ ТГЧ на различные физиологические системы человека и животных. Не вызывает сомнения тот факт, что в реализации биологических эффектов ЭМИ ТГЧ принимают участие центральная и периферическая нервные системы, а также защитнорегуляторные системы организма, к которым можно отнести, прежде всего систему гемостаза, иммунную и нейроэндокринную системы.

Проводилось исследование показателей гемодинамики белых крыс-самцов, подвергнутых острому иммобилизационному стрессу, при этом регистрировались следующие показатели: средняя линейная скорость кровотока, систолическая скорость кровотока, диастолическая скорость кровотока, градиент давления. Показано, что ТГЧ облучение животных на частотах оксида азота 150,176-150,664 ГГц в течение 15 минут, подвергнутых иммобилизационному стрессу, частично или полностью нормализует гемодинамические показатели в брюшной аорте, сонной и бедренной артериях [ Кораблева Т.С., и др. 2007]. 
Установлено, что на фоне общепринятой терапии при применении ЭМИ ТГЧ облучение на частотах оксида азота 150,176-150,664 ГГц отмечается благоприятное течение ожогового раневого процесса. Так, по данным Н.В. Островского и др. (2004) при лечении поверхностных ожогов после первого сеанса ТГЧ терапии микробная обсемененность ожогового отделяемого снизилась в сотни раз. После 2-3 сеанса у всех больных появились островки активной эпителизации раны, практически у всех больных снижалась выраженность болевого синдрома, улучшалось общее самочувствие, нормализовался режим сна, а после 5 -7 сеанса наступала полная эпителизация ожоговой раны. По мнению авторов, механизм комбинированной терагерцевой терапии на раневой процесс заключается в вазодилатации и нормализации микроциркуляторных расстройств, улучшении сосудистой трофики и тканевого обмена, усилении фагоцитоза, ингибиции свободных кислородных радикалов, прямым воздействием на пролиферацию фибробластов [Островский Н.В., Никитюк С.М., Киричук В.Ф. и др., 2004].

При локальной экспериментальной стафилококковой инфекции белых мышей положительный эффект воздействия ТГЧ волн (150,176-150,664 ГГц) проявлялся в снижении интенсивности воспалительного процесса, сокращении сроков выраженности его течения и выделения стафилококков как из очага поражения, так и регионарного лимфоузла [Шуб Г.М., Лепилин А.В., Финохина О.А. и др. 2004].

Впервые в клинической практике С.С. Паршиной, В.Ф.Киричуком, Т.В. Головачевой и др. (2004) использовано ЭМИ ТГЧ на частотах оксида азота 150,176-150,664 ГГц у здоровых добровольцах и пациентов с сердечно-сосудистой патологией. Так, в группе здоровых добровольцев во время сеанса отмечались некоторые субъективные ощущения: разнообразный дискомфорт в области шеи, чувство недостатка воздуха и жара в голове. Ни в одном случае появление вышеописанных симптомов не послужило причиной прекращения сеанса. В связи с этим авторы предполагают, что влияние ЭМИ ТГЧ на частотах оксида азота 150,176-150,664 ГГц на здоровый организм способно вызвать целый каскад физиологических и биохимических реакций, выраженность которых будет зависеть от исходного состояния организма пациента, индивидуальной функциональной особенности органов и систем.

При проведении сеансов ЭМИ ТГЧ на частотах оксида азота 150,176-150,664 ГГц у пациентов с патологией сердечно-сосудистой системы в анамнезе отмечено появление субъективных ощущений и колебаний показателей гемодинамики, аналогичных изменениям данных параметров при облучении у здоровых лиц. Вместе с тем, применение ЭМИ ТГЧ на частотах оксида азота 150,176-150,664 ГГц у пациентов с сердечнососудистой патологией в стадии ремиссии показало отсутствие серьезных осложнений и 
позволило авторам исследования перейти к следующему этапу - использованию ЭМИ ТГЧ на частотах оксида азота 150,176-150,664 ГГц у больных, находящихся на стационарном лечении по поводу ИБС: нестабильной стенокардии и гипертонической болезни. У всех больных в результате лечения отмечен выраженный антиангинальный эффект, отмечалось снижение артериального давления. Отмечено положительное действие ЭМИ ТГЧ на частотах оксида азота 150,176-150,664 ГГц на состояние системы гемокоагуляции: отмечалась нормализация времени свертывания крови и АЧТВ, снижение повышенного уровня фибриногена [Паршина С.С., Киричук В.Ф., Головачева Т.В. и др., 2004].

Авторы, делая выводы, отмечают, что ЭМИ ТГЧ на частотах оксида азота обладает мощным вазоактивным, антиангинальным и гипокоагуляционном эффектами и является эффективным методом лечения больных с патологией сердечно - сосудистой системы [Паршина С.С., Киричук В.Ф., Головачева Т.В. и др., 2004].

\section{2. Микроциркуляция и её составные компоненты}

9.2.1. Современные представления о гемореологии: понятия, факторы, ее определяющие. Роль качественного и количественного состава эритроцитов как компонента, определяющего реологические свойства крови

Нарушения в системе микроциркуляции определяются как неотъемлемое патогенетическое звено ряда патологических процессов, являясь при этом важной составляющей заболеваний различных нозологических форм [Чернух А.М., Александров П.Н., Алексеев О.В., 1975; Киричук В.Ф. и др., 1999-2009]. Расстройства микроциркуляции делят на внутрисосудистые изменения; нарушения, связанные с изменениями самих сосудов; внесосудистые изменения [Чернух А.М., Александров П.Н., Алексеев О.В., 1975].

В настоящее время общепризнанно влияние реологических свойств крови на состояние внутрисосудистого компонента микроциркуляции [Белоусов Ю.Б., 1986; Парфенов А.С., Белоусов Ю.Б., 1989; Киричук В.Ф., Воскобой И.В., 2000; Ройтман Е.В., Дементьева И.И., Азизова О.А. и др., 2000; Ройтман Е.В., 2003; Киричук В.Ф., Ребров А.П., Россошанская С.И., 2005; Глезер М.Г., Семенцов Д.П., Соболев К.Э., 2005; Помошникова О.И., 2006; Киричук В.Ф., Креницкий А.П., Майбородин А.В., Тупикин В.Д., 2006; Stols J.F., 1999].

Исследование реологических свойств крови и изучение влияния на текучесть крови сосудистой стенки служит источником ряда диагностических показателей и позволяет судить о некоторых патологических нарушениях и результатах лечебного вмешательства. В частности, они играют важную роль в патогенезе ряда заболеваний, в основе которых лежат ишемические нарушения [Киричук В.Ф., Шварц Ю.Г., 1998]. 
Нарушения в системе микроциркуляции могут привести к недостаточности кровообращения в пораженном участке, гипоксии тканей и их дистрофии [Никитина Н.М., Осипова О.В., Киричук В.Ф. и др., 1998; Ройтман Е.В., 2003; Шляхто Е.В., Моисеева O.М., Лясникова Е.А., 2004; Морозов Ю.А., Ройтман Е.В., Чарная М.А., 2004; Kirichuk V., Yudanova L., Voskoboy I., 1995; Ajmani R. S., Rifkind J.M., 1998; Lloyd-Jones D.M., Larsen M.S, 1999].

Реология - область механики, которая изучает деформационные (реологические) свойства жидкостей, газов и твердых тел, способы установления и описания этих свойств [Левтов В.А., Регирер С.А., Шадрина Н.Х., 1982]. Гемореология (реология крови) - наука, изучающая поведение крови при течении (в потоке), то есть свойства потока крови и её компонентов, а также реологию структур клеточной мембраны форменных элементов крови, прежде всего эритроцитов. Реологические свойства крови определяются вязкостью цельной крови и её плазмы, способностью эритроцитов к агрегации и деформации их мембран [Киричук В.Ф.,2005; Stols J.F., 1985-1987,1991]. Гемореология изучает изменение физических и коллоидных свойств крови в процессе циркуляции с различной скоростью и на различных отрезках сосудистого русла [Мищук И.И., 1993].

Задачей гемореологии является в том числе исследование деформации и текучести клеточных и плазматических элементов крови и их соотношения со стенками микрососудов. В этой связи, для характеристики кровотока в нормальных и патологических условиях важное значение имеет концентрация эритроцитов, взаимодействие их между собой, эластичность и форма эритроцитов, взаимодействие эритроцитов и крови в целом со стенкой микрососудов, вязкость плазмы и цельной крови [Чернух А.М., Александров П.Н., Алексеев О.В., 1975; Помошникова О.И., 2006; Киричук B.Ф., 1999, 2002, 2005; Stols J.F., 1985].

Кровообращение является сложной замкнутой системой, обеспечивающей жизнедеятельность всего организма. Закономерности, которые определяют движение жидкости в любой гидродинамической системе, несколько отличаются в системе кровообращения. Так, увеличение скорости потока зависит от величины сопротивления коронарных сосудов, чего нет в физических системах [Капелько В.И., 1996].

Скорость кровотока - один из важнейших параметров реологии крови и характеризует возможность адекватного обеспечения кислородом тканей. В реальных условиях организма скорость кровотока определяется пропульсивной способностью сердца, функциональным состоянием сосудистого русла, а также свойствами самой крови [Селезнев С.А., Назаренко Г., Зайцев В.С., 1985]. Максимальная скорость кровотока наблюдается в аорте, затем она постепенно снижается по мере перехода от артерий к 
капиллярам, где вновь происходит ее рост. Это не подчиняется физическому закону, утверждающему, что чем меньше калибр сосуда, тем больше линейная скорость [Смирнов И.Ю., Здюмаева Н.П., Дюкова А.С., 2001].

Реологические свойства крови характеризуются условиями потока, потоковыми свойствами частиц, т.е. свойствами частиц при определенных условиях потока, текучестью крови [Ройтман Е.В., 2003; Киричук В.Ф., 2005]. Условия потока - условия, при которых существует течение жидкости. Они определяются геометрией сосуда и прилагаемыми усилиями [Ройтман Е.В., 2003; Киричук В.Ф., 2005]..

Сократительная способность сердца является движущей силой течения крови. Кроме этого большое значение имеют функциональное состояние сосудов и свойства крови [Ройтман Е.В., Фирсов Н.Н., Дементьева М.Г., 2000].

Основными факторами, определяющими условия потока крови являются: диаметр сосуда и его изменения при вазоконстрикции и вазодилатации; сосудистые бифуркации и слияния; прилагаемое (движущее) давление крови (например, разница давлений на артериальном и венозном концах кровеносного сосуда); взаимодействие клеток крови, которое зависит от показателя гематокрита, скорости потока крови, близости форменных элементов к сосудистой стенке, физических свойств соседних клеток крови [Ройтман Е.В., 2003].

Скорость сдвига представляет собой меру деформации в единицу времени или градиент скорости двух смежных слоев жидкости при наличии их смещения относительно друг друга, т.е. быстроту изменения скорости перпендикулярно её направлению [Ройтман Е.В., Фирсов Н.Н., Дементьева М.Г. и др., 2000], измеряется в обратных секундах $\left(\mathrm{c}^{-1}\right)$ и означает величину градиента скорости движения между параллельно движущимися слоями жидкости на единицу расстояния между ними [Chien S., Vsami S., Skalak R., 1984].

Отношение силы, которую нужно приложить для достижения той или иной скорости сдвига, к площади называется сдвигающим напряжением или напряжением

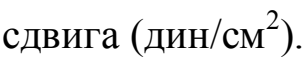

С точки зрения реологии кровь - неньютоновская вязко-упругая тиксотропная жидкость, относящаяся к концентрированным суспензиям обратимо агрегирующих частиц [Ройтман Е.В., 2003; Киричук В.Ф., 2005]. Отсюда следует, что кровь не имеет фиксированной вязкости, что обусловливается её негомогенностью за счет суспензирования в ней форменных элементов, белков, липидов и других веществ, т.е. вязкость крови зависит от величины градиента скорости кровотока. Поэтому условия кровообращения в мелких, средних и в меньшей мере в крупных сосудах зависят не только от пропульсивной деятельности сердца, но и от биофизических свойств самой 
крови, которые определяют ее текучесть. При этом текучие, или реологические, свойства крови обусловлены интегральной величиной - вязкостью [Белоусов Ю.Б., 1986, Киричук B.Ф., 2005].

Вязкость - это величина внутреннего трения, или свойство жидкости оказывать сопротивление при перемещении её слоёв [Громов А.Е., 1986; Андрейчин М.А., Толкачев В.С., Луцук А.С., 1987; Баринов В.Г., Забелин И.В., Соловьев В.В., 1989; Захарченко В.Н., 1997].

Согласно закону Ньютона, величина силы, приводящей в движение жидкость с той или иной скоростью, зависит от вязкости, площади сечения слоев жидкости, градиента скорости и описывается уравнением:

$$
\eta=\frac{\tau}{\gamma} ; \quad \text { где } \eta-\text { коэффициент, характеризующий вязкость жидкости, }
$$

именуемый также динамической вязкостью или внутренним трением [Галенок В.А., Гостинская Е.В., Диккер В.Е., 1987], измеряется в Па*с (для крови - мПа*с); $\tau$ напряжение сдвига (Па или Н/M²), т.е. тангенциальная касательная сила, приложенная к единичной площадке, которая обусловливает скольжение слоев жидкости относительно друг друга; $\gamma$ - скорость сдвига, характеризующая градиент скоростей между слоями жидкости в потоке. Таким образом, вязкость определяется коэффициентом, характеризующим сопротивление жидкости сдвигу, силу трения, возникающую между слоями жидкости, для гомогенных жидкостей пропорциональна скорости сдвига и соответствует уравнению Ньютона.

На вязкость крови влияют степень и обратимость агрегации эритроцитов, деформируемость эритроцитов, показатель гематокрита, скорость и напряжение сдвига, концентрация белков, температура и рН крови [Белоусов Ю.Б.,1986; Киричук В.Ф., 1999, 2003, 2005]. Все указанные параметры являются саморегулирующими.

Суммарный объем эритроцитов примерно в 50 раз превышает объем лейкоцитов и тромбоцитов, в связи с чем реологическое поведение крови определяет их концентрация и структурно-функциональные свойства [Кручинский Н.Г., Тепляков А.И., Гапанович В.Н. и др., 2000]. Эритроциты оказывают огромное влияние на формирование клеточного компонента вязкости крови [Андрейчин М.А., Толкачев В.С., Луцук А.С., 1987; Merril Е. W., 1969].

Ведущую роль в определении вязкости цельной крови играет соотношение плазмы и форменных элементов при течении крови в тех сосудах, где величина скоростей сдвига превышает $100 \mathrm{c}^{-1}$ [Фолков Б., Нил Э., 1976]. Отмечена прямая корреляционная связь между показателем гематокрита и вязкостью крови при низких скоростях сдвига [Ройтман 
Е. В., Дементьева И.И., Леонова С.Ф. и др., 1996; Fuchs J., Pinhas A., Davidson E. et al., 1990; Wannamethee G., Shaper A.G., Whincup P.H., 1994]. Величина стандартного гематокрита равна 45\%. Повышение показателя гематокрита приводит к увеличению вязкости крови, что вызывает снижение кровотока в сосудах с малым диаметром [Wannamethee G., Shaper A.G., Whincup P.H., 1994], уменьшение венозного возврата крови к сердцу, увеличение общего периферического сопротивления сосудов и снижение фракционного выброса крови [Gueston A.S.,Richardson T.Q., 1961].

Вязкость цельной крови зависит от скорости сдвига в диапазоне $0,1-120 \mathrm{c}^{-1}$. При скорости сдвига более $100 \mathrm{c}^{-1}$ изменения вязкости крови не столь выражены, а после достижения скорости сдвига $200 \mathrm{c}^{-1}$ вязкость крови практически не изменяется. Величину вязкости, измеренную при высокой скорости сдвига (более 120-200 c $\mathrm{c}^{-1}$ ), называют асимптотической вязкостью [Левтов R.А., Регирер C.А., Шадрина Н.Х., 1982].

Вязкость крови человека в норме составляет 4-5 мПа*с [Галенок В.А., Гостинская Е.В., Диккер В.Е., 1987], но при различной патологии может колебаться от 1,7 до 22,9 мПанс. Движение крови по большинству кровеносных сосудов здорового человека осуществляется ламинарным потоком, т.е. движение слоев и форменных элементов крови происходит параллельно [Левтов В.А., Регирер С.А., Шадрина Н.Х., 1982; Киричук В.Ф., 1999, 2002, 2005]. Основная характеристика этого вида течения - отсутствие перемешивания между соседними слоями жидкости. При различных патологических состояниях создаются условия для других типов кровотока, что требует значительно большего количества энергии и создаёт дополнительные затруднения течению крови [Белоусов Ю.Б., 1986; Ройтман Е.В., Фирсов Н.Н., Дементьева М.Г., 2000].

Турбулентность, то есть беспорядочное, вихревое движение в физиологических условиях возможна лишь в начале аорты и в местах ветвления крупных артериальных сосудов. Это течение сопровождается хаотическим перемешиванием между слоями (турбулентное перемешивание). Так, например, при стенозе сосуда ниже места окклюзии возникают «завихрения», зоны медленного круговорота и застоя, что является одним из условий оседания форменных элементов и развития тромбоза [Разумов В.Б., Белоусов Ю.Б, 1977; Chien S., King R.G., Schuessler G.B. et al., 1978]. Турбулентный тип кровотока нередко наблюдается в сосудах среднего и мелкого калибра, возникновение его в большей степени зависит от состояния агрегационной способности эритроцитов [Левтов В.А., Регирер С.А., Шадрина Н.Х., 1982; Ройтман Е.В., Фирсов Н.Н., Дементьева М.Г., 2000; Taylor D.E.M., 1981].

Если в системе макроциркуляции роль реологических свойств крови (в частности деформируемости и агрегации эритроцитов) невелика, то в мелких сосудах 
микроциркуляции они приобретают первостепенное значение в областях перераспределения крови, артериальных сужениях. Нарушение данных свойств крови приводит к повышению местного напряжения сдвига и вязкости крови, что в дальнейшем может послужить причиной травматического повреждения эндотелия и даже разрушения тромбоцитов [Катюхин Л.Н., 1995; Катюхин Л.Н., Ганелина Н.Е., Олесин А.И., Карабанова Э.П., 1996; Sheludko N.S., Kropacheva I.V., 1996].

Увеличение вязкости крови при низких скоростях и напряжении сдвига (менее $10 \mathrm{c}^{-1}$ ), при искусственном моделировании кровотока в вискозиметрах различного типа, наблюдаемого в основном в венулах, артериолах и капиллярах, определяет неньютоновское поведение цельной крови и в большей степени определяется агрегацией эритроцитов [Левтов В.А., Регирер С.А., Шадрина Н.Х., 1982; Никитина Н.М., 1998; Ройтман Е.В., Фирсов Н.Н., Дементьева М.Г., 2000; Ройтман Е.В., 2003; Киричук В.Ф., Андронов Е.В., Майбородин А.В. и др., 2004; Киричук В.Ф., Ребров А.П., Россошанская С.И., 2005; Россошанская С.И., 2005; Goldstone J., Schmid-Schönbein M., Wells R., 1970; Schmid-Shonbein M., Gallasch G., Gsoen J. et al., 1976; Dintenfass L., 1979; Samsel R.W., 1984; Gaspar-Rosas A., Thurston G., 1988; Chen S., Gavish B., Zhang S. et al. 1995; Bertoluzzo S.M., Bollini A., Rasia M. et al., 1999; Meiselman P., 1999].

Эритроцитам, в силу их большого объёмного и количественного содержания в крови, принадлежит ведущая роль в формировании клеточного компонента вязкости крови [Помошникова О.И., 2006; Merrill E,W.,1969]. Гематокрит, или объёмная концентрация эритроцитов, практически полностью определяет значение вязкости крови у здоровых лиц [Цюрюпович В.П., 1979]. Имеются данные о влиянии изменения вязкости крови на транскрипцию генов альбуминов и аполипопротенинов клетками печени, вызывающие ответную продукцию эритропоэтина клетками юкстагломерулярного аппарата [Reinhart W.H., 1995].

Гемоконцентрация влияет не только на вязкость крови, но и на микрореологические свойства эритроцитов. При её увеличении возрастает скорость агрегации эритроцитов, уменьшается прочность эритроцитарных агрегатов, причём гематокритное число возрастает, если деформируемость эритроцитов снижается [Цюрюпович В.П., 1979].

Агрегация эритроцитов - их способность создавать в цельной крови или модельной среде «монетные столбики» и их трехмерные конгломераты и цепи [Ройтман Е.В., 2003; Киричук В.Ф., 1999, 2003, 2005]. Агрегация эритроцитов зависит от условий кровотока, от времени, состояния и состава крови и плазмы, непосредственной близости прочих эритроцитов и других факторов [Селезнев С.А, Назаренко Г.И., Зайцев В.С., 1985]. 
Агрегацию эритроцитов при низких скоростях сдвига считают процессом исключительно физиологическим [Захаров Ю.М., 1998]. Физиологическая агрегация эритроцитов процесс обратимый. В здоровом организме непрерывно происходит динамический процесс “агрегация - дезагрегация”, и дезагрегация доминирует над агрегацией. При увеличении градиента скорости сдвига число агрегатов в крови постепенно уменьшается и при определенной скорости сдвига наступает полная дезагрегация [Селезнев С.А., Назаренко Г.И., Зайцев В.С., 1985; Моисеев С.И., Константинов И.В., Левыкина И.Г., 1991]. Для крови здоровых людей скорость сдвига, при которой разрушаются все крупные агрегаты эритроцитов и остаются лишь глыбки клеток не более 15 мкм в диаметре, равна примерно $46 \mathrm{c}^{-1}$ [Левтов В.А., Регирер С.А., Шадрина Н.Х., 1982]. Однако некоторые исследователи полагают, что в сосудах конъюктивы агрегация эритроцитов является процессом патологическим [Knisely M.N., Hamilton W.F., Dow P., 1965].

Агрегация эритроцитов, в основном, зависит от следующих факторов: 1) ионного состава среды: при повышении общего осмотического давления плазмы эритроциты сморщиваются и утрачивают способность к агрегации; 2) поверхностно-активных веществ, изменяющих поверхностный заряд, и их влияние может быть различным; 3) концентрации фибриногена и иммуноглобулинов; 4) контакта с инородными поверхностями, как правило, сопровождаемое нарушением нормальной агрегации эритроцитов [Киричук В.Ф., 1999, 2002, 2005].

Основная причина феномена агрегации эритроцитов - это существование силы адгезии между клетками. Общепринята молекулярная мостиковая теория формирования монетных столбиков в результате абсорбции макромолекул к поверхности клетки. Механизм агрегации эритроцитов в основном сводится к устранению поверхностного отрицательного заряда и образование фибринового мостика, когда высокомолекулярные соединения своими концами адсорбируются на соседних эритроцитах, образуя «мостикисшивки». Это приводит к сближению клеток друг с другом и появлению одно- или полимерных агрегатов («монетных столбиков»), выдерживающих большое напряжение [Киричук В.Ф., 1999, 2002, 2005; Schmid - Schöenbein H., Wells R.E., 1971].

Абсорбция отрицательно заряженных плазменных белков и нейтральных полимеров к поверхности эритроцитов осуществляется благодаря Ван-дер-Вальсовым или гидрогенным связям, которые значительно менее прочные, чем электростатические или ковалентные [Киричук В.Ф., Свистунов А.А., Глыбочко П.В., 1998]. Прочность агрегатов прямо пропорциональна концентрации фибриногена или его дериватов (высокомолекулярные растворимые комплексные соединения, ранние продукты плазминовой деградации фибрина), т.е. высокомолекулярных агентов [Смирнов И.Ю., 
Левин B.H., 2004; Gana-Pathyraman L., Shanthi P., Bada-Krishnan K. et al., 1996; Meiselman P., 1999]. Другие макромолекулярные белки плазмы, например, иммуноглобулины, альфа2-макроглобулины также способствуют агрегации эритроцитов, но играют незначительную роль в этом процессе [Schmid-Schonbein M., Volger E., 1976].

На агрегацию эритроцитов значительное влияние оказывают их физикохимические свойства. По данным А.Л. Чижевского (1951) эритроцит окружен двойным электрическим слоем. Нормальные эритроциты электронегативны, с чем связано их отталкивание даже в состоянии стаза крови. Плотность отрицательно заряженных групп на поверхности эритроцита в норме образует единое электроотрицательное облако, которое способно притягивать к себе из окружающей среды, положительно заряженные ионы.

О функциональном состоянии клеток крови можно судить по их электрическому заряду или косвенно по Z-потенциалу, который обеспечивает ориентацию клетки в потоке и суспензионную стабильность крови. В частности обнаружено, что уменьшение величины Z-потенциала у больных ИБС (по сравнению со здоровыми людьми) предшествует агрегации эритроцитов [Токалев Г.М., Китаева Н.Д., Столяр Г.М., Шабанов В.А., 1977]. В формировании заряда клетки большую роль играет рН-среды. Исследования показали, что при смещении рН в кислую сторону Z-потенциал снижается, а в щелочную - возрастает [Токалев Г.М., Китаева Н.Д., Столяр Г.М., Шабанов В.А., 1977; Киричук В.Ф. и др. 2002, 2003, 2005].

Рядом авторов доказано, что существуют факторы, препятствующие процессу агрегации эритроцитов: инсулин, фруктозо-1,6-дифосфат, глюкозо-6-фосфат [Галенок В.А., Гостинская Е.В., Диккер В.Е., 1987], глицеральдегиддегидрогеназа [Лакин К.М., Овнатанова М.С., 1979], низкомолекулярные декстраны [Чернух А.М., Александров П.Н., Алексеев О.В., 1984], карнитин и дериваты ацилкарнитина [Ramsohoye P., Fritz I.B., 1995], NO - доноры и простациклин [Starzik D., 1999].

Эритроциты имеют тенденцию мигрировать к оси сосуда, где располагается слой крови богатый плазмой и с малым содержанием форменных элементов, а, следовательно, с более низкой вязкостью [Goldsmith H.L., Cokelet G., Gaehtgens P. Robin., 1989; Cokelet G.R., Goldsmith H.L., 1991]. Степень эритроцитарного осевого перемещения обусловливается их тенденцией к агрегации и, наоборот, стремление к агрегации увеличивает осевое перемещение эритроцитов [Davis M.E., Cai H. Drummond G.R., Harrison D.G., 2001] и, при соответствующих условиях, уменьшает сопротивление потока [Laughlin M.H., Pollock J.S., Amann J.F., 2001]. M. Soutani et al. (1995) установили взаимосвязь между агрегацией эритроцитов и толщиной кровяного слоя в условиях in 
vivo в опыте с сосудами брызжейки кролика. Показано, что увеличение слоя бедного форменными элементами уменьшает величину периферического сопротивление потока крови в капиллярной сети [Soutani M., Suzuki Y., Tateishi N., Maeda N., 1995]. Однако необходимо отметить, что механизмы влияния агрегации эритроцитов на показатели гемодинамики очень сложны и зависят от множества факторов, в частности, ориентации кровеносных сосудов против градиента силы тяжести [Johnson L.R., Rush J.W., Turk J.R., et al., 2001] и времени прохождения крови через данный участок сосуда [Bishop J.J., Popel A.S., Intaglietta M., Johnson P.C., 2001].

Сила гидродинамической дезагрегации является одной из главных, препятствующих агрегации эритроцитов. Она определяется величиной напряжения сдвига в реальных условиях кровотока или при моделировании этих условий [Stoltz J.F., Donner М., 1991]. Нарушение гемодинамики происходит лишь в том случае, если сила агрегации эритроцитов больше, чем дезагрегирующая гидродинамическая сила потока крови, и скорость процесса агрегации быстрее, чем время, необходимое для пассажа крови через венулы [Шмид-Шонбейн Г., 1982].

В капиллярном русле огромное значение имеет ряд феноменов. Согласно феномену Fahreus-Lindquist (1924), при уменьшении радиуса сосудов происходит падение вязкости крови, связанное с появлением участков бесклеточной плазмы и аксиальным током эритроцитов. Однако при критическом радиусе капилляра, близком к диаметру эритроцита, вязкость резко возрастает (обратный эффект), что обусловлено внутренней вязкостью эритроцита и способностью его к деформации. Феномен «скользящей плазмы» связан, возможно, с механизмом регуляции гемоконцентрации в системе микроциркуляции.

В реальных условиях кровотока имеется достаточно высокий уровень “напряжения” сдвига, препятствующий образованию эритроцитарных агрегатов почти на всех участках микроциркуляции, за исключением посткапиллярных венул [SchmidSchonbein G., Gallasch G., Gsoen J. et al., 1976]. Таким образом, основное значение для оценки реологических свойств крови на уровне микроциркуляции имеет не только агрегация, но и деформируемость эритроцитов.

Деформируемость эритроцитов - их способность деформироваться в сдвиговом потоке при прохождении через капилляры и поры, способность к плотной упаковке [Ройтман Е.В., 2003; Киричук В.Ф., 2005]. Деформируемость эритроцитов самый лабильный показатель из всех гемореологических свойств. Деформационный индекс эритроцитов изменяется даже по ходу круга кровообращения, т.е. его величина может 
быть разной в артериальной и венозной крови. На нем отражаются нарушения любого метаболического процесса [Sakuta S., Tacamats S. et al., 1982].

Основными факторами, от которых зависит деформируемость эритроцитов, являются 1) осмотическое давление окружающей среды (плазмы крови); 2) соотношение внутриклеточного кальция и магния, концентрация АТФ; 3) продолжительность и интенсивность приложенных к эритроциту внешних воздейсвий (механических и химических), меняющих липидный состав мембраны или нарушающий структуру спектриновой сети; 4) состояние цитоскелета эритроцита, в состав которого входит спектрин; 5) вязкость внутриклеточного содержимого эритроцитов в зависимости от концентрации и свойств гемоглобина [Киричук В.Ф., 1999, 2002, 2005].

Эритроцит может подвергаться различным видам деформации своей конструкции (кручение, изгиб, растяжение-сжатие и т.д.) [Ройтман Е.В., Фирсов Н.Н., Дементьева М.Г., 2000]. Эластические свойства мембраны характеризуют ее сопротивление статической деформации. Все типы эластических деформаций мембраны эритроцита имеют общую молекулярную основу, так как зависят от поверхностной плотности мембранного белка спектрина [Whitmore R.Z., 1968]. Спектрин составляет примерно 75\% всей массы белка цитоскелета. Функция спектрина заключается в контролировании формы и деформируемости клетки, её вязкоэластичности и распределении поверхностных антигенов [Branton D., Cohen C.M., Tyler J., 1981].

Пластическое поведение мембраны определяется следующими независимыми деформациями: 1) удлинение или сдвиг мембраны без увеличения площади поверхности или ее изгиба; 2) изотропное растяжение поверхности мембраны без её сдвига или изгиба; 3) изгиб мембраны без сдвига или расширения [Левтов В.А., Регирер С.А., Шадрина Н.Х., 1982; Stolz J.F., 1985; Chien S., Dormandy J., Ernst E. et al.,1987]. Каждая из этих эластических деформаций характеризуется модулями эластичности: упругим модулем сдвига, модулем поверхностной растяжимости и модулем изгиба. Чем больше модуль, тем более значительное сопротивление оказывает структура данному типу деформации [Катюхин Л.Н., 1995].

Эритроциты способны противостоять значительной по величине сдвиговой деформации, возникающей в крупных сосудах, благодаря стабильности их мембран. При больших усилиях сдвига, например, в аорте, может произойти фрагментация мембран эритроцитов. Стабильность и деформируемость мембран эритроцита в основном зависит от жесткости белковой сети цитоскелета [Сторожок С.А., Санников А.Г., Белкин А.В., 2000; Bennet V., 1989]. Этот механизм необходим для прохождения эритроцита через сосуды, диаметр которых соизмерим с размерами самой клетки, а также создаёт 
возможность механической стойкости по отношению к различным сдвиговым напряжениям, возникающим в окружающей эритроцит среде [Шабанов В.А., Левин Г.Я., Терехина Е.В., 1997; Поворинская Т.Э., Ионова В.Г., Варакин Ю.Я. и др., 2000].

Нарушение деформируемости эритроцита обусловлено увеличением жесткости мембраны вследствие накопления в ней холестерина, отложением на её поверхности крупномолекулярных белков (дериваты фибриногена, иммуноглобулины, парапротены), повышением содержание натрия и воды в клетке и приводит к нарушению продвижения эритроцита по капилляру [Fuchs J., Pinhas A., Davidson E et al., 1990].

Существенное влияние на вязкость крови оказывает вязкость плазмы, которая, в свою очередь, зависит от температуры, белкового и липидного состава. Плазма крови является ньютоновской жидкостью. Большие плазменные белки, такие как фибриноген, фибронектин, фактор Виллебранда и макроглобулины (особенно, $\gamma$-глобулины), играют существенную роль в определении величины вязкости плазмы [Карпов В.Л., 1984].

Самое существенное влияние на величину вязкости плазмы оказывает фибриноген, несмотря на его низкую концентрацию в ней [Шмид-Шонбейн Г., 1982; Никитина Н.М., Киричук В.Ф., Юданова Л.С., 2000]. Это подтверждается известным фактом, что вязкость плазмы на 20\% выше вязкости сыворотки. По мнению некоторых исследователей более важным фактором, ведущим к изменению вязкости плазмы, является не абсолютное количество белков, а их соотношения: альбумин/глобулины, альбумин/фибриноген [Dormandy J., 1974; Dintenfass L., 1979]. Взаимодействие этих белков и клеток крови вызывает агрегацию эритроцитов при низком коэффициенте трения («монетные столбики»).

Доказано, что вязкость мембраны эритроцита существенно зависит от концентрации гемоглобина внутри клетки. Его концентрация в эритроците достигает 32 мг\%. Изменение концентрации гемоглобина в эритроците приводит к нарушению реологических свойств эритроцитов в силу того, что гемоглобин взаимодействует с мембраной эритроцитов и влияет на его деформируемость [Baker R.F., Clark L.J.,1983]. Вязкость внутри эритроцита зависит от конформации молекул гемоглобина [Murphy J.R., 1967]. Увеличение концентрации гемоглобина приводит к ухудшению реологических свойств эритроцитов за счёт взаимодействия с некоторыми компонентами мембран эритроцитов [Baker R.F.,1983].

Необходимо отметить, что вязкость крови - довольно лабильный показатель и в физиологических условиях может изменяться в довольно больших пределах. Описаны изменения реологических свойств при физической нагрузке, стрессовых ситуациях, 
изменениях атмосферного давления, смене сезона и т.д. [Мурашко В.В. и соавт, 1985; Китура Е.М., 1986; Киричук В.Ф. и др., 1999, 2002,2005].

Таким образом, основными факторами, которые определяют вязкость цельной крови являются: 1) агрегация и деформируемость эритроцитов; 2) величина гематокрита повышение показателя, как правило сопровождается увеличением вязкости крови; 3) концентрация фибриногена, растворимых комплексов фибринмономера и продуктов деградации фибрина/фибриногена - повышение их содержания в крови увеличивает её вязкость; 4) соотношение альбумин/фибриноген и соотношение альбумин/глобулин снижение данных соотношений сопровождается повышением вязкости крови; 5) содержание циркулирующих иммунных комплексов - при повышении их уровня в крови вязкость возрастает; 6) геометрия сосудистого русла [Киричук В.Ф., 2005].

Хорошо известно, что у здоровых людей эндотелиальная стенка сосудов антитромбогенна, обладает высокой антиагрегационной, антикоагулянтной и фибринолитической активностью, обусловленной синтезом эндотелиальными клетками простациклина, оксида азота и других естественных антиагрегантов, антитромбина III (АТIII) и активаторов плазминогена [Балуда В.П., Балуда М.В., Деянов И.И., 1995; Киричук В.Ф., 1999, 2002, 2005]. Эндотелий - место образования ряда факторов релаксации, в частности, NO, эндотелиального фактора гиперполяризации, простациклина, а также констрикторных агентов (эндотелинов, простаноидов и т.д.) [Vanhoutte P.M., 1993, 1997]. Считается, что баланс между факторами релаксации и констрикции определяет релаксацию сосудов и соответственно величину местного кровотока [Киричук В.Ф., Ребров А.П., Россошанская С.И., 2005], являясь одним из факторов, определяющих вязкость крови [Киричук В.Ф., 2005]. 


\section{ГЛАВА Х}

\section{ВЛИЯНИЕ ЭЛЕКТРОМАГНИТНОГО ИЗЛУЧЕНИЯ ТЕРАГЕРЦЕВОГО ДИАПАЗОНА НА ЧАСТОТАХ МОЛЕКУЛЯРНОГО СПЕКТРА ИЗЛУЧЕНИЯ И ПОГЛОЩЕНИЯ ОКСИДА АЗОТА 150,176-150,664 ГГЦ НА РЕОЛОГИЧЕСКИЕ СВОЙСТВА КРОВИ У БЕЛЫХ КРЫС В УСЛОВИЯХ СТРЕССА}

10.1. Изменения реологических свойств крови у белых крыс-самцов при остром и хроническом иммобилизационном стрессе и применение электромагнитного облучения на частотах молекулярного спектра излучения и поглощения оксида азота 150,176-150,664 ГГц различных временных режимов для их коррекции

10.1.1. Изменения реологических свойств крови у белых крыс-самцов при остром иммобилизационном стрессе

В настоящее время общепризнано, что стресс-реакции организма лежат в основе формирования различных патологических состояний, в том числе заболеваний сердечнососудистой системы [Парфенов А.С., Белоусов Ю.Б., 1989; Киричук В.Ф., Ребров А.П., Россошанская С.И., 2005; Киричук В.Ф., Креницкий А.П., Майбородин А.В. и др., 2006; Головачёва Т.В., Киричук В.Ф., Паршина С.С. и др., 2006]. Реологические свойства крови, в свою очередь, являются неотъемлемым компонентом возникающих при этом ишемических нарушений [Белоусов Ю.Б., 1986; Парфенов А.С., Белоусов Ю.Б., 1989; Киричук В.Ф., Воскобой И.В., 2000; Ройтман Е.В., 2003; Киричук В.Ф., Ребров А.П., Россошанская С.И., 2005; Глезер М.Г., Семенцов Д.П., Соболев К.Э., 2005].

Микроциркуляторные расстройства могут привести к недостаточности кровообращения в пораженном участке, гипоксии тканей и их дистрофии [Никитина Н.М., Осипова О.В., Киричук В.Ф. и др., 1998; Ройтман Е.В., 2003; Шляхто Е.В., Моисеева О.М., Лясникова Е.А., 2004; Морозов Ю.А., Ройтман Е.В., Чарная М.А., 2004; Kirichuk V., Yudanova L., Voskoboy I., 1995; Lloyd-Jones D.M., Larsen M.S., 1996; Ajmani R. S., Rifkind J.M., 1998].

Для установления степени воздействия острого и хронического вариантов иммобилизационного стресса на показатели гемореологии, в том числе на функциональные параметры эритроцитов -- их агрегационную способность и деформируемость, были последовательно исследованы показатели вязкости цельной крови при скоростях сдвига от $300 \mathrm{c}^{-1}$ до $5 \mathrm{c}^{-1}$ с расчётом индексов агрегации (ИАЭ) и деформируемости (ИДЭ) эритроцитов. Это даёт чёткое и полное представление о состоянии реологических свойств крови в сосудах различного калибра (от крупных, 
средних, малых артерий до сосудов микроциркуляторного русла) и соответствует современным требованиям методологии исследования вязкости крови согласно Ярославскому соглашению (Ярославль, 2003).

В результате проведённых исследований обнаружено статистически достоверное увеличение вязкости цельной крови при всех исследуемых скоростях сдвига после проведения однократной 3 -х часовой иммобилизации по сравнению с группой контроля у крыс-самцов, что свидетельствует о наличии стресс-зависимых сдвигов в показателях вязкости крови животных. Индексы агрегации и деформируемости эритроцитов у животных, подвергнутых острому иммобилизационному стрессу, статистически достоверно отличаются от показателей группы контроля. В группе стрессированных животных способность эритроцитов к агрегации и деформируемости увеличена. Об этом свидетельствует статистически достоверное увеличение индекса агрегации эритроцитов до 1,45 усл.ед. и увеличение индекса деформируемости мембран эритроцитов до 1,09 усл.ед. по сравнению с данными группы контроля, в которой эти показатели равны 1,33 и 1,05 усл.ед. соответственно.

Известно, что изменения деформируемости и агрегации эритроцитов значительно ухудшают реологические свойства крови и в значительной мере влияют на показатели вязкости, особенно при малых скоростях сдвига, характерных для сосудов микроциркуляции.

Таким образом, представленные данные свидетельствуют о том, что для животных, подвергнутых острому стрессу характерно нарушение реологических свойств крови - повышение вязкости крови на всех исследуемых скоростях сдвига, характеризующих кровоток в сосудах крупного, среднего и малого калибра (сосуды микроциркуляции) [Ройтман Е.В., 2000,2003], нарушение функциональной активности эритроцитов - увеличение их агрегационной способности и деформируемости по сравнению с группой контроля.

10.1.2. Изменения реологических свойств крови у белых крыс-самцов при хроническом иммобилизационном стрессе

Для исследования влияния длительного стресса на показатели вязкости цельной крови использовалась 5-ти дневная 3-х часовая иммобилизация животных, что в значительной мере отягощало их общее состояние, меняла поведенческие реакции и приводила к ухудшению показателей реологии крови.

На вторые - пятые сутки эксперимента после окончания 3-х часовой фиксации у этих животных отмечалось агрессивное поведение: в клетке они принимали вертикальную стойку в «позе боксёра» с поджатыми к туловищу верхними лапками, становились 
тревожными, нападали на друг на друга, слабый раздражитель из вне вызывал бурную ответную реакцию. Животные отказывались от пищи и воды, теряли в весе. Некоторые из них, напротив, выглядели вялыми, апатичными, слабо реагировали на внешние раздражители, и около $10 \%$ от общего количества животных не доживали до конца эксперимента.

Вязкость крови при длительном иммобилизационном стрессе увеличивалась более значительно, чем при остром: от 2,4 мПа*с в контрольной группе до 3,4 мПа*с в группе хронического стресса при скоростях сдвига $300 \mathrm{c}^{-1}$ и $200 \mathrm{c}^{-1}$ и в $13 \%$ случаев достигала 3,7 мПанс. В сосудах микроциркуляции после длительной иммобилизации отмечалось более выраженное ухудшение вязкостных свойств крови, чем при 3-х часовой: от 3,37 мПа*с в норме до 5,58 мПа сс при скорости сдвига $20 \mathrm{c}^{-1}$, от 3,74 мПа*с в норме до 6,83 мПа*с при скорости сдвига $10 \mathrm{c}^{-1}$ и от 4,2 мПа $*$ в норме до 8,67 мПа $*$ при скорости сдвига $5 \mathrm{c}^{-1}$ в группе хронического стресса. В 20,3\% случаев при скорости сдвига $5 \mathrm{c}^{-1}$ вязкость увеличивалась до 10,1-11,1 мПа*с, что являлось критическим состоянием, приводящим к возникновению тромбозов в сосудах микроциркуляции.

Индексы агрегации и деформируемости эритроцитов у животных, подвергнутых длительному иммобилизационному стрессу, в значительной степени увеличиваются по сравнению с группой контроля. В этой группе животных способность эритроцитов к агрегации существенно не отличается от группы животных, подвергнутых острому стрессу. Однако деформируемость эритроцитов увеличивается на 8\% по сравнению с группой острого стресса, что свидетельствует о дальнейшем ухудшении реологических свойств крови.

Таким образом, на основании анализа результатов вязкости крови при хроническом стрессе можно сделать вывод о дальнейшем ухудшении показателей гемореологии у животных, подвергнутых длительному воздействию стрессора. Это проявляется в увеличении вязкости крови при последовательном исследовании её на всех скоростях сдвига - от высоких до малых по сравнению с аналогичными показателями не только группы контроля, но и при остром стрессе. Особенно обращают на себя внимание такие показатели микроциркуляции, как агрегация и деформируемость эритроцитов, которые ухудшаются в большей степени, что является важным критерием оценки вязкостных свойств крови в целом [Киричук В.Ф. и соавт. 2003,2006]. 


\subsection{3. Влияние непрерывного облучения электромагнитными волнами}

молекулярного спектра излучения и поглощения оксида азота 150,176-150,664 ГГц в течение 30-ти минут на вязкость цельной крови и функциональные свойства эритроцитов у интактных крыс-самцов

Для изучения безопасности воздействия терагерцевыми волнами на частотах МСИП оксида азота 150,176-150,664 ГГц на реологию крови было проведено непрерывное облучение в течение 30 минут интактных крыс-самцов.

Установлено, что воздействие терагерцевых волн на частотах МСИП оксида азота 150,-150,776 ГГц не вызывает изменений вязкости крови при всех скоростях сдвига и не влияет на функциональную активность эритроцитов - способность их к агрегации и деформируемости. Об этом свидетельствует отсутствие статистической достоверности между показателями реологии крови группы контроля и группой сравнения, в которой животные подвергались 30-ти минутному облучению волнами указанного диапазона частот.

Комментируя данный эксперимент, необходимо пояснить, что крысы-самцы являются интактными условно в силу понятных причин, так как они, как и другие животные, подвергались фиксации. Но, вероятно, в данном случае происходит компенсированная (слабая) стресс-реакция, и в ответ на слабый раздражитель активируются ауторегуляторные механизмы - стресс-лимитирующие системы [Малышев И.Ю., Манухина Е.Б., 1998; Манухина Е.Б., Малышев И.Ю., 2000], которые способствуют сохранению вязкостных свойств крови и обеспечению нормальной функциональной активности эритроцитов.

Таким образом, данное наблюдение показывает отсутствие влияния ТГЧ облучения на частотах МСИП оксида азота 150, 176-150,664 ГГц на вязкостные свойства крови и функциональную активность эритроцитов (агрегацию, деформируемость) у интактных здоровых крыс-самцов, что согласуется с данными других авторов об отсутствии влияния на организм здорового человека и животных волн миллиметрового и субмиллиметрового диапазона частот [Бецкий О.В., Лебедева Н.Н., 1991; Киричук В.Ф. и др., 2001, 2006].

10.1.4. Изменения вязкости крови и функциональной активности эритроцитов у белых крыс-самцов в состоянии острого иммобилизационного стресса при непрерывном воздействии терагерцевых волн на частотах молекулярного спектра излучения и поглощения оксида азота 150,176-150,664 ГГц

Для изучения влияния волн терагерцевого диапазона частот оксида азота 150,176150,664 ГГц на вязкостные свойства крови и функциональную активность эритроцитов (агрегацию, деформируемость) была проведена серия экспериментов, в которых белые 
крысы-самцы подвергались непрерывному ТГЧ-облучению после однократной 3-х часовой иммобилизации (острый стресс). Продолжительность облучения составляла 5,15 и 30 минут.

При исследовании непрерывного влияния 5-ти минутного режима облучения установлено, что воздействие электромагнитными волнами ТГЧ диапазона на частотах МСИП оксида азота 150,176-150,664 ГГц на стрессированных животных не вызывает выраженного влияния как на вязкость цельной крови, так и функциональную активность эритроцитов - их агрегацию и деформируемость. На это указывает отсутствие статистически достоверных различий вязкости крови на всех исследуемых скоростях сдвига и показателей функциональной активности эритроцитов опытной группы с 5-ти минутным облучением на фоне острого стресса с показателями группы острого стресса и наличие статистически достоверных различий высокой степени достоверности по сравнению с группой контроля.

Изучение влияния 15 минутного режима облучения волнами МСИП оксида азота 150,176-150,664 ГГц на животных, подвергнутых острому иммобилизационному стрессу, показало полное восстановление вязкости крови до уровня, характерного для животных контрольной группы, на всех исследуемых скоростях сдвига, характеризующих кровоток в сосудах крупного, среднего и малого калибра (сосуды микроциркуляции) [Ройтман Е.В., 2000,2003]. Об этом свидетельствует отсутствие статистически достоверных отличий показателей опытной группы острого стресса с 15-ти минутным облучением по сравнению с показателями группы контроля и наличие высокой степени достоверности показателей по сравнению с аналогичными группы острого стресса. Исследование функциональной активности эритроцитов - агрегации и деформируемости также указывает на полное восстановление их функций под воздействием 15-ти минутного облучения электромагнитными волнами исследуемого диапазона частот. Это подтверждается отсутствием статистически достоверных различий между показателями агрегации и деформируемости эритроцитов опытной группы животных и группы контроля, а также наличием статистически достоверных различий по сравнению с группой острого стресса.

При исследовании влияния облучения электромагнитными волнами терагерцевого диапазона МСИП оксида азота 150,176-150,664 ГГц в течение 30-ти минут на вязкостные свойства крови стрессированных животных показано полное восстановление вязкости крови при больших, средних и малых скоростях сдвига. Об этом свидетельствуют отсутствие статистически достоверных различий показателей вязкости крови на всех исследуемых скоростях сдвига опытной группы с 30-ти минутным облучением и группы 
контроля и наличие статистически достоверных различий высокой степени достоверности по сравнению с группой острого стресса.

Воздействие 30-ти минутного режима облучения электромагнитными волнами указанного диапазона частот способствует восстановлению функциональных свойств эритроцитов, что в существенной мере положительно влияет на гемореологическую картину крови в целом [Киричук В.Ф. и соавт. 2003, 2006]. Об этом свидетельствует отсутствие статистически достоверных различий между показателями контрольной группы животных и опытной группы с 30-ти минутным облучением, а также наличие статистически достоверных отличий между опытной группой крыс-самцов и группой острого стресса.

Таким образом, при анализе результатов проведённого исследования, можно сделать следующие выводы: 1) облучение электромагнитными волнами терагерцевого диапазона частот МСИП оксида азота 150,176-150,664 ГГц способно восстанавливать в зависимости от временных режимов воздействия острые стресс-зависимые нарушения вязкости крови и функциональной активности эритроцитов - их деформируемость и агрегацию; 2) 5-ти минутное воздействие электромагнитными волнами указанного диапазона частот на фоне острого стресса не оказывает выраженного восстановительного эффекта нарушенной острым стрессом вязкости крови и функциональной активности эритроцитов; 3) 15-ти и 30-ти минутные режимы воздействия электромагнитными терагерцевыми волнами ТГЧ диапазона оксида азота 150,176-150,664 ГГц эффективны и полностью восстанавливают стресс-зависимых нарушения вязкости крови и функциональной активности эритроцитов - агрегации и деформитуемости..

10.1.5. Вязкость крови и функциональная активность эритроцитов у бельх крыс-самцов в состоянии длительного (хронического) иммобилизационного стресса при непрерывном воздействии терагерцевых волн на частотах молекулярного спектра излучения и поглощения оксида азота 150,176-150,664 ГГц

Для выявления эффекта влияния волн терагерцевого диапазона на частотах МСИП оксида азота 150,176-150,664 ГГц на нарушенные вязкостные свойства крови была применена модель длительного (хронического) стресса, для которой характерно дальнейшее ухудшение показателей гемореологии: вязкости крови и функциональной активности эритроцитов. Продолжительность облучения составляла 5, 15 и 30 минут.

При исследовании непрерывного влияния 5-ти минутного режима облучения электромагнитными волнами ТГЧ диапазона на частотах МСИП оксида азота 150,176150,664 ГГц на животных, подвергнутых хроническому стрессу, установлено, что воздействие ЭМИ указанного диапазона частот не вызывает выраженного 
положительного влияния на вязкость цельной крови, но изменяет её реологическую картину. На это указывает отсутствие статистически достоверных различий показателей вязкости крови на скоростях сдвига $300,200,150,50 \mathrm{c}^{-1}$ опытной группы с 5-ти минутным облучением на фоне хронического стресса по сравнению с показателями группы хронического стресса и наличие статистически достоверных различий высокой степени достоверности по сравнению с группой контроля. Исследование вязкости крови при скоростях сдвига $100,20,10$ и $5 \mathrm{c}^{-1}$ показало статистически достоверные отличия между показателями опытной группы хронического стресса с 5-ти минутным облучением и группой животных, подвергнутых хроническому стрессу, а также контрольной группой. Однако наличие статистической достоверности высокой степени между показателями опытной группы с 5-ти минутным облучением на фоне хронического стресса и группой контроля позволяет считать данный режим не эффективным.

Изучение влияния 5-ти минутного режима облучения электромагнитными волнами терагерцевого диапазона на частотах МСИП оксида азота 150,176-150,664 ГГц на функциональную активность эритроцитов - их агрегацию и деформируемость показало неэффективность указанного режима в восстановлении нарушенной агрегационной способности эритроцитов. Об этом свидетельствует отсутствие статистически достоверных отличий индекса агрегации эритроцитов опытной группы 5-ти минутного облучения и группы хронического стресса,

но наличие статистической достоверности высокой степени по сравнению с показателем группы контроля.

Деформируемость эритроцитов под воздействием 5-ти минутного режима облучения не восстанавливается, так как индекс деформируемости эритроцитов опытной группы и группы контроля имеют статистически достоверные отличия высокой степени при одновременном статистически достоверном отличии опытной группы 5-ти минутного режима облучения и группы хронического стресса.

При исследовании влияния 15-ти минутного режима облучения на животных, подвергнутых длительному стрессу, волнами ТГЧ диапазона оксида азота 150,176-150,664 ГГц установлено, что при этом режиме облучения полностью не восстанавливаются нарушенные вязкостные свойства крови. Об этом свидетельствуют статистически достоверные различия данных группы контроля и группы животных с 15ти минутным облучением на всех исследуемых скоростях сдвига. Однако они выражены в меньшей степени, чем у группы с 5-ти минутным облучением, что свидетельствует о более выраженном положительном влиянии терагерцевых волн на частотах МСИП оксида азота 150,176-150,664 ГГц на вязкостные свойства крови при длительной стресс-реакции. 
Об этом свидетельствует также наличие статистической достоверности высокой степени показателей вязкости крови на всех исследуемых скоростях сдвига опытной группы 15-ти минутного режима облучения терагерцевыми волнами МСИП оксида азота 150,176150,664 ГГц и группы животных, подвергнутых хроническому стрессу.

Изучение влияния терагерцевых волн МСИП оксида азота 150,176-150,664 ГГц в течение 15-ти минут на нарушенную функциональную активность эритроцитов агрегацию и деформируемость указывает на полное восстановление деформируемости эритроцитов и частичную нормализацию их агрегационной активности. Об этом свидетельствует отсутствие статистически достоверных различий между индексом деформируемости эритроцитов опытной группы 15-ти минутного режима облучения с данными контрольной группы, а также статистически достоверные различия с показателями группы хронического стресса. Индекс агрегации эритроцитов опытной группы с 15-ти минутным облучением статистически достоверно не отличается от данных групп контроля и хронического стресса. Полное и частичное восстановление функциональной активности эритроцитов, как известно, в значительной мере влияет на нормализацию вязкости крови в целом [Киричук В.Ф., Малинова Л.И., Креницкий А.П.и др., 2003; Киричук В.Ф., Креницкий А.П., Майбородин А.В., и др., 2006; Sakuta S., Tacamats S. et al., 1982].

При исследовании влияния 30-ти минутного режима терагерцевого облучения 150,176-150,664 ГГц на животных, подвергнутых длительному стрессу, установлено, что данный режим облучения полностью не восстанавливает нарушенные хроническим стрессом вязкостные свойства крови.

Об этом свидетельствуют статистически достоверные различия данных группы контроля и группы с 30-ти минутным облучением на всех исследуемых скоростях сдвига. Однако сравнительный анализ показателей вязкости крови опытной группы 30-ти минутного облучения и группы животных, подвергнутых хроническому стрессу, указывает на статистическую достоверность высокой степени между группами, что может быть расценено как частичное восстановление вязкости крови на всех исследуемых скоростях сдвига, моделирующих кровоток в сосудах крупного, среднего и малого калибра (сосудах микроциркуляции) [Ройтман Е.В., 2000,2003].

Указанный режим облучения электромагнитными волнами ТГЧ диапазона на частотах МСИП оксида азота 150,176-150,664 ГГц нормализует нарушенную деформируемость эритроцитов, но не восстанавливает их изменённую агрегационную способность. Об этом свидетельствует отсутствие статистически достоверной разницы в индексе, характеризующим деформируемость эритроцитов, по сравнению с группой 
контроля и наличие её по сравнению с группой хронического стресса. Индекс, характеризующий агрегационную активность эритроцитов, статистически достоверно отличается в опытной группе с 30-ти минутным облучением по сравнению с контролем и по сравнению с группой животных, подвергнутых хроническому стрессу, что может свидетельствовать о положительной тенденции восстановительного характера.

Таким образом, анализируя результаты проведённого исследования можно сделать следующие выводы о влиянии электромагнитных волн ТГЧ диапазона на частотах МСИП оксида азота 150,176-150,664 ГГц на вязкость крови и функциональную активность эритроцитов различных непрерывных временных режимов на белых крыс-самцов в условиях хронического стресса: 1) облучение электромагнитными волнами терагерцевого диапазона частот МСИП оксида азота 150,176-150,664 ГГц способно частично восстанавливать в зависимости от временных режимов воздействия хронические стрессзависимые нарушения вязкости крови и функциональной активности эритроцитов - их деформируемость и агрегацию; 2) 5-ти минутное воздействие электромагнитными волнами указанного диапазона частот на фоне хронического стресса не оказывает выраженного восстановительного эффекта нарушенной стрессом вязкости крови и функциональной активности эритроцитов, но способно изменять их деформируемость со слабо выраженной тенденцией к восстановлению; 3) 15-ти и 30-ти минутные режимы воздействия электромагнитными терагерцевыми волнами ТГЧ диапазона оксида азота 150,176-150,664 ГГц являются наиболее эффективными, так имеется положительная тенденция восстановительного характера вязкости крови и полная нормализация деформируемости эритроцитов у животных опытных групп. Однако агрегационная способность эритроцитов в этих группах восстанавливается частично.

10.1.6. Изменения вязкости крови и функциональной активности эритроцитов у белых крыс-самцов в состоянии острого иммобилизационного стресса при непрерывном превентивном воздействии терагерцевых волн на частотах молекулярного спектра излучения и поглощения оксида азота 150,176-150,664 ГГи

С целью изучения возможности предотвращения развития характерных для острой стресс-реакции нарушений вязкостных свойств крови, а так же функциональной активности эритроцитов была проведена серия экспериментов, в которых белые крысы-самцы подвергались непрерывному ТГЧ-облучению до начала действия острого стрессора. Продолжительность облучения животных в данных группах составляла 5,15 и 30 минут. 
При исследовании влияния непрерывного предварительного 5-ти минутного режима облучения установлено, что воздействие электромагнитными волнами ТГЧ диапазона на частотах МСИП оксида азота 150,176-150,664 ГГц перед проведением 3-х часовой иммобилизации (острый стресс) оказывает влияние как на вязкость крови стрессированных животных, так и на функциональную активность эритроцитов. На это указывают статистически достоверные различия вязкости крови животных, как группы контроля, так и острого стресса с аналогичными показателями животных, подвергнутых превентивному 5-ти минутному облучению волнами ТГЧ диапазона оксида азота (опытная группа) при скоростях сдвига 300, 200, 150, 100, 50 и $20 \mathrm{c}^{-1}$. Это свидетельствует о наличии положительной тенденции к предотвращению стрессорных повреждений при проведении превентивного 5-ти минутного ТГЧ облучения волнами на частотах МСИП оксида азота 150,176-150,664 ГГц. При скоростях сдвига 10 и $5 \mathrm{c}^{-1}$ статистически достоверных различий между группами стресса и опытной не наблюдается, что указывает на отсутствие эффективности превентивного непрерывного 5-ти минутного режима облучения в предотвращении гемореологических нарушений в сосудах микроциркуляторного русла.

Индексы деформируемости и агрегации эритроцитов группы стресса статистически достоверно не отличаются от группы животных, подвергнутых превентивному 5-ти минутному облучению волнами ТГЧ диапазона оксида азота, что свидетельствует о низкой эффективности изучаемого режима в предотвращении нарушений в функциональной активности эритроцитов. Показатели группы контроля с высокой степенью достоверности отличаются от показателей опытной группы, что подтверждает низкую эффективность превентивного 5-ти минутного облучения волнами ТГЧ диапазона на частотах МСИП оксида азота 150,176-150,664 ГГц перед проведением 3-х часовой иммобилизации (острого стресса) в восстановлении нарушенной функциональной активности эритроцитов - их агрегации и деформируемости.

При изучении влияния превентивного облучения электромагнитными терагецовыми волнами МСИП оксида азота 150,176-150,664 ГГц в течение 15-ти минут животных, подвергнутых острому стрессу, показано, что исследуемый временной режим приводит к сохранению уровня вязкости крови, характерной для животных контрольной группы. Об этом свидетельствует отсутствие статистически достоверной разницы показателей вязкости крови между группой 
контроля и опытной группой острого стресса с 15-ти минутным превентивным облучением электромагнитными волнами указанного диапазона частот, а также функциональной активности эритроцитов - деформируемости и агрегации.

Сравнивая показатели группы острого стресса и опытной группы с 15-ти минутным превентивным облучением, отмечается высокая статистически достоверная разница в показателях вязкости крови при всех исследуемых скоростях сдвига, а также в индексах функциональной активности эритроцитов деформируемости и агрегации, что подтверждает выраженный профилактический эффект превентивного облучения электромагнитными волнами ТГЧ-диапазона на частотах МСИП оксида азота 150,176-150,664 ГГц на реологические свойства крови животных, подвергнутых в дальнейшем острому стрессу.

Изучение влияния предварительного 30 минутного воздействия электромагнитными волнами терагерцевого диапазона МСИП оксида азота 150,176-150,664 ГГц на вязкость свойства крови и функциональную активность эритроцитов животных перед проведением острого иммобилизационного стресса показало, что данный временной режим облучения предотвращает развитие острых стрессорных изменений в вязкости крови. Статистически достоверные отличия в показателях вязкости крови группы контроля и опытной, в которой животные предварительно подвергались 30 -ти минутному воздействию терагерцевыми волнами, отсутствуют, но имеются статистически достоверные различия в показателях группы стресса и опытной группы.

Электромагнитные волны указанного диапазона частот при предварительном 30-ти минутном воздействии сохраняют функциональную активность эритроцитов - агрегацию и деформируемость. Об этом свидетельствует отсутствие статистически достоверных различий индексов агрегации и деформируемости эритроцитов группы контроля и опытной группой острого стресса с 30-ти минутным предварительным облучением волнами терагерцевого диапазона частот оксида азота 150,176-150,664 ГГц, но наличие высокой степени достоверности между группой острого стресса и опытной группой животных.

Таким образом, результаты проведённого исследования, можно сделать следующие выводы: 1) превентивное облучение электромагнитными волнами терагерцевого диапазона частот МСИП оксида азота 150,176-150,664 ГГц способно предотвращать в зависимости от временных режимов воздействия острые стресс-зависимые нарушения 
вязкости крови и функциональной активности эритроцитов - деформируемости и агрегации; 2) 5-ти минутное превентивное воздействие электромагнитными волнами указанного диапазона частот не предотвращает стрессорные нарушения вязкости крови в опытной группе при скоростях сдвига 300, 200, 150, 100, 50 и $20 \mathrm{c}^{-1}$ и не оказывает положительного эффекта при скоростях сдвига 10 и $5 \mathrm{c}^{-1}$, моделирующих кровоток в сосудах микроциркуляции, а также 5-ти минутный режим не эффективен в восстановлении функциональной активности эритроцитов; 3) 15-ти и 30-ти минутные режимы превентивного воздействия электромагнитными терагерцевыми волнами на частотах МСИП оксида азота 150,176-150,664 ГГц эффективны и полностью предотвращают стресс-зависимые нарушения вязкости крови и функциональной активности эритроцитов.

10.1.7. Вязкость крови и функциональная активность эритроцитов у бельх крыс-самцов в состоянии хронического иммобилизационного стресса при непрерывном превентивном воздействии терагерцевых волн на частотах молекуляроного спектра излучения и поглощения оксида азота 150,176-150,664 ГГи

При изучении влияния непрерывного превентивного воздействия терагерцевых волн на частотах МСИП оксида азота 150,176-150,664 ГГц на вязкостные свойства крови и функциональную активности эритроцитов белых крыс-самцов при развитии длительного (хронического) иммобилизационного стресса было исследовано два временных режима облучения - 15 и 30-ти минутные, так как данные предыдущих исследований показали недостаточную эффективность 5-ти минутного режима в условиях острого стресса.

При исследовании вязкости крови при высоких $\left(300,200,150 \mathrm{c}^{-1}\right)$ и средних $\left(100 \mathrm{c}^{-1}\right)$ скоростях сдвига, моделирующих кровоток в артериях крупного и среднего калибра [Ройтман Е.В., 2000,2003], обнаружено, что 15-ти минутное облучение животных электромагнитными волнами терагерцевого диапазона указанных частот предупреждает развитие нарушений в вязкости крови животных при хроническом стрессе. Об этом свидетельствует отсутствие статистически достоверной разницы между группой контроля и опытной группой животных, находящихся в состоянии хронического стресса, при 15 -ти минутном превентивном облучении электромагнитными волнами терагерцевого диапазона частот оксида азота 150,176-150,664 ГГц. В то же время исследование вязкости крови животных на скоростях сдвига 50, 20, 10 и 5 c $^{-1}$, отражающих кровоток в сосудах переходных от среднего $\left(50 \mathrm{c}^{-1}\right)$ калибра в прекапилляры и 
в микроциркуляторном русле $\left(20 \mathrm{c}^{-1}, 10 \mathrm{c}^{-1}, 5 \mathrm{c}^{-1}\right)$, показало недостаточную эффективность превентивного 15-ти минутного облучения. Об этом свидетельствуют статистически достоверные различия как между группой контроля и опытной группой животных, подвергнутых длительному стрессу с превентивным 15-ти минутным облучением электромагнитными волнами терагерцевого диапазона частот оксида азота 150,176-150,664 ГГц, так и группой хронического стресса и опытной группы с 15-ти минутным превентивным облучением.

Эффективность превентивного 15-ти минутного воздействия ЭМИ ТГЧ диапазона МСИП оксида азота 150,176-150,664 ГГц на показатели функциональной активности эритроцитов животных в состоянии хронического стресса однозначна: отмечается сохранение деформируемости эритроцитов и их агрегационной способности. Об этом свидетельствует отсутствие статистически достоверных различий в показателях индексов агрегации и деформируемости группы контроля и опытной группы хронического стресса с превентивным облучением. При сравнении показателей функциональной активности эритроцитов - индексов агрегации и деформируемости группы хронического стресса и опытной группы с превентивным 15-ти минутным облучением волнами терагерцевого диапазона частот оксида азота 150,176-150,664 ГГц показана статистически достоверная разница в показателях, что также подтверждает эффективность изучаемого режима облучения в профилактике нарушений функциональной активности эритроцитов.

Изучение влияния превентивного 30 минутного воздействия электромагнитными волнами терагерцевого диапазона на частотах МСИП оксида азота 150,176-150,664 ГГц на вязкость крови и функциональную активность эритроцитов животных при длительном иммобилизационном стрессе показало, что данный временной режим облучения предотвращает развитие стрессзависимых нарушений в вязкости крови.

Статистически достоверные отличия в показателях вязкости крови при исследуемых скоростях сдвига между группами контроля и опытной, в которой животные предварительно подвергались воздействию терагерцевыми волнами, отсутствуют. Однако имеются статистически достоверные различия высокой степени между показателями группы хронического стресса и опытной.

Показано, что электромагнитные волны указанного диапазона частот при предварительном 30 минутном воздействии на животных при хроническом стрессе также сохраняют функциональную активность эритроцитов - агрегацию 
и деформируемость, характерную для белых крыс-самцов контрольной группы. Об этом свидетельствует отсутствие статистически достоверных различий в индексах агрегации и деформируемости эритроцитов между группой контроля и опытной группой животных при хроническом стрессе с 30 минутным превентивным облучением волнами терагерцеваго диапазона частот оксида азота 150,176-150,664 ГГц, но наличие статистически достоверных отличий группы хронического стресса и опытной группы превентивным 30-ти минутным облучением электромагнитными волнами указанного диапазона частот.

Таким образом, анализируя результаты проведённого исследования, можно сделать следующие выводы: 1) эффективность превентивного воздействия электромагнитных волн терагерцевого диапазона частот МСИП оксида азота 150,176-150,664 ГГц в условиях хронического стресса не одинакова и зависит от временных режимов облучения; 2) при превентивном воздействии в течение 15 минут электромагнитные волны указанного диапазона частот способны предотвращать стресс-зависимые нарушения вязкости крови при скоростях сдвига, моделирующих кровоток в сосудах крупного и среднего калибра, но мало эффективны в сосудах переходных от среднего калибра в прекапилляры и в сосуды микроциркуляции; 3) воздействие волнами терагерцевого диапазона частот МСИП оксида азота 150,176-150,664 ГГц в условиях хронического стресса в течение 15-ти минут сохраняет функциональную активность эритроцитов: агрегацию и деформируемость; 4) превентивное воздействие ЭМИ указанного диапазона частот в течение 30-ти минут предупреждает развитие стрессзависимых нарушений вязкости крови и функциональной активности эритроцитов (агрегации, деформируемости).

10.1.8. Вязкость крови и функциональная активность эритроцитов у белых крыс-самцов на фоне острого иммобилизационного стресса при дробном воздействии терагерцевых волн на частотах молекулярного спектра излучения и поглощения оксида азота 150,176-150,664 ГГц

Для изучения возможности коррекции характерных для острой стрессреакции нарушений вязкостных свойств крови и функциональной активности эритроцитов при помощи дробного режима ТГЧ облучения была проведена серия экспериментов, в которых белые крысы-самцы подвергались дробному воздействию ТГЧ волн на фоне действия стрессора. Дробное облучение 
проводилось по схеме, представленной в п.2.1.1.4. Продолжительность облучения животных в опытных группах составляла 5,15 и 30 минут.

При исследовании влияния дробного режима облучения установлено, что воздействие электромагнитными волнами терагерцевого диапазона на частотах МСИП оксида азота 150,176-150,664 ГГц в течение 5-ти минут на фоне 3-х часового иммобилизационного (острого стресса) не оказывает выраженного восстановительного эффекта на вязкость цельной крови животных и на функциональную активность эритроцитов. На это указывает отсутствие статистически достоверных различий опытной группы этого режима облучения по сравнению с группой стресса и статистически достоверные различия высокой степени с показателями контрольной группы.

Дробное облучение терагецовыми волнами МСИП оксида азота 150,176150,664 ГГц в течение 15-ти минут животных, подвергнутых острому иммобилизационному стрессу, приводит к нормализации вязкости крови на всех исследуемых скоростях сдвига. Об этом свидетельствует отсутствие статистически достоверной разницы между показателями группы контроля и опытной группы с дробным 15-ти минутным облучением волнами указанного диапазона частот на фоне острого стресса и наличие статистически достоверных отличий высокой степени по сравнению с группой животных, подвергнутых острому стрессу.

Показано, что терагерцевое облучение МСИП оксида азота 150,176150,664 ГГц в течение 15 минут на фоне острого стресса способствует нормализации функциональной активности эритроцитов - их агрегации и деформируемости, что в целом положительно влияет на процесс восстановления вязкости крови [Киричук В.Ф., Малинова Л.И., Креницкий А.П.и др., 2003; Киричук В.Ф., Креницкий А.П., Майбородин А.В., и др., 2006; Sakuta S., Tacamats S. et al., 1982]. Об этом свидетельствует отсутствие статистически достоверных различий между показателями группы контроля и опытной группы острого стресса с дробным 15 ти минутным облучением волнами указанного диапазона частот на фоне иммобилизационного стресса, но наличие статистически достоверных отличий между опытной группой с 15 -ти минутным облучением на фоне острого стресса и группой острого стресса.

Изучение влияния 30-ти минутного дробного воздействия электромагнитными волнами терагерцевого диапазона частот МСИП оксида азота 150,176-150,664 ГГц на вязкостные свойства крови и функциональную 
активность эритроцитов животных, подвергнутых острому иммобилизационному стрессу, показало, что данный временной режим облучения полностью нормализует острые стрессорные нарушения вязкости крови на всех исследуемых скоростях сдвига. Об этом свидетельствует отсутствие статистически достоверных отличий между показателями вязкости крови на всех исследуемых скоростях сдвига опытной группы с 30-ти минутным облучением электромагнитными волнами указанного диапазона частот и данными группы контроля, но наличие статистически достоверных различий высокой степени показателей опытной группы и группы острого стресса.

Дробное воздействие электромагнитными волнами терагерцевого диапазона частот МСИП оксида азота 150,176-150,664 ГГц также нормализует функциональную активность эритроцитов - агрегацию и деформируемость. Об этом свидетельствует отсутствие статистически достоверных различий между показателями группы контроля и опытной группой животных, подвергнутых острому иммобилизационному стрессу, с последующим 30-ти минутным дробным облучением волнами указанного диапазона частот, но наличие статистической достоверности между данными опытной группы с 30-ти минутным облучением и показателями группы острого стресса.

Таким образом, анализируя результаты исследования можно сделать следующие выводы: 1) дробное облучение электромагнитными волнами терагерцевого диапазона частот МСИП оксида азота 150,176-150,664 ГГц способно нормализовать острые постстрессорные нарушения вязкости крови и функциональной активности эритроцитов - деформируемости и агрегации в зависимости от временных режимов воздействия; 2) 5-ти минутное дробное воздействие электромагнитными волнами на фоне острого иммобилизационного стресса указанного диапазона частот не оказывает выраженного восстановительного эффекта нарушенной острым стрессом вязкости крови и функциональной активности эритроцитов; 3) 15-ти и 30-ти минутные режимы дробного облучения электромагнитными терагерцевыми волнами на фоне острого иммобилизационного стресса эффективны, так как полностью нормализуют нарушенные постстрессорные показатели реологии крови.

10.1.9. Изменения вязкости крови и функциональной активности эритроцитов у белых крыс-самцов в состоянии острого иммобилизационного стресса при превентивном дробном воздействии терагерцевыми волнами на частотах молекулярного спектра излучения и поглощения оксида азота 150,176-150,664 ГГц 
$\mathrm{C}$ целью изучения возможности предотвращения развития характерных для острой стресс-реакции нарушений вязкостных свойств крови и функциональной активности эритроцитов при помощи дробного режима ТГЧ облучения была проведена серия экспериментов, в которых белые крысы-самцы подвергались дробному воздействию электромагнитными волнами терагерцевого диапазона МСИП оксида азота 150,176-150,664 ГГц до начала действия стрессора. Дробное облучение проводилось по схеме, представленной в Продолжительность облучения животных в данных группах составляла 5,15 и 30 минут.

При исследовании превентивного дробного влияния облучения установлено, что воздействие волнами ТГЧ диапазона на частотах МСИП оксида азота 150,176-150,664 ГГц в течение 5-ти минут перед проведением 3-х часовой иммобилизации крыс-самцов (острый стресс) не предотвращает развитие нарушений в вязкости крови на всех исследуемых скоростях сдвига за исключением скорости сдвига $5 \mathrm{c}^{-1}$, отражающей циркуляцию крови в мельчайших сосудах. Об этом свидетельствуют как статистически достоверные различия между показателями вязкости крови опытной группы с 5-ти минутным дробным облучением волнами указанного диапазона частот и группой контроля, так и статистически достоверные различия высокой степени между показателями опытной группы и группы острого стресса.

Изучение дробного 5-ти минутного превентивного влияния электромагнитных волн терагерцевого диапазона частот МСИП оксида азота 150,176-150,664 ГГц показало их предотвращающее влияние на постстрессорные нарушения в функциональной активности эритроцитов: их агрегации и деформируемости. На это указывает отсутствие статистически достоверных различий показателей опытной группы по сравнению с данными контрольной группы животных и её наличие между опытной группой и группой острого стресса.

Превентивное дробное облучение терагецовыми волнами МСИП оксида азота 150,176-150,664 ГГц в течение 15 минут животных, подвергнутых острому иммобилизационному стрессу, предотвращает развитие стресс-зависимых нарушений вязкости крови на всех исследуемых скоростях сдвига, характеризующих кровоток в сосудах крупного, среднего и малого калибра (сосуды микроциркуляции) [Ройтман Е.В.2000,2003]. Об этом свидетельствует отсутствие статистически достоверной разницы между показателями группы 
контроля и опытной группы острого стресса с 15-ти минутным предварительным дробным облучением волнами указанного диапазона частот и наличие статистически достоверных различий высокой степени опытной группы и группы острого стресса.

Показано, что превентивное дробное терагерцевое облучение МСИП оксида азота 150,176-150,664 ГГц в течение 15-ти минут способствует предотвращению стресс-зависимых нарушений функциональной активности эритроцитов - их агрегации и деформируемости. Об этом свидетельствует отсутствие статистически достоверных различий между показателями группы контроля и опытной группой острого стресса с превентивным 15-ти минутным облучением волнами указанного диапазона частот, но наличие статистически достоверной разницы показателей по сравнению с группой острого стресса.

Изучение влияния 30-ти минутного дробного превентивного воздействия электромагнитных волн терагерцевого диапазона МСИП оксида азота 150,176150,664 ГГц на вязкость крови и функциональную активность эритроцитов белых крыс-самцов, подвергнутых острому иммобилизационному стрессу, показало, что данный временной режим облучения полностью предотвращает острые стресс-зависимые нарушения вязкости крови. Об этом свидетельствует отсутствие статистически достоверных данных опытной группы с превентивным 30-ти минутным облучением и группы контроля и наличие статистически достоверной разницы между опытной группой и группой острого стресса.

Показано предотвращение стресс-зависимых нарушений функциональной активности эритроцитов - их агрегации и деформируемости. Об этом свидетельствует отсутствие статистически достоверных различий между показателями группы контроля и опытной группой животных, подвергнутых дробному превентивному 30-ти минутному облучению волнами указанного диапазона частот и группы иммобилизационного стресса, а также наличие статистически достоверной разницы в показателях по сравнению с группой острого стресса.

Таким образом, можно сделать следующие выводы: 1) дробное превентивное облучение электромагнитными волнами терагерцевого диапазона частот МСИП оксида азота 150,176-150,664 ГГц способно предотвращать в зависимости от временных режимов воздействия острые стресс-зависимые нарушения вязкости крови и функциональной активности эритроцитов - деформируемости и агрегации; 2) воздействие волнами ТГЧ диапазона на частотах МСИП оксида азота 150,176- 
150,664 ГГц в течение 5 минут перед проведением острого стресса не предотвращает развитие нарушений в вязкости крови на всех исследуемых скоростях сдвига, отражающих циркуляцию крови в сосудах крупного и среднего калибра, за исключением скорости сдвига $5 \mathrm{c}^{-1}$, отражающей поведение крови в сосудах микроциркуляции, и не оказывает восстановительного эффекта нарушенной острым стрессом функциональной активности эритроцитов - их агрегации и деформируемости; 3) 15-ти и 30-ти минутные режимы превентивного дробного воздействия электромагнитными терагерцевыми волнами на частотах МСИП оксида азота 150,176-150,664 предотвращают развитие стресс-зависимых нарушений вязкости крови у белых крыс-самцов на всех исследуемых скоростях сдвига, характеризующих кровоток в сосудах крупного, среднего и малого калибра (сосуды микроциркуляции).

10.2. Влияние электромагнитного облучения терагерцевого диапазона на частотах молекулярного спектра излучения и поглощения оксида азота 150,176150,664 ГГц на реологические свойства крови у белых крыс-самок, находящихся в условиях стресса

10.2.1. Изменения реологических свойств крови у белых крыс-самок при остром иммобилизационном стрессе в фазах Dioestrus и Oеstrus эстрального цикла

Для установления степени воздействия острого 3-х часового иммобилизационного стресса на показатели гемореологии крыс-самок в двух фазах эстрального цикла Dioestrus и Oestrus была исследована вязкость цельной крови при скоростях сдвига от $300 \mathrm{c}^{-1}$ до $5 \mathrm{c}^{-1}$ с расчётом индексов агрегации (ИАЭ) и деформируемости (ИДЭ) эритроцитов, характеризующих их функциональную активность. Определение фазы эстрального цикла осуществлялось с помощью микроскопии мазка. Наличие в мазке большого количества лейкоцитов, слущенного эпителия, свободных ядер разрушенных клеток, слизи свидетельствовало о наступлении стадии Oestrus эстрального цикла; отсутствие вышеуказанных элементов - о стадии Dioestrus [Эленберг В., Шейнерт А., 1930].

В результате проведённых исследований обнаружены статистически достоверные отличия вязкости крови у крыс-самок групп контроля в фазах Dioestrus и Oestrus эстрального цикла. Так, вязкость крови в фазе Oestrus была выше, чем в фазе Dioestrus при всех исследуемых скоростях сдвига. Однако индексы деформируемости и агрегации эритроцитов в группе контроля не зависели от фазы эстрального цикла. 
Данные проведённых исследований показывают статистически достоверное увеличение вязкости цельной крови у крыс-самок в фазах Dioestrus и Oestrus эстрального цикла при остром стрессе при всех скоростях сдвига.

Индексы агрегации и деформируемости эритроцитов у самок в стадиях Dioestrus и Oestrus, подвергнутых острому иммобилизационному стрессу, также статистически достоверно отличаются от показателей групп контроля. Так, у стрессированных животных в фазах Dioestrus и Oestrus способность эритроцитов к агрегации и деформируемости увеличена. Об этом свидетельствует статистически достоверное увеличение индексов агрегации и деформируемости эритроцитов по сравнению с группами контроля крыс-самок в фазах Dioestrus и Oestrus эстрального цикла.

При сравнении вязкости крови, индексов агрегации и деформируемости эритроцитов стрессированных крыс-самок в фазах Dioestrus и Oestrus эстрального цикла статистически достоверных отличий выявлено не было. Однако у белых крыс в фазе Dioestrus возрастание величины вязкости крови более выражено, чем в фазе Oestrus. Так, при скорости сдвига 300 и 200с ${ }^{-1}$ вязкость крови в фазе Dioestrus возрастала по сравнению с контролем на 29\%, в фазе Oestrus - на 9,6\%; при $150 \mathrm{c}^{-1}$ - на $30,9 \%$ и $25 \%$; при $100 \mathrm{c}^{-1}$ - на $34,3 \%$ и $24,6 \%$; при $50 \mathrm{c}^{-1}$ на $29,2 \%$ и $33,5 \%$; при $20 \mathrm{c}^{-1}$ - на $51,2 \%$ и $42,1 \%$; при $10 \mathrm{c}^{-1}$ - на $50,6 \%$ и 45,6\%; при $5 \mathrm{c}^{-1}$ - на 50,2\% и 41,1\% соответственно. Это свидетельствует о том, что самки в фазе Dioestrus более выражено реагируют на действие стрессорного фактора.

Таким образом, представленные данные свидетельствуют о том, что для крыссамок в стадиях Dioestrus и Oestrus, подвергнутых острому стрессу, характерно нарушение реологических свойств крови - повышение вязкости крови на всех скоростях сдвига, характеризующих кровоток в сосудах крупного, среднего и малого калибра (сосуды микроциркуляции) [Ройтман Е.В., 2000,2003], нарушение функциональной активности эритроцитов - увеличение их агрегационной способности и деформируемости по сравнению с группой контроля. Крысы-самки в фазе Dioestrus эстрального цикла более выражено реагируют на острый стрессор, чем в фазе Oestrus.

10.2.2. Изменения вязкости крови и функциональной активности эритроцитов у белых крыс-самок в фазе Dioestrus эстрального цикла в состоянии острого иммобилизационного стресса при непрерывном воздействии терагерцевых волн на частотах молекулярного спектра излучения и поглощения оксида азота 150,176$150,664 \Gamma \Gamma u$

С целью изучения эффекта облучения волнами терагерцевого диапазона частот МСИП оксида азота 150,176-150,664 ГГц на вязкость крови и функциональную активность эритроцитов (агрегацию, деформируемость) крыс-самок в фазе Dioestrus 
эстрального цикла была проведена серия экспериментов, в которых они подвергались непрерывному ТГЧ-облучению после однократной 3-х часовой иммобилизации (острого стресса). Продолжительность облучения составляла 5, 15 и 30 минут.

При исследовании непрерывного влияния 5-ти минутного режима облучения установлено, что воздействие электромагнитными волнами ТГЧ диапазона на частотах МСИП оксида азота 150,176-150,664 ГГц на стрессированных животных не вызывает выраженного влияния на нарушенную вязкость цельной крови и функциональную активность эритроцитов - их агрегацию и деформируемость. На это указывает отсутствие статистически достоверных различий вязкости крови на всех исследуемых скоростях сдвига и показателей функциональной активности эритроцитов опытной группы с 5-ти минутным облучением на фоне острого стресса с данными группы острого стресса и наличие различий высокой степени статистической достоверности по сравнению с группой контроля.

Изучение влияния 15-ти минутного режима облучения электромагнитными волнами МСИП оксида азота 150,176-150,664 ГГц на крыс-самок в фазе Dioestrus эстрального цикла, подвергнутых острому иммобилизационному стрессу, показало полное восстановление вязкости крови до уровня, характерного для животных контрольной группы аналогичной фазы эстрального цикла на всех исследуемых скоростях сдвига. Об этом свидетельствует отсутствие статистически достоверных отличий показателей реологии крови опытной группы острого стресса с 15-ти минутным облучением по сравнению с данными группы контроля и наличие высокой степени достоверности по сравнению с группой острого стресса.

Исследование функциональной активности эритроцитов - агрегации и деформируемости крыс-самок в стадии Dioestrus эстрального цикла, подвергнутых острому иммобилизационному стрессу, также указывает на полное восстановление их функций под воздействием 15-ти минутного облучения электромагнитными волнами исследуемого диапазона частот. Это подтверждается отсутствием статистически достоверных различий между показателями агрегации и деформируемости эритроцитов опытной группы животных и группы контроля, а также их наличием по сравнению с группой острого стресса.

Воздействие 30-ти минутного режима облучения электромагнитными волнами МСИП оксида азота 150,176-150,664 ГГц на крыс-самок в фазе Dioestrus эстрального цикла, подвергнутых острому иммобилизационному стрессу, также показало полное восстановление вязкости крови до уровня, характерного для диэстральных крыс-самок контрольной группы на всех исследуемых скоростях сдвига. Об этом свидетельствует 
отсутствие статистически достоверных отличий вязкости крови опытной группы острого стресса с 30-ти минутным облучением по сравнению с данными группы контроля и наличие высокой степени достоверности по сравнению с группой острого стресса крыссамок в фазе Dioestrus.

Исследование функциональной активности эритроцитов - агрегации и деформируемости крыс-самок в стадии Dioestrus эстрального цикла, подвергнутых острому иммобилизационному стрессу также показывает полное восстановление их функций под воздействием 30-ти минутного облучения электромагнитными волнами МСИП оксида азота 150,176-150,664 ГГц. Это подтверждается отсутствием статистически достоверных различий между величиной агрегации и деформируемости эритроцитов опытной группы животных и группы контроля, а также их наличием по сравнению с группой острого стресса.

Таким образом, при анализе результатов проведённого исследования можно сделать следующие выводы: 1) облучение электромагнитными волнами терагерцевого диапазона частот МСИП оксида азота 150,176-150,664 ГГц способно восстанавливать в зависимости от временных режимов воздействия острые стресс-зависимые нарушения вязкости крови и функциональной активности эритроцитов - их деформируемость агрегацию у крыс-самок в фазах Dioestrus эстрального цикла; 2) 5-ти минутное воздействие электромагнитными волнами указанного диапазона частот на фоне острого стресса не эффективно в восстановлении нарушенной острым стрессом вязкости крови и функциональной активности эритроцитов; 3) 15-ти и 30-ти минутные режимы воздействия электромагнитными волнами терагерцевого диапазона частот оксида азота 150,176150,664 ГГц полностью восстанавливают стресс-зависимые нарушения вязкости крови и функциональной активности эритроцитов - агрегации и деформируемости у крыс-самок в фазе Dioestrus эстрального цикла.

10.2.3. Изменения вязкости крови и функциональной активности эритроцитов у белых крыс-самок в фазе Оеstrus эстрального цикла в состоянии острого иммобилизационного стресса при непрерывном воздействии терагерцевых волн на частотах молекулярного спектра излучения и поглощения оксида азота 150,176$150,664 \Gamma \Gamma u$

Для выявления влияния электромагнитных волн терагерцевого диапазона частот МСИП оксида азота 150,176-150,664 ГГц на вязкость крови и функциональную активность эритроцитов (агрегацию, деформируемость) крыс-самок в фазе Oestrus эстрального цикла, подвергнутых острому иммобилизационному стрессу, была проведена серия экспериментов, в которых они подвергались непрерывному ТГЧ-облучению после 
однократной 3-х часовой иммобилизации (острого стресса). Продолжительность облучения составляла 5,15 и 30 минут.

При исследовании непрерывного влияния 5-ти минутного режима облучения установлено, что воздействие электромагнитными волнами ТГЧ диапазона на частотах МСИП оксида азота 150,176-150,664 ГГц на стрессированных животных не оказывает выраженного влияния как на нарушенную вязкость цельной крови, так и функциональную активность эритроцитов - их агрегацию и деформируемость. На это указывает отсутствие статистически достоверных различий вязкости крови на всех исследуемых скоростях сдвига и показателей функциональной активности эритроцитов опытной группы с 5-ти минутным облучением на фоне острого стресса с данными группы острого стресса и наличие различий высокой степени достоверности по сравнению с группой контроля.

Изучение влияния 15-ти минутного режима облучения электромагнитными волнами МСИП оксида азота 150,176-150,664 ГГц на крыс-самок в фазе Oestrus эстрального цикла, подвергнутых острому иммобилизационному стрессу, показало полное восстановление вязкости крови до уровня, характерного для животных контрольной группы аналогичной фазы эстрального цикла на всех исследуемых скоростях сдвига.

Об этом свидетельствует отсутствие статистически достоверных отличий показателей реологии крови опытной группы острого стресса с 15-ти минутным облучением по сравнению с данными группы контроля и наличие высокой степени их достоверности по сравнению с группой острого стресса.

Исследование функциональной активности эритроцитов - агрегации и деформируемости крыс-самок в стадии Oestrus эстрального цикла, подвергнутых острому иммобилизационному стрессу, также указывает на полное восстановление их функций под воздействием 15-ти минутного облучения электромагнитными волнами исследуемого диапазона частот. Это подтверждается отсутствием статистически достоверных различий между показателями агрегации и деформируемости эритроцитов опытной группы животных и группы контроля, а также их наличием по сравнению с группой острого стресса.

Воздействие 30-ти минутного режима облучения электромагнитными волнами МСИП оксида азота 150,176-150,664 ГГц на крыс-самок в фазе Oestrus эстрального цикла, подвергнутых острому иммобилизационному стрессу, также показало полное восстановление вязкости крови до уровня, характерного для эстральных крыс-самок контрольной группы на всех исследуемых скоростях сдвига. Об этом свидетельствует отсутствие статистически достоверных отличий вязкости крови опытной группы острого стресса с 30-ти минутным облучением по сравнению с данными 
группы контроля и наличие их высокой степени достоверности по сравнению с группой острого стресса крыс-самок в фазе Oestrus.

Исследование функциональной активности эритроцитов - агрегации и деформируемости крыс-самок в стадии Oestrus эстрального цикла, подвергнутых острому иммобилизационному стрессу, также показывает на полное восстановление их функций под воздействием 30-ти минутного облучения электромагнитными волнами МСИП оксида азота 150,176-150,664 ГГц. Это подтверждается отсутствием статистически достоверных различий между величиной агрегации и деформируемости эритроцитов опытной группы животных и группы контроля, а также их наличием по сравнению с группой острого стресса.

Таким образом, при анализе результатов проведённого исследования можно сделать следующие выводы: 1) облучение электромагнитными волнами терагерцевого диапазона частот МСИП оксида азота 150,176-150,664 ГГц способно восстанавливать в зависимости от временных режимов воздействия острые стресс-зависимые нарушения вязкости крови и функциональной активности эритроцитов - их деформируемость и агрегацию у крыс-самок в фазах Oestrus эстрального цикла; 2) 5-ти минутное воздействие электромагнитными волнами указанного диапазона частот на фоне острого стресса не оказывает выраженного нормализующего эффекта нарушенной острым стрессом вязкости крови и функциональной активности эритроцитов у крыс-самок в фазе Oestrus эстрального цикла; 3) 15-ти и 30-ти минутные режимы воздействия электромагнитными терагерцевыми волнами на частотах МСИП оксида азота 150,176-150,664 ГГц эффективны и полностью восстанавливают стресс-зависимых нарушения вязкости крови и функциональной активности эритроцитов - агрегации и деформируемости у крыс-самок в фазе Oestrus эстрального цикла.

10.2.4. Изменения вязкости крови и функциональной активности эритроцитов у белых крыс-самок в фазе Dioestrus эстрального цикла в состоянии острого иммобилизационного стресса под воздействием непрерывного превентивного облучения терагерцевыми волнами на частотах молекулярного спектра излучения и поглощения оксида азота 150,176-150,664 ГГц

Для исследования возможности предотвращения развития характерных для острой стресс-реакции нарушений вязкости крови и функциональной активности эритроцитов были проведены эксперименты, в которых белые крысы в фазе Dioestrus эстрального цикла подвергались непрерывному ТГЧ облучению до начала действия стрессора. Продолжительность облучения животных в данных группах составляла 5,15 и 30 минут. 
Установлено, что непрерывное превентивное 5-ти минутное облучение электромагнитными волнами ТГЧ диапазона на частотах МСИП оксида азота 150,176-150,664 ГГц с последующей 3-х часовой иммобилизацией животных (острый стресс) не препятствует развитию нарушений в вязкости крови. На это указывают статистически достоверные различия вязкости крови на всех исследуемых скоростях сдвига белых крыс группы контроля и группы животных, подвергнутых превентивному 5-ти минутному облучению, а также статистически достоверные различия между группами животных с острым стрессом и превентивным 5-ти минутным облучением, предшествующим действию острого стресса.

Индексы деформируемости и агрегации эритроцитов группы контроля статистически достоверно отличаются от группы животных, подвергнутых превентивному 5-ти минутному облучению, а также наличие статистически достоверных различий между группами острого стресса и превентивного 5-ти минутного облучения свидетельствует об отсутствии эффективности изучаемого временного режима в предотвращении нарушений функциональной активности эритроцитов.

Превентивное облучение в течение 15-ти минут терагецовыми волнами МСИП оксида азота 150,176-150,664 ГГц белых крыс в фазе Dioestrus эстрального цикла, подвергнутых острому стрессу, не приводит к изменению величины вязкости крови при всех скоростях сдвига, характерной для животных контрольной группы, так как отсутствует статистически достоверная разница вязкости крови у белых крыс групп контроля и опытной группой острого стресса с превентивным облучением электромагнитными волнами указанного диапазона частот и последующим действием стрессора.

Превентивное облучение в течение 15 -ти минут терагерцевыми волнами на частотах МСИП оксида азота 150,176-150,664 ГГц полностью предотвращает острые стресс-зависимые нарушения функциональной активности эритроцитов деформируемости и агрегации. Об этом свидетельствуют отсутствие статистически достоверных различий в показателях группы контроля и опытной с 15-ти минутным превентивным облучением, но наличие статистической достоверности между группой острого стресса и группой с превентивным облучением с последующим действием стрессора.

Изучение влияния превентивного 30-ти минутного воздействия электромагнитными волнами терагерцевого диапазона МСИП оксида азота 
150,176-150,664 ГГц на вязкость и функциональную активность эритроцитов белых крыс в фазе Dioestrus эстрального цикла показало, что данный временной режим облучения предотвращает развитие острых стрессорных изменений как в вязкости крови при всех скоростях сдвига, так и в функциональной активности эритроцитов - их способности к агрегации и деформируемости. Статистически достоверные различия вязкости крови при всех скоростях сдвига между группами контроля и опытной, в которой животные перед действием стрессора подвергались 30-ти минутному воздействию электромагнитными волнами терагерцевого диапазона указанных частот, отсутствуют, но имеется статистическая достоверность между животными в группах стресса и опытной.

Облучение электромагнитными волнами терагерцевого диапазона частот МСИП оксида азота 150,176-150,664 ГГц при превентивном 30-ти минутном воздействии на белых крыс в фазе Dioestrus эстрального цикла и последующем действии острого стрессора оказывает профилактический эффект, предотвращая стресс-зависимые нарушения в функциональной активности эритроцитов агрегации и деформируемости. Об этом свидетельствует отсутствие статистически достоверных различий в указанных показателях между группами контроля и опытной - острого стресса с 30-ти минутным превентивным облучением, но её наличие между группой стресса и опытной группой животных.

Таким образом, анализируя результаты проведённого исследования, можно сделать следующие выводы: 1) превентивное облучение терагерцевыми волнами на частотах МСИП оксида азота 150,176-150,664 ГГц крыс-самок в фазе Dioestrus эстрального цикла, подвергнутых в последствие острому иммобилизационному стрессу, является эффективным в зависимости от времени ТГЧ воздействия; 2) превентивное 5-ти минутное облучение электромагнитными волнами указанного диапазона частот не обладает выраженной эффективностью в предотвращении острых стресс-зависимых нарушений вязкости крови при всех скоростях сдвига и функциональной активности эритроцитов; 3) превентивные 15-ти и 30-ти минутные режимы облучения электромагнитными волнами терагерцевого диапазона на частотах оксида азота 150,176-150,664 являются эффективными и полностью предотвращают острые стрессорные нарушения вязкости крови при всех скоростях сдвига и функциональной активности эритроцитов - их способности к агрегации и деформируемости. 
10.2.5. Изменения вязкости крови и функциональной активности эритроцитов у белых крыс-самок в фазе Оеstrus эстрального цикла в состоянии острого иммобилизационного стресса под воздействием непрерывного превентивного облучения терагерцевыми волнами на частотах молекулярного спектра излучения и поглощения оксида азота 150,176-150,664 ГГц

С целью изучения эффективности электромагнитных волн терагерцевого диапазона на частотах оксида азота в предотвращении нарушений реологических свойств крови: её вязкости и функциональной активности эритроцитов, характерных для острой стресс-реакции, были проведены серии экспериментов, в которых белые крысы в стадии Oestrus эстрального цикла подвергались непрерывному ТГЧ облучению до начала действия острого стресса, продолжительность которого в группах составляла 5,15 и 30 минут.

Анализ результатов исследования влияния непрерывного превентивного 5-ти минутного режима облучения показал, что воздействие электромагнитными волнами ТГЧ диапазона на частотах МСИП оксида азота 150,176-150,664 ГГц не оказывает нормализующего влияния на нарушенные вязкостные свойства крови. На это указывают статистически достоверные различия вязкости крови белых крыс на всех исследуемых скоростях сдвига между группой контроля и группой животных, подвергнутых превентивному 5 -ти минутному облучению волнами ТГЧ диапазона оксида азота перед действием стрессора, а также между группой животных, находящихся в состоянии острого стресса, и группой с 5-ти минутным облучением, предшествующим действию стрессора.

Индексы деформируемости и агрегации эритроцитов у белых крыс-самок в фазе Oestrus эстрального цикла в группе стресса статистически достоверно не отличаются от данных животных, подвергнутых превентивному 5-ти минутному облучению волнами ТГЧ диапазона МСИП оксида азота 150,176-150,664 ГГц, что свидетельствует об отсутствии эффективности изучаемого режима в предотвращении нарушений функциональной активности эритроцитов. На это также указывает наличие статистической достоверности в указанных показателях реологии крови между группой контроля и группой животных при превентивном 5-ти минутном облучении с последующей 3-х часовой иммобилизацией.

Исследование влияния превентивного облучения в течение 15-ти минут терагецовыми волнами указанного диапазона частот оксида азота на белых крыс в фазе Oestrus эстрального цикла, перед действием стрессорного фактора, показало, 
что данный временной режим сохраняет уровень вязкости крови при всех скоростях сдвига, характерной для животных контрольной группы. Об этом свидетельствует отсутствие статистически достоверной разницы в величине вязкости крови между группой контроля и группой животных с острым стрессом при 15-ти минутном превентивном облучении электромагнитными волнами исследуемого диапазона частот оксида азота, но наличие статистически достоверной разницы между группами животных в состоянии острого иммобилизационного стресса и подвергнутых терагерцевому облучению.

Превентивное облучение терагерцевыми волнами на частотах МСИП оксида азота 150,176-150,664 ГГц в течение 15-ти минут полностью предотвращает острые стресс-зависимые нарушения функциональной активности эритроцитов - деформируемости и агрегации. Об этом свидетельствуют отсутствие статистически достоверных различий в их показателях группы контроля и опытной с 15-ти минутным превентивным облучением, а также наличие статистической достоверности между группами острого стресса и с превентивным облучением терагерцевыми волнами.

Изучение эффективности превентивного 30-ти минутного облучения электромагнитными волнами терагерцевого диапазона МСИП оксида азота 150,176-150,664 ГГц на вязкость крови и функциональную активность эритроцитов белых крыс в фазе Oestrus эстрального цикла показало, что данный временной режим облучения также предотвращает развитие острых стрессорных изменений в указанных показателях реологии крови. Это подтверждается отсутствием статистически достоверных различий в величине вязкости крови при всех исследуемых скоростях сдвига группы контроля и опытной, в которой животные перед действием стрессора подвергались 30-ти минутному воздействию электромагнитными волнами терагерцевого диапазона указанных частот, а также её статистическая достоверность между группой стресса и опытной группой. Кроме того облучение электромагнитными волнами указанного терагерцевого диапазона оксида азота при превентивном 30-ти минутном воздействии на белых крыс в фазе Oestrus эстрального цикла и последующем действии острого стрессора оказывает выраженный профилактический эффект, предотвращая стресс-зависимые нарушения в функциональной активности эритроцитов - агрегации и деформируемости. Об этом свидетельствует отсутствие статистически достоверных их различий между группами контроля и опытной острого стресса с 30-ти минутным превентивным 
облучением, но наличие высокой степени достоверности между группой стресса и опытной группой животных.

Таким образом, анализируя результаты проведённого исследования можно сделать следующие выводы: 1) превентивное облучение терагерцевыми волнами на частотах МСИП оксида азота 150,176-150,664 ГГц крыс-самок в фазе Oestrus эстрального цикла, подвергнутых в последствие острому иммобилизационному стрессу, является эффективным в профилактике стресс-опосредованных нарушений в реологии крови в зависимости от времени ТГЧ воздействия; 2) превентивное 5 -ти минутное облучение электромагнитными волнами указанного диапазона частот не предотвращает острые стрессорные нарушения в вязкости крови при всех исследуемых скоростях сдвига и функциональной активности эритроцитов; 3) превентивные 15-ти и 30-ти минутные режимы облучения электромагнитными волнами терагерцевого диапазона на частотах оксида азота 150,176-150,664 являются эффективными и полностью предотвращают острые стресс-зависимые нарушения гемореологии: вязкости крови при всех скоростях сдвига и функциональной активности эритроцитов - их агрегации и деформируемости.

10.3. Влияние ингибитора NO-синтазы - L-NAME на вязкость цельной крови, функциональную активность эритроцитов крыс-самцов, подвергнутых облучению электромагнитными волнами терагерцевого диапазона на частотах МСИП оксида азота 150,176-150,664 ГГц

В предыдущих сериях собственных исследований было показано восстанавливающее влияние волн терагерцевого диапазона частот МСИП оксида азота 150,176-150,664 ГГц на нарушенные реологические свойства крови и функциональную активность эритроцитов - агрегацию и деформируемость наиболее эффективных 15 -ти и 30-ти минутных временных режимов облучения в условиях иммобилизационного стресса, а также их профилактическое действие при превентивном -- непрерывном, дробном облучении. Рядом исследований установлено, что облучение крыс-самцов в течение 30 -ти минут электромагнитными волнами на частотах МСИП оксида азота 150,176-150,664 ГГц приводит к повышению концентрации нитритов в плазме крови, что косвенно указывает на повышение синтеза эндогенного оксида азота (Киричук В.Ф., Креницкий А.П. и др., 2008).

В настоящей главе для установления одного из механизмов положительного биологического эффекта терагерцевых волн на частотах МСИП оксида азота 150,176150,664 ГГц на нарушенные реологические свойства крови приводятся данные об изучении влияния ингибитора эндотелиальной NO-синтазы - L-Name как на интактных 
крыс самцов (с облучением и без него), так и на крыс-самцов, подвергнутых острому иммобилизационному стрессу, при котором нарушена вязкость цельной крови и функциональная активность эритроцитов - их способность к агрегации и деформируемости.

\subsection{1. Влияние ингибитора NO-синтазы - L-NAME и облучения} электромагнитными волнами на частотах МСИП оксида азота 150,176-150,664 ГГц на вязкость цельной крови и функциональную активность эритроцитов интактных крыс-самцов

С целью установления механизмов влияния терагерцевых волн на частотах МСИП оксида азота 150,176-150,664 ГГц на реологические свойства крови интактных крыссамцов, функциональную активность эритроцитов - их способность к агрегации и деформируемости, была проведена серия экспериментов с введением блокатора эндотелиальной NO-синтазы - L-Name. Исследовались образцы цельной крови до и после проведения облучения терагерцевыми волнами на указанных частотах в течение 15 минут.

Введение ингибитора NO-синтазы - L-Name приводило к резкому ухудшению реологических свойств крови. Так, при низких скоростях сдвига - $20 \mathrm{c}^{-1}, 10 \mathrm{c}^{-1}$ и $5 \mathrm{c}^{-1}$, отражающих реологию крови в сосудах микроциркуляции, вязкость крови интактных животных статистически достоверно увеличивалась по сравнению с группой контроля и составляла 5,28 ( $\left.\mathrm{P}_{1}=0,000003\right), 5,91 \quad\left(\mathrm{P}_{1}=0,000003\right)$ и 6,47 $\left(\mathrm{P}_{1}=0,000003\right)$ мПа.с соответственно. После облучения на фоне введения блокатора эндотелиальной NOсинтазы она равнялась, соответственно, 5,39 ( $\left.\mathrm{P}_{2}=0,000003\right), 6,0\left(\mathrm{P}_{2}=0,000003\right)$ и 6,53 $\left(\mathrm{P}_{2}=0,000003\right)$ мПа.с при низких скоростях сдвига и отличалась от группы контроля с высокой степенью достоверности, но соответствовала данным интактных животных с введением ингибитора NO-синтазы - L-Name, то есть статистически достоверных различий между группами не отмечалось.

При высоких и средних скоростях сдвига - 300, 200, 150, 100, 50 c $^{-1}$, отражающих вязкость крови в сосудах крупного и среднего калибра, уинтактных крыс-самцов также отмечалось резкое увеличение вязкости крови при введении ингибитора NO-синтазы - L-Name. Так, при скоростях сдвига - 300c ${ }^{-1}$, $200 \mathrm{c}^{-1}$ и $150 \mathrm{c}^{-1}$ вязкость крови у этой группы животных статистически достоверно возрастала по сравнению с данными группы контроля и составляла 3,35 ( $\left.\mathrm{P}_{1}=0,000003\right)$, $3,35\left(\mathrm{P}_{1}=0,000003\right)$ и $3,4\left(\mathrm{P}_{1}=0,000003\right)$ мПа.с соответственно.

После облучения животных на фоне введения блокатора эндотелиальной NOсинтазы вязкость крови равнялась, соответственно, 3,44 ( $\left.\mathrm{P}_{2}=0,000003\right), 3,44\left(\mathrm{P}_{2}=0,000003\right)$ и $3,49\left(\mathrm{P}_{2}=0,000003\right)$ мПа·с, то есть с высокой степенью достоверности отличалась от группы контроля. Однако, вязкость крови при указанных скоростях сдвига опытной группы интактных 
животных с введением ингибитора эндотелиальной NO-синтазы и опытной группы с введением ингибитора эндотелиальной NO-синтазы и 15-ти минутным облучением статистически достоверно не отличались друг от друга. Следовательно, представленные данные указывают на отсутствие эффекта облучения терагерцевыми волнами на частотах молекулярного спектра излучения и поглощения оксида азота 150,176-150,664 ГГц на вязкостные свойства крови в сосудах разного калибра при введении ингибитора NO-синтазы - L-Name интактным животным.

Показатели функциональной активности эритроцитов (индексы агрегации, деформируемости) у интактных крыс-самцов при введении ингибитора NO-синтазы L-Name и интактных крыс-самцов при введении ингибитора NO-синтазы - L-Name совместно с облучением волнами МСИП оксида азота на частотах 150,176-150,664 ГГц (опытные группы) статистически достоверно отличались от группы контроля. Так, отмечалось увеличение индекса деформируемости как у опытных групп интактных крыссамцов при введении ингибитора NO-синтазы - L-Name, так и интактных крыс-самцов при введении ингибитора NO-синтазы - L-Name совместно с облучением волнами МСИП оксида азота на частотах 150,176-150,664 ГГц до 1,1 ( $\left.\mathrm{P}_{1}=0,001620\right)$ и 1,09 $\left(\mathrm{P}_{2}=0,003691\right)$ усл. ед. соответственно по сравнению с контролем. Индекс агрегации эритроцитов увеличивался соответственно до $1,43\left(\mathrm{P}_{1}=0,00044\right)$ и $1,44\left(\mathrm{P}_{2}=0,000018\right)$ усл.ед. и статистически достоверно отличались от контрольной группы. Однако показатели функциональной активности эритроцитов - агрегации и деформируемости опытных групп статистически достоверно не отличались друг от друга. Следовательно, представленные данные указывают на отсутствие эффекта облучения терагерцевыми волнами на частотах молекулярного спектра излучения и поглощения оксида азота 150,176-150,664 ГГц на функциональные свойства эритроцитов при введении ингибитора NO-синтазы - L-Name.

Таким образом, при введении ингибитора NO-синтазы - L-Name интактным животным отмечается значительное увеличение вязкости крови на всех исследуемых скоростях сдвига, повышение функциональной активности эритроцитов (агрегации и деформируемости) и отсутствие эффекта на показатели реологии крови 15-ти минутного облучения интактных животных при введении им ингибитора NO-синтазы терагерцевыми волнами на частотах молекулярного спектра излучения и поглощения оксида азота 150,176-150,664 ГГц по сравнению с группой контроля.

Представленные данные свидетельствуют о том, что введение интактным животным ингибитора эндотелиальной NO-синтазы приводит к нарушению синтеза оксида азота, являющегося нейротрансмиттером, вазодилататором, антиагрегантом, мощным фактором гемостаза [Волин М.С. и др., 1998; Северина И.С., 1995,1998; Киричук 
В.Ф и др, 2002,2003,2006], что обусловливает нарушения в вязкостных свойствах крови интактных животных, функциональной активности эритроцитов. В то же время, облучение интактных животных терагерцевыми электромагнитными волнами на частотах молекулярного спектра излучения и поглощения оксида азота 150,176-150,664 ГГц в течение 15-ти минут на фоне введения ингибитора NO-синтазы не восстанавливает нарушенную вязкость крови и функциональную активность эритроцитов, что указывает на снижение или полное прекращение синтеза эндогенного оксида азота из аминокислоты L-аргинина под влиянием эндотелиальной NO-синтазы.

\subsection{2. Влияние ингибитора NO-синтазы - L-NAME и облучения} электромагнитными волнами на частотах МСИП оксида азота 150,176-150,664 ГГц на вязкость цельной крови и функциональную активность крыс-самцов, подвергнутых острому иммобилизационному стрессу

Для изучения механизма положительного биологического эффекта терагерцевых волн на частотах молекулярного спектра излучения и поглощения оксида азота 150,176150,664 ГГц на реологические свойства крови крыс-самцов, подвергнутых острому иммобилизационному стрессу, исследовались образцы цельной крови до и после проведения облучения в течение 15 минут на фоне введения ингибитора эндотелиальной NO-синтазы - L-Name.

В результате проведённых исследований обнаружено статистически достоверное увеличение вязкости цельной крови при всех исследуемых скоростях сдвига, отражающих реологию крови в сосудах крупного, среднего и малого калибра (сосудах микроциркуляции), после проведения однократной 3-х часовой иммобилизации крыссамцов по сравнению с группой контроля и статистически достоверное увеличение индексов агрегации и деформируемости эритроцитов соответственно, что свидетельствует о наличии стресс-зависимых сдвигов в показателях реологии крови животных (см. также раздел 3.1.1).

Введение ингибитора NO-синтазы — L-Name приводило к дальнейшему резкому ухудшению реологических свойств крови. При низких скоростях сдвига $\left(20 \mathrm{c}^{-1}, 10 \mathrm{c}^{-1}\right.$ и $5 \mathrm{c}^{-1}$ ), отражающих состояние реологии крови в сосудах микроциркуляции, вязкость крови животных, подвергнутых острому иммобилизационному стрессу на фоне действия LName, статистически достоверно увеличивалась как по сравнению с группой контроля, так и с группой стрессированных животных и составляла 6,22 $\left(\mathrm{P}_{2}=0,000242\right), 7,7\left(\mathrm{P}_{2}=0,000003\right)$ и 9,84 ( $\left.\mathrm{P}_{2}=0,000003\right)$ мПа.с соответственно. После облучения стрессированных животных в течение 15-ти минут на фоне введения блокатора эндотелиальной NO-синтазы вязкость крови продолжала быть увеличенной как по сравнению с контролем, так и группой 
животных в состоянии острого стресса и равнялась, соответственно, 6,32 ( $\left.\mathrm{P}_{3}=0,000105\right)$, $7,83\left(\mathrm{P}_{3}=0,000003\right)$ и $10,0\left(\mathrm{P}_{3}=0,000003\right)$ мПа.с, статистически достоверно не отличаясь от данных группы животных, находящихся в состоянии острого стресса, которым был введён L-Name.

При высоких и средних скоростях сдвига - 300, 200, 150, 100, $50 \mathrm{c}^{-1}$, отражающих реологические свойства крови в сосудах крупного и среднего калибра, у крыс-самцов, подвергнугых острому иммобилизационному стрессу, вязкость крови статистически достоверно увеличена при всех скоростях сдвига и статистически достоверно повышена функциональная активность эритроцитов - агрегация, деформируемость. Отмечалось также статистически достоверное увеличение вязкости крови при введении стрессированным животным ингибитора NO-синтазы - L-Name. Так при скоростях сдвига $300 \mathrm{c}^{-1}, 200 \mathrm{c}^{-1}$ и $150 \mathrm{c}^{-1}$ вязкость крови статистически достоверно увеличивалась по сравнению с острым стрессом и составляла $3,56\left(\mathrm{P}_{2}=0,002145\right), 3,56\left(\mathrm{P}_{2}=0,002145\right)$ и 3,62 $\left(\mathrm{P}_{2}=0,000361\right)$ мПа.с. После облучения терагерцевыми волнами на частотах МСИП оксида азота 150,176-150,664 ГГц на фоне введения блокатора эндотелиальной NO-синтазы вязкость крови равнялась, соответственно, 3,58 $\left(\mathrm{P}_{3}=0,002145\right), 3,58\left(\mathrm{P}_{3}=0,002145\right)$ и 3,65 $\left(\mathrm{P}_{3}=0,000361\right)$ мПа.с. Однако, вязкость крови при указанных скоростях сдвига группы животных, подвергнутых острому иммобилизационному стрессу, и введению ингибитора эндотелиальной NOсинтазы по сравнению с группой животных, подвергнутых острому иммобилизационному стрессу, и введением ингибитора эндотелиальной NO-синтазы с 15 минутным облучением статистически достоверно не отличались друг от друга. Это указывает на отсутствие эффекта на вязкостные свойства крови облучения терагерцевыми волнами на частотах молекулярного спектра излучения и поглощения оксида азота 150,176-150,664 ГГц на фоне действия ингибитора эндотелиальной NO-синтазы L-Name, что свидетельствует о возможном участии эндотелиальной NO-синтазы в реализации эффекта терагерцевых волн МСИП оксида азота 150,176-150,664 ГГц.

Показатели функциональной активности эритроцитов (индексы агрегации, деформируемости) у крыс-самцов, подвергнутых острому иммобилизационному стрессу, при введении ингибитора NO-синтазы - L-Name и крыс-самцов, подвергнутых острому иммобилизационному стрессу, при введении ингибитора NO-синтазы - L-Name совместно с облучением волнами МСИП оксида азота на частотах 150,176-150,664 ГГц статистически достоверно отличались от группы стрессированных животных. Так, отмечалось увеличение индекса деформируемости эритроцитов как у крыс-самцов, подвергнутых острому иммобилизационному стрессу, при введении ингибитора NO-синтазы - L-Name, так и подвергнутых острому иммобилизационному стрессу совместно с облучением волнами МСИП оксида азота на частотах 150,176-150,664 ГГц на 
фоне действия ингибитора NO-синтазы - L-Name до 1,14 и 1,14 усл. ед. соответственно как по сравнению с контролем, так и группой острого стресса $\left(\mathrm{P}_{2}=0,001620\right.$; $\left.\mathrm{P}_{3}=0,002823\right)$. Индекс агрегации эритроцитов увеличивался соответственно до 1,53 и 1,44 усл.ед. и статистически достоверно отличался как от контроля, так и от группы острого стресса $\left(\mathrm{P}_{2}=0,00044 ; \mathrm{P}_{3}=0,013590\right)$. Однако показатели функциональной активности эритроцитов - агрегации (1,53 и 1,44 усл.ед.) и деформируемости $(1,14$ и 1,14$)$ статистически достоверно не отличались друг от друга $-\mathrm{P}_{4}=0,520283$ и $\mathrm{P}_{4}=0,819546$ соответственно, что указывает на отсутствие эффекта облучения терагерцевыми волнами на частотах молекулярного спектра излучения и поглощения оксида азота 150,176-150,664 ГГц при введении ингибитора NO-синтазы - L-Name.

Таким образом, при введении ингибитора NO-синтазы - L-Name отмечается значительное увеличение вязкости крови животных, подвергнутых острому иммобилизационному стрессу, нарушение функциональной активности эритроцитов, что проявлялось в увеличении их способности к агрегации и деформируемости, а также отсутствие эффекта 15-ти минутного облучения терагерцевыми волнами на частотах молекулярного спектра излучения и поглощения оксида азота 150,176-150,664 ГГц животных, подвергнутых острому иммобилизационному стрессу на фоне действия ингибитора эндотелиальной NO-синтазы - L-Name.

\section{Резюме}

У белых крыс-самцов при острой и длительной (хронической) стрессорной реакции увеличена вязкость цельной крови, в большей степени выраженная у животных с хроническим стрессом, повышена агрегационная активность эритроцитов и их способность к деформации.

При непрерывном и дробном режимах облучения терагерцевыми волнами на частотах МСИП оксида азота 150,176-150,664 ГГц крыс-самцов, находящихся в состоянии острого иммобилизационного стресса, 5-ти минутное воздействие не оказывает нормализующего эффекта на нарушенную вязкость крови и функциональную активность эритроцитов, а превентивное облучение не предотвращает стресс-опосредованные нарушения указанных показателей реологических свойств крови. Облучение крыс-самцов в течение 15-ти и 30-ти минут обоими режимами на фоне острого стресса полностью восстанавливает нарушенные вязкостные свойства крови, функциональную активность эритроцитов: их агрегацию и деформируемость.

Превентивное дробное облучение ТГЧ волнами на частотах оксида азота 150,176150,664 ГГц в течение 5-ти минут не упреждает стресс-зависимые нарушения вязкости 
крови в сосудах крупного, среднего калибра, но лимитирует их развитие в сосудах микроциркуляции и предотвращает стрессорные нарушения в функциональной активности эритроцитов - их способности к агрегации и деформируемости. Превентивное облучение в течение 15-ти и 30-ти минут обладает антистрессорным эффектом на показатели реологии крови. Это проявляется в сохранении величины вязкости крови на всех исследуемых скоростях сдвига и в отсутствии стресс-опосредованных изменений функциональной активности эритроцитов - их способности к агрегации и деформируемости.

Непрерывное облучение животных в течение 5-и минут на фоне хронического (длительного) стресса ТГЧ волнами на частотах МСИП оксида азота 150,176-150,664 ГГц не оказывает нормализующего эффекта на нарушенные реологические свойства крови. 15ти и 30-ти минутные режимы облучения животных полностью не восстанавливают нарушенную вязкость крови, но нормализуют деформируемость и частично агрегацию эритроцитов.

Эффективность непрерывного превентивного воздействия электромагнитных волн терагерцевого диапазона на частотах МСИП оксида азота 150,176-150,664 ГГц в условиях хронического стресса не одинакова и зависит от временных режимов облучения: при воздействии в течение 15-ти предотвращает стресс-зависимые нарушения вязкости крови в сосудах крупного и среднего калибра, но мало эффективны в сосудах микроциркуляции, сохраняет нормальную агрегацию и деформируемость эритроцитов. 30-ти минутное воздействие предупреждает развитие стресс-зависимых нарушений вязкости крови и функциональной активности эритроцитов.

У белых крыс-самок в стадиях Dioestrus и Oestrus эстрального цикла при острой стрессорной реакции происходит увеличение вязкости цельной крови, увеличивается агрегационная активность эритроцитов и повышается их способность к деформации. Крысы-самки в фазе Dioestrus эстрального цикла более чувствительны к действию стрессора, чем в фазе Oestrus.

При непрерывном и превентивном ТГЧ облучении электромагнитными волнами на частотах МСИП оксида азота 150,176-150,664 ГГц крыс-самок в обеих стадиях эстрального цикла, находящихся в состоянии острого стресса, 5-ти минутное воздействие не нормализует стрессорные и не предотвращает развитие постстрессоных нарушений вязкости крови и функциональной активности эритроцитов не зависимо от фазы эстрального цикла. Непрерывные 15-ти и 30-ти минутные временные режимы полностью восстанавливают нарушенную вязкость крови, агрегацию и деформируемость 
эритроцитов, а превентивные - препятствуют развитию постстрессорных нарушений в реологических свойствах крови.

Показано отсутствие нормализующего эффекта 15-ти минутного облучения терагерцевыми волнами на частотах молекулярного спектра излучения и поглощения оксида азота 150,176-150,664 ГГц на животных, находящихся в состоянии острого иммобилизационного стресса, на фоне действия ингибитора эндотелиальной NO-синтазы -- L-Name. Это свидетельствует о роли эндогенного оксида азота и эндотелиальной NOсинтазы в механизмах потенцирования положительного корригирующего эффекта облучения на частотах МСИП оксида азота 150,176-150,664 ГГц на нарушенные реологические свойства крови: вязкость крови, функциональную активность эритроцитов - их агрегацию и деформируемость.

\author{
ГЛАВА ХІ
}

ВЛИЯНИЕ ЭЛЕКТРОМАГНИТНОГО ОБЛУЧЕНИЯ ТЕРАГЕРЦЕВОГО ДИАПАЗОНА НА ЧАСТОТЕ МОЛЕКУЛЯРНОГО СПЕКТРА ИЗЛУЧЕНИЯ И ПОГЛОЩЕНИЯ АТМОСФЕРНОГО КИСЛОРОДА 129 ГГЦ НА ОСТРЫЕ СТРЕССОРНЫЕ НАРУШЕНИЯ РЕОЛОГИЧЕСКИХ СВОЙСТВ КРОВИ У БЕЛЫХ КРЫС

11.1. Изменения вязкости крови и функциональной активности эритроцитов у белых крыс-самцов в состоянии острого стресса под воздействием терагерцевых волн на частоте молекулярного спектра излучения и поглощения атмосферного кислорода 129 ГГц

11.1.1. Исследование влияния различных временных режимов непрерывного электромагнитного излучения на частоте молекулярного спектра излучения и поглоцения атмосферного кислорода 129 ГГц на белых крыс-самцов, подвергнутых острому иммобилизационному стрессу

Для изучения влияния волн терагерцевого диапазона частот атмосферного кислорода 129 ГГц на вязкостные свойства крови и функциональную активность эритроцитов (агрегацию, деформируемость) была проведена серия экспериментов, в которых белые крысы-самцы подвергались непрерывному ТГЧ-облучению после однократной 3-х часовой иммобилизации (острый стресс). Продолжительность облучения составляла 5, 15 и 30 минут.

При исследовании влияния непрерывного 5-ти минутного режима облучения установлено, что воздействие электромагнитными волнами ТГЧ диапазона на частотах 
МСИП атмосферного кислорода 129 ГГц на стрессированных животных не вызывает выраженного влияния как на нарушенную вязкость цельной крови, так и изменённую функциональную активность эритроцитов - их агрегацию и деформируемость. На это указывает отсутствие статистически достоверных различий вязкости крови на всех исследуемых скоростях сдвига, а также показателей функциональной активности эритроцитов опытной группы с 5-ти минутным облучением на фоне острого стресса с показателями группы острого стресса и наличие статистически достоверных различий высокой степени достоверности по сравнению с группой контроля.

Изучение влияния 15 минутного режима облучения волнами МСИП атмосферного кислорода 129 ГГц на животных, подвергнутых острому иммобилизационному стрессу, показало полное восстановление вязкости крови до уровня, характерного для животных контрольной группы, на всех исследуемых скоростях сдвига, характеризующих кровоток в сосудах крупного, среднего и малого калибра (сосуды микроциркуляции) [Ройтман Е.В.,2000,2003]. Об этом свидетельствует отсутствие статистически достоверных отличий вязкости крови опытной группы острого стресса с 15-ти минутным облучением по сравнению с вязкостью крови группы контроля и их наличие высокой степени достоверности по сравнению с группой острого стресса.

Исследование функциональной активности эритроцитов - агрегации и деформируемости также указывает на полное восстановление их функций под воздействием 15-ти минутного облучения электромагнитными волнами исследуемого диапазона частот. Это подтверждается отсутствием статистически достоверных различий между индексами агрегации и деформируемости эритроцитов опытной группы животных и группы контроля, а также наличием статистически достоверных различий по сравнению с группой острого стресса.

При исследовании влияния облучения электромагнитными волнами терагерцевого диапазона МСИП атмосферного кислорода 129 ГГц в течение 30-ти минут на вязкостные свойства крови стрессированных животных показано также полное их восстановление при больших, средних и малых скоростях сдвига. Об этом свидетельствует отсутствие статистически достоверных различий в величине вязкости крови на всех исследуемых скоростях сдвига опытной группы с 30-ти минутным облучением и группы контроля и наличие статистически достоверных различий по сравнению с группой острого стресса.

Воздействие 30-ти минутного режима облучения электромагнитными волнами терагерцевого диапазона МСИП атмосферного кислорода 129 ГГц способствует также восстановлению функциональных свойств эритроцитов - их агрегации и деформируемости, что в существенной мере положительно влияет на вязкостные свойства 
крови в целом [Киричук В.Ф. и соавт. 2003, 2006]. Об этом свидетельствует отсутствие статистически достоверных различий между показателями контрольной группы животных и опытной группы с 30-ти минутным облучением, а также наличие статистически достоверных отличий между опытной группой крыс-самцов и группой острого стресса.

Таким образом, при анализе результатов проведённого исследования, можно сделать следующие выводы: 1) облучение электромагнитными волнами терагерцевого диапазона частот МСИП атмосферного кислорода 129 ГГц способно восстанавливать в зависимости от временных режимов воздействия острые стресс-зависимые нарушения вязкости крови и функциональной активности эритроцитов - их деформируемость и агрегацию; 2) 5-ти минутное воздействие электромагнитными волнами указанного диапазона частоты 129 ГГц на фоне острого стресса не оказывает выраженного восстановительного эффекта нарушенной острым стрессом вязкости крови и функциональной активности эритроцитов; 3) 15-ти и 30-ти минутные режимы воздействия электромагнитными терагерцевыми волнами ТГЧ диапазона атмосферного кислорода 129 ГГц эффективны и полностью восстанавливают стресс-зависимые нарушения вязкости крови и функциональной активности эритроцитов - агрегации и деформируемости.

11.1.2. Изменения вязкости крови и функциональной активности эритроцитов у бельх крыс-самцов в состоянии острого иммобилизационного стресса при непрерывном превентивном воздействии терагерцевых волн на частоте молекулярного спектра излучения и поглощения атмосферного кислорода $129 \Gamma \Gamma$

С целью изучения возможности предотвращения развития характерных для острой стресс-реакции нарушений вязкостных свойств крови, а так же функциональной активности эритроцитов была проведена серия экспериментов, в которых белые крысы-самцы подвергались непрерывному ТГЧ-облучению до начала действия стрессора. Продолжительность облучения животных в данных группах составляла 5,15 и 30 минут.

При исследовании влияния непрерывного предварительного 5-ти минутного режима облучения установлено, что воздействие электромагнитными волнами ТГЧ диапазона на частоте МСИП атмосферного кислорода 129 ГГц перед проведением 3-х часовой иммобилизации (острый стресс) не препятствует развитию нарушений в вязкости крови и в функциональной активности эритроцитов стрессированных животных. На это указывают статистически 
достоверные различия вязкости крови животных, как группы контроля, так и острого стресса с аналогичными показателями животных, подвергнутых превентивному 5-ти минутному облучению волнами ТГЧ диапазона атмосферного кислорода (опытная группа) на всех исследуемых скоростях сдвига. Индексы деформируемости и агрегации эритроцитов группы стресса также статистически достоверно не отличаются от группы животных, подвергнутых превентивному 5-ти минутному облучению волнами ТГЧ диапазона атмосферного кислорода, что свидетельствует об отсутствии эффективности изучаемого режима в предотвращении нарушений в функциональной активности эритроцитов.

При изучении влияния превентивного облучения в течение 15-ти минут электромагнитными терагецовыми волнами на частоте МСИП атмосферного кислорода 129 ГГц животных, подвергнутых острому стрессу, показано, что данный временной режим приводит к сохранению величины вязкости крови, характерной для животных контрольной группы. Об этом свидетельствует отсутствие статистически достоверной разницы вязкости крови между группой контроля и опытной группой острого стресса с 15-ти минутным превентивным облучением электромагнитными волнами частоты указанного диапазона, а также функциональной активности эритроцитов - деформируемости и агрегации.

Сравнивая показатели группы стресса и опытной группы с 15 -ти минутным превентивным облучением, отмечается высокая статистически достоверная разница в вязкости крови при всех исследуемых скоростях сдвига, а также в индексах функциональной активности эритроцитов - деформируемости и агрегации, что подтверждает выраженный профилактический эффект превентивного 15-ти минутного облучения электромагнитными волнами ТГЧдиапазона на частоте МСИП атмосферного кислорода 129 ГГц на показатели реологии крови.

Изучение влияния превентивного 30-ти минутного воздействия электромагнитными волнами терагерцевого диапазона частоты МСИП атмосферного кислорода 129 ГГц на вязкостные свойства крови и функциональную активность эритроцитов животных показало, что данный временной режим облучения предотвращает развитие острых стрессорных изменений в вязкости крови. Статистически достоверные отличия вязкости крови группы контроля и опытной, в которой животные предварительно перед действием стрессора 
подвергались 30-ти минутному воздействию электромагнитными волнами терагерцевого диапазона частоты МСИП атмосферного кислорода 129 ГГц, отсутствуют, но имеется статистическая достоверность в вязкости крови между группой стресса и опытной группой.

Электромагнитные волны указанного диапазона частот при предварительном 30-ти минутном воздействии сохраняют функциональную активность эритроцитов - агрегацию и деформируемость. Об этом свидетельствует отсутствие статистически достоверных различий между группой контроля и опытной группой острого стресса с 30-ти минутным предварительным облучением терагерцевыми электромагнитными волнами МСИП атмосферного кислорода 129 ГГц, но наличие статистически достоверных различий между группой стресса и опытной группой животных.

Таким образом, анализируя данные проведённого исследования, можно сделать следующие выводы: 1)превентивное облучение электромагнитными волнами терагерцевого диапазона частоты МСИП атмосферного кислорода 129 ГГц способно предотвращать в зависимости от временных режимов воздействия острые стрессзависимые нарушения вязкости крови и функциональной активности эритроцитов деформируемости и агрегации; 2) 5-ти минутное превентивное воздействие электромагнитными волнами указанного диапазона частоты 129 ГГц не предотвращает стрессорные нарушения вязкости крови при всех скоростях сдвига и в функциональной активности эритроцитов; 3) 15-ти и 30-ти минутные режимы превентивного воздействия электромагнитными терагерцевыми волнами на частоте МСИП атмосферного кислорода 129 ГГц полностью предотвращают стресс-зависимые нарушения вязкости крови и функциональной активности эритроцитов.

11.2. Влияние терагерцевых волн на частоте молекулярного спектра излучения и поглощения атмосферного кислорода 129 ГГц при остром иммобилизационном стрессе на реологические свойства крови белых крыс-самок в фазах Dioestrus и Oestrus эстрального цикла

11.2.1. Изменения вязкости крови и функциональной активности эритроцитов у белых крыс-самок в фазе Dioestrus эстрального цикла в состоянии острого иммобилизационного стресса при непрерывном воздействии терагерцевых волн на частоте молекулярного спектра излучения и поглощения атмосферного кислорода 129 ГГи

Для выявления возможности коррекции нарушенных острым стрессом реологических свойств крови (вязкости, функциональной активности эритроцитов - их 
способности к агрегации и деформируемости) волнами терагерцевого диапазона на частоте МСИП атмосферного кислорода 129 ГГц крыс-самок в фазе Dioestrus эстрального цикла была проведена серия экспериментов, в которых животные подвергались непрерывному ТГЧ облучению в течение 5, 15 и 30 мин после однократной 3-х часовой иммобилизации (острого стресса).

При исследовании непрерывного влияния 5-ти минутного режима облучения установлено, что воздействие электромагнитными волнами ТГЧ диапазона на частоте МСИП атмосферного кислорода 129 ГГц на стрессированных животных не вызывает выраженного влияния на нарушенную вязкость цельной крови. На это указывает наличие статистически достоверных различий вязкости крови на всех исследуемых скоростях сдвига группы с 5-ти минутным облучением на фоне острого стресса как по сравнению с данными группы острого стресса, так и с показателями группы контроля.

Показано, что ТГЧ облучение электромагнитными волнами указанного диапазона частот в течение 5-ти минут нормализует деформируемость эритроцитов, но не восстанавливает нарушения в их агрегационной активности. На это указывает отсутствие статистически достоверных различий индекса деформируемости эритроцитов (ИДЭ) по сравнению с данными группы контроля, но их наличие по сравнению с показателями группы острого стресса. Индекс агрегации эритроцитов статистически достоверно отличался как от группы контроля, так от группы острого стресса.

Изучение влияния 15-ти минутного режима облучения электромагнитными волнами на частоте МСИП атмосферного кислорода 129 ГГц на белых крыс в фазе Dioestrus эстрального цикла, подвергнутых острому иммобилизационному стрессу, показало полное восстановление вязкости крови до уровня, характерного для животных контрольной группы на всех исследуемых скоростях сдвига, что свидетельствует о нормализации показателей крови в сосудах крупного, среднего и малого калибра (сосуды микроциркуляции). На это указывает отсутствие статистически достоверных отличий вязкости крови опытной группы острого стресса с 15-ти минутным облучением по сравнению с данными группы контроля и её наличие по сравнению с группой острого стресса.

Исследование функциональной активности эритроцитов - агрегации и деформируемости крыс-самок в стадии Dioestrus эстрального цикла, подвергнутых острому иммобилизационному стрессу, также указывает на полное восстановление их функций под воздействием 15-ти минутного облучения электромагнитными волнами исследуемого диапазона частот. 
Это подтверждается отсутствием статистически достоверных различий между показателями агрегации и деформируемости эритроцитов опытной группы животных и группы контроля, а также их наличием по сравнению с группой острого стресса.

Воздействие 30-ти минутного режима облучения электромагнитными волнами на частоте МСИП атмосферного кислорода 129 ГГц на белых крыс в фазе Dioestrus эстрального цикла, подвергнутых острому иммобилизационному стрессу, также показало полное восстановление вязкости крови до уровня, характерного для диэстральных крыс контрольной группы на всех исследуемых скоростях сдвига. Об этом свидетельствует отсутствие статистически достоверных отличий вязкости крови опытной группы острого стресса с 30-ти минутным облучением по сравнению с данными группы контроля и её наличие по сравнению с показателями группы острого стресса.

Исследование функциональной активности эритроцитов - агрегации и деформируемости крыс-самок в стадии Dioestrus эстрального цикла, подвергнутых острому иммобилизационному стрессу, также показывает полное восстановление их функций под воздействием 30-ти минутного облучения электромагнитными волнами на частоте МСИП атмосферного кислорода 129 ГГц. Это подтверждается отсутствием статистически достоверных различий между показателями агрегации и деформируемости эритроцитов опытной группы животных и группы контроля, а также их наличием по сравнению с группой острого стресса.

Таким образом, при анализе результатов проведённого исследования можно сделать следующие выводы: 1) облучение электромагнитными волнами терагерцевого диапазона на частоте МСИП атмосферного кислорода 129 ГГц способно восстанавливать в зависимости от временных режимов воздействия острые стрессзависимые нарушения вязкости крови и функциональной активности эритроцитов - их деформируемость и агрегацию у крыс-самок в фазах Dioestrus эстрального цикла; 2) 5-ти минутное воздействие электромагнитными волнами указанного диапазона частот на фоне острого стресса не оказывает выраженного восстанавливающего эффекта на нарушенную острым стрессом вязкость крови, нормализует деформируемость эритроцитов и не влияет на их увеличенную агрегационную активность; 3) 15-ти и 30-ти минутные режимы воздействия электромагнитными волнами терагерцевого диапазона на частоте атмосферного кислорода 129 ГГц эффективны и полностью восстанавливают стресс-зависимые нарушения вязкости крови и функциональной активности эритроцитов - агрегации и деформируемости у крыс-самок в фазе Dioestrus эстрального цикла. 


\subsection{2. Изменения вязкости крови и функциональной активности эритроцитов}

у белых крыс-самок в фазе Оеstrus эстрального цикла в состоянии острого иммобилизационного стресса при непрерывном воздействии терагерцевых волн на частоте молекулярного спектра излучения и поглощения атмосферного кислорода $129 \Gamma \Gamma u$

С целью изучения эффективности влияния электромагнитных волн терагерцевого диапазона на частоте МСИП атмосферного кислорода 129 ГГц на нарушенную острым стрессом вязкость крови и функциональную активность эритроцитов (агрегацию, деформируемость) белых крыс в фазе Oestrus эстрального цикла, была проведена серия экспериментов, в которых они подвергались непрерывному ТГЧ-облучению, продолжительность которого составляла 5, 15 и 30 минут после однократной 3-х часовой иммобилизации (острого стресса).

Установлено, что непрерывное 5-ти минутное облучение электромагнитными волнами ТГЧ диапазона на частоте МСИП атмосферного кислорода 129 ГГц на стрессированных животных не оказывает выраженного влияния как на нарушенную вязкость цельной крови, так и функциональную активность эритроцитов - их агрегацию и деформируемость. На это указывает наличие статистически достоверных различий вязкости крови на всех исследуемых скоростях сдвига опытной группы с 5-ти минутным облучением на фоне острого стресса как по сравнению с данными группы острого стресса, так и показателями группы контроля, а также отсутствие статистически достоверных различий функциональной активности эритроцитов (агрегации, деформируемости) опытной группы по сравнению с группой острого стресса, но их наличие по сравнению с группой контроля.

Воздействие 15-ти минутного режима облучения электромагнитными волнами на частоте МСИП атмосферного кислорода 129 ГГц на белых крыс в фазе Oestrus эстрального цикла, подвергнутых острому иммобилизационному стрессу, показало полное восстановление вязкости крови на всех исследуемых скоростях сдвига и функциональной активности эритроцитов - их способности к агрегации и деформируемости до уровня, характерного для животных контрольной группы аналогичной фазы эстрального цикла. Об этом свидетельствует отсутствие статистически достоверных отличий изучаемых показателей реологии крови опытной группы острого стресса с 15-ти минутным облучением по сравнению с данными группы контроля и их наличие по сравнению с группой острого стресса.

Исследование 30-ти минутного режима облучения электромагнитными волнами на частоте МСИП атмосферного кислорода 129 ГГц на белых крыс в фазе Oestrus 
эстрального цикла, подвергнутых острому иммобилизационному стрессу, также показало полное восстановление вязкости крови до уровня, характерного для крыс-самок контрольной группы на всех исследуемых скоростях сдвига, что свидетельствует о её нормализации в сосудах крупного, среднего и малого калибра. На это указывает отсутствие статистически достоверных отличий вязкости крови опытной группы острого стресса с 30-ти минутным облучением по сравнению с данными группы контроля и наличие их достоверности по сравнению с группой острого стресса.

Изучение функциональной активности эритроцитов - агрегации и деформируемости крыс-самок в стадии Oestrus эстрального цикла, подвергнутых острому иммобилизационному стрессу, также указывает на полное восстановление их функций под воздействием 30-ти минутного облучения электромагнитными волнами на частоте МСИП атмосферного кислорода 129 ГГц. Это подтверждается отсутствием статистически достоверных различий между индексами агрегации и деформируемости эритроцитов опытной группы животных и группы контроля, а также их наличием по сравнению с группой острого стресса.

Таким образом, при анализе результатов проведённого исследования можно сделать следующие выводы: 1) облучение электромагнитными волнами терагерцевого диапазона на частоте МСИП атмосферного кислорода 129 ГГц способно восстанавливать в зависимости от временных режимов воздействия острые стрессопосредованные нарушения вязкости крови и функциональной активности эритроцитов их деформируемость и агрегацию у крыс-самок в фазе Oestrus эстрального цикла; 2) 5-ти минутное воздействие электромагнитными волнами указанного диапазона частот на фоне острого стресса не оказывает нормализующего эффекта нарушенной острым стрессом вязкости крови и функциональной активности эритроцитов у белых крыс в фазах Oestrus эстрального цикла; 3) 15-ти и 30-ти минутные режимы облучения терагерцевыми волнами на частоте МСИП атмосферного кислорода 129 ГГц эффективны и полностью восстанавливают стрессорные нарушения вязкости крови и функциональной активности эритроцитов - агрегации и деформируемости у крыс-самок в фазе Oestrus эстрального цикла. 


\subsection{3. Изменения вязкости крови и функциональной активности эритроцитов}

y белых крыс в фазе Dioestrus эстрального цикла в состоянии острого иммобилизационного стресса под воздействием непрерывного превентивного облучения терагерцевыми волнами на частоте молекулярного спектра излучения и поглощения атмосрерного кислорода 129 ГГи

С целью изучения возможности предотвращения развития характерных для острой стресс-реакции нарушений вязкости крови и функциональной активности эритроцитов были проведены эксперименты, в которых белые крысы в фазе Dioestrus эстрального цикла подвергались непрерывному ТГЧ облучению в течение 5,15 и 30 минут на частоте атмосферного кислорода 129 ГГц до начала действия стрессора. Выявлено, что непрерывное превентивное 5-ти минутное облучение электромагнитными волнами ТГЧ диапазона на частоте МСИП атмосферного кислорода 129 ГГц с последующей 3-х часовой иммобилизацией животных (острый стресс) не препятствует развитию нарушений в вязкости крови. На это указывают статистически достоверные различия вязкости крови на всех исследуемых скоростях сдвига белых крыс группы контроля и группы животных, подвергнутых превентивному 5-ти минутному облучению, а также статистически достоверные различия между группами животных с острым стрессом и превентивным 5-ти минутным облучением, предшествующим действию стрессора.

Индекс деформируемости эритроцитов опытной группы с превентивным 5-ти минутным ТГЧ облучением статистически достоверно не отличается от аналогичного показателя группы контроля, что свидетельствует о сохранении деформируемости эритроцитов под влиянием облучения на частоте атмосферного кислорода 129 ГГц в течение 5-ти минут перед проведением 3-х часовой иммобилизации животных. Индекс агрегации эритроцитов группы контроля статистически достоверно отличался от группы белых крыс, подвергнутых превентивному 5-ти минутному облучению с последующим действием стрессора, а также имелись статистически достоверные различия между группами острого стресса и превентивного 5-ти минутного облучения с последующим действием стрессора, что свидетельствует об отсутствии эффективности изучаемого временного режима в предотвращении нарушений агрегационной активности эритроцитов.

Превентивное облучение в течение 15-ти минут терагецовыми волнами на частоте МСИП атмосферного кислорода 129 ГГц белых крыс в фазе Dioestrus 
эстрального цикла, подвергнутых острому стрессу, не приводит к изменению величины вязкости крови при всех скоростях сдвига, характерной для животных контрольной группы, так как отсутствует статистически достоверная разница вязкости крови у белых крыс групп контроля и опытной группой острого стресса с превентивным облучением электромагнитными волнами указанного диапазона частот и последующим действием стрессора.

Превентивное облучение в течение 15 -ти минут терагерцевыми волнами на частоте МСИП атмосферного кислорода 129 ГГц полностью предотвращает острые стресс-зависимые нарушения функциональной активности эритроцитов деформируемости и агрегации. Об этом свидетельствуют отсутствие статистически достоверных различий в показателях группы контроля и опытной с 15-ти минутным превентивным облучением, но наличие статистической достоверности между группой острого стресса и группой с превентивным облучением с последующим действием стрессора.

Изучение превентивного 30 -ти минутного влияния электромагнитных волн терагерцевого диапазона на частоте МСИП атмосферного кислорода 129 ГГц на вязкость и функциональную активность эритроцитов белых крыс в фазе Dioestrus эстрального цикла показало, что данный временной режим облучения предотвращает развитие острых стресс-опосредованных изменений как в вязкости крови при всех скоростях сдвига, так и в функциональной активности эритроцитов - их способности к агрегации и деформируемости. Статистически достоверные различия вязкости крови при всех скоростях сдвига между группами контроля и опытной, в которой животные перед действием стрессора подвергались 30-ти минутному воздействию электромагнитными волнами терагерцевого диапазона указанной частоты, отсутствуют, но имеется статистическая достоверность между животными в группах острого стресса и опытной.

Облучение электромагнитными волнами терагерцевого диапазона на частоте МСИП атмосферного кислорода 129 ГГц при превентивном 30-ти минутном воздействии на белых крыс в фазе Dioestrus эстрального цикла и последующем действии острого стрессора предотвращает стресс-зависимые нарушения в функциональной активности эритроцитов - агрегации и деформируемости. Об этом свидетельствует отсутствие статистически достоверных различий в указанных показателях между группами контроля и 
опытной - острого стресса с 30-ти минутным превентивным облучением, но её наличие между группой стресса и опытной группой животных.

Таким образом, анализируя данные проведённого исследования можно сделать следующие выводы: 1) превентивное облучение терагерцевыми волнами на частоте МСИП атмосферного кислорода 129 ГГц белых крыс в фазе Dioestrus эстрального цикла, подвергнутых в последствие острому иммобилизационному стрессу, является эффективным в зависимости от времени ТГЧ воздействия; 2) превентивное 5-ти минутное облучение электромагнитными волнами указанного диапазона частот не обладает эффективностью в предотвращении острых стрессорных нарушений вязкости крови при всех скоростях сдвига, способствует сохранению деформационной способности мембран эритроцитов, однако не препятствует стресс-опосредованным нарушениям их агрегационной активности; 3) превентивные 15-ти и 30-ти минутные режимы облучения электромагнитными волнами терагерцевого диапазона на изучаемой частоте атмосферного кислорода 129 ГГц являются эффективными, полностью предотвращают острые стрессорные нарушения вязкости крови при всех скоростях сдвига и функциональной активности эритроцитов - их способности к агрегации и деформируемости.

11.2.4. Изменения вязкости крови и функциональной активности эритроцитов у бельх крыс-самок в фазе Оеstrus эстрального цикла в состоянии острого иммобилизационного стресса под воздействием непрерывного превентивного облучения терагерцевыми волнами на частоте молекулярного спектра излучения и поглощения атмосферного кислорода 129 ГГц

Для изучения возможности превентивного корригирующего эффекта электромагнитных волн терагерцевого диапазона на частоте МСИП атмосферного кислорода 129 ГГц в предотвращении нарушений реологических свойств крови - вязкости и функциональной активности эритроцитов, характерных для острой стресс-реакции, были проведены серии экспериментов, в которых белые крысы в фазе Oestrus эстрального цикла подвергались непрерывному ТГЧ облучению в течение 5,15 и 30 минут до начала действия стрессора.

Результаты проведённого исследования по воздействию непрерывного превентивного 5-ти минутного режима облучения показали, что электромагнитные волны ТГЧ диапазона на частоте МСИП атмосферного кислорода 129 ГГц не эффективны в предотвращении нарушений вязкости крови на всех исследуемых скоростях сдвига и функциональной активности эритроцитов - их 
способности к агрегации и деформируемости. На это указывают статистически достоверные различия вязкости крови белых крыс на всех скоростях сдвига между группой контроля и группой животных, подвергнутых превентивному 5 -ти минутному облучению волнами ТГЧ диапазона атмосферного кислорода перед действием стрессора, а также между группой животных, находящихся в состоянии острого стресса, и группой с 5-ти минутным облучением, предшествующим действию стрессора.

Индексы деформируемости и агрегации эритроцитов у белых крыс в фазе Oestrus эстрального цикла в группе острого стресса статистически достоверно не отличаются от данных животных, подвергнутых превентивному 5-ти минутному облучению волнами ТГЧ диапазона на частоте МСИП атмосферного кислорода 129 ГГц, что также свидетельствует об отсутствии эффективности изучаемого режима облучения в предотвращении нарушений функциональной активности эритроцитов. На это указывает наличие статистической достоверности в указанных показателях реологии крови между группой контроля и группой животных при превентивном 5-ти минутном облучении с последующей 3-х часовой иммобилизацией (опытной) и их отсутствие между группами острого стресса и опытной.

Исследование влияния превентивного облучения в течение 15-ти минут терагецовыми волнами указанного диапазона частоты атмосферного кислорода на белых крыс в фазе Oestrus эстрального цикла, перед действием стрессорного фактора, показало, что данный временной режим сохраняет уровень вязкости крови при всех скоростях сдвига, характерной для животных контрольной группы. Об этом свидетельствует отсутствие статистически достоверной разницы в величине вязкости крови между группой контроля и группой животных с острым стрессом при 15-ти минутном превентивном облучении электромагнитными волнами исследуемой частоты атмосферного кислорода 129 ГГц, но наличие статистически достоверной разницы между группами животных в состоянии острого иммобилизационного стресса и подвергнутых терагерцевому облучению.

Превентивное облучение терагерцевыми волнами на частоте МСИП атмосферного кислорода 129 ГГц в течение 15-ти минут полностью предотвращает острые стресс-зависимые нарушения функциональной активности эритроцитов - деформируемости и агрегации. Об этом свидетельствуют отсутствие статистически достоверных различий в их 
показателях группы контроля и опытной с 15-ти минутным превентивным облучением, а также наличие статистической достоверности между группами острого стресса и с превентивным облучением терагерцевыми волнами.

Изучение эффективности влияния превентивного 30-ти минутного режима облучения электромагнитными волнами терагерцевого диапазона частоты МСИП атмосферного кислорода 129 ГГц на вязкость крови и функциональную активность эритроцитов белых крыс в фазе Oestrus эстрального цикла показало, что данный временной режим облучения предотвращает развитие острых стрессорных изменений в указанных показателях реологии крови. Это подтверждается отсутствием статистически достоверных различий в величине вязкости крови при всех исследуемых скоростях сдвига группы контроля и опытной, в которой животные перед действием стрессора подвергались 30-ти минутному воздействию электромагнитными волнами терагерцевого диапазона на частоте атмосферного кислорода 129 ГГц, а также её статистическая достоверность между группой стресса и опытной группой. Кроме того облучение электромагнитными волнами указанного терагерцевого диапазона на частоте атмосферного кислорода при превентивном 30-ти минутном воздействии на белых крыс в фазе Oestrus эстрального цикла и последующем действии острого стрессора оказывает выраженный профилактический эффект, предотвращая стресс-зависимые нарушения в функциональной активности эритроцитов - агрегации и деформируемости. Об этом свидетельствует отсутствие статистически достоверных различий между группами контроля и опытной острого стресса с 30-ти минутным превентивным облучением, но наличие достоверности между группой стресса и опытной группой животных.

Таким образом, анализируя данные, проведённого исследования можно сделать следующие выводы: 1) превентивное облучение терагерцевыми волнами на частоте МСИП атмосферного кислорода 129 ГГц крыс-самок в фазе Oestrus эстрального цикла, подвергнутых в последствие острому иммобилизационному стрессу, является эффективным в профилактике стресс-зависимых гемореологических нарушений в зависимости от времени ТГЧ воздействия; 2) превентивное 5-ти минутное облучение электромагнитными волнами указанного диапазона частот не предотвращает острые стрессорные нарушения в вязкости крови при всех исследуемых скоростях сдвига и функциональной активности эритроцитов; 3) превентивные 15-ти и 30-ти минутные режимы облучения электромагнитными 
волнами терагерцевого диапазона на частоте атмосферного кислорода 129 ГГц являются эффективными и полностью предотвращают острые стресс-зависимые нарушения гемореологии: вязкости крови при всех скоростях сдвига и функциональной активности эритроцитов - их агрегации и деформируемости.

\section{Резюме}

При непрерывном ТГЧ облучении электромагнитными волнами терагерцевого диапазона на частоте молекулярного спектра излучения и поглощения атмосферного кислорода 129,0 ГГц крыс-самцов, находящихся в состоянии острого иммобилизационного стресса, 5-ти минутное воздействие не оказывает выраженного нормализующего эффекта на нарушенные вязкостные свойства крови и функциональную активность эритроцитов; воздействие в течение 15-ти и 30-ти минут полностью восстанавливает нарушенные вязкостные свойства крови, функциональную активность эритроцитов: их агрегацию и деформируемость.

Превентивное непрерывное 5-ти минутное облучение электромагнитными волнами терагерцевого диапазона на частоте МСИП атмосферного кислорода 129,0 ГГц не предотвращает у крыс-самцов развитие стрессорных нарушений вязкости крови и функциональной активности эритроцитов - их агрегации и деформируемости; 15-ти и 30ти минутные режимы облучения предотвращают развитие постстрессорных нарушений в изучаемых реологических свойствах крови.

Непрерывное ТГЧ облучение белых крыс-самок в фазах Dioestrus и Oestrus эстрального цикла, находящихся в состоянии острого стресса, электромагнитными волнами на частоте МСИП атмосферного кислорода 129,0 ГГц показало, что 5-ти минутное воздействие не оказывает нормализующего эффекта на нарушенную вязкость крови, не зависимо от фаз эстрального цикла, однако нормализует только способность эритроцитов к деформации у крыс в фазу Dioestrus. У эстральных крыс указанный временной режим не эффективен в восстановлении способности эритроцитов к агрегации и деформации. Воздействие на крыс-самок в стадии Dioestrus и Oestrus эстрального цикла в течение 15-ти и 30-ти минут полностью восстанавливает нарушенную вязкость крови и функциональную активность эритроцитов.

Превентивное 5-ти минутное ТГЧ облучение электромагнитными волнами на частоте МСИП атмосферного кислорода 129,0 ГГц крыс-самок в стадии Dioestrus эстрального цикла, находящихся в состоянии острого стресса, не препятствует развитию нарушений в вязкости крови, однако не однозначно влияет на функциональную активность эритроцитов: препятствует стрессорным изменениям их 
деформации, но не оказывает эффекта в предотвращении повышенной агрегационной активности. В стадии Oestrus этот временной режим не эффективен как в предотвращении стресс-зависимых нарушений вязкости крови, так и в сохранении активности способности эритроцитов к агрегации и деформируемости. Превентивное воздействие на крыс-самок в обеих стадиях эстрального цикла в течение 15-ти и 30-ти минут полностью сохраняет реологические свойства крови: вязкость крови и функциональную активность эритроцитов - их агрегацию и деформируемость, то есть препятствует развитию стрессорных нарушений в показателях гемореологии.

Следовательно, эффективность волн терагерцевого диапазона на частоте МСИП атмосферного кислорода 129,0 ГГц предотвращать стресс-зависимые нарушения вязкости крови и функциональной активности эритроцитов крыс-самок в фазах Dioestrus и Oestrus эстрального цикла зависит от стадии эстрального цикла и временной экспозиции ТГЧ воздействия.

\section{ЗАКЛЮЧЕНИЕ}

В настоящее время интерес к профилактике и лечению сердечно-сосудистых заболеваний определён их первостепенной и ведущей ролью в причинах нетрудоспособности и смертности населения, что придаёт проблеме не только медицинское, но и социальное значение [Тожиев М.С., Шестов Д.Б., Воробьёв В.И., 2000; Киричук В.Ф., 2007]. Наиболее важными этиологическими и патогенетическими факторами, приводящими к возникновению патологии сердечно-сосудистой системы, являются стрессорные ситуации - физические и психические перегрузки, эмоциональные перенапряжения, вызывающие развитие в организме общего адаптационного синдрома, сопровождающиеся возникновением целого комплекса симптомов, в частности, артериальной гипертензии, гиперкоагуляции, гиперлипидемии, развитием депрессивного состояния, иммунодефицита [Меерсон Ф.3., 1981; Оганов Р.Г., 2000].

При ишемической болезни сердца (ИБС) гемореологические изменения могут существенно влиять на течение данной патологии сердечно-сосудистой системы, вызывать развитие осложнений со стороны системы микроциркуляции. Они могут быть как предвестниками, так и первопричиной развития этого заболевания, поэтому на ранних заболевания показано лечение, направленное на коррекцию реологических нарушений [Ройтман Е.В., 2003; Головачёва Т.В., Паршина С.С., Киричук В.Ф. и др., 2006; Becker R.C., 1993; Ernst E., 1994; Levenson J., 1995]. В настоящее время общепризнано влияние реологических свойств крови на состояние микроциркуляции [Ройтман Е.В., Дементьева И.И., Азизова О.А. и др., 2000; Киричук В.Ф., Воскобой И.В., 2000; Whitmore, 
R.Z., 1968]. Гемореологические нарушения при неизмененных и особенно при измененных коронарных артериях могут существенно ухудшить коронарный кровоток на уровне микроциркуляции, значительно снижая перфузию миокарда [Киричук В.Ф., Воскобой И.В., 2000; Leschke M., Strauer B.E., 1989].

Наиболее важными факторами, оказывающими влияние на вязкость крови, являются величина показателя гематокрита, свойства плазмы, агрегация и деформируемость форменных элементов, причем вязкостные свойства крови определяются, в основном, эритроцитами [Фолков Б., Нил Э., 1976; Ройтман Е. В., Дементьева И.И., Леонова С.Ф. и др., 1996; Fuchs J., Pinhas A., Davidson E. et al., 1990; Wannamethee G., Shaper A.G., Whincup P.H., 1994; Erikssen G., Liestol K., Bjornholt J.V. et al., 2000]. Известно, что вязкостные свойства цельной крови обусловлены агрегацией и деформируемостью эритроцитов, гематокритом, концентрацией фибриногена, растворимых комплексов фибринмономера и продуктов деградации фибрина [Белоусов Ю.Б., 1986; Киричук В.Ф., 2002, 2005; Branton D., 1981; Bishop J.J., 1991; Yarnell J.W.G., 1991; Blomback B., 1994]. Также вязкость цельной крови определяется соотношением альбумин/фибриноген, альбумин/глобулин и геометрией сосудистого русла [Карпов В.Л., 1984; Киричук В.Ф., 2002, 2005; Branton D., 1981; Bishop J.J., 1991].

Эритроцитам, в силу их большого диаметра и количественного содержания в крови, принадлежит ведущая роль в формировании клеточного компонента вязкости крови [Кручинский Н.Г., Тепляков А.И., Гапанович В.Н. и др., 2000]. Способность эритроцитов к агрегации и деформации, их форма и размеры оказывают значительное влияние на вязкость крови [Селезнев С.А, Назаренко Г.И., Зайцев В.С., 1985; Ройтман E.B., 2003].

Агрегация эритроцитов опосредуется за счет существования силы адгезии между клетками. Данный процесс существенно зависит от концентрации фибриногена в плазме крови, так как он обладает способностью легко адсорбироваться на эритроцитарной мембране, приводя к агрегации и одновременно к увеличению деформируемости эритроцитов [Смирнов И.Ю., Левин В.Н., 2004; Bishop J.J., 1991; Gana-Pathyraman L., Shanthi P., Bada-Krishnan K. et al., 1996; Meiselman P., 1999].

Из физико-химических свойств эритроцитов наибольшее значение принадлежит электрическому заряду мембран эритроцитов. Эритроциты с нормальным Z потенциалом имеют электростатическую отталкивающую силу, достаточную для противодействия агрегации эритроцитов [Токалев Г.М., Китаева Н.Д., Столяр Г.М., Шабанов В.А., 1977]. 
Одним из важнейших реологических феноменов, позволяющим эритроцитам проходить через сосуды, является деформируемость эритроцитов [Киричук В.Ф., 1999, 2002, 2005; Ройтман E.B., 2003; Sakuta S., Tacamats S. et al., 1982]. Этот показатель определяется тремя основными факторами: вязкоэластичными свойствами мембраны, вязкостью внутриклеточной жидкости и непосредственно геометрией клетки [Ройтман Е.В., Фирсов Н.Н., Дементьева М.Г., 2000].

У больных ИБС увеличено холестерин-фосфолипидное соотношение в эритроцитах. Избыточное накопление холестерина в эритроцитах у больных ИБС приводит к изменению физико-химических свойств их мембран и ухудшению микрореологических свойств этих клеток [Киричук В.Ф., 2002, 2005]. Увеличение соотношения холестерин/фосфолипиды приводит к снижению дзета-потенциала поверхностной мембраны клеток [Киричук В.Ф., 2002, 2005]. Уменьшение поверхностного заряда связано с увеличением в плазме концентрации фибриногена и его дериватов [Киричук В.Ф., 2002, 2005].

Главными детерминантами вязкости крови являются мембранная и внутренняя вязкость содержимого эритроцитов, степень их агрегации и приложенное напряжение сдвига. Патологические изменения одного из этих параметров могут привести к синдрому «гипервязкости», при котором снижается скорость течения крови, провоцируется ишемический синдром, усиливается стенозирование сосудов, что способствует тромбообразованию [Stoltz J.F., Djnner M., 1991]. При усилении обратимой агрегации эритроцитов тромбоциты вытесняются в зону высоких скоростей сдвига, где происходит их разрушение и активация процесса свертывания крови [Reinhart W.H., 1995]. Снижение деформируемости эритроцитов при ИБС объясняется уплощением эритроцитов и дегидратацией гемоглобина [Катюхин Л.Н.. 1995; Катюхин Л.Н., Ганелина И.Е., А.И. Олесин и др., 1996]. Изменения реологических свойств крови у больных ИБС являются также следствием изменений в системе гемокоагуляции, причем наибольшее значение имеет тромбинемия, приводящая к повышению концентрации фибриногена и растворимого фибрина [Белоусов Ю.Б., 1986]. И.В. Родштат (1991) показано, что миллиметровые волны приводят к исчезновению из плазмы крови фибриногена В, способного тромбировать микроциркуляцию на уровне венозных капиллярлов. По его мнению этот эффект опосредуется через выход альфа 2- макроглобулина, который является вторым после антитромбина III фактором антитромбинового резерва и мощным усилителем фибринолизирующего действия плазмина. Это приводит к миниминизации тканевого некроза и нейтрализации продуктов свободнорадикального окисления. 
На молекулярном уровне в реакции организма на ТГЧ-воздействие участвуют биохимические механизмы, за счет которых в биообъектах, подвергнутых ТГЧ-облучению малой интенсивности, происходит активация различных ферментативных систем [Киричук В.Ф., Андронов Е.В., Майбородин А.В. и др., 2004].

Одним из факторов, регулирующих активность симпатоадреналовой системы и её структур и ограничивающих кардиотоксическое действие катехоламинов, является оксид азота NO [Малышев И.Ю., Манухина Е.Б]. Показано, что эстрогены способны усиливать такое действие NO, способствуя пресинаптическому ингибированию выброса норадреналина [Vargas R., Wreblewsa B., Rego A et al., 1993; Fei L., Baron, Henry D. et al., 1997], а также повышает уровень секреции NO клетками эндотелия сосудов [Нayashi T, Fucuto J et al., 1992], что вызывает релаксацию сосудов и ингибирует адгезию форменных элементов крови к эндотелию.

Тромбоциты являются весьма гибкой и удобной моделью для изучения обмена биологически активных веществ. [Киричук В.Ф., Волин М.В., Креницкий А.П. и др., 2002]. Кроме того, их функциональная активность изменяется при ряде заболеваний, в том числе и сердечно - сосудистой системы [Петрова Т.Р., Павлищук С.А., 1974; Киричук В.Ф., Шварц Ю.Г., 1999; Киричук В.Ф., Воскобой И.В., 2000; Kirichuk V., Voskoboy I., 2000].

В эксперименте воспроизвести нарушения во внутрисосудистом компоненте микроциркуляции, соответствующие в той или иной степени изменениям у больных кардиоваскулярной патологией, возможно используя модель иммобилизационного стресса у животных [Антонов А.М., Беликина Н.В., Георгиева С.А. и др., 1964]. Как известно, в основе изменения функционирования организма при стрессе лежит активация стрессреализующих систем и, соответственно, действие медиаторов этих систем [Гриневич В.В. и др., 1999; Пшенникова М.Г. и др., 2000]. Среди них центральное место занимают гормоны и медиаторы гипоталамо-гипофизарно-надпочечниковой и симпатоадреналовой систем: кортико-тропин-рилизинг-фактор, адренокортикотропный гормон, катехоламины, глюкокортикоиды [Селье Г., 1960; Панин Л.Е., 1983].

Нами изучены особенности вязкостных свойств крови, функциональной активности эритроцитов (способность к агрегации, деформируемости) у интактных и стрессированных животных. Обнаружено что у крыс-самцов в состоянии острого и длительного (хронического) иммобилизационного стресса увеличивается вязкость цельной крови, в большей степени в условиях хронического стресса; повышается агрегационная активность эритроцитов, способность эритроцитов к деформации. У крыссамок в фазах Dioestrus и Oestrus эстрального цикла, подвергнутых действию острого 
стрессора, отмечаются аналогичные изменения реологических свойств крови. Однако показано, что самки в фазе Dioestrus более чувствительны к действию стрессора, чем в фазе Oestrus. Этот факт согласуется с данными, полученными О.И.Помошниковой (2006), которые свидетельствуют о повышении количества эритроцитов, уровня гемоглобина в крови, гематокритного показателя, среднего диаметра эритроцитов, снижение цветового показателя, среднего содержания гемоглобина в эритроцитах у самок в фазе Dioestrus, в то время как у самок в фазе Oestrus эстрального цикла отмечалось лишь увеличение количества эритроцитов в крови, гематокритной величины и среднего диаметра эритроцитов, при этом не изменялись уровень гемоглобина, цветовой показатель, среднее содержание и средняя концентрация гемоглобина в эритроцитах, средний объём эритроцитов.

Стресс-опосредованные нарушения изучаемых гемореологических свойств животных связаны с воздействием гормонов и медиаторов стресс-реализующих систем, как непосредственно на клетки крови [Бышевский А.Ш. и др., 1996; Шитикова А.С., 2000, Киричук В.Ф., 2005], так и на сосудистую стенку, в частности эндотелий [Киричук В.Ф., 2005; Takeda H., 1992; Naesh O. et al., 1993]. В конечном итоге вследствие избыточного поступления катехоламинов и глюкокортикостероидов в кровь происходит вазоконстрикция, повышение вязкости крови, [Takeda H., 1992; Naesh O. et al., 1993].

В основе неблагоприятных последствий стресса лежит дисбаланс деятельности стрессреализующих и стресс-лиммитирующих систем [Манухина Е.Б., Малышев И.Ю. 2000]. При действии чрезмерных по силе или продолжительности раздражителей происходит срыв стресс-лимитирующих систем, которые способны ограничивать повреждающее действие гормонов и медиаторов стресс-реализующих систем. В настоящее время принято различать центральные (ГАМК, опиоидэргические) и периферические (простагландинов, антиоксидантов, оксида азота) стресс-лимитирующие системы. Абсолютно уникальной является стресс-лимитирующая система оксида азота, которая имеет как центральный, так и периферический компонент [Манухина Е.Б., Малышев И.Ю. 2000].

Ocобое значение в патогенезе заболеваний сердечно-сосудистой системы имеет нарушение функционирования системы микроциркуляции, нарушением реологических свойств крови [Киричук В.Ф., Воскобой И.В., Юданова Л.С., 2000; Киричук В.Ф., Воскобой И.В., 2000; Киричук В.Ф., Воскобой И.В., Ребров А.П., 2001; Воскобой И.В., Семенов А.В., Киричук В.Ф. и др., 2002; Никитина Н.М., Киричук В.Ф., Егорова А.Н., 2002; Киричук В.Ф., Малинова Л.И., Креницкий А.П. и др., 2003; Киричук В.Ф., Железнякова Н.А., Волин М.В. и др., 2005; Россошанская С.И., Киричук В.Ф., Ребров А.П., 2005]. Следовательно, изменения реологических свойств крови у животных в 
состоянии стресса являются не только аналогичными, но и гомологичными (имеющими одинаковую природу), изменениям у больных с заболеваниями сердечно-сосудистой системы. Все выше изложенное дает основания считать имммобилизационный стресс экспериментальной моделью нарушений внутрисосудистого компонента микроциркуляции у больных заболеваниям сердечно-сосудистой системы.

В настоящее время для коррекции нарушений микроциркуляции у больных с заболеваниями сердечно-сосудистой системы используется широкий спектр медикаментозных препаратов: прямые антикоагулянты (гепарин, фраксипарин, сулодексид), нестероидные противовоспалительные средства (ацетилсалициловая кислота) и дезагреганты (курантил, трентал) [Субботина В.Г., 1995]. Однако классические схемы медикаментозной терапии часто оказываются недостаточно эффективными, фармакотерапия сопровождается развитием различной степени выраженности побочных эффектов [Лоуренс Д.Р., Бенитт П.Н., 1993]. Все это обусловливает необходимость поиска новых немедикаментозных методов коррекции. Одним из таких методов является использование волн миллиметрового и субмиллиметрового диапазонов частот.

Электромагнитные волны крайне высокой частоты (КВЧ-волны) уже достаточно давно и успешно применяются в лечении ряда заболеваний [Девятков Н.Д., Голант М.Б., Бецкий О.В., 1991, 1994; Киричук В.Ф., Головачева Т.В., Чиж А.Г., 1999, Бецкий О.В., Девятков Н.Д., Лебедева Н.Н., 2000а, 2000б; Синицын Н.И., Петросян В.И., Елкин В.А. и др., 2000]. КВЧ-терапия, в частности, доказала свою эффективность в комплексном лечении болезней сердечно-сосудистой системы - острого инфаркта миокарда и нестабильной стенокардии [Головачева Т.В., 1991; Семенова С.В., 1994; Паршина С.С., Киричук В.Ф., Головачева Т.В., 1995; Киричук В.Ф., Головачева Т.В., Чиж А.Г., 1999; Люсов В.А., Волон Н.А., Гафурова Р.М. и др., 2000; Паршина С.С., Головачева Т.В., Старостина Н.В. и др., 2000]. К числу преимуществ данного способа следует отнести высокую результативность, неинвазивность, небольшое количество побочных реакций и противопоказаний к применению, невысокую стоимость лечения, возможность сочетания с другими методами терапии [Киричук В.Ф., Головачева Т.В., Чиж А.Г., 1999; Гедымин Л.Е., Голант М.Б., Колпикова Т.В. и др., 2000; Головачёва Т.В., Киричук В.Ф., Паршина С.С. и др., 2006].

Исследованиями установлено, что эффективность применения КВЧ-терапии в качестве компонента комплексного лечения различных заболеваний обусловлена, прежде всего, ее нормализующим воздействием на систему гемостаза. Так, обнаружен антиангинальный, гипокоагуляционный и гипохолестеринемический эффект данного вида воздействия [Головачева Т.В., 1991; Семенова С.В., 1994; Киричук В.Ф., Головачева Т.В., Чиж А.Г., 1999; Паршина С.С., Головачева Т.В., Старостина Н.В. и др., 2000; Головачёва Т.В., 
Киричук В.Ф., Паршина С.С. и др., 2006]. Среди особенностей воздействия электромагнитных волн КВЧ-диапазона можно отметить: отсутствие побочных эффектов и отдаленных неблагоприятных результатов, высокую эффективность в виде монотерапии, хорошую сочетаемость с другими методами лечения, невысокую стоимость лечения и удобство применения в стационаре [Девятков Н.Д., Голант М.Б., Бецкий О.В., 1991, 1994; Арзуманов Ю.Л., Бецкий О.В., Девятков Н.Д. и др.,1997; Гедымин Л.Е., и др., 2000; Головачёва Т.В., Киричук В.Ф., Паршина С.С. и др., 2006].

Как известно, при классической КВЧ-терапии электромагнитное воздействие осуществляется на частотах 42,2 ГГц и 53,5 ГГц [Девятков Н.Д., Голант М.Б., Бецкий О.В., 1994; Архипов М.Е., Новицкий Я.М., Перфильев В.Е. и др., 1999; Киричук В.Ф., Головачева Т.В., Чиж А.Г., 1999; Бецкий О.В., Девятков Н.Д., Лебедева Н.Н., 2000; Федоров А.С., Королев Л.С., Беляков С.В., 2000]. Помимо этого, в настоящее время изучаются вопросы взаимодействия биологических объектов с электромагнитными полями всего миллиметрового и субмиллиметрового диапазона частот. Исследования Е.Н. Чуяна и соавт. [2009] изменения процессов микроциркуляции крови при действии низкоинтенсивного миллиметрового излучения позволили раскрыть механизмы действия КВЧ-излучения на организм человека и определить первичные мишени для миллиметровых волн. Миогенный и эндотелиальный компоненты микроциркуляторной регуляции являются, с одной стороны, первичной мишенью для КВЧ-воздействия, а, с другой стороны, принимают активное участие в механизмах биологического действия этого физического фактора [Чуян Е.Н., Трибрат Н.С., Раваева М.Ю., 2009].

Терагерцевая терапия (ТГЧ-терапия) является относительно новым, но весьма перспективным методом физиотерапевтического воздействия [Бецкий О.В., Креницкий А.П. и др., 2003]. Терагерцевый диапазон частот лежит на границе между электроникой и фотоникой от 100 ГГц до 10 ТГц (1 ТГц $=10^{3}$ ГГц) или в длинах волн от 3 мм до 30 мкм. Этот диапазон волн находится на шкале электромагнитных волн между КВЧ - диапазоном и оптическим инфракрасным (ИК) диапазонами и частично перекрывает высокочастотную часть КВЧ диапазона (100 ГГц - 300 ГГц) и низкочастотную часть ИК диапазона.

Молекулярные спектры излучения и поглощения (МСИП) многих биологически активных веществ ( $\mathrm{NO}, \mathrm{O}_{2}, \mathrm{CO}_{2}, \mathrm{CO}$, активных форм кислорода, ОН- и др.) находятся терагерцевом диапазоне [Башаринов А.Е., Тучков Л.Г., Поляков В.М., Аланов Н.И., 1968; Марков Х.М. 1996, 2001; Креницкий А.П., Майбородин А.В., Бецкий О.В. и др., 2003; Бецкий О.В., Креницкий А.П., Майбородин А.В. и др., 2007; Adnot S, Raffestin B., Eddahibi S., 1995; Rothman L.S., Barbe A., Chris Benner D. et.al., 2003]. Среди перечисленных метаболитов наибольшим значением в регуляции физиологических 
процессов обладают, безусловно, оксид азота $(\mathrm{NO})$, молекулярный кислород $\left(\mathrm{O}_{2}\right)$ и его активные формы.

Проведенные нами исследования свидетельствуют, что электромагнитное излучение терагерцевого диапазона на частотах МСИП оксида азота 150,176 - 150,664 ГГц не оказывает влияния на вязкостные свойства крови, функциональную активность эритроцитов интактных животных.

При изучении влияния электромагнитного излучения терагерцевого диапазона на частотах МСИП оксида азота 150,176 - 150, 664 ГГц на постстрессорные нарушения реологии крови у белых крыс показали способность данного вида излучения нормализовать стресс-опосредованные нарушения, а также предотвращать их развитие в зависимости от времени экспозиции и режима облучения - непрерывного, дробного или превентивного.

Полученные результаты свидетельствуют, что непрерывное и дробное излучения терагерцевых волн на частотах МСИП оксида азота 150,176-150,664 ГГц, воздействуя на крыс-самцов в состоянии острого стресса продолжительностью 15-ть и 30-ть минут, оказывают нормализующий эффект на нарушенную вязкость крови и функциональную активность эритроцитов, а превентивное обладает антистрессорным эффектом на изменённые реологические свойства крови. Превентивное дробное излучение общей продолжительностью 5-ть минут предотвращает развитие стрессорных нарушений в сосудах микроциркуляции и функциональной активности эритроцитов. Непрерывное ТГЧ воздействие указанного диапазона частот оксида азота на животных в течение 15-ти и 30ти минут на фоне хронического (длительного) нормализует только деформируемость эритроцитов. Превентивное излучение в течение 15-ти минут предотвращает стрессзависимые нарушения вязкости крови в сосудах крупного и среднего калибра, сохраняет нормальную агрегацию и деформируемость эритроцитов. 30-ти минутное воздействие предупреждает развитие стресс-зависимых нарушений реологических свойств крови.

Доказано, что непрерывное и дробное ТГЧ воздействие электромагнитными волнами на частотах МСИП оксида азота 150,176-150,664 ГГц на крыс-самок в обеих стадиях эстрального цикла в течение 15-ти и 30-ти минут полностью восстанавливают нарушенную вязкость крови, агрегацию и деформируемость эритроцитов, а превентивные 15-ти и 30-ти минутные режимы - препятствуют развитию стресс-зависимых нарушений в реологических свойствах крови.

Установлено, что эффективность ТГЧ-воздействия на частотах МСИП оксида азота 150,176 - 150,664 ГГц зависит от времени экспозиции электромагнитных волн. 5-ти и 
15-ти минутные экспозиции вызывают частичное восстановление нарушенных функций тромбоцитов у крыс-самцов в состоянии острого иммобилизационного стресса, а 30-ти минутная - полное восстановление всех нарушенных показателей агрегации тромбоцитов.

В реализации биологического эффекта электромагнитных волн указанного диапазона частот ключевое значение имеет регуляция продукции и реакционной способности оксида азота, что согласуется с мнением других исследователей [Андронов Е.В., 2008; Киричук В.Ф., Цымбал А.А. и др., 2009; Murad F., 2003]. Нами показано отсутствие нормализующего эффекта 15-ти минутного облучения терагерцевыми волнами на частотах молекулярного спектра излучения и поглощения оксида азота 150,176-150,664 ГГц на реологические свойства крови у животных, находящихся в состоянии острого иммобилизационного стресса, на фоне действия ингибитора эндотелиальной NO-синтазы L-Name.

В настоящее время предложено несколько подходов к объяснению механизмов воздействия на биологические объекты (на организменном, клеточном и молекулярном уровнях) ЭМИ миллиметрового и субмиллиметрового диапазонов. Наиболее полным представляется подход, развитый в работах Н.Д. Девяткова, М.Б. Голанта, О.В. Бецкого [1991], О.В. Бецкого [1995, 1997], О.В. Бецкого, Н.Д. Девяткова, В.В. Кислова [1998], О.В. Бецкого, Н.Н. Лебедевой [2002]. В реализации эффектов ТГЧ-облучения участвуют биохимические механизмы, приводящие к активации различных ферментных систем [Девятков Н.Д., и др., 1991].

Установлено, что КВЧ-воздействие на классических частотах (42,2 и 53,5 ГГц) обладает выраженным воздействием на мембраны клеток, стимулирует перемешивание ее липидных слоев и белковых компонентов [Девятков Н.Д., Голант М.Б., Бецкий О.В., 1991]. Существуют данные о способности КВЧ-волн вызывать изменения гидратации белковых структур мембранных рецепторов [Бецкий О.В., 1997].

Возможным механизмом действия ТГЧ-облучения на частотах МСИП NO является активация эндогенного оксида азота [Киричук В.Ф. и др., 2005]. Согласно одной из теорий [Бецкий и др., 1998] при облучении энергия ТГЧ излучения расходуется на переходы молекул из одного энергетического состояния в другое. При используемых в медикобиологической практике уровнях мощности ТГЧ экзогенное воздействие электромагнитного излучения приводит к изменению вращательной составляющей полной энергии молекул. При совпадении частоты проводимого облучения с частотой вращения полярных молекул возможна перекачка энергии излучения молекуле, сопровождающаяся увеличением ее вращательной кинетической энергии, влияющей на ее реакционную способность. 
Согласно другому мнению, изменения вращательной составляющей энергии молекулы оксида азота не происходит [Ковалев А.А.,2006]. Полагают, что наличие на внешней орбитали неспаренного электрона придает молекуле NO парамагнитные свойства [Парселл Э., 1971]. При интеграции в пространственную сетку водородных связей воды (растворении) таких молекул, магнитные силы спинов их неспаренных электронов способны взаимодействовать с магнитными моментами протонов. В подобной магнитной системе внешнее высокочастотное поле может возбуждать относительные колебания спинов, называемые спиновыми волнами [Ивановский В.И., Черникова Л.А., 1981]. Периодическое изменение ориентации спина гидратированной парамагнитной молекулы способно инициировать волнообразную динамику спинов протонов пространственной сетки водородных связей [Захаров С.Д., Иванов А.В. и др., 2003]. Граничная частота спиновых волн составляет порядка $10^{10}-10^{11}$ Гц $(10-100$ ГГц) [Кулагин Н.А., Свиридов Д.Т., 1986], они имеют квантовую природу [Китель Ч., 1978] и возбуждаются по механизму спин-волнового резонанса [Ивановский В.И., Черникова Л.А., 1981]. Это означает, что спиновые волны могут возбуждаться электромагнитными излучениями определенных длин волн, относящихся к миллиметровому и субмиллиметровому диапазону. При растворении в водной фазе биосистемы молекула NO утрачивает вращательную активность, но сохраняет способность поглощать ЭМИ частотой своего вращательного спектра. Следовательно, одним из возможных механизмов действия ЭМИ на частотах МСИП оксида азота является преобразование энергии ЭМИ в поток магнитного порядка (спиновых волн) от растворенных молекул NO на гидратированный комплекс клеточных и внеклеточных белков [Ковалев А.А., 2006]. Изменение гидратации белковой молекулы изменяет и ее активность. Подобный механизм, как упоминалось выше, может регулировать активность тромбоцитарных гликопротеидовых рецепторов, а также изменять активность внутриклеточных белковых систем, в том числе ферментов NO-синтазного компонента цикла оксида азота [Реутов В.П., Сорокина Е.Г., 1998].

Не исключена возможность взаимодействия ТГЧ-волн с NO-синтазами. Результатом подобного взаимодействия может являться ускорение внутримолекулярного переноса электронов (с флавинадениндинуклеотид (FAD) на флавинмононуклеотид (FMN) и с FMN на оксидазный домен) [Горрен А.К.Ф., Майер Б. 1998], что приводит к увеличению скорости катализа. Кроме того, возможно взаимодействие ТГЧ-излучения с гемом NOсинтазы и/или гуанилатциклазы - главной мишени эндогенного оксида азота, приводящее к переходу его в высокоспиновое состояние, что сопровождается увеличением сродства NO-синтазы к L-аргинину и повышению активности фермента. Таким образом, при облучении ТГЧ-волнами на частотах МСИП NO возможно увеличение реакционной 
способности и/или концентрации эндогенного оксида азота. Исследования саратовских учёных выявили следующие факты: 1) введение ингибитора NO-синтазы - L-Name животным в состоянии оксидативного стресса блокирует восстанавливающий эффект терагерцевого облучения на частоте МСИП оксида азота 240 ГГц на нарушенную способность тромбоцитов к агрегации; 2) введение в цельную кровь больных нестабильной стенокардией, у которых вязкость повышена, в условиях in vitro донатора NO изокета, облучённого терагерцевыми волнами на частоте МСИП оксида азота 240 ГГц в течение 15 минут, вызывает выраженное снижение вязкости крови по сравнению с введением необлучённого изокета [Андронов Е.В., 2008; Киричук В.Ф., Цымбал А.А. и др., 2009]. Следовательно в реализации биологического эффекта электромагнитных волн терагерцевого диапазона указанных частот ключевое значение имеет регуляция продукции и реакционной способности оксида азота [Киричук В.Ф., Цымбал А.А. и др., 2009]. Для оценки концентрации эндогенного оксида азота наряду с прямым измерением активности $\mathrm{NO}-$ синтаз (по образованию цитрулина) использовали измерение концентрации стабильных метаболитов - нитритов и нитратов, являющихся объективным критерием активности нитридэргической системы [Карпюк В.Б., Черняк Ю.С., Шубич М.Г., 2000]. Установлено, что облучение крыс-самцов в состоянии иммобилизационного стресса электромагнитными волнами терагерцевого диапазона МСИП оксида азота (150 ГГц) приводит к повышению концентрации нитритов плазмы крови по сравнению с необлучёнными животными [Киричук В.Ф., Цымбал А.А и др., 2009].

Условно можно выделить три уровня реализации эффектов повышения активности NO под влиянием ТГЧ-воздействия на функционирование микроциркуляторного звена гемостаза при стрессе: непосредственное влияние на активность тромбоцитов аутокринное действие; эндотелий опосредованное паракринное действие и экстравазальные эффекты, NO-зависимыми изменениями нервной и гуморальной регуляции [Киричук В.Ф., Цымбал А.А. и др., 2009].

Непосредственное влияние на активность эритроцитов обусловлено активацией гуанилатциклазы за счет образования нитрозил-гемового комплекса [Matsuoka I., Suzuki T., 1983; Ignarro L.G. et al., 1987].

Паракринное влияние эндотелия сосудов может быть связано с выделением эндотелиальными клетками как непосредственно оксида азота, так и ряда антиагрегантов (важнейший из которых - простациклин), продукция которых регулируется оксидом азота [Киричук В.Ф., 2005; Halcox J.P.J., et al., 2001].

Оксид азота является важным фактором регуляции тонуса сосудов, что определяет функционирование микроциркуляции и системную гемодинамику. Проникая в 
гладкомышечные сосудистые клетки, он активирует растворимую гуанилатциклазу, которая увеличивает образование цГМФ. В результате увеличивается скорость продукции цГМФ в мышечных клетках. Высвобождение и накопление цГМФ приводит к активации фермента цГМФ - зависимой протеинкиназы [Волин М.С., Дэвидсон К.А., Камински П.М., 1998; Ванин А.Ф.,1998, 2000]. Потенциальными мишенями для цГМФ-зависимой протеинкиназы (тип I) в сосудистых гладкомышечных клетках являются $\mathrm{Ca}^{2+}$-зависимые калиевые каналы и IRAG - белки, участвующие в модулировании входа внеклеточного кальция и высвобождении внутриклеточного кальция [Feil R., Lohmann S.M., Hugo de Jonge et al., 2003]. Фосфорилирование этих двух белков может снижать концентрацию цитозольного кальция, что ведет к расслаблению сосудов.

В качестве альтернативного субстрата для цГМФ-зависимой протеинкиназы (тип I) может служить фосфоламбан (phospholamban), который модулирует активность кальцийзависимой АТФазы в эндоплазматическом ретикулуме [Koller A., Schlossmann J., Ashman K. et al., 2003]. Нельзя исключать, того, что кальций-зависимая АТФаза может активироваться посредством фосфорилирования цГМФ, что также приводит к уменьшению уровня цитозольного кальция, а следовательно и вазодилатации [Feil R., Lohmann S.M., Hugo de Jonge et al., 2003].

В опытах с использованием интактных и химически скинированных сосудистых гладких мышц и флуоресцентных методов измерения внутриклеточной концентрации Са ${ }^{2+}$ был обнаружен новый, цГМФ-независимый механизм расслабления гладких мышц, обусловленный прямым влиянием NO на сократительные белки гладкомышечных клеток. Было установлено, что NO обладает способностью снижать $\mathrm{Ca}^{2+}$-чувствительность сократительных белков и этот феномен обусловлен активацией внутриклеточных фосфатаз, ответственных за дефосфорилирование легких цепей миозина [Soloviev A., Hellstrand P., Stefanov A., 1996; Soloviev A., Hellstrand P., Stefanov A., 1997]. Это создает возможность избирательно модулировать $\mathrm{Ca}^{2+}$-чувствительность сократительных белков и тем самым уровень сосудистого тонуса.

До настоящего времени считалось, что электромагнитное излучение миллиметрового и субмиллиметрового диапазонов частот оказывает эффект только на организм с измененным функциональным состоянием, а интактные животные и здоровые люди невосприимчивы к этому виду излучения [Девятков Н.Д., Голант М.Б., Бецкий О.В., 1991]. Наши данные так же показывают, что при облучении интактных животных ТГЧ-волнами на частотах МСИП NO 150,176 - 150,664 ГГц не вызывает изменений реологических свойств крови. Однако предшествующее действию стрессора ТГЧ-облучение изменяет протекание стрессорной реакции, что выражается в отсутствии постстрессорных 
нарушений вязкостных свойств крови, фунциональной активности эритроцитов. По всей видимости, воздействуя на интактный организм ТГЧ-облучение не изменяет основных физиологических параметров, но воздействует на механизмы регуляции, изменяя реактивность организма.

Известно, что часть синтезированного оксида азота может связываться в комплексы, которые образуют физиологически активное депо. Это депо может не только связывать, но и постепенно высвобождать NO. Депонирование оксида азота происходит в стенках сосудов и начинается при повышении его концентрации. По-видимому, этим и объясняется эффективность профилактических курсов ТГЧ-облучения, так как доказано, что формирование NO-депо является важной частью адаптивных реакций [Малышев И.Ю., Манухина Е.Б., 1998; Пшенникова М.Г. и др., 2000; Машина С.Ю. и др., 2001; Манухина Е.Б. и др., 2004].

Отдельного внимания заслуживают NO-зависимые изменения нейрогуморальной регуляции функций организма. Активация NO-эргических нейронов в центральной нервной системе предупреждает гиперсекрецию основных гипоталамо-гипофизарных стрессорных гормонов, таких как адренокортикотропин, рилизинг-фактор кортикотропина и др. Так же NO-эргические нейроны богато иннервируют мозговое вещество надпочечников, непосредственно контактируя с хромаффинными клетками, и при активации блокируют выброс катехоламинов надпочечниками [Addicks K., 1994]. Кроме того, оксид азота способен блокировать выделение катехоламинов из нервных окончаний [Манухина Е.Б., Малышев И.Ю., 2000; Addicks К., 1994].

Исследования [Цымбал А.А., 2007] показали, что ТГЧ-излучение на частотах МСИП оксида азота 150,176 - 150,664 ГГц белых крыс самцов способно снижать уровень кортикостероидов у животных в состоянии стресса и предотвращать повышение их уровня при облучении до начала действия стрессора.

NO-эргическая система находится в тесной взаимосвязи с другими стресслимитирующими системами. Так, оксид азота потенцирует ГАМК-эргическую систему за счет блокады ГАМК-трансаминазы, приводя к увеличению концентрации ГАМК, и стимулирует высвобождение опиоидных пептидов в мозге, вследствие чего потенцирует опиоид-эргическую стресс-лимитирующую систему [Armstead W.M., 1998].

Увеличение активности NO-эргической стресс-лимитирующей системы, возможно, и объясняет более высокую эффективность предшествующего стрессу ТГЧ-воздействия на частотах МСИП оксида азота, поскольку при данном режиме облучения изначально блокируется гиперпродукция стресс-гормонов, обусловливающих развитие характерных нарушений микроциркуляции. 
Полученные нами данные хорошо согласуются с экспериментальными исследованиями других авторов. Так, Е.Н. Чуян и соавт. [2003] показали, что стресслимитирующее действие ЭМИ КВЧ с длинами волн 5,6 и 7,1 мм зависит от последовательности воздействия электромагнитного облучения.

Таким образом, предшествующее стрессу ТГЧ-воздействия изменяют протекание стресс-реакции, повышают устойчивость животных к действию стрессора. В современной литературе имеются данные других авторов о влиянии ТГЧ-излучения на частотах МСИП оксида азота 150,176 - 150,664 ГГц на микро- и макроциркуляцию, реологию крови, систему гемостаза. Так, в работах В.Ф. Киричука и соавт. 2004, 2005, 2006 показано, что проводимое параллельно с действием стрессорного агента ТГЧ-облучение на частотах молекулярного спектра излучения и поглощения оксида азота предупреждает развитие стресс-зависимых изменений в системе гемостаза, что свидетельствует о принципиальной возможности коррекции этих изменений данным видом излучения. Облучение животных в значительной мере предотвращает гиперкоагуляционный эффект стресса, что обусловлено снижением активности протромбинового комплекса, замедлением скорости формирования фибринового сгустка, нормализацией антикоагулянтной активности крови.

ТГЧ-воздействие на частотах молекулярного спектра излучения и поглощения оксида азота 150,176-150,664 ГГц оказывает положительное влияние на коагуляционные свойства крови у животных, находящихся в состоянии иммобилизационного стресса. Наиболее эффективными в восстановлении показателей гемокоагуляции являются 15 -ти и 30-ти минутные режимы облучения. При 5-ти минутном режиме облучения положительный эффект на показатели, характеризующие коагуляционный потенциал крови, незначителен [Киричук В.Ф., Цымбал А.А., Антипова О.Н., и др., 2004, 2005, 2006].

Экспериментальные исследования показали положительное восстанавливающее влияние ТГЧ-воздействия на частотах МСИП оксида 150,176 - 150664 ГГц азота на качественный и количественный состав эритроцитов крови белых крыс, находящихся в состоянии иммобилизационного стресса. Наиболее эффективным в этом отношении является 15-минутный режим облучения. При 5-ти и 30-ти минутных режимах облучения выраженность восстанавливающего эффекта на исследуемые показатели эритроцитов было менее значительно [Киричук В.Ф., Помошникова О.И., Антипова О.Н., и др. 2004, Помошникова О.И., 2006].

Кроме того, показано, что электромагнитное излучение ТГЧ диапазона на частотах МСИП оксида азота 150,176 - 150,664 ГГц способно нормализовать нарушения системной гемодинамики у белых крыс в состоянии острого иммобилизационного стресса. Установлено, что ТГЧ-облучение на частотах МСИП NO 150,176 - 150,664 ГГц в течение 
5 минут животных в состоянии острого иммобилизационного стресса полностью нормализует линейную скорость кровотока и градиент давления в магистральных сосудах (брюшной отдел аорты, сонные и бедренные артерии) [Кораблева Т.С., Сухова С.В., 2007; Киричук В.Ф., Кораблева Т.С. и др., 2007].

На основании всех выше изложенных данных можно сделать выводы о нормализующем влиянии электромагнитного излучения терагерцевого диапазона на частотах МСИП оксида азота 150,176 - 150,664 ГГц на нарушения микро- и макроциркуляции у животных в состоянии острого иммобилизационного стресса.

Изменение под влиянием ТГЧ-воздействия реологических свойств крови, коагуляционного звена гемостаза, качественного и количественного состава эритроцитов, поведенческой реакции животных и гормонального баланса позволяют говорить об общем антистрессорном эффекте ТГЧ-волн [Киричук В.Ф., Цымбал А.А., Антипова О.Н., и др., 2004, 2005, 2006; Киричук В.Ф., Помошникова О.И., Антипова О.Н., 2004, 2006; Киричук В.Ф., Кораблева Т.С. и др., 2007; Цымбал А.А., 2007].

Таким образом, для клинического использования ЭМИ ТГЧ на частотах МСИП оксида азота 150,176 - 150,664 ГГц имеются все необходимые теоретические и экспериментальные предпосылки. На основании результатов данной работы была проведена клиническая апробация действия электромагнитного ТГЧ-излучения на частотах МСИП оксида азота. В настоящее время изучено влияние ЭМИ ТГЧ на здоровых донорах-добровольцах и пациентах с заболеваниями сердечно-сосудистой системы [Паршина С.С., Киричук В.Ф., Головачева Т.В., 2004].

Первый опыт клинического использования электромагнитного излучения терагерцевого диапазона на частотах МСИП оксида азота 150,176 -150,664 ГГц свидетельствует о целесообразности дальнейшего изучения и применения ЭМИ КВЧ-NO у больных с сердечно-сосудистой патологией. ЭМИ КВЧ-NO обладает мощным вазоактивным эффектом, требующим всестороннего исследования. Полученные клинические данные об антиангинальном и гипокоагуляционном эффекте ЭМИ КВЧ-NO позволяют говорить о возможности его использования у больных с ишемической болезнью сердца, в частности, с нестабильной стенокардией [Паршина С.С., Киричук В.Ф., Головачева Т.В., 2004]

В современной литературе описано довольно перспективное использование терагерцевых волн частотой 129,0 ГГц, соответствующей второму максимуму спектра излучения и поглощения молекулярного кислорода [Киричук В.Ф., Малинова Л.И., Креницкий А.П. и др., 2003]. Поскольку недостаток кислорода в органах и тканях ведет к нарушению окислительных процессов, изменяя нормальное функционирование и 
жизнедеятельность всего организма в целом, обусловливая гипоксию и ишемию, важным является изучение ЭМИ именно на частоте МСИП молекулярного кислорода. Так, показано влияние ЭМИ частотой 129,0 ГГц на реологические свойства крови и структурно - функциональные особенности эритроцитов больных стабильной стенокардией в условиях in vitro [Киричук В.Ф., Малинова Л.И., Креницкий А.П. и др., 2003]. Отмечен факт увеличения содержания оксигемоглобина в крови человека на 3-5\% в процессе дыхания атмосферным воздухом, облучаемым электромагнитными волнами частотой 129,0 ГГц [Майбородин А.В., Креницкий А.П., Тупикин В.Д. и др., 2001]. Установлено, что облучение бактериальных взвесей стафилококка, кишечной и синегнойной палочек ЭМИ МСИП атмосферного кислорода (129 ГГц) и оксида азота (150 ГГц) приводит к повышению активности ферментов антиоксидантной защиты, что возможно объясняется увеличением синтеза кислорода в системе, как результат воздействия волн на резонансных частотах кислорода, так и способностью оксида азота активировать внутриклеточный кислород [Шуб Г.М. и соавт., 2000].

Результаты проведённых нами исследований влияния электромагнитных волн терагерцевого диапазона на частоте молекулярного спектра излучения и поглощения атмосферного кислорода 129,0 ГГц на реологические свойства крови белых крыс в состоянии острого иммобилизационного стресса свидетельствуют о высокой эффективности указанной частоты в нормализации вязкости цельной крови, функциональной активности эритроцитов животных. Эффективность восстановительных процессов зависит в большей степени от режимов облучения - непрерывный, дробный, превентивный и от времени экспозиции терагерцевых волн МСИП атмосферного кислорода 129,0 ГГц.

Установлено, что при непрерывном ТГЧ воздействии электромагнитными волнами терагерцевого диапазона на частоте МСИП атмосферного кислорода 129,0 ГГц на крыссамцов, находящихся в состоянии острого стресса, 15-ти и 30-ти минутные режимы полностью восстанавливает нарушенные вязкостные свойства крови, функциональную активность эритроцитов: их агрегацию и деформируемость, а аналогичные по продолжительности превентивные предотвращают развитие постстрессорных нарушений.

Выявлена эффективность непрерывного воздействия ТГЧ излучения на белых крыс-самок в фазах Dioestrus и Oestrus эстрального цикла, находящихся в состоянии острого стресса, электромагнитными волнами на частоте МСИП атмосферного кислорода 129,0 ГГц. Показано, что 5-ти минутное воздействие нормализует способность эритроцитов к деформации у самок в фазу Dioestrus, в то же время 15-ти и 30-ти минутные 
режимы полностью восстанавливают нарушенную вязкость крови и функциональную активность эритроцитов независимо от фазы эстрального цикла. Превентивное 5-ти минутное ТГЧ воздействие на самок в стадии Dioestrus препятствует стрессорным изменениям деформации эритроцитов, а 15-ти и 30-ти минутные - полностью сохраняет исследуемые реологические свойства крови независимо от фазы эстрального цикла.

Показано, что при непрерывном терагерцевом воздействии ЭМИ на частоте МСИП атмосферного кислорода 129,0 ГГц на крыс-самцов в состоянии острого стресса наиболее эффективным в восстановлении функциональной активности тромбоцитов является 5-ти минутный режим, а 15-ти и 30-ти минутные способствуют не только восстановлению нарушений функциональной активности тромбоцитов, но и её снижению. В то же время превентивные 15-ти и 30-ти минутные воздействия ЭМИ ТГЧ указанной частоты полностью препятствуют постстрессорным нарушениям функции тромбоцитов. Дробное излучение на фоне острого стресса общей продолжительностью 15-ть и 30-ть минут вызывает полное восстановление нарушенной функциональной активности тромбоцитов. Возможно, большая эффективность непрерывного режима обусловлена тем, что происходит последовательное изменение биохимических процессов кумулятивностью эффекта терагерцевого облучения на частоте 129,0 ГГц.

Данные литературы свидетельствуют о том, что процесс активации перекисного окисления липидов, в частности фосфолипидов, приводит к нарушению структуры мембран клеток и как следствие их функции [Бриль Г.Е., 2002]. Существует мнение, что именно активация перекисного окисления липидов (ПОЛ) является первичным медиатором стресса и запускает мобилизацию стресс - реализующих систем, то есть выброс катехоламинов и глюкокортикостероидов [Бриль Г.Е., 2002]. При различной патологии, в том числе и сердечно - сосудистой, образуется избыточное количество активных форм кислорода (АФК), активируется ПОЛ [Афанасьева Г.А., 1995]. Эти механизмы также лежат и в основе расстройств микроциркуляции.

Посредниками действия ЭМИ КВЧ, в том числе вероятно и ТГЧ - диапазона, в клетках и биологических жидкостях, в том числе форменных элементах крови, являются активные формы кислорода (АФК) [Поцелуева М.М., Пустовидко А.В., Евтодиенко Ю.В. и др., 1998]. Они предположительно образуются ферментативно за счет изменения гидратации белковых молекул и повышения до определенного уровня активности НАДФН оксидазы, циклооксигеназы, ксантиноксидазы, при этом их концентрация поддерживается на стационарном уровне. АФК, в свою очередь, с участием $\mathrm{Ca}^{2+}$ стимулируют растворимую гуанилатциклазу, накопление цГМФ в клетках эндотелия сосудов и повышение активности NO-синтазы, что увеличивает продукцию NO. Это 
может быть одним из механизмов осуществления как антистрессорного, так и антиагрегационного эффектов ТГЧ - волн на частоте МСИП атмосферного кислорода 129,0 ГГц. Синтезированный оксид азота способен связываться в комплексы и образовывать своеобразное депо в эндотелии сосудов, из которого при необходимости возможно освобождение NO [Пшенникова М.Г. и др., 2000; Машина С.Ю. и др., 2001; Манухина Е.Б. и др., 2004]. Показано, что облучение терагерцевыми волнами на частоте оксида азота 150,176-150,664 ГГц способно увеличивать концентрацию оксида азота в крови, в том числе за счет увеличения его секреции эндотелиоцитами [Андронов Е.В., 2008], а NO является естественным регулятором агрегационной активности тромбоцитов, оказывающего антиагрегационный эффект. Активация NO - эргической системы также ограничивает чрезмерный выброс гипоталамо - гипофизарных стрессорных гормонов (адренокортикотропина, релизинг - фактора кортикотропина и др.), блокирует выделение катехоламинов надпочечниками [Addicks K., 1994] и нервными окончаниями [Манухина Е.Б., Малышев И.Ю., 2000; Addicks K., 1994]. Оксид азота также потенциирует стресс лимитирующее действие ГАМК - эргической и опиоид - эргической систем [Armstead W.M., 1998] за счет снижения концентрации в крови стресс - реализующих гормонов, в том числе адреналина и кортикотропина, происходит восстановление агрегационной способности тромбоцитов, нарушенной при остром иммобилизационном стрессе.

Кроме того, NO-синтаза также может влиять на образование АФК в клетках эндотелия путем активации НАДФНН-оксидазы, что приводит к релаксации сосудов, а следовательно снижает возможность агрегации кровяных пластинок. АФК, в частности перекись водорода, вызывают эндотелийзависимую вазодилатацию микрососудов, которая опосредуется простагландинами $\mathrm{E}_{2}$ и $\mathrm{I}_{2}$ [Брилль Г.Е., 2002; Naesh O., Haedersdal C., Hindberg J., 1993].

Однако образование АФК, инициация продукции активных радикалов и перекисное окисление липидов (ПОЛ) являются, как уже отмечалось ранее, стандартной реакцией биомембран клеток на любое раздражение (стресс, ацидоз, гипоксия, ишемия) [Брилль Г.Е., 2002]. Активация ПОЛ изначально носит защитный характер: происходит изменение белково-липидного слоя плазматической мембраны таким образом, что ограничиваются функциональные перестройки, трансмембранное движение и латеральная диффузия мембранных белков (рецепторов, ферментов, антигенов) [Брилль Г.Е., 2002]. Благодаря этому может изменяться чувствительность рецепторов к специфическим медиаторам (в том числе и гликопротеиновых рецепторов тромбоцитов к медиаторам, способствующим их адгезии и агрегации). При этом образуются дополнительные ионные каналы, в частности для $\mathrm{Ca}^{2+}$, в результате чего его уровень в клетке повышается, 
активируются фосфолипазы, метаболизм арахидоновой кислоты и образование простагландинов, в том числе простациклина, тромбоксанов, лейкотриенов, влияющих на процесс агрегации тромбоцитов [Брилль Г.Е., 2002].

При чрезмерной активации ПОЛ, в условиях стресса, возникает разобщение процессов дыхания и окислительного фосфорилирования, что ведет к дефициту энергии и АТФ, стимуляции анаэробных процессов, развитию метаболического ацидоза, деструкции лизосомальных мембран и аутолизу клетки [Брилль Г.Е., 2002]. ЭМИ КВЧ и ТГЧ диапазонов приравнивают к аэрированию облучаемого объекта [Поцелуева М.М., Пустовидко А.В., Евтодиенко Ю.В. и др., 1998], в связи с чем восстанавливается аэробное дыхание клетки и ее физиологические функции. Подтверждением того, что посредниками влияния ЭМИ ТГЧ на частоте МСИП атмосферного кислорода 129,0 ГГц в организме являются АФК, возможно, служит то, что облучение после стресса уже на 5-й минуте нормализует функцию тромбоцитов, в то время как предшествующее стрессу облучение проявляет данный эффект на 15-й минуте воздействия. Это может быть связано с достаточным количеством образовавшихся АФК в первом случае для более быстрого проявления эффектов ЭМИ ТГЧ на частоте 129,0 ГГц.

Кроме того, возможно, по механизмам, описанным выше [Девятков Н.Д., Голанд Н.Б., Бецкий О.В., 1991; Бецкий О.В., Девятков Н.Д., Кислов В.В., 1998; Бецкий О.В., Лебедева Н.Н., 2001; Бецкий О.В., Кислов В.В., Лебедева Н.Н., 2004], под влиянием ЭМИ ТГЧ 129,0 ГГц происходит стимуляция ферментов антиоксидантной защиты и связанное с этим его антистрессорное действие, что сопровождается восстановлением реологических свойств крови и агрегационной способности тромбоцитов.

Предположительным механизмом действия ЭМИ ТГЧ на частоте МСИП атмосферного кислорода 129,0 ГГц на процесс агрегации эритроциов также является активация молекулы кислорода. Так, согласно одной из теорий [Бецкий О.В. и др., 2007], при облучении энергия ЭМИ ТГЧ диапазона расходуется на переходы молекул из одного энергетического состояния в другое, при этом реакционная способность этой молекулы увеличивается. Относительно ЭМИ ТГЧ на частоте МСИП атмосферного кислорода 129,0 ГГц следует отметить эффект, похожий на аэрацию среды культивирования микроорганизмов, но превосходящий по эффективности за счет повышения реакционной способности внутриклеточного кислорода [Поцелуева М.M., Пустовидко А.В., Евтодиенко Ю.В. и др., 1998]. Благодаря повышенной реакционной способности молекулы кислорода предположительно увеличивается кислородная емкость биологических жидкостей, улучшается доставка кислорода к органам, обеспечивается полноценное энергоснабжение, нормализация работы транспортной АТФ-азы, 
восстановление должной возбудимости клетки и адекватности ее ответа на внешние раздражители.

Восстанавливающий эффект терагерцевых волн на частоте 129,0 ГГц, доказанный нами, хорошо согласуется с данными литературы. В группе больных стабильной стенокардией, образцы крови которых облучались ЭМИ частотой 129,0 ГГц в течение 15 ти минут, происходит снижение вязкости цельной крови при всех исследуемых скоростях сдвига, при отсутствии изменений агрегационной способности эритроцитов и уменьшении пластичности эритроцитарных мембран. При этом в $50 \%$ случаев происходило снижение вязкости, в 11,1\% - изменений не отмечалось и в 38,9\% повышение вязкости цельной крови под влиянием ЭМИ КВЧ частоты МСИП атмосферного кислорода. Аналогичные изменения были выявлены в группе контроля [Киричук В.Ф., Малинова Л.И., Креницкий А.П. и др., 2003]. Полученные данные свидетельствуют о преимущественном понижении вязкости цельной крови больных стабильной стенокардией под влиянием облучения ЭМИ КВЧ частоты МСИП О 2 в течение 15-ти минут. При 30-ти минутном облучении цельной крови больных стабильной стенокардией в группе в целом отмечается тенденция к уменьшению вязкости цельной крови на всех исследуемых скоростях сдвига и снижение агрегационных свойств эритроцитов. Деформируемость их мембран при этом остается неизменной. При этом в $52,4 \%$ случаев отмечалось уменьшение вязкости цельной крови, в 23,8\% - повышение и в $23,8 \%$ случаев - изменений гемореологических параметров выявлено не было [Киричук В.Ф., Малинова Л.И., Креницкий А.П. и др., 2003].

Таким образом, при облучении образцов цельной крови больных стабильной стенокардией ЭМИ КВЧ частоты 129 ГГц в течение 30 минут отмечается более выраженный эффект понижения ее вязкости по сравнению с 15-ти минутным режимом облучения как по количеству образцов, так и по индексу эффективности [Киричук В.Ф., Малинова Л.И., Креницкий А.П. и др., 2003]. То есть, изменение гемореологических параметров существенно зависит от времени облучения ЭМИ КВЧ частоты 129 ГГц. С увеличением времени экспозиции происходит увеличение стереотипности изменения вязкости цельной крови больных стабильной стенокардией и практически здоровых лиц. 60-ти минутный режим облучения ЭМИ частотой 129 ГГц, в отличие от менее продолжительных, приводит к повышению вязкости цельной крови больных стабильной стенокардией и практически здоровых лиц [Киричук В.Ф., Малинова Л.И., Креницкий А.П. и др., 2003].

На основании указанного выше, можно выделить основные закономерности влияния электромагнитного излучения терагерцевого диапазона на частотах МСИП оксида азота 150,176-150,664 ГГц и атмосферного кислорода 129,0 ГГц на нарушения 
реологических свойств крови и функциональной активности тромбоцитов белых крыс в состоянии острого иммобилизационного стресса:

1. ЭМИ ТГЧ на частотах оксида азота 150,176-150-664 ГГц и атмосферного кислорода 129,0 ГГц является мощным эффективным методом коррекции нарушений во внутрисосудистом компоненте микроциркуляции, вызванных острым иммобилизационным стрессом.

2. Эффективность ЭМИ ТГЧ на указанных частотах МСИП оксида азота и атмосферного кислорода зависит в большей степени от времени и режимов облучения (непрерывного, дробного, превентивного).

3. ЭМИ терагерцевого диапазона на частотах МСИП оксида азота и атмосферного кислорода способно предотвращать нарушения реологических свойств крови, вызванные острым иммобилизационным стрессом.

Таким образом, в условиях эксперимента на животных получены новые данные о характере воздействия ТГЧ - излучения на частотах МСИП оксида азота 150,176-150,664 ГГц и МСИП атмосферного кислорода 129,0 ГГц на нарушенные реологические свойства крови. Выявлена способность указанных частот восстанавливать стресс-опосредованные изменения реологических свойств крови белых крыс в зависимости от временной экспозиции волнами терагерцевого диапазона частот, режима облучения, пола, особенностей эстрального цикла самок.

Результаты проведенных исследований позволяют рекомендовать использование электромагнитное излучение терагерцевого диапазона на частотах молекулярного спектра излучения и поглощения оксида азота 150,176-150,664 ГГц и атмосферного кислорода 129,0 ГГц в клинической практике для коррекции нарушений и их предотвращении во внутрисосудистом компоненте микроциркуляции - реологических свойствах крови, сосудисто-тромбоцитарном гемостазе с учетом половых различий при различных заболеваниях, в том числе и сердечно - сосудистой системы.

Доказанная экспериментально эффективность влияния терагецовых волн на частотах МСИП оксида азота 150,176-150,664 ГГц и атмосферного кислорода 129,0 ГГц является обоснованием для разработки и внедрения в практическую медицину концептуально новых направлений - «Терагерцевая терапия», «ТГЧ-профилактика» и «ТГЧдиагностика».

\section{ЛИТЕРАТУРА}

1. Адаптационные реакции организма и система свертывания крови / А.М. Антонов, Н.В. Беликина, С.А. Георгиева и др. // Х съезд всесоюзного физиологического общества им. И.П. Павлова: Матер. Всесоюзн. конф.-1964.-Т. 2.-С. 47. 
2. Адаптационные реакции организма как показатели, определяющие эффективность КВЧ-терапии у больных нестабильной стенокардией: новые подходы в лечении / С.С. Паршина, Т.В. Головачева, Н.В. Старостина и др. // 12-й Российский симпозиум с международ. участием "Миллиметровые волны в биологии и медицине": Сб. докладов. М.: ИРЭ РАН. - 2000. - С. 37-39.

3. Активность тромбоцитов и функциональное состояние эндотелия у больных с нестабильной стенокардией с благоприятными и неблагоприятными исходами / И.В. Воскобой, А.В. Семенов, В.Ф. Киричук и др. // Кардиология. - 2002. - № 9. - С. 4-11.

4. Алексеенко А.А. Применение КВЧ терапии в комбинированном лечении ортопедических больных / А.А. Алексеенко, Л.Б. Манкевич, М.Б. Голант // Миллиметровые волны в медицине. Сборник статей. Под ред. акад. Н.Д. Девяткова и проф. О.В. Бецкого.- Москва, 1991.- Том 1. - С. 120-124.

5. Амосова Е.Н. Клиническая кардиология / Е.Н Амосова. - Киев.: Наукова думка, 1998.- 202 c.

6. Амрофеев В.И. О возможном корреляционном механизме активации собственных электромагнитных полей клеток организма при внешнем облучении / В.И. Амрофеев, Т.И. Субботина, А.А. Яшин // Миллиметровые волны в биологии и медицине. - 1997. №9-10. - C.28-33.

7. Амрофеев В.И. Современные медицинские технологии, использующие высокочастотные поля, в аспекте новых концепций клеточных и субклеточных взаимодействий / В.И. Амрофеев, Т.И. Субботина, А.А. Яшин // Автоматизация и современные технологии. - 1998. - №4. - С.24-28.

8. Андронов Е.В. Экспериментальное изучение влияния электромагнитных волн терагерцевого диапазона на частотах оксида азота на внутрисосудистый компонент микроциркуляции: Автореф. дис... докт. мед. наук / Е.В. Андронов. - Саратов, 2008.$50 \mathrm{c}$.

9. Аппарат для воздействия электромагнитными волнами крайне высоких частот / Креницкий А.П., Майбородин А.В., Киричук В.Ф. и др. // Патент на полезную модель № 66961 от 10.10 .2007 .

10. Аппарат для лечения электромагнитными волнами крайне высоких частот / О.В. Бецкий, А.П. Креницкий, А.В. Майбородин и др. // Патент на полезную модель №50835 от 27.01.2006.

11. Афанасьева Т.Н. Электромагнитное излучение миллиметрового диапазона как средство купирования гипертонических кризов / Т.Н. Афанасьева, В.Д. Петрова // 
Миллиметровые волны в медицине и биологии: Сб. докладов 10-го Российского симпозиума с международ. участием. - М.:ИРЭ РАН, 1995.- С. 38-40.

12. Балуда В.П. Претромботическое состояние / В.П. Балуда, М.В. Балуда, А.П. Гольдберг // Тромбоз и его профилактика.- 1999.- № 1.- С. 11-20.

13. Балуда В.П. Физиология системы гемостаза / В.П. Балуда, М.В. Балуда, И.И. Деянов. - М.: «Медицина», 1995. - 245с.

14. Балуда М.В. О диагностике предтромботического состояния системы гемостаза / М.В. Балуда, И.К. Тлепшуков // Тромбоз, гемостаз и реология.- 2001.- № 5.- С. 19-21.

15. Баринов В.Г. Определение вязкости цельной крови с помощью ротационного вискозиметра у больных острым инфарктом миокарда / В.Г. Баринов, И.В. Забелин, В.В. Соловьев // Лаб. дело.-1989.-№10.-С.26-27.

16. Баркаган 3.С. Патология гемостаза / 3.С. Баркаган, А.И. Воробьев. - М.: Медицина, 1985. - 311с.

17. Баркаган 3.С. Гемморагические заболевания и синдромы / 3.С. Баркаган.-М.: «Медицина», 1988. -576 с.

18. Баркаган 3.С. Диагностика и контролируемая терапия нарушений гемостаза / 3.С. Баркаган, А.П. Момот. - М.: «Ньюдиамед- АО», 2001.- 296 с.

19. Белоусов Ю.Б. Гемореологические исследования при ишемической болезни сердца / Ю.Б. Белоусов // Кардиология. - 1986. - №6. - С.115-118.

20. Беляков С.В. Состояние и тенденции развития аппаратуры для КВЧ-терапии / С.В. Беляков, О.В. Бецкий, Ю.Г. Яременко // Биомед. технологии и радиоэлектроника 1998.-№3.- C. 50-56.

21. Берклеевский курс физики- Пер с англ. / Э. Парселл - М.: Наука, 1971. - Т. 2. - 323 c.

22. Берсудский С.О. Общий адаптационный синдром. В кн. Общая патология / С.О. Берсудский. - Саратов: Изд-во СарГМУ, 2002. - С.79-84

23. Бессонов А.Е. Информационная медицина / А.Е. Бессонов, Е.А. Калмыкова, Б.А. Конягин.-М.: «Парус», 1999. - 592 С.

24. Бецкий О.В. История становления КВЧ терапии и десятилетние итоги работы Медицинской ассоциации КВЧ / О.В. Бецкий, Н.Н. Лебедева // Миллиметровые волны в биологии и медицине. - 2002. - №4. - С. 10-17.

25. Бецкий О.В. Лечение электромагнитными полями. Ч. 1. Источники и свойства электромагнитных волн / О.В. Бецкий, Н.Д. Девятков, Н.Н. Лебедева // Биомедицинская радиоэлектроника. - 2000. - № 7. - С. 3-9. 
26. Бецкий О.В. Лечение электромагнитными полями. Ч. 2. / О.В. Бецкий, Н.Д. Девятков, Н.Н. Лебедева // Биомедицинская радиоэлектроника. - 2000. - № 10. - С. 3 13.

27. Бецкий О.В. Механизм воздействия низкоинтенсивных миллиметровых волн на биологические объекты (биофизический подход) / О.В. Бецкий // Миллиметровые волны в биологии и медицине. М. ИРЭ РАН. - 1997. - С. 135-137.

28. Бецкий О.В. Механизмы биологических эффектов взаимодействия ММ-волн с живыми организмами / О.В. Бецкий // Миллиметровые волны нетепловой интенсивности в медицине: Сб. докл. Международ. симпоз.- М., 1991.-Т. 3.- С. 521528.

29. Бецкий О.В. Механизмы воздействия низкоинтенсивных миллиметровых волн на организм человека /О.В. Бецкий, В.В. Кислов, Н.Н. Лебедева // Материалы 14 Российского симпозиума с международным участием «Миллиметровые волны в медицине и биологии». - М., 2007. - С.207-210.

30. Бецкий О.В. Механизмы первичной рецепции низкоинтенсивных миллиметровых волн у человека / О.В. Бецкий // 10-й Российский симпозиум с международ. участием «Миллиметровые волны в медицине и биологии»: Сб. докладов. - М.:ИРЭ РАН. 1995. C. $135-138$.

31. Бецкий О.В. Миллиметровые волны низкой интенсивности в биологии и медицине / О.В. Бецкий, Н.Д. Девятков, В.В. Кислов // Биомедицинская электроника. - 1998. №10. - С. 13-29.

32. Бецкий О.В. Современные представления о механизмах воздействия низкоинтенсивных миллиметровых волн на биологические объекты / О.В. Бецкий, Н.Н. Лебедева //Миллиметровые волны в биологии и медицине. - 2001. - № 3. - С. 5 18.

33. Бецкий О.В. Электромагнитные миллиметровые волны и живые организмы / О.В. Бецкий, Н.Д. Девятков // Радиотехника.-1996.- № 9. - С. 4-11.

34. Биофизика полей и излучений и биоинформатика. Физико-биологические основы информационных процессов в живом веществе / Е.И. Нефедов, А.А. Протопопов, А.А. Хадарцев и др. // Под ред. А.А. Яшина. - Тула: Изд-во Тульск. гос. ун-та.- 1998. - 333 с.

35. Биофизические эффекты волн терагерцевого диапазона и перспективы развития новых направлений в биомедицинской технологии: «Терагерцевая терапия» и «Терагерцевая диагностика» / О.В. Бецкий, А.П. Креницкий, А.В. Майбородин и др. // Биомедицинские технологии и радиоэлектроника. - 2003. - №12.- С. 2-6. 
36. Бокарев И.Н. Постоянное и диссеминированное внутрисосудистое свертывание крови / И.Н. Бокарев // Клин. мед.- 2000.- № 8.-С. 37-41.

37. Брискин Б.С. Влияние ММВ-терапии на гемомикроциркуляцию при остром деструктивном панкреатите / Б.С. Брискин, В.Н. Букатко, А.Н. Никитин // Миллиметровые волны в биологии и медицине: Сб. докладов 12-го Российского симпозиума с международным участием.- М.: ИРЭ РАН, 2000. - С.4-6.

38. Бышевский А.Ш. Свертываемость крови при реакциях напряжения / А.Ш. Бышевский, В.Н. Кожевников. - Свердловск: Среднеуральское книжное издательство, 1986.- $170 \mathrm{c}$

39. Ванин А.Ф. Динитрозильные комплексы железа и S-нитрозотиолы - две возможные формы стабилизации и транспорта оксида азота в биосистемах / А.Ф. Ванин // Биохимия. - 1998. - Т. 63. - № 7. - С. 924-928.

40. Ванин А.Ф. Оксид азота и его обнаружение в биосистемах методом электронного парамагнитного резонанса / А.Ф. Ванин // Успехи физических наук. - 2000. - Т. 170. №4. - C. 455-458.

41. Власов В.В. Реакция организма на внешние воздействия / В.В. Власов. - Иркутск: Изд-во ИГУ, 1994. - 344 с.

42. Влияние КВЧ терапии на гемодинамику и физическую работоспособность больных стенокардией / О.Д. Локшина, Н.Д. Грекова, Б.В. Брай и др. // Миллиметровые волны в медицине. Сборник статей. Под ред. акад. Н.Д. Девяткова и проф. О.В. Бецкого. Том 1. - Москва, 1991. - С. 52-58.

43. Влияние миллиметровой терапии на антиоксидантную систему у детей с нефропатиями / Л.М. Овсянникова, О.Я. Боярская, И.В. Богдасарова, Е.Н. Туманян // Миллиметровые волны в биологии и медицине: Сб. докладов 12-го Российского симпозиума с международ. участием. М.: ИРЭ РАН, 2000.-С.1-2.

44. Влияние миллиметровой терапии на нарушения локальной сократимости у больных острым инфарктом миокарда с эпизодами безболевой ишемии миокарда / В.А. Люсов, Н.А. Волон, Р.М. Гафурова и др. // 12-й Российский симпозиум с международ. участием "Миллиметровые волны в биологии и медицине": Сб. докладов. М.: ИРЭ РАН. - 2000. - С. 82-83.

45. Влияние низкоинтенсивного электромагнитного излучения миллиметрового диапазона на биоэлектрическую активность периферических, центральных нервных структур и системную гемодинамику больных гипертонической болезнью / П.Я. Гапонюк, А.Е. Столбиков, Т.Ю. Шерковина, В.Д. Жуковский // Вопр. курортол. 1988.-№3.-C.14-18. 
46. Влияние слабого импульса электромагнитного и ионизирующего излучения на нервную систему / А.О. Дудкин, Г.Т. Божко, Е.А. Дробченко и др. // Слабые и сверхслабые поля и излучения в биологии и медицине: Тез. докл. I Межд. Конгресса. 1997. - C. 124-125.

47. Влияние ТГЧ-излучения на частотах оксида азота на постстрессорные изменения гемодинамики у белых крыс / В.Ф. Киричук, Т.С. Кораблева и др.// «Миллиметровые волны в медицине и биологии»: Сборник трудов 14 Росс. Симп. с межд. участием.Москва, 2007.- С. 133-135.

48. Влияние терагерцевых волн на частоте оксида азота, находящихся в скрещенных магнитном и электрическом полях, на реологические свойства крови больных нестабильной стенокардией / В.Ф. Киричук, Е.В. Андронов, Н.В. Мамонтова и др. // Биомедицинские технологии и радиоэлектроника.- 2005.- № 3.-С. 34-38.

49. Влияние терагерцевых спектров излучения оксида азота на функциональную активность тромбоцитов больных нестабильной стенокардией / В.Ф. Киричук, Е.В. Андронов, А.В. Майбородин и др. // Биомед. технологии и радиоэлектроника -2004.№12.-C.27-33.

50. Влияние электромагнитного излучения терагерцевого диапазона на частотах молекулярного спектра излучения и поглощения оксида азота на восстановление качественного и количественного состава эритроцитов крови (in vivo) / В.Ф. Киричук, О.И. Помошникова, О.Н. Антипова и др. // Биомедицинские технологии и радиоэлектроника. - 2004. - №11. - С. 21 - 27.

51. Влияние электромагнитного поля миллиметрового диапазона малой мощности на регенерацию периферических нервов / Л.И. Колосова, В.Д. Авелев, Г.Н. Акоев, О.В. Рябчикова // Миллиметровые волны нетепловой интенсивности в медицине: Сб. докл. мжд симпозиума. - М., 1991. - Ч. 2. - С.398-402.

52. Влияние электромагнитных КВЧ-колебаний на частотах молекулярных спектров излучения и поглощения оксида азота на функциональную активность тромбоцитов / В.Ф. Киричук, М.В. Волин, А.П. Креницкий и др. // Цитология.- 2001. - №43(8) C.759-763.

53. Возможность регулирования жизнедеятельности микроорганизмов при воздействии на них электромагнитных колебаний ММ диапазона / М.Б. Голант, А.К. Брюхова, Е.А. Двадцатова и др. // Под ред. Девяткова Н.Д.- В сборн. «Эффекты нетеплового воздействия миллиметрового излучения на биологические объекты».- М.: ИРЭ АН СССР, 1983.- С. 115-122. 
54. Восстановление функций тромбоцитов белых крыс, находящихся в состоянии стресса, под влиянием КВЧ-облучения на частоте оксида азота / В.Ф. Киричук, О.Н. Антипова и др. // Матер. XIII Росс. симп. «Миллиметровые волны в биологии и медицине».- Москва.- 2003.- С.91-93.

55. Воторопин С.Д. Электронная промышленность / С.Д. Воторопин, А. М. Кожемякин // Электронная промышленность.-1998.-№1-2.-С. 178-181.

56. Гаврилов О.К. Актуальные проблемы гемостаза в клинической практике / О.К. Гаврилов, В.А. Макаров, Н.Я. Лагутина. - М.: Медицина, 1987.- 181 с.

57. Галенок В.А. Гемореология при нарушениях углеводного обмена / В.А. Галенок, Е.В. Гостинская, В.Е. Диккер.- Новосибирск: Наука, 1987.-259с.

58. Гапеев А.Б. Особенности действия модулированного электромагнитного излучения крайне высоких частот на клетки животных: Автореф. дисс... канд. физ.-мат. наук / А.Б. Гапеев. - Пущино, 1997. - 23 с.

59. Гапочка Л.Д. Механизмы функционирования водных биосенсоров / Л.Д. Гапочка // Биомедицинская радиоэлектроника. - 2000. - №3. - С.48-55.

60. Гафаров В.В. Смертность от инфаркта миокарда (эпид. исследование на основе программ ВОЗ «Регистр острого инфаркта миокарда», МОНИКИ) / В.В. Гафаров, М.Ю. Благинина // Кардиология.-2005.-№5.-С. 49-51.

61. Гемокоагуляция и электромагнитное излучение терагерцевого диапазона молекулярного спектра оксида азота / В.Ф. Киричук, А.А. Цымбал, О.Н. Антипова и др. // Биомедицинские технологии и радиоэлектроника. - 2004. - №11. - С. 28 - 34.

62. Гемореологические аспекты в лечении больных атеросклерозом / Н.М. Никитина, О.В. Осипова, В.Ф. Киричук и др. // Тез. докл. ХІХ Международного симпозиума по реологии.-Клайпеда, 1998.-С.104.

63. Гемореология и электромагнитное излучение КВЧ-диапазона / В.Ф. Киричук, Л.И. Малинова, А.П. Креницкий и др. // Изд-во СарГМУ. - Саратов, 2003. - 188c.

64. Геращенко С.И. Влияние нетеплового КВЧ-излучения на биоэлектрическую активность мышц / С.И. Геращенко, О.И. Писанко, Ю.Н. Муськин // Миллиметровые волны нетепловой интенсивности в медицине: Сб. докл. межд симпозиума. - М., 1991.Ч.2.-С.430-435.

65. Гершезон Е.М. Молекулярная физика / Е.М. Гершезон, Н.Н. Малов, А.Н. Мансуров. - М.: Академия, 2002. - 272 с.

66. Гланц С. Медико-биологическая статистика / С. Гланц.- М., 1999.- 459 с. 
67. Глезер М.Г. Лечение пациентов острым инфарктом миокарда в условиях типичной клинической практики / М.Г. Глезер, Д.П. Семенцов, К.Э. Соболев // Кардиология.2005.- № 1.- c. 9-13.

68. Голант М.Б. Аналогия между некоторыми системами живых организмов и техническими СВЧ-устройствами / М.Б. Голант, Т.Б. Реброва // Радиоэлектроника.1986.- №10. - С. 10-19.

69. Голант М.Б. Биологические и физические факторы, обусловливающие влияние монохроматических электромагнитных излучений миллиметрового диапазона малой мощности на жизнедеятельность / М.Б. Голант // Применение миллиметрового излучения низкой интенсивности в биологии и медицине: Сб. науч. работ.- М., 1985.C. 21-36.

70. Голант М.Б. К вопросу о механизме возбуждения колебаний в клеточных мембранах слабыми электромагнитными полями / М.Б. Голант, В.А. Шашлов // Применение электромагнитных излучений низкой интенсивности в биологии и медицине под. ред. Н.Д. Девяткова.- М.: ИРЭ АН СССР. - 1986. -С.127-132.

71. Голант М.Б. О проблеме резонансного действия когерентного ЭМИ ММД на живые организмы / М.Б. Голант // Биофизика. - 1989. - №2. - С.339-348.

72. Голант М.Б. Об ультраструктурном обеспечении электромагнитной связи в системах живых клеток / М.Б. Голант, О.С. Сотников // Медико-биологические аспекты миллиметрового излучения: Сб. науч. трудов.- М., 1987.- С. 131-137.

73. Голант М.Б. Об успехах КВЧ-медицины. К 90-летию академика Н.Д. Девяткова: Сб. докладов / М.Б. Голант // 11-й Российский симпозиум с межд. участием «Миллиметровые волны в биологии и медицине». М.: ИРЭ РАН. - 1997.- С.8-9.

74. Голант М.Б. Резонансное действие когерентных электромагнитных электромагнитных излучений миллиметрового диапазона волн на живые организмы / М.Б. Голант // В сборн.: «Вопросы использования ЭМИ малой мощности крайне высоких частот ММВ в медицине». - Ижевск.- 1991.- С.20-48.

75. Головачева Т.В. Изменение иммунной системы при КВЧ-терапии у больных острым инфарктом миокарда / Т.В. Головачева, В.М. Павлюк, В.Ю. Ушаков // Применение КВЧ-излучения низкой интенсивности в биологии и медицине: Сб. науч. трудов. - Звенигород, 1989.-С. 15-16.

76. Головачева Т.В. Эффективность КВЧ-терапии у больных с прогрессирующей стенокардией на фоне перенесенного инфаркта миокарда / Т.В. Головачева, С.С. Паршина, Н.В. Субботина // Микроволновые технологии в народном хозяйстве.- КиевОдесса.-2002.-Вып.4.-С. 10-13. 
77. Головачева, Т.В. Использование ЭМИ КВЧ при сердечно-сосудистой патологии / Т.В. Головачева // Миллиметровые волны нетепловой интенсивности в медицине: Сб. науч. работ.- М., 1991.-С. 54-57.

78. Горизонтов П.Д. Гомеостаз / П.Д. Горизонтов. - М.: «Медицина», 1981. -576 с.

79. Горизонтов П.Д. Стресс и система крови / П.Д. Горизонтов, О.И. Белоусова, М.М. Федотова. - М.: «Медицина», 1983. - 240 с.

80. Горрен А.К.Ф. Универсальная и комплексная энзимология синтазы оксида азота / А.К.Ф. Горрен, Б. Майер // Биохимия. - 1998. - Т. 63. - №7. - С. 870 - 880.

81. Грабовская Е.Ю. Реакция крыс с различными индивидуальными особенностями двигательной активности на действие слабого ПеМП СНЧ: Автореф. дисс... канд. биол. наук. / Е.Ю. Грабовская. - Симферополь, 1992. - 23с.

82. Громов А.Е. Автоматический поплавковый вискозиметр / А.Е. Громов // Лаб. дело.- 1986.-№9.-С. 569-570.

83. Грубник Б.П. Опыт применения технологии "Ситько-МРТ" для реабилитации онкологических больных III-IV стадии / Б.П. Грубник, С.П. Ситько, А.А. Шалимов // Physics of the Alive. - 1998. - V. 6, N 1. - P. 97-102.

84. Гурвич А.Г. Принципы аналитической биологии и теории клеточных полей / А.Г. Гурвич.- М.: «Наука», 1990. -102 с.

85. Девятков Н.Д. Миллиметровые волны и их роль в процессах жизнедеятельности / Н.Д. Девятков, Н.Б. Голант, О.В. Бецкий // М.: Радио и связь. - 1991. - 168с.

86. Девятков Н.Д. О механизме воздействий электромагнитных излучений миллиметрового диапазона нетепловой интенсивности на жизнедеятельность организмов: Сб. науч. трудов / Н.Д. Девятков, М.Б. Голант // Эффекты нетеплового воздействия миллиметрового излучения на биологические объекты. - М., 1983. - С.1833.

87. Девятков Н.Д. Особенности взаимодействия миллиметрового излучения низкой интенсивности с биологическими объектами / Н.Д. Девятков, О.В. Бецкий // Применение ММ излучения низкой интенсивности в биологии и медицине: Сб. науч. трудов.- М., 1985.- С. 108-117.

88. Девятков Н.Д. Особенности медико-биологического применения миллиметровых волн / Н.Д. Девятков, Н.Б. Голант, О.В. Бецкий // М.: ИРЭ РАН, 1994. - 160с.

89. Девятков Н.Д. Роль синхронизации в воздействии слабых электромагнитных сигналов миллиметрового диапазона волн на живые организмы / Н.Д. Девятков, М.Б. Голант, А.С. Тагер // Биофизика. - 1983. - Т.28, №5. - С.895-896. 
90. Дементьева И.И. Экспресс-диагностика реологических свойств крови у кардиохирургических больных / И.И. Дементьева, Е.В. Ройтман // Метод. рекоменд.: M., 1995.-25c.

91. Депонирование оксида азота у крыс различных генетических линий и его роль в антистрессорном эффекте адаптации к гипоксии / М.Г. Пшенникова, Б.В. Смирин, О.Н. Бондаренко и др. // Росс. физиол. журнал им. И.М. Сеченова. - 2000. - Т.86. - № 2. - C. $174-181$.

92. Деформируемость и агрегационные свойства эритроцитов при воздействии на организм человека электромагнитных излучений различных видов / Л.Н. Катюхин, Н.Е. Ганелина, А.И. Олесин, Э.П. Карабанова // Физиология человека.-1996.-Т.22, №6.-C.95-99.

93. Енин Л.Д. Особенности функционирования кожных афферентов белой крысы в условиях воздействия электромагнитного излучения миллиметрового диапазона малой интенсивности / Л.Д. Енин, Г.Н. Акоев И.Л. Потехина // Миллиметровые волны нетепловой интенсивности в медицине: Сб. докл.-М.- 1991.- Ч. 2. - С. 425-429.

94. Жуков Б.Н. Влияние ММ-волн на микроциркуляцию / Б.Н. Жуков, Н.А. Лысов // Миллиметровые волны в медицине и биологии: Сб. докл. 11 Росс. симпозиума с межд участием. - М.- 1997. - С. 120-121.

95. Жукова Т.А. О механизмах действия микроволновой резонансной терапии при лечении больных язвенной болезнью двенадцатиперстной кишки / Т.А. Жукова, П.П. Чаяло, М.В. Чайка // Клин. мед. - 1994. - № 4. - С. 12-15.

96. Закономерности сдвигов в функциональной активности тромбоцитов под влиянием электромагнитных КВЧ-колебаний на частотах молекулярного спектра излучения и поглощения оксида азота / В.Ф. Киричук, А.В. Майбородин, М.В. Волин и др. // 12 Российский симпозиум с межд. участием «Миллиметровые волны в биологии и медицине»: Сб. докладов. - М.: ИРЭ РАН. - 2001. - С. 96-97.

97. Захаров Ю.М. Лекции по физиологии системы крови / Ю.М. Захаров. Мед. Вестник. - 1998.- №19. - Т.74.- С.32-47.

98. Захарченко В.Н. Возможности и проблемы вискозиметрии крови / В.Н Захарченко // Реологические исследования в медицине, выпуск 1.-М.-1997.-С.1-5.

99. Выявление различных углеводных остатков в структуре гликопротеидных рецепторов на поверхности цитоплазматической мембраны тромбоцитов с использованием белков лектинов и изучение влияния иммобилизационного стресса на степень экспрессии гликопротеидных рецепторов / А.Н. Иванов, П.А. Каравайкин // 
Молодые ученые - здравоохранению региона: Материалы 68 науч.- практ. конф. студентов и молодых ученых Саратовского ГМУ. - Саратов, 2007. - С. 135 - 136.

100. Иванов С.Г. О сравнительной эффективности немедикаментозных и лекарственных методов лечения гипертонической болезни / С.Г. Иванов // Тер. архив.1993.- № 1.-C. 44-47.

101. Ивановский В.И. Физика магнитных явлений / В.И. Ивановский, Л.А.Черникова // Изд-во: МГУ, М. - 1981. - 112 С.

102. Изменение некоторых показателей энергетического обмена и структурнофункционального состояния клеточных мембран у больных острым инфарктом миокарда под влиянием КВЧ-терапии / В.И. Рубин, Д.В. Садчиков, Г.Я. Мельникова и др. // Актуальные проблемы применения магнитных электромагнитных полей в медицине. - Л., 1990. - С.207-208.

103. Изменение реологических свойств крови под влиянием дозированной физической нагрузки у больных ИБС и лиц с факторами риска / В.В. Мурашко, А.В. Струтынский, Н.И. Шабанова и др. // Кардиология. - 1985. - №8.- С.25-28.

104. Изменение функциональной активности тромбоцитов под влиянием электромагнитных КВЧ-колебаний на частотах молекулярного спектра излучения и поглощения оксида азота / В.Ф. Киричук, А.В. Майбородин, М.В. Волин и др. // «Вопросы медико-биологических наук». Экспериментальные исследования процессов адаптации. Межвузовский сб. научных работ. - Саранск, 2000. - вып.5. - С. 50-56.

105. Измерение радиотепловых и плазменных излучений в СВЧ-диапазоне / А.Е. Башаринов, Л.Г. Тучков, В.М. Поляков и др. - М.: Советское радио, 1968. - 380 с.

106. Изучение агрегатного состояния крови больных, оперированных в условиях искусственного кровообращения на основе математической модели / Е.В. Ройтман, И.И. Дементьева, С.Ф. Леонова и др. // Гематол. и трансфизиол.-1996.-№5.-С. 7-10.

107. Ильинский И.С. КВЧ-терапия в сочетании с аэроионо- и водолечением у больных с язвенной болезнью желудка и 12-перстной кишки / И.С. Ильинский // Миллиметровые $\begin{array}{lllllll}\text { волны } & \text { в }\end{array}$ C. 67-69.

108. Ингибирование Fc-рецептор-зависимой агрегации тромбоцитов моноклональным антителом против комплекса гликопротеинов IIb-IIIa / Д.В. Виноградов, Т.Н. Власик, Т.Г. Агафонова и др. // Биохимия. - 1991. - Т. 56. - № 5. - С. 787 - 798.

109. Индуцированная АДФ агрегация тромбоцитов у больных с гипертонической болезнью с различной степенью гипертрофии миокарда левого желудочка / 
Е.В.Балякина, Ш.Э. Аталанов., З.А. Габбасов и др.// Тер. Архив. - 1991. - Т. 63. - №12 -C. $50-54$.

110. Использование электромагнитного излучения низкой интенсивности в лечении хронического пиелонефрита и мочеполовых свищей / Д.Л. Перепечай, Д.В. Кан, О.Б. Лоран и др. // Миллиметровые волны в медицине. Сборник статей. Под ред. акад. Н.Д. Девяткова и проф. О.В. Бецкого. Том 1. - Москва, 1991. - С. 125-134.

111. Использование электромагнитных волн миллиметрового диапазона в комплексном лечении заболеваний сердечно-сосудистой системы / Головачёва Т.В., Киричук В.Ф., Паршина С.С. и др. // Учебное пособие.- Изд-во СарГМУ. - 2006.- 159 с.

112. Капелько В.И. Гидродинамические основы кровообращения / В.И. Капелько // Соровский образовательный журнал. - 1996. - №2. - С.44-45.

113. Карпов В.Л. Определение аминогликозидных антибиотиков в биологических жидкостях / В.Л. Карпов // Антибиотики.-1984.-№9.-С.695-703.

114. Карченова В.Е. Влияние немедикаментозных методов лечения на функциональную активность сосудистой стенки и реологические свойства крови у больных стенокардией: Автореф. дис. ... канд. мед. наук / В.Е. Карченова.- Саратов, 1998.-27с.

115. Катин А.Я. Фолль-метод 2 плюс: акупунктура, синдром хронической усталости, КВЧ в медицине, гомеопатия / А.Я. Катин // Каунас: Quo Vadis.- 1995.

116. Катюхин Л.Н. Реологические свойства эритроцитов. Современные методы исследования / Л.Н. Катюхин // Физиол. журнал им. И.М. Сеченова.- 1995.- Т.81, № 6.C. $122-128$.

117. Квазиоптический КВЧ генераторный комплекс моделирования детерминированных шумов для биофизических исследований / А.П. Креницкий, А.В. Майбородин, О.В. Бецкий и др. // Биомедицинские технологии и радиоэлектроника. 2003. - №2. - C. 17-24.

118. КВЧ - индуцированное взаимодействие в системе форменных элементов крови / В.Ф. Киричук, Креницкий А.П., Малинова Л.И. и др. // Миллиметровые волны в биологии и медицине. - 2004. - №1. - С.34-39.

119. КВЧ-излучение и клеточные метаболиты. Итоги и перспективы исследования влияния ЭМИ КВЧ на частоте оксида азота на сложные биологические объекты / В.Ф. Киричук, А.П. Креницкий, А.В. Майбородин и др. // Сб. докладов «Миллиметровые волны в медицине и биологии». - Москва. - 2003. - С.108-115.

120. КВЧ-радиофизические подходы к проблеме ускорения лечения локальных нарушений в организме, ослабленном возрастными или иными изменениями: Сб. докладов / М.Б. Голант, Л.Е. Гедымин, Л.Н. Новикова и др. // 10-й Российский 
симпозиум с межд. участием «Миллиметровые волны в биологии и медицине». - М.: ИРЭ РАН. - 1995. - С.91-94.

121. КВЧ-терапия в клинической практике / Л.Е. Гедымин, М.Б. Голант, Т.В. Колпикова и др. // 12 Российский симпозиум с межд. участием «Миллиметровые волны в биологии и медицине». М.: ИРЭ РАН. - 2000. - С.45-49.

122. Киричук В.Ф. ЭМИ ММД в лечении стенокардии: отдаленные результаты / В.Ф. Киричук, С.С. Паршина, Т.В. Головачёва // Миллиметровые волны в биологии и медицине: Сб. докладов 11-го Российского симпозиума с международным участием.М.: ИРЭ РАН, 1997.-С. 20-22.

123. Киричук В.Ф. КВЧ-терапия / В.Ф. Киричук, Т.В. Головачева, А.Г. Чиж // Саратов: Издательство СарГМУ. - 1999. - 360 с.

124. Киричук В.Ф. Антитромбогенная активность стенки сосудов, гемостаз и реологические свойства крови у больных нестабильной стенокардией / В.Ф. Киричук, И.В. Воскобой // Терапевт. Архив. - 2000а. - № 12. - С. 47-50.

125. Киричук В.Ф. Взаимосвязь антитромбогенной активности стенки сосудов и свойств крови у больных нестабильной стенокардией / В.Ф. Киричук, И.В. Воскобой, А.П. Ребров // Тромбоз, гемостаз, реология. -2001. - № 5. - С. 31-34.

126. Киричук В.Ф. Возможности коррекции патологии гемокоагуляции методом терагерцевой терапии / В.Ф. Киричук, А.А. Цымбал, О.Н. Антипова // Микроциркуляция в клинической практике: Материалы 2 Всероссийской конференции с международным участием. - Москва, 2006. - С. 86.

127. Киричук В.Ф. Механизмы сосудисто-тромбоцитарного звена системы гемостаза / В.Ф. Киричук, А.А. Свистунов, П.В. Глыбочко // Клинико-физиологические аспекты. Саратов. - Изд-во: СарГМУ, 1998. - 35с.

128. Киричук В.Ф. Показатели сосудисто-тромбоцитарного механизма гемостаза и ближайший прогноз нестабильной стенокардии / В.Ф. Киричук, Ю.Г. Шварц // Кардиология. - 1998. - № 5. - С. 14-17.

129. Киричук В.Ф. Состояние сосудисто-тромбоцитарного гемостаза у больных с различными формами нестабильной стенокардии / В.Ф. Киричук, И.В. Воскобой, Л.С. Юданова // Российские мед. вести. - 2000. - № 1. - С. 32-35.

130. Киричук В.Ф. Сравнительная оценка динамики показателей гемостаза у больных острым инфарктом миокарда при использовании различных режимов КВЧ-терапии: непрерывного и прерывистого / В.Ф. Киричук, Т.В. Головачёва, С.В. Семенова // Тезисы докл. 17 междунар. регион. симпоз. по реологии.- Саратов, 1994.-С.170. 
131. Киричук В.Ф. Физиология крови / В.Ф. Киричук. - Из-во СарГМУ. - Саратов, 1999. $-89 \mathrm{c}$.

132. Киричук В.Ф. Физиология крови / В.Ф. Киричук. - Из-во СарГМУ. - Саратов, 2002. $-102 \mathrm{c}$.

133. Киричук В.Ф. Физиология крови / В.Ф. Киричук. - Из-во СарГМУ. - Саратов, 2005. $-102 \mathrm{c}$.

134. Киричук В.Ф. Функциональная активность тромбоцитов у больных с фибрилляцией предсердий и ишемическая болезнь сердца. Механизмы патогенеза или компенсации? / В.Ф. Киричук, Н.А. Железнякова, М.В. Волин // Кардиология. - 2005. №2. - C.5-9.

135. Киттель Ч. Введение в физику твердого тела / Ч. Киттель // М.:Наука, 1978. - 150 с.

136. Китура Е.М. Влияние метеорологических факторов на реологические свойства крови больных стенокардией / Е.М. Китура // Врачебное дело. - 1986. - №9. - С.72-83.

137. Ковалев А.А. О биотропности вращательных спектров и нескомпенсированных магнитных моментов биологически активных молекул / А.А. Ковалев // Миллиметровые волны в биологии и медицине. 2006. - № 3(43). - С. 78 - 81.

138. Колбун Н.Д. Информационно-волновая терапия / Колбун Н.Д // Электронная промышленность - 1991. - № 5. - С. 43-44

139. Колбун Н.Д. Информационно-волновая терапия: Науч.-практ. рук. / Н.Д. Колбун, А.Е. Бессонов, Р.Р. Волянюк. - Киев: Укр. энцикл, 1993. - 304с.

140. Комплексное лечение ожоговых ран терагерцевыми волнами молекулярного спектра оксида азота / Н.В. Островский, С.М. Никитюк, В.Ф. Киричук и др. // Биомедицинские технологии и радиоэлектроника. - 2004. - №11. - С.55-61.

141. Конако Ф. Терагерцевые волны / Ф. Конако, Д. Фэйтс // Ж. «Ломоносов».-2002.№5. - 102 c.

142. Константинов В. М. Общая биология / В.М. Константинов, А.Г. Резанов, Е.О. Фадеева // Изд-во: Академия, М., 2004. - 256 с.

143. Кораблева Т.С. Влияние превентивного режима ТГЧ-облучения на показатели гемодинамики у белых крыс / Т.С. Кораблева, А.Н. Иванов, С.В. Сухова // Молодые ученые - здравоохранению региона: Материалы 68 науч.- практ. конф. студентов и молодых ученых Саратовского ГМУ. - Саратов, 2007. - С. 136 - 137.

144. Коррекция NO-зависимых сердечно-сосудистых нарушений с помощью адаптации к гипоксии / С.Ю. Машина, Б.В. Смирин, И.Ю. Малышев и др. // Росс. физиол. журнал им. И.М. Сеченова. - 2001. - Т. 87. - № 1. - С. 110 - 117. 
145. Коррекция острых стресс-зависимых нарушений системы гемостаза с помощью аппарата КВЧ-NO/ В.Ф. Киричук, А.А Цымбал., О.Н. Антипова и др.// Медицинская техника. - 2005. -№1. - С.29-33.

146. Кошелева Н.А. Особенности функциональной активности тромбоцитов и нейтрофилов у больных острым коронарным синдромом. Влияние антиагрегантной терапии: Автореф. дис. ... канд. мед. наук / Н.А. Кошелева. - Саратов, 2002.-25с.

147. Креницкий А.П. Электродинамическая и электрокинетическая модели взаимодействия терагерцевых волн с живыми системами / А.П. Креницкий // Миллиметровые волны в биологии и медицине. - 2008, №1. - С.27-61.

148. Кузманкова М. Влияние миллиметровых волн и Ј-радиации на поверхностный электрический заряд эритроцитов / М. Кузманкова, С. Иванов // 10-й Российский симпозиум с международным участием «Миллиметровые волны в биологии и медицине».- М.: ИРЭ РАН - 1995.- С.111-112.

149. Кузник Б.И. Физиология и патология системы крови / Б.И. Кузник // М.: Вузовская книга, 2004. - 286с.

150. Кузник Б.И. Иммуногенез, гемостаз и неспецифическая резистентность организма / Б.И. Кузник, В.Н. Васильев, Н.Н. Цыбиков // Изд-во.: «Медицина», М., 1989. - 320с.

151. Кузьменко А.П. Микроволновая резонансная терапия в профилактике и лечении парезов желудочно-кишечного тракта после операций на толстой кишке / А.П. Кузьменко, И.Е. Соловьев, А.В. Тофан // Physics of the Alive. - 2000. - V. 8.- N 1. - Р. 104-108.

152. Кулагин Н.А. Методы расчета электронных структур свободных и примесных ионов. / Н.А. Кулагин, Д.Т. Свиридов // Изд-во: Наука, М., 1986. - 117 с.

153. Куропатова Е.С. Микроволновая резонансная (информационно-волновая) терапия / Е.С. Куропатова. // Изд-во: «Елень» - Н. Новгород, 1994. - 80с.

154. Лазеро-стимулированные радиоизлучения биотканей и водных сред. / В.И. Петросян, Н.И. Синицин, В.А. Елкин и др. // Биомедицинская радиоэлектроника.2000.- № 4.-C. 52-57.

155. Лакин К.М. Исследование влияния некоторых промежуточных продуктов и ферментов углеводного обмена на агрегацию эритроцитов / К.М. Лакин, М.С. Овнатанова // Кардиология.-1979.-№8.- С.114-115.

156. Лебедева А. Ю. Применение электромагнитных волн миллиметрового диапазона в кардиологии / А. Ю. Лебедева // Биомед. радиоэлектроника. - 1998. - № 2. - С. 49-54. 
157. Лебедева Н.Н. Экспериментально-клинические исследования в области биологических эффектов миллиметровых волн (обзор, часть 1) / Н.Н. Лебедева, Т.И. Котровская // Миллиметровые волны в биологии и медицине - 1999. -№3.-С.3-13.

158. Левтов В.А. Реология крови / В.А. Левтов, С.А. Регирер, Н.Х. Шадрина - М.: Медицина, 1982. - 272 с.

159. Ленинджер А. Основы биохимии / А. Ленинджер.- М.: «Мир», 1985.- 734 с.

160. Лоуренс Д.Р. Клиническая фармакология / Д.Р. Лоуренс, П.Н. Бенитт // Изд-во: «Медицина», М., 1993. - Т. 1. - 640 с.

161. Мазуров А.В. Наследственные дефекты мембранных гликопротеидов тромбоцитов / А.В. Мазуров, С.А. Васильев // Гематол. и Трансфуз. - 1994б. - Т.39. - С.34-38.

162. Мазуров А.В. Структура и функции мембранных гликопротеидов тромбоцитов/ А.В. Мазуров, С.А. Васильев // Гематол. и Трансфуз. - 1994а. - Т.39. - С.29-34.

163. Майбородин А.В. Комплекс для исследования тонких структур молекулярных спектров физических и биологических сред / А.В. Майбородин, А.П. Креницкий, В.Д. Тупикин // Радиолокация-навигация-связь: VII Международ. конференция.- Воронеж, 2001.- C. 21-38.

164. Майбородин А.В. Панорамно-спектрометрический комплекс для исследования тонких структур молекулярных спектров физиологических и биологических сред / А.В. Майбородин, А.П. Креницкий, В.Д. Тупикин // Биомедицинские технологии и радиоэлектроника. - 2001. - №8. - С. 35-47.

165. Малышев И.Ю. Стресс, адаптация и оксид азота / И.Ю. Малышев, Е.Б. Манухина // Биохимия. - 1998. - Т.63. - №7. - С. 992 - 1006.

166. Мамонтова Н.В. Характер сдвигов в нарушенных реологических свойствах крови под влиянием ТГЧ-волн на частоте оксида азота 240 ГГц: Автореф. дис... канд. мед. наук / Н.В.Мамонтова. - Саратов, 2006.-24c.

167. Манухина Е.Б. Стресс-лимитирующая система оксида азота / Е.Б. Манухина, И.Ю. Малышев // Росс. физиол. журнал им. И.М. Сеченова. - 2000. - Т.86. - №. 10. - С. 1283 $-1292$.

168. Марков Х.М. Окись азота и окись углерода - новый класс сигнальных молекул / Х.М. Марков // Успехи физиологических наук. - 1996. - Т. 27, №4. - С. 30-44.

169. Марков Х.М. Оксид азота и сердечно-сосудистая система / Х.М. Марков // Успехи физиологических наук. - 2001. - Т. 32, № 3. - С. 49 - 65.

170. Махова Г.Е. Состояние сосудисто-тромбоцитарного звена системы гемостаза и эффективность ЭМИ ММД в его коррекции в комплексной терапии язвенной болезни 
желудка и двенадцатиперстной кишки: Автореф. дис... канд. мед. наук / Г.Е. Махова. - Саратов, 1998.- 25 c.

171. Медико-биологические аспекты миллиметрового излучения / В.Н. Запорожан, Т.Б. Реброва, О.В. Хаит и др.- М.: ИРЭ АН СССР, 1987. - С. 21-34.

172. Меерсон Ф.З. Адаптация, стресс и профилактика / Ф.З. Меерсон // Наука. - М. 1981. $-425 \mathrm{c}$.

173. Механизм действия терагерцевых волн на частотах оксида азота с физиологической точки зрения / Киричук В.Ф., Цымбал А.А. и др. // Миллиметровые волны в биологии и медицине. - 2009.- №1-2 (53-54). - С.47-55.

174. Механизмы передачи сигнала оксидант - оксид азота в сосудистой ткани / М.С. Волин, К.А. Дэвидсон, П.М. Каминска и др. // Биохимия. - 1998. - Т. 63 - № 7. - С. 958 -965 .

175. Микроциркуляция и электромагнитное излучение ТГЧ-диапазона / В.Ф. Киричук, А.П. Креницкий, А.В. Майбородин, В.Д. Тупикин // Саратов.- Изд - во: СарГМУ, 2006. $-391 \mathrm{c}$.

176. Миллиметровые волны в лечении гастродуоденальных язв / А.П. Алисов, О.В. Алисова, Т.В. Григорина-Рябова и др. // Миллиметровые волны в медицине. Сборник статей. Под ред. акад. Н.Д. Девяткова и проф. О.В. Бецкого, Москва.- 1991. - Том 1.- С. $5-15$.

177. Минцер О.П. Применение электромагнитного излучения крайне высокой частоты для лечения больных хроническим необструктивным бронхитом / О.П. Минцер, А.Я. Дзюблик, В.М. Кузьменко // Миллиметровые волны в медицине. Сборник статей под ред. акад. Н.Д. Девяткова и проф. О.В. Бецкого.- Том 1. - Москва.- 1991. - С. 135-150.

178. Миняев В.А. Общественное здоровье и здравоохранение / В.А. Миняев, Н.И. Вишнякова // Изд-во: Медпресс-информ.- М., 2002. - 528c.

179. Мищенко В.П. Влияние физических факторов на гемостаз / В.П. Мищенко, С.В. Мищенко // Изд-во: Медпресс, Полтава.- 2003.- 120 с.

180. Мищенко В.П. Физическая активность, гемостаз и здоровье / В.П. Мищенко, Е.Л. Еремина, И.В. Мищенко // Изд-во: Медпресс. - Полтава 2004.- 80 с.

181. Мищук И.И. Изменение реологических свойств крови у тяжелобольных и их коррекция / И.И. Мищук // Анестезиология и реаниматология.-1993.-№6.-С. 70-74.

182. Моисеев В.Н. Результаты лечения больных ишемической болезнью сердца электромагнитным излучением миллиметрового диапазона / В.Н. Моисеев, И.В. Константинов, И.Г. Левыкина // Миллиметровые волны в медицине. Сб.: М, 1991. - С. 48-51. 
183. Молекулярные HITRAN-спектры газов метаболитов в терагерцевом и ИК диапазонах частот и их применение в биомедицинских технологиях / О.В. Бецкий, А.П. Креницкий, А.В. Майбородин и др. // Биомедицинские технологии и радиоэлектроника. - 2007. - № 7. - С. 5 - 9.

184. Момот А.П. Патология гемостаза / А.П. Момот. - СПб.: ФормаТ, 2006. - 208 с.

185. Морозов Ю.А. Гемореологические изменения при операциях маммарноаортокоронарного шунтирования / Ю.А. Морозов, Е.В. Ройтман, М.А. Чарная // Кардиология.-2004.-Т. 44., №4.-С. 57-60.

186. Невзорова В.А. Роль окиси азота в регуляции легочных функций / В.А. Невзорова, М.В. Зуга, Б.И. Гельцер // Тер. архив. - 1997. - Т.69. - №3. - С. 68 - 73.

187. Некоторые механизмы влияния миллиметрового излучения на патогенез нестабильной стенокардии / В.А. Люсов, Н.А. Волов, А.Ю. Лебедева и др. // Миллиметровые волны в биологии и медицине: Сб. докладов 10-го Российского симпозиума с международ. участием. - М.: ИРЭ РАН, 1995.-С.26-27.

188. Никитина Н.М. Влияние терапии ципрофибратом (липанором) на некоторые показатели гемостаза и реологии у больных стабильной стенокардией / Н.M. Никитина, В.Ф. Киричук, Л.С.Юданова // Тромбоз, гемостаз и реология.-2000.№2(2).-C.22-25.

189. Никитина Н.М. Изменение реологических свойств крови и значение их коррекции в оптимизации лечения больных стенокардией: Автореф. дис....канд. мед. наук / Н.М. Никитина. - Саратов, 1998.-25с.

190. Никитина Н.М. Состояние антитромбогенной активности сосудистой стенки у больных стабильной стенокардией. Взаимосвязь с гемореологическими нарушениями / Н.М. Никитина, В.Ф. Киричук, А.Н. Егорова // Тромбоз, гемостаз и реология. - 2002. №2. - C. 33-37.

191. Новый высокочувствительный метод анализа агрегации тромбоцитов / В.А. Габбасов, Е.Г. Попков, И.Ю.Гаврилов и др. // Лабор. дело.-1989.-№10.-С. 15-18.

192. О лечебном эффекте КВЧ воздействия у неврологических больных / М.А. Ронкин, О.В. Бецкий, И.М. Максименко и др. // Миллиметровые волны в медицине: Сборник статей. Под ред. акад. Н.Д. Девяткова и проф. О.В. Бецкого.- Том 1. - Москва.- 1991. C. 92-95.

193. О связи Z-потенциала эритроцитов со степенью их агрегации при гипертонической болезни и ишемической болезни сердца / Г.М. Токалев, Н.Д. Китаева, Г.М. Столяр, В.А. Шабанов // Кардиология.-1977.- №5.-С. 7-10. 
194. Оганов Р.Г. Сердечно-сосудистые заболевания в Российской Федерации во второй половине XX века: тенденции, возможные причины, перспективы / Р.Г. Оганов, Г.Я. Масленикова // Кардиология. - 2000. - Т. 40, №6. - С. 4-8.

195. Оксид азота и электромагнитное излучение КВЧ / В.Ф. Киричук, А.П. Креницкий, А.В. Майбородин и др. // Биомедицинские технологии и радиоэлектроника. - 2002. №10. - С. 95-108.

196. Панин Л.Е. Биохимические механизмы стресса / Л.Е. Панин // Изд-во Наука, Новосибирск, 1983. - 232 с.

197. Папаян Л.П. Современное представление о механизме регуляции свертывания крови / Л.П. Папаян // Тромбоз, гемостаз и реология.- 2003.- № 2.-С. 7-11.

198. Парфёнов А.С. Взаимосвязь нарушений реологических свойств крови и системы гемостаза у больных ишемической болезнью сердца / А.С. Парфёнов, Ю.Б. Белоусов // Кардиология.- 1989.- № 10.- С.47-50.

199. Парфенов, А.С. Оценка реологических свойств крови с использованием ротационного вискозиметра / А.С. Парфенов // Клин. лаб. диагн.-1992.-№3-4.-С.42-45.

200. Паршина С.С. Адаптационные механизмы системы гемостаза и реологии крови у больных с различными формами стенокардии: Автореф. дис... докт. мед. наук / С.С. Паршина. - Саратов, 2006. - 48c.

201. Паршина С.С. Влияние электромагнитного излучения миллиметрового диапазона на функциональное состояние системы гемостаза у больных стенокардией: Автореф. дис. ... канд. мед. наук / С.С. Паршина. - Саратов, 1994. - 28c.

202. Паршина С.С. Действие электромагнитных волн миллиметрового диапазона на свёртывание крови и фибринолиз больных стенокардией / С.С. Паршина, В.Ф. Киричук // Военно-медицинский журнал. -1991.- № 11.-С.54-55.

203. Паршина С.С. Индивидуальный подход к назначению КВЧ-терапии у больных стенокардией / С.С. Паршина, В.Ф. Киричук, Т.В. Головачёва // Миллиметровые волны в медицине и биологии.-М.- 1995.-С.31-33.

204. Паршина С.С. Новые достижения в использовании электромагнитного излучения миллиметрового диапазона при лечении сердечно-сосудистой патологии / С.С. Паршина // Миллиметровые волны в биологии и медицине. - 2006. - №1(41). - C.32-48.

205. Паршина С.С. Первые результаты клинического применения электромагнитного излучения терагерцевого диапазона на частотах молекулярного спектра оксида азота в кардиологии / С.С. Паршина, В.Ф. Киричук, Т.В.Головачёва // Современные аспекты диагностики, лечения и профилактики в кардиологии: Сбор. науч. трудов.- Саратов, 2005.- C. 109-111. 
206. Патология гемокоагуляции, фибринолиза в условиях хронического стресса и терагерцевая терапия / В.Ф. Киричук, А.А. Цымбал, О.Н. Антипова и др. // Миллиметровые волны в биологии и медицине. - 2006. - №(43). - C.40-50.

207. Первый опыт клинического применения электромагнитного излучения терагерцевого диапазона на частотах молекулярного спектра оксида азота / С.С. Паршина, В.Ф. Киричук, Т.В. Головачева и др. // Биомедицинские технологии и радиоэлектроника. - 2004. - № 11. - С. 46 - 54.

208. Повышение фагоцитарной активности лейкоцитов крови больных язвенной болезнью желудка после облучения миллиметровыми волнами / Т.К. Шмелева, М.В. Пославский, В.А. Старшинина и др. // Миллиметровые волны в медицине. Сборник статей. Под ред. акад. Н.Д. Девяткова и проф. О.В. Бецкого.- Том 1. - Москва.- 1991. C. 240-245.

209. Показатели гемореологии и системы фибринолиза у пожилых больных с гипертонической болезнью и изолированной артериальной гипертонией / Т.Э. Поворинская, В.Г. Ионова, Ю.Я. Варакин и др. // Тромбоз, гемостаз и реология.-2000.№2.-C. 16-18.

210. Помошникова О.И. Влияние ТГЧ-излучения на частотах молекулярного спектра излучения и поглощения оксида азота 150,176 - 150,664 ГГц на качественный и количественный состав эритроцитов крови белых крыс, находящихся в состоянии иммобилизационного стресса: Автореф. дис... канд. мед. наук. / О.И. Помошникова. Саратов, 2006. - 23 c.

211. Пославский М.В. КВЧ-терапия при различных вариантах течения язвенной болезни желудка и двенадцатиперстной кишки / М.В. Пославский // Миллиметровые волны в медицине и биологии: Матер. Х Российского симпоз. с межд. участием. - М., ИРЭ PAH, 1995. - C. 63-64.

212. Пославский М.В. Физическая терапия крайне высокой частотой (КВЧ-терапия) в лечении и профилактике язвенной болезни / М.В. Пославский // Миллиметровые волны нетепловой интенсивности в медицине: Сб. науч. тр.- М., 1991.- С. 142-146.

213. Поцелуева М.М. Образование реактивных форм кислорода в водных растворах под действием электромагнитного излучения КВЧ-диапазона / М.М. Поцелуева, А.В. Пустовидко, Ю.В. Евтодиенко // Доклады академии наук.- 1998.- № 3.- С. 415-418.

214. Превентивное антистрессорное действие ЭМИ КВЧ / Е.Н. Чуян, Н.А. Темурьянц, Е.Н. Темурьянц и др. // Миллиметровые волны в биологии и медицине. - 2002. №2(26). - C.44-51. 
215. Пресман А.С. Электромагнитные поля и живая природа / А.С. Пресман - М.: Наука, 1968. - 230 с.

216. Применение методов спектрально-волновой диагностики и резонансно-волновой терапии при тиреоидной патологии / Л.А. Лисенкова, В.И. Петросян, Э.А. Житенева и др. // Миллиметровые волны в биологии и медицине: Сб. докладов 10-го Российского симпозиума с международ. участием.- М.: ИРЭ РАН, 1995.- С. 16-18.

217. Применение миллиметровых волн в клинической медицине (последние достижения) / Ю.Л. Арзуманов, О.В. Бецкий, Н.Д. Девятков, Н.Н. Лебедева // 11-й Российский симпозиум с международ. участием «Миллиметровые волны в медицине и биологии»: Сб. докладов. - М.:ИРЭ РАН.- 1997. С. 9-13.

218. Применение низкоинтенсивных электромагнитных миллиметровых волн в медицине: Сб. докладов / Н.Д. Девятков, Ю.Л. Арузманов, О.В. Бецкий и др. // 10-й Российский симпозиум с международным участием «Миллиметровые волны в биологии и медицине».- М.: ИРЭ РАН. - 1995.- С.6-8.

219. Применение ТГЧ-излучения на частоте молекулярного спектра поглощения оксида азота (NO) при лечении экспериментальной стафилококковой инфекции белых мышей / Г.М. Шуб, О.А. Финохина, А.П. Креницкий и др. // Материалы 14 Российского симпозиума с международным участием «Миллиметровые волны в медицине и биологии». - Москва. - 2007. - С.136-138.

220. Применение электромагнитного излучения терагерцевого диапазона на частотах молекулярного спектра оксида азота при лечении экспериментальной стафилококковой инфекции / Г.М. Шуб, А.В. Лепилин, О.А. Финохина и др. // Биомедицинские технологии и радиоэлектроника.- 2004.- № 11.-С. 62-64.

221. Проблемы косвенного и прямого наблюдения резонансной прозрачности водных сред в миллиметровом диапазоне / В.И. Петросян, Н.И. Синицин, В.А. Елкин и др. // Электронная промышленность.- 2000.- № 1.-С. 99-103.

222. Прохоров Б.Б. Здоровье населения России по регионам / Б.Б. Прохоров. - М.: МНЭПУ, 1999. - 324 c.

223. Пучиньян Д.М. Адаптационная гемокоагулология / Д.М. Пучиньян // Изд-во: «Слово», 1997. - 360 с.

224. Пшенникова М.Г. Феномен стресса. Эмоциональный стресс и его роль в патологии / М.Г. Пшенникова // Патол. физиол. и эксперим. терапия.- 1991.- № 6.-С. 54-58.

225. Разумов В.Б. Реологические свойства крови при ишемической болезни сердца / В.Б. Разумов, Ю.Б. Белоусов // Кардиология. - 1977. - №1.- С.99-103. 
226. Распространенность ишемической болезни сердца. Её связь с основными факторами риска и эффективность многолетней многофакторной профилактики на промышленных предприятиях / М.С. Тожиев, Д.Б. Шестов, В.И. Воробьев и др. // Терапевтический архив.- 2000.- № 9.-С. 23-26.

227. Резонансные свойства и структура воды / В.И. Петросян, А.В. Майбородин, С.А. Дубовицкий, и др. // Миллиметр. волны в биологии и медицине.-2005.-Т. 33, №1.C.18-31.

228. Реология крови и КВЧ-воздействие / В.Ф. Киричук, Л.И. Малинова, А.П. Креницкий и др. // Изд-во Сар ГМУ.- Саратов. 2003.-190 с.

229. Реутов В.П. NO-синтетазная и нитритредуктазная компоненты цикла оксида азота / В.П. Реутов, Е.Г. Сорокина // Биохимия. - 1998. - Т. 63. - №7. - С. 1029 - 1040.

230. Рецепторная регуляция активности тромбоцитов / А.Г. Муляр, М.Т. Гасанов, Е.Н. Ющук и др. // Экспериментальная и клиническая фармакология. - 2004. - Т. 67. - №1. - C. $61-68$.

231. Решенные и нерешенные проблемы спектрально-волновой диагностики и прецизионно-волновой терапии / А.И. Гуляев, Л.А. Лисенкова, В.Ф. Киричук и др. // Миллиметровые волны в медицине и биологии: Сб. докладов 11-го Российского симпозиума с международ. участием. - М.:ИРЭ РАН, 1997.- С. 92-95.

232. Родштат И.В. Некоторые новые физиологические подходы к оценке КВЧвоздействия на биологические объекты: Сб. докладов / И.В. Родштат // 11-й Российский симпозиум с международным участием «Миллиметровые волны в биологии и медицине». - М.: ИРЭ РАН - 1997. - С.151-153.

233. Родштат И.В. Интерстициальная (внеклеточная) и внутриклеточная вода: некоторые регуляторные механизмы адаптации в контексте КВЧ-воздействия низкой интенсивности / И.В. Родштат // Биомед. радиоэлектр.-2005.-№6.- С.28-33.

234. Родштат И.В. Механизмы КВЧ-терапии (миллиметровой терапии) - это механизмы продления жизни / И.В. Родштат // Материалы 14 Российского симпозиума с международным участием «Миллиметровые волны в медицине и биологии». - Москва. $-2007 .-$ C.233-239.

235. Родштат И.В. Физиологическая концепция взаимодействия миллиметровых радиоволн с организмом человека / И.В. Родштат // Миллиметровые волны нетепловой интенсивности в биологии и медицине: Сб. науч. тр.- М., 1991. - С. 548-553.

236. Ройтман Е.В. Клиническая гемореология / Е.В. Ройтман // Тромбоз, гемостаз, реология. - 2003.- № 3. - С. 13-27. 
237. Роль свободного и депонированного оксида азота в адаптации к гипоксии сердечно-сосудистой системы / Е.Б. Манухина, С.Ю. Машина, М.А. Власова и др. // Регионарное кровообращение и микроциркуляция. - 2004. - №3. - С. 4 - 11.

238. Роль электромагнитных волн в процессах жизнедеятельности / Н.И. Синицын, В.И. Петросян, В.А. Елкин и др. // Актуальные проблемы электронного машиностроения: Матер. междунар. научно-техн. конф. - Саратов, 2000. - С. 483-490.

239. Россошанская С.И. Антитромбогенная активность стенки сосудов у больных хронической сердечной недостаточности 2 функционального класса / С.И. Россошанская, В.Ф. Киричук, А.П. Ребров // Клиническая лабораторная диагностика. - 2005. - № 10. - C. 46 - 49 .

240. Россошанская С.И. Клиническое значение нарушений гемореологии у больных с хронической сердечной недостаточностью ишемической этиологии: Автореф. дисс.... канд. мед. наук / С.И. Россошанская.-Саратов, 2005.-26с.

241. Рубин В.И. Изменение биохимических тестов при КВЧ-терапии больных инфарктом миокарда / В.И. Рубин, Г.Я. Мельникова // Миллиметровые волны нетепловой интенсивности в медицине: Сб. науч. трудов.- М., 1991.-С. 355-361.

242. Руев В.В. Опыт применения миллиметровой терапии для лечения пациентов с рассеянным склерозом / В.В. Руев, В.В. Василенко, В.В. Кобаидзе // Миллиметровые волны в биологии им медицине: Сб. докладов 12-го Российского симпозиума с международ. участием. - М.:ИРЭ РАН, 2000.-С. 69-71.

243. Северина И.С. Растворимая гуанилатциклаза в молекулярном механизме физиологических эффектов окиси азота / И.С. Северина // Биохимя. - 1998. - Т. 63. № 7. - C. $939-997$.

244. Северина И.С. Растворимая форма гуанилатциклазы в молекулярном механизме физиологических эффектов окиси азота и в регуляции процесса агрегации тромбоцитов / И.С. Северина // Бюл. эксперим. биол. мед. - 1995. - № 3. - С. 230 -235.

245. Селезнев С.А. Клинические аспекты микрогемоциркуляции / С.А. Селезнев, Г.И. Назаренко, В.С. Зайцев.-Л.: «Медицина», 1985.- 178с.

246. Селье Г. Очерки об адаптационном синдроме / Г. Селье - М.: Медицина, 1960. $254 \mathrm{c}$.

247. Семенова С.В. Влияние электромагнитного излучения миллиметрового диапазона на функциональное состояние системы гемостаза у больных инфарктом миокарда: Автореф. дис.... канд. мед. наук / С.В. Семенова.- Саратов, 1994.- 25с. 
248. Семенова С.В. Способ определения индивидуальной чувствительности к КВЧтерапии / С.В. Семенова, В.Ф. Киричук, Т.В. Головачёва // Патент Роспатента, № 2082977 от 27.06.1997.

249. Сергеев П.В. Физико-химические механизмы и гормональная регуляция свертывания крови / П.В. Сергеев, Р.Д. Сейфулла А.И. Майнский // Изд-во: «Наука», M., 1974. - 264 c.

250. Ситько С.П. Введение в квантовую медицину / С.П. Ситько, Л.Н. Мкртчян. Киев: Паттерн, 1994. - 145 с.

251. Скопюк М.И. Эффективность и безопасность микроволновой резонансной терапии в лечении детского церебрального паралича: двойное; слепое перекрестное исследование / М.И. Скопюк, А.А. Соловьева // Physics of the Alive. - 1994. - V. 2, N1. P. 91-101.

252. Смирнов И.Ю. Влияние агрегационно-электростатических взаимодействий между эритроцитами на потоковые характеристики крови в артериальных сосудах / И.Ю. Смирнов, Н.П. Здюмаева, А.С. Дюкова // Матер. междунар. конф. по гемореологии.Ярославль, 2001.-С.26.

253. Смирнов И.Ю. Влияние адсорбированных протеинов на реологические характеристики эритроцитов / И.Ю. Смирнов, В.Н. Левин // Физиология человека.2004.- T. 30, №2.-C. 145-149.

254. Собственные электромагнитные излучения микроорганизмов / Г.М. Шуб, В.И. Петросян, Н.И. Синицын и др. // Биомедицинская радиоэлектроника. -2000.- № 2.- С. 58-60.

255. Соловьев В.В. Агрегация тромбоцитов, гемостаз и реологические свойства артериальной и венозной крови у больных острым инфарктом миокарда / В.В. Соловьев, И.В. Забелин, В.Г. Баринов // Кардиология.-1989.-№10.-С.40-43.

256. Солпов А.В. Механизмы лимфоцитарно-тромбоцитарной адгезии: Автореф. дис... канд. мед. наук / А.В. Солпов. - Чита, 2005.-24c.

257. Сравнительное изучение клинической эффективности электромагнитных волн миллиметрового диапазона при облучении различных рефлекторных зон у больных с гастродуоденальными язвами / П.Я. Гапонюк, Т.Ю. Шерковина, Е.А. Юркова и др. // Миллиметровые волны в медицине. Сборник статей. Под ред. акад. Н.Д. Девяткова и проф. О.В. Бецкого.- Москва.- 1991. -Том 1. - С. 32-36.

258. Сторожок С.А. Зависимость стабильности и цитоскелета / С.А. Сторожок, А.Г. Санников, А.В. Белкин // Научн. вестн. Тюменского университета.-2000.-Т. 1.-С. 73-84. 
259. Структурные перестройки в водной фазе клеточных суспензий белковых растворов при светокислородном эффекте / С.Д. Захаров, А.В. Иванов, Е.Б. Вольф и др. / Квантовая электроника. - 2003. - Т. 33. - №2. - С. 149 - 162.

260. Субботина В.Г. Влияние антагонистов кальции на агрегацию у больных с ишемической болезнью сердца: Автореф. дис... канд. мед. наук/ В.Г. Субботина. Саратов, 1995. - $25 \mathrm{c}$.

261. Субботина Н.В. Особенности клинического течения и динамики гемореологических показателей на фоне применения немедикаментозных методов лечения у больных нестабильной стенокардией: Автореф. дис... канд. мед. наук / Н.В. Субботина.- Саратов, 2003.-26c.

262. Суворов С.А. Изменение состояния системы гемостаза у больных хроническим простатитом под влиянием электромагнитного излучения миллиметрового диапазона нетепловой интенсивности: Автореф. дис... канд. мед. наук / С.А. Суворов.- Саратов, 1998.- $28 \mathrm{c}$.

263. Суточная продукция NO у больных артериальной гипертонией II стадии / Н.П. Лямина, В.Н. Сенчихин, П.В. Долотовская, А.Г. Сипягина // Рос. кард. журн. - 2001. № 32. - C.7- 34 .

264. Тамбиев А.Х. Некоторые новые представления о причинах формирования стимулирующих эффектов КВЧ-излучения / А.Х. Тамбиев, Н.Н. Кирикова // Биомедицинская радиоэлектроника. - 2000. - №1. - С.23-33.

265. Тенденция развития и схемотехнические решения аппаратуры для КВЧ-терапии / М.Е. Архипов, Я.М. Новицкий, В.Е. Перфильев и др. // Физика волновых процессов и радиотехнические системы.-1999.-№3-4.-С. 56-58.

266. Термины, понятия и подходы к исследованию реологии крови в клинике / Е.В. Ройтман, НН. Фирсов, М.Г. Дементьева и др. // Гемостаз, тромбоз, реология.- 2000.№3. - C.5-12.

267. Типовые реакции клетки на действие альтерирующих факторов. / Н.П. Чеснокова, В.В. Моррисон, Г.Е. Бриль и др. // В кн. Общая патология. - Саратов: Изд-во СарГМУ, 2002. - C. $18-37$.

268. Троицкий В.В. Влияние электромагнитного излучения миллиметрового диапазона на течение острого инфаркта миокарда / В.В. Троицкий // Миллиметровые волны в биологии и медицине: Сб. докладов 10-го Российского симпозиума с международ. участием. - М.: ИРЭ РАН, 1995.- С. 36-38.

269. Тромбоциты в реакциях системы гемостаза на КВЧ-воздействие / В.Ф. Киричук, М.В. Волин, А.П. Креницкий и др. // Изд. Сар.ГМУ. - Саратов, 2002. - 180с. 
270. Тромбоциты/ А.Ш. Бышевский, С.Л. Галян, И.А. Дементьева и др. - Тюмень, 1996. $-250 \mathrm{c}$.

271. Усовершенствование способа измерения вязкости жидкости / М.А. Андрейчин, В.С. Толкачев, А.С. Луцук и др. // Лаб. дело.-1987.-№5.- С. 342-344.

272. Ушаков В.Ю. Эффективность применения электромагнитного излучения миллиметрового диапазона в комплексе лечения больных острым инфарктом миокарда: Автореф. дисс.... докт. мед. наук / В.Ю. Ушаков.- Саратов, 2001.-43c.

273. Ушаков, В.Ю. Немедикаментозная терапия в неотложной кардиологии / В.Ю. Ушаков, Гончарова, Б.В. Брай // Тезисы докладов 4-го Всероссийского съезда терапевтов. - Горький, 1989.-С. 25.

274. Федоров А.С. Модифицированные аппараты серии «Явь» / А.С. Федоров, Л.С. Королев, С.В. Беляков // Миллиметровые волны в биологии и медицине: Сб. докладов. 12-й Российский симпозиум с международ. участием - М.: ИРЭ РАН, 2000. -С. 159163.

275. Физиологические механизмы биологических эффектов низкоинтенсивного ЭМИ КВЧ / Е.Н. Чуян, Н.А. Темурьянц, О.Б. Москвичук и др. - Симферополь, 2003. - 448c.

276. Фирсов Н.Н. Современные проблемы агрегатометрии цельной крови / Н.Н. Фирсов, И.В. Сирко, А.В. Приезжев // Тромбоз, гемостаз и реология.- 2000.-№2. - С.9-11.

277. Флетчер Б.Т. Ответ антикоагулянтных путей при ДВС / Б.Т. Флетчер // Тромбы, кровоточивость и болезни сосудов.- 2002.- № 2.-С. 12-20.

278. Фолков Б. Кровообращение / Б. Фолков, Э. Нил.-М.: «Медицина», 1976.- 164 с.

279. Характер изменений измененных коагуляционных и фибринолитических свойств крови под влиянием терагерцевых волн на частотах оксида азота 150,176-150,664 ГГц / В.Ф. Киричук, А.А. Цымбал, А.П. Креницкий и др. // Материалы 14 Российского симпозиума с международным участием «Миллиметровые волны в медицине и биологии». - Москва. - 2007. - С.124-127.

280. Цымбал А.А. Изменение концентрации кортикостерона - объективного маркера острого и хронического стресса и терагерцевая терапия/ А.А. Цымбал //Аспирантские чтения: Матер. межрегион. конф. посвящ. 150-летию В.И. Разумовского. - Саратов, 2007. - C. $175-176$.

281. Цымбал А.А. Характер изменений нарушенных коагуляционных и фибринолитических свойств крови под влиянием терагерцевых волн на частотах оксида азота 150,176-150,664 ГГц: Автореф. дисс... канд. мед. наук / А.А. Цымбал. Саратов, 2007. - 25 c. 
282. Цюрюпанович В.П. Вязкость крови у практически здоровых лиц и её зависимость от величины гематокритного показателя, содержания эритроцитов и их среднего объёма / В.П. Цюрюпанович // Здравоохранение Казахстана. - 1979.- №10. С.71-72.

283. Чазов Е.И. Руководство по внутренним болезням / Е.И. Чазов. - М.: Медицина, 1997. $-437 \mathrm{c}$.

284. Чернух, А. М. Микроциркуляция / А. М. Чернух, П. Н. Александров, О. В. Алексеев. - М.: Медицина, 1984. - 429 с.

285. Чижевский А.Л. Структурные образования из эритроцитов и движущейся по сосудам крови / А.Л. Чижевский // Бюлл. экспериментальной биологии и медицины. 1951. - №12. - С.443-449.

286. Чуян Е.Н. Изменение процессов микроциркуляции при действии низкоинтенсивного миллиметрового излучения / Е.Н. Чуян, Трибрат Н.С., Раваева М.Ю. // Материалы 15-го Российского симпозиума с международным участием «Миллиметровые волны в медицине и биологии».- Москва. - 2009.- С.92-96.

287. Шабанов В.А. Изменение реологии при артериальной гипертензии / В.А. Шабанов, Г.Я. Левин, Е.В. Терехина // Реологические изменения в медицине.- 1997.-вып.1.-С. 8493.

288. Шахматов И.И. Дизадаптивные реакции системы гемостаза при сочетанных стрессорных воздействиях // И.И. Шахматов, В.И. Киселев // Патофизиология и современная медицина: Материалы 2-й международной конф.- М., 2004.-С.417-419.

289. Шитикова А.С. Тромбоцитарный гемостаз / А.С. Шитикова. - СПб., 2000. - 224 с.

290. Шляхто Е.В. Реологические свойства крови и функция эндотелия у больных гипертонической болезнью / Е.В. Шляхто, О.М. Моисеева, Е.А. Лясникова // Кардиол.-2004.-Т.44, №4.- С. 20-23.

291. Шмид-Шонбейн Г. Клинические аспекты исследований реологических свойств крови / Г. Шмид-Шонбейн // Кардиология.- №6 - 1982.-С.82-85.

292. Экспресс-оценка реологических свойств крови и методы коррекции их нарушений у пациентов с атеросклерозом: Метод. рекоменд. / Н.Г. Кручинский, А.И. Тепляков, В.Н. Гапанович и др.- МЗ РБ, 2000.-27c.

293. Электромагнитное излучение миллиметрового диапазона как метод патогенетической терапии заболеваний сердечно-сосудистой системы / T.В. Головачева, В.Д. Петрова, С.С. Паршина и др. // Миллиметровые волны в биологии и медицине.-2000.-Т.17, №1.- С. 18-25.

294. Эленберг В. Руководство сравнительной физиологии домашних животных / В. Эленберг, А. Шейнерт // М., 1930. - С.539-531. 
295. Эффекты резонансного взаимодействия ММ-волн с водными и биосредами / В.И. Петросян, Н.Д. Девятков, Ю.В. Гуляев, Н.И. Синицын и др. // Миллиметровые волны в медицине и биологии: Сб. докл. 11 Росс. симпозиума с мжд участием. - М., 1997. - С. 139-142.

296. Якунов А.В. Особенности размножения одиночных клеток дрожжей в условиях электромагнитной изоляции / А.В. Якунов // Physics of the Alive. - 1997. - V.5, №1.-P. 55-59.

297. Яшин А.А. Явление стохастического резонанса в биосистемах при воздействии внешнего электромагнитного поля и его роль в регуляции свободной энергии / А.А. Яшин // Physics of the Alive. - 2000. - V. 8, N 2. - P.14-28.

298. Addicks K. Nitric oxide modulates sympathetic neurotransmission at the prejunctional level / K. Addicks, W. Bloch, M. Feelisch // Microsc. Res. Technique. - 1994. - №29. - P. $161-168$.

299. Adey W.R. Bioeffects of mobile communication fields; possible mechanisms for cumulative dose / W.R. Adey // Progress in safety assessments of mobile communications.1996.- P. 104-140.

300. Adnot S. NO in the lung / S. Adnot, B. Raffestin, S. Eddahibi // Respir. Physiology. 1995. - Vol.114, N6.-P.109-120.

301. Ajmani R. S. Haemorheological changes during human aging / R. S. Ajmani, J.M. Rifkind // Gerontology.-1998.-V.44, №2.-P. 111-120.

302. Alexander R.W. Nitric oxide and peroxinitrite / R.W. Alexander // Hypertension. - 1995. - Vol.25. - P.155-161.

303. Antibody responses of mice exposed to low-power microwaves under combined, pulseand-amplitude modulation / B. Veyret, C. Bouthet, P. Deschaux et al. // Bioelectromagnetics. - 1991. - V.12. - P. $47-56$.

304. Armstead W.M. Nitric oxide contributes to opioid release from glia during hypoxia / W.M. Armstead //Brain Res. - 1998. - V.813. - P. 398 - 401.

305. Association of phospholamban with a cGMP kinase signaling complex / A. Koller, J. Schlossmann, K. Ashman et al. // Biochem. Biophys. Res. Commun. - 2003. - V.300. - P. $155-160$.

306. Baker R.F. Assay of red cell membrane deformability with some applications / R.F. Baker, L.J. Clark // Biomed., Biochim. Acta, - 1983. - Vol.42, №11,12 - P.91-96.

307. Basal release of nitric oxide from aortic rings is greater in female rabbits than male rabbits: implications for atherosclerosis / T. Hayashi, J. Fucuto et al. // Proc. Nati. Acad. Sci. USA. - 1992. - Vol.89. - P. 1259-1263. 
308. Becker R.C. The role of blood viscosity in the development and progression of coronary artery disease / R.C. Becker // Cleveland Clin. J. Med.-1993.-V. 60, №5.- P. 353-358.

309. Bennet V. The spectrin-actin junction of erythrocyte membrane skeletons / V. Bennet // Biochim. Biophys. Acta.-1989.-V.32.-P. 107-121.

310. Betskii O.V. Electromagnetic millimeter waves and living organisms / O.V. Betskii // Biological aspects of low intensity millimeter waves.- Moscow, 1994.-P.8-38.

311. Blomback B. Fibrinogen structure, activation, polymerization and fibrin gel structure / B. Blomback // Thromb. Res.-1994.-V.75, №3.-P. 327-328.

312. Branton D. Interaction of cytoskeletal proteins on the human erythrocyte membrane / D. Branton, C.M. Cohen, J. Tyler // Cell.-1981.-V.24, №1.-P. 24-32.

313. Cell membrane permeabilization of human erythrocytes by athermal $2450-\mathrm{MHz}$ microwave radiation / G. Sajin, E. Covacs, R.P. Moraru, T. Savopol, M. Sajin // IEEE Transactions on microwave theory and techniques.- 2000.- Vol. 48, № 11.- P. 2072-2075.

314. Chien S. Blood flow in small tabes. Hand book of physiology. The cardiovascular System. Microcirculation / S. Chien, S. Vsami, R. Skalak // Amor. Physiol. Soc.- 1984.- Vol. 4, №.1.-P.217-249.

315. Chien S. Physiological and pathophysiological significance of hemorheology / S. Chien // Clinical Hemorheology.-Nijhoff.- 1987.-P. 125-164.

316. Cokelet G.R. Decreased hydrodynamic resistance in the two-phase flow of blood through small vertical tubes at low flow rates / G.R. Cokelet, H.L. Goldsmith // Circ Res.- 1991.-V. 68.-P. 1-17.

317. Coronary vasodilatation and improvement in endothelial dysfunction with endothelin ETA receptor blockade / J.P.J. Halcox, K.R.A. Nour, G. Zalos, A.A. Quyumi // Circ. Res. 2001. - V. 89. - P. $969-976$.

318. Cyclic GMP-dependent protein kinases and the cardiovascular system / R. Feil, S.M. Lohmann, H. de Jonge et al. // Circulation research. - 2003. - V. 93. - P. 907-916.

319. Dardelhon M. Determination of a Thermal Equivalent of Millimeter Microwaves in Living Cells / M. Dardelhon, D. Averbeck, A. Berteaud // J. Microwave Power. - 1979. №14. - P. 307-312.

320. Detection of an epitope specific for the dissociated form of glycoprotein IIIa of platelet membrane glycoprotein IIb-IIIa complex and its expression on the surface of adherent platelets / S.G. Khaspekova, T.N. Vlasik, T.V. Bysova et al. // Brit. J. Haematil.-1993.V.85.-P. 332-340.

321. Dintenfass L. Haemorheology of diabetes mellitus / L. Dintenfass // Adv. microcirc.1979.-V.8.- P. 14-36. 
322. Dormandy J.A. Medical and ingineering problems of blood viscosity / J.A. Dormandy // J. Physiol.-1974.-V.9, №7.-P. 284.

323. Effects of erythrocyte aggregation and venous network geometry on red blood cell axial migration / J.J. Bishop, A.S. Popel, M. Intaglietta, P.C. Johnson // Am J Physiol Heart Circ Physiol.-2001.-V. 281.-P.939-950.

324. Effects of low-level millimeter waves on cellular and subcellular systems / S. Matzkin, L. Benes, N. Block et al. // Coherent excitations in biological systems.-Berlin, Heidelberg, Springer-Verlag, 1983.-P.45-57.

325. Endothelium-derived relaxing factor produced and released from artery and vein is nitric oxide / L.G. Ignarro, G.M. Buga, K.S. Wood et al. // Proc. Nat. Acad. Shi. USA. - 1987a. V.84. - P. $9265-9269$.

326. Endotoxin stimulates an endogenous pathway regulating corticotrophin-releasing hormone and vasopressin release involving the generation of nitric oxide and carbon monoxide / I. Kostoglou-Athanassiou, A. Costa, P. Navarra et al. // J. Neuroimmunol. 1998. - V.86. - P. $104-109$.

327. Ernst E. Le fibrinogene comme facteur de risqué cardiovasculaire: une meta-analysa et une revu de la literature / E. Ernst // Energ Sant / Serv. etude med.-1994.-V.5, №1.- P. 151152.

328. Erythrocyte sedimentation rate: possible marker of atherosclerosis and a strong predictor of coronary heart disease mortality / G. Erikssen, K. Liestol, J.V. Bjornholt et al. // Eur. Heart J.-2000.-V. 21, №19.- P. 538-546.

329. Estradiol inhibition smooth muscle cell proliferation of pig coronary artery / R. Vargas, B. Wreblewska, A. Rego et al. // Br. J. Pharmacol. - 1993.- Vol. 109.- P.612-617.

330. Exercise training augments flow-dependent dilation in rat skeletal muscle arterioles. Role of endothelial nitric oxide and prostaglandins / A. Koller, A. Huang, D. Sun, G. Kaley // Circ. Res.- 1995.-V.76.-P. 544-550.

331. Fibrinogen, viscosity and white blood cells count are major risk factors for ischemic heart disease: the Caerphilly and Speedwell Collaborative Heart Disease Studies / J.W.G. Yarnell, I.A. Baker, P.M. Sweetnam et al. // Circulation.-1991.-V.83, №3.-P. 836-844.

332. Frohlich H. Collective behavior of non-linearly couple oscillating fields. With application to biological systems / H. Frohlich // Collective phenomena.- 1979.- Vol. 1.-P.101-109.

333. Frohlich H. Low-range coherence and energy storage in biological systems / H. Frohlich // Int. J. Quantum Chemistry.- 1968.- Vol. 11.- P. 641-649.

334. Frohlich H. The biological effects of microwave and related questions / H. Frohlich // Advances in electronics and electron physics.- 1980.- Vol. 53.- P. 85-110. 
335. Furchgott R.F. Endothelium-dependent and -independent vasodilation involving cyclic GMP: relaxation induced by nitric oxide, carbon monoxide and light / R.F. Furchgott, D. Jothianandan // Blood Vessels. - 1991. - V. 28. - P. 52 - 61.

336. Furchgott R.F. The obligatory role of endothelial cells in the relaxation of arterial smooth muscle by acetylcholine / R.F. Furchgott, J.V. Zawadzki // Nature.- 1980.-V.288.-P. 373376.

337. Gandhi O. Absorption of millimeter waves in humans beings with biological systems / O. Gandhi // URSJ: 21th General Ass.- Italy, 1984.-P.66.

338. Gaspar-Rosas A. Erythrocyte aggregate rheology by transmitted and reflected light / A. Gaspar-Rosas, G.B. Thurston // Biorheology.-1988.-V. 25.-P. 471-487.

339. Golant M.B. Acousto-electric waves in cell membranes of living organisms - a key problem for the understanding of MM-waves interaction with living organisms / M.B. Golant // Biological aspects of low intensity millimeter waves.- Moscow, 1994.- P. 229-249.

340. Goldsmith H.L. Robin Fahraeus: evolution of his concepts in cardiovascular physiology / H.L. Goldsmith, G. Cokelet, P. Gaehtgens // Am J Physiol Heart Circ Physiol.- 1989.-V. 257.-P.1005-1015.

341. Goldstone J. The rheology of red blood cells aggregates / J. Goldstone, M. SchmidSchönbein, R. Wells // Microvasc. Res. - 1970.-V. 2.-P. 273-286.

342. Gründler W. Resonator growth rate responses of yeast cells irradiated by weak microwaves / W. Gründler, F. Keilmann, H. Frohlich // Physical Letters. -1977.- Vol. 62.P.213-222.

343. Gueston A.C. Effect of Hematocrit or venous retirn / A.C. Gueston, T.Q. Richardson // Circulat. Res. - 1961.- Vol. 9.-P.157-163.

344. Halcox J.P.J. Coronary vasodilatation and improvement in endothelial dysfunction with endothelin ETA receptor blockade / J.P.J. Halcox, K.R.A. Nour, G .Zalos // Circ. Res. 2001. - V.89. - P.969- 976.

345. Heating and pain sensation prodused in human skin by millimeter waves: Comparison to a simple thermal model / T.J. Walters, D.W. Blick, L.R. Johnson et al. // Health Phys. 2000.-Vol. 78.-P.259-267.

346. HITRAN partition functions and weighted transition probabilities / A. Goldman, R.R. Gamache, A. Perrin et al. // JQSRT. - 2000. - №66. - P.455-486.

347. Ignarro L.G. Activation of purified soluble guanylate cyclase by arachidonic acid requires absence of enzyme-bound heme / L.G. Ignarro, K.S. Wood // Bichem. Biophys. Acta. - 1987b. - V.928. - P. $160-170$. 
348. Ignarro L.G. Biosynthesis and metabolism of endothelium-derived nitric oxide / L.G. Ignarro // Annu. Rev. Pharmacol. Toxicol. - 1990. - V.30. - P. 535 - 560.

349. Ignarro L.G. Nitric oxide: biochemistry, molecular biology and therapeutic implication / L.G. Ignarro, F. Murad // Adv. Pharmacol. - 1995. - V.34. - P. 1 - 516.

350. Inrapericardial delivery of L-arginine reducer the increased severity of venricular arythmias during sympathetic stimulation on dogs with acute coronary occlusion: nitric oxide modulatessympathetic effect on ventricular elecrophysiological properties / L. Fai, A. Baron, D. Henry et al. // Circulation. - 1997. - Vol.96. - P.4044-4049.

351. Intracellular calcium mobilization is triggered by clustering of membrane glycoprotein in concavalin A-stimulated platelets / G. Ramachi, M. Torti, F. Cinigaglia et al. // J. Cell Biochem.-1993.-V.11.-P.241-249.

352. Kaiser F. Theory of resonant effects of RF and MW energy / F. Kaiser // Biological effects and dosimetry of nonionizing radiation.- London, 1983.- P. 251-282.

353. Keilmann F. Experimental RF and MW resonant nonthermal effects / F. Keilmann // Biological effects and dosimetry of nonionizing radiation.- London, 1983.- P. 283-297.

354. Khurgin $\mathrm{Yu}$. I. The interaction of microwave radiation with simple biomolecular system in aqueous solutions in vitro / Yu. I. Khurgin, V.A. Kudryashova, V.A. Zavizion // Biological aspects of low intensity millimeter waves.- Moscow, 1994. -P.302-336.

355. Kinetic model for erythrocyte aggregation / S.M. Bertoluzzo, A. Bollini, M. Rasia et al. // Blood cells, Molecules, Diseases.-1999.-V. 25, №22. - P. 339-349.

356. Kirichuk V. Antithrombin activity of the vascular wall as an index of atherosclerosis development / V. Kirichuk, L. Yudanova, I. Voskoboy // Thrombosis and Haemostasis.1995.-V.73, №6.-P.1388.

357. Knisely M.H. Intravascular erythrocyte aggregation (blood sludge): Handbook of Physiology, Circulation III / Eds.: W.F. Hamilton, P. Dow.-Baltimore.: Williams, Wilkings, 1965. - P. 2249-2292.

358. Leopold, J.A. New developments in nitrosovasodilator therapy / J.A. Leopold, J. Loscalzo // Vasc. Med.- 1997.-№ 2.-P. 190-202.

359. Leschke M., Strauer B.E. Haemorheologic profile and precursors in myocardial ischemia / Ed.: Armin Th., Maseri A. Predisposing condition of acute ischemic syndromes. Darmstadt: Steinkopff Vergal, 1989.- P. 85-95.

360. Levenson J. Fibrinogen and silent atherosclerosis in subject with cardiovascular risk factors / J. Levenson, P. Giral // Arterioscler. Thromb. Vasc. Biol.-1995. - Vol.15, №9.-P. 1263-1268. 
361. Life-time risk of development coronary heart disease / D.M. Lloyd-Jones, M.S. Larsen,

A. Beiser et al. // Lancet.-1999.-V. 353.-P. 89-92.

362. Lloyd-Jones D.M. The vascular biology of nitric oxide and its role in atherogenesis / D.M. Lloyd-Jones, K.D. Bloch // Annu. Rev. Med.- 1996.-V.47.-P. 365-375.

363. Magnetic flux quantization and Josephson behaviour in living system / E. Del Giudice, S. Doglia, M. Milani et al. // Physica Scripta. - 1989. - V. 40. - P. 786-791.

364. Matsuoka I. Mepacrine-induced elevation of cyclic GMP levels and acceleration of reversal of ADP-induced aggregation in washed rabbit platelets / I. Matsuoka, T. Suzuki // J. Cyclic Nucleotide Protein Phosphor. Res. - 1983. - V.9. - P. 5341 - 5353.

365. Mechanism of vascular smooth muscle relaxation by organic nitrates, nitrites, nitroprusside and nitric oxide: evidence for the involvement of S-nitrosothiols as active intermediates / L.G. Ignarro, H. Lippton, J.C. Edwards et al. // J. Pharmacol. Exp. Ther. 1981. - V.218. - P. $739-749$.

366. Meiselman P. Red blood cell aggregation: current status and future directions / P. Meiselman // Микроциркуляция и гемореология: Матер. 2-й междунар. конф. Ярославль-Москва, 1999.-С. 18-20.

367. Melnik R.L. Effects of millimeter wave irradiation on ATP synthesis and calcium transport in mitochondria / R.L. Melnik, Ch.P. Rubenstein, L. Birenbaum // Radiat. Res.1982.- Vol.89, N.2.-P.348.

368. Merrill E.W. Rheology of blood / E.W. Merrill // Physiol. Rev.- 1969.- Vol.49, № 4.P.863-888.

369. Monitoring of erythrocytes aggregate morphology under flow by computerized image analysis / S. Chen, B. Gavish, S. Zhang et al. // Biorheology.- 1995.- V. 32, №4.- P. 487496.

370. Murad F. Nitric oxide - biogeneration, regulation, and relevance to human diseases / F. Murad // Frontiers in Bioscience. - 2003. - № 8. - P. 264-278.

371. Murphy J.R. The influence of $\mathrm{pH}$ and temperature on some physical properties of normal erythrocytes and erythrocytes from patients with hereditary spherocytosis / J.R. Murphy // J. Lab. Clin. Med. - 1967. - Vol.69, №5. - P.758-775.

372. Naesh O. Platelet activation in mental stress / O. Naesh, C. Haedersdal, J. Hindberg // Clin. Phisiol. - 1993. - V.13. - P. 299 - 307.

373. Nitric oxide as a signaling molecule in the vascular system: an overview / L.G. Ignarro, G. Cirino, A. Casino et al. // J. Cardiovasc Pharmacol. - 1999. - V.34. - P. 979 - 886.

374. Plasma viscosity, fibrinogen and haematocrit in the course of unstable angina / J. Fuchs, A. Pinhas, E. Davidson et al. // Eur. Heart.- 1990.-Vol. 11.- P.1029-1032. 
375. Protein cell levels in ishaemic heart disease / L. Gana-Pathyraman, P. Shanthi, K. BadaKrishnan et al. // Indian Heart J.-1996.-V.48, №2. - P.125-127.

376. Quantitative evaluation of flow dynamics of erythrocytes in microvessels: influence of erythrocyte aggregation / M. Soutani, Y. Suzuki, N. Tateishi, N. Maeda // Am J Physiol Heart Circ Physiol.-1995.-V.268.-P.1959-1965.

377. Ramsohoye P. Influences of silicates and carnitine-silicate mixtures on the inhibition of aggregation of erythrocytes elicited by the presence of fibrinogen / P. Ramsohoye, I.B. Fritz // J. Cell Physiol.-1995.-V.4, №1.-P. 145-154.

378. Red cell aggregation in blood flow / H. Schmid-Sconbein, G. Gallasch, J. Gsoen et al. // Klin. Wschr. - 1976.-Vol. 54.-P.149-152.

379. Reinhart W.H. Albumin affects erythrocyte aggregation and sedimentation / W.H. Reinhart, C. Nagy // Eur. J. Clin. Invest. - 1995.- Vol.25. - P.523-528.

380. Rheology of the circulation / R.Z. Whitmore.- Oxford: Perganon Press, 1968. - 67p. Acute stress affects cytokines and nitric oxide production by alveolar macrophages differently / J.H.A. Persoons, K. Schomagel, J. Breve et al. // Amer. J. Resp. Crit. Care Med. - 1995. - V.153. - P. $619-624$.

381. Role of spatial distribution of electromagnetic radiation absorption in formation of biological effects and morphological changes in skin during microwave radiation / Y. P. Khizhnyak, O.V. Betskii, V.N. Voronkov, Yu.D. Yaremenko // Biological aspects of low intensity millimeter waves.- Moscow, 1994.-P.250-261.

382. Roles of red cell deformability and aggregation in blood viskoelasticity / S. Chien, R.G. King, G.B. Schuessler et al. // Biorheology, AICHE Symposium Series.-1978.-P.56-60.

383. Sakuta S. Determination of deformability index / S. Sakuta, S. Tacamats // Microvasc. Res.-1982.-V.24, №2.-P.215.

384. Salbas K. Effect of acute smoking on the red blood cells deformability in healthy young and elderly non-smokers, and effect of verapamil on age- and acute smoking-induced change in red blood cell deformability / K. Salbas // Scand. J. Clin. Lab. Invest.-1994.-V.54, №6.P. 411-416.

385. Samsel R.W. Kinetics of rouleau formation / R.W. Samsel // Biophys. J. - 1984.-V. 45.-P. 805-824.

386. Schmid -Schonbein H. Rheological properties of human erytrocytes and their influence upon the "anomalous" viscosity of blood / H. Schmid -Schonbein, R.E. Wells // Ergeb. Physiol. Biol. Chem. Exp. Pharmacol. - 1971.-Vol. 63.-P.146-219.

387. Schmid-Schönbein M. Red cell aggregation and cell deformability in diabetes / M. Schmid-Schönbein, E. Volger// Diabetes.-1976.-V.25.-P.897-902. 
388. Shear stress regulates endothelial nitric oxide synthase expression through c-Src by divergent signaling pathways / M.E. Davis, H. Cai, G.R. Drummond, D.G. Harrison // Circ Res.-2001.-V.70.-P. 25-30.

389. Sheludko N.S. Turbiding of myofibril and actomyosin suspension and its change induced by ATP / N.S. Sheludko, I.V. Kropacheva // J. of Colloid and Interface sciences.-1996.V.179.-P.194-200.

390. Short-term exercise training increases ACh-induced relaxation and eNOS protein in porcine pulmonary arteries / L.R. Johnson, J.W. Rush, J.R. Turk et al. // J. Appl. Physiol.2001.-V.90.-P.1102-1110.

391. Skin Heating Effects of Millimeter-Wave Irradiation - Thermal Modeling Results / D.A. Nelson, M.T. Nelson, T.J. Walters, P.A. Mason // IEEE Transactions on microwave theory and techniques.- 2000.- Vol. 48, № 11.- P. 2111-2120.

392. Soloviev A. Nitric oxide but not peroxynitrite relaxes a-toxin permeabilized smooth muscle of rat tail artery / A. Soloviev, P. Hellstrand, A. Stefanov // J. Vasc. Res. - 1997. V. 34 (1). -P. 138.

393. Soloviev A. Nitric oxide decreases myofilament $\mathrm{Ca}^{2+}$-sensitivityi rat tail artery smooth muscle independent of guanylyl cyclase activation / A. Soloviev, P. Hellstrand, A. Stefanov // J. Vasc. Res. -1996. -V. 33 (2). -P. 43.

394. Starzik D. Effects of nitric oxide and prostocycline on deformability and aggregability of red blood cells of rats ex vivo and in vitro / D. Starzik // J. Physiol. Pharmacol.-1999.-T. 50.P. 629-637.

395. Sternberg E.M. Overview of neuroimmune stress interaction / E.M. Sternberg // Ann. N.Y. Acad. sci. -1995. - Vol. 771. - P. 364-371.

396. Stolz J.F. Jntroduction a l'etude de e'agregation erythrocytaire / J.F. Stolz, M. Donner // Arteres et veines. - 1986.-Vol. 4.-P.213-223.

397. Stolz J.F. Main determinans of red blood cell deformability. Clinical and pharmacological applications / J.F. Stolz // Clin Hemorheol. - 1985.- Vol. 2, № 1.-P.163173.

398. Stolz J.F. New trends in clinical hemorheology: an introduction to the concept of the hemorheology profile / J.F. Stolz, M. Donner // Schweiz. Med. Wochenschr. Suppl.- 1999.V.43.-P.41-49.

399. Stolz J.F. Red blood cell agregation: measurements and clinical application / J.F. Stolz, M. Donner // Turk. J. Med. Sciences. - 1991.-Vol.15, № 1.-P.26-30.

400. Stolz J.F. Role de l'agregation arythrocytaire on hemorheologie clinique / J.F. Stolz // Arteres et Veines. - 1987. - V.6, № 4.-P.311-314. 
401. Takeda H. Stress-induced gastric mucosal lesion and platelet aggregation in rats / $\mathrm{H}$. Takeda // J. Clin. Gastroenterol. - 1992. - V.14. - P. 145 - 148.

402. Taylor L.S. Brain cancer therapy using an implanted microwave radiation / L.S Taylor // Microwave J. - 1981.- Vol.24 - P.6-68.

403. The HITRAN molecular spectroscopic database: edition of 2000 including updates through 2001 / L.S. Rothman, A. Barbe, D. Chris Benner et al. // Journal of Quantitative Spectroscopy \& Radiative Transfer. - 2003. - № 82. - P. 5 - 44.

404. Training induces nonuniform increases in eNOS content along the coronary arterial tree / M.H. Laughlin, J.S. Pollock, J.F. Amann, M.L. Hollis et al // J Appl Physiol.-2001.-V. 90.-P. 501-510.

405. Tuengler P. Search for millimeter microwave effects on enzyme or protein function / P.

Tuengler, F. Keilmann, L. Gensel // Z. natirforsch, Sect. C.- 1979.-Vol. 34, №1-2.-P.60-64.

406. Vanhoutte P.M. Other endothelium - derived vasoactive factors / P.M. Vanhoutte // Circulation. - 1993. - Suppl. V: V9. - V.17.

407. Voskoboy I.V. Platelet aggregation in patient with unstable angina by influence of some lectins / I.V. Voskoboy, V.F. Kirichuk // Haemostasis.- 2000.-V.30, №1.-P. 79.

408. Wannamethee G. Usehemic heart discase: association with Haematocrit in the British Regional Heart Study / G. Wannamethee, A.G. Shaper, P.H. Whincup // J. Epidemiol. Community Health. - 1994.-Vol.48.-P.112-118.

409. Webb S.J. Coherent in biological system / S.J. Webb // Rpys. Rep. - 1980. - Vol.60.- 201 p.

410. Webb S.J. Microwave absorption by normal and tumor cells / S.J. Webb, A.D. Booth // Science. - 1971.- Vol. 174. - P.72-74.

411. Whitmore R.Z. Rheology of the circulation / R.Z. Whitmore.- Oxford: Perganon Press, 1968. - 67p. 


\section{РАЗДЕЛ IV}

\section{ЗАКОНОМЕРНОСТИ И МЕХАНИЗМЫ}

БИОЛОГИЧЕСКОГО ДЕЙСТВИЯ

\section{ЭЛЕКТРОМАГНИТНЫХ ВОЛН ТЕРАГЕРЦЕВОГО \\ ДИАПАЗОНА}

НА ЧАСТОТАХ АКТИВНЫХ КЛЕТОЧНЫХ

МЕТАБОЛИТОВ

НА ПОСТСТРЕССОРНЫЕ ИЗМЕНЕНИЯ

ПОКАЗАТЕЛЕЙ ГОМЕОСТАЗА 


\section{СПИСОК СОКРАЩЕНИЙ}

АЛТ - аланинаминотрансфераза

ACT - аспартатаминотрансфераза

АЧТВ - активированное частичное тромбопластиновое время

ИК - инфракрасный

КВЧ - крайне высокие частоты

ЛДГ - лактатдегидрогеназа

МНО - международное нормализованное отношение

МСИП - молекулярный спектр излучения и поглощения

РФМК - растворимые фибрин-мономерные комплексы

$\mathrm{T}_{3}-$ трийодтиронин

$\mathrm{T}_{4}-$ тетрайодтиронин (тироксин)

ТГ - тиреоглобулин

ТГЧ - терагерцевые частоты

Т-лучи - терагерцевые лучи (волны)

ТТГ - тиреотропный гормон гипофиза

ЭМИ - электромагнитное излучение

ADMA- ассиметричный диметиларгинин

ЕТ-1- эндотелин-1

ecNOS - эндотелиальная конститутивная синтаза оксида азота

$\mathrm{NO}$ - оксид азота

NOS - синтаза оксида азота 


\section{ВВЕДЕНИЕ}

Развитие радиоэлектроники за последние годы, ее внедрение во все области науки, техники, в быт является неотъемлемой стороной человеческой цивилизации. С каждым годом возрастают уровни мощности электромагнитного излучения, создаваемые всевозможными искусственными источниками, такими как теле- и радиопередающие центры, гражданские и военные радиолокационные установки, различные системы радиосвязи, в том числе системы сотовой и спутниковой связи, различные электробытовые приборы (микроволновые печи, телевизоры, компьютеры, холодильники, кондиционеры и т.д.), а также технологические установки в промышленности [Бецкий, Козьмин, Яременко; 2008, с. 48-54; Шеин, Марковская, 2010, с. 5-26; Федоров, 2011, с. 517; Hosako, Fukunaga, 2011, p. 722-731].

Живые организмы окружены электромагнитными полями естественных источников излучения, прежде всего космического, и миллионы лет в процессе эволюции успели к ним адаптироваться [Бецкий, Козьмин, Яременко; 2008, с. 48-54]. Искусственно созданные электромагнитные поля являются новым фактором окружающей среды, и пока не вполне понятно, какое именно действие они оказывают на процессы метаболизма, протекающие в биологических системах [Терагерцовые волны ... , 2005, с. 40-48; Киричук, 2007, с. 98-126; Родштат, 2008, с. 19-24; Terahertz generation ... , 2011, p. 426-433; Xiaofei, Zhang, 2011, p. 562-569; Emission of Terahertz ... , 2011, p. 629-645]. Пока отсутствует однозначный ответ на вопрос о механизме этого действия. И это ставит много задач, на которые ученые обратили внимание сразу после появления мощных источников радиоизлучений.

Одной из актуальных проблем физиологии является изучение закономерностей взаимоотношений организма с окружающей средой. Большинство абиотических факторов внешней среды, играющих важную роль в процессах жизнедеятельности человека, имеют электромагнитную природу [Бецкий, Козьмин, Яременко, 2008, с. 48-54]. В частности, именно электромагнитные излучения используются как носители разнообразной информации в биосфере.

Терагерцевый диапазон частот лежит на границе между электроникой и фотоникой от 100 ГГц до 10 ТГц или в длинах волн от 3 мм до $30 \mu$ м. [Гершензон, Малов, Мансуров, 2000, 272 с.]. Установлено, что рассматриваемый диапазон электромагнитных волн используется живыми организмами для связи и управления, при этом сами живые организмы излучают колебания миллиметрового диапазона [Информационные взаимодействия ... , 2001, с. 1042-1050]. Волны, возбуждаемые в организме при воздействии на него терагерцовым облучением, в известной мере имитируют сигналы 
внутренней связи и управления (информационные связи) биологических объектов. В результате восстанавливается нормальное по спектру и мощности излучение, свойственное здоровому организму [Информационные взаимодействия ..., , 2001, с. 10421050].

Есть мнение, что реакционная способность молекул, возбужденных терагерцовым квантом, будет на порядок выше, чем при возбуждении КВЧ-квантом [Биофизические эффекты ..., 2003, с. 3-6]. К особенностям терагерцовых волн относится также и то, что ТГЧ-излучение свободно проникает сквозь одежду и кожу до мышц человека [Конако, Фэйтс, 2002, 102 с.].

Терагерцевый диапазон частот все больше привлекает к себе внимание специалистов, занимающихся не только радиоэлектроникой, но и биомедицинскими технологиями. Это, прежде всего, связано с эффектами, проявляющимися при взаимодействии излучения именно этого диапазона с биологическими средами, а также с тем, что именно в нём, сосредоточены частотные молекулярные спектры излучения и поглощения важнейших клеточных метаболитов $\left(\mathrm{NO}, \mathrm{O}_{2}, \mathrm{CO}_{2}, \mathrm{CO}, \mathrm{OH}-\right.$ и др.) [Бецкий, Козьмин, Яременко, 2008, с. 48-54; The HITRAN molecular ... , 2003, p. 5-44; Emission of Terahertz ..., 2011, p. 629-645].

Фундаментальной основой функционирования сложных биологических систем являются молекулы-метаболиты, стабильные и строго воспроизводимые молекулярные структуры биосреды. Поэтому детерминированное управление их реакционной способностью излучением, совпадающим по спектрам их излучения и поглощения, может направленно регулировать процесс метаболизма в биосреде. Анализ биомедицинских эффектов электромагнитного излучения на частотах молекулярных спектров атмосферных газов-метаболитов показывает прямую связь спектров заданного метаболита и его свойств в биосреде. Это соответствует представлениям о веществе и поле как о единой системе [Панарамно-спектрометрический ..., 2001, с. 35-37].

Биофизические эффекты волн терагерцевого диапазона дают основания и открывают перспективы развития новых направлений в биомедицинской технологии: «терагерцевая терапия» и «терагерцевая диагностика» [Биофизические эффекты ..., 2003, c. 3-6].

Совершенно закономерно, что наибольший интерес вызывают электромагнитные волны молекулярного спектра излучения и поглощения активных клеточных метаболитов (NO, $\mathrm{O}_{2}$ и др.). Оксид азота является одним из важнейших биологических медиаторов, вовлеченных во множество физиологических и патофизиологических процессов. Он представляет собой уникальный по своей природе и механизмам действия вторичный 
мессенджер в большинстве клеток организма [Голиков, 2004, 180 с.; Ignarro, Murad, 1995, p. 1-516; The protective ..., 2012, p. 171-178].

В экспериментальных работах по изучению влияния терагерцевого облучения на частотах оксида азота 150,176-150,664 ГГц обнаружено, что оно частично или полностью нормализует постстрессовые изменения во внутрисосудистом компоненте микроциркуляции за счет восстановления количественного и качественного состава эритроцитов [Влияние электромагнитного ..., 2004, с. 21-27]. Также установлено, что в условиях эксперимента in vivo воздействие ТГЧ-облучения на частотах МСИП оксида азота 150,176-150,664 ГГц в течение 30 минут на животных, находящихся в состоянии острого иммобилизационного стресса, вызывает восстановление измененной функциональной активности тромбоцитов [Влияние КВЧ-NO ..., 2005, с. 64-70].

Определенный интерес в настоящее время вызывают также терагерцевые волны на частоте 129,0 ГГц, соответствующей спектру излучения и поглощения атмосферного кислорода [Бецкий, Козьмин, Яременко, 2008, с. 48-54]. Поскольку недостаток кислорода в органах и тканях ведет к нарушению окислительных процессов, изменяя нормальное функционирование и жизнедеятельность всего организма в целом, обусловливая гипоксию и ишемию [Влияние ЭМИ ТГЧ ..., 2008, с. 40-48].

Показано влияние ЭМИ на частоте атмосферного кислорода 129,0 ГГц на функциональную активность тромбоцитов белых крыс в состоянии иммобилизационного стресса. Выявлено, что под воздействием ТГЧ-облучения 129,0 ГГц в течение 5 минут уже происходит нормализация нарушенной функциональной активности тромбоцитов белых крыс на фоне иммобилизационного стресса [Влияние ЭМИ ТГЧ ..., 2008, с. 40-48].

В отдельных экспериментальных работах указывается возможность изменения активности стресс-реализующих систем электромагнитными волнами терагерцевого диапазона [Изменения концентрации ... , 2008, с. 1285-1290], однако отсутствуют исследования, доказывающие возможность использования терагерцевых волн на частотах активных клеточных метаболитов в качестве метода физиологической неинвазивной регуляции ряда важнейших функций организма. Все вышеизложенное дало основание для проведения настоящего исследования.

\section{ЦЕЛЬ ИССЛЕДОВАНИЯ}

Установить закономерности биологического действия электромагнитных волн терагерцевого диапазона на частотах активных клеточных метаболитов на измененные параметры гомеостаза у экспериментальных животных при различных моделях стресса. 


\section{ГЛАВА ХІІ}

\section{ИЗМЕНЕНИЕ ГИПОФИЗАРНО-ТИРЕОИДНОЙ АКТИВНОСТИ У}

СТРЕССИРОВАННЫХ КРЫС-САМЦОВ ПОД ВЛИЯНИЕМ

\section{ЭЛЕКТРОМАГНИТНЫХ ВОЛН ТЕРАГЕРЦЕВОГО ДИАПАЗОНА НА ЧАСТОТАХ АКТИВНЫХ КЛЕТОЧНЫХ МЕТАБОЛИТОВ}

В системе эндокринных желез гипофиз занимает центральное положение [Киричук, 1994, 64 с.]. Для щитовидной железы гипоталамо-гипофизарная регуляция является ведущей [Акмаев, 1999, с. 3-8].

Известно, что определенную роль в регуляции продукции ТТГ гипофизом играют дофамин, соматостатин, катехоламины [Городецкая, 2000, с. 519-520], а так же стрессреализующие гормоны, в частности, кортизол [Городецкая, 2000, с. 519-520].

Таким образом, можно сделать вывод о том, что уровень ТТГ является одним из наиболее значимых маркеров тиреоидной недостаточности и его концентрация может изменяться в ходе развития стресс-реакции за счет изменения баланса стрессреализующих гормонов.

В ходе выполнения диссертационного исследования обнаружено, что у интактных животных концентрация ТТГ гипофиза составляла 0,62 мМЕ/л, у иммобилизированных животных в условиях острого эксперимента она возрастала до 1,20 мМЕ/л и до 1,25 мМЕ/л - в условиях длительного стресса.

Щитовидная железа и система регуляции ее функциональной активности обладают высокой чувствительностью к многообразным и разнородным воздействиям, в том числе к стрессорным [Пальчикова, 2004, 200 с.]. В ответ на химические, физические или стрессорные (психо-эмоциональные) раздражения отмечаются изменения в гормонообразовательной активности железы [Пальчикова, 2004, 200 с.].

По мнению многих авторов, исследовавших гормональную активность щитовидной железы в условиях стрессирования, гипофизарно-тиреоидная система вовлекается в реакцию стресса уже на ранних стадиях и играет важную роль в общей реактивности организма на действие внешних факторов [Городецкая И.В., 2000, с. 519-520; Пальчикова, 2004, 200 c.].

Как показывают полученные в диссертационной работе результаты, имеются изменения синтетической и секреторной активности щитовидной железы. У крыс, находящихся в состоянии острого иммобилизационного стресса, наблюдалось угнетение функциональной активности щитовидной железы, что проявлялось в статистически достоверном снижении концентрации как свободных, так и связанных форм тироксина и 
трийодтиронина. Снижалось значение отношения $\mathrm{T}_{3} / \mathrm{T}_{4}$, статистически достоверно уменьшалась концентрация тиреоглобулина.

На фоне указанных изменений происходило статистически значимое увеличение концентрации тиреотропного гормона гипофиза.

Для более детального исследования функциональных перестроек щитовидной железы в условиях иммобилизационного стресса и исключения аутоиммунной патологии, была проведена серия экспериментов по изучению динамики концентраций в крови антител к тиреопероксидазе и тиреоглобулину.

В нашей диссертационной работе обнаружено, что в условиях острого стресса уровень антител к тиреопероксидазе и тиреоглобулину имел лишь тенденцию к незначительному повышению, однако не был статистически значим.

Воздействие терагерцевым облучением на частотах молекулярного спектра излучения и поглощения оксида азота 150,176-150,664 ГГц в течение 5 минут на животных, находящихся в состоянии острого иммобилизационного стресса, не вызывает статистически значимых изменений всех исследуемых показателей гипофизарнотиреоидной активности.

Показано, что при воздействии на крыс-самцов на фоне острого стресса электромагнитными волнами терагерцевого диапазона на частотах оксида азота в течение 15 минут наблюдается частичная нормализация гипофизарно-тиреоидной активности. Так, статистически достоверно восстанавливается концентрация свободного трийодтиронина, однако все другие исследуемые показатели функциональной активности гипофиза и щитовидной железы статистически достоверно отличаются от данных группы контроля.

При воздействии на животных при остром стрессе терагерцевым облучением на частотах молекулярного спектра излучения и поглощения оксида азота 150,176-150,664 ГГц в течение 30 минут отмечается полное восстановление измененной функциональной активности щитовидной железы. При этом концентрация как свободных, так и связанных фракций тироксина и трийодтиронина, уровень тиреоглобулина, отношение $\mathrm{T}_{3} / \mathrm{T}_{4}$ и активность ТТГ гипофиза полностью нормализовались и статистически достоверно не отличались от данных группы контроля.

Обнаружено, что у крыс, находящихся в состоянии длительного (хронического) иммобилизационного стресса, наблюдалось статистически достоверное угнетение функциональной активности щитовидной железы, что проявлялось в снижении концентрации как свободных, так и связанных форм тироксина и трийодтиронина. Снижалось значение отношения $\mathrm{T}_{3} / \mathrm{T}_{4}$. 
Уменьшение отношения $\mathrm{T}_{3} / \mathrm{T}_{4}$ в железе при длительном иммобилизационном стрессе указывает на снижение интенсивности процессов образования в ней трийодтиронина. Подобные изменения могут быть обусловлены тем, что при иммобилизационном стрессе в крови изменяется содержание тиреотропного гормона, а под его влиянием в щитовидной железе модулируется процесс дейодирования $\mathrm{T}_{4}$ в $\mathrm{T}_{3}$ [Пальчикова, 2004, 200 с.].

У длительно иммобилизированных крыс-самцов статистически достоверно уменьшалась концентрация тиреоглобулина. Снижение уровня тиреоглобулина в щитовидной железе, в свою очередь, может служить одной из причин замедления синтеза гормонов при стрессе, поскольку известно, что тиреоглобулин регулирует активность белка, облегчающего процесс выхода йода из фолликулярной клетки в просвет фолликула [Красноперов, Глумова, Трусов, 1992, с. 38-41].

У крыс, находящихся в состоянии длительного иммобилизационного стресса, наблюдалось более выраженное, чем при остром стрессе, статистически достоверное угнетение функциональной активности щитовидной железы, что проявлялось в снижении концентрации как свободных, так и связанных форм тироксина и трийодтиронина. Снижалось значение отношения $\mathrm{T}_{3} / \mathrm{T}_{4}$.

При ежедневном в течение 5 дней воздействии на белых крыс-самцов на фоне длительной иммобилизации электромагнитными волнами терагерцового диапазона на частотах оксида азота 150,176-150,664 ГГц по 5 минут не зафиксировано нормализации измененных показателей функциональной активности щитовидной железы. Об этом свидетельствует отсутствие статистически достоверных различий основных изучаемых параметров, характеризующих функции щитовидной железы, данной группы по сравнению с данными группы животных, находящихся в состоянии длительного стресса. Так, концентрация ТТГ гипофиза после ежедневного в течение 5 дней облучения терагерцевыми волнами по 5 минут статистически достоверно не изменилась и составила 1,19 мМЕ/л. Не восстанавливались также концентрации свободных и связанных форм трийодтиронина и тироксина, а, следовательно, отношение $\mathrm{T}_{3} / \mathrm{T}_{4}$ статистически значимо отличалось от аналогичного у интактных животных. Концентрация тиреоглобулина на фоне ежедневного в течение 5 дней воздействия терагерцевыми волнами на частотах оксида азота 150,176-150,664 ГГц по 5 минут статистически значимо не изменялась и составила $0,62 \mathrm{нг/л.}$

Показано, что при ежедневном в течение 5 дней воздействии терагерцевыми волнами на указанном диапазоне частот по 15 минут на животных на фоне длительного стресса наблюдается частичная нормализация функциональной активности щитовидной 
железы. Обнаружено, что при данном режиме воздействия наблюдается полное статистически достоверное восстановление концентрации тиреоглобулина, однако все другие исследуемые показатели активности щитовидной железы статистически достоверно отличались от данных группы контроля.

При ежедневном в течение 5 дней воздействии терагерцевым облучением на частотах МСИП оксида азота 150,176-150,664 ГГц по 30 минут на экспериментальных животных, находящихся в состоянии длительной иммобилизации, обнаружено полное восстановление нарушенной функциональной активности щитовидной железы. При этом концентрация как свободных, так и связанных фракций тироксина и трийодтиронина, концентрация тиреоглобулина, отношение $\mathrm{T}_{3} / \mathrm{T}_{4}$ и активность тиреотропного гормона гипофиза полностью нормализовались и статистически достоверно не отличались от данных группы контроля.

Таким образом, 30-минутное облучение крыс-самцов терагерцевыми волнами на частотах МСИП оксида азота 150,176-150,664 ГГц при остром и длительном стрессах является наиболее эффективным режимом в нормализации гипофизарно-тиреоидной активности у экспериментальных животных.

\section{ГЛАВА ХIII}

\section{СТРЕСС-ЛИМИТИРУЮЩЕЕ ДЕЙСТВИЕ ЭЛЕКТРОМАГНИТНЫХ ВОЛН ТЕРАГЕРЦЕВОГО ДИАПАЗОНА}

\section{1. Влияние электромагнитных волн терагерцевого диапазона на частоте} молекулярного спектра атмосферного кислорода 129,0 ГГц на концентрацию кортикостерона - маркера стресс-реакции

Для оценки способности электромагнитных волн терагерцового диапазона на частоте молекулярного спектра излучения и поглощения атмосферного кислорода 129,0 ГГц ограничивать (модулировать) течение стресс-реакции была проведена серия экспериментов, в которых изучалась динамика концентраций маркера стресс-реакции кортикостерона у облученных белых крыс-самцов на фоне острого и длительного иммобилизационного стресса.

В результате проведенных экспериментов нами обнаружено, что концентрация кортикостерона у интактных животных составила 62,2 нмоль/л. Показано, что у крыс, находящихся в состоянии острого и длительного иммобилизационного стрессов, 
повышалась функциональная активность коры надпочечников. Это сопровождалось статистически достоверным по сравнению с группой контроля увеличением концентрации кортикостерона в сыворотке крови. Так, в условиях острого стресса она возрастает практически в 2,5 раза до 175,0 нмоль/л, в условиях длительного стресса - в 3,5 раза до 200,0 нмоль/л.

Воздействие терагерцевыми волнами на частоте молекулярного спектра излучения и поглощения атмосферного кислорода 129,0 ГГц в течение 5 минут на фоне острого стресса приводило к статистически достоверному снижению концентрации кортикостерона в крови до уровня 102,0 нмоль/л. Однако до показателей интактных животных концентрация стресс-реализующего гормона- кортикостерона не снижалась, о чем свидетельствует наличие статистически достоверных отличий между интактными и облученными в течение 5 минут животными.

Применение электромагнитных волн терагерцевого диапазона на частоте молекулярного спектра атмосферного кислорода 129,0 ГГц в течение 15 минут при остром стрессе сопровождается полной статистически достоверной нормализацией уровня кортикостерона в сыворотке крови у экспериментальных животных. Так, концентрация изучаемого гормона после облучения снизилась более чем в 2 раза и составила 71,1 нмоль/л.

Результаты экспериментов на животных, которые на фоне острой иммобилизации подвергались 30-минутному воздействию терагерцевым облучением на частоте МСИП атмосферного кислорода 129,0 ГГц, свидетельствуют о статистически достоверном восстановлении концентрации кортикостерона до уровня 68,3 нмоль/л. При анализе полученных результатов обнаружено отсутствие статистически достоверных различий в концентрациях изучаемого гормона у животных данной группы и интактных белых крыссамцов.

На фоне длительного иммобилизационного стресса ежедневное в течение 5 дней применение терагерцевых волн на частоте молекулярного спектра излучения и поглощения атмосферного кислорода 129,0 ГГц по 5 минут не приводило к статистически достоверным изменениям концентрации в сыворотке крови глюкокортикоидов, в частности, кортикостерона. Об этом свидетельствуют статистически достоверные различия в изучаемом показателе по сравнению с данными группы контроля. Так, концентрация кортикостерона после облучения составила 212,9 нмоль/л.

Ежедневное в течение 5 дней воздействие терагерцевыми волнами на частоте атмосферного кислорода 129,0 ГГц по 15 минут на фоне длительной иммобилизации 
приводит лишь к частичному восстановлению измененной концентрации кортикостерона. После облучения уровень изучаемого гормона снизился до 141,7 нмоль/л, однако сохранялись статистически достоверные отличия между интактными и облученными в течение 15 минут животными.

Применение электромагнитных волн терагерцевого диапазона на частоте атмосферного кислорода 129,0 ГГц ежедневно в течение 5 дней по 30 минут на фоне длительной иммобилизации сопровождается полной нормализацией, измененной в ходе развития длительной стресс-реакции, концентрации кортикостерона, что подтверждается отсутствием статистически достоверных различий в изучаемом показателе по сравнению с интактными животными. При данном временном режиме облучения уровень кортикостерона составил 73,0 нмоль/л.

Таким образом, обнаружено нормализующее влияние электромагнитных волн терагерцевого диапазона на частоте МСИП атмосферного кислорода 129,0 ГГц на измененную при стрессе концентрацию кортикостерона в крови у крыс-самцов. Наиболее эффективными оказались, облучение в течение 15 минут на фоне острого стресса и ежедневное воздействие в течение 5 дней по 30 минут на фоне длительной иммобилизации животных.

13.2. Изменения концентрации кортикостерона у экспериментальных животных при облучении их терагерцевыми волнами на частоте атмосферного кислорода 129,0 ГГц на фоне введения неселективного ингибитора конститутивных изоформ NO-синтаз

Для раскрытия некоторых механизмов действия электромагнитных волн терагерцового диапазона на частоте МСИП атмосферного кислорода 129,0 ГГц, заключающихся в нормализации измененной концентрации кортикостерона в крови при остром стрессе, применяли конкурентный неселективный ингибитор конститутивных изоформ NO-синтаз L-NAME - метиловый эфир $\mathrm{N}^{\mathrm{G}}$-нитро-L-аргинина (Sigma, CШA), который предварительно вводился внутримышечно в дозе 25 мг/кг [Голиков, 2004, 180 с.].

Облучение животных терагерцовыми волнами на частоте молекулярного спектра излучения и поглощения атмосферного кислорода 129,0 ГГц в течение 5 минут на фоне предварительного введения неселективного ингибитора конститутивных изоформ NOсинтаз - L-NAME при остром стрессе не приводило к нормализации измененной в ходе развития стресс-реакции концентрации кортикостерона. Так в условиях острого иммобилизационного стресса уровень кортикостерона составлял 175,0 нмоль/л, а после облучения на фоне L-NAME - 181,3 нмоль/л, то есть не произошло статистически 
значимых изменений в концентрациях изучаемого гормона пучковой зоны коры надпочечников.

При воздействии на крыс-самцов электромагнитными волнами терагерцового диапазона на частоте молекулярного спектра излучения и поглощения атмосферного кислорода 129,0 ГГц в течение 15 минут на фоне предварительного введения неселективного ингибитора конститутивных изоформ NO-синтаз - L-NAME концентрация кортикостерона не изменялась по сравнению с иммобилизированными животными и составила 166,6 нмоль/л.

Облучение стрессированных животных электромагнитным излучением терагерцового диапазона на частоте атмосферного кислорода 129,0 ГГц в течение 30-ти минут на фоне предварительного введения неселективного ингибитора конститутивных изоформ NO-синтаз также не приводило к восстановлению измененной концентрации кортикостерона в сыворотке крови, о чем свидетельствуют статистически достоверные различия в концентрациях изучаемого гормона у животных группы контроля и группы, подвергнутой облучению на фоне предварительного введения L-NAME.

Таким образом, предварительное введение стрессированным животным неселективного ингибитора конститутивных изоформ NO-синтаз - L-NAME эффективно блокирует стресс-лимитирующий эффект терагерцового излучения на частоте атмосферного кислорода 129,0 ГГц. Это проявляется у облученных животных в сохранении высоких концентраций кортикостерона сопоставимых с уровнем стрессированных животных.

Отсутствие статистически значимых изменений концентрации кортикостерона у облученных животных, предварительно получавших L-NAME, указывает на роль конститутивных изоформ NO-синтаз в механизмах положительного корригирующего влияния электромагнитных волн терагерцового диапазона на частоте молекулярного спектра излучения и поглощения атмосферного кислорода 129,0 ГГц.

\section{ГЛАВА ХIV}

ЭЛЕКТРОМАГНИТНЫЕ ВОЛНЫ ТЕРАГЕРЦЕВОГО ДИАПАЗОНА НА ЧАСТОТЕ АТМОСФЕРНОГО КИСЛОРОДА 129,0 ГГЦ В НОРМАЛИЗАЦИИ ИЗМЕНЕННЫХ ПОКАЗАТЕЛЕЙ СИСТЕМЫ ГЕМОСТАЗА И ФИБРИНОЛИЗА У ЭКСПЕРИМЕНТАЛЬНЫХ ЖИВОТНЫХ

Результаты проведенного исследования свидетельствуют о том, что у животных, находящихся в состоянии острого иммобилизационного стресса, выявлены значительные 
гиперкоагуляционные изменения, проявляющиеся сокращением АЧТВ, протромбинового времени, снижением МНО; одновременной активацией III фазы гемокоагуляции, так как тромбиновое время имело четкую тенденцию к укорочению, а концентрация фибриногена и активность фактора XIII повышены. Вместе с этим падала антикоагулянтная активность крови. Так, активность протеина С у крыс в состоянии острого стресса снижалась с 0,87 усл.ед. до 0,54 усл.ед.

У крыс-самцов, подвергшихся острой иммобилизации, зафиксировано угнетение фибринолитической активности крови, что проявляется в удлинении времени лизиса эуглобулинового сгустка с 14 минут до 24,0 минут, а также времени индуцированного стрептокиназой эуглобулинового фибринолиза со 130,0 секунд до 180,0 секунд. Индекс резерва плазминогена статистически достоверно снизился с 70,1% до 50,5 \%.

В ходе развития острой стресс-реакции у экспериментальных животных не обнаружено статистически достоверных изменений в концентрациях Д-димеров, растворимых фибрин-мономерных комплексов и продуктов деградации фибриногена.

Воздействие терагерцевого облучения на частоте МСИП атмосферного кислорода 129,0 ГГц в течение 5 минут на животных, находящихся в состоянии острого иммобилизационного стресса, не вызывало значительного изменения нарушенных показателей гемостаза и фибринолиза, что подтверждается отсутствием статистически достоверных различий в показателях, характеризующих коагуляционный каскад и фибринолиз, по сравнению с животными, находящимися в состоянии стресса. Однако имеется статистически достоверная разница в показателях коагуляционного звена системы гемостаза и фибринолитической активности крови по сравнению с интактными животными.

Выявлено, что при воздействии на животных на фоне острого стресса электромагнитными волнами указанного диапазона в течение 15 минут, наблюдается частичная нормализация показателей, характеризующих коагуляционный каскад и фибринолиз, так как полностью восстанавливались и статистически достоверно не отличались от группы интактных животных активированное частичное тромбопластиновое время, тромбиновое время. Однако все остальные показатели гемостаза статистически достоверно отличались от данных интактных животных.

Облучение животных терагерцевыми волнами на частоте 129,0 ГГц в течение 30 минут вызывает полную нормализацию процессов гемокоагуляции и фибринолиза, так как все изучаемые показатели коагуляционного звена системы гемостаза и фибринолиза статистически достоверно не отличались от данных интактных животных. 
При исследовании коагуляционного звена системы гемостаза и фибринолитического потенциала крови у длительно иммобилизированных крыс выявлены статистически достоверные, по сравнению с группой контроля, значительные изменения: удлинение активированного частичного тромбопластинового времени, увеличение протромбинового времени и МНО, что свидетельствует о развившемся дефиците кровяной и тканевой протромбиназы; одновременно снижена активность III фазы коагуляционного каскада, так как тромбиновое время имело четкую тенденцию к удлинению, что обусловлено гипофибриногенемией и избыточным накоплением в плазме продуктов деградации фибрина, обладающих антитромбиновым действием. Происходило снижение активности фибринстабилизирующего фактора.

Длительный иммобилизационный стресс у крыс-самцов сопровождался статистически достоверными изменениями показателей антикоагулянтной и фибринолитической активности крови. Так, происходило падение уровня протеина С до 0,42 усл. ед. Хагеман-зависимый фибринолиз активировался, что сопровождалось укорочением времени эуглобулинового лизиса с 14 мин. до 11 мин., также ускорялся индуцированный стрептокиназой эуглобулиновый фибринолиз со 130 секунд до 120 секунд, при этом возрастал индекс резерва плазминогена до 72,8 \%.

При длительном иммобилизационном стрессе у крыс-самцов обнаружено статистически достоверное увеличение количества Д-димеров до 0,5 мг/л, ранних продуктов деградации фибриногена и растворимых фибрин-мономерных комплексов, характерных для внутрисосудистого тромбообразования.

При ежедневном в течение 5 дней воздействии терагерцевым облучением на указанных частотах по 5 минут на животных, находящихся в состоянии длительного стресса, не наблюдается статистически достоверных изменений изучаемых показателей коагуляционного звена гемостаза и фибринолиза.

Ежедневное в течение 5 дней облучение длительно стрессированных белых крыс по 15 минут электромагнитными волнами терагерцевого диапазона молекулярного спектра атмосферного кислорода 129,0 ГГц приводило к частичному восстановлению измененных показателей коагуляционного звена системы гемостаза, антикоагулянтной активности крови и ее фибринолитических свойств. Полностью восстановились и статистически достоверно не отличались от группы интактных животных АЧТВ, протромбиновое время и индуцированный стрептокиназой эуглобулиновый фибринолиз. Однако все остальные изучаемые показатели гемостаза и фибринолиза у экспериментальных животных достоверно отличались от данных интактных животных. 
Облучение в течение 5 дней животных терагерцовыми волнами на частоте 129,0 ГГц по 30 минут вызывает полную нормализацию измененных процессов гемокоагуляции и фибринолиза, так как все изучаемые показатели коагуляционного звена системы гемостаза, антикоагулянтной активности крови и ее фибринолитический потенциал статистически достоверно не отличались от данных интактных животных.

На основании представленных данных можно сделать вывод о положительном влиянии терагерцевого облучения на частоте МСИП атмосферного кислорода 129,0 ГГц на измененные коагуляционные свойства крови и процессы фибринолиза у стрессированных животных. При остром и длительном стрессах наиболее эффективным в восстановлении показателей гемокоагуляции и фибринолитической активности крови является ежедневный 30-минутный режим воздействия.

\section{ГЛАВА XV \\ ВЛИЯНИЕ ЭЛЕКТРОМАГНИТНОГО ИЗЛУЧЕНИЯ ТЕРАГЕРЦЕВОГО ДИАПАЗОНА НА ЧАСТОТАХ ОКСИДА АЗОТА 150,176-150,664 ГГЦ НА ПОКАЗАТЕЛИ ПОЛ, АНТИОКСИДАНТНОЙ АКТИВНОСТИ КРОВИ У СТРЕССИРОВАННЫХ КРЫС}

Свободнорадикальное окисление является одним из универсальных механизмов повреждения клеток, но вместе с тем это и необходимый для нормального функционирования клеток процесс [Типовые патологические ..., 2001, 324 с.].

Состояние процессов липопероксидации в условиях нормы определяет характер модификации фосфолипидного бислоя биологических мембран, энергетического и пластического обеспечения клеток, активности транспортных и рецепторных систем мембран, возбудимость клетки и многие внутриклеточные метаболические процессы [Владимиров, 2000, с. 13-19; Саидов, Каримов, Юлдашев, 2006, с. 33-35].

В то же время интенсификация свободнорадикального окисления является закономерным процессом потенцирования патогенных эффектов воздействия этиологических факторов инфекционной и неинфекционной природы [Афанасьева, 2009, 47 c.].

Активация процессов свободнорадикального окисления описана при ишемии, гипоксиях различного генеза, эндокринопатиях, опухолевом процессе, аутоиммунных заболеваниях, стрессорных ситуациях. 
Показано, что у крыс, находящихся в состоянии острого иммобилизационного стресса, активировались процессы ПОЛ, что сопровождалось статистически достоверным по сравнению с группой контроля увеличением промежуточных продуктов липопероксидации - малонового диальдегида, гидроперекисей липидов. Избыточное накопление продуктов ПОЛ при остром иммобилизационном стрессе сопровождалось развитием синдрома цитолиза, о чем свидетельствовало избыточное накопление в крови молекул средней массы.

Выявленный факт избыточного накопления в крови промежуточных продуктов липопероксидации в условиях острого иммобилизационного стресса является следствием недостаточной функциональной активности ферментных и неферментных звеньев антиоксидантной защиты клеток, так как активность каталазы и супероксиддисмутазы (СОД) крови, уровень общих сульфгидрильных групп (SH-) сыворотки крови, а также перекисная резистентность эритроцитов снижались по сравнению с показателями группы контроля.

Воздействие терагерцевого облучения на частотах оксида азота 150,176-150,664 ГГц в течение 5 минут на животных, находящихся в состоянии острого иммобилизационного стресса, не вызывает значительного изменения исследуемых показателей процессов липопероксидации и антиоксидантной системы крови.

При воздействии на животных на фоне острого иммобилизационного стресса электромагнитными волнами терагерцевого диапазона на частотах оксида азота в течение 15 минут наблюдается частичная, но более выраженная, чем при 5-минутном режиме облучения, нормализация процессов липопероксидации и активности антиоксидантов, что проявляется в снижении концентрации токсических промежуточных продуктов перекисного окисления липидов и частичном восстановлении антиоксидантных свойств крови.

Воздействие терагерцевым облучением на указанных частотах в течение 30 минут вызывает полную нормализацию процессов липопероксидации, что выражается в снижении концентрации токсических промежуточных продуктов перекисного окисления липидов до уровня интактных животных. Функциональная активность ферментного и неферментного звеньев антиоксидантной защиты клеток также восстанавливается и статистически достоверно не отличается от уровня интактных животных.

У крыс-самцов при длительном стрессе по сравнению с животными в состоянии острой иммобилизации обнаружены аналогичные, но более выраженные изменения в изучаемых показателях ПОЛ. Образование продуктов липопероксидации коррелировало с развитием аутоинтоксикации, о чем свидетельствует избыточное накопление в крови 
молекул средней массы. В состоянии длительного стресса у крыс наблюдалось более значительное, чем у животных в остром стрессе, угнетение как ферментного, так и неферментного звеньев антиоксидантной системы. Это проявлялось в статистически достоверных изменениях показателей активности СОД и каталазы в эритроцитах, снижении количества общих SH-групп и витамина Е в сыворотке крови.

При ежедневном воздействии в течение 5 дней на животных на фоне длительного стресса электромагнитными волнами терагерцевого диапазона на частотах оксида азота 150,176-150,664 ГГц в течение 5 минут не наблюдается нормализации процессов липопероксидации и активности антиоксидантов.

Показано, что при ежедневном воздействии на животных на фоне длительного иммобилизационного стресса электромагнитными волнами терагерцевого диапазона на частотах оксида азота 150,176-150,664 ГГц по 15 минут наблюдается только частичная нормализация процессов липопероксидации и активности антиоксидантов, что проявляется в некотором снижении концентрации токсических промежуточных продуктов ПОЛ - малонового диальдегида и гидроперекисей липидов и частичном восстановлении антиоксидантных свойств крови.

Ежедневное пятидневное воздействие терагерцевым облучением на указанных частотах на животных в условиях длительного стресса по 30 минут вызывает полную нормализацию процессов липопероксидации, что выражается в подавлении интенсификации процессов ПОЛ до уровня интактных животных. При данном режиме воздействия одновременно с вышеуказанными изменениями отмечается реактивация ферментного и неферментного звеньев антиоксидантной системы крови, что проявлялось в нормализации активности ферментов супероксиддисмутазы и каталазы, увеличении концентрации витамина Е и общих сульфгидрильных групп до уровня животных контрольной группы.

Таким образом, терагерцевое облучение на частотах МСИП NO 150,176-150,664 ГГц частично или полностью угнетает интенсификацию процессов липопероксидации, снижает явления цитолиза, восстанавливает состояние всех звеньев антиоксидантной защиты в зависимости от условий эксперимента и времени облучения. 


\section{ГЛАВА ХVI}

ПРИМЕНЕНИЕ ЭЛЕКТРОМАГНИТНЫХ ВОЛН ТЕРАГЕРЦЕВОГО ДИАПАЗОНА НА ЧАСТОТАХ ОКСИДА АЗОТА 150,176-150,664 ГГЦ ДЛЯ КОРРЕКЦИИ ПОСТСТРЕССОРНЫХ ИЗМЕНЕНИЙ ГАЗОВОГО И ЭЛЕКТРОЛИТНОГО СОСТАВОВ КРОВИ У КРЫС-САМЦОВ

Газовый состав крови и кислотно-основное состояние организма являются одними из важнейших и наиболее строго контролируемых параметров гомеостаза [Мороз, Герасимов, 2008, с. 79-85]. Известно, что состояние стресса характеризуется перераспределением крови в организме и централизацией кровотока [Мороз, Герасимов, 2008, с. 79-85]. Как следствие, этого происходят ухудшение кровоснабжения различных органов и тканей, развитие гипоксемии и комплекса вторичных неспецифических метаболических и функциональных расстройств [Мороз, Герасимов, 2008, с. 79-85].

У крыс, находящихся в состоянии острого стресса, нами обнаружены изменения газового состава крови. Это выражается в статистически достоверном, по сравнению с группой контроля, снижении напряжения углекислого газа, выраженном уменьшении напряжения кислорода, а также уменьшении рН среды, и концентрации бикарбоната.

У этой группы животных также происходят изменения в электролитном составе крови, что выражается в статистически достоверном повышении концентрации ионов калия. На концентрацию ионов натрия острая иммобилизация не оказывает статистически достоверного влияния.

Воздействие электромагнитного облучения терагерцевого диапазона на частотах оксида азота 150,176-150,664 ГГц в течение 5 минут на животных, находящихся в состоянии острого стресса, не вызывает значительного изменения в исследуемых показателях газового и электролитного составов крови.

Применение терагерцевых волн на частотах МСИП оксида азота 150,176-150,664 ГГц в течение 15 минут у крыс-самцов, находящихся в состоянии острого иммобилизационного стресса, вызывает частичную нормализацию показателей газового и электролитного составов крови. Это проявляется в статистически достоверной нормализации напряжения углекислого газа и тенденции к увеличению содержания кислорода в крови. Статистически достоверно, по сравнению со стрессированными животными, нормализуется концентрация ионов калия в крови. На все остальные изучаемые показатели терагерцевое облучение в данном временном режиме статистически значимых изменений не оказывает. 
При действии терагерцевого облучения на частотах оксида азота 150,176-150,664 ГГц в течение 30 минут на крыс-самцов, находящихся в состоянии острого иммобилизационного стресса, наблюдается полная нормализация нарушенных газового и электролитного составов крови. При этом все исследуемые показатели статистически достоверно не отличаются от данных группы контроля. Следует отметить, что напряжение кислорода в крови после 30-минутного воздействия терагерцевыми волнами на частотах оксида азота 150,176-150,664 ГГц у облученных крыс становится даже несколько выше, чем в контрольной группе.

У крыс, находящихся в состоянии длительной иммобилизации, выявлены более значительные статистически достоверные изменения газового и электролитного составов крови, чем у животных при остром стрессе. Это проявляется в более выраженном снижении напряжения углекислого газа и кислорода, уменьшении $\mathrm{pH}$ среды и бикарбоната. Происходит более значительное статистически достоверное, по сравнению с группой контроля, увеличение концентрации ионов калия, но при этом не изменяется концентрация потенциалобразующих ионов натрия.

Облучение электромагнитными волнами терагерцевого диапазона на частотах МСИП оксида азота 150,176-150,664 ГГц ежедневно в течение 5 дней по 5 минут крыссамцов, находящихся в состоянии длительного стресса, не вызывает изменений в исследуемых показателях газового и электролитного составов крови.

Воздействие указанным облучением ежедневно в течение 5 дней по 15 минут на крыс-самцов, находящихся в состоянии длительного иммобилизационного стресса, вызывает частичную нормализацию показателей оксигенации и электролитного состава крови: происходит статистически достоверная, по сравнению с длительно иммобилизированными животными, нормализация концентрации бикарбоната, напряжения углекислого газа и концентрации ионов калия. В то же время не выявлено статистически достоверных различий в уровне напряжения кислорода, $\mathrm{pH}$ среды и концентрации ионов натрия при данном режиме облучения по сравнению с группой животных, находящихся в состоянии длительного иммобилизационного стресса.

Ежедневное в течение 5 дней воздействие терагерцевыми волнами на частотах МСИП оксида азота 150,176-150,664 ГГц по 30 минут на крыс-самцов, находящихся в состоянии длительного иммобилизационного стресса, характеризуется полной нормализацией нарушенных газового и электролитного составов крови. При этом все исследуемые показатели статистически достоверно не отличаются от данных группы контроля. 
Таким образом, наиболее эффективным в восстановлении измененных показателей газового и электролитного составов крови как при длительном стрессе, так и при острой иммобилизации, является 30-минутный режим облучения электромагнитными волнами терагерцевого диапазона на частотах МСИП оксида азота 150,176-150,664 ГГц. 15минутный режим облучения указанными волнами нормализует измененные показатели газового и электролитного составов крови у стрессированных крыс только частично; 5-минутная экспозиция терагерцевых волн неэффективна.

\section{ГЛАВА XVII \\ ВОССТАНОВЛЕНИЕ ОСНОВНЫХ ПОКАЗАТЕЛЕЙ МЕТАБОЛИЧЕСКОГО СТАТУСА У СТРЕССИРОВАННЫХ КРЫС ТЕРАГЕРЦЕВЫМИ ВОЛНАМИ НА ЧАСТОТАХ ОКСИДА АЗОТА 150,176-150,664 ГГЦ}

Стресс-реакция - это генерализованная реакция организма. В связи с этим в ее формировании существенную роль играют межсистемные связи, в первую очередь, реализующиеся между нервной, эндокринной и висцеральными системами организма [Пшенников, Попкова, Бондаренко, 2001, с. 26-32]. При этом основные показатели метаболического статуса приобретают существенную значимость для диагностирования острых и хронических стрессов [Пшенников, Попкова, Бондаренко, 2001, с. 26-32].

При анализе результатов исследования показано, что у крыс-самцов, находящихся в состоянии острого стресса, наблюдались статистически достоверные, по сравнению с группой интактных животных, изменения в метаболическом статусе, что выражалось в увеличении концентрации глюкозы и снижении общего количества белка в сыворотке крови. При этом изменялся и качественный состав белкового спектра крови: уровень альбуминов в крови статистически достоверно снижался, а процентное содержание белков глобулиновой фракции статистически значимо увеличивалось. Наблюдалось увеличение количества общего холестерина, триглицеридов, общей активности ЛДГ, уровня трансаминаз - АСТ, АЛТ и нарастание в крови концентрации мочевины и креатинина. У крыс-самцов при остром стрессе также статистически достоверно увеличивалась активность глутатион-S-трансферазы, что, вероятно, связано с дополнительным синтезом фермента в ответ на постстрессорные изменения гомеостаза животных. Наблюдалось повышение уровня церулоплазмина в крови, что рассматривается нами как компенсаторная реакция организма, направленная на ферментативное окисление 
биогенных аминов (катехоламинов) и других биологически активных веществ и стрессмедиаторов.

На фоне острого стресса применение электромагнитных волн терагерцевого диапазона на частотах оксида азота 150,176-150,664 ГГц у экспериментальных животных в течение 5 минут не приводит к нормализации измененных показателей метаболического статуса.

Облучение стрессированных животных электромагнитными волнами терагерцевого диапазона на частотах азота 150,176-150,664 ГГц в течение 15 минут приводит к частичному восстановлению измененных показателей метаболического статуса. Так, статистически достоверно нормализовались и не отличались от соответствующих показателей у интактных животных концентрация триглицеридов, активность АСТ и глутатион-S-трансферазы.

Применение электромагнитных волн терагерцевого диапазона на частотах МСИП оксида азота 150,176-150,664 ГГц в течение 30 минут вызывает полную нормализацию постстрессорных изменений метаболического статуса у экспериментальных животных. Полностью нормализовались измененные показатели углеводного, липидного обменов, белковый спектр крови, активность основных ферментов и статистически достоверно не отличались от данных группы контроля.

В условиях длительного стресса у крыс-самцов наблюдаются более выраженные изменения в основных характеристиках метаболического статуса, чем при острой иммобилизации. Это проявляется в более значительном увеличении концентрации глюкозы, более выраженном снижении концентрации общего белка, в том числе альбумина, диспротеинемии, увеличении количества холестерина и триглицеридов, а также уровня мочевины и креатинина в крови. Концентрация сывороточных трансаминаз - АСТ, АЛТ и общая активность ЛДГ возрастали более значительно, чем при остром стрессе. В условиях длительного стресса концентрация церулоплазмина и активность глутатион-S-трансферазы также претерпевали более значительные изменения, чем при остром иммобилизационном стрессе.

Обнаружено, что при ежедневном в течение 5 дней воздействии на экспериментальных животных на фоне длительной иммобилизации электромагнитными волнами терагерцевого диапазона на частотах оксида азота 150,176-150,664 ГГц по 5 минут не наблюдается нормализации измененных показателей метаболического статуса.

При облучении животных в течение 5 дней на фоне длительного стресса электромагнитными волнами терагерцевого диапазона на частотах МСИП оксида азота 150,176-150,664 ГГц по 15 минут наблюдается только частичная нормализация 
метаболического статуса. Так статистически достоверно восстанавливается только уровень триглицеридов, в то время как все другие исследуемые метаболические показатели статистически достоверно отличаются от данных группы контроля.

При ежедневном в течение 5 дней применении терагерцевого облучения на частотах молекулярного спектра излучения и поглощения оксида азота 150,176-150,664 ГГц по 30 минут наблюдается полное восстановление всех изучаемых показателей, характеризующих метаболическую активность внутренней среды организма. При этом показатели липидного, углеводного обменов, белковый спектр крови, основные показатели обмена азотистых соединений, сывороточные трансаминазы (АСТ и АЛТ) и лактатдегидрогеназа полностью нормализовались и статистически достоверно не отличались от данных группы контроля. Представленные данные указывают на то, что при данном режиме облучения происходит полная нормализация измененной метаболической активности у белых крыс-самцов при длительном стрессе.

Таким образом, на основании представленных данных можно сделать вывод о положительном влиянии терагерцевого облучения на частотах оксида азота 150,176150,664 ГГц на измененные показатели метаболического статуса экспериментальных животных, находящихся в состоянии острого и длительного иммобилизационного стрессов. Наиболее эффективным в нормализации изучаемых показателей является 30минутный режим облучения. При 15-минутном режиме облучения на фоне острого и длительного стрессов положительный эффект на показатели, характеризующие процессы обмена веществ и метаболизм, - частичный, а при 5-минутном режиме он отсутствует.

\title{
ГЛАВА XVIII \\ БИОЛОГИЧЕСКИЕ ЭФФЕКТЫ ЭЛЕКТРОМАГНИТНЫХ ВОЛН ТЕРАГЕРЦЕВОГО ДИАПАЗОНА НА ЧАСТОТАХ АКТИВНЫХ КЛЕТОЧНЫХ МЕТАБОЛИТОВ НА МОЛЕКУЛЯРНОМ УРОВНЕ
}

\author{
Проведенные экспериментальные исследования взаимодействия
} электромагнитного излучения терагерцевого диапазона на частотах активных клеточных метаболитов с биообъектами позволили выявить ряд положительных эффектов волн указанных частот, которые могли бы использоваться в клинической практике [Киричук, 2007, с. 98-126]. Большой научный интерес вызывает также изучение механизмов реализации данных эффектов. 
В настоящее время предложено несколько подходов к объяснению механизмов воздействия на биологические объекты (на молекулярном, клеточном и организменном уровнях) ЭМИ миллиметрового и субмиллиметрового диапазонов. Особый интерес вызывают молекулярные механизмы рецепции указанных электромагнитных волн.

При облучении 2,5\% водного раствора белка альбумина человека электромагнитными волнами на частоте атмосферного кислорода 129,0 ГГц в течение 30 минут, обнаружены следующие спектральные изменения (Молекулярную спектроскопию, в частности флуоресцентную спектроскопию белка альбумина, производили на однолучевом люминесцентном спектрометре «LS 55 Fluorescence Spectrometer», фирмы PerkinElmer (США), использовали режим флуоресценции, спектральная ширина щели 15 нм ×15 нм, скорость сканирования 500 нм/мин., спектры возбуждения снимали при люминесценции в области 420 нм, спектральный анализ производили в диапазоне длин волн 250 нм - 320 нм). Поглощение: нет изменений формы спектров, изменяется только амплитуда. Возбуждение: также изменяется только амплитуда полос, это может быть связано, в том числе и с изменением окружения триптофанила (триптофановых остатков) вследствие изменения структуры глобул. В этом случае меняется степень тушения люминесценции.

Методом флуоресцентной спектроскопии показано, что при 30-ти минутном воздействии на 2,5 \% водный раствор белка альбумина терагерцевыми волнами на частотах оксида азота 150,176-150,664 ГГц в спектрах возбуждения наблюдаются три полосы: фениалалнина (258 нм), тирозина (275 нм), и триптофана (297 нм). Так как регистрировалась люминесценция триптофановых остатков (420 нм), в которую дает вклад перенос энергии возбуждения от фенилаланина и тирозина на триптофан, изменение соотношения амплитуд полос возбуждения свидетельствует об изменении эффективности переноса энергии. В свою очередь, это объясняется изменением пространственной конфигурации белковой глобулы под воздействием излучения. Увеличение полосы 275 нм свидетельствует об уменьшении расстояния тирозинтриптофан. Общее увеличение амплитуды полос может быть вызвано уменьшением тушения люминесценции вследствие, например, уменьшения доступа воды в область люминесценции.

Таким образом, методом молекулярной (флуоресцентной) спектроскопии подтверждено положение о том, что излучение терагерцевого диапазона на частотах активных клеточных метаболитов индуцирует конформационные переходы (изменения) в молекулах биополимеров, в частности, белка альбумина. 


\section{ГЛАВА ХІХ}

\section{ВЛИЯНИЕ ЭЛЕКТРОМАГНИТНОГО ИЗЛУЧЕНИЯ ТЕРАГЕРЦЕВОГО ДИАПАЗОНА НА ЧАСТОТАХ АКТИВНЫХ КЛЕТОЧНЫХ МЕТАБОЛИТОВ НА ФУНКЦИОНАЛЬНУЮ АКТИВНОСТЬ ЭНДОТЕЛИЯ СОСУДИСТОЙ СТЕНКИ}

Как известно, основным компонентом интимы сосудистой стенки является эндотелий - единичный слой тонких клеток, обладающих крайне высокой метаболической и секреторной активностью, поэтому эндотелий сосудов называют гормонально активной тканью, которую условно обозначают как самая большая “эндокринная железа” человека [Киричук, Глыбочко, Пономарева, 2008, с.129].

Исследования последних 10-15 лет существенно изменили представление о роли эндотелия сосудов в общем гомеостазе. Оказалось, что эндотелий синтезирует огромное количество биологически активных веществ, играющих весьма важную роль во многих процессах в норме и в патологии (гемодинамике, гемостазе, иммунных реакциях, регенерации и др.).

Эндокринная активность эндотелия зависит от его функционального состояния, которое в значительной мере определяется поступающей к нему информацией.

Биологически активные вещества, вырабатываемые эндотелием, действуют в основном паракринно и аутокринно-паракринно (на эндотелий), однако сосудистая стенка-структура динамичная. Ее эндотелий постоянно обновляется, отжившие фрагменты вместе с БАВ попадают в кровь, разносятся по всему организму и могут оказывать влияние на системный кровоток. При нарушении функции или изменении структуры эндотелия резко меняется спектр выделяемых им эндотелиальных факторов.

Таким образом, о функциональной активности эндотелия можно судить по содержанию его различных биологически активных веществ в крови.

Для оценки выраженности влияния электромагнитных волн терагерцевого диапазона на частотах активных клеточных метаболитов на функциональное состояние эндотелия сосудистой стенки нами было изучено влияние указанных волн на ряд биологически активных веществ эндотелиального происхождения, влияющих, в первую очередь, на тонус сосудов.

Уровень eNOS, ET-1, ADMA определяли методом конкурентного иммуноферментного анализа в плазме крови.

Несмотря на то, что NO-синтазная реакция в эндотелии - основной, но не единственный источник $\mathrm{NO}$ и нитрит-ионов, уже на протяжении ряда лет определение суммарной концентрации нитрит - и нитрат-ионов является общепризнанным методом 
оценки активности eNOS и продукции оксида азота в организме человека [A rapid. Simple spectrophotometric ..., 2001, P. 62-71].

В результате проведенных биохимических исследований показано, что у крыссамцов, находящихся в состоянии острого стресса изменяется функциональная активность эндотелия сосудов, что выражается в изменении концентрации биологически активных веществ (БАВ) эндотелиального происхождения. Так, происходит не только статистически значимое снижение содержания и активности eNOS в крови у экспериментальных животных, но и наблюдается увеличение концентрации ее эндогенного конкурентного ингибитора - ADMA. Ассиметричный диметиларгинин предотвращает превращение аргинина в цитруллин под действием NO-синтазы, т.е. нарушает синтез оксида азота. Нами обнаружена корреляция между концентрацией ADMA в плазме крови и уровнем общей продукции NO. Одновременно с указанными изменениями в крови животных статистически достоверно нарастала концентрация ЕТ-1.

Таким образом, острый иммобилизационный стресс приводит к изменению функциональной активности эндотелия сосудов, что закономерно сопровождается изменением содержания и активности его БАВ в крови.

Облучение белых крыс-самцов, находящихся в состоянии острого иммобилизационного стресса, терагерцевыми волнами на частоте атмосферного кислорода 129,0 ГГц в течение 30 минут приводило к статистически достоверному повышению содержания и активности eNOS, по сравнению с группой животных в состоянии стресса, не подвергавшихся воздействию терагерцевого излучения. Так, уровень eNOS возрастал до 379 пг/мл, а уровень стабильных метаболитов оксида азота нитритов - 0,69 мкг/мл. Одновременно с нормализацией концентрации и активности в крови NOS-3, происходило статистически значимое снижение в 2 раза уровня ADMA до 0,62 мкмоль/л. На фоне облучения указанными волнами в течение 30 минут происходила полная нормализация уровня ЕТ-1 и его концентрация у животных восстанавливалась до 12,13 фмоль/л.

Таким образом, облучение электромагнитными волнами терагерцевого диапазона на частоте атмосферного кислорода 129,0 ГГц белых крыс-самцов на фоне острой иммобилизации восстанавливает функциональную активность эндотелия сосудистой стенки, что выражается в нормализации уровня эндотелий-зависимых БАВ.

30-ти минутное воздействие терагерцевых волн на частотах оксида азота 150,176150,664 ГГц у крыс-самцов, находящихся в состоянии острого стресса, также приводит к статистически значимому снижению уровня ассиметричного диметиларгинина, являющегося эндогенным конкурентным ингибитором eNOS. На фоне нормализации L- 
аргинин/NO-метаболизма повышалась функциональная активность и уровень эндотелиальной NO-синтазы в крови у облученных животных, это выражалось в восстановлении продукции эндотелиальными клетками NO, а, следовательно, и его стабильных метаболитов-нитритов в сыворотке крови у крыс-самцов. Одновременно с указанными выше изменениями происходило статистически достоверное снижение концентрации бициклического полипептида - ЕТ-1.

Итак, электромагнитное излучение терагерцевого диапазона на частотах оксида азота 150,176-150,664 ГГц способно нормализовывать измененную эндокринную активность эндотелия сосудистой стенки у экспериментальных животных в условиях стресса.

Таким образом, электромагнитные волны терагерцевого диапазона на частотах оксида азота 150,176-150,664 ГГц и частоте атмосферного кислорода 129,0 ГГц эффективно восстанавливают функциональное состояние эндотелия сосудистой стенки и его эндокринную активность, что выражается в нормализации баланса продукции им вазоконстрикторных и вазодилататорных веществ, что, в свою очередь, препятствует развитию его дисфункции при остром иммобилизационном стрессе.

\section{1. Влияние терагерцевого облучения на частоте атмосферного кислорода} 129,0 ГГц на содержание и активность eNOS при остром стрессе на фоне введения LNAME

Для выяснения механизмов действия терагерцевого излучения на частоте атмосферного кислорода 129,0 ГГц при остром стрессе у крыс-самцов применяли конкурентный неселективный ингибитор конститутивных изоформ NO-синтаз L-NAME метиловый эфир $\mathrm{N}^{\mathrm{G}}$-нитро-L-аргинина (Sigma, США), который предварительно вводился внутримышечно в дозе 25 мг/кг [Голиков, 2004, 180 с.].

Установлено, что облучение экспериментальных животных при остром стрессе терагерцевыми волнами на частоте атмосферного кислорода 129,0 ГГц в течение 30 минут на фоне предварительного введения неселективного ингибитора конститутивных изоформ NO-синтаз сопровождалось статистически достоверным восстановлением уровня eNOS в крови крыс, но не приводило к нормализации ее функциональной активности, так как не происходило изменения концентрации стабильных метаболитов NO - нитритов в сыворотке крови, об этом свидетельствуют статистически достоверные различия в концентрациях нитритов у животных группы контроля и групп, подвергнутых 30минутному облучению на фоне предварительного введения блокатора L-NAME

Таким образом, механизм действия терагерцевых волн на частоте атмосферного кислорода 129,0 ГГц реализуется при участии NO-синтазного компонента цикла оксида 
азота. Терагерцевые волны при блокаде эндотелиальной NO-синтазы не реализуют своего положительного эффекта на измененные показатели гомеостаза у экспериментальных животных при иммобилизационном стрессе.

\section{Резюме}

Достижения последних лет в изучении структуры и функции эндотелия сосудов открыли совершенно новые его свойства. Эндотелий оказался огромной эндокринной железой, вырабатывающей широкий спектр биологически активных веществ. Биологически активные вещества эндотелия участвуют во многих механизмах гомеостаза, в том числе и в регуляции местного кровотока. Состав БАВ, вырабатываемых эндотелием, определяется состоянием последнего. Активность эндотелия в норме обеспечивает трофику органов и выполняет защитную функцию благодаря наличию в эндотелии высокоорганизованных механизмов саморегуляции. Электромагнитные волны терагерцевого диапазона положительно воздействуют на активность и состояние эндотелия сосудистой стенки и препятствуют развитию его дисфункции при стрессе.

\section{ЛИТЕРАТУРА}

1. Акмаев И.Г. Проблемы и перспективы развития нейроиммуноэндокринологии // Проблемы эндокринологии.-1991. - № 5. - С. 3-8.

2. Афанасьева Г.А. Механизмы индукции и потенцирования системных цитопатогенных эффектов токсинов Yersinia pestis и принципы их медикаментозной коррекции: автореф. дис. ... док. мед. наук. - Саратов: «Саратовский ГМУ им. В.И. Разумовского» Минздравсоцразвития России, 2009. - 47 с.

3. Бецкий О.В., Козьмин А.С., Яременко Ю.Г. Возможные применения терагерцовых волн // Биомедицинская радиоэлектроника. - 2008. - № 3. - С. 48-54.

4. Биофизические эффекты волн терагерцового диапазона и перспективы развития новых направлений в биомедицинской технологии: «Терагерцовая терапия» и «Терагерцовая диагностика» / О.В. Бецкий, А.П. Креницкий, А.В. Майбородин [и др.] // Биомедицинские технологии и радиоэлектроника. - 2003. - № 12. - С. 3-6.

5. Влияние КВЧ-NO облучения на функции тромбоцитов и эритроцитов белых крыс, находящихся в состоянии стресса / В.Ф. Киричук, А.Н. Иванов, О.Н. Антипова [и др.] // Цитология. - 2005. - Т. 47. - №1. - С. 64-70.

6. Влияние электромагнитного излучения терагерцового диапазона на частотах молекулярного спектра излучения и поглощения оксида азота на восстановление количественного и качественного состава эритроцитов крови (in vivo) / В.Ф. Киричук, 
О.И. Помошникова, О.Н. Антипова [и др.] // Биомедицинские технологии и радиоэлектроника. - 2004. - № 11. - С. 21-27.

7. Влияние ЭМИ ТГЧ на частоте молекулярного спектра излучения и поглощения кислорода на функциональную активность тромбоцитов белых крыс в состоянии иммобилизационного стресса / В.Ф. Киричук, С.В. Сухова, О.Н. Антипова [и др.] // Биомедицинская радиоэлектроника. - 2008. - № 12. - С. 40-48.

8. Гершензон Е.М., Малов Н.Н., Мансуров А.Н. Молекулярная физика. - М.: Академия, 2000.-272 С.

9. Голиков П.П. Оксид азота в клинике неотложных заболеваний / П.П. Голиков - М.: Медпрактика-М, 2004. - 180 с.

10. Городецкая И.В. Влияние тиреоидных гормонов на активность протеиназ при иммобилизационном стрессе // Вопросы медицинской химии. - 2000. - № 5. - С. 519-520.

11. Дедов И.И. Свириденко Н.Ю. Йоддефицитные заболевания в Российской Федерации // Вестник РАМН. - 2001. - № 6. - С. 3-12.

12. Изменение концентрации кортикостерона - маркера стресс-реакции под влиянием терагерцового излучения на частотах оксида азота 150,176 - 150,664 ГГц / В.Ф. Киричук, А.А. Цымбал, О.Н. Антипова [и др.] // Росс. физиол. журн. им. И.М. Сеченова. 2008. - T. 94. - № 11. - C. 1285-1290.

13. Информационные взаимодействия в системе тромбоцитов человека / В.Ф. Киричук, А.В. Майбородин, М.В. Волин [и др.] // Цитология. - 2001. - № 12. - С.1042 1050 .

14. Карпюк В.Б., Черняк Ю.С., Шубич М.Г. Лабораторный мониторинг нитроксидергической вазорелаксации при субарахноидальном кровоизлиянии // Клиническая и лабораторная диагностика. - 2000. - № 5 - С. 16-19.

15. Киричук В.Ф. Физиология желез внутренней секреции. - Саратов: Изд-во СарГМУ, 1994. - 64 с.

16. Киричук В.Ф. Саратовские ученые медики о физиологических эффектах электромагнитных волн КВЧ- и ТГЧ-диапазонов // Биомедицинские технологии и радиоэлектроника. - 2007. - № 2-4. - С. 98-126.

17. Киричук В.Ф., Глыбочко П.В., Пономарева А.И. Дисфункция эндотелия. Изд-во СГМУ, 2008.- 129 с.

18. Конако Ф., Фэйтс Д. Терагерцовые волны. - М.: Ломоносов, 2002. - 102 с.

19. Красноперов Р.А., Глумова В.А., Рящиков С.Н. Влияние хронического экспериментального стресса и эндогенных опиоидов на гистофизиологические параметры щитовидной железы // Бюллетень экспериментальной биологии. - 1992. - № 1. - С. 33-35. 
20. Манухина Е.Б., Малышев И.Ю. Стресс-лимитирующая система оксида азота // Росс. физиол. журнал им. И.М. Сеченова. - 2000. - Т.86. - № $\quad$ 10. - С. 1283 - 1292.

21. Пальчикова Н.А. Функциональное состояние щитовидной железы при действии на организм экологических факторов разной природы: дис... докт. биол. наук. Новосибирск:, 2004. - 200 с.

22. Панорамно-спектрометрический комплекс для исследования тонких структур молекулярных спектров физических и биологических сред / А.П. Креницкий, А.В. Майбородин, О.В. Бецкий [и др.] // Биомедицинские технологии и радиоэлектроника. 2001. - № 8. - C. 35-47.

23. Пшенникова М.Г., Попкова Е.В., Бондаренко Н.А. Катехоламины, оксид азота и устойчивость к стрессорным повреждениям: влияние адаптации к гипоксии // Российский физиологический журнал им. И.М. Сеченова. - 2001. - № 1. - С. 26-32.

24. Родштат И.В. Дискуссионные вопросы КВЧ-терапии // Биомедицинская радиоэлектроника. - 2008. - № 5. - С. 19-24.

25. Терагерцовые волны и их применение. Биомедицинские аспекты / O.В. Бецкий, В.Ф. Киричук, А.П. Креницкий [и др.] // Миллиметровые волны в биологии и медицине. - 2005. - № 3. - С.4-16.

26. Типовые патологические процессы / Н.П. Чеснокова, В.В. Моррисон, Г.Е. Брилль [и др.] / под ред. проф. Н.П. Чесноковой. - Саратов: Изд-во СГМУ, 2001. - 324 с.

27. Шеин А.Г., Марковская Л.А. Клетка и электромагнитное излучение // Миллиметровые волны в биологии и медицине. - 2010. - № 4. - С. 5-26.

28. Emission of terahertz radiation from two-dimensional electron systems in semiconductor nano- and hetero-structures / T. Otsuji, T. Watanabe, A. Moutaouakil [et. al.] // Journal of infrared, millimeter and terahertz waves. - 2011. - № 5. - P. 629-645.

29. Furchgott, RF. The obligatory role of the endothelial cells in relaxation of arterial smooth muscle by acetylcholine/R.F. Furchgott, J.V. Zawadzki // Nature.-1980.- Vol.288.-P.373376.

30. Hosako I., Fukunaga K. Terahertz technology research at NICT from the source to industrial applications // Journal of infrared, millimeter and terahertz waves. - 2011. - № 5. P. 722-731.

31. Ignarro L.G., Murad F. Nitric oxide: biochemistry, molecular biology and therapeutic implication // Adv. Pharmacol. - 1995. - V.34. - P. 1-516.

32. Miranda K.M. et al. A rapid. Simple spectrophotometric method for simultaneous detection of nitrate and nitrite // Nitric oxide: biology and chemistry.-2001 - № 5.- P. 62-71. 
33. Terahertz generation and optical properties of lithium ternary chalcogenide crystals / K. Takeya, Y. Takemoto, I. Kawayama [et. al.] // Journal of infrared, millimeter and terahertz waves. - 2011. - № 4. - P. 426-433.

34. The HITRAN molecular spectroscopic database: edition of 2000 including updates through 2001 / L.S. Rothman, A. Barbe, D. Chris Benner [et. al.] // Journal of quantitative spectroscopy \& radiative transfer. - 2003. - № 82. - P. 5-44.

35. The protective effect of cilostazol on isolated rabbit femoral arteries under conditions of ischemia and reperfusion: the role of the nitric oxide pathway / M.R. Santos, A.C. Celotto, V.K. Capellini [et. al.] // Clinics (Sao Paulo). - 2012. - № 67(2). - P. 171-178.

36. Xiaofei L., Zhang X.-C. Terahertz wave gas photonics: sensing with gases // Journal of infrared, millimeter and terahertz waves.- 2011.- № 5. - P. 562-569. 
РАЗДЕЛ І ВЛИЯНИЕ ЭЛЕКТРОМАГНИТНОГО ОБЛУЧЕНИЯ ТЕРАГЕРЦЕВОГО ДИАПАЗОНА НА ЧАСТОТАХ МОЛЕКУЛЯРНОГО СПЕКТРА ИЗЛУЧЕНИЯ И ПОГЛОЩЕНИЯ ОКСИДА АЗОТА 150,176 - 150,664 ГГЦ НА ПОСТСТРЕССОРНЫЕ НАРУШЕНИЯ СИСТЕМНОЙ ГЕМОДИНАМИКИ..................................6

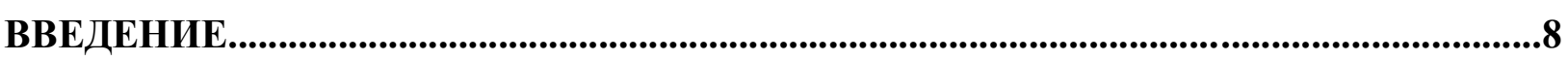

ГЛАВА I БИОЛОГИЧЕСКИЕ И БИОФИЗИЧЕСКИЕ ЭФФЕКТЫ ЭЛЕКТРОМАГНИТНОГО ИЗЛУЧЕНИЯ КВЧ И ТГЧ ДИАПАЗОНОВ И ПРИМЕНЕНИЕ ИХ В МЕДИЦИНСКОЙ ПРАКТИКЕ (ОБЗОР ЛИТЕРАТУРЫ).

1.1. Современные представления о физических и биологических механизмах КВЧ воздействия

1.2. Биофизические основы применения волн терагерцевого диапазона частот 21

1.2.1. Влияние электромагнитного излучения терагерцевого диапазона на экспериментально вызванные нарушения внутрисосудистого компонента микроциркуляци.

1.2.2. Клинические исследования влияния электромагнитного излучения терагерцевого диапазона на течение различных патологических процессов 28

ГЛАВА ІІ ВЛИЯНИЕ НЕПРЕРЫВНОГО РЕЖИМА ЭЛЕКТРОМАГНИТНОГО ОБЛУЧЕНИЯ ТЕРАГЕРЦЕВОГО ДИАПАЗОНА НА ЧАСТОТАХ МОЛЕКУЛЯРНОГО СПЕКТРА ИЗЛУЧЕНИЯ И ПОГЛОЩЕНИЯ ОКСИДА АЗОТА 150,176 - 150,664 ГГЦ НА СИСТЕМНУЮ ГЕМОДИНАМИКУ У БЕЛЫХ КРЫССАМЦОВ В УСЛОВИЯХ ОСТРОГО ИММОБИЛИЗАЦИОННОГО CTPECCA.

2.1. Изменение линейной скорости кровотока в магистральных сосудах у интактных крыс-самцов под влиянием электромагнитного облучения терагерцевого диапазона на частотах МСИП 150,176 - 150,664 ГГц. .30

2.2 Изменение линейной скорости кровотока в магистральных сосудах у белых крыссамцов при остром иммобилизационном стрессе.

2.3. Влияние непрерывного режима ТГЧ-облучения на частотах МСИП оксида азота 150,176 - 150,664 ГГц на нарушенную линейную скорость кровотока в 
магистральных сосудах у белых крыс-самцов, находящихся в состоянии острого

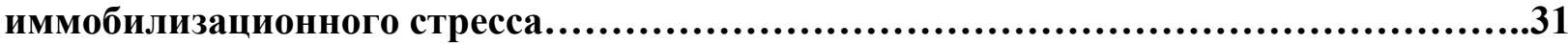

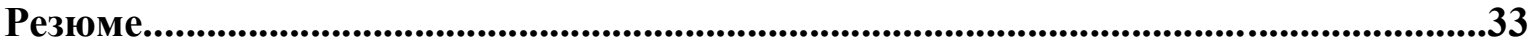

ГЛАВА ІІІ ВЛИЯНИЕ ПРЕДВАРИТЕЛЬНОГО НЕПРЕРЫВНОГО РЕЖИМА ТГЧ-ОБЛУЧЕНИЯ НА ЧАСТОТАХ МОЛЕКУЛЯРНОГО СПЕКТРА ИЗЛУЧЕНИЯ И ПОГЛОЩЕНИЯ ОКСИДА АЗОТА 150,176 - 150,664 ГГЦ НА СТРЕССОРНЫЕ НАРУШЕНИЯ СИСТЕМНОЙ ГЕМОДИНАМИКИ У БЕЛЫХ КРЫССАМЦОВ. 34

3.1. Линейная скорость кровотока в различных магистральных сосудах при превентивном облучении на частотах оксида азота 150,176 - 150,664 ГГц у белых крыс - самцов при остром стрессе.

3.1.1.Влияние предварительного непрерывного режима ТГЧ - облучения на частотах МСИП оксида азота 150,176 - 150,664 ГГц на показатели линейной скорости кровотока в брюшной аорте у белых крыс-самцов, находящцхся в состоянии острого иммобилизационного стресса. 34

3.1.2.Влияние предварительного непрерывного ТГЧ - облучения на частотах МСИП оксида азота 150,176 - 150,664 ГГц на показатели линейной скорости кровотока в бедренной артерии у белых крыс-самцов, находящихся в состоянии острого иммобилизационного стресса .35

3.1.3. Влияние предварительного непрерывного ТГЧ - облучения на частотах МСИП оксида азота 150,176 - 150,664 ГГц на показатели линейной скорости кровотока в сонной артерии у белых крыс-самцов, находящихся в состоянии острого

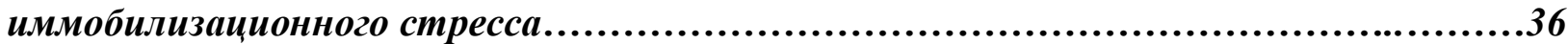

3.2. Сравнительная характеристика линейной скорости кровотока в различных магистральных сосудах при острой стресс - реакции и различных режимах облучения терагерцовыми волнами на частотах МСИП оксида азота .38

3.2.1. Сравнительная характеристика показателей системной гемодинамики в брюшной аорте жживотных, подвергнутых ТГЧ - облучению до и после иммобилизации 38

3.2.2. Сравнительная характеристика показателей системной гемодинамики в бедренной артерии жсивотных, подвергнутых ТГЧ - облучению до и после иммобилизации. 
3.2.3. Сравнительная характеристика показателей системной гемодинамики в сонной артерии жнивотных, подвергнутых ТГЧ - облучению до и после иммобилизации....................................................................40

Резюме. . .41

ГЛАВА IV ВЛИЯНИЕ ДРОБНОГО РЕЖИМА ТГЧ-ОБЛУЧЕНИЯ НА ЧАСТОТАХ МОЛЕКУЛЯРНОГО СПЕКТРА ОКСИДА АЗОТА 150,176 - 150,664 ГГЦ НА СИСТЕМНУЮ ГЕМОДИНАМИКУ БЕЛЫХ КРЫС-САМЦОВ, НАХОДЯЩИХСЯ В СОСТОЯНИИ ОСТРОГО ИММОБИЛИЗАЦИОННОГО CTPECCA .42

4.1. Влияние дробного режима ТГЧ - облучения на частотах МСИП оксида азота 150,176 - 150,664 ГГц на нарушенные показатели линейной скорости кровотока в брюшной аорте у белых крыс-самцов, находящихся в состоянии острого иммобилизационного стресса............................................................42

4.2. Влияние дробного режима ТГЧ - облучения на частотах МСИП оксида азота 150,176 - 150,664 ГГц на нарушенные показатели линейной скорости кровотока в бедренной артерии у белых крыс-самцов, находящихся в состоянии острого иммобилизационного стресса

4.3. Влияние дробного режима ТГЧ - облучения на частотах МСИП оксида азота 150,176 - 150,664 ГГц на нарушенные показатели линейной скорости кровотока в сонной артерии у белых крыс-самцов, находящихся в состоянии острого иммобилизационного стресса.

4.4. Сравнительная характеристика показателей линейной скорости кровотока в брюшной аорте животных, подвергнутых ТГЧ - облучению на фоне острого стресса в непрерывном и дробном режимах. . .45

4.5. Сравнительная характеристика показателей линейной скорости кровотока в бедренной артерии животных, подвергнутых ТГЧ - облучению на фоне острого стресса в непрерывном и дробном режимах.........................................46

4.6. Сравнительная характеристика показателей линейной скорости кровотока в сонной артерии животных, подвергнутых ТГЧ-облучению на фоне острого стресса в непрерывном и дробном режимах .47

Резюме. .47

ГЛАВА V ВЛИЯНИЕ ИНГИБИТОРА NO - СИНТАЗЫ L-NAMЕ И ОБЛУЧЕНИЯ ЭЛЕКТРОМАГНИТНЫМИ ВОЛНАМИ ТЕРАГЕРЦОВОГО ДИАПАЗОНА НА ЧАСТОТАХ МОЛЕКУЛЯРНОГО СПЕКТРА ИЗЛУЧЕНИЯ И ПОГЛОЩЕНИЯ ОКСИДА АЗОТА 150,176 - 150,664 ГГЦ НА СИСТЕМНУЮ 
ГЕМОДИНАМИКУ КРЫС - САМЦОВ, ПОДВЕРГНУТЫХ ОСТРОМУ ИММОБИЛИЗАЦИОННОМУ СТРЕССУ ................................................................48

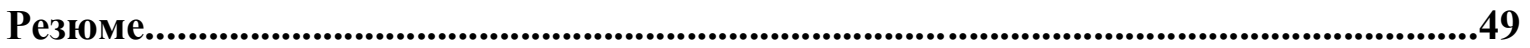

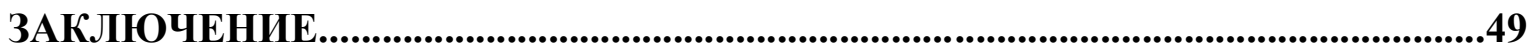

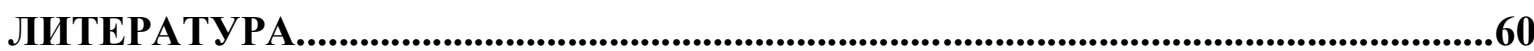

РАЗДЕЛ II ВЛИЯНИЕ ЭЛЕКТРОМАГНИТНОГО ОБЛУЧЕНИЯ ТЕРАГЕРЦЕВОГО ДИАПАЗОНА НА ЧАСТОТАХ МОЛЕКУЛЯРНОГО СПЕКТРА ИЗЛУЧЕНИЯ И ПОГЛОЩЕНИЯ ОКСИДА АЗОТА 150,176 - 150,664 ГГЦ НА СТРЕССОРНЫЕ ИЗМЕНЕНИЯ ПЕРФУЗИИ МИКРОЦИРКУЛЯТОРНОГО РУСЛА И ФУНКЦИОНАЛЬНОГО СОСТОЯНИЯ СОСУДОВ

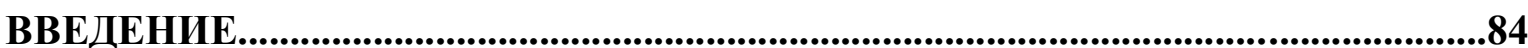

ГЛАВА V ВЛИЯНИЕ ЭЛЕКТРОМАГНИТНЫХ ВОЛН ТЕРАГЕРЦЕВОГО ДИАПАЗОНА НА РАЗЛИЧНЫЕ КОМПОНЕНТЫ МИКРОЦИРКУЛЯЦИИ (ОБЗОР ЛИТЕРАТУРЫ) .88

5.1. Влияние электромагнитного облучения крайне высокочастотного и терагерцевого диапазонов на нарушенные процессы микроциркуляции. 88

5.2. Влияние электромагнитного облучения терагерцевого диапазона на $\begin{array}{lll}\text { стрессорные нарушение внутрисосудистого } & \text { компонента }\end{array}$

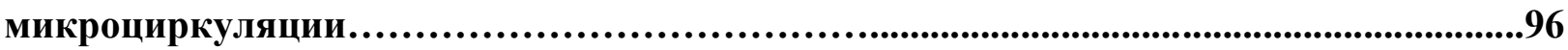

5.2.1 Влияние электромагнитного облучения терагерцевого диапазона на частотах 240 ГГц и 400 ГГц МСИП оксида азота на стрессорные нарушение внутрисосудистого компонента микроциркуляции. 96

5.2.2. Влияние электромагнитного облучения терагерцевого диапазона на частотах 150,176-150,664 ГГц МСИП оксида азота на стрессорные нарушения внутрисосудистого компонента микроциркуляции..............................98

5.2.3. Влияние электромагнитного облучения терагерцевого диапазона на частоте 129,0 ГГи МСИП атмосферного кислорода на нарушение внутрисосудистого компонента микроциркуляции при остром cmpecce..... 101

5.3. Влияние электромагнитного облучения терагерцевого диапазона на стрессорные нарушения реологических свойств крови. 103 ГЛАВА VІ ВЛИЯНИЕ НЕПРЕРЫВНОГО ТЕРАГЕРЦЕВОГО ОБЛУЧЕНИЯ НА ЧАСТОТАХ ОКСИДА АЗОТА 150,176-150,664 ГГЦ НА ИЗМЕНЕНИЯ 
ПЕРФУЗИИ МИКРОЦИРКУЛЯТОРНОГО РУСЛА И ФУНКЦИОНАЛЬНОГО СОСТОЯНИЯ ЭНДОТЕЛИЯ СОСУДОВ У БЕЛЫХ КРЫС ПРИ ОСТРОМ CTPECCE 110

6.1 Влияние облучения терагерцевыми волнами на частотах молекулярного спектра излучения и поглощения оксида азота 150,176-150,664 ГГц на показатели перфузии микроциркуляторного русла и функциональное состояние эндотелия сосудов у интактных крыс-самцов.

6.2 Изменение перфузии микроциркуляторного русла и функционального состояния эндотелия у белых крыс-самцов при остром иммобилизационном стрессе.

6.3. Влияние непрерывного ТГЧ-облучения на частотах МСИП оксида азота 150,176 - 150,664 ГГц на изменения перфузии микроциркуляторного русла и функционального состояния эндотелия $\mathbf{y}$ белых крыс при остром иммобилизационном стрессе.

Резюме .114

ГЛАВА VII ВЛИЯНИЕ НЕПРЕРЫВНОГО ПРЕВЕНТИВНОГО ТЕРАГЕРЦЕВОГО ОБЛУЧЕНИЯ НА ЧАСТОТАХ МОЛЕКУЛЯРНОГО СПЕКТРА ИЗЛУЧЕНИЯ И ПОГЛОЩЕНИЯ ОКСИДА АЗОТА 150,176-150,664 ГГЦ НА ИЗМЕНЕНИЯ ПЕРФУЗИИ МИКРОЦИРКУЛЯТОРНОГО РУСЛА КОЖИ И СОСТОЯНИЕ ЭНДОТЕЛИЯ СОСУДОВ ПРИ ИММОБИЛИЗАЦИОННОМ СТРЕССЕ..........................................115

7.1. Влияние предшествующего иммобилизации облучения терагерцевыми волнами на частотах молекулярного спектра излучения и поглощения оксида азота 150,176 - 150,664 ГГц на показатели перфузии тканей и состояние эндотелия у белых крыс-самцов при остром стрессе.

7.2. Сравнительная характеристика влияния различных режимов облучения терагерцевыми волнами на частотах МСИП оксида азота 150,176-150,664ГГц на изменения перфузии микроциркуляторного русла кожи и состояния эндотелия сосудов при острой стресс - реакции. .118

Резюме .120

ГЛАВА VIII ХАРАКТЕР ИЗМЕНЕНИЙ МИКРОЦИРКУЛЯТОРНОГО РУСЛА И ФУНКЦИОНАЛЬНОГО СОСТОЯНИЯ ЭНДОТЕЛИЯ СОСУДОВ ПОД ВЛИЯНИЕМ ОБЛУЧЕНИЯ ТЕРАГЕРЦЕВЫМИ ВОЛНАМИ НА ЧАСТОТАХ МСИП ОКСИДА АЗОТА 150,176 - 150,664 ГГЦ ПРИ 
ОСТРОМ СТРЕССЕ У БЕЛЫХ КРЫС-САМЦОВ НА ФОНЕ ДЕЙСТВИЯ БЛОКАТОРА NO-СИНТАЗЫ L-NAMЕ.

8.1. Изменение перфузии микроциркуляторного русла и функционального состояния эндотелия сосудов у интактных белых крыс-самцов под влиянием блокатора NO-синтазы L-NAME

8.2. Изменение перфузии микроциркуляторного русла и функционального состояния эндотелия сосудов у белых крыс-самцов, находящихся в состоянии острого иммобилизационного стресса, на фоне введения блокатора NO-синтазы L-NAME .123

8.3. Влияние облучения терагерцевыми волнами на частотах молекулярного спектра излучения и поглощения оксида азота 150,176 - 150,664 ГГц на изменения в сосудистом компоненте микроциркуляции у белых крыс-самцов, находящихся в состоянии острого иммобилизационного стресса, на фоне введения блокатора NO-

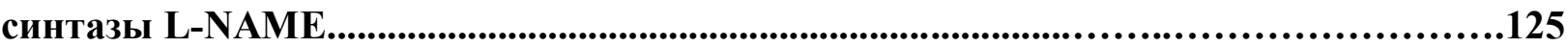

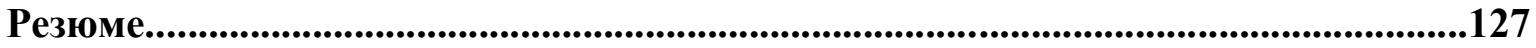

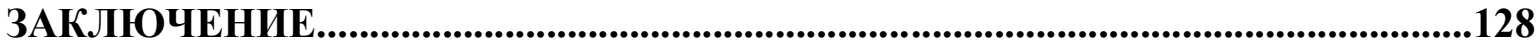

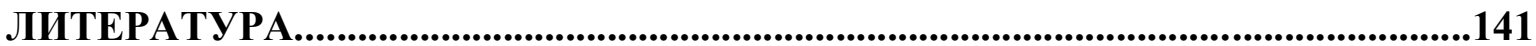

РАЗДЕЛ III ИСПОЛЬЗОВАНИЕ ЭЛЕКТРОМАГНИТНЫХ ВОЛН ТЕРАГЕРЦЕВОГО ДИАПАЗОНА ДЛЯ ВОССТАНОВЛЕНИЯ НАРУШЕННЫХ РЕОЛОГИЧЕСКИХ СВОЙСТВ КРОВИ.................................................160

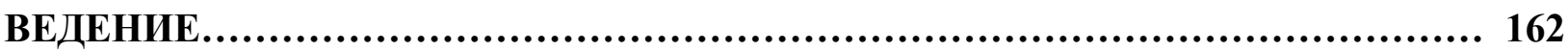

ГЛАВА ІХ. ВЛИЯНИЕ ИЗЛУЧЕНИЯ КРАЙНЕ ВЫСОКОГО И ТЕРАГЕРЦОВОГО ДИАПАЗОНОВ ЧАСТОТ НА НАРУШЕННЫЕ ПРОЦЕССЫ В СИСТЕМЕ МИКРОЦИРКУЛЯЦИИ (ОБЗОР ЛИТЕРАТУРЫ)...............................164

9.1. Биологические и биофизические эффекты электромагнитного излучения КВЧ и ТГЧ диапазонов и применение их в медицинской практике........................164

9.1.1. Современные представления о физических и биологических механизмах КВЧ воздействия на микро - и макросистемы организма 164

9.1.2. Биофизические основы применения волн терагерцевого диапазона частот и влияние ЭМИ ТГЧ диапазона на микро - и макросоставляющие структуры организма. 174

9.2. Микроциркуляция и её составные компоненты. .181

9.2.1. Современные представления о гемореологии: понятия, факторы, ее определяющие. Роль качественного и количественного состава эритроцитов как компонента, определяющего реологические свойства крови 
ГЛАВА Х. ВЛИЯНИЕ ЭЛЕКТРОМАГНИТНОГО ОБЛУЧЕНИЯ ТЕРАГЕРЦЕВОГО ДИАПАЗОНА НА ЧАСТОТАХ МОЛЕКУЛЯРНОГО СПЕКТРА ИЗЛУЧЕНИЯ И ПОГЛОЩЕНИЯ ОКСИДА АЗОТА 150,176-150,664 ГГЦ НА РЕОЛОГИЧЕСКИЕ СВОЙСТВА КРОВИ У БЕЛЫХ КРЫС В УСЛОВИЯХ СТРЕССА 193

10.1. Изменения реологических свойств крови у белых крыс-самцов при остром и хроническом иммобилизационном стрессе и применение электромагнитного облучения на частотах молекулярного спектра излучения и поглощения оксида азота различных временных режимов для их коррекции.........................193

10.1.1. Изменения вязкостных свойств крови у белых крыс-самцов при остром иммобилизационном стрессе

10.1.2. Изменения реологических свойств крови у белых крыс-самцов при хроническом иммобилизационном стрессе .194

10.1.3. Влияние непрерывного облучения электромагнитными волнами молекулярного спектра излучения и поглощения оксида азота 150,176-150,664 ГГц в течение 30 минут на вязкость цельной крови и функциональные свойства эритроцитов у интактных крыс-самцов 196

10.1.4. Изменения вязкости крови и функциональной активности эритроцитов у белых крыс-самцов в состоянии острого иммобилизационного стресса при непрерывном воздействии терагерцевых волн на частотах МСИП оксида азота 150,176-150,664 ГГи

10.1.5. Вязкость крови и функциональная активность эритроцитов у белых крыссамцов в состоянии длительного (хронического) иммобилизационного стресса при непрерывном воздействии терагерцевых волн на частотах МСИП оксида азота 150,176-150,664 ГГц 198

10.1.6. Изменения вязкости крови и функциональной активности эритроцитов у белых крыс-самцов в состоянии острого иммобилизационного стресса при непрерывном превентивном воздействии терагерцевых волн на частотах МСИП оксида азота 150,176-150,664 ГГц .201

10.1.7. Вязкость крови и функциональная активность эритроцитов у белых крыссамцов в состоянии хронического иммобилизационного стресса при непрерывном превентивном воздействии терагерцевых волн на частотах МСИП оксида азота 150,176-150,664 ГГц 204

10.1.8. Вязкость крови и функциональная активность эритроцитов у бельх крыс-самцов на фоне острого иммобилизационного стресса при дробном 
воздействии терагерцевых волн на частотах МСИП оксида азота 150,176$150,664 \Gamma \Gamma и$ 206

10.1.9. Изменения вязкости крови и функциональной активности эритроцитов у белых крыс-самцов в состоянии острого иммобилизационного стресса при превентивном дробном воздействии терагерцевыми волнами на частотах МСИП оксида азота 150,176-150,664 ГГц

10.2. Влияние электромагнитного облучения терагерцевого диапазона на частотах МСИП оксида азота 150,1760150,664 ГГц на реологические свойства крови у белых крыс-самок, находящихся в условиях стресса

10.2.1. Изменения реологических свойств крови у белых крыс-самок при остром иммобилизационном стрессе в фазах Dioestrus и Oеstrus эстрального цикла. .211

10.2.2. Изменения вязкости крови и функциональной активности эритроцитов у бельх крыс-самок в фазе Dioestrus эстрального цикла в состоянии острого иммобилизационного стресса при непрерывном воздействии терагерцевых волн на частотах МСИП оксида азота 150,176-150,664 ГГц

10.2.3. Изменения вязкости крови и функциональной активности эритроцитов у белых крыс-самок в фазе Оеstrus эстрального циикла в состоянии острого иммобилизационного стресса при непрерывном воздействии терагерцевых волн на частотах МСИП оксида азота 150,176-150,664 ГГи

10.2.4. Изменения вязкости крови и функциональной активности эритроцитов у белых крыс-самок в фазе Dioestrus эстрального цикла в состоянии острого иммобилизационного стресса под воздействием непрерывного превентивного облучения терагерцевыми волнами на частотах МСИП оксида азота 150,176-150,664

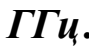

10.2.5. Изменения вязкости крови и функциональной активности эритроцитов у бельх крыс-самок в фазе Оеstrus эстрального цикла в состоянии острого иммобилизационного стресса под воздействием непрерывного превентивного облучения терагерцевыми волнами на частотах МСИП оксида азота 150,176-150,664 $\Gamma \Gamma и$ 219

10.3. Влияние ингибитора NO-синтазы - L-NAME на вязкость цельной крови, функциональную активность эритроцитов крыс-самцов, подвергнутых облучению электромагнитными волнами терагерцевого диапазона на частотах МСИП оксида азота 150,176-150,664 ГГц.

10.3.1. Влияние ингибитора NO-синтазы - L-NAME и облучения электромагнитными волнами на частотах МСИП оксида азота 150,176-150,664 ГГц 
на вязкость цельной крови и функциональную активность эритроцитов интактных крыс-самцов.

10.3.2. Влияние ингибитора NO-синтазы - L-NAME и облучения электромагнитными волнами на частотах МСИП оксида азота 150,176-150,664 ГГц на вязкость цельной крови и функциональную активность крыс-самцов, подвергнутых острому иммобилизационному стрессу .............................224

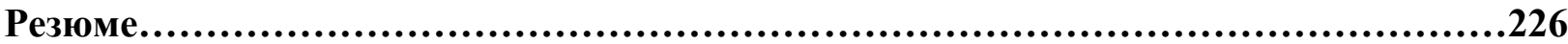

ГЛАВА ХI. ВЛИЯНИЕ ЭЛЕКТРОМАГНИТНОГО ОБЛУЧЕНИЯ ТЕРАГЕРЦЕВОГО ДИАПАЗОНА НА ЧАСТОТЕ МОЛЕКУЛЯРНОГО СПЕКТРА ИЗЛУЧЕНИЯ И ПОГЛАЩЕНИЯ АТМОСФЕРНОГО КИСЛОРОДА 129 ГГЦ НА ОСТРЫЕ СТРЕССОРНЫЕ НА РУШЕНИЯ РЕОЛОГИЧЕСКИХ СВОЙСТВ КРОВИ У БЕЛЫХ КРЫС .228

11.1. Изменения вязкости крови и функциональной активности эритроцитов у белых крыс-самцов в состоянии острого стресса под воздействием терагерцевых волн на частоте молекулярного спектра излучения и поглощения атмосферного кислорода 129 ГГц .228

11.1.1. Исследование влияния различных временных режимов непрерывного электромагнитного излучения молекулярного спектра излучения и поглощения на частоте атмосферного кислорода 129 ГГц на белых крыс-самцов, подвергнутых острому иммобилизационному стрессу .228

11.1.2. Изменения вязкости крови и функциональной активности эритроцитов у белых крыс-самцов в состоянии острого иммобилизационного стресса при непрерывном превентивном воздействии терагерцевых волн на частоте молекулярного спектра излучения и поглощения атмосферного кислорода 129 ГГи

11.2. Влияние терагерцевых волн на частоте молекулярного спектра излучения и поглощения атмосферного кислорода 129 ГГц при остром иммобилизационном стрессе на реологические свойства крови белых крыс-самок в фазах Dioestrus и Oestrus эстрального цикла 232

11.2.1. Изменения вязкости крови и функциональной активности эритроцитов у белых крыс-самок в фазе Dioestrus эстрального цикла в состоянии острого иммобилизационного стресса при непрерывном воздействии терагерцевых волн на частоте молекулярного спектра излучения и поглощения атмосферного кислорода $129 \Gamma \Gamma u$ 
11.2.2. Изменения вязкости крови и функциональной активности эритроцитов у бельх крыс-самок в фазе Оеstrus эстрального цикла в состоянии острого иммобилизационного стресса при непрерывном воздействии терагерцевых волн на частоте молекулярного спектра излучения и поглощения атмосферного кислорода $129 \Gamma \Gamma u$

11.2.3. Изменения вязкости крови и функциональной активности эритроцитов у бельх крыс в фазе Dioestrus эстрального цикла в состоянии острого иммобилизационного стресса под воздействием непрерывного превентивного облучения терагерцевыми волнами на частоте молекулярного спектра излучения и поглощения атмосферного кислорода 129 ГГц...

11.2.4. Изменения вязкости крови и функциональной активности эритроцитов у белых крыс-самок в фазе Оеstrus эстрального цикла в состоянии острого иммобилизационного стресса под воздействием непрерывного превентивного облучения терагерцевыми волнами на частоте молекулярного спектра излучения и поглощения атмосферного кислорода 129 ГГц 239

Резюме. .242

ЗАКЛЮЧЕНИЕ. .243

ЛИТЕРАТУРА 263

РАЗДЕЛ IV ЗАКОНОМЕРНОСТИ И МЕХАНИЗМЫ БИОЛОГИЧЕСКОГО ДЕЙСТВИЯ ЭЛЕКТРОМАГНИТНЫХ ВОЛН ТЕРАГЕРЦЕВОГО ДИАПАЗОНА НА ЧАСТОТАХ АКТИВНЫХ КЛЕТОЧНЫХ МЕТАБОЛИТОВ НА ПОСТСТРЕССОРНЫЕ ИЗМЕНЕНИЯ ПОКАЗАТЕЛЕЙ ГОМЕОСТАЗА...........299

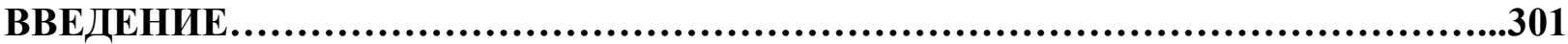

ГЛАВА ХІІ ИЗМЕНЕНИЕ ГИПОФИЗАРНО-ТИРЕОИДНОЙ АКТИВНОСТИ У СТРЕССИРОВАННЫХ КРЫС-САМЦОВ ПОД ЭЛЕКТРОМАГНИТНЫХ ВОЛН ТЕРАГЕРЦЕВОГО ДИАПАЗОНА НА ЧАСТОТАХ

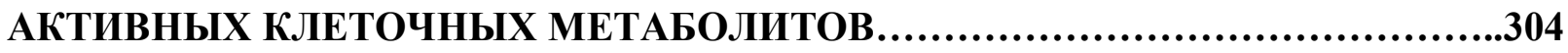
ГЛАВА ХІІІ СТРЕСС-ЛИМИТИРУЮЩЕЕ ДЕЙСТВИЕ ЭЛЕКТРОМАГНИТНЫХ ВОЛН ТЕРАГЕРЦЕВОГО ДИАПАЗОНА

13.1. Влияние электромагнитных волн терагерцевого диапазона на частоте молекулярного спектра атмосферного кислорода 129,0 ГГц на концентрацию кортикостерона - маркера стресс-реакции 307

13.2. Изменения концентрации кортикостерона у экспериментальных животных при облучении их терагерцевыми волнами на частоте атмосферного кислорода 129,0 ГГц 
на фоне введения неселективного ингибитора конститутивных изоформ NOсинтаз........................................................................................309

ГЛАВА ХІV ЭЛЕКТРОМАГНИТНЫЕ ВОЛНЫ ТЕРАГЕРЦЕВОГО ДИАПАЗОНА НА ЧАСТОТЕ АТМОСФЕРНОГО КИСЛОРОДА 129,0 ГГЦ В НОРМАЛИЗАЦИИ ИЗМЕНЕННЫХ ПОКАЗАТЕЛЕЙ СИСТЕМЫ ГЕМОСТАЗА И ФИБРИНОЛИЗА У ЭКСПЕРИМЕНТАЛЬНЫХ ЖИВОТНЫХ............................................310

ГЛАВА ХV ВЛИЯНИЕ ЭЛЕКТРОМАГНИТНОГО ИЗЛУЧЕНИЯ ТЕРАГЕРЦЕВОГО ДИАПАЗОНА НА ЧАСТОТАХ ОКСИДА АЗОТА 150,176-150,664 ГГЦ НА ПОКАЗАТЕЛИ ПОЛ, АНТИОКСИДАНТНОЙ АКТИВНОСТИ КРОВИ

У СТРЕССИРОВАННЫХ КРЫС. .313

ГЛАВА ХVІ ПРИМЕНЕНИЕ ЭЛЕКТРОМАГНИТНЫХ ВОЛН ТЕРАГЕРЦЕВОГО ДИАПАЗОНА НА ЧАСТОТАХ ОКСИДА АЗОТА 150,176-150,664 ГГЦ ДЛЯ КОРРЕКЦИИ ПОСТСТРЕССОРНЫХ ИЗМЕНЕНИЙ ГАЗОВОГО И ЭЛЕКТРОЛИТНОГО СОСТАВОВ КРОВИ У КРЫС-САМЦОВ......................316 ГЛАВА ХVII ВОССТАНОВЛЕНИЕ ОСНОВНЫХ ПОКАЗАТЕЛЕЙ МЕТАБОЛИЧЕСКОГО СТАТУСА У СТРЕССИРОВАННЫХ КРЫС ТЕРАГЕРЦЕВЫМИ ВОЛНАМИ НА ЧАСТОТАХ ОКСИДА АЗОТА................318 ГЛАВА ХVIII БИОЛОГИЧЕСКИЕ ЭФФЕКТЫ ЭЛЕКТРОМАГНИТНЫХ ВОЛН ТЕРАГЕРЦЕВОГО ДИАПАЗОНА НА ЧАСТОТАХ АКТИВНЫХ КЛЕТОЧНЫХ МЕТАБОЛИТОВ НА МОЛЕКУЛЯРНОМ УРОВНЕ 320

ГЛАВА ХІХ ВЛИЯНИЕ ЭЛЕКТРОМАГНИТНОГО ИЗЛУЧЕНИЯ ТЕРАГЕРЦЕВОГО ДИАПАЗОНА НА ЧАСТОТАХ АКТИВНЫХ КЛЕТОЧНЫХ МЕТАБОЛИТОВ НА ФУНКЦИОНАЛЬНУЮ АКТИВНОСТЬ ЭНДОТЕЛИЯ СОСУДИСТОЙ СТЕНКИ 322

19.1. Влияние терагерцевого облучения на частоте атмосферного кислорода 129,0 ГГц на содержание и активность eNOS при остром стрессе на фоне введения L-

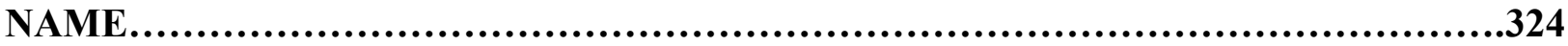

Резюме.................................................................................325

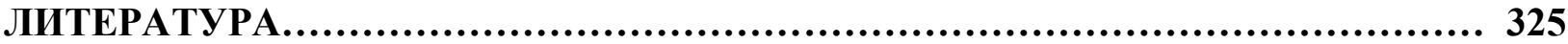

ОГЛАВЛЕНИЕ..........................................................................329 
Влияние терагерцевых волн на сложные живые биообъекты

Авторский коллектив: В.Ф. Киричук, О.Н. Антипова, А.А. Цымбал, Т.С. Великанова, Т.С. Кириязи.

Под редакцией заслуженного деятеля науки РФ, профессора В.Ф. Киричука.

Редактор М.С. Гусева

Подписано к печати 16.10.2013 г.

Бумага типографская № 2 . Гарнитура литературная.

Печать офсетная. Усл.-20,2 печ. л.

Тираж 500 экз

Саратовский государственный медицинский университет им. В.И. Разумовского 410012 Саратов, ул. Большая Казачья, 112

Отпечатано: ИП Беглакова Е.С., г. Саратов, ул Чернышевского, д. 46 